\author{
TSP \\ Universidade de São Paulo \\ Faculdade de Saúde Pública \\ Doutorado em Saúde Global e Sustentabilidade
}

\title{
SAÚDE GLOBAL E INTEGRAÇÃO REGIONAL: A RESPOSTA SUL-AMERICANA À EMERGÊNCIA DA SÍNDROME CONGÊNITA DO VÍRUS ZIKA
}

Global Health and Regional Integration: the South American response to the Emergency of the Congenital Zika Syndrome

Candidata: Flávia Thedim Costa Bueno

Orientadora: Deisy de Freitas Lima Ventura 


\title{
UNIVERSIDADE DE SÃO PAULO
}

\section{FACULDADE DE SAÚDE PÚBLICA}

\author{
Saúde global e integração regional: a resposta sul-americana à \\ emergência da síndrome congênita do vírus Zika
}

Flávia Thedim Costa Bueno

Tese apresentada ao Programa de Pósgraduação de Programa de Saúde Global e Sustentabilidade para obtenção do título de Doutor em Ciências

Área de Concentração: Políticas, sistemas e instituições internacionais de saúde global e ambiente sustentável

Orientadora: Deisy de Freitas Lima Ventura

São Paulo 
Saúde global e integração regional: a resposta sul-americana à emergência da síndrome congênita do vírus Zika

Flávia Thedim Costa Bueno

Tese apresentada ao Programa de Pósgraduação de Programa de Saúde Global e Sustentabilidade para obtenção do título de Doutor em Ciências

Área de Concentração: Políticas, sistemas e instituições internacionais de saúde global e ambiente sustentável

Orientadora: Deisy de Freitas Lima Ventura

São Paulo 
Autorizo a reprodução e divulgação total ou parcial deste trabalho, por qualquer meio convencional ou eletrônico para fins de estudo e pesquisa, desde que citada a fonte. Bibliotecária da FSP/USP: Maria do Carmo Alvarez - CRB-8/4359

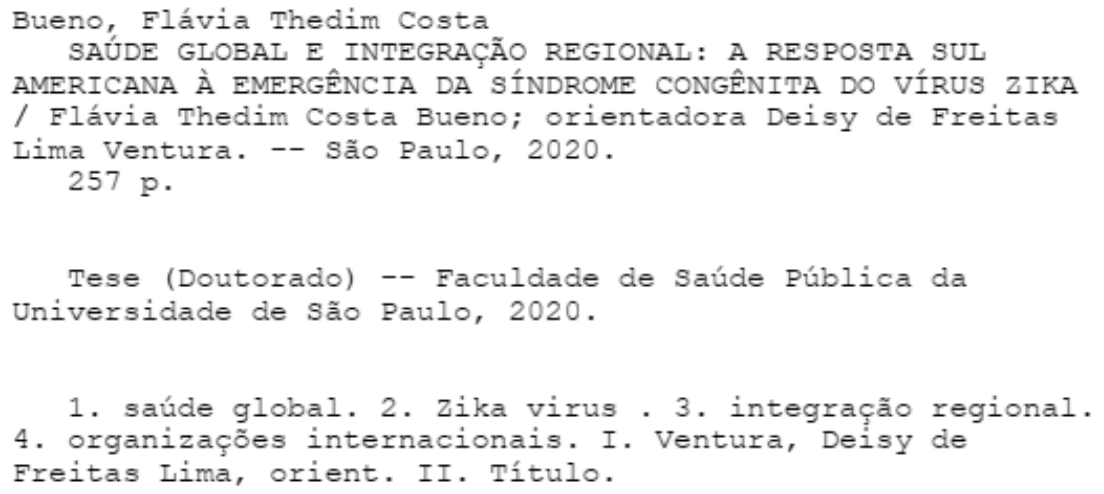




\section{AGRADECIMENTOS}

Começo agradecendo aos meus pais. Meu pai e minha mãe foram estruturantes na minha vida. Agradeço especialmente por este último ano, em que foram cruciais por todo apoio, mas especialmente por serem os cuidadores, com todo amor, responsabilidade e respeito, da minha filha Olívia. Agradeço também ao meu "rimão" Felipe, pela parceria e amor.

À minha filha, agradeço por ser essa menina incrível, cheia de personalidade, que enche meus dias de amor e descobertas. Que eu possa ser para ela o que meus pais foram para mim.

Ao meu esposo, João Victor, por tentar equilibrar as equações e não me deixar pirar. Por trazer amor e força e por entender, como Doutor que é, minha tensão e minhas ausências.

Quando eu nasci, ganhei uma segunda mãe. Minha dinda, Flor, não há palavras para agradecer seu apoio incondicional, seu abrigo e sua sabedoria.

Fundamentais. Agradeço à minha tia Fatinha (e dinda da Olívia) e ao José Alonso, pela oportunidade de ficar na casa da Vila Ida em São Paulo. Sem o apoio de vocês, eu não poderia ter feito meu doutorado na USP. Serei sempre grata!

Aos meus únicos primos, Ju e Tata. Obrigada por estarem perto.

Agradeço também ao meu dindo, tio Beto, e aos meus avós maternos Nena e Oscar, pelo carinho desde sempre. E, por que não, agradeço aos meus avós paternos que onde quer que estejam, olham e torcem por mim: vovô Vicente, vovó Leda e vovó Bibi.

À minha família "in law”, Sessé, Chris, Pedro e Rafa e, especialmente, aos meus afilhados Miguelito e Mary Flower. Obrigada estarem presentes. Aqui não pode faltar a Fatimoca, tia querida que sempre nos acolheu.

À minha orientadora, Deisy Ventura, pelo olhar atento, acolhida e orientação.

À equipe do Programa de Saúde Global e Sustentabilidade e aos meus colegas de turma.

À equipe do ISAGS, com quem dividi o dia a dia da integração regional. Lá, pude trabalhar com gente incrível competente e que trazia no peito a vontade de fazer um bom trabalho. Cito alguns grandes nomes Henri Jouval, Carina Vance, Francisco Armada, José Gomes Temporão, Mariana Faria, Eduardo Hage, Felix Rigoli e Alessandra Ninis.

Não posso deixar de citar os amigos de trabalho que ficaram para toda a vida. A gente formava um time incrível: Camilla Ibiapina, Luana Bermudez, Beatriz Nascimento, Mariana Moreno, Manoel Giffoni, Gabriela Jaramillo, Laura Santana, Raquel Cerqueira, Julia Dias, Karla Menezes, Rakel Cogliatti e Mario Camelo.

Aos meus (outros) amigos, que sempre estiveram próximos mesmo à distância, que entendem minhas ausências e continuam me amando: Camila Coura, Priscila Gonçalves, Marina Souza, Danielle Araújo, Roberta Stelling, Bruno David Sztern, Vinícius Duarte, Glauce Pinto, Ana Portela, Fernanda Elias, Carla Souza, Vanice da Silva, Ana Paula Aizcorbe, Carolina Vizeu, Débora Bastos, Iara Rossman, Dayane Kelly, só para nomear alguns.

Aos meus informantes e pessoas que me ajudaram na construção desta tese.

À CAPES pelo financiamento do último ano de trabalho. 
Bueno FTC. Saúde Global e Integração Regional: a resposta Sul-americana à Emergência da Síndrome Congênita do vírus Zika [tese]. São Paulo: Faculdade de Saúde Pública da USP; 2020.

\section{Resumo}

Em 2015, um aumento incomum do número de bebês nascidos com problemas neurológicos foi detectado no Nordeste do Brasil, suscitando a suspeita de um vínculo entre a infecção pelo vírus Zika em mulheres grávidas e as malformações em seus bebês. O Brasil declarou Emergência Nacional em novembro de 2015 e os dados foram reportados à Organização Pan-Americana da Saúde (OPAS), de acordo com o Regulamento Sanitário Internacional (RSI). Em fevereiro de 2016, a Organização Mundial de Saúde declarou uma Emergência de Saúde Pública de Interesse Internacional (ESPII), apesar de muitos atores da comunidade internacional ainda não estarem convencidos do vínculo entre o vírus Zika e as malformações. Naquele momento de grande turbulência política no Brasil, que desaguou no impeachment da Presidente Dilma Rousseff, assuntos internacionais não eram uma prioridade e a América do Sul perdia paulatinamente a sua centralidade, o que contribuiu para uma crise sem precedentes da integração regional. Como todos os países da região relataram casos de Zika, esperava-se que organizações regionais, como OPAS, União Sul-americana de Nações (Unasul) e Mercado Comum do Sul (Mercosul), colocassem em prática seus planos de resposta a emergências. O objetivo desta tese é avaliar se houve circulação internacional de políticas públicas na resposta à ESPII em nível regional; e se havia um sistema regional de vigilância e resposta, identificando os principais fatores que influenciaram a resposta regional. A metodologia qualitativa foi empregada por meio de levantamento bibliográfico, análise de documentos e entrevistas com os atores-chave do governo brasileiro e das organizações em foco. Concluiu-se que a OPAS destacou-se em relação às outras organizações regionais por ser a mais antiga, por ter grande permeabilidade nos países e por oferecer apoio técnico, facilitando suas ações mesmo em meio a crises políticas. Já a resposta da Unasul e do Mercosul foi prejudicada pela crise política. Nesse contexto, dois processos diferentes foram identificados na resposta regional à ESPII. O primeiro foi a difusão da tese brasileira de que havia um vínculo entre a infecção de gestantes pelo vírus Zika e as malformações congênitas em bebês. $O$ segundo processo foi a circulação do arcabouço normativo do RSI. Estas descobertas comprovam que havia um mecanismo regional de resposta a emergências que operou no caso do Zika na América do Sul. A OPAS, como guardiã do RSI na região, atuou com destaque no reconhecimento de emergências e na ativação de seus mecanismos. Não foi confirmada a hipótese de que um equipamento regional foi operado pela UNASUL.

Descritores: saúde global; Zika vírus; integração regional; organizações internacionais. 
Bueno FTC. [Global Health and Regional Integration: the South American response to the Emergency of the Congenital Zika Syndrome] [thesis]. São Paulo: Faculdade de Saúde Pública da Universidade de São Paulo; 2020. Portuguese.

\begin{abstract}
In 2015, an uncommon increase in the number of babies born with neurological problems was detected in Northeast Brazil, raising suspicious there was a link between infection by the Zika virus in pregnant women and their babies' malformations. Brazil declared a National Emergency in November 2015, and data was reported to the Pan-American Health Organization (PAHO), according to the International Health Regulations (IHR). In February 2016, the World Health Organization declared the situation a Public Health Emergency of International Concern (PHEIC), even though many actors of the international community were still not convinced that the Zika virus was the agent behind the malformations. At that moment of great political turmoil in Brazil, which lead to the impeachment of President Dilma Rousseff, international affairs were not a priority and the central role of South America was lost progressively, resulting in an unprecedented crisis of the regional integration process. As all countries in the region reported Zika cases, it was expected regional organizations, such as PAHO, the Union of South American Nations (Unasur) and the Common Market of the South (Mercosur) to put in practice their emergency response plans. The aim of this thesis is to assess whether there was international circulation of public policies in the response to the PHEIC at the regional level and whether there was a regional health surveillance and response system in place, identifying the main factors that influenced the regional response. Qualitative methodology was conducted through bibliographic survey, document analysis and interviews with key actors from the Brazilian government and the organizations focused in this thesis. The following conclusions were reach: on the one hand, PAHO stood out in relation to the other regional organizations for being the oldest, having great permeability in the countries and offering countries technical support, facilitating its actions, even during a political crisis. On the other, Unasur and Mercosur had a poor performance in responding due to the political crisis. In this context, two different processes were identified as operating in the regional response to the PHEIC. The first one was the diffusion of the Brazilian thesis of the link between the infection of pregnant women by the Zika virus and the congenital malformations in babies. The second, was the circulation of the IHR normative framework. The above findings show that there was a regional emergency response mechanism that operated in the Zika case in South America. PAHO, being the body that enforces the application of the IHR in the region, acted prominently in both emergency recognition and the activation of its mechanisms. The hypothesis of a regional gear operated by Unasur was not confirmed.
\end{abstract}

Descriptors: global health; Zika virus; regional integration; international organizations. 


\section{Lista de Figuras}

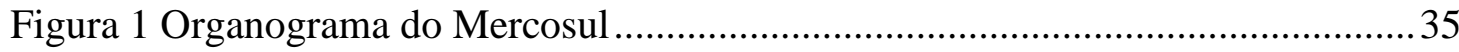

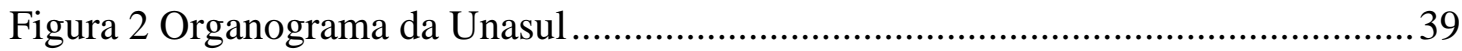

Figura 3 Organograma do Conselho de Saúde Sul-americano da Unasul ....................54

Figura 4 Escopo geográfico das Organizações Regionais .........................................59

Figura 5 Continuum: das lições aprendidas à transferência coercitiva.........................68

Figura 6: Grade de análise - circulação de políticas públicas ....................................... 81

Figura 7 Situação do vírus Zika no Brasil em relação às Américas ............................ 123

Figura 8 Recursos financeiros desembolsados pelas principais entidades financiadoras

Figura 9: Identificação de Prioridades de Pesquisa Regionais .................................... 139

Figura 10 Difusão da tese brasileira sobre a causalidade das malformações congênitas 167

Figura 11 A circulação do Regulamento Sanitário Internacional 172 


\section{Lista de Siglas}

ACE

ACS

ADI

AISA

AMEXID

AMS

ANADEP

ANVISA

Bahiafarma

BID

BM

BNDES

BPC

CAN

CAPS

CASA

CCEG

CCMASM

$\mathrm{CD}$

CDC

Cdel

CE

CEED

CELAC

CGDEP/SVS/MS

CI

CICETV

CIDSS

CIEVS

CIOCS

CIRSI

CISM

CISSR

CMC

CMRE

$\mathrm{CN}$

COES
Agente de Combate a Endemias

Agente Comunitário de Saúde

Ação Direta de Inconstitucionalidade

Assessoria para Assuntos Internacionais em Saúde

Agência Mexicana de Cooperação Internacional para o Desenvolvimento Assembleia Mundial da Saúde

Associação Nacional de Defensores Públicos

Agência Nacional de Vigilância Sanitária

Fundação Baiana de Pesquisa Científica e Desenvolvimento Tecnológico

Banco Interamericano de Desenvolvimento

Banco Mundial

Banco Nacional de Desenvolvimento Econômico e Social

Benefício de Prestação Continuada

Comunidade Andina

Centos de Apoio Psicossocial

Comunidade Sul-americana de Nações

Conselho de Chefas e Chefes de Estado e de

Comissão de Coordenação de Ministros de Assuntos Sociais do Mercosul

Conselho Diretivo da OPAS

Centro de Controle e Prevenção de Doenças dos Estados Unidos

Conselho de Delegados

Comitê Executivo da OPAS

Centro de Estudos Estratégicos de Defesa

Comunidade de Estados Latino-Americanos e Caribenhos

Coordenação Geral de Desenvolvimento da Epidemiologia em Serviços do

Departamento de Gestão da Vigilância em Saúde da Secretaria de Vigilância em

Saúde

Comissão Intergovernamental do Mercosul

Comissão Intergovernamental de Controle de enfermidades de Transmissão

Vetorial

Comissão Intergovernamental de Determinantes Sociais de Saúde e Sistemas de Saúde

Centros de Informações Estratégicas em Vigilância em Saúde

Centro Integrado de Operações Conjuntas da Saúde

Comissão Intergovernamental Implementação do RSI

Conselho do Instituto Social do Mercosul

Comissão Intergovernamental Saúde Sexual e Reprodutiva

Conselho Mercado Comum

Conselho de Ministras e Ministros de Relações Exteriores

coordenador/diretor de cooperação internacional em saúde da sua instituição

Centro de Operações de Emergência de Saúde 


\begin{tabular}{|c|c|}
\hline COMISCA & Consejo de Ministros de Salud de Centroamérica \\
\hline CONASEMS & Conselho Nacional de Secretarias Municipais de Saúde \\
\hline CONASS & Conselho Nacional de Secretários de Saúde \\
\hline COSEMS & Conselho de Secretarias Municipais de Saúde \\
\hline COSERATS & Comissão de Serviços de Atenção à Saúde \\
\hline COSERATS & Comissão de Serviços de Atenção à Saúde do Mercosul \\
\hline COVIGSAL & Comissão de Vigilância em Saúde \\
\hline CQCT & Convenção-Quadro da OMS para o Controle do Tabaco \\
\hline CRAS & Conselho Nacional de Secretários de Saúde \\
\hline CSS & Conselho de Saúde Sul-americano \\
\hline DG & Diretor Geral da OMS \\
\hline DZC & Dengue, Zika e Chikungunya \\
\hline ERAES & Enhancing Research Activity in Epidemic Situations \\
\hline ESPII & Emergência de Saúde Pública de Importância Internacional \\
\hline ESPIN & Emergência de Saúde Pública de Importância Nacional \\
\hline FDA & Food and Drug Administration dos Estados Unidos \\
\hline FHC & Fernando Henrique Cardoso \\
\hline FIC & Fundo de Iniciativas Comuns da Unasul \\
\hline FILIS & Fabricate Laboratory Information System \\
\hline FINEP & Financiadora de Estudos e Projetos \\
\hline FOCEM & Fundo de Convergência Estrutural do Mercosul \\
\hline GMC & Grupo Mercado Comum \\
\hline GOARN & $\begin{array}{l}\text { Global Outbreak Alert and Response Network ou Rede Mundial de Alerta e } \\
\text { Resposta ante Surtos Epidêmicos }\end{array}$ \\
\hline GT & Grupo técnico da Unasul \\
\hline GT-CCMASM & $\begin{array}{l}\text { Grupo Técnico da Comissão de Coordenação de Ministros de Assuntos Sociais } \\
\text { do Mercosul }\end{array}$ \\
\hline ICB & Instituto de Ciências Biomédicas \\
\hline IEC & Instituto Evandro Chagas \\
\hline IMS & Sistema de Gerenciamento de Incidentes da OPAS \\
\hline INCQS & Instituto Nacional de Controle de Qualidade \\
\hline IPPDH & Instituto de Políticas Públicas em Direitos Humanos \\
\hline ISAGS & Instituto Sul-americano de Governo em Saúde \\
\hline ISARIC & International Severe Acute Respiratory and Emerging Infection Consortium \\
\hline ISM & Instituto Social do Mercosul \\
\hline LACEN & Laboratório Central de Saúde Pública \\
\hline Lafepe & Instituto Nacional de Saúde Pública dos Estados Unidos \\
\hline LIRAa & Levantamento Rápido de Índices para o Aedes Aegypti \\
\hline $\mathrm{LRN}$ & Laboratório de Referência Nacional \\
\hline MAC & Mecanismo de Adaptação Competitiva \\
\hline MDS & Ministério do Desenvolvimento Social \\
\hline MEC & Ministério da Educação \\
\hline Mercosul & Mercado Comum do Sul \\
\hline MIN & Ministério da Integração Nacional \\
\hline
\end{tabular}




\begin{tabular}{|c|c|}
\hline MRE & Ministério das Relações Exteriores \\
\hline $\mathrm{NIH}$ & Instituto Nacional de Saúde Pública dos Estados Unidos \\
\hline OCDE & Organização para a Cooperação e Desenvolvimento Econômico \\
\hline OCHA & Escritório das Nações Unidas para a Coordenação de Assuntos Humanitários \\
\hline OEA & Organização dos Estados Americanos \\
\hline OI & Organização Internacional \\
\hline OI & Organização Internacional \\
\hline OMC & Organização Mundial do Comércio \\
\hline OMS & Organização Mundial da Saúde \\
\hline OMSS & Observatório Mercosul de Sistemas de Saúde \\
\hline ONG & Organização Não-governamental \\
\hline ONU & Organização das Nações Unidas \\
\hline OPAS & Organização Pan-americana da Saúde \\
\hline ORAS-CONHU & Organismo Andino de Saúde Convênio Hipólito Unanue \\
\hline ORIS & Oficinas de Relações Internacionais \\
\hline OTCA & Organização do Tratado de Cooperação Amazônica \\
\hline PEB & política externa brasileira \\
\hline $\mathrm{PF}$ & $\begin{array}{l}\text { ponto focal de vigilância em saúde com participação em reuniões das } \\
\text { Organizações Internacionais estudadas }\end{array}$ \\
\hline POA & Plano Operativo Anual do ISAGS \\
\hline POL & entrevistado com interface política \\
\hline PPT & Presidência Pro Tempore \\
\hline PQ & Plano Quinquenal do Conselho de Saúde da Unasul \\
\hline PSDB & Partido da Social Democracia Brasileira \\
\hline PT & Partido dos Trabalhadores \\
\hline RAADH & Reunião de Altas Autoridades em Direitos Humanos \\
\hline $\mathrm{RC}$ & responsáveis ou coordenadores da resposta ao Zika na sua instituição \\
\hline RELDA & Red de Laboratorios de Dengue de las Américas \\
\hline ReneZika & Rede Nacional de Especialistas em Zika e Doenças Correlatas \\
\hline RESP & Registro de Eventos em Saúde Pública \\
\hline RESS & Revista Epidemiologia e Serviços de Saúde \\
\hline RMS & Reunião de Ministros de Saúde \\
\hline RSI & Regulamento Sanitário Internacional \\
\hline SARS & Síndrome Respiratória Aguda Grave \\
\hline SCOCONTS & $\begin{array}{l}\text { Subcomissão de Controle Sanitário de Portos, Aeroportos, Terminais e } \\
\text { Fronteiras Terrestres do Mercosul }\end{array}$ \\
\hline $\mathrm{SCZV}$ & Síndrome Congênita do Zika Vírus \\
\hline SGB & Síndrome de Guillain-Barré \\
\hline SGT & Subgrupo de Trabalho do Mercosul \\
\hline SGT11 & Subgrupo Nº11 Saúde do Mercosul e a OTCA \\
\hline SICA & Sistema de Integração Centro-americano \\
\hline SIRAM & Sistema de Registro de Atendimento às Crianças com Microcefalia \\
\hline SNCC & Sala Nacional de Coordenação e Controle \\
\hline STF & Superior Tribunal Federal \\
\hline
\end{tabular}


SUAS

SUS

SVS

TC

UFBA

Unasul

UNFPA

UNICEF

ZIKV
Sistema Único de Assistência Social

Sistema Único de Saúde

Secretaria de Vigilância em Saúde

Termo de Cooperação

Universidade Federal da Bahia

União de Nações Sul-americanas

Fundo de População das Nações Unidas

Fundo das Nações Unidas para a Infância

Vírus Zika 


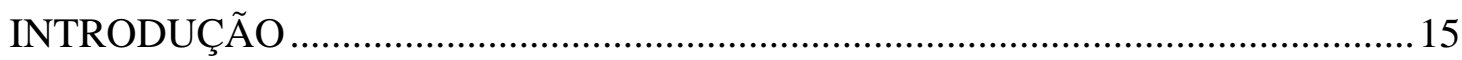

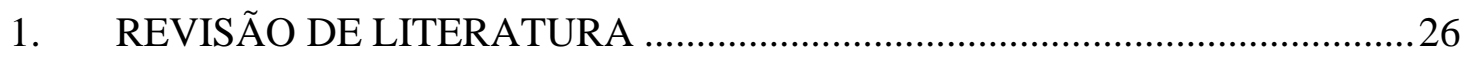

1.1 UM PANORAMA DA POLÍTICA EXTERNA BRASILEIRA ....................26

1.1.1 O papel da América do Sul: integração e regionalização .........................31

1.2 O LUGAR DA SAÚDE NA POLÍTICA EXTERNA, A DIPLOMACIA E A

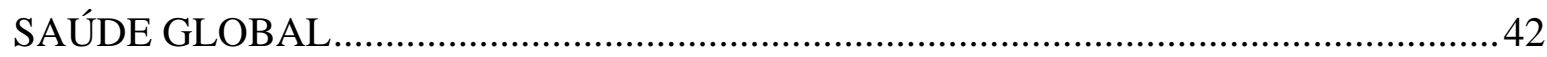

1.2.1 Cooperação internacional em saúde......................................................46

1.2.2 A Organização Pan-americana da Saúde (OPAS) ..................................49

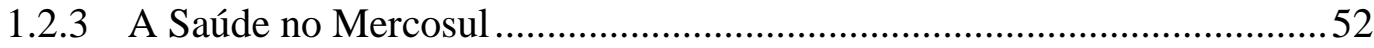

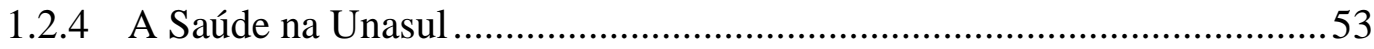

1.3 O PAPEL DA OMS, O RSI E A PRIMEIRA ESPII NA AMÉRICA DO SUL 60

1.3.1 O Regulamento Sanitário Internacional (2005) ..................................6 61

1.4 A DISSEMINAÇÃO INTERNACIONAL DE POLÍTICAS PÚBLICAS COMO RESULTADO DA COOPERAÇÃO INTERNACIONAL .................................... 66

Considerações finais deste capítulo ............................................................ 72

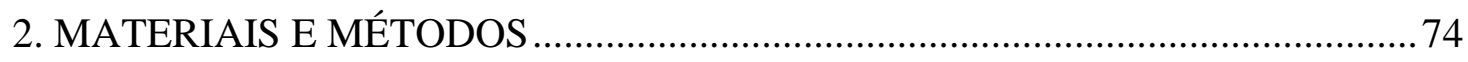

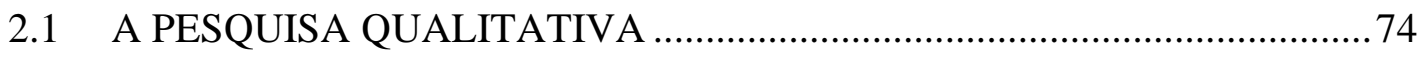

2.1.1 TÉCNICAS DE COLETA DE INFORMAÇÕES ................................ 75

2.1.2 Elaboração de uma grade de análise dos resultados da pesquisa .............. 80

3. AS RESPOSTAS: BRASIL, OPAS, MERCOSUL E UNASUL …........................... 82

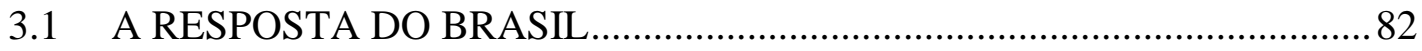

3.1.1 A estruturação da resposta e a aplicação do RSI .................................... 82

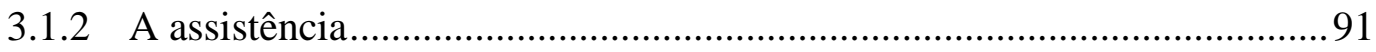

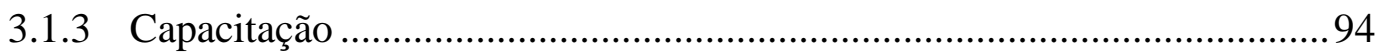

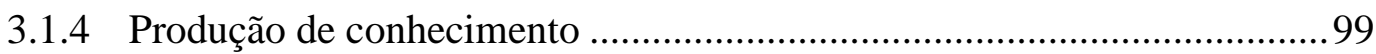


3.1.5 O contexto político e o ambiente de coalizão

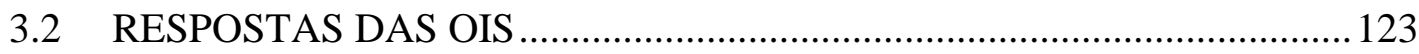

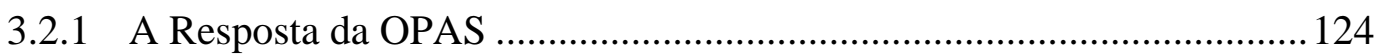

3.2.2 Controle vetorial como demanda dos países ........................................ 132

3.2.3 Ética, Saúde Sexual e reprodutiva, e atenção à saúde............................ 134

3.2.4 A indução por meio de missões, capacitações e workshops ....................135

3.2.5 Cooperação com outras organizações ................................................... 142

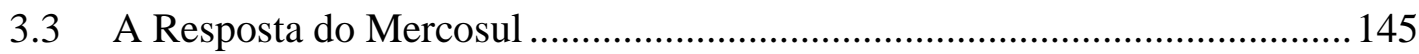

3.3.1 Os espaços transacionais do Mercosul ................................................. 145

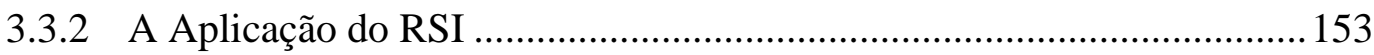

3.4 União de Nações Sul-americanas - Unasul ................................................155

3.4.1 Os espaços transnacionais e a inatividade do GT de Vigilância .............. 156

3.4.2 A desmobilização política .................................................................... 159

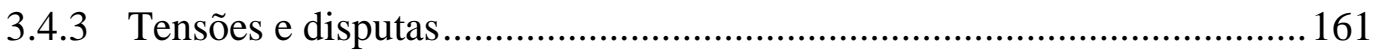

Considerações finais deste capítulo ............................................................... 164

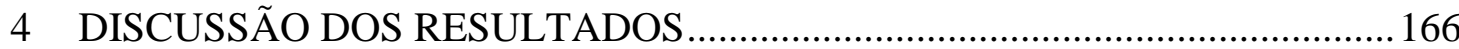

4.1 A DIFUSÃO DA TESE BRASILEIRA SOBRE O VÍNCULO ENTRE O VÍRUS ZIKA E AS MALFORMAÇÕES CONGÊNITAS EM BEBÊS..........................166

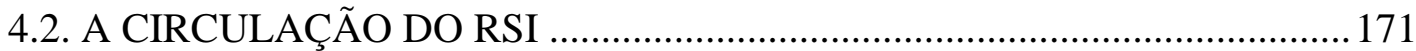

4.1 A ENGRENAGEM REGIONAL DE VIGILÂNCIA ..................................176

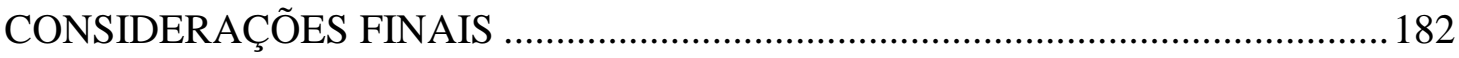

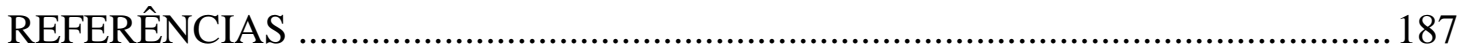

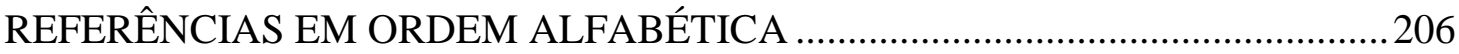

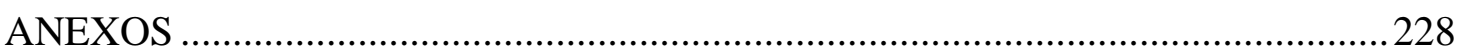

ANEXO I: Linha do tempo - Síndrome Congênita do Vírus Zika como ESPII ....228

ANEXO II: Sistematização de documentos do Ministério de Relações Exteriores do

Brasil 
ANEXO III: Lista de notícias do Ministério da Saúde do Brasil

ANEXO IV: Lista de documentos do Mercado Comum do Sul

ANEXO V: Lista de documentos da União de Nações Sul-americanas 269

ANEXO VI: Lista de documentos da OPAS 270

ANEXO VII: Modelo de entrevista 280

ANEXO VII: Modelo de Termo de Consentimento Livre e Esclarecido 281 


\section{INTRODUÇÃO}

No início dos anos 1950, o vírus Zika foi identificado em humanos na África. Desde então, outros países deste continente, das Américas e da Ásia foram afetados por epidemias do vírus sem despertar grande interesse da comunidade global.

$\mathrm{O}$ vírus Zika é transmitido, principalmente, pela picada do mosquito Aedes Aegypti, vetor que transmite doenças endêmicas na América do Sul como a Dengue e a Chikungunya. A situação de endemia dessas doenças revela a ineficácia de ações de prevenção e controle de vetores e coloca luz sobre problemas de urbanização, saneamento, uso do solo e desigualdade social, que exigem mudanças estruturais para além do enfoque biomédico ou de vigilância pura e simples. Além disso, recolocam e reforçam debates relevantes e inescapáveis sobre saúde sexual e direito reprodutivo das mulheres $(1,2)$.

Seus sintomas - febre, dor de cabeça, dores nas articulações, conjuntivite, náuseas e exantemas - foram considerados leves até pouco depois do meio do ano de 2015. Nesse momento, porém, médicos de beira de leito de alguns estados do Nordeste do Brasil, região mais pobre do país e historicamente negligenciada por políticas públicas(2), começaram a observar um aumento anormal de casos de microcefalia em bebês. Em meio a esse cenário e com registros de infecções em todas as unidades da federação(3), em 11 de novembro de 2015, o governo brasileiro decretou que a "alteração do padrão de ocorrência de microcefalias no Brasil”(4) era uma Emergência de Saúde Pública de Importância Nacional (ESPIN).

Os indícios apontavam que a infecção pelo vírus Zika em gestantes era a possível causa desse aumento de bebês nascidos com danos neurológicos. Esses dados foram comunicados à Organização Mundial da Saúde (OMS) e à Organização Pan-americana da Saúde (OPAS), seguindo o previsto no Art. 6 do Regulamento Sanitário Internacional (RSI), de 2005(5).

Seguindo a declaração de emergência nacional feita pelo governo brasileiro, em 8 de dezembro de 2015, a OPAS ativou seu Sistema de Gerenciamento de Incidentes (IMS, em inglês), estruturando sua resposta para essa "nova fase" da epidemia do vírus Zika(6).

Outros países da região não estavam apresentando o mesmo padrão da epidemia brasileira naquele momento, apesar de haverem detectado o vírus em seus territórios. Esse conflito de informações levantou dúvidas entre cientistas e autoridades, gerando uma série de boatos(7) sobre as possíveis causas para o fenômeno: vacinas, inseticidas liberados no 
ambiente, outras doenças que poderiam causar síndromes congênitas como a sífilis, entre outros.

Cerca de dois meses depois, em $1^{\circ}$ de fevereiro de 2016, evidências dessa ligação apresentadas não apenas pelo Brasil, mas também por países do Norte como Estados Unidos e França, levaram à OMS a declarar a "potencial” relação entre o vírus Zika e o aumento de casos de malformações e desordens neurológicas em bebês como uma Emergência de Saúde Pública de Importância Internacional (ESPII)(8).

A situação de epidemia no Brasil sinalizava para a América do Sul que o vírus Zika poderia se espalhar, afetando os demais países e potencialmente causando as mesmas malformações em bebês nascidos de mães infectadas. Nesse sentido, a ativação dos mecanismos de vigilância e resposta regionais pactuados para dar conta desse problema era esperada, no sentido de conter o vírus e mitigar suas consequências para a população da região.

A atuação de organizações regionais nesse sentido era uma demanda e uma necessidade. O papel das organizações internacionais é considerado fundamental para a promoção de políticas públicas $(9,10)$, fazendo-as circular e serem adotadas entre seus membros, visto que possuem diversos mecanismos para fomentar esse processo. Tendo em sua gênese a cooperação internacional, essas instituições têm papel fundamental para a disseminação internacional de políticas.

Na América do Sul, além da OPAS, que representa a OMS na região das Américas, naquele período outras organizações regionais também atuavam na área da Saúde, como a União de Nações Sul-americanas (Unasul) e o Mercado Comum do Sul (Mercosul). Essas organizações são consideradas atores importantes no cenário da diplomacia regional e global da saúde, com destaque para a Unasul, que entre 2010 e 2016 apresentou diversas intervenções comuns como bloco em arenas como a Assembleia Mundial da Saúde (AMS), dando visibilidade ao processo de integração da América do Sul que se desenrolava naquele momento(11).

Operando como um $h u b$ de produção e disseminação de conhecimento na região, o Instituto Sul-americano de Governo em Saúde (ISAGS), vinculado à Unasul, buscou apoiar a tomada de decisão dos seus países membros, além de visibilizar e viabilizar ações do bloco. Certamente, a ação do ISAGS poderia ter colaborado em uma resposta coordenada da região a uma emergência internacional que teve como epicentro um de seus Estados-membros. Não obstante, meus quase sete anos de trabalho neste Instituto permitiram o conhecimento profundo 
de uma instituição pioneira e sem paralelo no mundo, mas também me familiarizaram com o cenário de crise cíclica da integração na região sul-americana. Como atores da arena política regional e global, órgãos de integração têm sua atuação afetada não apenas por fatores econômicos ou técnicos, mas principalmente por elementos políticos.

O contexto político e econômico da região desde 2015 é de notória instabilidade, com a emergência de governos conservadores e a exacerbação de conflitos, somados às crises econômicas que vêm afetando diversos países da América do Sul.

O Brasil, além de ser o epicentro da emergência internacional do Zika, é considerado um dos países mais poderosos da região e atuou diplomaticamente, principalmente nos governos do ex-presidente Luís Inácio Lula da Silva, para transformar a América do Sul em protagonista no cenário internacional. Após seu último mandato (2007-2010), observou-se mudanças nos rumos da política externa brasileira - nos governos Dilma Rousseff(12) e no do seu sucessor Michel Temer - no que diz respeito à região e à preponderância da saúde nesse contexto.

A declaração da síndrome congênita do vírus Zika como uma ESPII exigia respostas intersetoriais, não apenas no âmbito técnico-biológico, mas também no fortalecimento dos sistemas de saúde e proteção social, na melhoria da infraestrutura e na criação de um arcabouço jurídico que apoiasse as mulheres na sua decisão sobre sua saúde reprodutiva. Soluções conjuntas no âmbito regional teriam como um dos possíveis resultados a potencialização dos efeitos dessa resposta e o fortalecimento da cooperação internacional e da diplomacia da saúde na América do Sul.

Pela primeira vez um país da América do Sul foi o epicentro de uma ESPII, ficando com o Brasil a responsabilidade de dar uma resposta vultosa, assim como é seu sistema de saúde. Sob esse prisma, a declaração de uma ESPII demanda estudos que analisem os mecanismos de resposta dos diversos atores, em diferentes níveis, razão pela qual a presente tese pretende preencher uma lacuna de conhecimento no que se refere ao âmbito regional sul-americano ${ }^{1}$, eis que não foram encontradas pesquisas ou relatórios consagrados a esta perspectiva.

Esta tese está inserida no campo da saúde global, que tem lugar de destaque para captar os fenômenos que transcendem fronteiras e envolvem uma multiplicidade de atores, sejam

\footnotetext{
${ }^{1}$ Uma linha do tempo com os principais acontecimentos relacionados à infecção pelo vírus Zika e a
} Síndrome congênita estão no Anexo I. 
Estados, organizações, entre outros. Os estudos críticos da saúde global dão um passo adiante na compreensão desses fenômenos, na medida em que colocam "as pessoas em primeiro lugar", como o grande personagem a quem ações no campo da saúde global deveriam se dirigir. Além disso, demonstram claramente os limites desse campo, que, por vezes, falha em considerar os inúmeros contextos que intervêm sobre o processo saúde-doença, sejam sociais, políticos e ideológicos, além de privilegiar ações de curto prazo, que têm efeitos imediatos, favorecendo interesses de países desenvolvidos (2).

Assim, esta tese procura contribuir tanto com os estudos sobre integração regional como sobre saúde global, ao descrever e refletir como o Brasil e as organizações regionais em foco operaram e reagiram à ESPII de forma a subsidiar compreensão e o enfrentamento das próximas emergências. O objeto da pesquisa encontra-se então na convergência entre dois problemas teóricos maiores. O primeiro é o de saber quais são as causas e os efeitos das declarações de ESPIIs, e em que medida elas de fato contribuem para a saúde das populações envolvidas. $\mathrm{O}$ segundo é o de saber qual é o papel desempenhado pelas organizações regionais na resposta a emergências de saúde pública, e o quanto as rivalidades entre Estados e organizações, mas também entre diferentes organizações, pode limitar o seu aporte à saúde das populações.

Neste sentido, a tese enfrenta dois debates marginais, que estão longe de atrair grandes atenções da comunidade acadêmica, especialmente no Brasil. O senso comum recomenda, quanto às emergências, uma dura crítica à OMS, em particular o argumento de que o RSI não é uma resposta adequada aos imperativos de segurança que existem no campo da saúde global; e quanto ao regionalismo, o entendimento de que a integração regional serve a interesses comerciais e econômicos, ou a convergências políticas, mas não visa especialmente a construção e a implementação de políticas públicas regionais.

Na tentativa de contribuir para a reflexão sobre tais problemas, ainda que nos limites de uma tese de doutoramento com vasta pesquisa empírica a realizar para obtenção de informações fundamentais, optou-se por aferir se houve disseminação internacional de políticas públicas na resposta à ESPII no ano de 2016, formulada no âmbito sul-americano, com especial ênfase nas relações entre OPAS, Unasul e Mercosul.

O método para a análise da disseminação de políticas (e/ou alguns dos seus elementos) torna-se um ferramental indispensável para compreender o fenômeno e, entendendo que esse processo sofre influências internas e externas, busca compreender as razões pelas quais governos e organizações adotam políticas aplicadas anteriormente em outros lugares. 
O papel das organizações internacionais na disseminação internacional de políticas ainda é pouco estudado no Brasil e no mundo, e o estudo desse processo desde a perspectiva regional também se apresenta como uma lacuna de conhecimento na literatura.

A hipótese da disseminação de políticas no âmbito regional ficou evidenciada já na primeira etapa da pesquisa documental. Passou-se então a identificar as estratégias utilizadas para consubstanciar esta disseminação, as tensões que emergiram neste processo e os resultados do movimento de adoção de políticas e seus elementos.

Assim, como objetivos específicos, buscou-se: identificar, descrever e analisar o modo pelo qual os principais atores regionais relacionaram-se entre si no âmbito da resposta regional ao vírus Zika; descrever a resposta brasileira e analisar especificamente como o Brasil se posicionou nos âmbitos regional e internacional em relação à ESPII; e avaliar se existiu uma engrenagem regional operante no âmbito da vigilância em saúde para responder a emergências como a da Síndrome Congênita do Vírus Zika, identificando os principais fatores que influenciaram a resposta regional.

A união dos fatores previamente apresentados torna este um caso único. É um entrelaçamento entre contextos nacional e regional de crise política, com a primeira mulher à frente da presidência do Brasil; uma emergência de saúde internacional, das poucas declaradas até o presente, sendo a primeira da América do Sul; a eminência dos primeiros Jogos Olímpicos da região. A ocorrência de tantos fatores simultâneos é a riqueza deste caso, que pode contribuir para as repostas a futuras emergências internacionais de saúde, para os estudos críticos da saúde global e para a literatura de relações internacionais.

\section{O VÍRUS ZIKA NO BRASIL E A PRIMEIRA ESPII NA AMÉRICA DO SUL}

Em abril de 2015, a transmissão autóctone do vírus Zika foi identificada no Brasil(13) por pesquisadores da Universidade Federal da Bahia (UFBA), em amostras de pessoas da cidade de Camaçari(7). Desde então, houve um aumento de mais de 20 vezes em casos suspeitos de microcefalia no país. Somado a esse fenômeno, a Polinésia Francesa, afetada entre 2013 e 2015 por uma epidemia do vírus, observou, retrospectivamente, casos de problemas neurológicos vinculados à infecção pelo vírus Zika em bebês $(14,15)$.

Segundo Informe epidemiológico №57(16) - Monitoramento dos casos de Microcefalia no Brasil, de novembro de 2015 a dezembro de 2016, 10.867 casos suspeitos de microcefalia e 
outras alterações do sistema nervoso central foram registrados. O vínculo com a infecção pelo vírus Zika foi confirmado em 2.366, sendo 1804 concentrados no Nordeste do país. 3183 ainda permaneciam em investigação.

Nesse momento, o Brasil vivia uma tríplice epidemia: Dengue, Zika e Chikungunya (DZC). A emergência dessas duas últimas doenças, entre outras novas doenças, coloca desafios para o sistema de saúde(17). Doenças novas não encontram muitos obstáculos para se espalhar pela população, ainda suscetível. Outro ponto é o modo de transmissão: o controle vetorial ainda é um desafio, que se soma a questões ambientais, de desordenamento urbano e mudanças climáticas. Além disso, o diagnóstico diferencial dessas arboviroses também é difícil, seja pela semelhança nos sintomas, seja pela falta de insumos para a realização de testes mais específicos(17) e, quando presentes estão limitados a laboratórios de referência(18).

\section{A Síndrome Congênita do Vírus Zika}

No início de 2015, houve um aumento do número de casos de uma doença exantemática, inicialmente identificadas como dengue. Para definir esses casos, médicos de pelos menos cinco Estados do Nordeste começaram a reunir características comuns: exantema, quase ausência de febre, edemas nas extremidades e dores articulares.

Alguns desses médicos conversavam via Whatsapp, em um grupo chamado "CHIKV: A missão", iniciado na Bahia, para discutir casos de Chikungunya, doença que havia atingido o Estado em 2014. Essa forma de comunicação contribuiu bastante para os debates relacionados ao vírus Zika.(19)

Inicialmente tida como uma dengue leve, pesquisadores começaram a reunir argumentos para refutar esta hipótese: 1) o padrão era bastante diferente daquele apresentado pela dengue (exantema em quase 100\% dos casos, febre ausente, frequente presença de dor articular e edema e conjuntivite não purulenta); 2) evidências da literatura apontavam para um novo vírus e não uma mutação do vírus da dengue; "mutação viral capaz de mudar padrão de doença é um evento raro" (7)p. 30. Foram construídos protocolos em busca de casos tardios da dengue; finalmente os exames laboratoriais indicavam uma outra doença exantemática.

Diniz(1) destaca a importante participação dos médicos da ponta para a descoberta da circulação do novo vírus. Foram eles que alertaram às autoridades e aos cientistas dos grandes centros de pesquisa do país sobre o surgimento de pacientes com uma novidade clínica.

Os especialistas indicavam que era um arbovírus, pela sua dispersão geográfica. A hipótese do vírus Zika foi inicialmente levantada pelo Dr. Kleber Luz do Rio Grande do 
Norte(7). Amostras de sangue de pessoas infectadas de Currais Novos (RN) foram enviadas pelo Dr. Luz para a Dra. Claudia Duarte, da Fiocruz Paraná, em abril de 2015.

Mais ou menos ao mesmo tempo, os médicos Gúbio Soares Campos e Silvia Sardi também detectaram o vírus em amostras de Camaçari (BA). As amostras da Bahia também foram testadas pelo Instituto Evandro Chagas (IEC): eram positivas para Zika! Esse anúncio foi em 14 de maio de 2015. (1)

Outros médicos nordestinos estavam notando uma mudança importante em casos de microcefalia e outras anormalidades em bebês. No Município de Cariri (PB), a médica obstetra Adriana Melo começava a se espantar com esses efeitos nos bebês de suas pacientes, que relatavam ter tido uma "virose" na gravidez. Ela também estava no grupo de Whatsapp mencionado anteriormente. (1) O Dr. Carlos Brito insistia na hipótese de vinculação entre o vírus e os casos cada vez mais frequentes de microcefalia no Nordeste; ele estava em contato com outras médicas de PE e da BA que também relatavam fenômeno semelhante. $(1,7)$

A detecção do vírus em casos de doenças neurológicas foi realizada pela primeira vez em 14 de junho de 2015, quando os médicos Ernesto Marques, Marli Tenório e Lindomar Pena detectaram o vírus em amostras de sangue e líquor de 6 pacientes(7).

Foi em 16 de novembro de 2015 que a Dra. Adriana Melo anunciou que havia isolado o ZIKV no líquido amniótico de duas de suas pacientes: Géssica e Maria da Conceição(1); e dia 28, pesquisadores do IEC demonstraram a correlação entre a infecção pelo vírus Zika e a microcefalia(7).

Apenas após a dupla testagem da Fiocruz PR e do IEC foi que o então Ministro da Saúde, Marcelo Castro, anunciou a circulação do vírus Zika(1), tratando de minimizar os efeitos nocivos da infecção pelo novo vírus.

Naquele mês, especialistas passaram a usar o termo "Síndrome associada à infecção congênita por Zika" ou "Zika congênito", visto que as malformações não estavam apenas relacionadas a microcefalia(20). Ambulatórios especializados em microcefalia foram montados pelos próprios médicos tanto na $\mathrm{PB}$ quanto em $\mathrm{PE}$, facilitando seu diagnóstico e tratamento(1).

Em Pernambuco ${ }^{2}$, o Sistema Nacional de Nascidos Vivos nesta época já apresentava um aumento de mais de $100 \%$ em relação às medidas dos últimos anos, porém nenhum alerta havia sido dado pelo sistema. A hipótese da correlação entre o vírus Zika e a microcefalia foi

\footnotetext{
${ }^{2}$ No caso do SINAN/PE, destaca Diniz(1), a recomendação da Nota Técnica no 59/2015 era de que casos suspeitos de ZIKV fossem notificados como dengue. As consequências dessa orientação podem ser observadas no boletim epidemiológico de 10 de outubro, onde havia apenas 04 casos de Zika confirmados no Estados.
} 
levantada, tomando em consideração os seguintes aspectos: o aumento do número de casos em curto espaço temporal; exames compatíveis com infecções congênitas; outras doenças genéticas comuns descartadas; quadro viral das mães compatível com a infecção pelo vírus, que tem um neurotropismo maior que outras arboviroses e o fato de que outras arboviroses conhecidas não estarem associadas a malformações congênitas. (7)

Após a descoberta, a definição de casos de microcefalia utilizada pelo Brasil foi questionada(21), sob a justificativa de que estaria causando sobrenotificação, ou seja, casos de crianças normais com cabeças pequenas estavam sendo considerados como suspeitos de microcefalia. Victora e colaboradores(21) enfatizaram a importância de utilizar parâmetros mais específicos (que poderiam aumentar a capacidade de detectar casos negativos), aliados à testes laboratoriais ou radiológicos.

Em 9 de março de 2015, o país adotou novos parâmetros, alinhados aos da OMS, que são diferentes para meninas e meninos, menor ou igual a 31,5 e 31,9, respectivamente, aumentando sua sensibilidade (capacidade de detectar casos positivos). Entretanto é preciso ressaltar que o diagnóstico de microcefalia deve ser feito não apenas por essa medida, mas também pela sua conjugação com outros exames como a tomografia e a ultrassonografia transfontanela.(22)

Um estudo publicado em 29 de junho pela Universidade Federal de Pelotas - em colaboração com a Sociedade Brasileira de Genética Médica, o Centro Latino-Americano de Perinatologia da OPAS e a Universidade de Harvard, dos Estados Unidos, concluiu que outros sinais e sintomas deveriam ser incluídos no protocolo de triagem de bebês, independentemente de a condição de microcefalia estar presente ou não. Nesse sentido, o MS avaliou a implementação de mudanças no protocolo de microcefalia, visto de cerca de $20 \%$ das crianças apresentam outras condições clínicas que não a microcefalia.(23)

A Emergência de Saúde Pública de Importância Internacional relacionada à Síndrome Congênita do Vírus Zika

Após cerca de três meses da notificação do Brasil sobre o aumento alarmante dos casos de microcefalia no país, a Diretora Geral da OMS, Margaret Chan, convocou o Comitê de Emergência, que se reuniu pela primeira vez em $1^{\circ}$ de fevereiro de 2016 . Neste mesmo dia, os recentes "surtos" de microcefalia e distúrbios neurológicos foram declarados Emergência de Saúde Pública de Importância Internacional (ESPII). O Diretor do IEC, Pedro Vasconcelos, era um dos membros do Comitê, o único brasileiro. 
Nesse ponto, nota-se que foi apenas quando países de grande expressão no cenário mundial - Brasil, França e Estados Unidos - foram afetados ou alertaram para o vínculo potencial entre o vírus Zika e distúrbios neurológicos é que a comunidade internacional se mobilizou para dar conta da epidemia em curso, evidenciando que "a cooperação internacional surge, portanto, marcada por uma preocupação fundamental: a contenção de determinadas doenças infecciosas, impedindo a sua chegada ao mundo desenvolvido ocidental"(2)p. 25.

Ainda em fevereiro (23), Margaret Chan visitou o Brasil. Em uma conversa com jornalistas em Brasília, ela elogiou a liderança da então Presidente, Dilma Rousseff, bem como o empenho e transparência em compartilhar as informações sobre a epidemia no país. Além disso, também reforçou o apoio da OMS e da OPAS para que o Brasil assegurasse condições para atletas e turistas para os Jogos Olímpicos, que aconteceria naquele ano.

Sobre a relação causal, foram levantadas algumas polêmicas como a exposição da população a alguma fonte ambiental ou que fossem transmitidas pessoa-pessoa, já que houve aparição simultânea de casos em diversos Estados. Além disso, houve boatos envolvendo a vacinação contra o sarampo, que ocorreu em Pernambuco (2013) e no Ceará (2014-2015); e a possível contaminação por larvicidas ${ }^{3}$ usados no combate ao mosquito, entre outros. Das publicações mais compartilhadas no Facebook relacionadas à epidemia, pelo menos $30 \%$ eram boatos ou de conteúdo humorístico.(7)

Após seu primeiro encontro, o Comitê emitiu duas recomendações principais: a primeira, foi padronizar e incrementar a vigilância de microcefalia nas áreas afetadas pelo vírus Zika e a segunda foi aumentar a pesquisa sobre a etiologia desses surtos para determinar se havia relação causal com o vírus. Para seus membros, a diferença entre a declaração do Ebola como ESPII para a da Zika, é que no primeiro caso, a emergência foi declarada pelo que já se sabia sobre a doença e no segundo, é pelo que não se sabia(15).

Novamente, a atuação da OMS foi alvo de críticas quanto à sua liderança e tempo de ação, o que já havia ocorrido no caso do Ebola. Lucey e Gostin(24), em artigo publicado em 27 de janeiro, consideravam que a emergência mundial era um fato e que o Comitê já deveria ter sido convocado, naquele tempo.

Para boa parte da comunidade científica brasileira, o vínculo entre a infecção pelo vírus Zika e os casos de microcefalia e outras alterações neurológicas como a Síndrome de Guillain-

${ }^{3}$ Em 13 de fevereiro de 2016, o Ministério da Saúde publicou uma nota de esclarecimento sobre o uso do Larvicida Pyriproxifen: http://portalms.saude.gov.br/noticias/agencia-saude/22161-esclarecimento-sobre-o-uso$\underline{\text { do-larvicida-pyriproxifen }}$ 
Barré (SGB) era bastante claro já no início da ESPII. Em 8 de março, na segunda reunião do Comitê(25), entretanto, ainda não se determinava essa ligação como certa. Foi durante a terceira reunião, em 14 de junho, que a declaração do órgão foi taxativa: o vírus Zika é a causa da microcefalia e um gatilho para a $\operatorname{SGB}(26)$.

Durante esse encontro, os especialistas consideraram muito baixo o risco de aumento de casos de infecção pelo vírus Zika devido às aglomerações resultado da concentração de pessoas no Rio de Janeiro para os Jogos Olímpicos - temperaturas mais baixas e ações de vigilância nas proximidades dos jogos -, reforçando que não fariam recomendações gerais sobre restrições a viagens e comércio com os países afetados.

Após a finalização dos jogos, durante sua quarta reunião, o comitê informou não haver casos confirmados entre os frequentadores dos locais de realização, congratulando o Brasil por suas ações de prevenção e controle(27). Devido à contínua expansão geográfica e às consideráveis lacunas no conhecimento sobre a infecção pelo vírus Zika, a ESPII foi mantida (28).

Em geral, as recomendações do Comitê giraram em torno da necessidade de melhorar as ações de vigilância, comunicação e avaliação de risco, controle vetorial, indicações clínicas, e pesquisa e desenvolvimento - que envolvem a investigação de novos diagnósticos e tratamentos, o desenvolvimento de vacinas e outras medidas de controle vetorial.

A quinta reunião do Comitê de Emergências, em 18 de novembro de 2016, decidiu pela extinção da ESPII, sob a alegação de que seria estabelecido um mecanismo de longa duração para responder à epidemia(29).

\subsection{Estrutura da Tese}

Esta tese está dividida em quatro partes principais.

O primeiro capítulo tem como objetivo contextualizar o objeto de estudo por meio de uma revisão da literatura de elementos relacionados a: 1) política externa brasileira e o posicionamento do Brasil quanto à integração regional; 2) o papel da saúde nesse contexto, cooperação internacional e organismos que tratam de saúde na América do Sul; 3) o enfoque da disseminação de políticas no contexto da cooperação; 4) a Organização Mundial da Saúde, o regulamento sanitário internacional e seus mecanismos. 
O segundo capítulo apresenta a escolha por metodologia qualitativa e os métodos de coleta e de análise dos dados, descrevendo e justificando as decisões que fazem parte da construção deste trabalho.

O terceiro capítulo apresenta os resultados da análise documental e das entrevistas realizadas, descrevendo como cada um dos atores foco desta tese; a saber: o Brasil, o Mercosul, a Unasul e a OPAS responderam a esta ESPII.

O último capítulo discute as implicações desses achados para a circulação de políticas públicas na região no que se refere tanto à tese brasileira sobre o vínculo entre a infecção pelo vírus Zika e o aumento de casos de malformações congênitas no país; bem como do RSI nos países e organizações estudadas.

Alguns desdobramentos não explorados nesta tese podem ser objeto de estudos futuros como, por exemplo, o quanto as decisões sobre a ESPII atingiram a vida das mães e crianças diagnosticadas com Síndrome Congênita do vírus Zika; ou resultados alcançados para a saúde na América do Sul como fruto das ações do Conselho de Saúde da Unasul e do ISAGS; ou ainda, como o funcionamento do referido Conselho transformou a Unasul, por um certo tempo, em um ator influente na saúde global. 


\section{REVISÃO DE LITERATURA}

A revisão de literatura tem como objetivo contextualizar o objeto da tese e está dividida em quatro partes principais. Inicialmente, trata-se de um panorama da Política Externa Brasileira (PEB) que traz elementos para compreensão das escolhas feitas pelo Brasil no âmbito da resposta à ESPII e a forma como o país se relacionou com Estados e organizações internacionais. A revisão limita-se à PEB porque o país foi o epicentro da emergência em apreço, o que aumenta a já reconhecida relevância política da atuação do Brasil na América do Sul, em particular no que se refere à criação e ao funcionamento das organizações regionais.

Por esta razão, a seção traz uma apresentação de duas das principais organizações da região: o Mercosul e a Unasul; e apresenta a evolução dos posicionamentos dos governos Dilma (2011-2016) e Temer (2016) com relação à integração regional. Algumas características desses governos contribuem para contextualizar o lugar do país nessas organizações e, posteriormente, ajudam a entender seu posicionamento frente à ESPII.

A segunda parte trata política externa e saúde global. Nesse ponto, são apresentados o lugar da saúde na política externa e uma visão crítica sobre a saúde global e a cooperação internacional. Contextualiza também a saúde nas organizações supracitadas e introduz a Organização Pan-americana da Saúde como ator dessa arena na região. A OPAS se distingue das demais instituições estudadas porque faz parte de um sistema multilateral e também foi criada especificamente para atuar no âmbito da saúde, o que não é a realidade da Unasul e do Mercosul.

A terceira parte apresenta literatura sobre disseminação de políticas públicas no contexto de organizações internacionais e seus principais conceitos. E, finalmente, a quarta parte faz uma breve apresentação sobre a Organização Mundial da Saúde e do seu instrumento vinculante, o Regulamento Sanitário Internacional, base para a declaração da Síndrome Congênita do vírus Zika como uma Emergência de Saúde Pública de Importância Internacional.

\subsection{UM PANORAMA DA POLÍTICA EXTERNA BRASILEIRA}

O estudo sobre a condução da política externa de um país pode nos revelar a forma como esse ator político se posiciona e se relaciona com demais Estados e atores do cenário internacional. De acordo com Pinheiro(30), a política externa: 
Pode ser definida como o conjunto de ações e decisões de um determinado ator, geralmente, mas não necessariamente o Estado, em relação a outros Estados ou atores externos - tais como organizações internacionais, corporações multinacionais ou atores transnacionais -, formulada a partir de oportunidades e demandas de natureza doméstica e/ou internacional. (p.7)

Dessa forma, os parâmetros definidos pela confluência de oportunidades e demandas internas e externas servem como guia para a atuação internacional de um determinado país/organização. No caso do Brasil, a formulação e implementação da política externa foi considerada uma política de Estado durante muito tempo. A existência de um serviço diplomático tradicional e de grande influência, cujos membros são recrutados por disputado concurso público, fez do Itamaraty (Ministério das Relações Exteriores - MRE) a principal referência da PEB.

Na prática, a estabilidade desta corporação que assessora a Presidência da República na condução das Relações Internacionais do Brasil ${ }^{4}$, vinha garantindo elementos de continuidade à PEB. Entretanto, a paulatina diversificação dos atores que atuam nas relações internacionais para além dos Estados, levou a literatura acadêmica nacional a definir a política externa como uma política pública(31), reconhecendo a relevância da interferência e das influências das coalizões domésticas e seus interesses nesse processo. Assim, a política externa deve ser entendida como responsabilidade do governo que as implementa, passível de influência política, cuja formulação e implementação inserem-se na "dinâmica das escolhas de governo que, por sua vez, resultam de coalizões, barganhas, disputas, acordos entre representantes de interesses diversos, que expressam, enfim, a própria dinâmica da política.” (31)p.24.

Os estudos sobre a Política Externa Brasileira foram desenvolvidos ao longo da alternância de poder no plano federal, identificando a variação dos projetos políticos de cada governo no que se refere à inserção brasileira no cenário internacional, e especialmente na América do Sul. Diversos estudiosos do tema divergem quanto a se determinadas mudanças nos governos acarretaram também mudanças paradigmáticas no campo como se verá a seguir.

\footnotetext{
${ }^{4}$ De acordo com o direito brasileiro, o Ministério das Relações Exteriores tem como área de competência os seguintes assuntos: I - assistir direta e imediatamente o Presidente da República nas relações com Estados estrangeiros e organizações internacionais; II - política internacional; III - relações diplomáticas e serviços consulares; IV - participação em negociações comerciais, econômicas, financeiras, técnicas e culturais com Estados estrangeiros e organizações internacionais, em articulação com os demais órgãos competentes; V programas de cooperação internacional; VI - apoio a delegações, comitivas e representações brasileiras em agências e organismos internacionais e multilaterais; VII - coordenação das atividades desenvolvidas pelas assessorias internacionais dos órgãos e das entidades da administração pública federal;" entre outras atribuições, conforme o Decreto n. 9.683, de 09/01/2019.
} 
Desde o governo Collor (1990-1992), pode-se atribuir as mudanças na condução da PEB tendo como consequência a divisão do corpo diplomático em duas correntes de pensamento ${ }^{5}$ : autonomistas e institucionalistas pragmáticos $(32)^{6}$. Saraiva apresenta três características que podem ser consideradas como fios condutores da PEB: universalismo das relações do Brasil com outros Estados; autonomia, ou seja, certa flexibilidade de ação em suas relações e em sua atuação internacional, e crença no destino de grandeza do país(32). Foi durante o governo Collor que foi firmado o acordo que deu origem ao Mercosul.

No que concerne ao Governo de Fernando Henrique Cardoso (FHC)(1995-2002), ainda que os autores tenham diferentes visões quanto ao status dessa nova abordagem, sua política externa é definida tanto por Pinheiro quanto por Saraiva como institucionalista pragmática(32,33). De um lado, havia visível adesão aos regimes e às instituições internacionais, como os direitos humanos, ou seja, era maior o grau de institucionalização; de outro, buscava regionalmente uma liderança a fim de obter maior autonomia global, sendo porém resistente à institucionalização ${ }^{7}$ do Mercosul, por exemplo, para preservar o diferencial regional de poder(33). Na mesma linha, Saraiva(32) afirma que os países da América do Sul foram identificados como parceiros importantes no segundo mandato de FHC, como veremos adiante, a fim de fortalecer o Brasil nos foros multilaterais. De modo geral, o pragmatismo foi privilegiado em relação à autonomia, ao universalismo e ao destino de grandeza do Brasil.

Entre 2003 e 2016, o Brasil foi governado por uma coalizão liderada pelo Partido dos Trabalhadores (PT). Após a redemocratização do país, Luiz Inácio Lula da Silva (Lula) candidatou-se sem êxito à Presidência da República em 1989, 1994 e 1998, sendo eleito em 2002 e reeleito em 2006. Sua sucessora, Dilma Rousseff, foi eleita em 2010. Em 2013, eclodiu no Brasil um movimento político de contestação do governo federal, de grandes proporções, complexo e heterogêneo, cuja interpretação ainda é controversa. Embora reeleita em 2014

\footnotetext{
${ }^{5}$ Para Miriam Saraiva(32,270) não teria havido espaço para a consolidação de um consenso ou um novo paradigma.

${ }^{6} \mathrm{O}$ conceito "institucionalismo pragmático" foi cunhado por Pinheiro(33), que o sugere como um novo paradigma em PEB. Para a autora, quanto maior o grau de institucionalidade de uma relação ou organismo internacional, ou seja, a conformidade entre o comportamento e as regras institucionais, maior é a limitação da autonomia do Estado.

7 “Assim sendo, a diplomacia brasileira afirma-se internacional e regionalmente com base no discurso da cooperação, fundamento do liberalismo, mas se utiliza de mecanismos de escape que se traduzem em baixa institucionalidade e relativa durabilidade de alguns arranjos institucionais, desviando-se e, no limite, adiando a questão da justiça no plano regional onde o equilíbrio na balança de poder tem preponderância” (33)p. 325.
} 
contra o candidato do Partido da Social Democracia Brasileira (PSDB), Aécio Neves, Dilma obteve uma vantagem de apenas $3,28 \%$ dos votos válidos.

A destacada polarização política ocorrida neste processo eleitoral não foi superada ao longo do segundo mandato, que foi interrompido, em 2016, por um processo de impedimento. Às dificuldades políticas, somou-se o agravamento da crise econômica, com a decorrente limitação do papel de destaque que o Brasil vinha desempenhando na diplomacia regional e global (1).

Durante o governo Lula (2003-2010), a corrente que se destacou foi a dos autonomistas. Essa corrente tem como característica a política desenvolvimentista e a relevância da autonomia, do universalismo e da presença brasileira na política internacional. Com relação aos regimes internacionais, destaca-se a posição reformista, em favor dos países do Sul e pelo esforço de transformar o país em uma liderança regional; o que na América do Sul é colocado como o "caminho para melhor inserção internacional e que possibilitaria a realização do potencial brasileiro e da formação de um bloco capaz de exercer influência internacional" (32) p. 49-50. Para tanto recuperou princípios como da não intervenção, incluindo em sua agenda a cooperação e a integração regional ${ }^{8}$.

De acordo com Vigevani e Cepaluni(34), entretanto, o que houve entre FHC e Lula não foi uma ruptura ou uma mudança de paradigmas, mas alterações de estratégia, buscando manter o desenvolvimento e a autonomia. Os autores apontam o ataque de 11 de setembro e as dificuldades nas negociações na Rodada de Doha como fatores que colaboraram para a mudança na política externa brasileira em curso desde o governo de FHC, que, no final de seu mandato, deu início ao processo de negociação com países como a China, a Índia e a África do Sul, considerados parceiros não tradicionais do Brasil.

Ainda de acordo com os autores(34), Lula empenhou-se por conseguir nova inserção internacional para o Brasil e realizou mudanças mais sutis em sua política externa, por meio da diversificação de parcerias e buscando mais autonomia no cenário mundial. Essa estratégia é denominada de Autonomia pela Diversificação, em contraposição à Autonomia pela Participação, que eles relacionam a FHC. A Autonomia pela participação caracteriza-se pela

\footnotetext{
${ }^{8}$ Nesse contexto, a Unasul passou a ser o meio central de ação multilateral na região pelo seu caráter intergovernamental e sua baixa institucionalidade, que dá maior margem de manobra, autonomia de ação na região. Além disso, é um mecanismo importante para a concertação política dos países membros frente a situações de crise. No que tange o Mercosul, a posição autonomista assemelha-se à dos institucionalistas pragmáticos, com a conservação da baixa institucionalidade e da autonomia da política externa, e da macroeconomia.(32)
} 
adesão aos regimes internacionais vigentes, com o objetivo de modificar as regras e princípios do sistema internacional. Já a Autonomia pela Diversificação tem como marco a adesão aos princípios e às normas internacionais, enfatizando a Cooperação Sul-Sul e consolidando relações com parceiros não tradicionais.

Apesar de divergirem quanto à mudança ou não de paradigmas, observa-se que o desejo pela autonomia e o desenvolvimento, buscado de diferentes maneiras pelos governos citados, permanece em todas as categorias de análise apresentadas. Além disso, demonstram aproximação dos países do Sul e a intensificação de relações de cooperação internacional como característica relevante da PEB desde o início dos anos 2000. Nesse contexto, as relações privilegiadas com os países do Sul são uma característica do governo Lula, o que explica, por exemplo, o apoio em 2008 à criação da União de Nações Sul-americanas, a Unasul.

Na transição do governo de Lula para o mandato de Dilma (2011-2014), era esperado que as principais estratégias de PEB do primeiro fossem mantidas(35,36): "uma trajetória revisionista das instituições internacionais, uma atuação ativa em fóruns multilaterais colocando-se como representante dos países do sul, e uma orientação proativa para a dimensão sul-americana"(35)p.25 . Entretanto, progressivamente, houve a mudança de uma política externa proativa para uma reativa e para uma perda do protagonismo do Brasil na cena global(35,37) e regional.

Os atores que participavam da formulação da PEB no governo Lula, tais como líderes políticos e outras agências de governo, como o Ministério da Saúde, foram perdendo espaço. Ao mesmo tempo, o Itamaraty ${ }^{9}$ também foi esvaziado, com redução do seu orçamento e do número de vagas para seu concurso, que passou de mais de 100 para cerca de 30, a partir de 2011. Nesse sentido, a formulação da agenda da Política Externa do Brasil ficou sem uma liderança clara, visto que o MRE estava desmobilizado e a presidência, voltada para assuntos internos. Houve ainda distanciamento de parceiros como os países europeus e Estados Unidos ${ }^{10} \cdot(35-37)$

${ }^{9}$ Paixão e Casarões(38) descrevem o MRE como pouco atrativo politicamente porque os cargos, exceto o de Ministro, são providos por concurso público, sem possibilidade de nomeação de cargos em comissão; a política externa e seu objeto de atuação possuem tempos e dinâmicas diferentes, depende de terceiros para ser viabilizada e constitui um tema pouco visível para a opinião pública.

${ }^{10} \mathrm{Em}$ 2013, as relações com os Estados Unidos sofreram prejuízos devido à revelação de que o país espionou a Presidente(35). 
Já no governo Temer (2016-2018), observou-se uma "súbita ruptura com as linhas do governo anterior"(38)p. 81. O então presidente nomeou José Serra como Ministro de Relações Exteriores, quem tinha pretensões eleitorais em 2018. À frente de uma agenda menos destacada do que seu principal campo de interesse, qual seja a economia, o então Ministro tomou diversas atitudes para chamar a atenção da classe política e dos meios de comunicação, reforçando o rompimento com o legado deixado pelo $\mathrm{PT}$ no que se refere à $\mathrm{PEB}(36,38)$.

Desde sua posse, Serra criticou países como Venezuela, Bolívia e Equador, e rebateu comentários do então Secretário Geral da Unasul, Ernesto Samper, que aventou acionar a cláusula democrática da organização contra o Brasil $(36,38)$. Nas diretrizes da sua política, o então Ministro, entre outras temáticas, reforçou suas intenções de desideologização ${ }^{11}(36,38)$ e reiterou princípios da PEB em termos de democracia e direitos humanos, meio ambiente e multilateralismo político e comercial. Em termos comerciais, observa-se a vontade de abertura para acordos bilaterais, indicando o papel secundário que daria às organizações intergovernamentais nesse aspecto. No tema "América Latina" e parceiros "colocam, em linhas claras, aquilo que já vinha ocorrendo desde o início do governo Dilma" (38): aproximação de outros países, fora do Cone Sul, e também da Europa e Estados Unidos. A América do Sul estava ausente do discurso da PEB pela primeira vez em 20 anos (38).

\subsubsection{O papel da América do Sul: integração e regionalização}

Já nos anos 90, com a criação do Mercosul, o Brasil participava de forma ativa do processo de integração da América do Sul. Mas foi no início dos anos 2000, ainda no governo FHC, que a região ganhou centralidade na PEB no sentido da intencionalidade de transformar esse continente em um protagonista na cena global. A região também passava por um momento em que a maior parte dos seus países experimentava governos progressistas(36) e pode ser considerada como o "eixo diplomático mais polarizado nos últimos anos, sobretudo nas eleições de 2002 a 2014" como demonstra Nery(39) em um breve estudo sobre as propostas para a PEB dos principais candidatos à presidência do Brasil.

${ }^{11}$ A utilização da palavra desideologização tem se tornado central dos discursos dos políticos da direita brasileira, no sentido de reforçar seu posicionamento contrário a tudo o que a esquerda teria feito nos seus anos à frente do governo federal. 
Para tratar dos principais blocos que agregam países sul-americanos, faz-se necessário distinguir os processos de integração e regionalização, muitas vezes utilizados como sinônimos na literatura.

De acordo com Lima(40), integração relaciona-se com a construção de um espaço econômico e de coordenação de políticas públicas. Um exemplo de integração é o Mercosul, criado originalmente como um projeto com países do Cone Sul, que se expandiu para outros países ao longo de sua trajetória, principalmente com a participação de Estados associados. Por sua vez, a regionalização é um processo mais amplo, porém menos ambicioso que a construção de um mercado comum, mas com cooperação em diversas áreas, como o reflexo das prioridades de política externa. A regionalização pode ser caracterizada, então por um processo intergovernamental com baixa delegação de soberania; que, como veremos adiante, tem como exemplo a Unasul.

Pese a aproximação dos países sul-americanos por meio de diversos arranjos de cooperação nas últimas décadas, Lima(40) chama atenção para a heterogeneidade da região como resultado da combinação dos "modelos de integração, regimes produtivos, modelos de democracia e opções de política externa entre os países latino-americanos, bem como suas respectivas agendas bilaterais com os Estados Unidos”(p.174). Nesse contexto, as diferenças na área comercial fomentaram modelos de cooperação sub-regional, e os processos de integração (comercial) se descolaram dos de regionalização. A região ganhou um caráter político, de protagonismo como ator no cenário global, e tem como expressão e símbolo a criação da Unasul, em 2008.(40)

É importante destacar que esses processos não são imunes ao contexto político e econômico dos países deles participam(41), respondendo às mudanças de diversas formas, assumindo novas facetas e experimentando maior ou menor dinamismo em suas atividades.

O Brasil integra como membro fundador tanto o Mercosul como a Unasul, ambos focos desta tese. Para além desse papel, o país se destacou também como ator fundamental para a própria criação dessas organizações e, portanto, seu apoio é crucial para a continuidade das suas ações e projetos.

\subsubsection{A posição do Brasil sobre a integração regional: de Lula a Temer}

Os dois principais blocos regionais atuantes na América do Sul foram criados em contextos políticos distintos e foram assumindo novas características com o passar do tempo. 
Da mesma forma, o Brasil atuou de maneiras diferentes nesses processos ao longo dos sucessivos governos.

Uma breve descrição de seus principais objetivos e estrutura desses mecanismos regionais ajuda a compreender melhor sua forma de funcionamento, colocando luz também sobre como os países podem operar dentro de cada uma dessas organizações.

\section{Mercosul}

O Mercosul foi instituído em 1991 por meio do Tratado de Assunção e é resultado de um processo de concertação e construção de confiança iniciados durante a redemocratização do Brasil, entre este e a Argentina. Originalmente, a organização era composta por Argentina, Brasil, Paraguai e Uruguai, aos quais agregou-se a Venezuela, em 2012, após a ratificação de seus Estados Partes ${ }^{12}$. Além desses, o bloco conta ainda com países associados (Chile, Peru, Colômbia, Equador, Guiana e Suriname), que participam das reuniões, mas não têm direito à $\operatorname{voto}(42)$.

O Mercosul tem como objetivo criar um mercado comum que pressupõe a livre circulação de bens, serviços e pessoas; o estabelecimento de uma política comercial comum; a coordenação de políticas macroeconômicas, e o compromisso de harmonização das legislações entre os Estados Partes(42); podendo ser caracterizado como um processo de integração. Suas decisões são tomadas por consenso e todas as normas devem ser incorporadas ao ordenamento jurídico nacional(43).

${ }^{12}$ Em dezembro de 2005, a Venezuela solicitou formalmente a adesão ao Mercosul. Por meio da Decisão n. 29/05 do Conselho do Mercado Comum, de 08/12/2005, o bloco deu início ao processo de negociação com a Venezuela que culminou com a assinatura do Protocolo de Adesão em 4 de julho de 2006, cuja entrada em vigor dependia da ratificação de todos os membros plenos. Após um longo impasse devido à recusa de ratificação do Protocolo de Adesão pelo Parlamento paraguaio, o instrumento entrou finalmente em vigor e a Venezuela passou a ser considerada como membro pleno do Mercosul em 2012, quando o Paraguai foi suspenso do bloco por violação da "cláusula democrática" instituída pelo Protocolo de Ushuaia, de 1998. Naquela ocasião, o então Presidente paraguaio Fernando Lugo sofreu impedimento (impeachment) por "mau desempenho das funções presidenciais". A ambiguidade das acusações e a extraordinária celeridade do processo contra um Presidente eleito caracterizaram, segundo os Presidentes dos membros plenos do Mercosul, uma ruptura democrática que justificou a referida suspensão, conforme Declaração Presidencial assinada em Mendoza, Argentina, em junho de 2012. Um debate jurídico instalou-se à época sobre a legalidade da adesão da Venezuela, ver Pedro Muniz Pinto Sloboda, A legalidade da entrada da Venezuela no Mercosul, Anuario Mexicano de Derecho Internacional, Volume 15, Issue 1, 2015, p. 701-716, Atualmente, o Paraguai foi reintegrado ao bloco e a Venezuela encontra-se suspensa desde 5 de agosto de 2017, por violação do mesmo Protocolo de Ushuaia. 
A estrutura do bloco (Figura 1) ${ }^{13}$ é composta por um órgão supremo, o Conselho do Mercado Comum (CMC), encarregado de sua condução política e formado pelos Ministros das Relações Exteriores e da Economia dos Estados Partes, que se reúne semestralmente para o estabelecimento de acordos com a presença dos presidentes dos países envolvidos. Submetidas ao CMC estão as reuniões dos Ministros de diversas pastas em encontros temáticos, como a Reunião dos Ministros de Saúde (RMS). Seu órgão executor, que também tem poder de decisão, é o Grupo Mercado Comum (GMC), conformado por quatro membros titulares e quatro alternos, provenientes dos segundo e terceiro escalões dos governos. Para tomar suas decisões, também se utiliza de debates especializados em distintos fóruns como Grupos Ad Hoc e Subgrupos de Trabalho, como o SGT N¹1 Saúde. (44)

Além disso, a cada semestre um país membro é designado, por ordem alfabética, como Presidência Pro Tempore do bloco (PPT), sendo responsável pelo estabelecimento de agendas e convocação e organização de reuniões das instâncias do bloco. Até julho de 2016, o Uruguai foi a PPT do Mercosul, devendo passá-la para a Venezuela. Entretanto, por decisão dos mandatários do bloco $^{14}$, de setembro a dezembro daquele ano houve uma gestão conjunta, devido a desavenças políticas com aquele país.

${ }^{13}$ Além disso, o organograma do Mercosul é formado pela Comissão de Comércio do Mercosul (CCM), que zela pela implementação da política comercial do bloco; a Comissão Parlamentar Conjunta (CPC), que visa fomentar a adaptação das legislações nacionais; o Fórum Consultivo Econômico-Social (FCES), que reúne representantes da sociedade civil; e a Secretaria Técnica do Mercosul (STM), sediada no Uruguai e que presta serviços técnicos a todos os órgãos do CMC e do GMC. (25)

14 http://agenciabrasil.ebc.com.br/internacional/noticia/2016-09/venezuela-reage-decisao-do-mercosulsobre-presidencia-conjunta-do 
Figura 1 Organograma do Mercosul

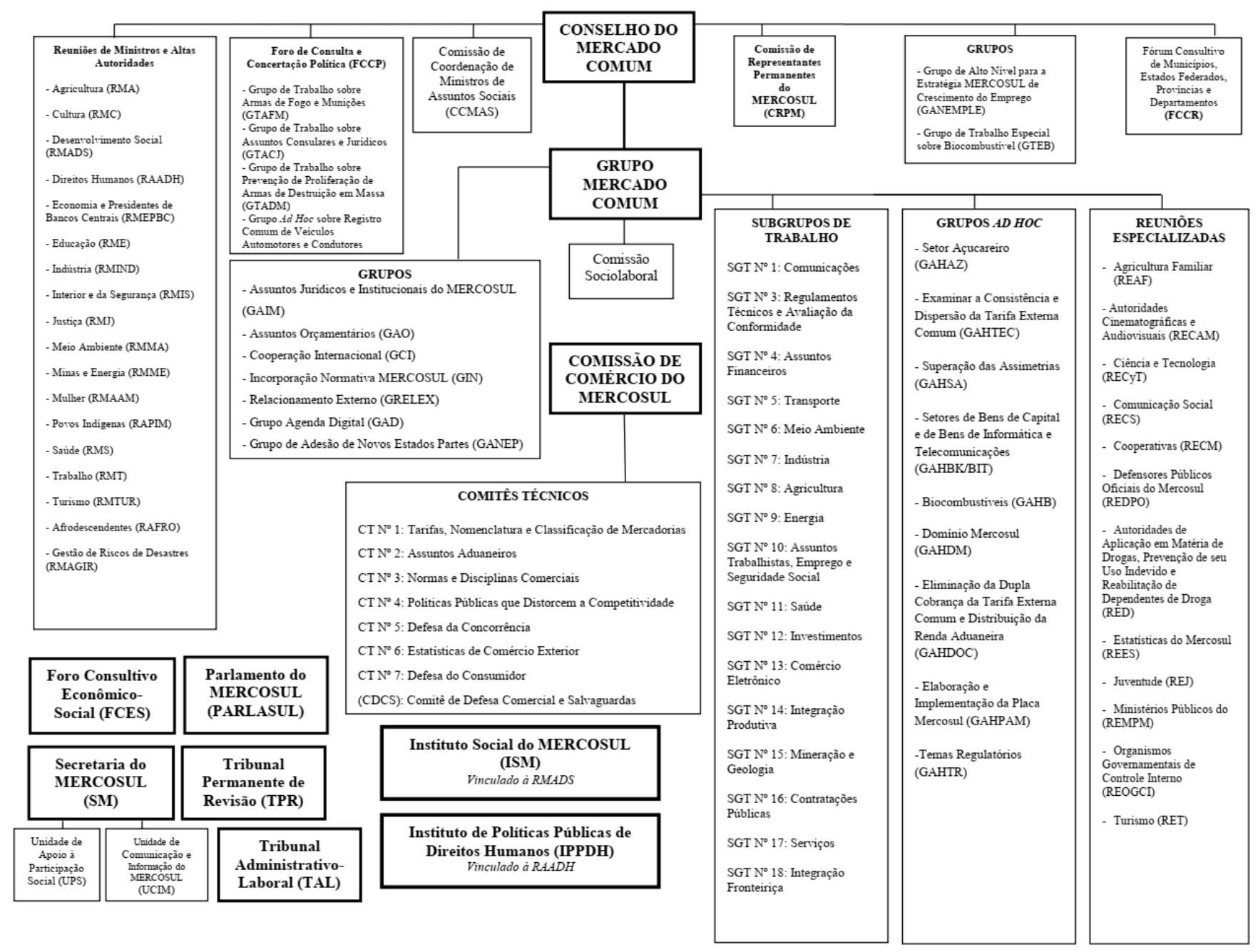

Fonte: (45) 


\section{Unasul}

Já a União de Nações Sul-americanas (Unasul) teve um processo de criação mais recente, que remonta ao início dos anos 2000, quando o continente Sul-americano começou a tornar-se um espaço político de integração por meio da convocação da I Reunião de Presidentes da América do Sul, em Brasília. A reunião reiterou que, além da contiguidade geográfica, existia entre os países da região uma comunidade de valores, que instavam a construção de uma agenda comum (46).

O contexto político da região naquele momento era de governos considerados progressistas, liderados por nomes como Ernesto Kirchner, da Argentina, Lula, do Brasil, Hugo Chaves, da Venezuela e Evo Morales, da Bolívia. Esse legado presidencialista era sua fortaleza, mas também foi apontado como um dos principais desafios para o bloco construir credibilidade e demonstrar sua legitimidade e relevância $(41,47)$.

Após algumas reuniões e encontros políticos, em 2004, foi criada a Comunidade Sulamericana de Nações (CASA), com o objetivo de desenvolver um espaço de integração política, social, econômica, ambiental e de infraestrutura para fortalecer a identidade sul-americana, bem como aprofundar a convergência com organizações regionais antecedentes como o Mercosul e a Comunidade Andina (CAN) (48).

Na I Reunião dos Chefes de Estado da CASA (2005), além do diálogo político e da integração de infraestruturas econômica e ambiental, também constava da agenda a promoção da coesão social, da inclusão social e da justiça social na região(49). No ano seguinte, a declaração Colocando a pedra fundamental para a União Sul-americana (Declaração de Cochabamba) (50) estabeleceu um novo modelo de integração para a região, seguindo os princípios de solidariedade e cooperação para equidade; soberania e respeito à integridade territorial e autodeterminação dos povos; paz; democracia e pluralismo; universalidade, interdependência e indivisibilidade dos direitos humanos, e harmonia com a natureza para um desenvolvimento sustentável.

Na mesma ocasião, em 9 de dezembro de 2006, foi aprovado documento que trata, brevemente, da construção de uma política e agenda regionais em matéria de saúde, a ser elaborada em convergência com organizações já estabelecidas na região nesse campo, como o Organismo Andino de Saúde Convênio Hipólito Unanue (ORAS-CONHU), o Subgrupo №11 Saúde do Mercosul e a Organização do Tratado de Cooperação Amazônica (OTCA), tendo em conta a participação social(51). 
Em 17 de abril de 2007, ficou definido que o nome do bloco mudaria União de Nações Sul-americanas (Unasul), que teria sede em Quito, Equador(52). A mudança de nome marcou a transformação de um “fórum de concertação política em uma organização internacional"(53)p.69.

A Unasul é uma organização internacional de caráter regional, formada pelos 12 países independentes da América do Sul; a saber: Argentina, Bolívia, Brasil, Chile, Colômbia, Equador, Guiana, Paraguai, Peru, Suriname, Uruguai e Venezuela. Seu Tratado Constitutivo foi assinado em 23 de maio de 2008 no Brasil, entrando em vigência em 2011.

A assinatura desse documento(54) aumentou a institucionalidade do bloco, dotando-o de personalidade jurídica internacional. Seus objetivos reforçam e ampliam os da Declaração de Cochabamba(50), por exemplo com a inclusão do acesso universal à seguridade social e aos serviços de saúde, a cooperação em matéria de migração, a cooperação setorial como forma de aprofundar a integração mediante a troca de informações, experiências e capacitação, etc.

Nesse sentido, a Unasul é considerada inovadora em comparação a experiências anteriores, que avançaram pouco em relação a uma efetiva integração do continente $(39,55)$. Além de ser a primeira organização a integrar os 12 países independentes da região, apresenta um projeto de desenvolvimento regional amplo, que alia não apenas propósitos econômicos ou de defesa, mas também questões sociais em busca de uma cidadania sul-americana e tem nessas políticas, principalmente a saúde, como um motor para integração(56), sendo um bom exemplo do processo de regionalização (em contraposição ao de integração anteriormente descrito).

O bloco retomou a noção de que o regionalismo deve ter uma função mais abrangente em políticas voltadas para o desenvolvimento, criando espaços e métodos para o fomento da cooperação e da formação política(47).

Segundo seu tratado Constitutivo(54), a estrutura da Unasul (Figura 2) é composta pelo Conselho de Chefas e Chefes de Estado e de Governo (CCEG), instância máxima do bloco que realizada sua condução política, decidindo sobre as propostas dos Conselhos Setoriais. Todas as decisões no bloco são tomadas por consenso, ou seja, a aprovação de um projeto é feita por unanimidade. A tomada de decisões por meio do consenso é entendida como um processo que pode levar à lentidão das ações, mas também a possibilidade de construir uma integração de fato entre os países(41), na medida em que as diferentes matizes negociam e acordam sobre uma determinada temática, dando legitimidade regional. 
Subordinado ao CCEG está o Conselho de Ministras e Ministros de Relações Exteriores (CMRE), formada pelos chanceleres dos países. Sua função é implementar as decisões tomadas no âmbito do Conselho de Chefas e Chefes de Estado e de Governo. Para tanto, estabelece Grupos de Trabalho e aprova o orçamento geral do bloco. Subordinado, por sua vez, ao CMRE está o Conselho de Delegados (CDel), formado por representantes dos países, em geral diplomatas, que promovem negociações prévias do que será elevado aos Conselhos superiores. Outra instância do bloco é a Secretaria Geral, com sede no Equador ${ }^{15}$. Ela executa o que lhe é atribuído pelos Conselhos superiores e exerce a representação do bloco quando delegada. Além disso, zela pela documentação gerada por todas as instâncias do bloco e prepara suas reuniões. O Secretário ou Secretária Geral é indicado pelo CMRE e aprovado pelo CCEG para um mandato de dois anos, renovável por uma vez.

A PPT é exercida por um dos Estados-membros anualmente, seguindo a ordem alfabética dos países. Entre suas responsabilidades estão convocar e presidir as reuniões, além de apresentar o programa anual de atividades de Unasul. Entre abril de 2016 e abril de 2017, a PPT foi exercida pela Venezuela.

A Unasul possui três instâncias permanentes: A Secretaria Geral (Quito), o Instituto Sulamericano de Governo em Saúde (ISAGS) (Rio de Janeiro) e o Centro de Estudos Estratégicos de Defesa (CEED) (Buenos Aires). Atualmente, o bloco conta com 12 conselhos setoriais, instâncias políticas de consulta formadas pelos ministros das pastas referentes à temática dos Conselhos de cada país. Para Lima(40), essas estruturas criam capacidade institucional que proporciona a cooperação em políticas públicas e fomentam a criação de "atores comprometidos com a regionalização" na sociedade civil.

Até 2012, os Conselhos Setoriais tinham liberdade para tomar decisões sobre os temas concernentes às suas áreas de atuação. Entretanto, com a aprovação do novo Regulamento(57) em junho de 2012, todas as decisões tomadas deveriam ser submetidas ao CDel e ao CMRE antes de entrarem em vigor, esvaziando a importância política dessas instâncias.

\footnotetext{
15 Em 17 de setembro de 2019, o Assembleia Nacional equatoriana aprovou a denúncia do tratado constitutivo da UNASUL pelo Equador. Segundo a Presidência da República, a sede da UNASUL será convertida em uma universidade indígena. https://www.efe.com/efe/america/politica/ecuador-notificara-en-breve-a-losmiembros-de-unasur-su-denuncia-del-tratado/20000035-4103989
} 
Figura 2 Organograma da Unasul

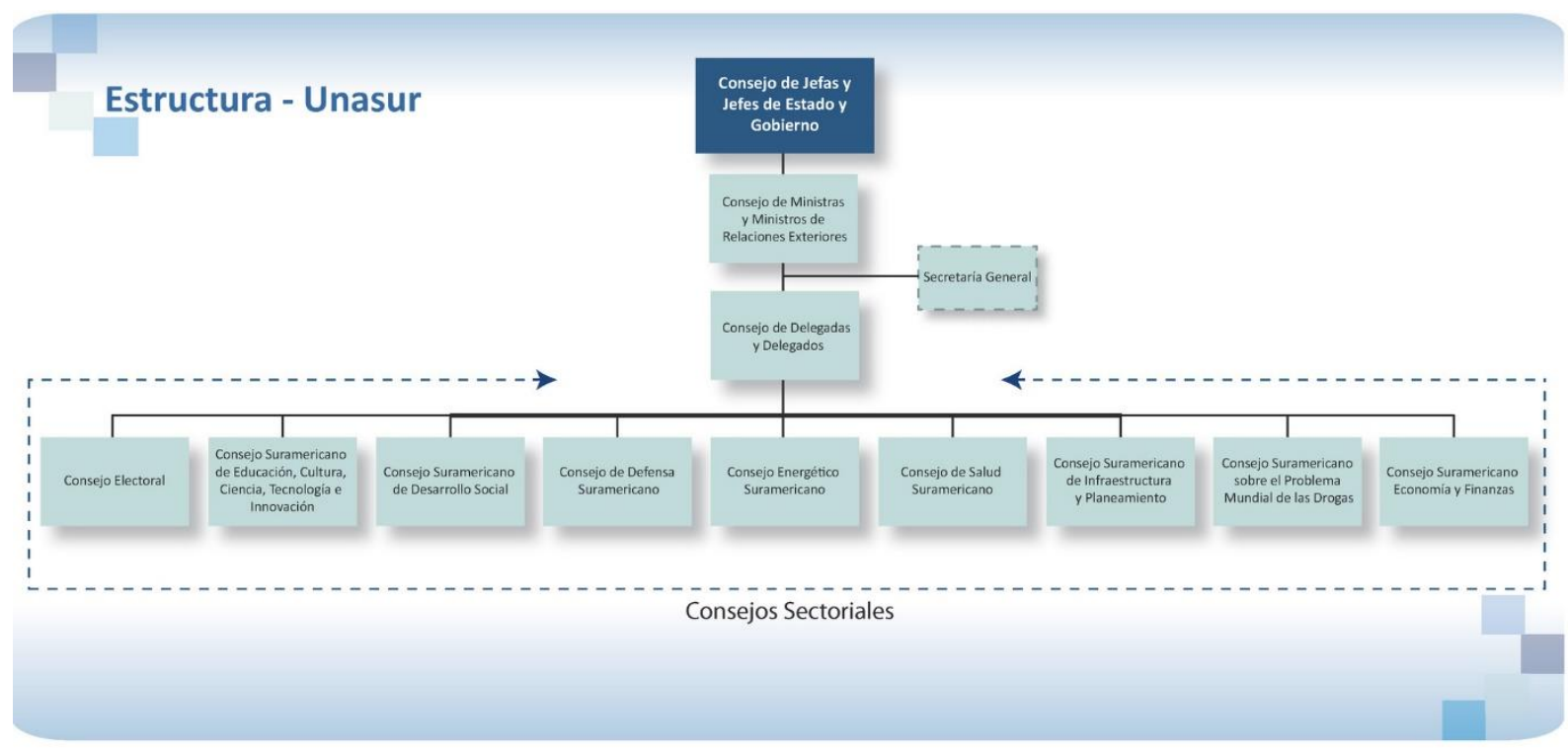

Fonte: acervo próprio. ${ }^{16}$

Para entendermos o processo de ascensão e declínio da América do Sul como polo de poder político, vamos nos deter à maneira pela qual os governos Lula, Dilma e Temer se posicionaram frente aos processos de integração e regionalização na região. A escolha dessas gestões se justifica visto que o processo de ganho de centralidade e perda de protagonismo se deu, principalmente, nesse interim.

Durante o governo Lula, pode-se observar que o Brasil assumiu centralidade na projeção da América do Sul como região, reconhecendo essa como uma estratégia para a manutenção da sua autonomia, o que também era reconhecido pelos países vizinhos(36). "[...] o Brasil assumiria central responsabilidade sobre o processo de integração e de regionalização"(36)p. 301) ou, como diria Cervo(58): “a integração da América do Sul depende do Brasil”. A ideia era superar a cooperação puramente econômica, reafirmando sua liderança regional.(53)

No caso do Mercosul, o desejo por autonomia se refletiu na maneira como o Brasil se comportou no sentido de manter sua baixa institucionalidade, dando margem para ação nacional. Após 2003, o país passou a reconhecer efetivamente as assimetrias presentes no bloco(59), já que havia a necessidade de medidas que superassem essas diferenças entre os países membros. O que foi feito, por exemplo, sob liderança brasileira, foi a criação do Fundo

\footnotetext{
${ }^{16} \mathrm{O}$ website da Unasul foi retirado do ar.
} 
de Convergência Estrutural do Mercosul (Focem), que atenderia os sócios menores, e um Mecanismo de Adaptação Competitiva (MAC), com o objetivo de corrigir as assimetrias com a Argentina.(36)

Além disso, foi durante o governo Lula que houve impulso para a concertação dos mandatários sul-americanos no sentido de criar uma nova organização, a Unasul. Sua consolidação, com o seu Tratado Constitutivo, se deu no seu segundo mandato, quando o Brasil também se ofereceu para ser a sede do ISAGS (o instituto de saúde da Unasul), que funcionou de 2011 a 2019 no Rio de Janeiro.

No tocante ao tratamento dado à região, Dilma procurou manter as estratégias relativas ao continente, mas o protagonismo da presidente frente às questões políticas não foi conservado. Devido ao período de crise econômica, os custos de arcar com a liderança regional não foram bem aceitos. A Unasul, no entanto, manteve-se como referência da atuação brasileira na região $(35,37)$. O bloco se destacou como iniciativa que projetava a América do Sul no cenário internacional, mas também por possibilitar a coexistência de "autonomia, cooperação, integração seletiva e um espaço comum em que as relações correspondem a outra geografia, atenuando (não eliminando) o peso de fatores extrarregionais"(59) p. 536. Autonomia e estabilidade eram tidas como ponto de concertação entre os países membros. (59)

Por conta da crise, o Brasil parou de pagar cotas de diversas Organizações Internacionais, como a Unasul, da qual era responsável por quase $40 \%$ do orçamento global. Apesar disso, entende-se que houve sinalização da Presidente para a manutenção do que havia sido construído no governo Lula. Com o congelamento dos pagamentos e a diminuição do protagonismo na região, iniciativas brasileiras como o Conselho de Defesa da Unasul ficaram em suspenso(35).

O Mercosul não foi tratado como prioridade, mas mantido "para administrar as relações do Brasil com países vizinhos” (37)p.33, porém sem fazer concessões econômicas aos argentinos. Aumentaram as pressões para o estabelecimento de acordos bilaterais, em detrimento daqueles intermediados pelo Mercosul, como o que vinha sendo negociado com a União Europeia ${ }^{17}$. O bloco seguiu sendo ampliado, com a entrada da Venezuela em meio à suspensão do Paraguai devido à deposição do Presidente Fernando Lugo, por força da cláusula

\footnotetext{
${ }^{17}$ Em 28 de junho de 2019, ambos os blocos divulgaram a finalização do acordo comercial que já vinha sendo negociado há mais de duas décadas. Para entrar em vigor, entretanto, o documento precisa ser ratificado pelos parlamentos de todos os Estados-membros das duas Organizações.
} 
democrática vigente; e também com a solicitação de entrada pela Bolívia, Guiana e Suriname. (35-37)

Além disso, Nery(39) ressalta que o projeto regional refletido na dimensão social do Mercosul e na política da Unasul nunca obtiveram apoio de parte da população brasileira. Entretanto, esse projeto se sustentou durante o governo Lula devido a uma coalização entre diversos setores produtivos, beneficiados por uma conjuntura econômica favorável. Essa coalizão empresarial foi substituída por uma rentista, denotando uma mudança de visão dessa elite sobre a inserção do Brasil no campo internacional. Na realidade, "a ideia da integração nunca chegou a ser assimilada pelo conjunto das elites brasileiras e por uma parte da população de maneira geral"(59)p. 529.

Pese não ser, geralmente, um tema popular, o debate sobre a política externa na região veio à tona não apenas pela crise na Venezuela e a posição do Brasil, mas também pelas obras de infraestrutura financiadas pelo país nos seus vizinhos, o que foi posto em xeque $(35,36)$. Além disso, não se pode ignorar todos os efeitos da operação Lava-Jato na região. Essa operação é um conjunto de investigações, ainda em curso, sobre casos de corrupção e lavagem de dinheiro que levou inúmeros empresários, como Marcelo Odebrecht, e políticos, como o expresidente Lula, para a prisão. Existem muitas críticas sobre o viés político das ações da LavaJato e da atuação dos seus principais líderes, como o atual Ministro da Justiça e ex-juiz da operação, Sérgio Moro. Entretanto, os efeitos desses processos foram sentidos também em países como o Peru, por exemplo, onde figuras políticas importantes também foram presas.

Nesse contexto, a eleição de Maurício Macri, na Argentina em 2015, o impeachment da Presidente Dilma Rousseff no Brasil em 2016 "foram marcos importantes no desmonte de uma comunidade epistêmica pró-integração orientada por um regionalismo pós-liberal que teve um importante papel na criação [...] da Unasul [...]”(36)p.311.

Com a ascensão de Temer, estabeleceu-se uma crise sobre a transferência da PPT do Mercosul para a Venezuela, com a justificativa conveniente de que o país não havia internalizado os compromissos do bloco(36,38). Como afirmado anteriormente, o Brasil é considerado fundamental no empreendimento da integração sul-americana(36,38,58). Nesse sentido, a posição extremada (38) causou preocupação com o futuro da integração, caso se perdurasse, aprofundando cisões já existentes e comprometendo iniciativas na região como o 
Mercosul e a Unasul. Especialistas previam que “[...] o brinkmanship ${ }^{18}$ de Serra poderá(ia) colocar a perder dois grandes ativos brasileiros - o papel de liderança regional do país e as estruturas de integração regional sul-americanas" (38)p.89.

Durante o governo Temer, destacou-se o caráter eminentemente comercial do Mercosul e o esvaziamento da Unasul, com o abandono do empreendimento de projeção política da América do Sul.(39)

As divergências políticas da região, que tiveram impactos bastante expressivos no Mercosul também tiveram suas implicações na Unasul, visto que boa parte dos países membros daquele bloco, também são parte da União. Nesse contexto, o relacionamento entre os países e a PPT da Unasul, que em 2016 estava a cargo da Venezuela, também sofreram um desaquecimento, culminando na desaceleração de estruturas e projetos.

Outro fator importante foi o anúncio da saída do Secretário Geral em janeiro de 2017 (60) - considerado um líder mobilizador importante na região. O cargo continua vago até os dias atuais por falta de consenso e pela decisão de 6 dos 12 países (Argentina, Brasil, Chile, Colômbia, Paraguai e Peru) membros de congelar suas ações no bloco, tomada em abril de 2018; logo após da troca da PPT da Argentina para a Bolívia. Tudo isso confirma o que Riggirozzi e Grugel(47) destacaram: “futuras conjunturas poderiam afetar as bases políticas e sociais do ativismo regional"p.194.

Os resultados dessa desmobilização política foram sentidos em todos os setores, inclusive na área da saúde. Nesse sentido, a seção seguinte traz alguns elementos importantes para entender essa área, ajudando a compreender melhor a evolução no campo no Brasil e o contexto na qual se inseriu a resposta brasileira e regional à ESPII.

\subsection{O LUGAR DA SAÚDE NA POLÍTICA EXTERNA, A DIPLOMACIA E A SAÚDE GLOBAL}

Um importante marco da entrada da saúde na agenda dos governos no mundo como tema internacional foi a realização da primeira Conferência Sanitária Internacional, em 1851(61). Esse encontro tinha objetivos claros de debater o campo da saúde e sua relação com

\footnotetext{
${ }^{18}$ Diplomacia arriscada.
} 
os obstáculos que doenças infecciosas impunham ao comércio internacional. Nesse momento, o grande papel da área da saúde era assegurar as trocas comerciais.

Para viabilizar ações coordenadas nesse âmbito, foram criadas diversas organizações internacionais como o Escritório Sanitário Pan-americano (1902) - precursor da Organização Pan-americana da Saúde - OPAS, o Office International de L'Hygiène Publique (1907), a Organização de Saúde da Liga das Nações (1923), e a própria Organização Mundial da Saúde (1948).

Nesse contexto, visto que a saúde era tema da agenda internacional dos países havia muito tempo, a entrada do tema saúde na agenda de política externa brasileira é considerada tardia(62). Santiago Alcázar(62), ex-assessor para Assuntos Internacionais do MS e diplomata de carreira, explica as razões para isso: 1) a saúde era uma área extremamente fechada aos não especialistas (médicos e sanitaristas), pouco acessível aos diplomatas; 2) durante muito tempo foi subordinada a assuntos econômicos relacionados ao comércio e a força laboral, familiares à diplomacia, mas adversos à cultura sanitária - ou seja, a saúde não era central nesse processo; 3) as estruturas estatais ligadas à saúde tinham papel reduzido no aparato estatal brasileiro.

Segundo o autor(62), a adoção de um discurso de natureza aberta, independente, universal e integral, concretizada pela implantação do Sistema Único de Saúde - SUS, a partir de 1988; a ampliação do papel do Ministério da saúde, permitindo uma atuação externa como propositor de uma agenda internacional de saúde; o aumento significativo de sua dotação orçamentária; e, no plano externo, a renovação do interesse internacional por temas sociais, demonstrado pela série de Conferências da ONU realizadas na década de 1990, justificam a emergência da saúde como tema da PEB.

Essa renovação foi impulsionada no momento pós-Guerra Fria, intensificando o movimento de cooperação internacional no mundo $(33,34,63,64)$, sob a justificativa de que o fim do mundo bipolar e da dominância de assuntos de guerra e paz possibilitou a emergência de novos interesses e relações entre países. Essa dinâmica também promoveu a diversificação de temas e atores em política externa, que no caso brasileiro pôde ser observada na participação cada vez maior do Brasil em assuntos relacionados à saúde, capitaneado pelo Ministério da Saúde, com apoio de sua Assessoria para Assuntos Internacionais em Saúde - AISA (que é a Oficina de relações Internacionais em Saúde - ORIS - do Brasil) e seus órgãos, como a Fiocruz, que participam da coordenação e execução de diversos projetos de cooperação internacional(65). 
Esse movimento de cooperação internacional se consolidou já no século XXI, com um importante marco da governança da saúde global. Em 2007, Ministros das Relações Exteriores do Brasil, França, Indonésia, Noruega, Senegal, África do Sul e Tailândia estabeleceram um compromisso de valorizar a saúde global como questão de política externa(66).

Como vimos anteriormente, a política externa de um país é formulada de acordo com demandas e oportunidades internas e externas. Sobre as influências do campo da saúde na política externa e vice-versa, alguns autores(67) sugerem que cada vez mais a política externa está sendo direcionada pela saúde a fim de proteger a segurança nacional, o livre comércio e os avanços econômicos. Um dos exemplos citados é como o Brasil, pelo menos até o último mandato do presidente Lula, tinha a saúde como ponto chave para seu próprio desenvolvimento e base da Cooperação Sul-Sul. Em contraposição, outros(68) acreditam que são os interesses de política externa que influenciam a agenda da diplomacia da saúde global e, geralmente, determinam o financiamento para suas ações; o que explica porque determinados assuntos como arboviroses endêmicas, como a Dengue, não recebem atenção e dinheiro proporcionalmente a sua alta carga de doença. Na realidade, a comunidade internacional não se mobiliza apenas por questões epidemiológicas, a gravidade ou a carga de doenças $(69,70)$.

Nesse sentido, as escolhas em saúde global não são imunes a outros interesses. Diversos especialistas reunidos numa comissão apoiada pela Revista The Lancet, cunharam a expressão “determinantes políticos da saúde"(71) que são "normas, políticas e práticas que emergem da interação política global multisetorial e que afetam a saúde"(p.3). Assim, entendem que os resultados da interação desses fatores poderiam ser amenizados com o estabelecimento de uma governança global da saúde, baseada em valores como solidariedade e responsabilidade compartilhada, desenvolvimento sustentável, etc. Essa ideia, entretanto, ignora que a governança global se mantém da forma atual por vontade dos governos e que uma reforma que de fato mude o status quo não parece estar no horizonte.

A operacionalização da Política Externa de um país é feita por meio de instrumentos como a diplomacia, entendida como a arte e a prática de conduzir as relações internacionais. A diplomacia da saúde, por sua vez, objetiva capturar processos de negociação que envolvem diversos níveis e atores, e administrar o ambiente de política global para a saúde(72). É um processo eminentemente político(73).

A partir do momento em que a saúde se torna relevante para a política externa, estruturas internas aos Ministérios de Saúde são criadas para exercerem a diplomacia da saúde(74,75), os 
escritórios de Relações Internacionais (Oris, em espanhol ${ }^{19}$ ). Como forma de apoiar a tomada de decisão no campo da saúde, as Oris desenvolvem ações estratégicas de acordo com os interesses nacionais e os contextos políticos, econômicos e sociais(74), fazendo uma ponte entre o nacional e o global e em consonância com os respectivos MRE(75).

Todas essas relações estão inseridas em um domínio mais abrangente que, em tese, nos afeta a todos, mesmo que de forma desigual. A saúde global ${ }^{20}$ é definida de distintas formas na literatura, ainda como campo em construção e constante evolução. Pode ser entendida, de forma simples, como a referência a questões de saúde consideradas como transfronteiriças e de responsabilidade coletiva, o que exige esforços conjuntos dos países(76) ou como termo que indica as necessidades de saúde das pessoas acima dos interesses dos Estados(77). Uma definição bastante utilizada é a de Koplan e colaboradores(78): "uma área de estudo, pesquisa e prática que coloca prioridade na melhoria da saúde e em atingir equidade em saúde para todas as pessoas no mundo"(p.1995). Esta definição, entretanto, não leva em conta o contexto político(79) e os interesses(80) que movem o campo da saúde global.

Nesse sentido, optou-se por uma definição ampla, porém mais detalhada:

a Saúde Global envolve o conhecimento, o ensino, a prática e a pesquisa de questões e problemas de saúde supraterritoriais que extrapolam as fronteiras geográficas nacionais; seus determinantes sociais e ambientais podem ter origem em quaisquer lugares, assim como as suas possíveis soluções necessitam de intervenções e acordos entre diversos atores sociais, incluindo países, governos e instituições internacionais públicas e privadas(81), 370 .

Entender o contexto político das decisões e os atores envolvidos é extremamente importante e necessário. Em tempos de globalização perversa(82), Milton Santos apontou que suas benesses afetam as populações do mundo de forma desigual e que os países se fortalecem, não mais para garantir os direitos de seus cidadãos, mas para atender aos imperativos do mercado, mantendo ou aumentando as desigualdades e iniquidades intra e inter-nações. Nesse sentido, os danos à saúde das população tampouco atingem a todos da mesma forma, mas é seletivo no sentido de acometer pessoas historicamente vulneráveis(80).

Os críticos da saúde global argumentam ainda que ela traz consigo um projeto neocolonial, que reflete interesses neoliberais e aspectos de securitização, além de a

${ }^{19}$ Desde 2009, o Conselho de Saúde Sul-americano da Unasul incorporou uma Rede que congregava as ORIS de todos os 12 países-membros do bloco. Isso permitiu um importante intercâmbio e coordenação de ações entre os governos durante alguns anos. Entretanto, o trabalho da rede foi descontinuado devido aos "altos e baixos da dinâmica de trabalho e a conjuntura do Conselho de Saúde Sul-americano"(75)p.603.

${ }^{20}$ Nesta tese, entendemos que existe uma diferença entre saúde internacional e saúde global. A primeira, referindo-se à época colonial, em que as ações em saúde eram destinadas ao controle epidêmico de doenças que ultrapassavam as fronteiras nacionais(77,271). Entretanto, este debate conceitual não será abordado. 
identificarem como um humanitarismo transnacional(83). Além disso, aponta-se que os verdadeiros beneficiários das inúmeras iniciativas em saúde global são alijados do processo de construção de políticas e da sua implementação $(84,85)$.

Dessa forma, uma visão crítica da saúde global deve considerar os contextos sociais, políticos e ideológicos que interferem nas políticas e ações implementadas nesse âmbito. Alguns limites do campo apontados por Nunes e Pimenta(2) no caso da emergência do vírus Zika e que podem ser extrapolados para a saúde global de forma geral: age de forma reativa, privilegiando resultados de curto prazo; negligencia ações estruturantes, atuando superficialmente em questões tecno-biológicas e ignorando elementos que agem na determinação social da saúde; privilegia interesses dos países desenvolvidos, com a contenção de doenças infecciosas que os ameaçam especificamente; contribui para uma agenda que colabora para manter iniquidades quando ignora as diferentes dinâmicas do processo saúdedoença.

\subsubsection{Cooperação internacional em saúde}

Pode-se dizer que a cooperação internacional é uma das expressões da diplomacia, no sentido de que viabiliza e coloca em prática os objetivos e interesses da política externa, resultado das negociações empreendidas pelos distintos atores.

Em um exercício de conceituar os diversos tipos de cooperação internacional, Oliveira e Luvizotto(86) identificaram quatro categorias principais: a) vertical: de caráter assistencial, com a transferência vertical de conhecimentos e técnicas de países mais desenvolvidos para os menos; b) tout court: que trata os países em desenvolvimento como parceiros, passando a uma posição mais ativa; c) horizontal: cooperação entre países em vias de desenvolvimento, deixando de ser Norte-Sul e assumindo a posição Sul-Sul, com objetivo de troca de conhecimentos mútuos; e d) descentralizada: incorpora características da cooperação horizontal, mas sem, necessariamente, envolver o Estado-nação; como a desenvolvida entre municípios, conhecida como paradiplomacia.

Com a proliferação de temas e atores no campo da política externa, também aumentaram as iniciativas de cooperação internacional em saúde. Pode-se dizer que as organizações internacionais funcionando como produtoras e condutoras de cooperação entre seus membros e entre ela e outros atores do campo. 
Como forma de integrar as agendas e evitar a duplicação de esforços, visando melhorar a eficácia das atividades de cooperação, foram realizados vários debates intergovernamentais no âmbito da Organização para a Cooperação e Desenvolvimento Econômico (OCDE). A organização internacional agrega 36 países, entre os mais ricos do mundo, que em geral estão envolvidos em cooperações verticais e tout-court. Entretanto, esse movimento de revisão visa estabelecer relações mais horizontais entre os parceiros e reconhecer novas formas de colaboração.

Em 2003, a Declaração de Roma(87) trata da harmonização das políticas, procedimentos e práticas dos doadores, não apenas para uma ajuda mais eficaz, mas também para aproximar os resultados dos Objetivos de Desenvolvimento do Milênio (ODM). Em 2005, em Paris, foi assinada a "Declaração de Paris"(88) sobre a eficácia da ajuda para o desenvolvimento, documento que estabelece diretrizes para o relacionamento entre países cooperantes na busca de maior coordenação e melhor gestão dos fundos, horizontalidade das relações e respeito às diretrizes nacionais.

Para acelerar o progresso das melhorias propostas, foi proposta a Agenda de Ação de Acra(89), que possui três desafios importantes: melhorar o controle dos países na definição e implementação de políticas de desenvolvimento, construir parcerias eficazes e inclusivas, que envolvam outros atores no cenário internacional e aumentem a coordenação de esforços, e alcançarem resultados de desenvolvimento com responsabilidade para obter maior transparência dos que foi realizado. A última reunião foi realizada em Busan, em 2011, e sua declaração(90), além de fortalecer Acra, promove a construção de novas parcerias de desenvolvimento baseadas em princípios comuns. A declaração reconhece a nova realidade geopolítica com a importância de países emergentes e atores não-governamentais no processo, além de considerar a cooperação Sul-Sul e triangular (envolvendo, em geral, dois países em desenvolvimento e um desenvolvido) como parte da agenda de desenvolvimento global.

O conceito de Cooperação Sul-Sul, entretanto, não é homogêneo e, de modo geral, é marcado por certa ausência de especificidade, normativismo e reducionismo. Leite(91) propõe que esse modalidade de cooperação seja vista como um processo complexo de trocas, que, em longo prazo, pressupõe recompensas mútuas entre os atores da cooperação, ou seja, na reciprocidade. Essa abordagem tenta evitar a reprodução de uma lógica vertical de assistência, que marcou por muito tempo a cooperação Norte-Sul. Suas “ações visam construir pontes de transmissão e intercâmbio de conhecimento, lealdades políticas e sociais com outros países em desenvolvimento"(65)p.34. 
A abordagem brasileira de cooperação em saúde está inserida num modelo de Cooperação Sul-Sul e pode ser identificada como "Cooperação Estruturante em saúde"(92), cujos aspectos inovadores são a ênfase na formação de recursos humanos, o fortalecimento organizacional e o desenvolvimento institucional, bem como a utilização de capacidades e recursos autóctones. Seus principais pilares são a cooperação horizontal; o desenvolvimento de capacidades em saúde, fortalecendo os sistemas de saúde locais; a coordenação regional da cooperação; o maior envolvimento dos Ministros da saúde, e a parceria Ministério da Saúde MRE.

O tema Saúde se consolidou como tema de PEB, o durante o governo Lula(93). Especificamente na América do Sul, o Balanço de Política Externa (2003-2010)(94) confirma que o país atuou na região em diversas frentes como na Unasul, com a criação do ISAGS; e em temas como DST-HIV/AIDS, Banco de Leite Humano, vacinas, saúde nas fronteiras, entre outros. Entretanto, como observamos pelo panorama político apresentado anteriormente, essa tendência começou a declinar a partir de 2012(95).

No governo Dilma, no entanto, houve uma desaceleração expressiva, ou, nas palavras de Cervo e Lessa(12), houve um declínio sistêmico da PEB impulsada por Lula. Para Gómez e Perez(96) (2016), isso se deve a fatores como a falta de apoio orçamentário - tanto da Presidência como do Congresso Nacional - para o MRE e o foco da Presidente em assuntos internos, que resultou na falta de interesse em assuntos externos, culminando num afastamento entre gabinete presidencial e o Ministério. Este declínio também impactou no empenho do governo federal no sentido de unir o Estado e a sociedade civil para trabalharem juntos no plano internacional.

As dificuldades encontradas pela diplomacia da saúde no governo Dilma afetaram expressivamente a possibilidade de resposta internacional brasileira à epidemia do vírus Zika e da articulação dos atores regionais para realizar ações conjuntas de maneira coordenada. A seguir, houve o redirecionamento da PEB no governo Temer, suscitando tensões diplomáticas no âmbito da América do Sul, em especial nos organismos de integração regional.

A formação dessas organizações intergovernamentais é um dos símbolos mais claros de como a cooperação internacional em saúde opera, pois, essas estruturas propiciam, pela vontade dos países, espaços de coordenação, negociação e concertação. Elas são consideradas especialmente relevantes na área da saúde; de um lado pela conciliação de interesses econômicos e direitos humanos no que tange à construção de uma governança comercial e, de 
outro, pela capacidade de gerar melhorias no acesso à saúde das populações dos seus Estadosmembros(43).

Além disso podem se tornar espaços privilegiados de ação conjunta e atores centrais na defesa do direito à saúde(56), como protagonistas na diplomacia da saúde, representando, por exemplo, a voz de uma região. A saúde tem destaque especial nas agendas de cooperação e da integração regional "como ferramenta e marco de ação para ampliar as margens das políticas públicas e redefinir contornos da ação coletiva"(97)p.2.

Essas estruturas formam parte de espaços de governança em saúde global, como definido por Kickbusch e Szabo(98). Seriam três espaços políticos de governança em saúde global: o primeiro é Governança da Saúde Global, relacionadas àquelas instituições que têm mandatos explicitamente relacionados à saúde, como a OMS. O segundo é a Governança Global para a Saúde, relacionada a instituições cujas ações têm impactos diretos ou indiretos na saúde, como a Organização Mundial do Comércio (OMC). O terceiro é a Governança para a saúde global, referente a instituições e mecanismos que operam a nível nacional ou regional e que contribuem para os outros dois níveis de governança. Nesta tese, trata-se especificamente dos primeiro e terceiro níveis de governança, começando pelo terceiro, das organizações regionais e depois do primeiro nível, quando trataremos da OMS.

$\mathrm{Na}$ América do Sul, existem diversas iniciativas que permitem essa interação, tais como o Mercosul, a Unasul e a OPAS. A autora reconhece a existência de inúmeras iniciativas intergovernamentais que atuam na América do Sul, tais como a ORAS-CONHU, a CELAC, a OTCA, entre outras. Para fins desta tese foram selecionadas apenas as três organizações em questão e, por isso, as descrições e análises ficarão restritas às mesmas.

\subsubsection{A Organização Pan-americana da Saúde (OPAS)}

A mais antiga das organizações regionais atuantes na área da saúde é a Organização Pan-americana da Saúde (OPAS). A OPAS é o escritório regional para as Américas da Organização Mundial da Saúde (OMS), criado em 1902, e absorvido posteriormente pelo Sistema das Nações Unidas. Sua missão é "liderar esforços colaborativos estratégicos entre os Estados-membros e outros aliados, para promover a equidade em saúde, combater doenças, melhorar a qualidade e prolongar a duração da vida dos povos das Américas”(99). 
Sua estrutura é conformada(99) pela Conferência Sanitária Pan-Americana, o Conselho Diretor e o Comitê Executivo. Além disso, existe o órgão assessor do Comitê Executivo, que é o Subcomitê de Programa, Orçamento e Administração(100).

A Conferência Sanitária Pan-Americana é a instância superior da OPAS e determina suas políticas gerais a cada cinco anos. Também tem a função de ser um fórum para a troca de informações sobre prevenção, tratamento e promoção da saúde. É a Conferência que elege o Diretor(a) da OPAS e aprova o programa e orçamento bianual da Organização.

O Conselho Diretor reúne-se anualmente, exceto quando a Conferência acontece, atuando em seu nome entre as suas sessões. Elege os membros do Comitê Executivo, avaliando os relatórios finais do seu Presidente e do(a) Diretor(a) da OPAS. Além disso, também avalia e aprova seu programa e orçamento bianual. Além disso, aprova a criação de escritórios filiais da Organização.

Já o Comitê Executivo é composto por nove Estados-membros da OPAS, eleitos por mandatos de três anos. Se reúne duas vezes ao ano, atuando como um grupo de Trabalho da Conferência ou do Conselho. Tem um subcomitê permanente, o Subcomitê de Programa, Orçamento e Administração, uma instância assessora que tata do programa, orçamento e administração da Organização e aconselha o Comitê nesses temas. Se reúne ao menos uma vez ao ano e é composto por sete membros, quatro com mandatos simultâneos e três indicados pelo Diretor anualmente, sempre tendo em mente o equilíbrio na distribuição geográfica.

Além do aporte orçamentário da OMS, a OPAS também compõe seu orçamento bianual com base nas cotas recebidas dos seus Estados-membros, determinadas de acordo com a tabela da Organização dos Estados Americanos (OEA)(101). Atualmente, a Organização tem 35 Estados-membros e observadores (como Portugal e Espanha)(101), 27 escritórios nacionais e três centros especializados (BIREME, CLAP e PANAFTOSA)(102). Das organizações que atuam na América do Sul na área da Saúde, a OPAS é a única com "filiais" nos países, o que proporciona maior capilaridade das ações, mas também maior proximidade com os principais Ministérios da Saúde. Na região, a OPAS tem escritórios em todos os 12 países independentes.

Nesse sentido, a Organização desempenha um importante papel no que se refere à cooperação em saúde na região. Na 52ª sessão do seu Conselho Diretivo, em 2013, os países membros acataram a resolução CD52/11 sobre cooperação para o desenvolvimento sanitário, aprovando uma política renovada sobre o tema, que objetiva: "fortalecer a cooperação entre países e parcerias horizontais dentro de e em todas as regiões para compartilhar preventivamente soluções de saúde que tratem de forma eficaz e sustentável os problemas comuns de saúde [...]”(103)p.7. A resolução ainda afirma como uma das funções da Diretora 
da Organização o fortalecimento das relações entre as organizações sub-regionais, reforçando o que foi proposto em 1947, na Constituição da OPAS.

Em 2007, os Ministros dos países membros se reuniram na cidade do Panamá para conformar uma Agenda de Saúde para a região das Américas e que guiaria suas ações de 2008 a 2017(104). A ideia era definir diretrizes de ação e retomar compromissos assumidos por seus Estados-membros, dando subsídios para a construção de planos nacionais de saúde que respeitem a heterogeneidade entre as nações. O documento reitera a visão institucional que é de alcançar uma região mais saudável, tendo em conta os determinantes sociais, o acesso aos serviços e bens de saúde, contribuindo para a realização das potencialidades das pessoas. Seus princípios e valores são a acessibilidade, a universalidade, os direitos humanos, a inclusão, a cooperação, a solidariedade panamericana, a equidade, a participação social e a intersetorialidade.

Em termos de vigilância em saúde, de acordo com a Agenda de Saúde para a Américas (2008-2017), a Organização objetiva fortalecer a segurança sanitária, ou seja, a preparação para enfrentar desastres, pandemias e doenças, fortalecer ações conjuntas no nível sub-regional, regional e global, prevenção e controle de doenças, entre outras ações(104). Uma das funções da OPAS é reunir e analisar a situação de saúde e possíveis surtos de doenças epidêmicas na região(101).

O Código Sanitário Pan-americano(99), aprovado em 1923, já tratava de questões relacionadas à vigilância. Em seu artigo $1^{\circ}$, que descreve seus objetivos, estão a prevenção da propagação de doenças e a promoção de cooperação para esse fim. O contexto desse código e das Conferências Sanitárias Pan-americanas e internacionais é o da prevenção de doenças para a proteção econômica, como visto anteriormente. Esse instrumento é considerado um marco, como "uma iniciativa que vela pela saúde de todos neste território"(101)p.404.

O Plano Estratégico 2014-2019 da OPAS reflete as prioridades estabelecidas pela Agenda supracitada, servindo como mecanismo de planejamento, com resultados esperados e prazos de execução. Dentre suas metas, estão a redução da mortalidade por doenças transmissíveis e a eliminação de outras consideradas prioritárias na região, bem como "evitar mortes, doenças e deficiências resultantes de situações de emergência"(101)p.5.

A Organização, por meio dos seus escritórios-país, garante proximidade com os Ministérios da Saúde e trabalha conjuntamente com estes para apoiá-los no fortalecimento dos 
seus sistemas de saúde. Com o Brasil, por exemplo, tem atualmente 31 termos de cooperação ${ }^{21}$ em vigor, que financiam projetos diversos como o fortalecimento da AISA, vigilância em saúde, Complexo Econômico Industrial da Saúde, entre outros.

Um dos mais famosos termos de cooperação, é o TC80 Acordo de cooperação técnica para ampliar o acesso da população brasileira à atenção básica em saúde ${ }^{22}$, assinado em 2013 e que financiou o Programa Mais Médicos no país ${ }^{23}$. O principal objetivo do programa era promover o acesso à saúde a populações em zonas com baixa densidade de médicos, diminuindo as iniquidades em municípios priorizados. Esse é um exemplo relevante de como a OPAS atua com os países, apoiando, mas também influenciando suas políticas de saúde.

\subsubsection{A Saúde no Mercosul}

O objetivo fundacional do Mercosul, como vimos anteriormente, era tratar de questões relacionadas à economia e comércio, mas temas sociais foram se incorporando à sua agenda paulatinamente, principalmente a partir de 2003(59). O tema saúde entrou na agenda do Mercosul através, primeiramente, de uma comissão dentro do SGT n 3 "Normas Técnicas" em 1992(105). Atualmente, a saúde conta com dois fóruns principais: a Reunião de Ministros de Saúde (RMS), que, como o nome diz, reúne os responsáveis pela pasta nos países e é submetido ao CMC; e o Subgrupo de Trabalho Saúde (SGT no 11 "Saúde") entre outros $18^{24}$ que estão submetidos ao GMC.

A RMS foi criada em 1995 para tratar de temas políticas relacionados ao tema saúde no bloco. Se reúne a cada Presidência Pro Tempore (presidência do CMC exercida por rodízio semestral seguindo a ordem alfabética dos Estados Partes) e é precedida por uma reunião preparatória, realizada pelos Coordenadores Nacionais dos países, que são, em geral, os chefes das Oris. Eles definem as pautas que serão elevadas aos Ministros.

Para definir suas políticas, a RMS criou uma estrutura de governança que conta com inúmeras Comissões Intergovernamentais (CI) que tratam de temas específicos, Programas e

\footnotetext{
${ }^{21}$ http://portalarquivos2.saude.gov.br/images/pdf/2019/abril/04/TCS-OPAS-04-04-2019.pdf

22 http://portalarquivos2.saude.gov.br/images/pdf/2016/dezembro/06/TC\%2080\%201.pdf

${ }^{23}$ Para saber mais sobre o desenvolvimento do Programa, veja a tese defendida por Matheus Falcão: https://teses.usp.br/teses/disponiveis/6/6140/tde-30082019-101730/publico/MatosMFM_DR_R.pdf

${ }^{24}$ Para saber mais: www.mercosur.int
} 
Comitês e Grupos Ad Hoc(44), como por exemplo a CI de Vigilância em Saúde, a CI de a VI de Saúde Sexual e Reprodutiva, a CI de Controle de enfermidades de Transmissão Vetorial, entre outras.

O SGT n ${ }^{\circ} 11$, foi criado pelo GMC em 1996 com o objetivo de:

$$
\begin{aligned}
& \text { harmonizar legislações e coordenar ações entre os Estados Partes referentes à atenção } \\
& \text { à saúde, bens, serviços, matérias-primas e produtos da área da saúde, vigilância } \\
& \text { epidemiológica e controle sanitário, com a finalidade de promover e proteger a saúde } \\
& \text { e a vida das pessoas e eliminar os obstáculos ao comércio regional e à atenção integral } \\
& \text { e de qualidade, contribuindo desta maneira ao processo de integração. (44)p. } 23 \text {. }
\end{aligned}
$$

Sua pauta é mais burocrática, tendo como principais objetos a harmonização e coordenação das legislações dos Estados Parte e a compatibilização dos seus sistemas de Controle Sanitário, além da articulação dos sistemas de saúde; a promoção de ações que apontem para a integração regional; o incremento atenção integral à saúde à população no âmbito do Mercosul, entre outras. (44)

A Vigilância em saúde é tema transversal de diversas instâncias que fazem parte do "Mercosul Saúde". Em estudo(106) sobre os temas tratados na agenda de saúde do bloco, a Vigilância na RMS pode ser identificada nos debates já no ano 2000. A CI de Controle de dengue (CICD) é uma das que promove discussões nesse âmbito, além da CI que trata sobre a Implementação do Regulamento Sanitário Internacional (RSI), criada em 2005, ano de aprovação do instrumento. Já no SGT 11, a vigilância em saúde (2006) corresponde a 15\% das resoluções emitidas pela instância, sendo a implementação do RSI também parte de sua agenda.

\subsubsection{A Saúde na Unasul}

A Saúde na Unasul é tratada especificamente no Conselho de Saúde Sul-americano (CSS), que foi um dos primeiros a ser estabelecidos no âmbito do bloco. Em abril de 2008, o CCEG o criou com o objetivo de consolidar a América do Sul como um espaço de integração em saúde, contribuindo para a saúde para todos e o desenvolvimento, agregando esforços já instituídos no continente como já citado(107).

O CSS é conformado por um Conselho de Ministras e Ministros de Saúde dos 12 países membros do bloco, instância máxima de decisão; um Comitê Coordenador, constituído por delegados dos ministros; e um representante do Mercosul, do ORAS-CONHU, da Organização 
do Tratado de Cooperação Amazônica (OTCA) e OPAS na qualidade de observadores ${ }^{25}$; uma secretaria técnica, conformada por representantes das Presidências Pro Tempore atual, passada e futura ${ }^{26}$; Grupos Técnicos e Redes Estruturantes.

Figura 3 Organograma do Conselho de Saúde Sul-americano da Unasul

\section{Conselho Sul-Americano de Saúde}

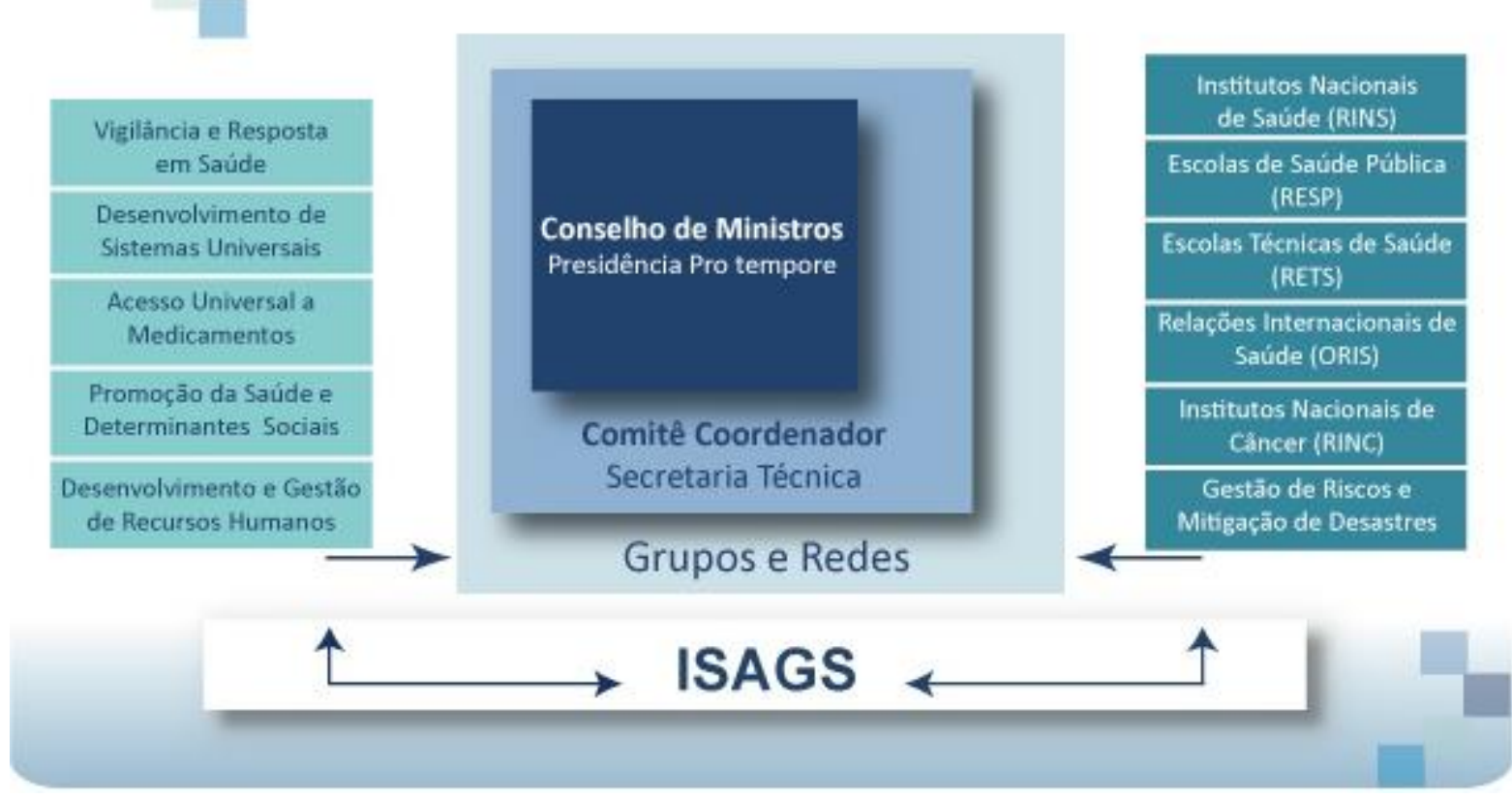

Fonte: Acervo próprio

Um passo importante para o conselho foi a criação do ISAGS, em 2011. Com sede no Rio de Janeiro, o ISAGS foi uma organização intergovernamental de caráter público criado para constituir-se como centro de altos estudos e debates de políticas para o desenvolvimento de lideranças e recursos humanos estratégicos em saúde(108). Entretanto, o Instituto enfrentou diversas dificuldades para sua institucionalização, além do baixo compromisso dos países, afetando sua capacidade de cumprir os objetivos para os quais fora criado $(41)^{27}$.

O ISAGS foi considerado uma experiência única no mundo, atuando de forma destacada em relação a outros organismos internacionais do campo da saúde(109), e chave para o alcance implementado.

${ }^{25}$ Inicialmente cogitou-se admitir observadores durante das reuniões do CSS, o que jamais foi de fato

${ }^{26}$ Essa modalidade de PPT tampouco foi implementada de fato.

${ }^{27} \mathrm{O}$ Instituto encerrou suas atividades, ao menos temporariamente, em junho de 2019. 
dos objetivos do CSS. Para tal fim, o Instituto trabalhava no desenvolvimento de pesquisas e disseminação de conhecimentos, além de promover treinamentos e capacitações $(47,56)$ orientadas pelas prioridades estabelecidas pelos países, glosadas em seu Plano Operativo Anual (POA). Além disso, foi apontado como "agente catalisador" de articulação as instâncias que conformam o Conselho de Saúde, apoiando seus processos de tomada de decisão(41).

[...] o ISAGS surgiu e se consolidou como uma estrutura de apoio permanente para gerar informação e produzir conhecimento, formar líderes em saúde, assessorar tecnicamente e possibilitar a formulação de políticas inovadoras para as instituições e sistema de saúde dos países membros.(97)p.2.

As ações do CSS foram guiadas pelas diretrizes contidas no Plano Quinquenal 20102015(PQ)(110). A visão do bloco sobre o tema da saúde é fortalecer o subcontinente como um espaço de integração que favoreça a saúde para todos. Entre seus valores e princípios estão os direitos humanos, a solidariedade, a equidade, a participação cidadã, a cooperação, a concertação, a integração e a interculturalidade.

Seus eixos temáticos deram origem aos Grupos Técnicos para operacionalizá-los (vide Figura 3). Cada GT tem uma coordenação principal e uma alterna e são conformados por representantes dos Ministérios da Saúde, com competência na área temática.

A Rede ${ }^{28}$ de Vigilância e Resposta em Saúde é onde são concentradas as discussões sobre o tema. Estabelecido em 2009, as ações do GT tinham como resultados esperados no Plano a seleção de indicadores comuns, um sistema de informação, monitoramento e avaliação e, entre outros, ter capacidades básicas de vigilância e respostas referentes à aplicação do RSI e a criação de uma Rede de Dengue, a fim de mitigar o impacto da doença na região (110).

Entre seus avanços, estão a criação de um plano quinquenal para prevenção e controle de dengue e a seleção de 14 doenças prioritárias para notificação dos países membros (111), que incluem não apenas a dengue, mas a febre amarela e a malária, também transmitidas por mosquitos. Os desafios se referem à necessidade de elaborar definições e procedimentos comuns na área, a implementação efetiva de um sistema de informação e a maior integração do GT que também se relacionam ao tema vigilância, como a Rede de Institutos Nacionais de Saúde (112).

Sobre o RSI, se observa a necessidade e de intensificar as estratégias de cooperação a partir das brechas existentes e exercitar "um olhar regional para os eventos com o objetivo não

\footnotetext{
${ }^{28}$ Apesar do nome, este é o Grupo Técnico e não uma Rede Estruturante como estabelecida pela Unasul.
} 
apenas de compartilhar informações sobre eventos, que ocorrem nos países da região, mas também de aprender com as experiências dos países" (112).

Já as Redes Estruturantes foram incorporadas ao CSS em 2009(113), um ano após a construção do Plano Quinquenal e por isso não fazem parte do seu conteúdo programático. Dependendo da Rede, elas são geridas por um país ou por uma secretaria executiva, que fica a cargo de uma das instituições que a conformam. Atualmente, seis redes compõem o Conselho (Figura 3) e seu objetivo é a construção de capacidades e a produção de conhecimento para ao fortalecimento dos sistemas de saúde por meio do trabalho em rede(114), iniciativa considerada inovadora e também promissora para o fomento à cooperação sul-sul(115).

Após o término da vigência do Plano, iniciou-se um processo de revisão e sua nova versão não foi finalizada até a publicação deste capítulo. Isso ocorreu devido à falta de uma conjuntura política favorável, fazendo com que coexistam múltiplas agendas que regem a saúde no bloco, que age de forma reativa a depender de outros agentes, que ditam agendas das Américas e global(41). Também reflete o momento político por qual o bloco passa.

Apesar de não haver uma nova agenda estabelecida em um documento desde 2015, "uma agenda política, não plasmada em um documento único, segue direcionando as ações do Conselho de Saúde" (41)p.159; guiadas de alguma forma pelos Planos Operativos do ISAGS, projetos de Iniciativas Comuns em desenvolvimento e atuação do Conselho em fóruns multilaterais.

Em estudo sobre a saúde no bloco, Teixeira(41) identificou algumas críticas que dificultam o funcionamento pleno das instâncias que compõem a Unasul. A complexidade da estrutura, com as redes, grupos, conselho, e o papel das instâncias é uma delas, outra é a falta de comunicação entre esses mecanismos. Além disso, chama atenção para as diferenças de atuação de GTs e Redes, que dependem muito da sua composição, das lideranças (ou não) que levam as ações adiante. Outro ponto importante a ser destacado é a própria falta de coordenação entre o CSS e os outros conselhos com temáticas afins. Muitos tiveram projetos envolvendo o tema saúde, mas não contaram com contribuições do Conselho ou foram incluídos nos debates políticos cabíveis, gerando duplicação de esforços dentro do bloco. (41)

Nesse sentido, aponta fatores que influenciam nas dinâmicas de governança do bloco:

As relações do Conselho de Saúde com os Estados-membros estão influenciadas pelo nível de compromisso político dos países; pelas mudanças constantes de autoridades e funcionários nos Ministérios de Saúde que geram descontinuidades nos trabalhos do Conselho de Saúde e; pela ideologia política dos governos de cada Estado membro. (41) p.133. 
As diferenças de abordagem de alguns países na Unasul podem ser vistas como um revés para o bloco, mas uma solução possível seria encontrar uma saída mais técnica(41), sobrepondo questões políticas que possam afetar a continuidade das ações.

Em seu orçamento global aprovado apenas em 2012, os Conselhos Setoriais não foram incluídos, ficando cobertos financeiramente apenas as instâncias físicas e pelo Fundo de Iniciativas Comuns (FIC) para o qual os Conselhos podem submeter projetos. O FIC poderia ser uma forma de financiar as atividades do $\mathrm{PQ}$, porém os valores disponíveis não seriam suficientes. (115) Dessa forma, muitas vezes o ISAGS foi o financiador de atividades de outras instâncias do Conselho de Saúde(41).

Uma característica relevante que destaca a Unasul de outras organizações da América do Sul é sua atuação como porta-voz da região em fóruns multilaterais como a Assembleia Mundial da Saúde da OMS(11,97). De 2010 a 2016, o bloco apresentou sistematicamente posicionamentos comuns, somando 35 no total(97), demonstrando o que Riggirozzi(56) apontou: que a região tornou-se confiante em negociações como bloco para intervir sobre a governança da saúde global.

Nesse sentido, para Teixeira(41), a Unasul seria uma forma de expressar o que chama de soberania sanitária, ou seja, por meio da integração regional, agregar autonomia frente às condições assimétricas do sistema internacional, controle e construir sua legitimidade, bem como ampliar sua atuação na saúde global. Além disso, chama atenção para o fato de ser uma prática negociada e compartilhada, de resistência, e não uma negação da soberania nacional. Para a autora:
A soberania sanitária se expressa em duas dimensões, uma interna e outra externa, que são complementares e se retroalimentam. Na dimensão interna, que se expressa no âmbito do Estado nacional, a soberania sanitária é a capacidade de definir políticas públicas a partir da concepção de que a saúde é um direito humano e de que as necessidades das pessoas devem ser atendidas por sistemas de saúde sustentáveis. Na dimensão externa, que se expressa no âmbito regional e se fortalece a partir da integração entre os países, a soberania sanitária é a capacidade de defender os interesses em saúde de sua população em espaços multilaterais e frente aos interesses transnacionais mercadológicos. A soberania sanitária estabelece um mecanismo regional de resistência à medida que reforça a independência e a autonomia em saúde dos Estados (p.179).

Desse modo, a Unasul reivindicou sua soberania sanitária em relação a outros agentes do sistema internacional, mas também reforçou as soberanias sanitárias nacionais. Teixeira afirma ainda que a resposta a emergências sanitárias globais é a primeira "manifestação concreta do exercício da soberania sanitária, através da qual os Estados nacionais exercem sua soberania a fim de evitar a disseminação de determinadas doenças transmissíveis em seu território" (p.175). 
O relacionamento das Organizações Internacionais que atuam na América do Sul não está isento de conflitos(41). Pese as iniciativas de cooperação, plasmadas na participação de reuniões umas das outras, declarações políticas e até acordos formais de cooperação como o que foi assinado, mas ainda não formalizado pela Unasul com a OPAS, existiam disputas por espaços de poder.

Como se pode observar, as três organizações acima descritas atuam com escopos geográficos distintos (Figura 4), e foram criadas em contextos políticos e com objetivos diferentes. Apesar de uma certa interoperabilidade, com participações mútuas previstas, como o caso do Mercosul e OPAS no CSS da Unasul ou mesmo uma comissão tratar de um instrumento da OPAS/OMS, como o RSI, as instituições guardam suas especificidades.

A OPAS se destaca no sentido de ser específica para o tema Saúde e por englobar a quase totalidade dos países das Américas, além de ser muito mais antiga que as demais, atuando de forma bastante próxima aos Ministérios dos países membros. Suas ações também assumem um caráter bastante técnico, de apoio aos países, inclusive com financiamento de programas cruciais para a sustentação dos sistemas de saúde da região.

A OPAS tem sede nos EUA, que também é um dos seus membros e seu maior financiador. A agenda da Organização, portanto, é bastante influenciada pelo grupo liderado por eles, que inclui países como o Canadá. No caso de uma emergência na região, sua contenção para que não afete sua população é, sem dúvidas, uma grande motivação. 


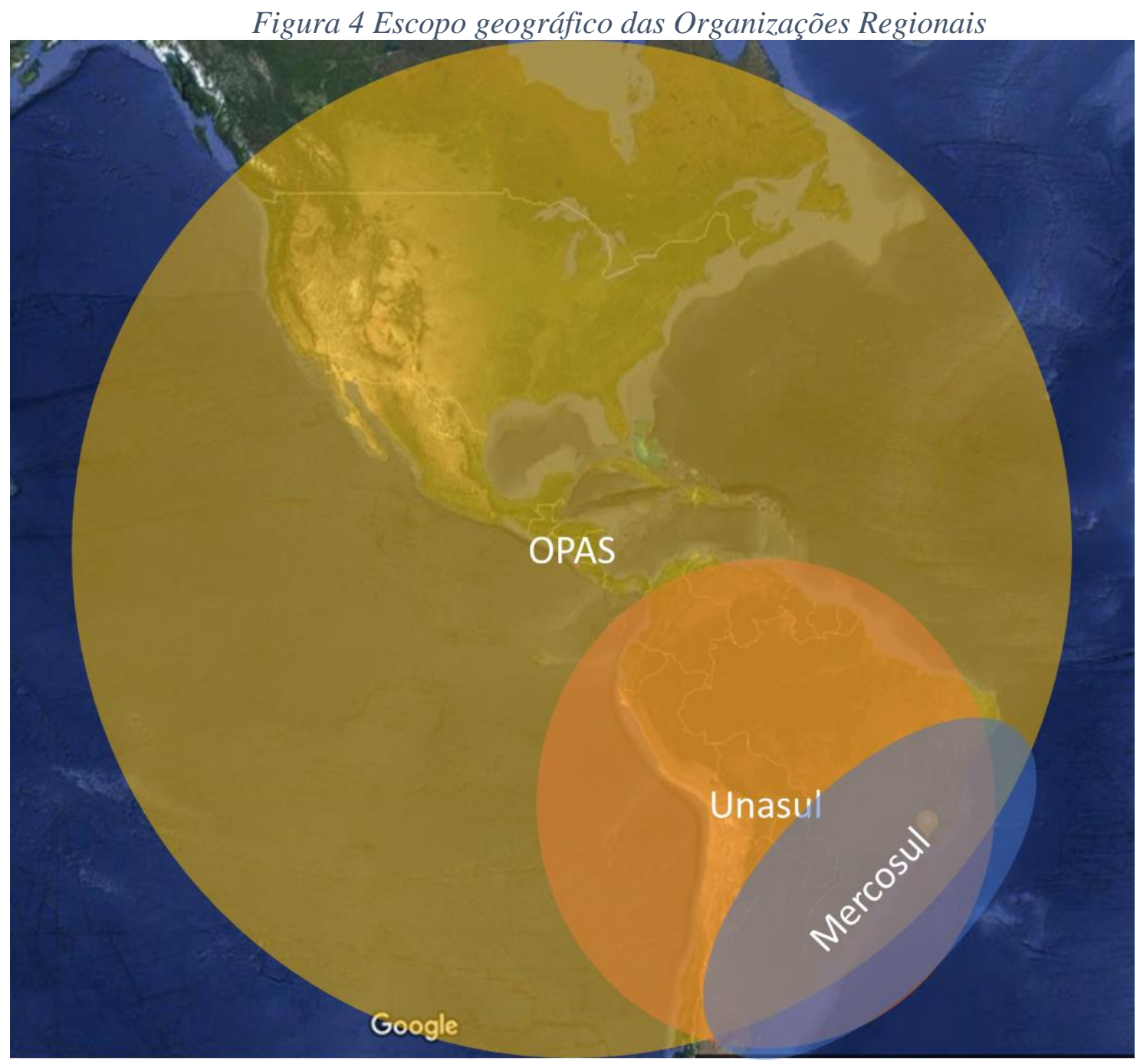

Fonte: elaboração própria com imagem do Google Maps.

Já o Mercosul e a Unasul são organizações que atuam de forma mais ampla, em outras áreas temáticas. O Mercosul, com seus objetivos de integração econômica coloca a ênfase de um grupo de trabalho para tratar da harmonização de legislações, como forma de facilitar o comércio intrabloco. Esse propósito, pese a expansão para outros temas, continua pautando as agendas da organização e deixam suas ações em saúde com uma fachada mais pragmática e técnica. Com quase 40 anos de história, o Mercosul se manteve em funcionamento em maior ou menor grau com todas as mudanças políticas que ocorreram no cone Sul. Uma das hipóteses para essa manutenção é seu caráter mais técnico, o que se soma à maior capacidade decisória de suas instâncias.

O caso da Unasul é especialmente relevante quando se trata das mudanças políticas. A Organização veio como um contraponto ao poderio norte-americano na região, como uma tentativa de posicioná-la de uma forma mais autônoma, pautando suas próprias agendas. Nesse caso, o apoio do Brasil era crucial não apenas pela força política, mas principalmente pelo 
financiamento, já que 39\% do total cabia ao país. É sabido que o país não paga suas cotas há alguns anos. Além disso, existe uma onda de saída de países do bloco, que se enfraquece com o abandono de sócios importantes (incluindo seu país Sede, o Equador). Quando um país forte não paga de forma sistemática, e essa situação se une a uma profunda mudança nos rumos políticos, o resultado é o seu esfriamento e paralização, como tem ocorrido.

Como um bloco político, a Unasul tende a sofrer mais com mudanças na conjuntura política da região. Além disso, apesar de ter um papel relevante na projeção da região no cenário internacional, como vimos com o caso da Assembleia Mundial da Saúde, o novo regulamento obstaculizou que suas instâncias pudessem tomar decisões diretamente, sem o aval dos Conselhos de Delegados, por exemplo.

As mudanças políticas e as vontades dos países dão o tom das ações de cada Organização dentro do seu escopo de atuação. Entretanto, elas seguem sendo espeço privilegiado para coordenação e cooperação.

\subsection{O PAPEL DA OMS, O RSI E A PRIMEIRA ESPII NA AMÉRICA DO SUL}

A Organização Mundial da Saúde, criada em 1948 no pós-segunda guerra mundial, é o órgão especializado em saúde das Nações Unidas. Diferente das organizações que são foco nesta tese, seu escopo de atuação é global. A OMS foi criada com a finalidade de alcançar para todos os povos o mais alto grau possível de saúde, tendo entre suas funções atuar como autoridade diretiva e coordenadora em assuntos de saúde internacional e estabelecer e manter colaboração eficaz com organismos especializados. São suas obrigações colaborar com governos e agências especializadas; oferecer assistência técnica; propor convenções, acordos e regulamentos (vinculantes) e recomendações em saúde internacional(117).

A posição da OMS como autoridade diretiva e coordenadora do campo da saúde no mundo vem sendo confrontada com a perda do seu protagonismo frente a outras organizações(118), como o Banco Mundial(77). A crise no seu financiamento (apenas 25\% provêm de contribuições regulares dos países(119), deixando a Organização com pouca ingerência sobre o manejo e direcionamento do orçamento(101), e, recentemente, a pandemia de gripe A (H1N1) exacerbaram a situação e revelaram conflitos de interesse(120), dificuldades de comunicação e problemas de governança interna(118).

Para responder a essas críticas, a OMS iniciou em 2010 um processo amplo de reforma, com foco em questões operacionais e financeiras, para reforçar o papel da instituição como líder 
da saúde global, fortalecer sua relação com outros atores e atender às expectativas dos seus membros(121). Além disso, sua área de atuação foi bastante estendida, dificultando o cumprimento efetivo de sua missão e sua capacidade de responder rapidamente a emergências globais (101).

Apesar desse processo de questionamento e reforma, a OMS ainda é o lugar onde questões de saúde que afetam o mundo são debatidas, deliberadas e aprovadas, não encontrando substituto entre as organizações existentes(122).

Até o presente momento, a Organização aprovou dois instrumentos legais internacionais vinculantes: a Convenção-Quadro para Controle do Tabaco (2003) e o Regulamento Sanitário Internacional (2005) (RSI).

O RSI figura como uma das 6 prioridades estabelecidas no Plano Geral de Trabalho (PGT) 2014-2019 da OMS.

\subsubsection{O Regulamento Sanitário Internacional (2005)}

O Regulamento Sanitário Internacional (RSI), como supramencionado, é uma política reguladora e um instrumento jurídico internacional vinculante, cujo objetivo é "prevenir, proteger, controlar e prover uma resposta de saúde pública à disseminação internacional de doenças proporcional e restrita a riscos à saúde pública, e que evite interferência à circulação e comércio internacionais" (123) p.10. Esse documento obriga os países a reportar à OMS a ocorrência de eventos graves de saúde pública e descreve procedimentos que a Organização deve cumprir para responder ao evento.

A última versão do RSI, foi aprovada pela $58^{\mathrm{a}}$ AMS em 2005, entrando em vigor em junho de 2007, tornando todos os membros da Organização como parte do Regulamento, salvo em caso de refutação ou reservas explícitas pelo país, estando comprometidos com a sua aplicação mesmo antes de sua internalização(120). De acordo com a Constituição da OMS, os Tratados assinados no âmbito da organização necessitam da anuência explícita dos países e sua incorporação às ordens jurídicas internas. No caso dos Regulamentos, ocorre o contrário. Os Estados Partes devem explicitamente negar ou apresentar reservas ao texto caso não queiram aderir ao Regulamento, mecanismo conhecido como opting-out. 
Esta edição inova em relação à sua antecessora, de 1969, porque não limita sua aplicação a determinados eventos ${ }^{29}$; pressupõe que cada país reúna capacidades para responder a suas obrigações no regulamento; obriga o país a notificar eventos que possam se constituir em uma Emergência de Saúde Púbica de Importância Internacional (ESPII); autoriza a OMS a utilizar informações não oficiais e obter a verificação dos Estados partes; autoriza o(a) Diretor(a)-Geral (DG) da OMS a determinar uma ESPII e a emitir recomendações após a reunião do Comitê de Emergência; protege os direitos humanos de pessoas e viajantes e estabelece pontos focais nos países para comunicações urgentes entre os membros(123).

Na medida em que suas decisões são tomadas a partir de um Comitê de especialistas selecionados sem a participação deliberativa dos Estados-membros, possibilita à OMS de atuar de forma independente da vontade dos Estados, em uma espécie de direito da emergência, como uma intersecção entre o direito interno e o direito internacional(120).

De acordo com Ventura(120) "ser parte do RSI implica, então, estar vinculado a um direito de emergência sanitária, mas igualmente a dotar-se de condições objetivas para sua aplicação, que deve se aferível e controlada por um mecanismo internacional" (p. 163). Isso aponta para a necessidade de mudanças estruturais nos sistemas de saúde e de vigilância, muitas vezes difíceis de serem alcançadas. As avaliações sobre o estado das capacidades básicas dos Estados-membros frente ao RSI (são 13 capacidades básicas listadas no instrumento) podem ser consideradas frágeis $(120,124)$ e pouco confiáveis(125) por não serem obrigatórias e por serem autodeclaradas.

As capacidades básicas que os países devem desenvolver relacionam-se com:

1. Legislação e financiamento;

2. Coordenação da resposta;

3. Eventos zoonóticos;

4. Segurança alimentar;

5. Capacidade laboratorial;

6. Vigilância;

7. Recursos humanos;

8. Marco de emergências em saúde;

9. Provisão de serviços de saúde;

10. Comunicação de risco;

11. Pontos de entrada;

12. Eventos químicos;

13. Emergências de radiação.

${ }^{29}$ Um evento para o RSI é "uma manifestação de doença ou uma ocorrência que cria um potencial para doença"(123)p.7. Isso significa que não se restringe a enfermidades per se, mas inclui a problemas de saúde causados por agentes químicos ou radionucleares(272), por exemplo. 
Para Ventura e Torronteguy(126), a aplicação do RSI é uma das principais funções da OMS. Entretanto, a capacidade da Organização de garantir sua implementação é questionada por diversas razões(125). Além da já citada autoavaliação, não existem mecanismos que garantam o financiamento nem por parte dos países membros ou doadores para que as nações mais vulneráveis possam estruturar seus sistemas de vigilância. Outro fator apontado é o fato de os países não serem $100 \%$ transparentes ou adiarem as notificações por razões econômicas, já que pode haver impacto e restrições na circulação de pessoas e mercadorias dos seus países. Para Gostin e Katz(125), a OMS não teve autoridade ou capacidade de impedir que seus Estados-membros ignorassem suas recomendações. Adicionalmente, apontam que a Organização já demonstrou que não foi capaz de mobilizar e coordenar uma resposta à emergência em larga escala, como no caso do Ebola. Nesse sentido, recomendam que sejam feitas mudanças no texto e nos mecanismos de financiamento, já que algumas omissões importantes como a troca de amostras dos agentes etiológicos e ameaças zoonóticas.

Até junho de 2014, apenas 11 dos países da região das Américas reportaram ter as capacidades básicas e formas de mantê-las(124), demonstrando fragilidade na região para responder às exigências do RSI. A autoavaliação foi facilitada por conta de um checklist organizado pela própria OMS, quando da possível introdução do Ebola na região. Além disso, autores(124) identificam que serão necessárias missões de acompanhamento, além de cooperação Sul-Sul e triangular como forma de garantir a evolução e manutenção das capacidades alcançadas naquele contexto.

Este tema gerou polêmica durante a 69 ${ }^{\text {a }}$ Sessão da AMS em 2016, quando os países debateram a possibilidade de uma avaliação externa dessas capacidades, defendendo que a mesma tenha caráter voluntário(127). Além disso, estas dizem respeito não apenas à estrutura dos sistemas de saúde de cada país, mas também de uma estrutura legal para responder às exigências do instrumento. Nesse sentido, Marks-Sultan e colaboradores(128) entendem que a OMS deveria atuar no fortalecimento da estrutura jurídica como forma de aprimorar a resposta a emergências.

\subsubsection{As Emergências de Saúde Pública de Importância Internacional}

Sempre que houver a possibilidade de um evento ser considerado uma ESPII, a notificação à OMS deve ser realizada pelo país afetado. Para isso, duas das seguintes perguntas devem ser respondidas positivamente(123):

- As repercussões do evento sobre a saúde pública são graves? 
- O evento é inabitual ou inesperado?

- Há um risco importante de propagação internacional?

- Há um risco importante de restrição a viagens internacionais ou ao comércio internacional?

Após a notificação, o DG pode convocar um Comitê de Emergência, composto por expertos no tema, para avaliação do caso. A decisão de determinar uma ESPII é baseada na informação do Estado membro, no instrumento de decisão contido no Anexo 2, nas recomendações do Comitê, em evidências científicas e na avaliação dos riscos para a saúde humana, do potencial de alastramento da doença e no risco de interferir no tráfego internacional, segundo Art. 12 do RSI. Observa-se, entretanto, que "o que define uma ESPII é sua dimensão internacional, e não a sua gravidade ou letalidade. Trata-se de uma decisão técnica, apesar de suas evidentes consequências políticas"(129); ou, ainda, refere-se ao próprio risco de uma doença extrapolar seu local de origem(130).

É certo que a declaração de uma ESPII aumenta a consciência da população a respeito do evento de saúde pública em questão, também pode empoderar os Ministérios da Saúde e aumentar a captação de recursos internacionais, além de aumentar a coordenação e a cooperação internacional no sentido de dar cabo desses eventos; entretanto, muitas vezes a ESPII também traz consequências negativas para o trânsito de pessoas e bens para os locais afetados, causando prejuízos à economia, riscos de estigmatização das populações atingidas e de pânico(129).

Até 2015, a OMS declarou três vezes um evento como ESPII: a epidemia da gripe A H1N1 (2009), o poliovírus selvagem (2014) e o ebola (2014). Todas essas doenças têm em comum serem transmissíveis por diversas vias, em geral, pelo contato humano. A peculiaridade Síndrome Congênita do vírus Zika é que ela é, principalmente, causada por um vetor, um mosquito, e também por causar sintomas leves na população geral, não levando todos os doentes necessariamente a procurar ajuda médica. Essa característica torna seu controle especialmente difícil.

\subsubsection{O RSI e a Securitização da Saúde}

O processo de revisão do RSI estava em curso desde 1995, mas só foi finalizado em 2005. Esse longo debate foi acelerado por duas razões: os atentados de 11 de setembro de 2001, que trouxeram à tona o temor do terrorismo e a guerra biológica, com os envelopes de anthrax enviados pelos correios nos Estados Unidos e a epidemia de Síndrome Respiratória Aguda Grave (SARS), ocorrida em 2003 (120). 
Com o surgimento desses eventos, o debate sobre a relação entre a saúde global e a segurança nacional se acirrou. A securitização ${ }^{30}$ é "o processo pelo qual um tema é socialmente construído como um problema de segurança"(131). No caso da saúde, a securitização pode ser uma ameaça à democracia e aos direitos humanos(131) na medida em que, quando transformadas em questão de segurança, tópicos de saúde demandam ações emergenciais, medidas excepcionais(132), reinterpretados sob a justificativa de interesses maiores(133). O RSI, nesse sentido, pode ser considerado uma expressão e um instrumento da e para a securitização de assuntos de saúde pública.

Com relação ao RSI, Hanrieder e Kreuder-Sonnen(134) chamam a governança da OMS para emergências de "variante globalizada do excepcionalismo", no sentido de que a própria burocracia da decisão é um promotor da securitização, uma "armadilha da emergência". Para os autores, a transferência do processo decisório para a autoridade de uma Organização Internacional como a OMS pode gerar um mecanismo de retroalimentação da securitização e das medidas de exceção, que obviamente recebem influências dos grandes doadores e países mais fortes.

Outra face dessa questão é a utilização de uma gramática da securitização, no sentido de conter um vocabulário específico que integra e constrói o discurso do medo e da guerra. Além de fazer parte de um discurso, que é político, mimetiza uma lógica de guerra, com uma ameaça a ser eliminada. Ao retirar uma epidemia, por exemplo, do âmbito da saúde e da agenda de direitos humanos, a coloca como uma ameaça à ordem política internacional em vigor. (132) Não é de se estranhar que muito países, quando afetados por grandes emergências, acionem seus exércitos para apoiar no "combate". No sentido de reverter esse processo, alguns autores $(132,134)$ têm falado em "dessecuritização", num esforço de retomar a agenda de saúde e direitos humanos nas respostas às emergências.

Algumas consequências desse processo de securitização são a disseminação do pânico, o preconceito contra trabalhadores da saúde e populações acometidas, podendo chegar a restrições de mobilidade(131), por exemplo. Nunes(133) chama a atenção para o perigo de se considerar medidas burocráticas que colocam a imigração, crime e a disseminação de doenças como características vinculadas. Ou ainda:

[...] confinar a resposta às emergências internacionais ao prisma da segurança condenaria a saúde global a uma sucessão infinita de períodos de 'guerra' intercalados por 'tréguas' focadas nos

${ }^{30}$ Diversos são os temas que podem ter a securitização como pano de fundo. Para fins desta tese, o processo será analisado no escopo da aplicação do RSI. 
sistemas de vigilância, e não no enfrentamento das causas das epidemias, vinculadas aos determinantes sociais da saúde.(131)p.3

Ventura(130) aponta, ainda, para a ineficiência de tais medidas. Primeiro, porque é impossível que o isolamento de um território, de fato, impeça a introdução de doenças. Da mesma forma, a "bala mágica" como solução para a erradicação de doenças se mostrou inócua, já que as causas das doenças são muito mais complexas e, na maior parte das vezes, resultado de condições estruturais ou desequilíbrios na relação do homem com o meio ambiente. Dessa modo, seria necessário dar conta dos problemas estruturais existentes, dos determinantes sociais da saúde e do fortalecimento de ações de atenção primária, pois "não há segurança sem acesso universal e gratuito à saúde" (130).

\subsection{A DISSEMINAÇÃO INTERNACIONAL DE POLÍTICAS PÚBLICAS COMO RESULTADO DA COOPERAÇÃO INTERNACIONAL}

As Organizações como vimos têm, em seus documentos fundacionais, objetivos e missões distintas. No caso da saúde, uma das funções principais do Mercosul é harmonização e legislações e políticas; a Unasul, é promover políticas comuns e ações coordenadas entre seus membros; a OPAS, é ser um catalizador e liderar cooperação entre os membros. Apesar das diferenças, existe um fio condutor entre elas, que é a cooperação internacional.

Nesse sentido, OIs advogam pela implementação de políticas similares em seus países membros(135), em geral, dando algum tipo de suporte para essa implementação, como é o caso da OMS com o RSI. Esse fenômeno tem aumentado nas últimas décadas, provavelmente pelos avanços tecnológicos que ampliaram a capacidade dos tomadores de decisão de se comunicar e trocar experiências $(10,135)$, o fato de as nações industrializadas não viverem alijadas das pressões econômicas, e o surgimento desses OIs promotoras de políticas. O papel dos atores internacionais nos processos de circulação de políticas públicas é fundamental e tem sido reconhecido recentemente $(9,10)$.

Uma das mais usadas definições sobre transferência de política é de Dolowitz e Marsh(135). Essa definição é um marco e ajuda a compreender os demais fenômenos relacionados como circulação e difusão de políticas. Para eles, a transferência é o processo pelo qual "o conhecimento sobre políticas, arranjos administrativos, instituições e ideias em um ambiente político (passado e presente) são usados no desenvolvimento de políticas, arranjos administrativos, instituições e ideias em outro ambiente político" (p.5). 
Esta definição sinaliza que não apenas políticas completas podem ser adotadas, mas outros elementos que compõem aquela política como seus objetivos, conteúdo, ferramentas, programas, bem como ideias, instituições, ideologias, atitudes e até lições negativas. Além disso, podem estar inseridos em distintos níveis de governança seja local, nacional ou internacional.

A literatura sobre transferência, circulação e difusão de políticas muitas vezes emprega esses termos como sinônimos, pois tratam da adoção de uma política ou elemento originada em um lugar, em outro. Entende-se que esses termos são, na verdade, complementares(10). A transferência é algo pontual que ocorre no tempo e no espaço(136), restrito a poucos agentes políticos e suas interações(10); enquanto a difusão seria um movimento coletivo de adoção de uma política(10,136). Por sua vez, a circulação seria um movimento mais amplo no tempo e no espaço, com a política recebendo influências diversas(136), um processo multidirecional, mais abstrato "um movimento contínuo de produção de modelos, emissão, apropriação e tradução de seu conteúdo por múltiplos atores” (10)p. 22.

Embora seja um processo de adoção coletiva, a difusão não é necessariamente um processo organizado, coordenado, recebendo influências de diversos fatores. Além disso, não é um processo $100 \%$ racional; políticas bem-sucedidas chamam atenção e podem ser adotadas sem a devida avaliação(10).

Para Porto de Oliveira e Pal(137), “a difusão de políticas é o que conecta naturalmente a política doméstica à internacional" p. 199. Os autores destacam o papel dos atores privados, como consultores, empresas e ONGs, na difusão de políticas, que têm sido negligenciados nos estudos sobre o tema. Também ressaltam a importância das coalizões domésticas na promoção de uma política, como grupos que a apoiam e que se asseguram de que a transferência dessa política será bem-sucedida, reforçando sua posição.

Os organismos internacionais têm diversos mecanismos que promovem políticas. Um dos mais óbvios são os espaços transnacionais, como reuniões, fóruns e cúpulas (136), bem como espaços menores como workshops, capacitações e outras reuniões(137), que também funcionam como campos de conformação de políticas públicas. São locais nos quais tomadores de decisão se comunicam, constituindo-se em espaços de "produção, circulação e legitimação de ideias, modelos e instrumentos de ação pública"(10) p.15. Também é nesses espaços que os 
agentes de transferência legitimam as políticas que eles defendem seja por premiações ou reconhecimento de outra natureza.

Esse intercâmbio também pode ocorrer entre organizações internacionais(9); e, partindo do princípio de que a cooperação entre instituições é intensa, De Faria(138) chama atenção para o fato de que elas disputam umas com as outras a "prevalência de uma dada orientação ou diretriz no sistema internacional ou na sua área de influência, pela atenção e pelos favores dos atores mais poderosos e para a manutenção de certos monopólios temáticos"p.33. Um exemplo dessas disputas seria o caso da Unasul com a OPAS/OMS, como vimos anteriormente.

Alguns fatores podem facilitar ou restringir essa transferência, como a complexidade das políticas, meios de comunicação, políticas anteriores, viabilidade estrutural e institucional, ideologia, proximidade cultural, questões econômicas e burocráticas e idioma. E isso pode afetar o sucesso ou fracasso do processo de implementação desses elementos.

As razões para um agente se engajar num processo desses podem se situar dentro de um continuиm(135) (Figura 5) entre transferência voluntária e coercitiva, variando de razões como lições aprendidas, pressões internacionais, condicionamentos (como empréstimos), obrigações e imposição. Em busca de soluções para problemas novos ou em mutação, existe uma tendência a buscar essas soluções em outros países/organizações.

Figura 5 Continuum: das lições aprendidas à transferência coercitiva

\section{From Lesson-Drawing to Coercive Transfer}

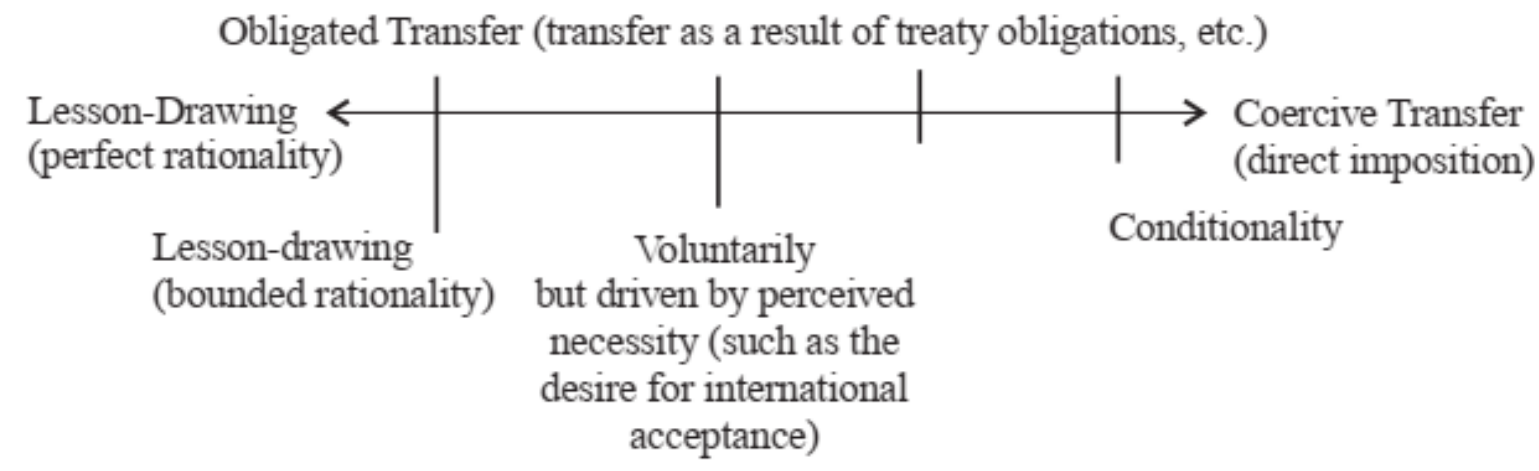

Fonte: (135)p. 13. 
Essa onda de adoção de políticas por diversos países demonstra a prevalência do fenômeno, mas também o papel importante dos indivíduos e instituições, e a dificuldade em categorizar o processo no continuum da transferência de políticas. Esse continuum varia entre uma transferência totalmente voluntária para uma totalmente forçada, coercitiva.(135)

Na ponta, a adoção de políticas seria uma resposta racional a uma determinada questão. Entretanto, essa racionalidade pura é improvável, sendo os atores influenciados por suas próprias percepções da situação, por vezes afetadas pela disponibilidade de informações incompletas ou errôneas, causando uma transferência baseada em avaliações imprecisas. Adicionalmente, países podem ser impelidos a adotar determinados programas e políticas, por exemplo, com empréstimos condicionados ou mesmo motivados por crises(135).

Assim como nas relações de cooperação internacional, Dolowitz e Marsh(135) entendem que, pese haja alguma dominância entre países doadores e países receptores de políticas, essa classificação nem sempre é verdadeira. Além disso, existiriam graus de transferência: cópia (transferência direta e completa); emulação (transferência das ideias de um programa ou política); combinações ou síntese (mistura de diversas políticas); inspiração (uma política inspira uma mudança de política em outra jurisdição). O grau de transferência, segundo os autores, depende também de quem está envolvido no processo. Políticos tenderiam a buscar soluções rápidas, optando por cópia ou emulação; enquanto burocratas estariam mais propícios a adotar combinações.

Com relação à influência de Organizações Internacionais, Dolowitz e Marsh(135) explicam que uma OI pode ter influência direta na transferência, como acontece quando elas impõem condicionalidades a determinado benefício aos países; ou indireta, gerando políticas e disseminando informações.

Durante a circulação de uma política e mesmo durante sua transferência é inevitável que ocorram modificações e novas interpretações, que sejam incluídos elementos e "ocorram apropriações que transformam seu conteúdo ideológico ou o projeto político que nele está contido”(139),p.220. Um exemplo de circulação de política pública é o Orçamento participativo, fenômeno que foi estudado em profundidade por Osmany Porto de Oliveira. Originada em Porto Alegre, essa política começou a ser difundida e adotada em várias partes do mundo, inclusive sendo promovida pelo Banco Mundial. O fato é que, ao circular, a política de origem, que defendia a participação social na definição do orçamento público já não era a que o Banco promovia. 
Para tornar-se uma "boa prática" conhecida e legitimada, são descolados das políticas o que é contextual, seu conteúdo ideológico, recebendo uma roupagem mais técnica e podendo moldar-se, ao menos em tese, aos mais diversos contextos(10).

Ao circular pelo mundo, o OP se tornou uma política pública de conteúdo vazio e sua
maleabilidade é um requisito indispensável para que esse processo se cumpra. De fato,
é necessário que o OP seja adaptado para que sua transferência possa ocorrer em
distintos contextos. (p.244)

Seriam três os mecanismos que podem facilitar o processo de difusão: o institucional, o social e o individual. O Institucional, que seria o eixo contínuo apresentado por Dolowitz e Marsh(135) e descrito acima. O social, argumenta que a produção e disseminação de informações também podem ser mecanismo de difusão, bem como o prestígio de uma prática ou instituição que a adota, além de aspectos culturais de pertencimento, como "países do sul", "América do Sul" e "América Latina". O terceiro é o individual, a circulação internacional de indivíduos, definida como "um processo por meio do qual indivíduos estabelecidos em uma determinada instituição transitam para outras instituições facilitando a difusão"(139)p. 225, o que autor chama de "embaixadores".

Os embaixadores funcionam como promotores, ativistas de determinada política e são fundamentais no processo de difusão internacional. Para exercer esse papel, eles têm autoridade sobre a política (política, teórica, prática ou técnica); sua ação é independente da instituição a que pertencem; e agem continuamente no processo. Porto de Oliveira(139) também descreve o "ponto de virada" da política, quando existe o reconhecimento dessa política como uma boa prática por um determinado conjunto de pessoas e o seu transbordamento seria quando a política começa a passar de um lugar a outro (pessoas, instituições, regiões), processo anterior à difusão massiva de uma política.

Além desses fatores, os arranjos de governança são especialmente importantes quando falamos de circulação e difusão de políticas de e por OIs. Em um artigo sobre transferência de políticas na União Europeia, Bulmer e Padgett(140) identificaram três níveis de governança que coexistem na Organização. Hierárquica, Negociada e Facilitada. A hierárquica seria aquela em que as instituições da UE exercitam sua supranacionalidade, impondo coercitivamente determinadas políticas nos seus Estados-membros. A negociada, quando seus Estados-membros buscam regras comuns para gerir o processo de integração por consenso ou maioria. Podem gerar desde leis vinculantes a entendimentos informais, quando ideias ou modelos de um ou mais países são incorporados pela Organização. Já a facilitada seria quando as nações reforçam 
sua soberania nacional, porém coordenam políticas por meio das Instituições da própria UE. Em vez de leis e regras vinculantes, essa forma de governança gera diretrizes e modelos.(140)

Os autores valorizam o papel das instituições como meio de transferência de políticas. A hierárquica, seria responsável por transferências mais fortes, resultando em algo entre a emulação ou a síntese, caracterizado por um alto grau de institucionalização. Além disso, esse modo de governança é marcado por mecanismos coercitivos de transferência, verticalizada, cujas fontes são tratados, por exemplo.(140)

Existiria ainda uma forma mais fraca de governança hierárquica, proveniente de legislação secundária, que seria mais branda. Aqui, existe uma brecha maior para que os países apliquem as políticas da maneira como lhes melhor convém, adaptando-a. Nesse caso, as regras tendem a ser mais lenientes e, portanto, as sanções mais fracas. Além disso, o monitoramento da aplicação se foca mais em termos das políticas que podem não ser muito específicos. Outro mecanismo para transferência é a condicionalidade financeira, em que o financiamento se apoio na implantação de determinada política.(140)

Já a negociação, poderia produzir emulação, mas em geral resultariam em síntese ou apenas influência; enquanto a facilitada seria responsável por uma mútua influência ou até uma transferência abortiva, quando há um veto na jurisdição que recebe a política. O processo de negociação acomoda as distintas preferências dos atores envolvidos, competindo para moldar as políticas ao seu modo. Os resultados dessa transferência são dependentes das regras para a tomada de decisão e das formas de negociação.(140)

Na governança facilitada, a soberania nacional prevalece e a transferência é facilitada pela instituição, empregando regras mais flexíveis para convencer as nações a aplicar as novas práticas. Aqui, a transferência ocorre horizontalmente entre as nações. Para Pereira e colaboradores(141), o Mercosul seria um exemplo de governança facilitada, entendendo que os países o mantêm com baixa institucionalidade de maneira a manter sua soberania, mas realizando intercâmbio de experiências e boas práticas. Eles apontam para dificuldades de o bloco harmonizar políticas, já que cada Estado internaliza as normas e políticas do Mercosul de forma diferente; mas destacam o papel do bloco na formulação de políticas públicas nacionais. Não foram encontradas pesquisas semelhantes relacionadas ao caso da Unasul.

Uma OI mais burocratizada e institucionalizada é uma OI mais formal e mais “autônoma" em relação aos seus países-membros. Nesse ponto, é importante chamar atenção para a forma como cada país instrumentaliza e faz uso de sua participação nas diversas 
organizações internacionais de acordo com seus interesses e estratégias de política externa(138).

\section{Considerações finais deste capítulo}

Este Capítulo buscou contextualizar o cenário em que se deu a Emergência do Zika, tanto no plano nacional brasileiro, como no regional, bem como demonstrar como as estruturas de governança global e regional, por meio das relações entre as organizações internacionais e seus países membros, operam e se interconectam. Também apresentou como essas organizações promovem políticas e seus elementos e como contextos, estruturas de governança e mecanismos institucionais, de construção social e individuais podem interferir no processo de disseminação de políticas no âmbito internacional.

No plano nacional, observou-se uma inflexão da direção de política externa entre os governos Dilma e Temer que, somados à crise política aguda por que passava o Brasil, afetaram seu papel como um líder diplomático e mobilizador das organizações regionais sul-americanas.

No plano regional, também pode-se notar uma evolução para a crise. A Unasul surgiu como uma promessa de integração inovadora, como uma forma de projetar a região no cenário internacional como um ator relevante. Essa promessa era bastante apoiada pelo Brasil, ao menos até o primeiro mandato da presidente Dilma Rousseff, sendo o país fundamental para o seu estabelecimento e desenvolvimento pleno. A Organização diferenciou-se do Mercosul não apenas pela amplitude de seus objetivos fundacionais, mas também pelo caráter político de sua organização; contrastando com a vertente mais econômica do último.

Unindo os esforços de integração anteriores, a área da saúde na Unasul inspirava expectativas de coordenação e de maior cooperação entre os seus 12 membros. Em seus planos estava consolidar um mecanismo regional de vigilância e resposta que se integrasse com esforços de outras organizações mais antigas, ampliando seu poder de ação. Nesse sentido, “[...] em um contexto globalizado, no qual os desafios de saúde transcendem as fronteiras nacionais, o nível regional aparece como bastante adequado para se abordar os determinantes sociais da saúde, unindo esforços e propiciando ações coletivas e diplomáticas no campo da saúde"(114)p.422.

Da OPAS, como organização regional mais antiga na área da saúde que também é a responsável pela implementação do Regulamento Sanitário Internacional nas Américas, era esperada uma participação importante. Apoiando os países na estruturação da sua resposta, 
trabalha em diversas áreas de forma próxima aos Ministérios de Saúde dos seus membros, financiando projetos, enviando pessoal especializado e promovendo capacitações.

Com o epicentro de uma Emergência de Importância Internacional na região, a expectativa era de um mecanismo regional sul-americano ativo e operativo, que pudesse unir a América do Sul com a finalidade de dar uma resposta coordenada e efetiva, que se reorientasse para ações de longo prazo que pudessem evitar novas situações afins. 


\section{MATERIAIS E MÉTODOS}

Este capítulo apresenta os materiais e métodos utilizados para a construção do presente trabalho. Inicialmente, traz uma pequena explanação sobre a pesquisa qualitativa como campo fundamental para esta pesquisa, destacando suas características principais. Depois, são descritas as técnicas para a coleta de informações; a saber: pesquisa bibliográfica; pesquisa documental, e entrevistas semiestruturadas.

Finalmente, é apresentada a grade de análise, elaborada com base na revisão de literatura feita com base no enfoque de disseminação internacional de políticas, como apresentada no capítulo 1.

\subsection{A PESQUISA QUALITATIVA}

Para alcançar o objetivo principal desta tese, qual seja o de aferir se houve disseminação internacional de políticas públicas na resposta à ESPII no ano de 2016, formulada no âmbito sul-americano, além dos instrumentos oferecidos pela teoria sobre circulação/difusão de políticas, serão utilizadas algumas técnicas da pesquisa qualitativa.

A abordagem qualitativa de pesquisa trabalha com um conjunto de fenômenos humanos que não podem nem deveriam ser quantificados, mas sim entendidos por meio de relações, representações e intencionalidade(142)

Deslauriers e Kérisit(143) pressupõem essa abordagem como um trabalho não linear de pesquisa, em que as etapas se transpõem, são objeto de revisão e retificação constantes, de contínua adaptação. Além disso, ressaltam que uma das peculiaridades da pesquisa qualitativa é a possibilidade de incluir pesquisa de campo tanto para esclarecer informações quanto para descobrir novos dados.

Outra vantagem dessa abordagem para o desenvolvimento deste trabalho é a promoção de "maior profundidade aos dados, dispersão, riqueza interpretativa, contextualização do ambiente ou entorno, detalhes e experiências únicas", além da flexibilidade da metodologia(144)p.41. Além disso, é adequada a fenômenos pouco explorados - como é o caso desta proposta - proporcionando ferramentas para promover maior familiaridade com o tema.

A fim de elaborar um panorama mais completo do caso, buscou-se a utilização de múltiplas fontes de dados, como documentos de origens diversas no âmbito do governo 
brasileiro e das organizações estudadas e entrevistas com atores-chave de diferentes instituições, de modo a tentar evitar possíveis vieses pelo uso de uma única fonte.

\subsubsection{TÉCNICAS DE COLETA DE INFORMAÇÕES}

Como técnicas para o desenvolvimento desse estudo e levantamento de informações foram utilizados extensa pesquisa bibliográfica, análise documental e entrevistas com atoreschave.

A pesquisa bibliográfica foi importante para a contextualização do problema, bem como para reconhecer a existência de conhecimento prévio que pode auxiliar na detecção de conceitos-chave, no emprego métodos de coleta e análise de dados, na sua interpretação e entendimento (144). A pesquisa bibliográfica foi feita em bancos de dados como Scielo, CAPES periódicos, Pubmed e Google Scholar. Os resultados dessa pesquisa estão no capítulo "Revisão Bibliográfica".

A análise documental foi feita pelo estudo de documentos oficiais como decisões, resoluções, atas, tratados, pronunciamentos e notas oficiais, entre outros, emitidos no pelos atores identificados e organizações internacionais em foco, referentes ao escopo do estudo. Para selecionar a amostra documental levou-se em consideração critérios como capacidade de coleta e análise por parte do pesquisador e a capacidade da amostra levar à compreensão do fenômeno(144).

Esse componente foi importante para informar detalhes sobre decisões oficiais e sua implementação, compreender o contexto no qual foram realizadas tais escolhas, identificar possíveis entrevistados e limitar o volume de informações a ser esclarecido por meio de entrevistas. Além disso, tornou disponíveis dados para a descrição e comparação das respostas do Brasil e das organizações internacionais selecionadas. Os resultados dessa análise podem ser encontrados no capítulo sobre as Respostas à ESPII.

No caso do governo brasileiro, foram realizadas pesquisas nos sites dos Ministério da Saúde (MS) e no de Relações Exteriores (MRE).

No site do MRE, foram realizadas pesquisas em dois momentos, com foco na busca de atos internacionais. No dia 20 de setembro de 2016 e no dia 10 de janeiro de 2019. Na primeira busca, ainda na plataforma gerida pelo SERPRO (Serviço Federal de Processamento de Dados) e pela Divisão de Atos Internacionais (DAI/MRE), o termo "Zika" foi pesquisado tanto de 
forma geral, quanto pelo tema saúde. Também foi acrescido o filtro de tempo, com celebração de janeiro a setembro de 2016. Não foram encontrados atos naquele momento.

Em 2019, a nova Plataforma Concórdia para pesquisa da Atos Internacionais do Itamaraty já estava no ar. Estima-se que o novo site esteja no ar desde julho $2018^{31}$. Na nova busca, tampouco foram encontrados resultados para a busca pela palavra "Zika". A nova plataforma não disponibiliza a busca por temas pré-determinados. Além disso, quando se coloca a data de celebração do acordo, o filtro não é implementado e aparecem todos os acordos sobre a palavra ou expressão pesquisada.

Na busca geral pela palavra "Zika", foram encontradas 49 entradas. 37 delas são notas de Embaixadores do Brasil em países estrangeiros, 6 da América do Sul (Argentina, Bolívia, Chile, Colômbia, Equador e Uruguai), 3 dos Estados Unidos. Também foram encontrados um pronunciamento e uma nota presidencial sobre o tema e um comunicado conjunto com um país sul-americano, o Chile. A lista de entradas encontradas encontra-se no Anexo II.

No site do MS, foram encontradas informações relevantes na área da Assessoria de Assuntos Internacionais, como uma lista de Instrumentos Internacionais da Área da Saúde, pesquisada em 20 de setembro de 2016 e revisada em 27 de fevereiro de 2019. Nesta lista, encontram-se dois atos celebrados em 2016 com os Estados Unidos tendo o vírus Zika como tema.

Ainda no site do MS, foi realizada uma busca geral sobre notícias com o tema Zika, em 09 de julho de 2017. Foram encontradas 353 notícias relacionadas, uma média de 29 notícias por mês. Uma lista das notícias encontradas com as respectivas datas de publicação e os dois atos internacionais está no Anexo III.

O MS reuniu, ainda, muitas informações sobre a resposta do Sistema Único de Saúde em um documento lançado em 2017: vírus Zika no Brasil: a resposta do SUS. As informações epidemiológicas foram retiradas dos Boletins epidemiológicos disponibilizados pelo MS: http://www.saude.gov.br/boletins-epidemiologicos.

No site do Mercosul (www.mercosur.int) existe uma pesquisa por documentos. A primeira dificuldade encontrada foi escolher exatamente qual tipo de documento buscar: textos

31 Não foram encontrados dados precisos sobre o lançamento da Plataforma Concórdia, visto que a notícias que se segue não tem data: http://www.portalconsular.itamaraty.gov.br/sem-categoria/lancamentoconcordia. Acesso em 02/04/2019. 
fundacionais; Tratados, protocolos e acordos; Atas e anexos; Comunicados; Declarações e Decisões Presidenciais. Foram realizadas buscas na seção Tratados, Protocolos e Acordos; Normativa; Atas e anexos; e Declarações e Decisões Presidenciais, entendendo que nelas se encontrariam as informações sobre os acordos e decisões relevantes para esta pesquisa.

Na seção de Declarações e Decisões Presidenciais, não foram encontrados documentos referentes ao Zika para 2016, apenas uma Declaração dos Ministros de Relações Exteriores sobre as negociações do acordo com a União Europeia. Na seção Protocolos e Acordos, não existem documentos com a palavra-chave Zika e nenhum foi firmado em 2016.

Na seção de Atas e Anexos, a busca pela palavra-chave Zika não funcionou. Nenhum documento foi encontrado por este método. Dessa forma, buscou-se manualmente reuniões dos anos de 2015 e 2016 que tivessem relação com a Saúde e ao mesmo tempo tratassem de temática relacionada ao tema Zika e malformações congênitas:

- Reunião de Ministros de Saúde (RMS);

- Comitê Coordenador da RMS;

- Comissão Intergovernamental Implementação do RSI (CIRSI);

- Comissão Intergovernamental de Controle de enfermidades de Transmissão Vetorial (CICETV);

- Comissão Intergovernamental Saúde Sexual e Reprodutiva (CISSR);

- Comissão de Serviços de Atenção à Saúde (COSERATS);

- Comissão Intergovernamental de Determinantes Sociais de Saúde e Sistemas de Saúde (CIDSS);

- SGT No11 Saúde;

- Comissão de Vigilância em Saúde (COVIGSAL).

Durante a pesquisa, pese não haver menção à esta reunião de junho de 2016 no site do Mercosul, o documento foi solicitado ao coordenador nacional do Uruguai, país que era a PPT do bloco naquele momento. Entretanto, não foi possível acessar o documento. Além disso, foi obtido informe final da PPT Uruguai em pesquisas na internet.

Para outras instâncias do bloco, que poderiam ter tratado do tema, mas não são fóruns diretamente relacionados, foram buscados documentos de 2016: Grupo Técnico da Comissão de Coordenação de Ministros de Assuntos Sociais do Mercosul (GT-CCMASM); Comissão de Coordenação de Ministros de Assuntos Sociais do Mercosul (CCMASM); Grupo de Trabalho Gênero e Direitos Humanos das Mulheres (GT-GDHM); Instituto de Políticas Públicas em 
Direitos Humanos (IPPDH); Instituto Social do Mercosul (ISM); Conselho do Instituto Social do Mercosul (CISM); Reunião de Altas Autoridades em Direitos Humanos (RAADH); Comissão Permanente de Promoção dos Direitos de Pessoas com Deficiência(CPD); Observatório Mercosul de Sistemas de Saúde (OMSS). A tabela com detalhes sobre os documentos encontrados está no Anexo IV.

Para documentos da Unasul, utilizou-se o site da Secretaria Geral (SG) do bloco (www.unasursg.org) e do Instituto Sul-americano de Governo em Saúde (ISAGS), ambos retirados do ar em setembro de 2019. Pelo Regulamento da Unasul, a SG tem como uma de suas funções ser o repositório de documentos do organismo. Nesse sentido, realizou-se uma busca na plataforma digital pela palavra Zika em 10 de julho de 2017 e foram encontrados 2 documentos. Uma Declaração do Conselho de Ministras e Ministros de Relações Exteriores e uma ata do Conselho de Saúde da Unasul. Também foram realizadas buscas no site do ISAGS em 10 de julho de 2017, quando foi encontrado um Informe do Instituto com matéria jornalística a respeito do vírus Zika e a mesma ata do Conselho de Saúde. Os detalhes sobre os documentos estão no Anexo V.

No site da Organização Pan-americana da Saúde, foram realizadas buscas também de 10 de julho de 2017 pelas reuniões de 2016 do Conselho Diretivo e do Comitê Executivo. Não foi realizada busca pela Conferência Sanitária Pan-americana, pois ela se reúne apenas a cada 5 anos. Os informes finais das reuniões funcionam como suas atas, contendo resumo das discussões e encaminhamentos. Dessa forma, foi possível encontrar as menções ao Zika e os documentos que possivelmente tratariam do tema.

Buscou-se documentos referentes a última reunião dessas instância de 2015 e aquelas realizadas em 2016. Nesse período, foram realizadas 3 sessões do Comitê Executivo $\left(157^{\mathrm{a}}, 158^{\mathrm{a}}\right.$ e $159^{\mathrm{a}}$ ), tendo o Zika mencionado em 1 informe final, da $158^{\mathrm{a}}$ sessão; e duas do Conselho Diretivo $\left(54^{\mathrm{a}}\right.$ e $\left.55^{\mathrm{a}}\right)$, com o tema presente em ambos informes finais. Com a análise dos informes, foram identificados outros 12 documentos em que a discussão dos pontos tiveram menção ao Zika; mas 4 desse documentos não mencionam o tema. Os detalhes sobre os documentos estão no Anexo VI. Além disso, foi utilizado como base um documento síntese da resposta da organização, "Response to the Epidemics of Zika Virus", obtido quando da visita da autora à sede da Organização.

Os alertas epidemiológicos de 2016 também foram encontrados no site da OPAS em: https://www.paho.org/hq/index.php?option=com_content $\&$ view=article\&id=10898:2015archive-by-disease-Zika-virus-infection \&Itemid=41443\&lang=en. 
Após a pesquisa documental, foram realizadas entrevistas semiestruturadas. A utilidade desse método de coleta de dados foi múltipla: (i) clarificou informações coletadas durante a fase de pesquisa documental; (ii) foi importante para compreender os contextos em que as respostas das organizações foram desenhadas e operacionalizadas; (iii) porque o objeto de estudo requer uma abordagem qualitativa, as entrevistas foram importantes para entender o julgamento, percepção e atitude dos envolvidos nas atividades de resposta das organizações.

Foram entrevistados 7 informantes-chave. As entrevistas foram realizadas pessoalmente, por videoconferência ou chamada de voz, com participação de pessoas do alto escalão das organizações estudadas. Os critérios para seleção dos entrevistados foram: o fato de terem participado como responsáveis ou coordenadores da resposta ao Zika na sua instituição (RC); ser coordenador/diretor de cooperação internacional em saúde da sua instituição $(\mathrm{CN})$; ser ponto focal de vigilância em saúde com participação em reuniões das Organizações Internacionais estudadas (PF). Ainda, foi selecionado um entrevistado devido à sua interface política com as três organizações estudadas (POL). Os vícios de linguagem e outros elementos semelhantes foram retirados das falas para melhor compreensão do seu conteúdo, desde que não alterassem o sentido das sentenças.

O contato inicial foi feito por e-mail ou Whatsapp, para agendar previamente as entrevistas. Alguns contatos inicialmente selecionados não responderam aos e-mails ou mensagens. A estratégia para lidar com essas perdas foi tentar buscar outras pessoas que tivessem relações semelhantes com o tema proposto, ou que estivessem em posição análoga. Isso não foi possível em dois casos: os representantes da Venezuela, que era PPT do Mercosul no segundo semestre de 2016 (não reconhecida pelos demais membros) e da Unasul em 2016; e da Argentina, que assumiu a PPT do Mercosul em dezembro daquele ano. Além desses, não houve resposta de mais um selecionado para tratar da interface política.

Foi realizada pesquisa sobre o contexto de inserção e história profissional dos entrevistados selecionados para que as perguntas fossem adequadas a cada perfil. Um modelo de entrevista pode ser encontrado no Anexo VII.

O roteiro de entrevistas foi semiestruturado, permitindo flexibilidade nas respostas e serviu antes como guia do que como um rigoroso modelo de entrevista. Além disso, cada entrevista foi precedida de leitura e de assinatura de um Termo de Consentimento Livre e Esclarecido como requerido pela Plataforma Brasil (uma base nacional e unificada de registros de pesquisas envolvendo seres humanos para todo o sistema CEP/CONEP) (Anexo VIII). 
2.1.2 Elaboração de uma grade de análise dos resultados da pesquisa

As informações coletadas por meio da pesquisa documental e das entrevistas foram organizadas primeiro, com uma descrição das respostas do Brasil e das organizações estudadas frente à emergência do vírus Zika.

A partir da literatura sobre transferência/circulação/difusão de políticas apresentada, foi construída uma grade de análise. Aos mecanismos de difusão apresentados por Porto de Oliveira, foram acrescentados também outros elementos, presentes por exemplo nos estudos de Dollowitz e Marsh, além dos níveis de governança de Bulmer a Padget.

Os elementos das respostas foram organizados dependendo de dados que pudessem fazer referência à grade, como mecanismos de indução institucional, espaços transnacionais e produção de conhecimento, além de outros elementos, como a aplicação do RSI, de acordo com as evidências coletadas. Versões completas desta grade serão apresentadas no capítulo 4, que faz uma análise dos resultados apresentados no anterior. 
Figura 6: Grade de análise - circulação de políticas públicas

\begin{tabular}{|c|c|c|}
\hline \multicolumn{3}{|r|}{ Grade de análise } \\
\hline & categoria & descrição \\
\hline $\begin{array}{l}\text { Elemento } \\
\text { difundido }\end{array}$ & $\begin{array}{l}\text { Concretos } \\
\text { Abstratos }\end{array}$ & $\begin{array}{l}\text { ideia, paradigma, instituição, soluções para ação pública, } \\
\text { dispositivos normativos, programas, modelos, tecnologias }\end{array}$ \\
\hline Direção & & Lugar de origem da política e lugar de adoção \\
\hline \multirow{2}{*}{$\begin{array}{l}\text { Mecanismos } \\
\text { Institucional }\end{array}$} & $\begin{array}{l}\text { Indução institucional } \\
\text { (continuum) }\end{array}$ & $\begin{array}{l}\text { Alguma instituição/país promotor induziu a adoção da política } \\
\text { ou elemento, adotada de forma racional, voluntária, } \\
\text { condicionada ou coercitiva }\end{array}$ \\
\hline & Espaços transnacionais & $\begin{array}{l}\text { A instituição/país promotor oferece espaços para o debate e } \\
\text { legitimação de políticas/elementos em reuniões, cúpulas, } \\
\text { capacitações e workshops, etc. }\end{array}$ \\
\hline \multirow{4}{*}{$\begin{array}{l}\text { Mecanismo } \\
\text { Construção } \\
\text { social }\end{array}$} & $\begin{array}{c}\text { Produção de } \\
\text { conhecimento } \\
\end{array}$ & $\begin{array}{l}\text { Teorias, paradigmas e teses, produzidas pela instituição/país } \\
\text { promotor promovem a legitimidade da política/elemento }\end{array}$ \\
\hline & $\begin{array}{l}\text { Legitimidade da instituição } \\
\text { promotora }\end{array}$ & $\begin{array}{l}\text { A instituição/país promotor da política tem legitimidade/ é } \\
\text { reconhecida como autoridade no assunto }\end{array}$ \\
\hline & Coalização de apoio & $\begin{array}{l}\text { Houve coalização interna que apoiasse a adoção de uma } \\
\text { determinada política em uma instituição/país }\end{array}$ \\
\hline & Pressão internacional & $\begin{array}{l}\text { Diversos atores como Instituições, imprensa, populações } \\
\text { exercem pressão para a adoção da política/elemebro }\end{array}$ \\
\hline $\begin{array}{l}\text { Mecanismo } \\
\text { individual }\end{array}$ & $\begin{array}{l}\text { Embaixadores/circulação } \\
\text { internacional de indivíduos }\end{array}$ & $\begin{array}{l}\text { Indivíduos que têm autoridade sobre a política (política, teórica, } \\
\text { prática ou técnica); cuja ação é independente da instituição a } \\
\text { que pertencem; e agem continuamente no processo de sua } \\
\text { promoção }\end{array}$ \\
\hline Outros fatores & Tensões e disputas & $\begin{array}{l}\text { Tensões entre instituições ou discursos para a adoção de uma ou } \\
\text { outra política. Entre países, entre instituições e entre instituições } \\
\text { e países }\end{array}$ \\
\hline $\begin{array}{c}\text { Nível de } \\
\text { Governança }\end{array}$ & $\begin{array}{l}\text { Hierárquica/ } \\
\text { supranacional }\end{array}$ & Vertical/coercitiva \\
\hline
\end{tabular}

Fonte: elaboração própria. 


\section{AS RESPOSTAS: BRASIL, OPAS, MERCOSUL E UNASUL}

Este Capítulo descreve as respostas à Síndrome Congênita do vírus Zika de maneira geral, e especificamente à Emergência de Saúde Pública de Importância Internacional respectiva.

São apresentadas informações referentes às ações realizadas no âmbito do governo brasileiros, pela OPAS, o Mercosul e a Unasul, coletadas por meio de análise documental e das entrevistas.

\subsection{A RESPOSTA DO BRASIL}

O governo brasileiro atuou em diversas frentes para responder à epidemia do vírus Zika e à Emergência de Saúde Pública de Importância Internacional decorrente. A resposta do Sistema Único de Saúde foi fundamental, atuando na área de vigilância em saúde, na assistência e também na área de pesquisa e desenvolvimento.

Além disso, o governo também atuou por meio da mobilização de forças políticas internas e de cooperação internacional com países e instituições a fim de obter soluções comuns para as consequências dessa emergência.

\subsubsection{A estruturação da resposta e a aplicação do RSI}

A detecção do aumento dos casos de microcefalia em Estados do Nordeste, como a Bahia e Pernambuco, foram fundamentais para a declaração de emergência em tela. Entre a aparição do vírus e a tomada de ações contundentes devido ao aumento incomum de malformações congênitas em bebês, houve um lapso temporal importante, já que as autoridades acreditavam tratar-se de mais uma arbovirose com sintomas leves.

Um dos fatores apontados como fundamentais para que o Brasil conseguisse reconhecer, notificar e responder ao problema foi a existência de um Sistema Único de Saúde (SUS), com capacidade para a pronta detecção e para a estruturação de uma resposta.

Bom, acho que o principal fator no Brasil é um fator precedente, que é a existência do SUS. [...] isso permitiu não apenas a detecção da microcefalia, mas o acesso das pessoas a esse sistema e a conexão de informações entre coisas que vinham acontecendo e sendo absorvidas na atenção básica, com informações geradas por um sistema de vigilância que é parte integrante desse sistema [...]. RCG2(145) 
A operacionalização desse sistema de vigilância é feita em todos os Estados de forma integrada pelos Centros de Informações Estratégicas em Vigilância em Saúde (CIEVS) ${ }^{32}$, que formam uma Rede Nacional de Alerta e Resposta às Emergências em Saúde Pública. Essas estruturas são fundamentais para levar informação oportuna às autoridades de vigilância do país, o que foi feito ainda quando não se sabia qual era o agente etiológico que acometia a população, como demonstra o entrevistado RCG1/PF1(146).

Como o ministério tinha uma rede, a rede CIEVS, que permitia essa detecção rápida e comunicação entre os estados e o nível central, ofereceram apoio aos estados, mandaram equipe pra investigar nos estados do nível nacional. Então documentaram o surto, mas não chegou a esclarecer qual foi o agente e qual era efetivamente a doença em 2014. RCG1/PF1(146)

Outro entrevistado apontou o fato de o Brasil ter esse sistema de vigilância forte e destacou a equipe que ocupava o Ministério naquele momento. A citação da equipe é relevante porque indica o contexto em que a resposta começou a ser desenhada, ainda no governo da Presidente Dilma Rousseff.

O sistema de informação do Brasil é bom, o alerta epidemiológico funciona, funcionou. Eu acho que seria mais grave se isso acontecesse em países com sistemas mais débeis de vigilância. A comunicação, compartilhar informação dos clínicos foi chave, a consciência de que tinham que avisar as autoridades foi chave, isso feito em tempo recorde. Portanto, a resposta também. A equipe do ministério era sólida naquele momento e foi uma resposta contundente, clara e bem articulada. RCOI2(147)

Essa capacidade de ter um sistema de vigilância que reagiu rapidamente e produziu informação confiável também foi apontada como determinante para que a OMS declarasse a ESPII.

Yo creo que, para mí es por un lado contar con información muy fiable. Más allá del tamaño y la extensión de Brasil, tiene una capacidad de recolección de información muy desarrollada, y pudo demostrar en un periodo muy corto, la magnitud del problema. [...] y eso fue lo que determinó que la OMS pudiera tomar la decisión de que eso fuera de importancia de salud pública internacional. CN1(148)

A situação emergencial e incomum que se desenrolava levou o Ministério da Saúde a ativar estruturas de resposta a emergências, como o COES (Centro de Operações de Emergência de Saúde) de acordo com o Plano de Resposta às Emergências em Saúde Pública(149). Esse mecanismo objetiva coordenar as ações da resposta nacional, mobilizando recursos e produzindo análises de dados para basear as decisões de gestores e técnicos, articulando o ciclo

32 Todos os Estados do país têm Centros de Informações Estratégicas em Vigilância em Saúde (CIEVS), que formam uma Rede Nacional de e Alerta e Resposta às Emergências em Saúde Pública. Essas estruturas são fundamentais para levar informação oportuna às autoridades de vigilância do país. 
de informações nas três esferas de governo. Além disso, é o COES o responsável pela produção de dados enviados a organizações como a OPAS, como preconiza o $\operatorname{RSI}^{33}$. (149)

Em 23 de outubro de 2015, a OMS foi notificada do aumento de casos de microcefalia no país por meio do Ponto de Contato Regional do Regulamento Sanitário Internacional; e após nova avaliação, no dia 29, identificou o evento como potencial ESPIN(150).

Nesse sentido, um dos entrevistados enfatizou que o Brasil cumpriu rigorosamente o que estava estabelecido pelo RSI, e notificou desde a situação inicial de infecção pelo vírus, como a suspeita da associação entre ele e as malformações congênitas:

Como o Brasil atuou foi exatamente o que o regulamento buscava implementar na prática da Vigilância [...] Se tem um evento que é novo (no caso, infecção: primeira vez que se tem detectado infecção pelo vírus Zika no Brasil), se notifica. É isso que o regulamento diz. E foi feita a notificação imediata. [...] No segundo momento, quando se tinha suspeita de uma possível relação causal entre a infecção materna pelo vírus Zika e a ocorrência de microcefalia e, depois, com síndrome congênita, se notifica. Era uma suspeita ainda baseada em algumas evidências: se fez a notificação. RCG1/PF1(146)

Esse alerta às autoridades e a forma transparente com que o país transmitiu seus dados foi destacada pelos entrevistados, enfatizando a colaboração com a OPAS e a OMS desde o primeiro momento.

Eu percebi total transparência. Em nenhum momento eles buscaram (de longe!) esconder, nem mesmo retardar, como às vezes acontece com a Vigilância - "não, deixa eu ter uma confirmação, espera mais um pouco", - não; eles souberam da suspeita que havia relação causal, comunicaram imediatamente à OPAS, à OMS; e se prontificaram a fornecer todas as informações. RCG1/PF1(146)

Desde o início desta investigação houve uma comunicação intensa do Ministério da Saúde com a Organização Pan-americana de Saúde e com a OMS. Já na primeira reunião que nós tivemos em Pernambuco, a primeira reunião mesmo, onde não se sabia nada sobre o que estava acontecendo, apenas as informações sobre o número de crianças nascidas com microcefalia, nós já convidamos a representação da Organização da Pan-americana da Saúde para participar. RCG2(145)

Em 10 de novembro de 2015, a SVS/MS ativou o COES e, no dia seguinte, foi declarada a Emergência em Saúde Pública de importância Nacional “por alteração do padrão de ocorrência de microcefalias no Brasil, com base no Decreto ${ }^{\circ}$ 7616, de 17 de novembro de $2011 \%$. (150)

33 De acordo com o informado à 69a Sessão da AMS, como consta no documento CD55/12(210) do Conselho Diretivo da OPAS, em 2016, o Brasil tinha 99\% de cumprimento das capacidades básicas do RSI. Apenas a capacidade laboratorial $(96 \%)$ e de resposta a eventos químicos (92\%) constavam como inferior a $100 \%$, segundo a autoavaliação do país. 
A declaração da ESPIN pelo governo brasileiro certamente serviu de alerta para os países vizinhos, mas o comportamento do país também contribuiu para uma comunicação transparente e uma parceria intensa com a OPAS como já demonstrado, e com OMS, como reforça RCG2(145):

\begin{abstract}
Uma vez que as informações foram ganhando uma configuração mais precisa, entrando no mês de novembro, no momento em que nós declaramos a emergência de saúde pública, nós fizemos uma sugestão à OMS de que acompanhasse a declaração de emergência brasileira, uma vez que havia uma possibilidade grande de que o Zika atingisse outros países como tinha acontecido no passado recente com o Chikungunya transmitido pelo mesmo vetor. RCG2(145)
\end{abstract}

Isto é corroborado pela fala de CN1 sobre a relevância de a epidemia ter se localizado no Brasil.

Es el hecho de que más allá que Brasil es uno de los países vinculados a este vector, tiene anualmente la taja más grande de dengue que los demás países en la región, la importancia es que, igualmente el vector existe en Paraguay - en Paraguay hay dengue, en Argentina hay dengue, en Uruguay hace dos años hubo un caso de dengue, y por lo tanto está el vector. Y eso hace con que toda la región, esa advertencia, ese llamado, esa alerta de Brasil, genera las condiciones para pensar que también esto puede ocurrir al resto de los países y ahí a intensificar las medidas de prevención en lo que tiene que ver con el combate al vector. CN1(148)

Em 05 de dezembro, o governo Federal, em parceria com Estados e Municípios, lançou o Plano Nacional de Enfrentamento à Microcefalia(151). A estratégia é dividida em três eixos de ação: 1) Mobilização e Combate ao Mosquito (atuação intersetorial, com mobilização de pessoas para ações de educação em saúde e visita a residências; apoio logístico para transporte de insumos como inseticidas, ações nas escolas e campanhas de conscientização); 2) Atendimento às Pessoas (criação de protocolos e diretrizes, ampliação de coberturas de exames diagnósticos, ampliação do Programa Viver sem Limite, voltado para pessoas com deficiências); e 3) Desenvolvimento Tecnológico, Educação e Pesquisa (ações de incentivo a pesquisa e desenvolvimento de novas tecnologias).

A notificação à OPAS e à OMS do evento incomum e a adoção dos mecanismos contidos no RSI indicam que o Brasil incorporou e pôs em prática essa política. Entretanto, como vimos, isto apenas não é suficiente para uma declaração de ESPII. No caso da emergência do Zika, o tempo da declaração suscitou críticas já que como algo grave, esse tipo de situação demanda uma resposta rápida e bem articulada. A defasagem entre as declarações de emergência entre o Brasil, em outubro, a OPAS, em dezembro, e a OMS em fevereiro do ano seguinte, provocaram críticas importantes dos entrevistados, corroborando também aquela feita à OMS por Lucey e Gostin(24), como já citado. 
Quando perguntado sobre se a declaração potencializou a resposta, RCG1/PF1(146) foi enfático:

Eu acho que potencializar não porque já foi tarde em relação ao início do evento no Brasil; porque os casos de microcefalia começaram a ocorrer de outubro a novembro de 2015 . O reconhecimento se deu quase uma semana, dez dias depois, logo no início de o surto detectado. [...] E a declaração internacional foi em $1^{\circ}$ de fevereiro, quero dizer, quase três meses depois. Então toda a resposta já estava em execução. RCG1/PF1(146)

As incertezas, de algumas autoridades e instituições, sobre a causalidade daquele fenômeno podem ter contribuído para isso, embora grande parte da comunidade científica brasileira já tivesse certeza da vinculação entre o vírus Zika e os casos de malformações congênitas que aumentavam.

Tanto foi que a declaração da emergência nacional veio meses antes da declaração da emergência internacional. [...] O Brasil, quando declarou a emergência, a declarou como já reconhecendo a associação. Naquele momento, grupos de pesquisa fortes questionavam, criticavam inclusive, de que essa associação não estava estabelecida. Então, chegou a ser até um gesto ousado da equipe que estava na época. [...] Meses depois, o CDC publicou um estudo com base no critério de causalidade que demonstrou que realmente era uma associação causal. RCG1/PF1(146)

Pese as críticas feitas ao timing da OMS para finalmente decretar a ESPII, a declaração trouxe algumas vantagens, que podem ser entendidas como uma ferramenta de indução institucional à implementação do RSI. Uma análise detalhada à luz dos conceitos da abordagem de disseminação internacional de políticas será feita no próximo capítulo. No caso do Brasil, com a série de dúvidas que giravam em torno da causalidade do aumento de malformações congênitas, a declaração agregou legitimidade e peso ao fenômeno, vindo de uma instituição global de prestígio.

Então, toda a resposta já estava em execução. Agora, facilitou, claro [...] Com o reconhecimento da OMS, com a declaração da OMS, se reconhecia a causalidade e chamava a atenção de que 'olha, esse evento merece que seja dada a devida importância'. RCG1/PF1(146)

Do ponto de vista nacional, isso reforçou, digamos que foi um reforço técnico e um reforço político à declaração que o governo havia feito, uma vez que tudo que se referia a microcefalia e a Zika naquele momento despertava muito a polêmica na sociedade, muito questionamento. [...].RCG2(145)

Além disso, favoreceu a captação de recursos para a resposta e permitiu a compra de insumos em caráter emergencial para o acompanhamento dos casos doença congênita associada ao vírus. De fevereiro a abril de 2016, foram distribuídas 500 mil reações (7).

De acordo com o informante RCG1/PF1, a partir desse momento, não foram criadas novas medidas,

Só facilitou, incluindo aí a própria aprovação pelo congresso de uma liberação emergencial de 500 milhões de reais, que foi aprovado no primeiro semestre. Então isso tudo facilitou o ambiente para que o Ministério continuasse desenvolvendo suas atividades. E não só o Ministério, mas 
todas as instituições envolvidas (Fiocruz). Ou seja, ficava mais fácil para as instituições justificarem o que estavam desenvolvendo, as atividades, bem como conseguirem recursos pra priorizar aquilo. RCG1/PF1(146)

De acordo com informações coletadas, essas incertezas eram também alimentadas pela falta de informações semelhantes ao que estava ocorrendo no Brasil em países que também estavam sofrendo uma epidemia de Zika. De acordo com o entrevistado abaixo, alguns países não teriam sido transparentes com seus dados naquele momento:

\begin{abstract}
A meu ver, alguns países ou retardaram a detecção, ou retardaram o reconhecimento, ou a comunicação. Não vou citar nomes de países, [...]. Mas, basta analisar as publicações de profissionais de outros países, você vai ver que a ocorrência do aumento de casos de microcefalia se deu logo após (senão quase conjuntamente) o que ocorreu no Brasil. Ou seja, o Brasil partiu pra fazer logo a comunicação, enquanto os outros países não fizeram comunicação, esperaram um pouco para ver. Alguns, talvez, tenham até escondido os dados. Outros, como sempre acontece, disseram que 'não, são viajantes, são mulheres que viajaram nas áreas de ocorrência, no Brasil ou mesmo na América/outros países da América do Sul, e se infectaram': não reconheceram que estava ocorrendo no seu território. RCG1/PF1(146)
\end{abstract}

Outro entrevistado chama atenção para a diferença temporal na identificação de países como a Colômbia:

No período em que eu estava no Ministério nós tivemos uma troca de informações importantes com a Colômbia. Vamos lembrar que houve um certo lapso temporal entre a identificação da emergência no Brasil e a identificação de aumento importante de casos de microcefalia lá na Colômbia também, e foi o momento de maior conturbação política no Brasil. RCG2(145)

Uma das hipóteses para o não aparecimento de casos de microcefalia e outras malformações em países e territórios como a Polinésia Francesa, que apenas posteriormente identificou o surto, é a legislação favorável ao aborto seguro. Isso pode ter feito com que as mulheres que detectaram anomalias fetais tenham optado por essa via, sem alarmar as autoridades. Segundo o entrevistado RCOI2(147), essa informação poderia ter acelerado o entendimento do quadro no Brasil.

Na Polinésia francesa, o que aconteceu? Que a legislação francesa permite a interrupção da gravidez, o aborto. Então, claro que houve malformações congênitas, mas foram abortadas. Foram detectadas antes do parto, e podem abortar até a semana trinta e tantos. Então, as mulheres abortaram. E não documentaram isso. [...] Então, se os franceses tivessem notificado ou documentado que aquelas mulheres grávidas com Zika na Polinésia, houve tantos fetos com síndrome congênita e que foram feitos abortos. Aqui estaria tudo mais claro um pouco antes. RCOI2(147)

O combate ao vetor Aedes Aegypit tomou grande parte dos esforços do governo federal ${ }^{34}$. Nesse sentido, observamos características típicas dos processos de securitização como a

${ }^{34}$ Foram realizadas 274.333 .376 visitas a imóveis até 28 de outubro de $2016,83,91 \%$ deles foram de fato inspecionados. Além disso, a realização da Semana de Mobilização da Família e Comunidade na Escola pelo 
utilização de uma gramática da guerra, ações de curto prazo, mas com grande visibilidade, que objetivam acalmar os ânimos da população e demonstrar ação, e até a evocação das forças armadas. Além disso, forças políticas como entes da federação e também as instituições se uniram numa com a formação de uma verdadeira coalização de apoio para essa resposta.

O entrevistado RCG2(145) destacou a participação de autoridades de diversos setores, convocadas pela própria presidente Dilma. Ele descreveu esse momento como o combate ao Aedes Aegypti mais vigoroso da história do país.

Uma das grandes ações que foram organizadas naquele momento, foi uma estratégia que envolveu todos os segmentos do governo, envolveu todos os estados, boa parte dos municípios numa ação concentrada, muito intensa de combate aos mosquitos. Nós tivemos pela primeira vez o envolvimento da própria presidente da república, na época, que chamou, convocou todos os ministros, os diretores e os presidentes autarquias, de fundações, empresas estatais... convidou todos os governadores, convidou a frente nacional dos prefeitos, para em cada uma dessas reuniões apontar, difundir informação e compartilhar planos ou sugerir que cada um deles elaborasse um plano[...] para combate ao vetor, inclusive com a constituição de uma sala de coordenação e controle localizada aqui em Brasília [...] com o forte apoio de vários ministérios, buscando justamente estimular, fazer a coordenação e recolher continuamente informações sobre atividades desenvolvidas em cada um dos estados. Então, essa foi uma resposta muito intensa, acho que foi a resposta mais intensa e concentrada que nós já tivemos para combate ao Aedes aegypti na nossa história. RCG2(145)

As ações de controle vetorial se deram, principalmente, por meio da mobilização das Forças Armadas, reforçando o caráter securitário da resposta. Também foram acionados agentes de combate a endemias (ACE) e trabalhadores da saúde, como agentes comunitários (ACS), no sentido de realizar inspeções domiciliares e de lugares públicos em busca de focos do mosquito. Nessa linha, esse eixo tem como um dos pilares a participação comunitária com a finalidade de eliminar possíveis criadouros nas suas vizinhanças.(152)

Como estrutura de governança desse eixo para controle e monitoramento das visitas, foi criada a Sala Nacional de Coordenação e Controle (SNCC), em dezembro de 2015. Suas atribuições se relacionam a coordenação, supervisão, atualização e avaliação das ações de combate, produção e disseminação de informações relacionadas, além da gestão dos estoques de insumos para as ações; estímulo a implantação de Salas Estaduais ${ }^{35}$ e ao desenvolvimento de ações para o engajamento de instâncias locais e planejamento de comunicação estratégica.

combate ao Aedes Aegypti, realizada de 4 a 9 de abril de 2016, mobilizou 32 mil equipes de atenção básica, e envolveu mais de 77 mil escolas em 4787 municípios no país. (7)

${ }^{35}$ Foram criadas salas em todas as Unidades da Federação, e 1796 em municípios. (7) 
A SNCC foi coordenada pelo MS e situada no Ministério da Integração Nacional ${ }^{36}$, com participação do Ministério da Defesa (cedeu pessoal e participou de mobilizações da população) (152), em articulação com o MS (se comprometeu a intensificar as orientações em visitas a imóveis urbanos e em suas infraestruturas), MIN (participou da organização e do planejamento das ações), MEC (atuou com ações educativas nas escolas), MDS (atuou em parceria com o MS no acolhimento às famílias de crianças com microcefalia e na concessão do BPC), da Secretaria de Governo e da Casa Civil. (7)

Houve grande articulação das empresas federais; mobilizando recursos e pessoal para ações de resposta à epidemia. (7) Além disso, foram realizadas ações como o "Dia da Faxina", que mobilizou em janeiro 1,6 milhão de trabalhadores no sentido de inspecionar edifícios públicos federais em busca de potenciais focos do Aedes Aegypti.(153)

A importância dos Estados e Municípios brasileiros na detecção do vírus é inegável. Como já falamos anteriormente, a ação conjunta dos CIEVS e o trabalho articulado entre as três esferas de governo foi fundamental para que houvesse de fato uma resposta contundente das autoridades.

Esse eixo de resposta também demandou intensa articulação das três esferas de governo. Nesse sentido, o entrevistado RCOI1(154) resume bem, apontando a complexidade em atuar em três níveis, muitas vezes com capacidades diferentes de resposta.

En Brasil el control vectorial aún hay un LIRAa ${ }^{37}$, decidido a nivel nacional, con un manual actualizado, y ¿quién lo hace? El científico del control vectorial en nivel municipal. Y entre dos municipios tú tienes, en el mismo estado, diferencias abismales. De inversión, de formación de recursos humanos, de material, y de nivel científico. Yo te diría, es el aspecto más complejo de la respuesta en Brasil. RCOI1(154)

Além disso, houve participação importante dos Laboratórios de Referência Nacional (LRN) para arboviroses que, a partir da confirmação da circulação dos vírus no Brasil, diagnosticava de casos suspeitos junto com o IEC e a Fiocruz. Após a declaração da ESPIN, uma rede de laboratórios sentinela foi definida, composta pelo IEC, Fiocruz RJ, Fiocruz PE, Fiocruz PR e Instituto Adolfo Lutz (AL), tornando-se os laboratórios de referência para Zika(7).

Cerca de $90 \%$ da rede capacitada no país para realizar a técnica RT-qPCR para detecção da infecção pelo Zika vírus é composta por Laboratórios Centrais de Saúde Pública (Lacen).

${ }^{36}$ Esta informação é conflitante com a contida no documento da Casa Civil de resposta à epidemia, que afirma que a SNCC fica situada no Ministério da Defesa (152).

${ }^{37}$ Levantamento Rápido de Índices para o Aedes Aegypti. 
Estes são vinculados às SES e têm a finalidade de prover diagnostico laboratorial para os sistemas de vigilância em saúde. Seu perfil se difere dos demais laboratórios porque "realiza atividades técnicas de pesquisa, prevenção e promoção da saúde coletiva. Atua principalmente no diagnóstico laboratorial de agravos de notificação compulsória [...]” (7)p. 101.

Os municípios foram chamados a dar respostas no campo da atenção à saúde e muitas vezes estavam sobrecarregados pela falta de recursos financeiros e humanos especializados. No sentido de financiar algumas das ações, em 29 de dezembro de 2016, o MS publicou uma portaria repassando R 152 milhões para municípios reforçarem as ações contra o Aedes aegypti (155)

Também nesse sentido, o CONASEMS coordenou atividades como a realizada em parceria com a Johnson \& Johnson e o Instituto de Pesquisa e Apoio ao Desenvolvimento Social (Ipads), o projeto Zika Labs - Laboratório de Formação do Trabalhador de Saúde no Contexto da Microcefalia. Seu objetivo é capacitar trabalhadores do SUS para o cuidado de gestantes e crianças com microcefalia em regiões afetadas. Foram contemplados os municípios de Recife/PE; Campina Grande/PB; Salvador/BA; Juiz de Fora/MG; Araguaína/TO e Cuiabá/MT.

O estabelecimento do COES e da SNCC por conta da declaração da ESPIN fomentou a criação de Salas estaduais e municipais, estas compostas por representantes de secretarias e do Conselho de Secretarias Municipais de Saúde (COSEMS). A representação dos municípios pelo Conselho Nacional de Secretarias Municipais de Saúde (CONASEMS) na SNCC foi importante para a articulação tripartite nas ações e a intersetorialidade da composição da SNCC possibilitou novas formas de pensar o combate ao mosquito, desconcentrando a atenção da área da Saúde.

Para disseminação dos dados coletados, o MS divulgou diversos boletins e relatórios periódicos relacionados à epidemia. Esses documentos contém dados relevantes para a tomada de decisão e permitem que se tenha um panorama da epidemia no país e sobre a eficácia da resposta(152), legitimando e reforçando as ações no âmbito da resposta. Entre eles estão:

- Informe epidemiológico semanal do monitoramento de casos de microcefalia/Zika no Brasil: com dados por Unidade da Federação e evolução dos casos;

- Informe sobre o monitoramento de visitas domiciliares no Brasil: informe diário, com informações sobre a estratégia de visitas e gestão de insumos;

- Boletim epidemiológico de monitoramento dos casos de dengue, febre Chikungunya e febre pelo vírus Zika: boletim semanal, com dados por Unidade da Federação, com foco nas arboviroses dengue, Chikungunya e Zika;

- Boletim de microcefalia: boletim com dados sobre a microcefalia no país, por Unidade da Federação, com indicadores de cuidado e acolhimento. 


\subsubsection{A assistência}

No âmbito da assistência, uma parte sensível da resposta à epidemia do Zika diz respeito ao cuidado e ao acolhimento. O número de casos de bebês com microcefalia e outras malformações congênitas instava respostas rápidas e eficientes nesse sentido, para que o desenvolvimento pleno dessas crianças fosse alcançado. Para que isso ocorresse de forma eficiente, o sistema como um todo deveria estar preparado para dar suporte aos pacientes e suas famílias.

Nesse sentido, o SUS disponibilizou exames de diagnóstico do Zika e também da microcefalia, além do estímulo precoce às crianças com distúrbios neurológicos com acompanhamento fisioterápico e psicológico. Para o diagnóstico da microcefalia, além da medição do perímetro cefálico são necessários exames complementares de ultrassom transfontanela ou ultrassom para fechar o diagnóstico. O MS disponibilizou equipamentos portáveis para que a realização de telediagnósticos em cidades do interior, com pouca infraestrutura(152).

Entretanto, as dificuldades de estruturação de serviços de forma rápida, num contexto em que instituições e níveis de governo não estavam preparados previamente foram apontadas como entraves para uma adequada atenção por alguns entrevistados (RCOI1(154) RCG1/PF1(146)). Os desafios apontados referem-se a questões que não se resolvem instantaneamente como era exigido pela situação, tais como o treinamento de profissionais, diagnóstico diferencial, o fato de a rede não estar estruturada de antemão, o Sistema de Nascidos Vivos não estar adaptado para, por exemplo, qualificar o tamanho do perímetro cefálico etc.

Foi uma resposta que teve todas as dificuldades [...] de lidar com algo novo e algo para qual a rede não estava estruturada. Porque os casos da síndrome congênita, eles são muito semelhantes com alterações congênitas em recém-nascidos por outros agentes infecciosos. A rede não tinha uma resposta adequada para isso, estamos falando da rede de atenção ao neonato; ou mesmo no pré-natal, de detectar e abordar adequadamente depois do nascimento. Então você não tinha, no país, uma estrutura voltada pra isso, nem mesmo para registrar isso. $\mathrm{O}$ registro das anomalias congênitas era muito deficiente. Embora o SINASC permitisse um pouco detectar e monitorar essas alterações, mesmo o SINASC ele tinha deficiências, por exemplo, não permitia a quantificação do perímetro cefálico. [...] A resposta, ela lidou com essas dificuldades, de uma ausência de uma experiência prévia de tratar alterações congênitas pra recém-nascido (desde a detecção); a abordagem para essas crianças era totalmente insuficiente [...] Porque de certa forma se negligenciava isso. [...] E teve de estruturar uma rede pra isso, no meio de uma epidemia, já com milhares de casos ocorrendo, especialmente na região Nordeste, região com séria deficiência de infraestrutura de serviços. RCG1/PF1(146)

E complementa, apontando para dificuldades de padronização, como para a medição do perímetro cefálico, leitura de exames que identificavam de fato a presença de alguma anomalia e o desafio de lidar com uma rede despreparada para identificar e acolher os novos pacientes: 
Numa maternidade, a precisão da medição do perímetro cefálico é muito baixa quando você comprava uma unidade com outra, ou quando você ia verificar os métodos que eram utilizados. Então, coisas básicas como essa, que permitiriam você dizer se tinha ou não microcefalia, eram deficientes - e isso no momento de uma epidemia você não consegue corrigir imediatamente. Então você teria que, teoricamente, treinar todo mundo em coisa básica, desde medir o perímetro cefálico, realizar e analisar adequadamente ultrassonografia transfontanela. Então, procedimentos que já deveriam estar disponíveis e que não estavam para a rede como um todo. Tinham algumas unidades de referência, mas não era suficiente, obviamente. Então teve de treinar muita gente, teve de comprar equipamentos, teve de estender a rede (para o interior, principalmente); montar uma rede, na verdade. E isso teve de contar com redes estruturadas, com estruturas do serviço privado, por exemplo... RCG1/PF1(146)

RCG1/PF1(146) destaca, ainda, que foi necessário desenvolver o Registro de Eventos em Saúde Pública - RESP (Microcefalia) para a notificação dessa condição, que precisava da precisão da coleta de dados para seu bom funcionamento.

E ao mesmo tempo, houve necessidade de desenvolver um sistema de registro, que foi o RESP. Esse foi montado relativamente rápido, pela SVS; mas um sistema de informação só, não dá conta. Se você não tem uma forma adequada, sensível e precisa de capturar os dados adequadamente, o sistema não funciona bem. E além disso, é um sistema que precisa de dados da Vigilância e da rede de atenção, o que não era bem integrado... para o sistema tanto neonatal quanto pós-neonatal. [...]. Quando se foi ver na prática, não existia nada estruturado em termos dessa integração de vigilância com a atenção, que permitiria acrescentar um novo [...] o agente causador daquelas alterações congênitas [...] Mas de alguma maneira conseguiu-se montar isso, tanto que o sistema permitiu monitorar, a partir de determinado momento e de forma relativamente adequada, o que estava ocorrendo. RCG/P1F1(146)

O apoio psicossocial também é fornecido pelo SUS, nos Centros de Referência de Assistência Social (CRAS) e nos Centos de Apoio Psicossocial (CAPS). A Constituição de 1988 instituiu a Seguridade Social como "um conjunto integrado de ações de iniciativa dos Poderes Públicos e da sociedade, destinadas a assegurar os direitos relativos à saúde, à previdência e à assistência social"(156). Nesse sentido, o então Ministério do Desenvolvimento Social (MDS) trabalhou em articulação com o Instituto Nacional de Seguro Social para orientar equipes de assistência social e da previdência para o encaminhamento e instrução às famílias acometidas pela microcefalia no processo de requerimento do Benefício de Prestação Continuada - BPC(152).

Em 15 de março, o MS e o MDS publicaram uma Portaria Interministerial Conjunta ${ }^{\circ}$ 405(157), que institui no âmbito do SUS e Sistema Único de Assistência Social (SUAS) a Estratégia de Ação Rápida para o Fortalecimento da Atenção à Saúde e da Proteção Social de Crianças com Microcefalia. Seu objetivo geral foi

esclarecer, no mais curto prazo e na forma mais confortável para as crianças e suas famílias, o diagnóstico de todos os casos suspeitos, otimizando o uso da capacidade instalada disponível, e orientando a continuidade da Atenção à Saúde de todas as crianças com diagnóstico confirmado ou excluído para microcefalia. (157) 
A portaria também funcionou como um mecanismo de indução institucional no sentido de fomentar ações direcionadas pelo âmbito federal. Foram liberados recursos na ordem de $\mathrm{R} \$ 10,9$ milhões para apoiar Estados e Municípios na busca ativa de casos suspeitos de microcefalia, acesso a serviços diagnósticos (incluindo transporte e hospedagem) e melhoria na articulação entre os setores da Saúde e da Assistência social no cuidado com esses pacientes. (157) A estratégia estava prevista para findar em maio, mas foi prorrogada por mais 60 dias (153).

O Ministério das Cidades priorizou o acesso das famílias de crianças com microcefalia ao Programa "Minha Casa, Minha vida", dispensando o sorteio de praxe(7). Foi instituído também o programa de prevenção e proteção individual de gestantes em situação de vulnerabilidade socioeconômica contra o Aedes aegypti. As gestantes beneficiárias do Bolsa Família seriam favorecidas com a compra e distribuição de insumos como repelentes. (158)

Foi instituído ainda, o SIRAM, o Sistema de Registro de Atendimento às Crianças com Microcefalia, em abril de 2016. Seu objetivo era registrar os dados referentes ao monitoramento das crianças com microcefalia para aperfeiçoar as investigações epidemiológicas e o acompanhamento em saúde(159).

Pese as medidas tomadas no âmbito federal, a questão da vulnerabilidade da região e da população mais acometida pela epidemia também foi levantada pelos entrevistados, retomando a ideia de desigualdade apontada por Milton Santos(80) no acesso e também nas consequências que uma emergência internacional pode causar. Nesse sentido, apontam a falta de profissionais qualificados, de um sistema de vigilância materno-infantil bem estabelecido e da assistência às crianças afetadas; o que se aprofunda no caso do Zika.

As áreas mais pobres dos estados mais afetados não iam de uma hora pra a outra receber ultrassonografia com profissional adequado para fazer diagnóstico e dar o acompanhamento adequado. Uma deficiência (e essa é uma das grandes deficiências), foi exatamente o acompanhamento dessas crianças. [...] Mas dar ou acompanhamento adequado para essas crianças -que até hoje não é suficiente, exige muitos recursos. RCG1/PF1(146)

Além disso, destacam também para o perfil socioeconômico e para a situação ainda mais vulnerável da mulher no caso do Zika, que muitas vezes ficavam sozinhas para cuidar do bebê doente.

[...] que mulheres de classe econômica baixa, negras no geral, e jovens, muito jovens; formavam um perfil socioeconômico bem diferenciado. [...] Estou falando de áreas marginais, de áreas oprimidas, populações vulneráveis... levavam associado a aparição de uma criança com microcefalia ou o abandono do homem, da casa, do casal. Então ficaram muitas mulheres lá sozinhas. RCOI2(147)

E por outro lado, estamos falando de famílias pobres que, independentemente do apoio do Estado, da sua própria condição social, que [...] a mesma vulnerabilidade dessas famílias 
também é vulnerabilidade que as expõe a residir em áreas mais afetadas pela infecção por Zika. RCG1/PF1(146)

A maior parte das mulheres que haviam dado à luz a essas crianças eram de localidades, cidades ou bairros pobres da região Nordeste, particularmente dos estados de Pernambuco, da Grande Recife [...]. Em várias partes de todos os estados da região Nordeste, [...] esta correlação até hoje não está completamente esclarecida: de pobreza e ocorrência da infecção pelo Zika. Uma correlação que pareceu muito mais intensa do que aquela que era reconhecida com relação à dengue, transmitida pelo mesmo vetor. RCG2(145)

\subsubsection{Capacitação}

Diante dessa situação, a capacitação de recursos humanos se tornou fator essencial para que o sistema conseguisse se adaptar à nova realidade da epidemia, além de disseminar a ideia da causalidade e estabelecer protocolos de cuidado. No caso da emergência do Zika, as ações desse eixo objetivaram dar conta de falhas estruturais nos serviços que ficaram evidenciadas com a novidade da epidemia.

O treinamento de recursos humanos nessas ações e a produção de conhecimento pode ser enquadrado no âmbito do mecanismo de construção social no contexto da disseminação de políticas. Com a formação de pessoas e a disseminação de informações referentes à epidemia e ações necessárias, o país contribuiu para a legitimação de suas políticas e práticas.

Em janeiro de 2016, foi lançada uma portaria para a criação de Centros Colaboradores(160), que possibilitaria que serviços de saúde e instituições de ensino pudessem compartilhar conhecimentos e capacitar profissionais de saúde para o tratamento a pacientes afetados pelo Vírus Zika. A ideia era potencializar os recursos já existentes e promover a multiplicação desse conhecimento.(161)

Foi ainda instituído um serviço de consultoria gratuito pela internet e por telefone para médicos e enfermeiros; e para ACS, ACE, militares e para a população para tirar dúvidas sobre diagnóstico e tratamento. Além disso, as Secretarias Estaduais e o MS por meio de Núcleos de Telessaúde desenvolveram aplicativos de celular para divulgar estratégias de combate ao Aedes Aegypti. (153)

Com a OPAS, o Ministério de Saúde do Brasil disponibilizou curso oferecido pela pasta desde fevereiro sobre atendimento a pacientes infectados pelo Zika em inglês e espanhol. A Organização disponibilizou o Campus Virtual de Saúde Pública e fez os ajustes necessários para que a oferta atingisse o maior número de profissionais possível.(162)

Foram disponibilizados diversos cursos e módulos de capacitação para profissionais de saúde, assistência social, defesa civil e militares sobre temas como abordagem Clínica na 
Atenção Básica, Estimulação Precoce, Combate vetorial, Telediagnóstico para USG transfontanela, triagem ocular neonatal, entre outro. (153)

Na ocasião do Dia Mundial de Doação de Leite, dia 19 de maio, o país ainda lançou material em espanhol para orientação de profissionais de mais de 40 países. O foco do evento, feito por vídeo conferência, foi no atendimento a bebês nascidos com microcefalia, especialmente no que tange a amamentação. Esse conteúdo também estava disponível em português, oferecido pelo Observatório Zika de Amamentação.(163)

Além disso, Ministério da Saúde anunciou o financiamento de mais 1000 bolsas de residência médica, priorizando propostas que considerassem necessidades do SUS como a demanda de respostas à tríplice epidemia de Zika, Dengue e Chikungunya - e a assistência a pessoas com microcefalia. A priorização também seria por regiões: Nordeste, Norte e CentroOeste.(164)

Como forma de padronizar o conhecimento e a atuação dos profissionais e serviços de saúde, o SUS disponibilizou diversos protocolos e diretrizes clínicas para apoiar a prática médica.

- $\quad$ Guia de Vigilância em Saúde;

- $\quad$ Protocolos de Atenção Básica à Saúde da Mulher;

- Diretrizes para a Organização das Serviços de Atenção à Saúde em Situação de Aumento de Casos ou de Epidemia de Dengue;

- Dengue - Aspectos Epidemiológicos, Diagnóstico e Tratamento

- Dengue - Diagnóstico e manejo clínico

- $\quad$ Febre Chikungunya - Manejo clínico

- $\quad$ Protocolo de Vigilância e Resposta à Ocorrência de Microcefalia Relacionada à Infecção pelo Vírus Zika

- $\quad$ Protocolo de Atenção à Saúde e Resposta à Ocorrência de Microcefalia Relacionada à Infecção pelo Vírus Zika

- Diretrizes de Estimulação Precoce - Crianças de zero a três anos com Atraso no Desenvolvimento Neuropsicomotor Decorrente de Microcefalia

- $\quad$ Protocolo Clínico e Diretrizes Terapêuticas - Síndrome de Guillain-Barré

O documento "Diretrizes de Estimulação Precoce" é considerado o primeiro a reunir o conhecimento acumulado sobre a estimulação precoce de crianças com atrasos no desenvolvimento e abrange temas como desenvolvimento neuropsicomotor, o uso de tecnologia assistiva e a participação da família no processo. A ideia era promover um curso de EAD para capacitação.(165)

Com vistas a monitorar a assistência em termos de diagnóstico e tratamento para os bebês nascidos com microcefalia no Nordeste, o MS realizou, a partir de 22 de fevereiro, um mapeamento por telefone. As entrevistas questionavam sobre os procedimentos clínicos e 
laboratoriais contidos no Protocolo de Atenção à Saúde e nas Diretrizes de Estimulação Precoce, sobre o atendimento nos serviços de estimulação precoce e o acompanhamento na puericultura. (166)

Em novembro de 2016, o governo federal anunciou um repasse de $\mathrm{R}$ 52,6 milhões de reais por ano para a ampliação do diagnóstico e acompanhamento de gestantes infectadas (com recomendação de duas ultrassonografias durante o pré-natal) pelo vírus Zika e seus bebês até os três anos. Essa iniciativa expandiu o monitoramento da síndrome congênita associada ao vírus, com a inclusão de mais crianças. (167)

\subsubsection{Comunicação}

A novidade da epidemia e o que não se sabia sobre ela pautaram o grande desafio de lidar com esse tema na esfera pública. Transparência e prudência deveriam dar o tom dos discursos. Além do engajamento da população em ações de vigilância, a comunicação é fundamental para evitar pânico e subsidiar a sociedade de forma transparente sobre a situação da epidemia e as medidas necessárias para prevenção, e formas de acesso a diagnóstico e tratamento; sendo peça chave para fomentar a tomada de consciência e a adoção de medidas prioritárias. Além disso, é parte importante do mecanismo de construção social, a exemplo da capacitação, apoiando o processo de disseminação de políticas.

Nesse sentido, a comunicação foi apontada como uma das prioridades do governo brasileiro nesse no contexto da epidemia.

Houve um esforço enorme para que as informações adequadas fossem transmitidas para a
população e acho que nesse sentido os principais veículos ou mesmo veículos menores se
engajaram, participavam ativamente não apenas da difusão de informações, mas dos momentos
das entrevistas coletivas, buscavam uma compreensão conjunta melhor do que vinha
acontecendo. A construção de um conjunto de conhecimentos e informações que deveria ser
transmitido de uma maneira ampla a população. RCG2(145)

Para dar conta dessa necessidade, o governo agiu proativamente para comunicar as ações tomadas no âmbito da epidemia, sobre as formas de acolhimento e cuidado, além de fomentar a população a apoiar na eliminação de criadouros e prevenção (como uso de repelentes e roupas). (152).

A participação da população nessas ações é considerada fundamental para o sucesso das ações de combate ao vetor. Para isso, o governo programou o engajamento dos líderes comunitários para sensibilização da população local; produziu aplicativos para smartphones para que os usuários pudessem comunicar a localização de criadouros(152). 
Para consolidar as principais informações sobre a epidemia, foi criado um hotsite: www.combateaedes.saude.gov.br. Outra iniciativa, realizada em conjunto pelo MS, a OPAS e a UNICEF com o canal infantil de TV paga Cartoon Network, foi o lançamento de um vídeo ${ }^{38}$ que convoca crianças para a missão de combater o mosquito Aedes Aegypti, como se fossem super-heróis. Foi também lançado um jogo itinerante e uma campanha sobre a tripla epidemia.

Como peça fundamental na resposta a uma epidemia, a comunicação deve ser feita de forma estratégica e sensível. No caso em questão, pode-se destacar algumas lições aprendidas, como a que trataremos a seguir.

\subsubsection{Saúde Sexual e Reprodutiva}

Quando do início da epidemia no país, o então Ministro da Saúde, Arthur Chioro, declarou que "O vírus Zika não nos preocupa [...] Toda a nossa preocupação é com a dengue, porque dengue mata”, o que mais adiante revelou-se um equívoco; assuntos como controle de natalidade, aborto e más condições de saneamento vieram à tona no debate (7).

Nesse sentido, a recomendação inicial ${ }^{39}$ do então chefe da Secretaria de Vigilância em Saúde, Claudio Maierovitch, para que as mulheres em áreas de surto de microcefalia evitassem engravidar foi recebida com reservas. Logo depois de fazer esta recomendação, o Ministério da Saúde reviu sua posição e o próprio Maierovitch justificou esse episódio pela falta de informações naquele momento, além da necessidade de formular recomendações ainda que no plano individual (7).

Em $1^{\circ}$ de dezembro de 2015 foi realizada a primeira coletiva de imprensa sobre a relação Zika e microcefalia. O foco dos discursos foi "eliminar os criadouros dos mosquitos; proteger principalmente as mulheres grávidas e as em idade fértil, usar roupas que cubram a maior parte do corpo e evitar áreas com infestação do mosquito" (7)p. 48.

As gestantes ficaram em evidência nos discursos sobre o Zika, embora fossem secundárias na maior parte das ações. Levando em consideração a fraca apresentação de medidas de longo prazo, estruturantes, no sentido de evitar novas epidemias, e a necessidade de medidas individuais para evitar a exposição e infecção pelo vírus, o debate sobre saúde sexual e reprodutiva ganhou força.

${ }^{38} \mathrm{https}: / /$ www.youtube.com/watch?v=AFG2VA_H1Yc

39 http://g1.globo.com/hora1/noticia/2015/11/nao-engravidem-agora-diz-ministerio-da-saude-por-causada-microcefalia.html 
A mulher, vítima do Zika, e mãe que surgia nesse processo não foram colocadas como centrais no debate e nas ações de resposta à epidemia. Diniz(168) argumenta que "a terminologia epidemiológica nos faz esquecer que esses casos foram antecedidos por mulheres adoecidas"(p.1) e destaca a naturalidade com que é tratada a precariedade das políticas de acolhimento mulheres, em geral, pobres e nordestinas.

A questão do aborto foi levantada principalmente pela pesquisadora da UnB e do Instituto de Bioética Anis, Debora Diniz. Planejamento familiar e acesso à informação de qualidade estão plasmados na Constituição de 1988. Nesse sentido, em agosto de 2016, a Associação Nacional de Defensores Públicos (ANADEP) protocolou a Ação de Inconstitucionalidade (ADI) 5581(169) junto ao Superior Tribunal Federal (STF). Essa ADI solicitava inúmeras ações relativas ao controle da epidemia tais como acesso à informação às mulheres em idade reprodutiva, oferta de métodos contraceptivos, distribuição de repelente, além do direito ao aborto para mulheres infectadas pelo Zika em sofrimento mental. Além disso, 11 juristas de todo o país lançaram o "Manifesto 11 por 11 "40 apoiando a iniciativa e dando suporte jurídico às demandas da ADI.

No Brasil, o aborto é permitido em três casos: gravidez decorrente de estupro, risco à vida da mulher ou feto anencéfalo. Algumas interrupções de gravidez foram permitidas pelo acúmulo de líquido amniótico que causava risco de vida para a mãe(168) .

Diniz(168) chama atenção para a importância de se destacar o protagonismo da mulher no planejamento familiar e que esse debate não foi à frente no caso da epidemia do ZIKV, mesmo após as suspeitas de contaminação pela via sexual. Abstinência sexual e infecundidade soavam como recomendações absurdas diante das próprias dificuldades de se conseguir realizar um planejamento familiar no país ou um aborto seguro. Além disso, essas recomendações ressaltam a questão como uma responsabilidade individual da mulher, sem levar em consideração pontos estruturais já apontados(170).

Nesse sentido, Wenham e colaboradores(170) destacam a necessidade de implementar abordagens em saúde baseadas em direitos quando se trata de emergências de saúde. Entretanto, apontam desafios para essa aplicação, como resistências em incorporar um sistema consistente de direitos nesses casos e a ideologização do debate sobre o aborto, que foca nos direitos do feto.

40 http://www.justificando.com/2016/11/10/manifesto-11-por-11-uma-iniciativa-do-justificando-e-doanis-pela-saude-de-pessoas-afetadas-pelo-Zika/ 
Todos os esforços se voltaram para a eliminação do vetor e a pesquisadora ressalta: "Não ignoro que eliminar o Aedes Aegypti é medida urgente, mas soa como solução mágica para o desamparo que é hoje planejar uma gravidez no Brasil”(1) p. 141.

\subsubsection{Produção de conhecimento}

Um braço importante da resposta brasileira foi a Pesquisa e o Desenvolvimento. O vírus Zika, apesar de não ser uma novidade no mundo científico, tampouco havia tido tamanho protagonismo. Nesse sentido, diversas instituições brasileiras se mobilizaram para contribuir para a resposta nacional dentro de suas atribuições e especialidades. A produção de conhecimento nacional foi fundamental para embasar não apenas a relação causal entre o ZIKV e as malformações congênitas, mas também para elevar a qualidade da resposta de forma geral, disseminando informação qualificada sobre a epidemia. Além disso, é peça fundamental para promover uma política e fomentar sua adoção.

Do último trimestre de 2015 ao primeiro de 2016, o aumento de publicações sobre o Zika no Brasil aumentou mais de 300\%(152), fenômeno que também teve repercussões em âmbito mundial, com pesquisadores brasileiros encabeçando esta onda científica(7). São pesquisas entomológicas, clínicas, epidemiológicas e políticas. Esse dado contrasta com as afirmações de Diniz(168), que alega que quando comparados à quantidade de estrangeiros que escreveram sobre o Zika, os brasileiros não chegavam a $8 \%$.

A coordenação dessas ações com as políticas e prioridades estabelecidas pelo MS são fundamentais para maximizar essas ações. Nesse sentido, foi criada uma Rede Nacional de Especialistas em Zika e Doenças Correlatas ${ }^{41}$ (ReneZika), em maio de 2016, no âmbito do governo federal com o objetivo de prover informações para subsidiar a produção, monitoramento e avaliação de políticas e ações; promover alinhamento na comunicação sobre as investigações; mapear pesquisas relacionadas no Brasil e no mundo; identificar fontes de financiamento de pesquisas, entre outros. (152)

Um dos entrevistados destacou a ReneZika como exemplo de cooperação e ressaltou a capacidade científica do país.

(No) eixo de desenvolvimento científico e tecnológico, coordenado pela secretaria ciência e tecnologia, eles estabeleceram a ReneZika, que é uma rede de pesquisa pra Zika, formada por centenas de instituições de ensino e pesquisa, [...] inclusive com recursos. Foram feitas chamadas pra um volume de recursos importante. [...] Quando eu cheguei. [...] A gente não

\footnotetext{
${ }^{41}$ http://reneZika.org/portal/
} 
procurou criar nenhum projeto, mas aqueles que a gente viu que tinha mais viabilidade, houve financiamento. Mas muitos projetos foram financiados com o apoio, ou de recurso próprio do Ministério da Saúde, por meio da emenda parlamentar ou de outras fontes de financiamento foram abertas pelo Ministério de Ciência e Tecnologia. Houve muito financiamento nessa época pra pesquisa em Zika. Por isso que o Brasil se despontou nesse período [...], não só por estar ocorrendo aqui, mas por ter recursos e ter uma capacidade de investigação importante, mas permitiu fazer várias pesquisas com recursos. Foi uma área que foi bastante priorizada desde 2015, 2016. Então 2017 já começou a diminuir. RCG1/PF1(146)

A robusta rede científica do país e a transparência dos pesquisadores foi apontada como um diferencial para a capacidade de resposta brasileira à emergência.

Recife, ciudad enorme, barrios muy pobres, pero el instituto de pesquisas Aggeu Magalhães de primera línea con virólogos, con epidemiólogos. La relevancia es que ya existía una presencia, no estamos hablando de un desierto científico. Quiero decir que para mí hubo una metabolización mucho más rápida de las evidencias, y [...] la transparencia cultural que tienen los científicos brasileiros. Ponen el problema en el tapete, a mí eso es lo que cambió un poco el perfil de la respuesta inicial. RCOI1(154)

Muitas instituições científicas do Brasil também trabalharam conjuntamente para estabelecer a relação entre o Zika e a microcefalia.

[...] tivemos uma outra coisa que foi bastante importante também, que eu mencionei, que foi o envolvimento das instituições de pesquisas, então várias... Vários grupos acadêmicos, principalmente de universidades públicas, se dedicaram à pesquisa com o Zika. Num primeiro momento, a pesquisa para a identificação da causa da microcefalia e para a busca de conexões que pudessem confirmar ou descartar a relação com a infecção pelo Zika, assim como a busca da compreensão dos mecanismos específicos na área de ciência básica, na área de Patologia, por exemplo, ou de imunologia, que pudessem explicar a ocorrência da microcefalia. RCG2(145)

O fomento à produção de conhecimento, desde elaboração de documentos clínicos até editais de pesquisa foram apontados como importantes dentre as prioridades governo brasileiro.

Houve outras coisas que foram muito importantes como a elaboração de protocolos assistenciais, organização dos serviços de referência, de editais de pesquisas dirigidos especificamente para o Zika. Isso aconteceu não só no governo federal, mas em vários estados que têm as suas fundações de apoio à pesquisa. RCG2(145)

Entretanto, embora se reconheça que houve mobilização e fortalecimento da ciência, o entrevistado RCG2(145) chama atenção para a continuidade das ações de pesquisa no logo prazo.

Do ponto de vista da vigilância, o Brasil já tinha uma estrutura voltada para o controle das doenças de transmissão pelo Aedes aegypti, particularmente dengue, tinha a estrutura há 30 anos. Houve um fortalecimento dessa estrutura, houve uma permeabilidade maior para a entrada de novas tecnologias pro desenvolvimento de novos instrumentos de controle, tudo isso pensando no longo prazo. Acho que tudo aquilo que se fez em termos de pesquisas deixa algum resultado de longo prazo, embora a gente tenha a notícia de que muita coisa está ameaçada, porque as pesquisas não têm um desfecho tão rápido. Então, na medida em que se corta um financiamento, algumas pesquisas podem ficar pelo caminho. RCG2(145)

Na resposta à ESPII, podem ser destacadas a Fiocruz e o IEC, como consta da fala do entrevistado RCG1/PF1(146) 
[...] É, mas assim, primeiro, a Fiocruz, as unidades da Fiocruz, tanto Fiocruz de Pernambuco, Fiocruz Rio, depois Fiocruz Bahia. [...] mas, a Fiocruz em geral deu um apoio muito forte nisso. O Evandro Chagas, que é da própria SVS, mas é um instituto de pesquisa, que se envolveu não só na parte diagnóstico, por exemplo, foi um dos primeiros a detectar a relação da ocorrência de Zika com a microcefalia. RCG1/PF1(146)

A participação do IEC, instituto de pesquisa vinculado à Secretaria de Vigilância em Saúde (SVS), foi essencial. Foram pesquisadores do Instituto que demonstraram, de maneira irrefutável o nexo causal do vírus e da microcefalia ${ }^{42}$. Suas pesquisas também resultaram em provas de que o Zika pode causar mortes em pessoas com baixa imunidade. Além disso, o Instituto conduziu pesquisa em colaboração com a Universidade Texas Medial Brunch em um projeto financiado integralmente pelo MS do Brasil para o desenvolvimento de uma vacina. (7)

Em 20 de maio de 2016, o então presidente do Instituto, Pedro Vasconcelos, anunciou a previsão de novembro para que a vacina estivesse disponível para testes pré-clínicos, e estudos em humanos, até fevereiro de 2017. A prioridade nos testes seria para mulheres em idade fértil.(171)

A produção de artigos também foi destacada no Instituto, com a publicação de 6 estudos relevantes que discorreram sobre a agenda científica relacionada ao Zika; a dispersão do vírus no Brasil; a resposta da OMS e a situação do vírus no Brasil, nas Américas e o risco de disseminação para o resto do mundo; descrição das três primeiras mortes de adultos pela infecção; tratamentos e vacinas, e os potenciais riscos da epidemia nas américas. (7)

A participação da Fiocruz foi organizada com a criação, em dezembro de 2015, do Gabinete para o Enfrentamento à ESPIN e consolidada com um Plano Fiocruz para contribuir com o Plano Nacional. O documento previa o fortalecimento da rede de laboratórios de referência; a produção de imunobiológicos; participação no controle de qualidade em saúde; formação de profissionais de vigilância; realização de investigações; a mobilização de Centros Colaboradores da OMS, entre outros. (7)

Em 2016, a instituição publicou 56 artigos, que contribuíram para a disseminação de importantes achados como o primeiro sequenciamento genético do vírus; a presença do Zika no tecido cerebral de um bebê com microcefalia; a potencial infecção pela urina, via sexual ${ }^{43}$ e

${ }^{42}$ Em setembro de 2016, uma pesquisa caso-controle encomendada pelo Ministério da Saúde, que contou com a participação de Instituições como a Fiocruz Pernambuco (Fiocruz/CPqAM), Instituto de Medicina Integral Professor Fernando Figueira (IMIP), Universidade Federal de Pernambuco, Fiocruz Brasília, Secretaria de Estado de Saúde de Pernambuco, London School of Hygiene \& Tropical Medicine e OPAS/OMS, reforçou a relação entre o Zika e casos de microcefalia (273).

43 Também foi lançado pelo MS o documento "Orientações para a prevenção da transmissão sexual do Zika vírus", que recomenda que sejam reforçados, por exemplo, o uso de preservativos para gestantes e suas 
saliva; entre outros. Seus laboratórios realizaram mais de 20 mil testes moleculares em todo Brasil e a Fundação ainda participou da produção de protocolos de manejo clínico e na formação de profissionais, oferecendo o curso de manejo com a UNA-SUS. Além disso, na área de atenção, o Instituto Fernandes Figueira teve especial destaque com uma abordagem multiprofissional a gestantes e crianças portadoras da Síndrome Congênita pelo Vírus Zika. A Instituição também colaborou com o desenvolvimento e métodos de controle vetorial; o desenvolvimento de kits diagnóstico molecular, e estudos para a produção de uma vacina contra o Vírus Zika. (7)

Em dezembro daquele ano, foi inaugurado o Centro Henrique Penna, novo centro de produção de insumos e medicamentos, vinculado ao Instituto de Tecnologia em Imunobiológicos Bio-Manguinhos. Nele, seriam produzidos os testes sorológicos para Zika e o Kit Molecular ZDC, que aguarda a liberação pela Agência Nacional de Vigilância Sanitária (ANVISA). (172)

Para o desenvolvimento de pesquisas relacionadas ao combate ao mosquito, o Ministério da Saúde anunciou, em 10 de março de 2016, um investimento de R \$ 10,4 milhões, sendo $\mathrm{R}$ \$ 4,4 milhões para o financiamento da vacina contra o vírus Zika e cerca de $\mathrm{R} \$ 6$ milhões para projetos de cooperação bilateral para pesquisas de Zika e microcefalia com o National Institutes of Health (NIH)(173).

Além disso, o Ministério da Saúde e o Instituto Butantan trabalharam numa iniciativa para o desenvolvimento de um soro para mitigar os efeitos da infecção pelo Zika, para o qual foi assinado documento no valor de R\$ 8,5 milhões(174). Entretanto, em nota, o MS informou que o Instituto não havia entregado documento constante no contrato, o que causou o não repasse da verba (175).

Outro importante destaque foi a Revista Epidemiologia e Serviços de Saúde (RESS), editado pela Coordenação Geral de desenvolvimento da Epidemiologia em Serviços do Departamento de Gestão da Vigilância em Saúde da Secretaria de Vigilância em Saúde (CGDEP/SVS/MS). Para fomentar publicações, passou a adotar a modalidade de publicação ahead of print ${ }^{44}$, motivada pela declaração da ESPII. A Coordenação também participou da construção, em parceria com a UNA-SUS, de três cursos de Educação a Distância sobre manejo

\footnotetext{
parcerias em consultas individuais e de pré-natal; destacando também a necessidade de ampliação do acesso de homens a métodos de prevenção.

${ }^{44}$ Outros periódicos adotaram formas de facilitar a publicação com processos mais rápidos de avaliação e preprint eletrônico(168).
} 
clínico das arboviroses a abordagem da atenção primária para o Zika, este último com tradução para o espanhol, sendo oferecido pela OPAS. Outras parcerias foram feitas com o Hospital Sírio Libanês, oferecendo o Curso de Especialização em Vigilância em Saúde; e com a Johns Hopkins Bloomberg School of Public Health, que priorizou em 2016 a formação de 8 profissionais brasileiros no Programa Certificado em Epidemiologia, tendo 1 dos projetos sendo sobre o aumento de casos de microcefalia no Brasil. Foram realizados ainda ciclos de estudos e participações em espaços como o COES, oficinas e na Rede Nacional de Especialistas. (7)

O MS também recebeu colaboração da Universidade de São Paulo, com a integração entre laboratório, vigilância, entomologia, clínica médica e pediátrica. Houve parceria da USP com a Universidade Federal de Sergipe para o estudo de casos de microcefalia e a Implantação e validação do PCR em tempo real quantitativo para DZC no Lacen-SE. (153)

Com relação às fontes de financiamento, o governo fez um mapeamento não exaustivo, levantando as principais fontes internacionais tais como o CDC, o BID, a ONU, a Fundação Gates, o Banco Mundial, a EU, a OMS, entre outros (152). Além disso, o Ministério da Saúde abriu um edital de R\$ 20 milhões para pesquisas sobre o controle do Aedes aegypti e diagnóstico, prevenção e tratamento de doenças transmitidas por ele. A previsão do Ministério era de investir R 258 milhões em novas tecnologias nos quatro anos seguintes, no âmbito do Plano Nacional de Enfrentamento ao Aedes aegypti e à Microcefalia. Seriam disponibilizados também R \$ 649 milhões para investimentos em ações de combate ao mosquito e doenças relacionadas, diagnóstico, controle vetorial, pesquisas sobre o vírus Zika, vacinas, tratamentos e inovação em gestão de serviços de saúde, saneamento e de políticas públicas. Além da Saúde, outras pastas como Educação e da Ciência, Tecnologia e Inovação também investiriam, bem como mais R\$ 550 milhões do Banco Nacional de Desenvolvimento Econômico e Social (BNDES) e Financiadora de Estudos e Projetos (FINEP) para o desenvolvimento, produção e comercialização de tecnologias.(176)

Em junho, uma iniciativa do MS, MEC e MCTIC, foi lançado outro edital de fomento à pesquisa sobre o vírus Zika, desta vez no valor de $\mathrm{R} \$ 65$ milhões, sendo $\mathrm{R} \$ 20$ milhões parte do Ministério da Saúde. Os estudos tinham prazo de conclusão de 48 meses e deveriam estar incluídos em um dos seguintes eixos: desenvolvimento de novas tecnologias diagnósticas; desenvolvimento e avaliação de repelentes e de imunobiológicos; inovação em gestão de serviços em saúde; imunologia e virologia; epidemiologia e vigilância em saúde; estratégias para controle de vetores; desenvolvimento de tecnologias sociais e inovação em educação ambiental e sanitária, além de Fisiopatologia e clínica (177). 
Em reunião com 24 embaixadores da União Europeia, foi anunciado que o bloco ofereceria uma linha de crédito de EUR 10 milhões para pesquisa sobre o Zika. O edital seria lançado em 15 de março e poderiam participar quaisquer instituições do mundo.(178)

Apesar do ambiente favorável para a formação de parcerias e de aberturas de editais de financiamento, após um ano da declaração da ESPIN, os resultados não foram como o esperado.

\begin{abstract}
Mesmo com a declaração da ESPIN e toda inovação ocorrida nos aspectos legais para a ciência brasileira a partir da promulgação do composto de leis que regem o código nacional de C\&T em janeiro deste ano, o Brasil não conseguiu criar meios de rápido financiamento para fomentar, de forma dinâmica, a produção de conhecimento de emergência. Um ano após o decreto de ESPIN ainda não houve a liberação de financiamento por parte das principais agencias de financiamento da ciência e tecnologia brasileira, mostrando que o País deve se preparar de forma mais dinâmica para o enfrentamento de novas emergências sanitárias que poderão ocorrer devido a dinâmica do mundo globalizado. (7),p. 78.
\end{abstract}

Um dos entrevistados criticou as ações de controle vetorial feitas no país, que não conseguiu impedir a introdução de novas doenças, e reforçou esse ponto como uma das prioridades da resposta brasileira.

Em relação ao Zika, a grande deficiência é a total ineficácia, inefetividade das ações de controle do vetor (baseado no que se tem hoje de abordagem preventiva e de controle). Quer dizer, nunca se conseguiu controlar o vetor [...] Então, a Zika só foi mais um ingrediente nessa história de insucesso, porque não tem hoje ferramentas pra você evitar ou mesmo reduzir o impacto da transmissão; então essa continua sendo até hoje a grande deficiência. RCG1/PF1(146)

\title{
3.1.4.1 A cooperação técnica internacional em meio à Emergência
}

Após a declaração da ESPII pela OMS, o Ministério da Saúde divulgou nota valorizando o evento no sentido de ampliar a possibilidade de parcerias internacionalmente, "reunindo esforços de governos e especialistas para enfrentar a situação" (179). As ações de cooperação internacional empreendidas pelo Brasil foram essencialmente na área de pesquisa e desenvolvimento, dando um caráter bastante técnico a essa colaboração, sem negar aspectos políticos que envolvem essas parcerias.

Além de mais recursos para a resposta, a ESPII também propiciou maior cooperação internacional entre o Brasil e outras instituições internacionais, legitimando as pesquisas e hipóteses já levantadas por cientistas brasileiros.

A declaração da OMS, fortaleceu os estudos que vinham sendo conduzidos pelo Ministério e as hipóteses que haviam sido levantadas e que apareciam com mais força. Foram justamente elas que justificavam declaração e passaram por revisão e por um estudo profundo pelo comité (de Emergências da OMS). Do ponto de vista internacional, esta declaração ampliou a abertura para cooperação internacional. Nós tivemos a cooperação com alguns grupos na investigação inicial do Zika, particularmente com o Centro de Controle de Doenças dos Estados Unidos. Eles já tinham enviado gente para cá no momento da investigação dos casos de síndrome de Guillain Barré, na metade de 2015, e passaram a se interessar mais intensamente ainda quando nós 
tivemos a emergência da saúde pública. Tivemos a cooperação, por exemplo, do Instituto Pasteur do Senegal de Dakar que enviou equipe pra cá, de pesquisadores da London School of Hygiene and Tropical Medicine. Então, essa declaração da emergência da saúde pública, ajudou nesta mobilização. RCG2 (145)

E acrescentou também instituições de ensino.

[...] houve outras eu não vou me lembrar de todas, a Universidade do Texas, houve diversas outras que foram em geral estabelecidas a partir de cooperações pré-existentes de grupos acadêmicos brasileiros com grupos estrangeiros, que se dispuseram a cooperar. RCG2 (145)

A OPAS teve participação e deu apoio fundamental ao Brasil na resposta à ESPII. A participação da Organização será tratada na seção seguinte deste trabalho. Por ser o escritório regional da OMS nas Américas, é natural que a Organização tenha papel relevante em conjunto com o governo brasileiro. De acordo com documento do MS, seus representantes acompanharam de perto as ações levadas a cabo pelo Ministério e também participaram das pesquisas. "Muito mais do que os comunicados oficiais, o envolvimento institucional e das pessoas que atuam em tais organismos foi muito importante" (7)p. 22.

A OPAS foi apontada como ator chave na cooperação internacional para a resposta a emergência do Zika, mantendo um canal constante de contato com o governo brasileiro, destacando a transparência no trato entre as instâncias. Nesse contexto, observamos claramente o mecanismo institucional de disseminação de políticas operando, além do individual, com a participação ativa de pessoal da organização na resposta nacional brasileira.

Desde o primeiro momento, tinha um canal de diálogo com a OPAS. Diariamente. A OPAS Brasil estava acompanhando. Foi criado um centro de comando e controle da emergência e a OPAS participava ativamente, a OPAS Brasil. [...] Então, o representante da OPAS participava ali no COES, das reuniões ordinárias e, também, a OMS, após a declaração da emergência, quer instituir um comitê de emergências. Se reunia virtualmente, periodicamente, com o Brasil, pra saber a situação e propor as medidas e o diálogo. Eu acompanhei duas reuniões, participei de duas reuniões com a OMS, virtuais, e o diálogo era franco, aberto, tranquilo, sem nenhuma grande tensão. RCG1/PF1(146)

A primeira sem dúvida é o sistema multilateral de entendimento, a Organização Pan-Americana da Saúde, Organização Mundial da Saúde, no engajamento muito importante, não apenas no comprimento do seu papel formal de declaração de emergência etc. Mas, no acompanhamento concreto, com o envio de pessoas para cá, com a cooperação pelo mecanismo do chamado GOARN [...] mobilizando o CDC, por exemplo. RCG2(145)

Com outras organizações regionais, o entrevistado RCG1/PF1(146) cita que o Mercosul não teve reuniões no segundo semestre de 2016, sem razão conhecida para ele. Além disso, menciona que o CIEVS enviava comunicações para os chefes de epidemiologia dos países da Unasul. Ambos os blocos também contam com seção especial adiante.

Com os países do Mercosul, eu não acompanhei. Acho que não teve nenhuma reunião do Mercosul [...] no segundo semestre de 2016 [...]. Não sei por que, já que são reuniões semestrais. $\mathrm{Eu}$ acho que esse período não teve, por algum motivo. E Unasul, o CIEVS mandava as 
comunicações frequentemente, quer dizer, todos os boletins, eles transmitiam para os parceiros. Dirigentes de epidemiologia da Unasul. RCG1/PF1(146)

Sobre cooperação com um país específico, o entrevistado RCG1/PF1(146) não se recorda, mas chama atenção para a falta de transparência entre os países com as informações epidemiológicas e ressalta a importância de espaços transnacionais, como as reuniões proporcionadas pela Unasul e pelo Mercosul para a construção de confiança entre as nações.

Agora cooperação com algum país assim, eu não lembro. [...] O que eu, analisando retrospectivamente, acho que houve muita deficiência, por esse aspecto. Por parte de países que efetivamente não foram transparentes com seus dados ou queriam ter certeza de algumas informações pra divulgar e isso, certamente, dificultou um pouco a integração. Se tivesse uma coisa muito mais proativa de instâncias, por exemplo, reuniões, seja da comissão de vigilância do Mercosul, seja da comissão de vigilância da Unasul, de estar trazendo os países e estar trocando informações sobre o que de fato está ocorrendo aí, eu acho teria sido mais produtivo. Me parece que isso não funcionou bem, porque os países não divulgaram. RCG1/PF1(146)

No modelo da SNCC, foi anunciada a criação de uma sala Binacional Brasil-Colômbia, que funcionou entre as cidades gêmeas de Tabatinga e Letícia (7). A sala seria composta por três representantes de cada cidade e os encontros se iniciariam a partir de junho de 2016, com o objetivo de que os municípios compartilhassem informações e colaborassem em ações conjuntas. Sobre a importância dessa iniciativa, o coordenador da Sala Estadual do Amazonas, Bernardino Albuquerque, disse: "É impossível combater o vetor unilateralmente nesses dois locais onde há casas que possuem o quarto num país e a cozinha em outro. Temos que discutir ações integradas na região e esse local bilateral possibilitará uma maior integração entre os gestores". (180)

Entretanto, ao serem indagados sobre a relação entre o Brasil e a Colômbia e o funcionamento dessa Sala, os entrevistados tinham pouca informação, revelando que houve pouca ressonância dessas ações no nível central.

Na fronteira com Tabatinga. Existe esse plano, mas não me parece que chegou a ser implantado. E o plano era desde antes, de ter uma sala, um CIEVS lá. E nessa época do Zika foi aventado. Agora, pode ser que tenham instalado uma sala em situação provisória no momento, mas aí eu não conheço. RCG1/PF1(146)

Eu não participei dessa sala binacional. [...] logo em seguida eu saí do ministério não acompanhei o que aconteceu a partir de maio - junho de 2016. RCG2(145)

Em janeiro de 2016, o Brasil desenvolveu ações de treinamento para diagnóstico laboratorial no IEC com cinco países da América do Sul, a saber Bolívia, Equador, Paraguai, Peru e Uruguai(153). Além disso, em reunião extraordinária do Mercosul(181), o Brasil se disponibilizou a realizar treinamentos para testes laboratoriais que detectam o vírus Zika, a serem realizados por instituições brasileiras. O objetivo era reforçar o sistema de vigilância regional, preocupação exposta pelo próprio Ministro: "Temos o desafio de reforçar o sistema 
de vigilância na região. Para isso, o Brasil quer compartilhar a sua experiência e receber equipes interessadas neste conhecimento. Estamos construindo uma resposta integrada da região contra o vírus Zika", afirmou Castro"(182).

Essa necessidade de aprimoramento, se coaduna com a fala do entrevistado PF2(183), que aponta que a maior dificuldade para o Paraguai foi o diagnóstico laboratorial

\begin{abstract}
Ahora sabemos que realmente, sí, detectamos muchos casos. Solamente que los métodos de laboratorios que usamos no eran tan sensibles en ese momento. Ahora en los estudios retrospectivos, estamos teniendo muchísimas muestras positivas. Entonces, hubo un trabajo conjunto con Brasil y con Colombia en compartir la experiencia en cuanto al diagnóstico laboratorial, que yo creo que fue una de las debilidades en la región. La vigilancia laboratorial. Pero sí, yo creo que lo importante, y no me animaría decir sólo Unasur, fue en la región de Sudamérica en compartir experiencias y utilizar esa experiencia aportada por los países que tenían mayor casuística, que tenían estudios de cohorte establecidos, como Brasil y Colombia. PF2(183)
\end{abstract}

Essa última fala ressalta a deficiência e a desigualdade de capacidades no sentido de detectar, notificar e responder a eventos inesperados e desconhecidos entre os países, o que também pode justificar o retardo de alguns na informação sobre os casos nos seus territórios.

\title{
3.1.4.1.1 A Relação Brasil-Estados Unidos
}

A agenda bilateral com os Estados Unidos desenvolvida pelos países da América Latina é um eixo de análise importante da política externa e é uma das características que tornam a região heterogênea (40). No Brasil da resposta à ESPII, a relação entre o Brasil e os EUA foi priorizada em relação ao outros parceiros, como países em desenvolvimento(184), refletindo a reorientação da PEB, especialmente durante o governo Temer(38).

Pouco antes da declaração da ESPII, a Presidente Dilma Rousseff procurou o Presidente dos EUA, Barack Obama, com a preocupação de reforçar a colaboração entre os países no sentido de intensificar o combate ao mosquito e pesquisas para o desenvolvimento de uma vacina(185). Apesar de ser avaliada como uma mandatária que não priorizava a política externa, Dilma foi uma agente fundamental para a resposta brasileira à emergência, funcionando como uma embaixadora das ações empreendidas pelo Brasil.

Um dos desdobramentos dessa chamada foi a reunião virtual entre o Ministro da Saúde, Marcelo Castro, e a Secretária de Saúde dos Estados Unidos, Sylvia Burwell. Os gestores definiram em reunião uma agenda de cooperação para o desenvolvimento conjunto de pesquisas para diagnósticos, tratamento e para uma vacina contra o Zika. Acordaram também trabalhar para catalisar as pesquisas sobre a relação entre as infecções por arbovírus e transtornos neurológicos.(186) 
Em reunião bilateral, dias 18 e 19 de fevereiro, entre os países na sede da OPAS em Brasília - com a participação de representantes do MS, do IEC, do Instituto Butantan, de BioManguinhos, da ANVISA e de delegação da embaixada americana -, os países acordaram intensificar a cooperação para pesquisa e o desenvolvimento de diagnósticos, vacinas, tratamentos contra o Zika.

"Os EUA e o Brasil têm um papel fundamental na busca de uma resposta para enfrentar o surto do vírus Zika. As doenças infecciosas não respeitam fronteiras. Nossos esforços conjuntos e ações estratégicas podem produzir resultados que vão beneficiar a todos", disse a Embaixadora dos EUA, Liliana Ayalde. (187)

Na ocasião, foi construído o "Plano de Cooperação em Saúde Brasil-Estados Unidos para o enfrentamento ao Zika e suas complicações" (188), de caráter bastante técnico-biológico. No documento, são pontuadas ações a serem desenvolvidas pelos países como o desenvolvimento de vacinas e tratamentos; de ferramentas de diagnóstico; fortalecimento do acompanhamento e atenção à saúde; pesquisa e vigilância.

Outra parceria importante entre instituições dos dois países foi a que se desenrolou entre a ANVISA e o FDA (Food and Drug Administration), a agência reguladora dos EUA. O objetivo foi acelerar o processo de registro e validação da inclusão do teste para o vírus Zika no teste NAT realizado em bolsas de sangue e produzido por Bio-manguinhos. O teste já detectava o vírus do HIV e das hepatites B e C e a inclusão do Zika daria mais segurança aos hemocentros do país. (189)

\section{$O C D C$}

O Centro de Controle e Prevenção de Doenças dos Estados Unidos (CDC - Centers for Disease Control and Prevention) também trabalhou de forma estreita com o MS, desde a declaração de ESPIN ${ }^{45}$. Desde 2012, o CDC e a SVS têm um acordo de cooperação em vigilância em Saúde - Carta de Intenções entre CDC/HHS e SVS/MS para Cooperação em Saúde Pública e Vigilância em Saúde.

Sobre o destaque dessa parceria entre Brasil e EUA, o entrevistado RCG2(145) reforça a informação de que instituições, como o CDC, de ambos países têm relações que precedem o surgimento da epidemia.

\footnotetext{
Saúde(7).

${ }^{45} \mathrm{Na}$ realidade, o CDC tem um escritório no Brasil cuja sede fica nas instalações do Ministério da
} 
É inegável a capacidade tecnológica dos Estados Unidos particularmente a excelência do CDC na resposta a emergências. Isso ganha uma relevância maior ainda quando se pensa em diagnósticos, em investigação. A própria estruturação dos nosso sistema de resposta a emergências da saúde pública ou os treinamentos feitos aqui, tiveram apoio importante do CDC, que já vinha desde a década de 90 , praticamente, com um intercâmbio muito intenso. Do ponto de vista da Organização Mundial, para diversos assuntos, nas Américas os centros colaboradores da OMS são do CDC. RCG2(145)

Além de a ESPII com epicentro nas Américas gerar um alerta para toda a região, o entrevistado complementa que o CDC é referência para questões de vigilância para o país.

A emergência da epidemia no continente americano também criava uma sensibilidade maior [...]. Então, isso trazia o centro gravidade da situação da epidemia de Zika para o continente americano e aí a nossa maior referência do ponto de vista técnico e científico na área de vigilância é o CDC, especialmente pela tecnologia, pela qualidade dos recursos humanos que eles têm na instituição. RCG2(145)

O CDC participou da investigação de óbitos em recém-nascidos com malformações congênitas(190); e fez parte de pesquisa em Salvador/BA que coletou material em campo para investigar a relação entre a infecção pelo Zika e a SGB(7). Desse material, 2/3 seguiria para análise nos EUA(185). O compartilhamento de dados e amostras no caso do Zika é uma problemática importante a ser mais bem aprofundada, que coloca em foco a forma como os países que cedem esses materiais recebem de fato os benefícios resultados dessas análises ou são apenas considerados mercados para as soluções que ajudaram a construir.

Após o encerramento dessa primeira colaboração, o Brasil e o CDC realizaram um estudo de caso controle de microcefalia relacionada a infecção pelo vírus Zika na Paraíba, cujo objetivo foi avaliar o risco de infecção pelo vírus e estimar a proporção de recém-nascidos com microcefalia relacionada ao Zika. (191) Um dos seus resultados apontou que a infecção no primeiro trimestre gestacional tem maior probabilidade de resultar em bebês com microcefalia.

Sobre a parceria entre o governo brasileiro e o CDC, o entrevistado RCG1/PF1(146) afirmou o caráter, por vezes intrusivo da instituição.

[...] Por exemplo, eu estive acompanhando o estudo na Paraíba, no qual o CDC contribuiu. Claro, o CDC sempre busca, primeiro, forçar a contribuição. Mas aí, depois de acertar as regras do jogo, o CDC contribuiu em um estudo junto com a SVS, coordenado pela SVS, em um estudo da Bahia de Guillain Barré e o estudo sobre microcefalia, na Paraíba. RCG1/PF1(146)

Apesar do já reconhecimento pelas autoridades brasileiras da relação entre o vírus Zika e os casos de microcefalia, apenas em 13 de abril o CDC confirmou o fato, com base em uma revisão de evidências. Esse reconhecimento, apesar de tardio, foi importante para dar mais legitimidade à tese brasileira da relação causal entre a infecção pelo vírus Zika e as malformações congênitas em bebês. 


\section{Outras instituições norte-americanas}

Uma importante iniciativa de cooperação internacional para a pesquisa e o desenvolvimento tem a ver com a produção de uma vacina contra o vírus Zika, considerada a grande solução da epidemia pelo então Ministro da Saúde, Marcelo Castro (192); e tida como uma decisão política(18). Em maio de 2016, havia 14 iniciativas internacionais com esse objetivo, duas delas no Brasil (152).

A parceria entre o Instituto Butantan e o NIH já vinha ocorrendo para o desenvolvimento de uma vacina contra a dengue (192). Além disso, o Instituto também avaliava a possibilidade de produzir uma vacina pentavalente, que combateria os 4 tipos de dengue e a Zika.

O país anunciou parceria com a Universidade do Texas Medical Branch para o desenvolvimento da vacina contra o vírus Zika dia 11 de fevereiro, com a previsão de investimento nacional de US\$1.9 milhão nos 5 anos seguintes. A colaboração seria feita entre a Universidade e o IEC, podendo contar com apoio da OPAS(193). O acordo foi formalizado em uma carta de intenções em 02 de abril de 2016 e prevê a inclusão de pesquisa, troca de informações e melhores práticas, intercâmbio, formação e treinamento de pessoal, além de estabelecer que, sempre que possível, as ações conjuntas sejam coordenadas com aquelas de órgãos como a OMS. Além disso, prevê a criação de um Comitê de Coordenação que deve se reunir duas vezes ao ano para analisar o andamento da cooperação(194).

Sobre o status desse desenvolvimento, o entrevistado RCG1/PF1(146) aponta para problemas relacionados a discussão sobre patentes e a falta de interesse atual na continuidade desses processos.

[...] começaram a discutir questão de patente, aí o negócio esfriou. Ou esquentou (risos). Porque isso estaria, agora, sob a responsabilidade de Bio-Manguinhos produzir. [...] Há duas semanas, teve um simpósio internacional de imunobiológicos [...]. A questão da vacina de Zika foi (tratada) em um slide só, que o pesquisador de Bio-Manguinhos apresentou, mostrou lá quatro vacinas e o estágio de desenvolvimento delas, mas muito rápido. Então, a impressão que eu tive [...] é que isso não tem nenhuma fase avançada. Nenhuma, pra Zika. Mas é impressão. Agora, é muito estranho também, porque Bio-Manguinhos não começou testes pré-clínicos. Porque que os outros não começaram e tem alguma coisa que não está muito clara [...] mas hoje me parece que não há muito interesse. RCG1/PF1(146) 
A Fiocruz também trabalhou com a empresa americana ChemBio para o desenvolvimento de um kit molecular para a identificação simultânea de anticorpos IgG dos três vírus: Dengue, Zika e Chikungunya ${ }^{46}$ (7).

Além disso, a Fundação é coordenadora, junto ao Instituto Nacional de Saúde Pública dos Estados Unidos (NIH), de um estudo de coorte em três países (Brasil, Bolívia e Colômbia) a fim de estudar a história natural das infecções pelo Vírus Zika(7). Os dois países também colaboraram em uma investigação internacional que iria acompanhar cerca de 10 mil gestantes em Porto Rico, Colômbia e no Brasil (Rio de Janeiro/RJ, Salvador/BA, Recife/PE e Ribeirão Preto/SP) e outras regiões em que existe circulação do Zika. O objetivo é fazer o seguimento dessas mulheres e comparar as consequências daquelas que forem infectadas para seus fetos, com acompanhamento até 1 ano de vida(195).

Além a expertise das instituições americanas, outras possíveis razões para o interesse do país na questão têm a ver, por exemplo, com a própria localização da emergência, muito próxima ao seu território, sob risco de disseminação interna. Soma-se a isso o deslocamento da centralidade da América do Sul na PEB. Esse interesse explica os motivos pelos quais o CDC, que é referência, como vimos, em ações de vigilância e controle, é braço fundamental para os EUA no caso em tela. Além disso, não se pode deixar de notar que grandes corporações farmacêuticas são norte-americanas, explicando porque o desenvolvimento de vacinas e testes foram a grande tônica desse intercâmbio.

\subsection{Outras parcerias}

A Fiocruz desenvolveu com a Universidade de Monash (Australia) como parte da iniciativa internacional Elliminate Dengue: our challenge, mosquitos geneticamente modificados, o Aedes Aegypti com a bactéria Wolbachia pipientis, que tem potencial de inibir a transmissão dos vírus da dengue, Zika e Chikungunya(7). Representantes da Fundação Bill e Melinda Gates visitariam o Brasil no final de março para definir os próximos passos da pesquisa, ampliando a área de atuação desse mosquito que cobriria uma população maior (176).

Além disso, o Instituto de Ciências Biomédicas (ICB) da Universidade de São Paulo desenvolveram um teste específico para o Zika; e o laboratório da Fundação Baiana de Pesquisa

${ }^{46}$ O Kit NAT Discriminatório para DZC permitia mais agilidade no diagnóstico e o Ministério da Saúde encomendou 500 mil unidades em janeiro de 2016, com previsão das primeiras 50 mil começarem a ser produzidas a partir de fevereiro. Além da distribuição aos Lacens, o acordo previa capacitação de pessoal para a execução das diferentes etapas do teste molecular.(195) 
Científica e Desenvolvimento Tecnológico (Bahiafarma) e o Laboratório Farmacêutico de Pernambuco (Lafepe) estabeleceram uma colaboração para desenvolver um kit diagnóstico para as três arboviroses em circulação DZC (152). No dia 13 de junho, a BahiaFarma apresentou ao MS o teste rápido que para Zika que consegue identificar infecções agudas e pregressas; entretanto, ainda faltava ser aprovado pelo Instituto Nacional de Controle de Qualidade (INCQS) para serem incorporados ao sistema público(196). Em outubro, foi realizada a compra de 3,5 milhões de unidades, com previsão de distribuição de 2 milhões até o final de 2016 e o resto até fevereiro de 2017. Foram aplicados R\$ 119 milhões de reais na compra do teste, desenvolvido em conjunto com a empresa sul-coreana Genbody Inc. (197).

Segundo Antonio Nardi(7), então Secretário de Vigilância em Saúde, esse momento histórico permitiu que o Brasil pudesse fortalecer sua participação na comunidade cientifica; revisasse as estratégias de combate ao mosquito com a implantação de tecnologias como a bactéria Wolbachia, que causa a esterilização de mosquitos e o emprego de biolarvicidas, e que saída na dianteira para o desenvolvimento de uma vacina contra o vírus Zika.

Esse momentum também foi citado pelos entrevistados RCG1/PF1(146) e RCG2(145), indicando a oportunidade que o Zika trouxe para as alternativas de controle do Aedes Aegypti.

Já havia uma estratégia que, se eu não me engano, contava com financiamento do Ministério, então foram impulsionadas alternativas ao controle do vetor, como a Wolbachia [...] $\mathrm{O}$ Ministério já estava acompanhando e apoiando isso para o controle do vetor, mas de uma forma muito incipiente. Com a entrada do Zika, isso foi reforçado (inclusive reforçou a quantidade de recurso pra esse projeto, bem como pra outros projetos), então abriu mais a possibilidade de buscar alternativas. Não se encontrou nenhuma até então, mas de investir mais recursos nessas alternativas, incluindo a vacina. Foi daí que começou o investimento inicial na produção de uma vacina contra Zika. RCG1/PF1(146)

RCG2(145) ainda enfatizou a diferença entre o tempo da emergência e o das pesquisas científicas.

Nós tivemos também uma mobilização grande em relação à identificação de tecnologias para combate ao vetor, embora não houvesse grandes novidades do ponto de vista científico que surgiram. Naquele momento só foi possível acelerar alguns processos como é o caso da pesquisa com a bactéria Wolbachia e outras tecnologias como o combate ao mosquito, que infelizmente não têm o desfecho tão rápido quanto se desejaria, mesmo havendo disponibilidade de recursos como houve naquele momento. Então alguns desses grupos que iam trabalhar na pesquisa de tecnologia, foram chamados pelo Ministério pra saber se caso fosse liberado um recurso adicional vultoso, se eles seriam capazes de acelerar a pesquisa e de colocar novas tecnologias de controle do vetor em campo... e isso foi muito mais lento do que se desejava que fosse. Não estou dizendo que a resposta foi lenta no ponto de vista absoluto, mas face à ansiedade, face à situação emergencial, havia um desejo de que fosse tudo mais rápido. RCG2(145)

Apesar do momento oportuno, com aumento de financiamento e ebulição do tema, o interesse no desenvolvimento dessas novas tecnologias, principalmente da vacina, não se manteve ao longo do tempo e muitas iniciativas foram abandonadas. 
Também despertou o interesse pelo desenvolvimento de pesquisas e tecnologias fora do país, embora até hoje - eu acho que inclusive em função da brevidade da situação epidêmica no Brasil - tivemos poucos resultados objetivos. No caso no desenvolvimento da vacina, desenvolvimento dos kits para diagnóstico do Zika, assim como de qualquer opção de proposta de tratamento, que no momento inicial despertou muito interesse. O interesse não se manteve, aparentemente, de forma sustentável a ponto de os investidores de novas tecnologias dessem a continuidade plena a esse trabalho. Nós tivemos notícias, por exemplo, alguns meses atrás de que iniciativas para o desenvolvimento da vacina por parte de... agora eu não me lembro se foi pela SANOFI, mas de uma das empresas grandes produtoras imunobiológicos de que o trabalho havia sido interrompido... algumas instituições, inclusive brasileiras e com parcerias com o exterior continuam o trabalho de desenvolvimento de vacina, de métodos diagnósticos, mas isso reduziu bastante desde que foi encerrada a emergência internacional. RCG2(145)

Esta subseção deixa evidente a operação de alguns mecanismos que atuam na disseminação internacional de políticas. A cooperação, neste caso, além de uma concretização das negociações diplomáticas entre os diversos atores, também opera como um vetor para que as políticas e seus elementos circulem e sejam assim adotadas por outros países e instituições.

\subsubsection{O contexto político e o ambiente de coalizão}

Toda a resposta a epidemia foi organizada e executada sob grande crise política no Brasil, que culminou, como dito anteriormente, no impedimento da Presidente Dilma Rousseff, durante seu segundo mandato. O calendário da crise política tem alguns marcos importantes.

Em 6 de outubro de 2015, Marcelo Castro assumiu o Ministério da Saúde e poucos dias depois a epidemia de Zika e o grande aumento de casos de microcefalia foram identificados(7). Em dezembro daquele ano, o pedido de impeachment apresentado por Hélio Bicudo e pelos advogados Miguel Reale Júnior e Janaina Paschoal foi aceito pelo então presidente da Câmara dos Deputados, Eduardo Cunha e em abril de 2016, o processo foi votado nessa casa e também aceito no Senado federal. Em 31 de agosto daquele ano, o mandato da presidente Dilma foi cassado e começava, então, um governo bastante controverso do seu vice, Michel Temer.

Mesmo sob forte crise, ao saber do aumento de casos e da situação de emergência que viviam os Estados do Nordeste, Dilma Rousseff encabeçou a resposta à emergência, tornandose uma verdadeira embaixadora da resposta nacional. Ela recebeu todos os governadores, chamando todos os entes da federação para agirem. Além disso, tanto o Senado como a Câmara dos Deputados convocaram audiências para tomar conhecimento da situação e debater a questão da microcefalia. Houve também mobilização dos Ministros, Comandantes das Forças Armadas e gestores de instituições federais (7).

O entrevistado RCG1/PF1(146) relata que em 2015, apesar de a crise já existir, ainda havia um ambiente favorável de trabalho no sentido de construir a resposta. Ele aponta, ainda, 
que apesar disso, boa parte da resposta já estava estruturada e, por isso, havia pouca margem de manobra para mudanças.

2015 ainda era um período, embora já existisse uma crise, talvez, de legitimidade política, mas existia um poder bem estabelecido (na presidência da República e consequentemente no Ministério da Saúde), então havia um ambiente muito mais tranquilo para se trabalhar; e isso favorecia, por exemplo, a comunicação rápida pra OMS. [...]A partir do momento em que o Brasil começa a entrar na crise institucional, com o impeachment (na minha avaliação, o golpe), se cria um ambiente não muito favorável. Felizmente, aquela fase da comunicação já tinha passado, então isso não foi testado -não sei como seria o comportamento se fosse nessa fase. Mas, de qualquer forma, com o momento do golpe, começou a haver mudanças no Ministério; e isso afetou, de alguma maneira, a gestão da epidemia. Ainda que, como eu falei, estava um pouco resguardado [...]Quer dizer, não poderia haver, naquele momento, ruptura em termos do que já estava programado pra ser desenvolvido mesmo com o cenário político desfavorável[...] RCG1/PF1(146)

Mesmo com a crise, a formação dessa coalização de apoio foi considerada sem precedentes:

Uma mobilização que não tinha sido conseguida em 30 anos de epidemias de dengue foi organizada em pouco mais de um mês, com a constituição de uma sala de Coordenação Nacional, de funcionamento contínuo, articuladora de uma rede de iniciativas equivalentes, multisetoriais, em todos os estados e muitos municípios. (Brasil, 2017, p. 22)

Outro entrevistado enfatiza um movimento político de coalização, mesmo durante a crise.

Do ponto de vista político, acho que houve um momento interessante. Houve quase um consenso entre as forças políticas atuantes no Brasil de que esse era um tema importante, de que merecia prioridade. Então, por exemplo, estive pessoalmente em algumas audiências públicas no Senado Federal e na Câmara dos Deputados em que havia unanimidade quanto à disposição dessas duas casas de apoiar a destinação de recursos para a emergência em saúde pública. Lembrando que esse foi um momento muito turbulento da vida política brasileira. Nós estávamos justamente nos meses que antecederam o golpe que retirou a presidenta do poder... então, em torno deste tema a polêmica era muito pouca. Houve sim algumas tentativas de politização, em que acusavam a inefetividade de programas de controle ou eventual desperdício de recursos, mas isso praticamente desapareceu face ao impacto da emergência e a mobilização para a emergência. RCG2(145)

Entretanto, esse ambiente foi se deteriorando com a mudança de quadros de funcionários-chave no Ministério, após a mudança de governo.

Logo depois do afastamento da presidenta, houve mudança no Ministério. [...] o ministro que entrou começou a fazer algumas mudanças, inclusive em coordenações [...] Nesse momento eu cheguei, por substituição a Cláudio (Cláudio estava saindo). E aí total incompatibilidade política com a atual gestão. Mas, como eu já estava lá (mas como um técnico), me propuseram de continuar o trabalho, então foi possível dar uma certa continuidade, embora não com a total liberdade que tinha até então. RCG1/PF1(146)

Ele ainda relata que, apesar de tentativas de interferências pouco ortodoxas, provas científicas conseguiram barrar ações pouco embasadas.

[...] o ambiente começou a se tornar mais desfavorável, em termos de gerenciamento (inclusive técnico gerencial) da resposta, relacionado diretamente à essa mudança política institucional [...]. Houve, durante um período em que eu estive lá, tentativas de influências de introduções de 
tecnologias totalmente descabidas para atender os interesses os mais diversos possíveis. [...] A gente conseguiu bloquear isso, colocando à prova na UNB, e a UNB mostrou que não tinha eficácia nenhuma. Mas só pra mostrar como uma mudança institucional, político-institucional, pode afetar (e às vezes afeta mesmo) o nível técnico-gerencial. Quero dizer, esse nível não é imune a isso, mesmo mantendo em alguns determinados escalões, pessoas qualificadas. RCG1/PF1(146)

\subsubsection{Política Externa, Jogos Olímpicos e a securitização como decisão política}

Pesem as recomendações da OMS de não restrição de viagens, houve enorme discussão quanto a realização ou não dos Jogos Olímpicos no Brasil. O evento, há muito sendo planejado e aguardado, tornou-se um importante foco de pressão internacional sobre o país.

Um grupo de mais de 200 signatários enviou uma carta ${ }^{47}$ à $\mathrm{OMS}$ pedindo o adiamento e até o cancelamento do evento, alegando que a linhagem do mosquito brasileiro provocava danos à saúde não observados anteriormente e que a realização dos Jogos seria expor milhares de pessoas a uma possível infecção, que poderia levar essa linhagem para outras partes do mundo.

Em resposta, pesquisadores brasileiros da Fiocruz e da Fundação Getúlio Vargas (FGV) rebateram essa ideia em um artigo baseado em evidências científicas(198). Seu principal argumento para que a realização dos Jogos fosse mantida como planejado foi a sazonalidade das infecções por arboviroses, já que em agosto - época da realização dos Jogos, os índices de infestação diminuem de forma considerável. Além disso, alegaram que àquela época, o vírus já se encontrava em circulação em pelo menos 60 países.

A realização do evento também recebeu apoio da Sociedade Brasileira de Infectologia que, em 13 de junho, divulgou posicionamento destacando o notório trabalho desenvolvido pelo país na comunicação transparente de informações e orientações para a população em relação ao Zika, bem como as ações de vigilância desenvolvidas(199).

De fato, as notificações de Zika caíram $87 \%$ entre fevereiro e maio de 2016, tendo o pico de incidência na 3a semana de fevereiro; antes do previsto pela série histórica(200).

A OMS manteve a posição de que os Jogos deveriam ser mantidos, assim como assegurava o Ministério da Saúde. Em Genebra, Suíça, por ocasião da Assembleia Mundial da Saúde, o então Ministro da Saúde Ricardo Barros visitou a sede do Comitê Olímpico

47 A página original (http://rioolympicslater.org/) onde a carta foi publicada não está mais disponível. Uma versão da mesma pode ser encontrada aqui: http://www.center4research.org/letter-urging-postponementmovement-brazil-olympics-due-concerns-Zika/ 
Internacional e apresentou as ações do Brasil em relação à saúde. O objetivo foi tranquilizar as autoridades sobre a realização dos $\operatorname{Jogos}(201)$.

De acordo com a Diretora da OPAS, Carissa Etienne, a Organização e o MS, por meio de um convênio com o Comitê Olímpico Internacional e com autoridades brasileiras, ofereceram apoio para a redução de risco de contágio durante os Jogos Olímpicos, com recomendações como a eliminação dos criadouros e fumigação, além de participação da comunidade e distribuição de repelentes e materiais informativos para os atletas e turistas(202).

O entrevistado RCG1/PF1(146) entende que a OMS tomou uma decisão sensata no sentido de apoiar a realização dos Jogos, seguindo o que informava o Brasil.

[...] em 2016 teve a discussão sobre as olimpíadas sobre postergar ou não as olimpíadas e essa discussão pegou em cheio a OMS. Foi pra pauta da reunião da OMS, do comitê de emergência [...]. E o comitê ouviu a posição do Ministério e acatou. Baseado, claro, nas evidências que o Ministério apresentou e também nas evidências que tinha na literatura e que não fazia sentido nenhum postergar o evento, sob o risco da epidemia de Zika. Então, em linhas gerais, também em 2016, eu senti a posição da OMS, sensata. RCG1/PF1(146)

O país desenvolveu duas frentes importantes de vigilância no período das Olimpíadas, com a Agência de Vigilância Sanitária (ANVISA) produzindo e implementando Guias para atuação de vigilância em eventos de massa (gerenciamento de risco e regulação de serviços de alimentação e saúde) e o Plano Operativo Integrado de Vigilância Sanitária, destacando-se o planejamento de laboratórios para análises clínicas, em colaboração com as demais esferas de governo. (203)

O Ministério atuou para reforçar a atenção à saúde durante o evento, com a disponibilização de ambulâncias, leitos, contratação de profissionais e liberação de R\$30 milhões para o Governo do Estado do Rio de Janeiro. Para isso, foi montado um CIOCS ${ }^{48}$ (Centro Integrado de Operações Conjuntas da Saúde) para monitorar situações de risco, demandas por atendimento, vigilância e atuar na coordenação das respostas em relação a emergências de saúde pública(204). Além disso, disponibilizou recursos de informática com informações sobre acesso a saúde como a página Saúde do Viajante (205) e o aplicativo Guardiões da Saúde, usado durante a Copa do Mundo de 2014(204). ${ }^{49}$

${ }^{48}$ O Centro foi inaugurado com atraso, em 19 de julho, com previsão de funcionamento até 20 de setembro, contando com 125 profissionais destacados para o monitoramento do atendimento a atletas, delegações e expectadores dos $\operatorname{Jogos}(211)$.

${ }^{49}$ Por meio dele, o usuário pode obter orientações e indicar sua condição de saúde todos os dias, possibilitando a detecção oportuna da proliferação de possíveis doenças. (204) 
Durante os Jogos, a Fiocruz desenvolveu o Projeto Olimpioma, que objetivou analisar a transformação provocada pelo megaevento no microbioma do Rio de janeiro, com a coleta de amostras nos trens do metrô e suas estações. Seu objetivo era tornar mais eficaz a prevenção e a resposta à entrada de novos vírus, cepas ou bactérias causadoras de doenças(203).

Além do Rio de Janeiro, outros 5 Estados receberam jogos durante as Olimpíadas (São Paulo, Minas Gerais, Bahia, Distrito Federal e Amazonas) e se comprometeram a realizar ações de combate ao mosquito(206).

Como resultado das ações viabilizadas pelo Governo Brasileiro, foram registrados 11.235 atendimentos durante os Jogos, com apenas 2 casos suspeitos de infecção pelo Vírus Zika: um descartado e um inconclusivo(207).

A disseminação do vírus foi preocupação constante antes e durante os Jogos, especialmente pela grande quantidade de visitantes que o país receberia. Nesse sentido, foi o principal foco da atuação do Ministério das Relações Exteriores do Brasil.

A parceria óbvia entre o Ministério da Saúde e o MRE não foi a tônica da resposta internacional do Brasil ao Zika. De acordo com estudo de Pittas(184), a atuação do MRE foi bastante diminuta, restringindo-se, basicamente, à emissão de notas por parte de Embaixadores em outros países e a garantia de uma boa imagem do país no exterior, que mantivesse as relações comerciais e turísticas, principalmente durante o evento.

Sendo o Brasil o epicentro de uma Emergência de Saúde Pública de Importância Internacional, era de se esperar que a autoridade em relações internacionais no país participasse intensamente da resposta. Entretanto, como demonstrado anteriormente, durante os governos Dilma e Temer o MRE teve seu papel enfraquecido e isso se refletiu nas ações em política externa sobre o caso. Além disso, como destacou Teixeira(41), por vezes as posições dos Ministérios frente a determinado tema são conflitantes, dificultando a coordenação de ações.

Em busca realizada no site do MRE, não foram encontrados documentos sobre parcerias formadas ou acordos internacionais relativos ao tema ${ }^{50}$. A maior parte das entradas era notas de embaixadores, com conteúdo bastante similar: tratam do empenho do governo em combater a epidemia, a transparência com que o país tem tratado seus dados, a segurança em se realizar os

50 Das 49 entradas encontradas, 37 são notas de embaixadores, 2 são calendários de eventos, 2 pronunciamentos de presidentes, 1 é informação sobre o hotsite de arboviroses, 1 nota sobre a resposta do Zika no contexto das Olimpíadas, 1 declaração conjunta entre o MRE e o MS sobre o fim da ESPII, 1 nota sobre a visita da Diretora da OMS ao Brasil, 2 comunicados de visitas oficiais a países, 1 entrevista com o Vice-Presidente do COI e uma menção ao Zika em nota sobre a comemoração do Primeiro "Ano Conjunto de Ciência e Inovação" entre Brasil e Reino Unido. 
Jogos Olímpicos no país e reforçam ações como a mobilização de forças armadas para o controle vetorial. É possível observar, como já demonstrou Pittas (184), que essas notas e, por conseguinte, a preocupação do Itamaraty, tinham o objetivo de, por meio da difusão dessas informações, assegurar que a boa imagem brasileira no exterior, evitando que isso afetasse viagens e comércio com o país, principalmente na iminência da realização das Olimpíadas. Nesse sentido, o autor(184) conclui que a atuação do MRE nesse tema foi bastante pragmática, visando questões econômicas.

A disseminação da ideia de segurança para os jogos foi fundamental para sua realização e a diplomacia se empenhou nesse processo, evocando diversos atores que pudessem dar legitimidade à mesma. Vale ressaltar que das 37 notas encontradas, três são de embaixadores nos Estados Unidos, e o CDC é mencionado em diversos desses documentos, com a finalidade de dar legitimidade às ações do governo brasileiro. Para isso, os diplomatas também lançam mão de outras instituições como a Fiocruz, o Instituto Pasteur, o NIH, o Butantan e o IEC, destacando o trabalho desenvolvido no âmbito científico.

Quando se olha para as notas emitidas na América do Sul, fóruns regionais também aparecem como espaços de troca de informações e demonstram o trabalho que o país estava realizando na região. São citados, por exemplo, a reunião da CELAC, o Mercosul e a Unasul; além de salientarem o contato permanente do país com a OPAS.

A menção aos Jogos Olímpicos predominou entre os documentos encontrados no site do MRE que citavam o vírus Zika, presentes em quase todas as notas dos embaixadores, com exceção apenas da nota do embaixador no Chile, o que reforça a preocupação com a imagem e a segurança do evento para turistas e delegações de atletas.

Isso é corroborado pela fala do entrevistado RCG2(145). A preocupação em esclarecer que era seguro realizar os jogos no Brasil naquele momento para os países que viriam participar, o que se tornou ainda mais relevante após as suspeitas de transmissão sexual do Zika.

Nós estávamos no início de 2016, ano de realização das Olimpíadas no Brasil, então houve também uma ansiedade, uma expectativa internacional em relação à possibilidade [...] no sentido de mudanças na sede das Olimpíadas, mais na possibilidade que a epidemia no Brasil representasse risco para os participantes do evento, particularmente para os participantes que vinham de outros países. Nós chegamos a ter uma reunião aqui em Brasília, com o conjunto dos embaixadores dos países da [...] União Europeia [...], que essa é uma grande preocupação que expressavam, ou seja, os países que viviam diretamente os problemas que estavam nas suas vizinhanças, se aproximaram mais, no sentido de entender que tipo de medidas podiam ser adotadas, de que forma eles poderiam se engajar num problema que, se ainda não era também deles, poderia se tornar a qualquer momento. Em relação aos países mais distantes, a preocupação em evitar qualquer tipo de risco de propagação pros seus territórios ou para as suas populações [...] essa preocupação se tornou ainda maior quando o conhecimento de que a Zika poderia ter a transmissão sexual por um período longo. Pessoas poderiam ter infecção 
assintomática e se tornarem transmissores dessa doença por vários meses, por quase um ano, segundo algumas das pesquisas. RCG2(145)

Também foi encontrada no site do MRE uma entrevista feita com Nawal El Moutawakel, vice-presidente do Comitê Olímpico Internacional, cujo tema central foi a realização dos jogos e, novamente, trata-se da não restrição de viagens ao Brasil e do risco mínimo de infecção durante o evento.

O único documento conjunto entre o MRE e o MS é uma nota sobre o fim da ESPII, declarada pela OMS, destacando que o Comitê de Emergências entende que o vírus Zika e suas consequências mantêm-se como um desafio que demanda ações intensas e indicando a necessidade de o tema ser tratado em um programa de trabalho permanente. Ainda, informa que o presidente do Comitê, David Heymann, e o Diretor-Executivo do Programa de Emergências de Saúde da OMS, Peter Salama, apoiaram a decisão de manter a emergência no plano nacional.

Além disso, foram encontrados dois pronunciamentos presidenciais. Um da Presidente Dilma Rousseff, realizado um dia após a Declaração da ESPII, feito em TV aberta. Dilma fez um chamado à população para a eliminação de criadouros de mosquitos e focou seu discurso nas ações de controle vetorial, com envolvimento das forças armadas. Falou de luta, guerra e defesa, numa gramática bélica e securitizadora. Ela enfatizou o investimento governamental na resposta à epidemia, tanto financeiro como tecnológico e humano e também mencionou a conversa com o presidente dos EUA sobre a parceria no desenvolvimento de uma vacina contra o Zika. No final do pronunciamento, citou as mães e crianças atingidas pela doença, enfatizando que faria de tudo para apoiá-las.

A nota do Presidente Temer teve como foco os Jogos Olímpicos e foi lançada em 5 de julho de 2016, um mês antes da abertura do evento. Temer destacou a estrutura criada para receber atletas e turistas e enfatizou o esquema de segurança disponível, assim como o fato do Brasil ser uma democracia consolidada com grande potencial para negócios. Além disso, também mencionou o período de baixa densidade vetorial em que os jogos seriam realizados, o que teria levado a uma diminuição expressiva de casos de Zika no país.

A resposta, ou falta de resposta, em termos de política externa no caso da ESPII reflete o enfraquecimento do Ministério das Relações Exteriores brasileiro, agravado pela mudança brusca de governo e pela crise econômica por que passava o país. Nesse sentido, alguns autores apontam para um horizonte em que os governos futuros abandonariam a tradição diplomática brasileira, diminuindo sua capacidade de responder ativa e adequadamente a ameaças à saúde pública(208). 
Transformar uma questão de saúde pública em uma questão de segurança é uma decisão política e traz consigo, não apenas o emprego de toda uma gramática de guerra, mas também ações excepcionais, que normalmente não seriam facilmente aceitas, como forma de dar conta de uma ameaça à ordem política internacional em vigor(132). De fato, quando uma Emergência de Importância Internacional é declarada, ela já carrega a ideia de exceção, na medida em que o RSI pode ser considerado um promotor da securitização(134). Por que, então, securitizar a emergência do Zika?

Uma das hipóteses, levantada por Pittas(184), é que "a securitização foi instrumentalizada, com vistas, sobretudo, a aspectos econômicos, como a obtenção de recursos e a normalização do turismo e das relações comerciais"(p.151). Segundo o autor,

O governo brasileiro, comandado pelo MS e pela SVS, de fato tomou movimentos securitizadores importantes, sem sequer problematizar as orientações provenientes de atores como a OMS. Tampouco buscou parceiros tradicionais como os países em desenvolvimento. No entanto, isso foi em função da via pragmática e não necessariamente por definição de princípios ideológicos. Ainda assim, há pluralidade na posição tomada entre agências [do MS]. Mesmo que não tenha sido o foco central, algumas destacaram o papel de alguns determinantes [sociais da saúde]. O país necessitava de recursos, ainda mais porque vivia num ambiente de crise e diminuição de montantes destinados à saúde. Por isso, entendia que necessitava buscar financiamento com aqueles que eram capazes de ajudá-lo. Também acreditava que deveria garantir a normalidade das relações comerciais, do turismo e das Olimpíadas, cujo cancelamento prejudicaria outras esferas e a imagem do Brasil no exterior. A OMS e os EUA demonstraram intenção de ajudar, a partir dos seus interesses e visões de mundo (...). Interpreta-se, portanto, que independente da via que o governo brasileiro gostaria de adotar, ele acreditou que a única possível era a securitizadora, capaz de angariar mais recursos para um problema grave. Por isso, houve instrumentalização da securitização (Ibid., p.152).

Não obstante, Pittas(184) concluiu que os agentes brasileiros apostaram na securitização para atrair atenção e recursos internacionais, mas que não teria havido continuidade na obtenção destas vantagens. Essa experiência brasileira demonstraria que, assim como a securitização em si, os benefícios dela oriundos seriam de curto prazo. Além da questão econômica, o pragmatismo revelado na atuação do MRE em relação à securitização da resposta pode ser uma consequência da falta de protagonismo que esse Ministério já vinha tendo desde o governo Dilma, ficando a ele relegado o papel de promover a sensação de segurança para a realização dos Jogos.

Por outro lado, de acordo com Wenham e Farias(209), no caso do Zika, houve uma combinação de cinco elementos para que a securitização ocorresse: 1) Onde: Brasil, país em que inúmeras tentativas de controle vetorial falharam e que sofria à época uma crise política importante; 2) Quando: imediatamente após a emergência do Ebola, o que colocou as autoridades em alerta; 3) Quem: afetou principalmente fetos e bebês, que geram maior sensibilidade junto aos atores políticos e sociais; 4) Como: o desconhecimento sobre como essa 
doença, as malformações, estavam ocorrendo; e 5) Qual ameaça: uma doença vetorial desconhecida. Nesse sentido, argumentam que houve uso político da securitização da emergência do Zika por Dilma Rousseff como uma oportunidade para o governo melhorar sua imagem doméstica no contexto da crise institucional. A visibilidade das ações levadas a cabo, a exemplo da convocação das Forças Armadas, teria colaborado para demonstrar liderança e comprometimento para acabar com aquela ameaça. Além disso, quando medidas excepcionais são tomadas, são raras as vezes em que o governo é questionado; pelo contrário, é ovacionado pela grande redução de incidência da doença.

Embora a tese elaborada por Wenham e Farias para explicar a securitização do Zika no Brasil resulte de um excelente esforço analítico e mereça a maior consideração, cabe ponderar a pertinência da ênfase no uso político da securitização. Em primeiro lugar, se por um lado é verdade que a declaração de emergência foi capaz de oferecer objetivos e uma agenda em comum entre atores governamentais e sociais, por outro, o reconhecimento pelo governo Rousseff da existência de uma crise sanitária relevante e das incertezas sobre a resposta a ser dada, assim como a iminência do adiamento ou da suspensão dos Jogos Olímpicos, representaram, por si só, um grande desgaste para a Presidência da República, que já passava por uma crise política importante.

Em segundo lugar, a escolha pelo combate ao mosquito como foco da resposta mostrouse natural não apenas pela já mencionada história brasileira de combate ao vetor, mas igualmente porque uma resposta focada nos direitos sexuais e reprodutivos das mulheres e/ou em soluções estruturais para o déficit também histórico de acesso à água potável e ao saneamento básico não encontrariam naquele momento, assim como na atualidade, a sustentação política necessária no seio do governo federal e fora dele. Nesse sentido, ao apostar em uma escolha consciente de Dilma para melhorar sua imagem doméstica como justificativa do processo de securitização, o trabalho de Wenham e Farias parece não levar em conta a extraordinária ascensão no Brasil das forças conservadoras com atuação no campo dos costumes, assim como a brutal perda de força da agenda de minimização das desigualdades sociais e econômicas que se encontrava em curso no país. Parece, ainda, subestimar a necessidade de oferecer uma resposta imediata e enfática aos atores internacionais, uma resposta capaz de evitar o adiamento ou a suspensão dos Jogos Olímpicos. Assim, o engajamento de diferentes atores para o combate ao vetor, inclusive das Forças Armadas, parecia uma necessidade real e objetiva naquele momento. É de se perguntar, a esta altura, se o 
Estado brasileiro de fato conhece outra forma de combate ao vetor que não inclua, ainda que em diferentes graus, processos de securitização.

Logo, do ponto de vista objetivo, tudo indica que as alternativas de fato viáveis postas ao governo Dilma foram essencialmente as de não priorizar a resposta, ou de priorizá-la pela via do combate imediato ao vetor. Note-se que a denúncia contra a Presidente Dilma por crime de responsabilidade junto à Câmara dos Deputados ocorreu após a declaração nacional de emergência, em 2 de dezembro de 2015; ela foi afastada do cargo pelo Senado Federal em 12 de maio de 2016 e sua destituição ocorreu em 31 de agosto do mesmo ano. Os Jogos Olímpicos ocorreram entre 5 e 21 de agosto de 2016, já sob o governo interino de Michel Temer. Não há elementos que permitam concluir que o contexto político oferecia espaço para uma resposta inovadora, baseada nos direitos humanos, especialmente os das mulheres e das crianças, além dos direitos sociais e econômicos relacionados às causas da propagação da epidemia. Não priorizar a resposta representaria, porém, o risco concreto de adiamento dos Jogos.

Em terceiro lugar, as futuras análises da securitização da resposta brasileira ao Zika precisam levar em conta a evidência de que a "guerra contra o mosquito" foi um retumbante fracasso. Em outras palavras, os limites do recurso à securitização mostram-se evidentes na história do Brasil, o que suscita a hipótese, a ser aferida em estudos futuros, de que a securitização de certas respostas envolve menos o eventual proveito político a ser obtido via securitização e mais a incapacidade política de promover outras dinâmicas em prol do combate ao vetor. Provavelmente o estudo das campanhas contra a dengue possa contribuir para que a expectativa de proveito político possa ser redimensionada.

Por fim, vale recordar que a securitização da emergência do Zika é uma facetas que remete aos limites da saúde global apontados por Nunes e Pimenta(2). Certamente, no curto prazo, essa resposta tem sentido prático e político, já que responde a uma situação alarmante, ou seja, é reativa a um "ataque". Mesmo privilegiando ações de curto prazo e negligenciando as mudanças estruturais necessárias, a securitização atinge a opinião pública que passa a acreditar que o problema está sendo combatido com as devidas prioridade e urgência. Outro ponto de correlação é a proteção aos cidadãos de países desenvolvidos, que buscou tranquilizar as delegações estrangeiras no caso das Olimpíadas. Também privilegia uma agenda de manutenção de iniquidades, atingindo apenas parte do problema, no caso, o vetor, e ignorando os determinantes sociais que incidem sobre esse caso. 


\subsection{RESPOSTAS DAS OIS}

Em dezembro de 2016, 48 países e territórios das Américas haviam identificado transmissão autóctone do vírus Zika; 5 reportaram transmissão por outra via que não o vetor, como a via sexual (Argentina, Chile, Canadá, Peru e Estados Unidos) e 22 confirmaram casos de Síndrome Congênita do Vírus Zika. (6)

Até 29 de dezembro, o Brasil era o recordista de casos de microcefalia associadas ao Zika, seguido por Estados Unidos, Colômbia e República Dominicana. (6)

Figura 7 Situação do vírus Zika no Brasil em relação às Américas

\begin{tabular}{|l|r|r|r|}
\hline & Américas & Brasil & \multicolumn{1}{|c|}{ \% } \\
\hline casos suspeitos & 534553 & 211770 & $40 \%$ \\
\hline casos confirmados & 177614 & 109596 & $62 \%$ \\
\hline casos importados & 5278 & 0 & $0 \%$ \\
\hline casos confirmados de SCZ & 2525 & 2289 & $91 \%$ \\
\hline
\end{tabular}

Até dezembro de 2016, dez dos doze países independentes da América do Sul reportaram ter casos autóctones de febre do vírus Zika (Argentina; Bolívia; Brasil; Colômbia; Equador; Paraguai; Peru; Suriname; e Venezuela). Três países da região reportaram casos transmitidos por via sexual (Argentina, Chile e Peru). Seis países constavam como tendo reportado casos confirmados de Síndrome congênita (Argentina, Bolívia, Brasil, Colômbia, Paraguai e Suriname), com Brasil e Colômbia tendo as maiores incidências da América do Sul.

O número indicado pelo Brasil é de longe o maior da região, 2.289, seguido pela Colômbia, com 72 casos. Entretanto, duas observações são importantes nesse documento: o número de casos confirmados por laboratório no Brasil foi de $469^{51}$ e, em artigo feito em conjunto com o CDC e publicado em 9 de dezembro, a Colômbia confirmou 147 casos da síndrome em laboratório. Se pensarmos que a população total no Brasil é cerca de quatro vezes a da Colômbia, pode-se extrapolar indicando que as taxas de incidência, ou seja, que leva em conta a população de risco, de ambos os países é similar.

$\mathrm{Na}$ atualização sobre o progresso da aplicação do RSI nas Américas feita na $55^{\mathrm{a}}$ Sessão do $\mathrm{CD}(210)$, consta que, em 2015, 99 eventos foram avaliados como possível evento de importância internacional, 45 foram considerados comprovadamente de importância

${ }^{51}$ Os casos reportados pelo Brasil, 2289, incluem não apenas casos confirmados em laboratório, mas também casos prováveis. 
internacional, 15 deles relacionados ao Zika. Das capacidades básicas regionais, apenas as capacidades de responder a emergências químicas (57\%) e os riscos relacionados à radiação (55\%), a média das demais capacidades nas Américas está acima de 75\%. Na América do Sul, esses valores são ainda mais elevados, com pelo menos seis capacidades com percentuais superiores a 90\% (legislação, políticas e financiamento; coordenação e comunicação com o Centro Nacional de Ligação; Vigilância; resposta; Comunicação de riscos; e eventos zoonóticos). As menores percentagens ficaram com capacidade de responder a emergências químicas $(68 \%)$ e recursos humanos (70\%).

Esses dados demonstram que o RSI, pese não estar 100\% implementado no que se refere às capacidades básicas, foi adotado pelos países e é empregado de fato na medida em que eles notificam a OPAS sobre possíveis eventos de importância internacional. Uma análise sobre a o processo de adoção e implementação do RSI será realizada mais adiante.

\subsubsection{A Resposta da OPAS}

Como escritório regional da OMS para a região da Américas, a OPAS também é a responsável por velar pela aplicação do RSI e, por isso, espera-se que sua atuação em se tratando de uma Emergência de Saúde nas Américas, como no caso da Zika, seja bastante ativa. Para fomentar a aplicação do Regulamento, são realizadas ações empreendidas de maneira contínua com os países membros, que funcionam tanto como mecanismos institucionais como de construção social para a disseminação e adoção dessa política regulatória. São exemplos o fortalecimento das capacidades básicas dos países, bem como a manutenção de uma rede de comunicação de risco, a cooperação intensa entre os escritórios país e os Ministérios da Saúde, bem como o fomento à cooperação internacional e a produção de conhecimento.

Nesse sentido, o RSI é um instrumento que fomenta e apoia os países a melhorarem seus sistemas de vigilância e a pressão popular e política por essa melhoria influenciam as autoridades a levarem em consideração os relatórios de avaliação, como se nota no trecho da entrevista abaixo.

Cuando hablamos de reglamento sanitario internacional, hablamos de 13 capacidades básicas del reglamento. [...] Pero permite poner una presión positiva en los estados, los gobiernos, para subir el nivel de calidad de la vigilancia. [...] Si a la primera evaluación de la capacidad, se detectan aspectos débiles en los tres pilares de la vigilancia, la clínica, la epidemióloga, la viróloga, tenemos como OPS la protesta de decir "eso tiene que cambiar, tiene que elevar el nivel, estamos aquí para apoyarlos". Entonces, como estamos invitados a hacer una fotografía interna para el Ministerio y a dar muy rápidamente recomendaciones para elevar el nivel. Nos da una entrada en mecanismos que son nacionales, es eso la finesa. Es no olvidar que el objetivo nuestro no es hacer pesquisas. Es de servir a estados, a gobiernos, para mejorar su trabajo. Con un privilegio 
de tener acceso a una información confidencial. Pero nos da esta protesta, un informe final de una misión, de primera evaluación de la vigilancia de Zika a un ministro. Te puedo decir, con la presión comunitaria, la presión de la población, la presión política, lo tomaban en cuenta. RCOI1(154)

Na mesma linha, outra característica levantada como chave é a articulação da resposta como um todo, mantendo os sistemas de vigilância alertas, como no caso do Brasil com relação ao surgimento do vírus Zika. Além disso, destaca o fato de o RSI ser incorporado à prática dos países.

O regulamento sanitário serve para rearticular a notificação, a resposta [...] O regulamento
sanitário, o que promove, é que os sistemas de vigilância estejam ativos, bem articulados. Então
aí vai a implantação do regulamento, avaliações do sistema de vigilância epidemiológica, de
saúde pública. [...] O Brasil foi o primeiro país nas Américas a cumprir os requisitos básicos de
vigilância. E assim foi, e assim funcionou por isso, porque há capacidade de vigilância, há
capacidade de detecção. [...]. O regulamento promove a melhora os sistemas de vigilância e
notificação, de alerta e de resposta. [...] o regulamento está incluído na prática, está integrado
na prática diária dos ministérios de saúde. [...] RCOI2(147)

A intensificação do apoio da OPAS para o controle do Zika na região se deu de forma ampla, pelo acompanhamento da epidemia, redução de riscos, melhoria da capacidade de resposta com foco nos serviços de saúde, comunicação de riscos e controle de vetores, e enfoque nas pesquisas sobre o vírus. Mobilização de recursos, em coordenação com outras agências da ONU, BID, BM e a OMS; produção e difusão de diretrizes técnicas; organização de reuniões virtuais e capacitação presencial em serviços laboratoriais, vigilância entomológica e controle de vetores, monitoramento de gestantes e comunicação de risco nacional, regional e subregional. Além disso, enviou missões técnicas e distribuiu insumos como reativos de laboratórios, trabalhando na coordenação de esforços de pesquisa, com a elaboração de uma agenda de pesquisa regional, entre outras ações.

Antes da Declaração da ESPII, ainda em 2014, a Organização vinha acompanhando pequenos surtos do Zika na região, como na Ilha de Páscoa, Chile. No início de 2015, começou a receber informações do Brasil sobre casos de uma doença ainda não identificada no Maranhão, o que se confirmou em abril ser infecção pelo Zika.

No primeiro Alerta Epidemiológico da Organização, lançado em 7 maio(211), a OPAS chamou atenção para a possibilidade de disseminação da arbovirose para países com a presença do vetor Aedes Aegypti. Nesse momento, as autoridades brasileiras ainda investigavam a nova doença. De maio de 2015 a dezembro de 2016, a OPAS emitiu 41 alertas e atualizações epidemiológicas sobre o Zika, 37 deles em 2016.

O Conselho Diretivo da OPAS, reunido em setembro de 2015(212), já tinha o Zika como pauta de debates. Muitos dos seus membros já apresentavam casos em seus territórios, 
aumentando a pressão internacional por ações da Organização. Na apresentação do documento "Abogar por la salud hacia el desarrollo sostenible y la equidad: liderar con el ejemplo", a diretora Carissa Etienne falou sobre a resposta à introdução recente do vírus Zika no Brasil, em trabalho em colaboração com o CDC, prestando cooperação em diagnóstico e acompanhamento da doença, focando na promoção da saúde em todas as políticas e em atividades multisetoriais.

Em junho de 2016, já com a ESPII em curso, estimava-se que seriam necessários US\$ 17.300.000 para a reposta integral, incluindo ações de vigilância, prevenção e resposta, além da promoção da agenda de pesquisa, coordenação e gestão e as necessidades dos escritórios de país (213).

\subsubsection{A ativação do sistema de emergências}

De acordo com o entrevistado RCOI1(154), a OPAS mantém uma vigilância geral, que combina vigilância baseada em três pilares: indicadores fornecidos pelos Estados, diretamente ou em seus veículos de comunicação (como portais de internet ou documentos internos); vigilância baseada em sistemas de informação de laboratórios de saúde pública (Fabricate laboratory information system - FILIS); e finalmente a vigilância baseada em eventos que corresponde ao seu mandato.

Eso es el mandato de nosotros bajo el Reglamento Sanitario Internacional. Quiere decir, cualquier evento, que es lo inusitado, que sale del normal, del esperado, investigamos. De manera formal, con Ministerios, pero también tenemos la propuesta de cruzar información ("match information"), con la información que viene de ONGs, redes profesionales tipo PROMED, individuos que tienen la (incomprensível) de reportarnos. Nuestro trabajo es de combinar todo esto, y sacar una primera evaluación de riesgo, que vamos refinando paso a paso. RCOI1(154)

O entrevistado prossegue afirmando que, no caso do Zika, havia um quarto pilar. Tratase de uma bateria de indicadores que a organização não estava acostumada a supervisionar, relacionados a informações congênitas, que existe em poucos países. Adiciona:

Es que en cada país tenemos una oficina-país. En cada país, tenemos un doctor Enrique Vázquez $^{52}[\ldots]$. Quien está en contacto directo con la sociedad científica, con los hospitales, con los ministerios de salud, con la autoridad estadual y hasta la autoridad municipal manejando este tipo de información. Detectamos señales a través de la vigilancia basado en eventos, quiere decir, artículos de prensa, reportes informales, conversaciones en sitios de profesionales tipo médicos. A finales de 2014, inicio de 2015, había brotes de una enfermedad como el dengue, pero que salía negativo en el laboratorio. Lo que los brasileiros llamaron de "dengue niño", el "pequeño dengue", y eso lo detectamos a partir de finales de 2014. [...] Después, es por información basada

\footnotetext{
${ }^{52}$ Enrique Vázquez foi o responsável pela coordenação da resposta da OPAS no Brasil.
} 
en laboratorio y también información muy preliminar, compartida por la autoridad nacional en Brasil, a partir del mes de mayo 2015, que detectamos la emergencia del Zika. RCOI1(154)

Uma das preocupações da OPAS, especialmente do seu escritório no Brasil, era estabelecer a causa para aquele aumento anormal dos casos de microcefalia em crianças. Esse foi um dos desafios apontados pelo entrevistado RCOI2, que destaca as disputas discursivas:

Então, nossa prioridade, em primeiro lugar, (era) definir a causalidade. Era saber se realmente o Zika produzia microcefalia. Para mim foi um dos maiores de desafios porque havia inclusive muita oposição interna, na área científica no país, a reconhecer que o Zika produzia a microcefalia. [...] Então essa foi uma luta dialética, debate bastante desgastante, que também aconteceu com a própria OMS. RCOI2(147)

As suspeitas sobre a causalidade, entretanto, fizeram epidemiologistas questionarem dados de epidemias anteriores, como a que acometeu a Polinésia Francesa em 2013. A discussão, então, ganhou novas dimensões e uma rede de especialistas se reuniu para se aprofundar no tema.

Pasó a nivel regional, pasó a nivel global, y a partir de octubre, noviembre, inicio de noviembre, conectamos como una red, a tres fuentes de información entre OPS, Brasil y la red de los epidemiólogos de laboratorios franceses en la Polinesia Francesa, Tahití, que ya había sufrido un brote de Zika, un par de años antes. Y, en este momento fue realmente casual, diciendo, pero 'ustedes no han observado malformaciones' y la respuesta fue 'no, pero observamos muchos abortos terapéuticos, porque en la Polinesia Francesa es la misma ley de Francia'. El aborto para malformación, en el marco de la ley está autorizado y está medicalizado. [...] El momento clave para nosotros, lo que ha precedido la declaración de emergencia de la OPS que fue el 08 de diciembre [...] Es una misión solicitada por el gobierno de Brasil a finales de noviembre. Y a finales de la misión hubo evidencia, que decía 'algo está pasando', estamos detectando únicamente el pico del iceberg. RCOI1(154)

Nesse contexto, outro informante destaca, ainda, o papel do WhatsApp na transmissão de informações. Ressalta ainda, o papel relevante nas missões enviadas in loco para averiguação de uma situação potencialmente emergencial.

Eu lembro que foi dia 24 de outubro, antes começou a se mover pelas redes sociais, Whatsapp, especialmente. Os clínicos, pediatras, começaram a sentir que havia um aumento de incidência, de prevalência de microcefalia. [...] Isso se notificou oficialmente ao Ministério da saúde em 23, 24 de outubro e no dia 26 mesmo fomos lá, Ministério e OPAS, para Recife. Quando chegamos, imediatamente percebemos, Claudio Maierovitch e eu, com as equipes, [...] que estávamos diante de um evento muito importante, e que aquilo não era normal. (...) Primeiro: que havia um surto de microcefalia evidente, e segundo que a principal hipótese causal era Zika. [...]. RCOI2 (147)

Em 17 de novembro de 2015, dois dias após o governo brasileiro declarar ESPIN, foi lançado o primeiro alerta sobre o aumento de casos de microcefalia na região Nordeste do Brasil, instando os demais países membros a reportarem casos semelhantes em seus territórios pelos canais do RSI e a fazerem uma análise de bases de dados de nascimentos para avaliar aumentos incomuns de problemas neurológicos em bebês(214). 
Seguindo o aumento de casos de Zika e de microcefalia, em novembro, uma equipe de especialistas do GOARN ${ }^{53}$ (Global Outbreak Alert and Response Network ou Rede Mundial de Alerta e Resposta ante Surtos Epidêmicos) visitou o Brasil. Entre suas conclusões, estão que a capacidade de testagem naquele momento deveria ser ampliada e que o potencial de uma epidemia de microcefalia teria impactos imediatos e de longo prazo. (6)

Em dezembro, o alerta foi mais específico, associando o aumento de casos a regiões onde circulava o Zika, seguindo o que pesquisadores brasileiros já haviam indicado. Nesse alerta, a OPAS chamou atenção para a necessidade de que os países estivessem preparados para detectar e responder a um possível aumento da demanda para esses casos. (214)

Em 8 de dezembro de 2015, o Sistema de Gerenciamento de Incidentes (Incident Management System, IMS) foi acionado, sob o comando do francês Dr. Sylvain Aldighieri. Esse sistema inclui ações em áreas como vigilância, cooperação técnica e cooperação internacional, o desenvolvimento de guias clínicos e a disponibilidade de produtos médicos e medicamentos, logística, informação e comunicação, mobilização de recursos humanos, preparação de serviços de saúde, captação de recursos, entre outros. (6)

A ativação do sistema de emergências da OPAS denota que a Organização reconhecia a emergência na região e também a relação de causalidades apontada por cientistas brasileiros entre o vírus Zika e as malformações congênitas, legitimando a esse e ajudando a disseminação da tese brasileira. A mobilização dos mecanismos do RSI trouxe incentivos para sua aplicação como mecanismos de indução institucional, permitindo, por exemplo acesso ao Fundo de Emergência para Epidemias da OPAS e, com a deflagração da ESPII, o Fundo de Contingência da OMS para Emergências. Esse fundo tem a finalidade de financiar ações de um marco estratégico que envolvem o acompanhamento da epidemia, o controle de vetores, o fortalecimento dos sistemas de saúde e o fomento a pesquisas sobre o Vírus Zika. Entretanto, em setembro de 2016 existia uma lacuna de $70 \%$ no orçamento total necessário para dar cabo das ações propostas pela Organização.(215)

Seguindo a lógica dos incentivos à aplicação do RSI, a captação de recursos foi apontada como resultado da declaração da ESPII, que incrementou o orçamento já ativado do fundo da OPAS.

${ }^{53}$ O GOARN é uma colaboração de instituições e redes que disponibilizam recursos humanos e técnico, de forma a apoiar na rápida identificação, confirmação e resposta a epidemias e surtos de importância internacional. A OMS é coordenadora da rede. Saiba mais em: https://www.who.int/ihr/alert_and_response/outbreak-network/en/ 
Yo te diría que grandes donantes internacionales pusieron plata en la mesa. A nivel mundial, a nivel global, pero también a nivel regional y eso apartó bastante. Esto es lo que cambió, porque entre diciembre, declaración el día 08 de diciembre, declaración de la emergencia por la OPS, utilizamos los fondos de emergencia que teníamos: mandando equipos, virólogos, clínicos, epidemiólogos, control de vectores a los países. Pero ya habíamos aquí, finales de enero, llegado a un nivel de solicitud en términos de plata, de parte de los países, que superaba nuestras posibilidades. Tengo acceso, puedo activar como comandante de incidente un fondo de emergencia. Pero la declaración de la OMS involucra los grandes donantes, y entra en el juego y ellos activan otras redes, no regionales, sino globales, de investigadores ${ }^{54}$. RCOI1(154)

Segundo apresentação feita por Enrique Vázquez(216), então coordenador de Doenças Transmissíveis e Análise de Situação de Saúde da OPAS, entre agosto e setembro de 2016 US\$6,59 milhões foram liberados pelas principais agências financiadoras (Figura 9). Esse valor foi distribuído em 6 áreas técnicas: Vigilância/Laboratórios, Apoio aos Sistemas de Saúde, Comunicação de Risco, Controle Vetorial, Coordenação e Pesquisa.

Figura 8 Recursos financeiros desembolsados pelas principais entidades financiadoras

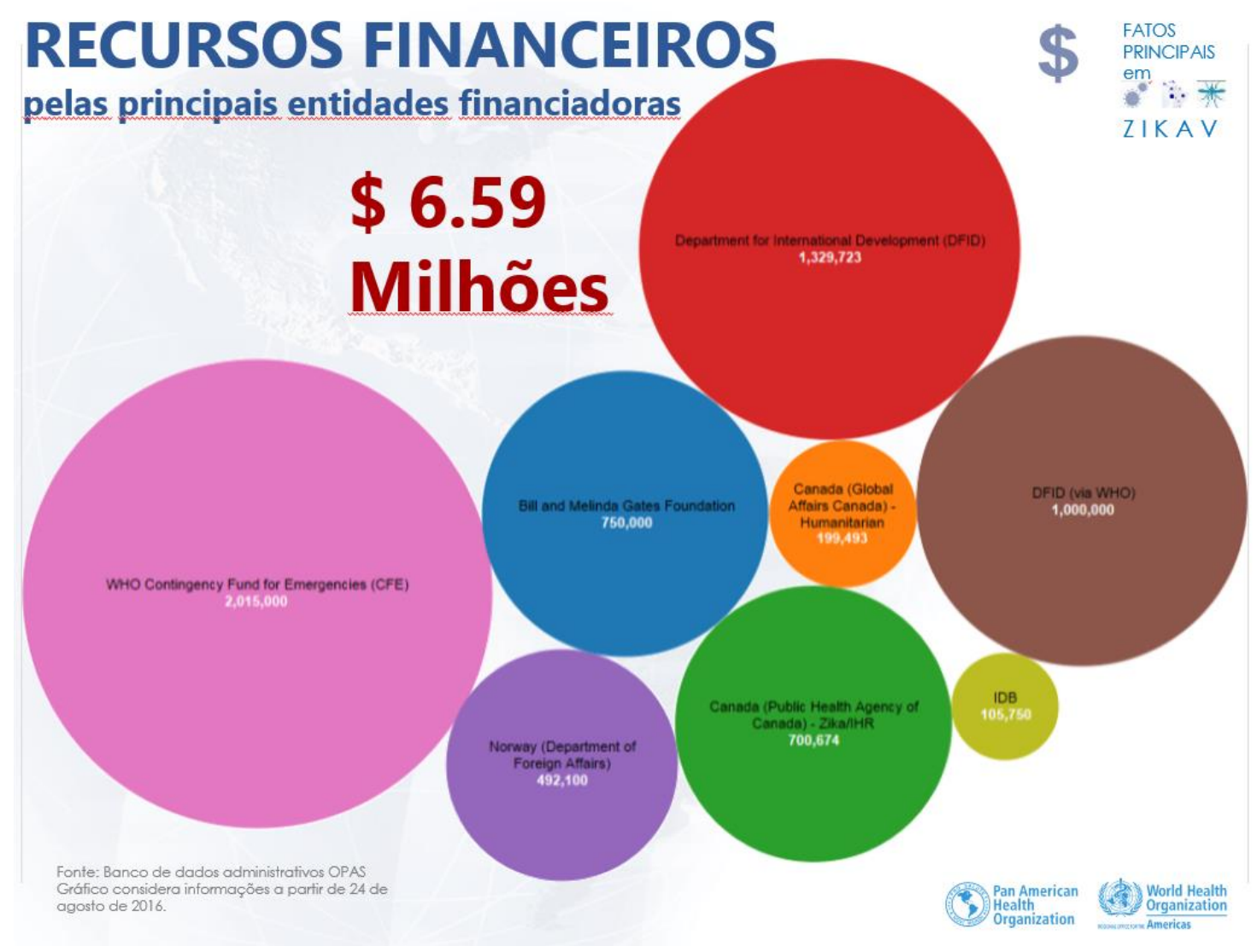

Fonte: (216)

\footnotetext{
${ }^{54}$ Nesse ponto, pelo contexto é possível inferir que seria investidores e não pesquisadores. Entretanto, a frase está como dita pelo entrevistado.
} 
No mesmo sentido, outro entrevistado descreve o RSI como um grande guarda-chuva para a vigilância, enfocando no seu papel de se integrar ao ordenamento jurídico dos países e apontando vantagens de uma ESPII como estabelecer mecanismos como a arrecadação recursos financeiros de forma ágil.

Mira, yo creo que, en línea general, el reglamento sanitario da un enorme paragua de lo que es
vigilancia. O sea, te permite establecer herramientas que, a lo mejor, dentro del marco legal del
país, por sí sólo, con estos marcos legales va a ser imposible de hacerlo [...] En Zika, [...]
estamos hablando, de una enfermedad emergente nueva. Estamos hablando de una ESPII, y
plantearnos ya como una ESPII, con esa figura, permitió que se pueda generar fondos adicionales
en la respuesta que se pueda implementar rápidamente estrategias de vigilancia a nivel nacional.
Que de repente, tiene como un ritmo más lento, si no está enmarcado dentro del RSI. Es como
que uno puede distribuir instrumentos, puede fortalecer estructuras de vigilancia. Por ejemplo,
con el tema de Zika, nos permitió que nosotros podamos capacitar a nuestros especialistas en
imágenes. Que nosotros podamos comprar más equipos de imágenes para el país, que se pueda
fortalecer los centros de desarrollo infantil. Todo ese tipo de cosa, por el doble, la doble figura.
Una que era enfermedad nueva, emergente y que estaba infectando a niños, que lógicamente ya
crea una sensibilidad especial. Pero sobre todo porque estaba catalogado como una ESPII por el
reglamento sanitario internacional, y eso había una obligación de responder y de, como te iba a
decir, y de informarlo avances a la OPS. PF2(183)

No sentido de promover suas políticas, a OPAS se utiliza de diversos tipos de mecanismos de construção social. A comunicação foi um dos focos importantes da resposta da OPAS, com a criação de um hotsite (http://www.paho.org/zikavirus) com informações agregadas e perguntas comuns sobre o tema. (6) Outra estratégia nessa linha, que envolveu participação comunitária se deu em Barranquilla, Colômbia: "Meu quarteirão sem dengue”, que mobilizou profissionais de saúde no sentido de promover ações de educação em saúde e como eliminar os focos dos mosquitos. (6) Além disso, promove capacitações e realiza missões aos países no contexto do Zika.

É preciso destacar que a OPAS tem lugar privilegiado no sentido de promover espaços transnacionais de discussão, parte importante do mecanismo institucional para a disseminação de políticas e seus elementos. Não apenas por meio das reuniões de suas instâncias decisórias, que emitem resoluções e estabelecem acordos, mas também pela promoção de inúmeros workshops e outros encontros. Nesses espaços, a Organização legitima suas políticas e fortalece suas ações por meio da diplomacia da saúde. Sem mencionar o relacionamento estreito com os países por meio dos seus escritórios nacionais e o estabelecimento dos termos de cooperação que financiam projetos específicos, induzindo políticas nesses territórios.

Todas as reuniões ordinárias e outras programadas na sua agenda de trabalho no período da epidemia foram realizadas, o que não ocorreu no caso das demais organizações como veremos adiante. Nesse sentido, os mecanismos de operação foram mantidos e sua ação potencializada no caso da emergência. 
Como forma de legitimar sua decisão frente aos membros da Organização, a Diretora Carissa Etienne chamou atenção, em documento apresentado diante a 55 . Reunião do Conselho Diretivo, para a coordenação interagencial promovida pela da OPAS para conduzir uma ação conjunta de resposta à emergência do Zika e salientou o papel da Organização na resposta a emergências. Apresentou a resposta da Organização até então, ressaltando que a OPAS ativou sua equipe de Operações de Alerta e Resposta (OAR) e o Sistema de Gestão de Incidentes (IMS) mesmo antes da declaração da ESPII. Com isso, reforçou a informação sobre o acesso a recursos para a compra de materiais, insumos, envio de missões, capacitações etc.(202), fortalecendo seus principais mecanismos de indução para a adoção e implementação do RSI.

O entrevistado RCOI1(154) esclarece que a OPAS enviou uma equipe de virologistas à América Central, ao Caribe e à América do Sul, sobretudo à Colômbia, cuja rede de laboratórios em nível estadual é muito consistente. E que considerando as dúvidas constatadas a OPAS declarou a emergência antes da OMS e explica:

Declaramos la emergencia en la OPS. Pero tú sabes, la OMS es una casa grande, con varias regiones y con matices de pensamiento. Aún no teníamos información perfecta desde la parte del Pacífico, que se llama WPRO para información que venía fluyente. La verdad es que en ningún momento en las demás regiones que habían reportado Zika AFRO, SEARO, el Sureste de Asia, la India, y África habían detectado problemas asociados con malformaciones. ¿Ok? Entonces, es el fin del año y la OPS actúa, declara la emergencia, quiere decir: refuerza vigilancia, de refuerza laboratorio, refuerza guías de vigilancia en malformaciones congénitas, afinadas con información para tener una definición de caso. Que fue, yo te diría, el aspecto más complicado. RCOI1(154)

Nesse mesmo sentido, na opinião do informante RCOI2(147), a OMS tardou a declarar a emergência. Em sua opinião pessoal, as críticas direcionadas à atuação da OMS na crise do Ebola (2014-2015) engendraram, nos quadros da organização, um receio de errar novamente.

Bom, eu acho que havia um certo medo de meter os pés pelas mãos. Quer dizer, era preciso ter certeza absoluta de que estava acontecendo algo incomum antes de declarar emergência. Essa é a minha impressão como funcionário. Não é assim na OPAS, a OPAS é OMS também, mas na OPAS estávamos muito mais cientes de que estávamos diante de um fato histórico na saúde pública, com o tema do Zika. Então, a resposta local, regional desde Washington, foi muito antes da OMS em Genebra. É uma organização que possui todo tipo de contradições, é normal. RCOI2(147)

Ele afirma, no entanto, que a Declaração foi o reconhecimento de havia uma situação atípica em curso:

[...] mais que uma declaração pra avisar que havia um problema, foi a constatação de que havia um problema. Problemas que sabíamos que existiam. Fomos trabalhar no final de outubro, todo novembro, todo dezembro, um estudo caso controle já havia começado, (incompreensível), e por isso se falava que essa declaração de emergência chegou tarde. RCOI2(147) 
O entrevistado RCOI1 sintetiza os eventos que levaram à declaração da seguinte forma. Destacou a apresentação feita por Claudio Maierovitch ${ }^{55}$ na reunião do Conselho Executivo da OMS, em 28 de janeiro de 2016, que apresentou todos os dados disponíveis sobre o Brasil naquele momento. Houve, na mesma ocasião, apresentações do CDC americano e do governo francês, que resultaram a convocação de um Comitê de Emergências pela então Diretora da OMS, Margaret Chan.

Hay tres, cuatro momentos clave. Una señal a finales de 2014, inicio de 2015, vigilancia basada
en eventos. Segundo momento clave: capacidad de laboratorio para detección, fue la biología
molecular del virus. Tercer momento: las redes profesionales en Brasil entre pediatras, obstetras,
epidemiólogos y virólogos, que logran compartir información y hacer una lluvia de ideas, y a
hacer el balance de hipótesis y la relación de causalidad entre biología molecular y la
histoquímica, la detección en muestras. Y después, yo te diría para agregar, de la declaración de
emergencia, el artículo publicado en el New England Jornal of Medicine, de Lyle Petersen que
pone las bases de la definición de caso clínica de la microcefalia provocada por Zika.
RCOI1(154)

\subsubsection{Controle vetorial como demanda dos países}

Assim como o Brasil, os demais países das Américas solicitaram apoio para a melhoria da vigilância por meio da detecção e monitoramento de arboviroses. Já em 2015, a Organização debatia a introdução do vírus Zika na região das Américas, mesmo sem o tema constar especificamente em documento de discussão(217), enfatizando a necessidade de acelerar as medidas de controle vetorial, além de melhorar o manejo de resíduos sólidos para a eliminação dos criadouros.

Em fevereiro de 2016, a OPAS desenvolveu uma estratégia regional, cujos objetivos incluíam melhorar a capacidade de resposta dos países membros para detectar de forma oportuna e monitorar a epidemia; prevenir e responder. O trabalho intersetorial é evidenciado como fundamental para esse controle; além da vigilância da resistência a inseticidas e infestação pelo Aedes Aegypti, a comunicação oportuna e o fortalecimento de ações para a mudança de comportamentos individuais e para aumentar a participação comunitária.

Para fomentar melhores resultados desse eixo, foi criado um Grupo Técnico Assessor em Saúde Pública Entomológica, que se reuniu em março de 2016. Suas recomendações incluíram o incremento do controle vetorial e da vigilância, e do treinamento nessas áreas; o

55 Claudio Maierovitch foi diretor do Departamento de Vigilância das Doenças Transmissíveis (DEVIT/SVS) da Secretaria de Vigilância em Saúde do Ministério da Saúde até meados de 2016, quando assumiu Eduardo Hage. 
desenvolvimento de um novo protocolo para monitorar a resistência a inseticidas; e a avaliação de custo-efetividade e impacto das ações de controle atualmente implementadas, além das alternativas existentes, como os mosquitos geneticamente modificados. (6)

Em junho de 2016, a Diretora da OPAS, Carissa Etienne, reforçou o compromisso e liderança políticos para o avanço da resposta e a importância de sistemas de vigilância fortalecidos, como o do Brasil; pontuou ainda que o desafio da região é manter o mesmo nível de compromisso no médio e longo prazo(218). Além disso, ressaltou a falta de vontade política de levar a cabo o esforço iniciado em 1996 para erradicar o Aedes Aegypti nas Américas(215), reforçando o desafio do controle de arboviroses na região. Nesse sentido, o controle vetorial foi apontado como uma das grandes prioridades da OPAS no contexto da emergência em foco, como uma necessidade levantadas pelos países.

Una grande demanda de todos los países fue el aspecto del control vectorial. Yo te diría que todavía el desafío sigue. [...] Aún países grandes porque, en todos estos países la autoridad que está a cargo del control vectorial es la autoridad local, municipal. La entidad, muchas veces, la más pobre. RCOI1(154)

$\mathrm{Na} 55^{\mathrm{a}}$ Sessão do CD, a OPAS adotou a Estratégia para a prevenção e o controle de arboviroses (219) por meio da Resolução CD55.R6(220). Essa estratégia glosa ações de longo prazo no sentido de demandar a integração das estratégias de combate às arboviroses de importância para a saúde pública das Américas.

Os debates que antecederam a aprovação, (221) como ocorreu na $158^{\mathrm{a}}$ sessão do seu Comitê Executivo, os membros propuseram que, com a introdução do Zika, a estratégia devesse fazer frente à todas as arboviroses com um enfoque abrangente e holístico. Houve também consenso sobre a necessidade de ações sustentáveis de resposta: controle vetorial, diagnóstico, fortalecimento dos sistemas de vigilância, diagnóstico laboratorial.

Já no CD, os delegados felicitaram a OPAS pela resposta rápida ao surto e também a disseminação de informação sobre a situação da região. Além disso, reforçaram a necessidade de ações que evitassem que o Zika se tornasse endêmico e, ainda, que era necessária a vigilância das malformações congênitas e da SGB e orientar a gestantes, acompanhando os bebês por um prazo longo. Para os países membros, a prioridade máxima deveria ser na redução de risco das mulheres grávidas e em idade reprodutiva.

Nesse sentido, como o vírus Zika ainda era pouco conhecido, a estratégia reforça que pesquisas deveriam focar em seu comportamento clínico e epidemiológico. O objetivo principal é estabelecer formas de fortalecer a vigilância, diagnóstico e manejo das arboviroses 1) 
promovendo um enfoque integrado; 2) fortalecendo os serviços de saúde para diagnóstico e manejo; 3) fortalecendo a capacidade dos países para vigilância e manejo de vetores e, 4) estabelecendo e fortalecendo a capacidade da Rede de Laboratórios de Diagnóstico de Arbovírus nas américas (RELDA ${ }^{56}$ ).

\subsection{3 Ética, Saúde Sexual e reprodutiva, e atenção à saúde}

Durante as reuniões CE158 e CD55, observou-se a necessidade de um enfoque integrado e o fortalecimento dos serviços de atenção primária e de Saúde sexual e reprodutiva, bem como apoio psicossocial e proteção às famílias afetadas. (202,218)

Ao CD, a Diretora da OPAS apresentou os resultados da Consulta internacional sobre a epidemia do Zika e ética, feita em abril de 2016, com financiamento da Wellcome Trust. O produto dessa consulta coloca em evidência a necessidade de não apenas informar, mas de promover o acesso a planejamento familiar que tenha a mulher como protagonista. Entretanto, como vimos anteriormente, pelo menos no caso do Brasil, esse não foi foco das ações do governo.

- Todas as mulheres devem ter acesso a informações e serviços integrais em matéria sexual e reprodutiva, inclusive planejamento familiar, saúde materna, testagem pré-natal, interrupção segura da gravidez, orientação e serviços de atenção pós-natal.

- $\quad$ O direito moral das mulheres de escolherem suas opções reprodutivas deve ser respeitado durante o surto do vírus Zika.

- As mulheres devem poder escolher livremente com base nas opções relevantes, inclusive a contracepção, a interrupção da gravidez e a manutenção de uma gravidez potencialmente afetada. Nenhuma opção deve ser associada à contingência de um diagnóstico específico ou à probabilidade de um resultado negativo da gravidez.

- As mulheres devem receber apoio social adequado a suas decisões reprodutivas e assistência para administrar as dificuldades relacionadas à infecção causada pelo vírus Zika e à Síndrome Congênita do vírus Zika (SCZ).

- As autoridades sanitárias devem se esforçar por minimizar a discriminação e a estigmatização, prestando continuamente informações ao público sobre a importância de se respeitarem as diferentes crenças, valores e escolhas.

- Devem ser proporcionadas às mulheres informações honestas, completas, corretas e atualizadas sobre o vírus Zika e a SCZ.

56 “A Rede de Laboratórios de Diagnóstico de Arbovírus (RELDA) é composta por 22 laboratórios nacionais de referência nas Américas. Seu objetivo é fortalecer as capacidades técnico-científicas dos laboratórios da Região para fornecer uma resposta oportuna e de qualidade à vigilância epidemiológica e resposta a surtos de dengue e outros arbovírus. De 2008 a fevereiro de 2016, o RELDA funcionou como Rede de Laboratórios Dengue das Américas" (274). 
- $\quad$ O avanço da pesquisa sobre o Zika é um imperativo ético, e os pesquisadores têm uma responsabilidade ética de divulgar os dados e os resultados de pesquisa para permitir respostas imediatas a essa emergência de saúde. (202)p.8.

A assistência também foi pauta entre os países membros da OPAS, embora sem destaque nos documentos de trabalho, o que era esperado visto o caráter multifatorial da emergência. $O$ vírus Zika e suas consequências eram mencionados apenas nos debates sobre determinados temas, como o da atenção à mãe, ao recém-nascido e à criança. Durante o CE158, foi ressaltada a necessidade de cooperação para enfrentar os impactos do Zika, em virtude das possíveis consequências para a saúde de crianças e das brechas nos programas de saúde materno infantil, reforçando a importância do fortalecimento desses programas e do pré-natal e parto.

No CD55, o documento CD55/INF/11(222), continuava sem mencionar o vírus e suas consequências; e, novamente, no debate, os delegados apontaram as consequências do Zika para bebês e crianças, solicitando à OPAS que mantivesse o fluxo de informações para que os países possam tomar decisões baseados em evidências sobre o vírus. Já nos Relatórios de progresso sobre assuntos técnicos(223), foi destacado que não foram mencionados os vínculos ou ações necessárias para fechar as brechas na conexão entre o tema do Plano de ação para a saúde do adolescente e do jovem e a resposta ao Zika, como a falta de acesso à informações de saúde sexual e reprodutiva. Naquele momento o plano estava sendo ajustado para se adequar à nova realidade, como a inclusão de atenção especial para gestantes, inclusive adolescentes.

\subsubsection{A indução por meio de missões, capacitações e workshops}

No contexto da epidemia do Vírus Zika, a OPAS realizou diversas missões (224) aos países afetados com o objetivo de apoiar os governos na vigilância, controle e prevenção não apenas do Zika, como também da dengue e chikungunya, realizando treinamentos, oficinas e dando apoio técnico para a realização de estudos e políticas. A atuação da organização nesse sentido, evidencia ferramentas importantes para a disseminação de suas políticas e práticas e também funciona como um incentivo para quem as adota, no sentido de qualificar sua mão-deobra e legitimar a atuação interna dos seus membros.

Como forma de cumprir com os objetivos da resposta da Organização, foram criados guias sobre Vigilância do Zika e suas complicações. Dessa forma, a OPAS cumpriu o papel de homogeneizar nos países das Américas o manejo e atuação clínica no caso em foco. 
O informante RCOI2(147) resume o papel da OPAS para com os países, de suporte em todos os níveis da resposta:

Esclarecer e apoiar em todas as frentes [...] Nossa prioridade foi apoio ao ministério - na resposta. Uma resposta múltipla de assistência, sistemas epidemiológicos, de sistema de informação, o sistema de registro que se montou para recolher esses casos de microcefalia, de síndrome neurológico congênito. Tomamos a iniciativa, apoiando o governo para a definição de guias, protocolos, definição de caso... [...] Apoio às definições ligadas à vigilância epidemiológica, definições de caso [...]. RCOI2(147)

Com o objetivo de desenvolver uma abordagem integral em relação à epidemia do Zika, com base na Estratégia supracitada, mais de 30 países se reuniram em Cuba, em outubro de 2016. (6) A RELDA e a OPAS já haviam se reunido anteriormente, em fevereiro, para definir pautas comuns e padrões para a detecção e monitoramento do vírus Zika nas Américas (224). Adicionalmente, foram realizadas 21 missões técnicas em 15 países para apoiar os países no estabelecimento de uma estrutura para a detecção e a capacidade de fazer o diagnóstico diferencial ente o Zika e as demais arboviroses. (6)

A Organização realizou oito reuniões regionais nos temas: bioética, vigilância clínica, a SCZV, gerenciamento gestacional, pesquisa, entomologia, saúde sexual e reprodutiva e comunicação de risco. Também organizou 12 oficinas sub-regionais sobre vigilância e controle de vetores, gerenciamento gestacional, vigilância, gerenciamento de resposta, gestão de severas complicações neurológicas associadas ao ZIKV e comunicação de risco e laboratórios. Dessas, cinco foram realizadas na América Central e do Sul.(6)

Foram 103 eventos de treinamento, com aproximadamente 7000 profissionais treinados em 23 países. 20 países receberam apoio técnico em comunicação de risco e 27 comemoraram a "Mosquito Awareness Week", buscando sensibilizar a população e profissionais de saúde para a questão. (6)

Outra frente importante de trabalho foi a elaboração e produção de material com vistas a orientar as respostas dos países e também harmonizar definições de caso e práticas referentes à emergência. Em 2016, a OPAS publicou cerca de 30 documentos entre recomendações, guias e outras publicações para orientar a respostas dos países-membros ${ }^{57}$ No caso das consequências do Zika, para o Dr. Sylvain Aldighieri, um dos desafios para a vigilância, por exemplo, era a melhor definição de malformações neurológicas (225), demonstrando a necessidade desses protocolos e diretrizes.

57 https://www.paho.org/hq/index.php?option=com content\&view=article\&id=11600:Zika-technicalreports-and-guidelines\&Itemid=41693\&lang=en 
- Practical recommendations for the implementation of guidelines for the detection and care of GuillainBarré Syndrome related to Zika in the Region of the Americas (Only in Spanish)

- Zika Virus Infection: Step-by-Step Guide to Risk Communication and Community Engagement; 2016

- Cross-sectional seroprevalence study of Zika virus infection in the general population

- Case-control study to assess potential risk factors related to Guillain-Barré Syndrome including Zika virus infection

- $\quad$ Prospective longitudinal cohort study of Zika-infected patients to measure the persistence of Zika virus in body fluids

- Prospective longitudinal cohort study of women and newborns exposed to Zika virus during the course of pregnancy

- Prospective longitudinal cohort study of newborns and infants born to mothers exposed to Zika virus during pregnancy

- Case-control study to assess potential risk factors related to microcephaly including Zika virus infection during pregnancy

- $\quad$ Guidelines for the serological diagnosis of Zika virus infection - October 2016

- WHO: Identification and management of Guillain-Barré syndrome in the context of Zika virus Interim guidance; 2016

- OMS: Prevenção da transmissão do vírus Zika por via sexual Actualização das orientações provisórias; 2016 (Portuguese only)

- WHO: Prevention of sexual transmission of Zika virus. Interim guidance; 2016

- Zika Ethics Consultation: Ethics Guidance on Key Issues Raised by the Outbreak; 2016

- Pregnancy management in the context of Zika virus infection. Interim guidance update; 2016

- $\quad$ Guidelines for surveillance of Zika virus disease and its complications; 2016

- Knowledge, Attitudes and Practice surveys Zika virus disease and potential complications. Resource pack; 2016

- $\quad$ Risk Communication and Community Engagement for Zika Virus Prevention and Control A Guidance and Resource Package for country Offices for Coordination, Planning, Key Messages and Actions; March 2016

- WHO: Assessment of infants with microcephaly in the context of Zika virus

- $\quad$ Risk communication in the context of Zika virus Interim guidance; 2016

- WHO: Pregnancy management in the context of Zika virus

- WHO: Psychosocial support for pregnant women and for families with microcephaly and other neurological complications in the context of Zika virus Interim guidance for health-care providers; 2016

- OMS: Apoio Psicossocial para mulheres grávidas e famílias com microcefalia e outras complicações neurológicas no contexto do Vírus Zika. Guia preliminar para provedores de cuidados à saúde; 2016 (Portuguese only)

- Amamentação no contexto do vírus Zika Orientações provisórias; 2016 (Portuguese only)

- Breastfeeding in the context of Zika virus. Interim guidance; 2016

- Provisional considerations for the care of pregnant women in settings with high Zika virus circulation: Document for health care professionals

- Zika virus infection: step by step guide on Risk Communications and Community Engagement; 2016

- Comunicación para impactar en conducta - COMBI (Only in Spanish)

- Zika virus (ZIKV) Surveillance in the Americas: Recommendations for laboratory detection and diagnosis; 2016

- $\quad$ Guidance for reporting ZIKV

A produção de evidências científicas para subsidiar a tomada de ação foi outra preocupação da OPAS no contexto da epidemia do ZIKV. A OPAS se associou ao CDC e coordenou atividades de pesquisa, por exemplo com a organização da reunião: "Hacia la elaboración de una agenda de investigaciones para caracterizar el brote del virus del Zika y sus consecuencias para la salud pública en las Américas", realizada em março de 2016, em Washington, D.C. Entre os pontos identificado a melhorar estavam a distribuição, propagação 
e natureza da infecção; assegurar a definição uniforme de casos e protocolos e coleta e organização de dados e fortalecer os sistemas de vigilância e as capacidades dos laboratórios.(218)

Durante o CD55 (202), a Diretora da Organização citou o caso do Zika como a emergência mais complexa e salientou que a epidemia seria ponto central até que uma vacina eficaz e acessível fosse criada, ressaltando também a necessidade de fomentar a cooperação para aumentar o acesso a serviços de saúde sexual e reprodutiva. Infelizmente, passada a emergência da OMS e até a publicação desta tese, a vacina contra o vírus Zika, assim como o da Dengue ou da Chikungunya, não estão disponíveis e as atenções das empresas farmacêuticas estão voltadas para outras questões, reforçando as críticas à Saúde global(2) tendente à privilegiar interesses dos países desenvolvidos, com a contenção de doenças infecciosas que os ameaçam especificamente e contribuindo para a manutenção de iniquidades.

No campo da pesquisa, a OPAS construiu uma Agenda Regional de Pesquisa com base na opinião de 52 especialistas de 28 instituições sobre as prioridades de investigação no contexto da epidemia. A ideia era coordenar as iniciativas e catalisar as pesquisas. Os especialistas identificaram algumas áreas críticas como vetores e reservatórios; epidemiologia; patogênese da doença e consequências da infecção; intervenções de saúde pública e gerenciamento clínico; sistemas e serviços de saúde, e pesquisa e desenvolvimento de produtos. A figura 9 detalha os achados(226).

Foi criada também uma plataforma de pesquisa $^{58}$ que reuniu diversos protocolos de investigação, com cerca de 400 relacionados ao ZIKV, a maior parte do Brasil ou da Colômbia. Além disso, a OPAS, com a OMS, o Instituto Pasteur, a rede Internacional, a Fiocruz e a ISARIC (International Severe Acute Respiratory and Emerging Infection Consortium) desenvolveram seis protocolos e questionários padrão para pesquisa clínica e epidemiológica relacionados principais questões de saúde pública relacionadas ao Zika. A ideia é que esses documentos possam apoiar pesquisadores em suas investigações de forma a gerar conteúdo facilmente identificado, agregado, tabulado e analisado.

Os protocolos são:

1. Estudo de caso-controle para avaliar potenciais fatores de risco relacionado à microcefalia, incluindo infecção pelo vírus Zika durante a gravidez.

2. Estudo prospectivo de coorte longitudinal de recém-nascidos e lactentes nascidos de mães expostas a vírus Zika durante a gravidez.

\footnotetext{
${ }^{58}$ http://www.paho.org/Zika-research
} 
3. Estudo prospectivo de coorte longitudinal de mulheres e recém-nascidos expostos ao vírus Zika durante a gravidez.

4. Estudo prospectivo de coorte longitudinal de pacientes infectados com Zika para medir a persistência do vírus Zika em fluidos corporais.

5. Estudo de caso-controle para avaliar potenciais fatores de risco relacionadas com a síndrome de Guillain-Barré, incluindo Infecção pelo vírus Zika.

6. Estudo transversal de soroprevalência do vírus Zika infecção na população em geral.

Figura 9: Identificação de Prioridades de Pesquisa Regionais

\begin{tabular}{|c|c|c|}
\hline Relevance and implementation by subtopic: & Delphi Classification & $\begin{array}{c}\text { Time of } \\
\text { implementation }\end{array}$ \\
\hline \multicolumn{3}{|l|}{ Virus vectors and reservoirs } \\
\hline Effectiveness of vector control measures on the transmission of ZIKV & Critical & Short-term \\
\hline Effectiveness of dengue, urban yellow fever and CHIKV vector control & Very important & Short-term \\
\hline $\begin{array}{l}\text { What vectors are responsible for most human transmission (Culex, } \\
\text { Mansonia and Anopheles genuses)? }\end{array}$ & Very important & Short-term \\
\hline \multicolumn{3}{|l|}{ Epidemiology } \\
\hline What is the absolute risk of congenital malformation by gestational week? & Critical & Short-term \\
\hline Perinatal transmission and trans-placental transmission & Critical & Short-term \\
\hline $\begin{array}{l}\text { Characterization of clinical and subclinical ZIKV infections in pregnant } \\
\text { women }\end{array}$ & Critical & Short-term \\
\hline $\begin{array}{l}\text { Diagnostic tools: Effective methodologies and validation of new process } \\
\text { and platforms for serology, antigenic and molecular detection }\end{array}$ & Critical & Short-term \\
\hline Sensitivity/specificity/predictive value of serum ZIKVIgM & Critical & Short-term \\
\hline \multicolumn{3}{|l|}{ Disease pathogenesis and consequences of ZIKV infection } \\
\hline ZIKV infection teratogenic effect in function of the gestational age & Critical & Short-term \\
\hline $\begin{array}{l}\text { What types of samples are needed and how should they be collected and } \\
\text { transported? }\end{array}$ & Critical & Short-term \\
\hline Zika infection pathogenesis to the fetus & Critical & Short-term \\
\hline \multicolumn{3}{|l|}{ Public health interventions and clinical management } \\
\hline Prevention strategies and risk communication & Critical & Short-term \\
\hline Strategies to prevent congenital infections & Critical & Short-term \\
\hline $\begin{array}{l}\text { Interventions for the protection from mosquito bites in endemic areas } \\
\text { (including the application of selective indoor residual insecticide } \\
\text { spraying,in houses and around them, source reduction and larviciding } \\
\text { application, with their corresponding evaluation) }\end{array}$ & Critical & Short-term \\
\hline \multicolumn{3}{|l|}{ Health systems and services response } \\
\hline Efficient financing mechanisms for addressing ZIKV outbreaks & Critical & Short-term \\
\hline $\begin{array}{l}\text { Mechanisms to ensure the provision of health services for patients with } \\
\text { complications from ZIKV infection }\end{array}$ & Critical & Short-term \\
\hline $\begin{array}{l}\text { Mechanisims to ensure the availiabilty of trained human resources in the } \\
\text { clinical management and complications of ZIKV }\end{array}$ & Critical & Short-term \\
\hline \multicolumn{3}{|l|}{ Research and development of products } \\
\hline Development of serologic, blood, and urine tests & Critical & Short-term \\
\hline Validation and field testing of kits for the serological diagnosis of ZIKV & Critical & Short-term \\
\hline $\begin{array}{l}\text { Construction of a panel of samples from arbovirus endemic areas for } \\
\text { validation of kits; to be used as reference in the standardization of } \\
\text { laboratory methodologies }\end{array}$ & Critical & Short-term \\
\hline Assurance of reliable, accurate, and standardized testing & Critical & Short-term \\
\hline
\end{tabular}

Fonte:(226) p.10. 
A OPAS participou ativamente dos estudos de coorte realizados na região e foi um membro do consórcio Zika Virus IPD-MA (Individual Participant data meta-analysis ${ }^{59}$ ) formado pela FIOCRUZ, OMS, CDC, NIH e OPAS. Pela primeira vez essa metodologia foi utilizada para o estudo no contexto de um patógeno emergente. (6)

Um estudo de coorte(227) foi patrocinado pela OPAS, o MS do Brasil e o Enhancing Research Activity in Epidemic Situations (ERAES), cujos resultados preliminares foram publicados em setembro de 2016, indicando a associação entre a infecção pelo Zika e os casos de microcefalia.

Em 2017, outros 17 projetos seriam conduzidos como parte de uma iniciativa conjunta entre a OPAS e dois programas da OMS: o Programa Especial de Pesquisa e Treinamento em Doenças Tropicais e o Programa Especial de Pesquisa, Desenvolvimento e Treinamento em Pesquisa em Reprodução Humana, cada um receberia US\$ 20 mil.

O aprimoramento das capacidades laboratoriais foi destaque na atuação da OPAS. Essa ação, em parceria com o CDC, começou já em 2014, quando o vírus da Chikungunya foi introduzido no Caribe. Foi realizado uma avaliação das capacidades dos laboratórios da região em 2016. Com o advento da epidemia de Zika, oficinas regionais e sub-regionais foram realizadas em 22 países do Caribe, América Central e do Sul entre janeiro e outubro de 2016. O foco das atividades variou entre diagnóstico laboratorial do vírus, com ênfase no diagnóstico molecular e interpretação serológica e oficinas práticas e teóricas sobre diagnóstico molecular (com a participação de 5 laboratórios do Brasil). Reagentes importantes e outros insumos foram adquiridos e distribuídos pela OPAS a 23 laboratórios de referência. (6)

Essa informação corrobora o que informou o entrevistado RCOI1(154), que afirma que a OPAS trabalhou no sentido de promover melhorias no sistema de laboratórios da região, fazendo uma diferença entre os países mais deficientes nesse ponto, priorizados, e outros, mais desenvolvidos.

Uno de los trabajos y de las prioridades de la OPS es de apoyar países priorizados, que necesitan más. El trabajo de la OPS no fue de establecer redes de laboratorio en los países que ya tenían redes de laboratorio. En eses países, tipo Brasil, tipo Colombia, tipo México, tipo Argentina nuestro rol fue bien preciso, control de calidad. Calidad externa, recuperar información. Pero en países más priorizados, [...] Establecer sistemas de vigilancia, establecer al menos un laboratorio central nacional, que pueda hacer una diferencia entre flavivirus, ligar la vigilancia con el sistema de investigación perinatal existente, y agregar a sistemas existentes de vigilancia perinatal módulos que permitían detectar este nuevo síndrome, ¿ok?[...] cuando clínicos no están

\footnotetext{
${ }^{59}$ Para mais informações (em inglês): https://www.cochrane.org/MR000007/METHOD_meta-analysisusing-individual-participant-data-or-summary-aggregate-data
} 
acostumbrados a hacer diferencias entre los varios síndromes, la capacitación toma muchísimo tiempo. RCOI1(154)

Outro eixo de ação da OPAS foi o apoio aos países membros na estruturação de uma resposta ao ZIKV, disponibilizando recomendações e ferramentas para: promover o gerenciamento e a vigilância de casos de SGB, Zika entre gestantes e casos de anomalias neurológicas; preparação dos sistemas de saúde; apoio na preparação para os Jogos Olímpicos de 2016; compra e distribuição de insumos estratégicos e realizando treinamentos em comunicação de risco. (6)

No Brasil, especificamente, a OPAS trabalhou de forma bastante próxima ao MS. Essa proximidade se refletiu na resposta brasileira e no cumprimento do RSI como instrumento que guiou sua atuação. Após a Declaração da ESPII, as demandas para a organização tiveram aumento significativo, resultando na ativação, em fevereiro, de uma Sala de Situação para melhorar a articulação e troca de informações com as autoridades nacionais e outras instâncias da OPAS. Seu principal objetivo foi receber e tratar informações para apoiar as decisões da representação da Organização no Brasil, do MS e das Secretarias de Saúde estaduais e municipais, além de demandas e outras agências da ONU e outros interessados.(7)

A sala de situação pretendeu ajudar a responder perguntas que não tinham ou ainda não têm respostas claras, como qual era a magnitude e tendência do problema, quais os possíveis cenários futuros, qual é a população mais vulnerável, quais são as medidas com maior efetividade no controle da infecção, como estavam sendo desenvolvidos os aspectos logísticos e de resposta da própria organização e como e quais informações estavam sendo divulgadas para a população, entre outras. (7) p.90.

Esta informação corrobora o que contou o entrevistado RCOI2(147)

Nós instalamos internamente uma sala de situação para ver como estavam evoluindo as distintas frentes. Porque desde o controle vetorial, a pesquisa, desde a atenção à saúde das mães das crianças, seguimento, muitas frentes (confluem) num surto deste tipo. RCOI2(147)

O trabalho da OPAS com o MS também se deu para a articulação para pesquisa e a coordenação para evitar a duplicação de esforços; apoio dado ao Ministério da Saúde do Brasil:

$[\ldots]$ é um fluxo, [...] mais ou menos claro, um fluxo de recursos, uma articulação nas pesquisas porque isso foi, imagina, outubro, novembro, dezembro, uma erupção imensa de grupos de pesquisa, que ante a novidade, começaram a articular pesquisas sobre estudos de coorte, estudos de caso-controle, etc. E o ministério tentou, e conseguiu em grande parte coordenar, evitar duplicações, somar esforços, juntar as competências que sempre são uma questão humana. [...] Nós ajudamos nisso bastante, tentar racionalizar a pesquisa, coordenar, fazer grupos, fazer redes. Por exemplo, [...] como articular estudos de coorte para fazer com que fossem comparativos, que os protocolos fossem iguais ou similares para poder comparar resultados, inclusive somar os casos de um ou outro para ter mais potência nos resultados. RCOI2(147) 
Além disso, a OPAS estabeleceu em julho de 2016 o Núcleo Nordeste de Cooperação Técnica decentralizada em Zika para trabalhar com cinco estados: Alagoas, Paraíba, Pernambuco, Rio Grande do Norte e Sergipe. O núcleo funcionou na Fiocruz em Recife e trabalhou em coordenação com o MS e as secretarias estaduais de saúde dos estados. Algumas áreas de atuação definidas junto com os estados desse mecanismo foram a vigilância epidemiológica, a assistência a gestantes, mães e bebês com malformações congênitas, a melhoria da capacidade de resposta dos laboratórios (LACEN), entre outros. (7)

A OPAS também enviou missões relacionadas aos Jogos Olímpicos (215). Das atividades previstas até 22 de setembro de 2016 estavam: treinamento dos LACEN; treinamento de epidemiologistas para análise de informação epidemiológica; utilização do instrumento OPAS de vigilância e resposta dos sistemas de saúde com PB e AL; capacitação de profissionais da atenção básica; apoio para a revisão dos Planos Estaduais e no treinamento de profissionais para a adesão aos novos protocolos, entre outras (216).

\subsubsection{Cooperação com outras organizações}

Além do apoio mais direto aos países, a OPAS também atuou conjuntamente a outras instituições, trabalhando em rede para promover sua resposta e potencializar suas ações.

A colaboração com o GOARN teve bastante destaque no contexto da epidemia de ZIKV nas Américas. Apenas com esse mecanismo, a OPAS realizou 86 missões em 30 países e territórios levando expertise técnica para implementar ações de controle e prevenção da infecção e também de fortalecer os sistemas de saúde e serviço social para as crianças acometidas por problemas neurológicos. As missões da GOARN tiveram a participação de instituições como o CDC, a Rede Internacional do Instituto Pasteur, a Universidade do Texas Medical Branch, A Agência de Saúde Pública do Canadá, O Instituto Robert Koch, a Universidade de New South Wales e o ICC. (6) Com o CDC especificamente, a Organização distribuiu insumos diagnósticos para 26 países e territórios e conduziu oficinas multipaíses para realização de treinamentos em vigilância e diagnóstico laboratorial.

Quando questionado sobre as organizações com as quais a OPAS trabalhou conjuntamente, o entrevistado RCOI1(154) destacou as redes que se conformaram de forma inédita para encontrar soluções comuns.

Las redes nacionales e internacionales son palabras que voy a repetir sin parar. La red Fiocruz en Brasil fue un socio fantástico, la red del Ministerio (incompreensível), en ese momento donde se inició un pensamiento digamos, bien colectivo, porque se había se enfrentado a Chikunguña un par de años antes. Y después, yo te he mencionado las redes del Instituto Pasteur. Pasteur, teniendo institutos en el Pacífico, en África del este, en Dakar, Senegal. Teniendo algunos 
asociados en Brasil, como la Fiocruz en Paraná, las Fiocruz en Rio de Janeiro, que son asociados a la red Pasteur. [...] Y la activación de contactos internacionales, por ejemplo, Dakar con un famoso virólogo senegalense que se llama Amadou Sall, que es el director del Instituto Pasteur de Dakar. Uno de los pocos que sabían de Zika en el mundo, logró asesorar directamente la USP y la Fiocruz. Al inicio para montar desde el laboratorio y hacer pesquisas fundamentales, el aspecto genético del virus, etcétera. [...] montar una respuesta con el apoyo exterior, a través de Océanos, es algo que pocas veces había visto con tanta intensidad. Es muy personal, tal vez por mi formación. Catalizar redes científicas globales en esto. [...]. RCOI1(154)

As redes também foram tema da fala de RCOI2, que tratou da primeira visita do GOARN, do trabalho dos especialistas em conjunto. O entrevistado também citou o Ministério da Saúde do Brasil e acrescentou:

A principal parceria foi o Ministério de Saúde, as Secretarias Estaduais de Saúde ligadas especialmente a Pernambuco. Essa foi o nosso principal foco quando estávamos no Brasil. [...] também a parceria com os (incompreensível) foi para visita e intervenção de consultores, de especialistas das distintas áreas. Por exemplo, o GOARN foi ativado, [...]na qual também estava a OPAS, para avaliar [...]se realmente estamos diante de um evento inusitado ou não. Na verdade, eu lembro que os colegas do CDC que vieram no grupo do GOARN ficaram surpreendidos com o que estavam olhando, que nunca viram coisa igual [...] RCOI2(147)

De acordo com RCOI1(154), após a declaração, a articulação entre essas redes aumentou
un nivel más alto de conversaciones entre investigadores. Y de manera, utilizando redes resistentes y estructuradas. La red que para mí fue la más importante, logramos activar desde diciembre. Su sigla en inglés es GOARN [...] A partir de inicio de febrero entraron otras redes como ISARIC (International Severe Acute Respiratory and Emerging Infection Consortium) [...] redes creadas para otras patologías, se recalibraron para enfrentarse la emergencia del Zika. RCOI1(154)

Nesse mesmo sentido, foi criado um Grupo Técnico Assessor de Entomologia em Saúde Pública em março de 2016, com participantes da OMS, Fiocruz, CDC, USAIS, Universidade Monash da Austrália, a Fundação Bill e Melinda Gates e o escritório da Casa Branca para Políticas de Ciência e Tecnologia dos EUA. Esse grupo recomendou a melhoria do controle e vigilância dos vetores e capacitação nessas áreas, a preparação de um protocolo para vigilância de resistência a inseticidas, uso de alternativas como mosquitos estéreis e transgênicos e ação intersetorial, com participação da comunidade para eliminar focos do mosquito. (202)

Com a América Central/Caribe, destaca-se a colaboração com o SICA (Sistema de Integração Centro-americano), participando de reunião virtual extraordinária de Chefes de estado e de Governo para apresentar diretrizes gerais para a resposta à epidemia. Com base nessas orientações, seus Conselho de Ministros (COMISCA) criou o Plano de ação para a prevenção e Controle do vírus Zika na América Central e República Dominicana. (228). 
Com o Projeto Mesoamérica, no marco do Convênio entre a OPAS e a AMEXID (Agência Mexicana de Cooperação Internacional para o Desenvolvimento), apoiou a elaboração de planos nacionais contra o Zika. (228).

No Caribe, a OPAS trabalhou com a Agência de Saúde Pública do Caribe (CARPHA, parte do Comunidade do Caribe - CARICOM) para promover capacitações, a Primeira Semana de Conscientização sobre os Mosquitos no Caribe (9-15 maio), além de promover treinamentos em conjunto com o CDC e o Organismo de Saúde Pública do Canadá, em que 10 técnicos de laboratório de 6 países foram treinados. (228).

Já na América do Sul, o documento menciona a reunião entre o Mercosul, a Unasul e a CELAC, realizada em fevereiro de 2016, para a qual a Diretora apresentou informação e respaldou os acordos realizados, que serão analisados mais adiante. Aponta também que o plano de trabalho subregional pra a América do Sul tem como componente a promoção da Cooperação Sul-Sul e a prevenção e controle de doenças transmissíveis, o que respalda sua participação na reunião do Mercosul.

Além disso, a OPAS trabalhou em conjunto com outras agências da ONU, como demonstram os achados documentais e o entrevistado RCOI2(147), que descreve um pouco a dinâmica da colaboração.

Também havia uma vertente importante que foi o trabalho interagencial, com outras agências do
sistema das Nações Unidas, UNICEF, ONU Mulheres, [...] do qual não houve resultados muito
claros, mas foi mais compartilhar informação, tentar se coordenar, não sobrepor as atividades de
cada agência. [...] ter um pouco de coordenação interna. Então, temos um comitê, nos reunimos
periodicamente para ver que estamos fazendo cada um. Não teve muita interferência exterior,
esse trabalho foi mais interno de coordenação nossa. RCOI2(147)

O Fundo das Nações Unidas para a Infância (UNICEF) colaborou em campanhas de comunicação nas escolas sobre água e saneamento; também desenvolveu uma Guia que estabeleceu diretrizes para o acompanhamento de crianças com SZV. O Fundo de População das Nações Unidas (UNFPA) apoiou nas ações de cuidado para as mulheres e famílias afetadas e desenvolver kits com informações sobre prevenção e cuidado com foco em gestantes e mulheres em idade fértil planejando uma gravidez.

O OCHA (O Escritório das Nações Unidas para a Coordenação de Assuntos Humanitários) emprestou um funcionário para o IMS para monitorar e gerenciar os indicadores de resposta e a produção de informação dos 4Ws (Who is Where, When, Doing What - Quem está Onde, Quando, Fazendo o quê) (6). Além disso, a OPAS disponibilizou um Portal de 
Emergência 4ws para a resposta ao vírus $\mathrm{Zika}^{60}$ para coletar informações e gerar relatórios fornecidas por parceiros em tempo real para uma melhor coordenação da resposta global. Até 24 de agosto 39 organizações e 43 países reportaram atividades ao Portal(216).

Outra parceria destacada por um dos entrevistados foi com a Colômbia, que ressaltou a coordenação para o entendimento dos distintos caminhos percorridos pela epidemia na região.

[...] depois outra parceria foi da OPAS em nível regional, ou seja, primeiro serviu para conhecer e debater com outros países que também estavam tendo, pouco posteriormente ao Brasil, o mesmo problema, caso da Colômbia, mas com peculiaridades. Lembro que houve muito debate porque na Colômbia havia Zika, mas teoricamente não havia microcefalia. Então, isso parecia que era assim, ao final se mostrou que não, que havia. Então, essa comunicação de informação, esse debate, sobre os distintos cursos que estavam tendo a epidemia foi bem coordenada pela OPAS em Washington. RCOI2(147)

Com o Banco Mundial e o Banco Interamericano de Desenvolvimento, a OPAS desenvolveu um mecanismo de avaliação e custeio para identificar as capacidades nacionais de respostas dos sistemas de saúde e estimar o custo necessário para a realização das ações e o custo associados a emergência do ZIKV.(6,202)

\subsection{A Resposta do Mercosul}

Como veremos adiante, a resposta do Mercosul foi bastante tímida no que se refere à Declaração da ESPII. Apesar de ter tratado do tema de forma tangencial já em 2015 e em 2016 ter mobilizado uma reunião regional com a Unasul, ações concretas não foram encabeçadas pelo bloco. Destaca-se, entretanto, a promoção de espaços debates e redes de comunicação promovidas no âmbito do Mercosul, que permitiram, em alguma medida, o intercâmbio de informações e de boas práticas no que se refere à epidemia do vírus Zika.

\subsubsection{Os espaços transacionais do Mercosul}

O principal fórum político do Mercosul no âmbito da Saúde é, como vimos, a RMS. Logo após a declaração de ESPIN pelo Brasil, um dos seus sócios mais importantes, o fórum não debateu a questão em reunião realizada dias após o fato, durante a PPT do Uruguai. (229). A própria reunião dos Coordenadores Nacionais, anterior à RMS, não menciona o vírus ou suas 
consequências no informe epidemiológico apresentado durante o encontro ${ }^{\mathrm{i}}$, tampouco figurase entre os temas propostos para ingressar na lista. (230)

Como um caso bastante atípico na região, uma emergência desse tipo deveria surtir algum tipo de reação política. Porém, sua discussão se manteve naquele ano no bojo do programa de vetores vinculado ao combate à dengue, tema bastante abordado pelo Mercosul.

Foi apenas em 2016, dois dias após da declaração da ESPII pela OMS, que o bloco convocou uma reunião extraordinária de Ministros(233). O objetivo era tratar da epidemia de doenças transmitidas pelo Aedes Aegypti. Nota-se que o escopo do bloco pretendia ser mais abrangente, focado nas arboviroses e não no caso específico de bebês com malformações congênitas, central para a declaração da ESPII.

Nesse sentido, o entrevistado CN1 considera que o Mercosul foi o primeiro bloco a dar uma resposta coordenada ao evento. Destacou, ainda, que a prioridade nessa resposta foi o controle vetorial.

Cuando comenzó a suceder lo de Brasil, fue el primer bloque que dio una respuesta coordinada.
No solamente con los estados parte, sino también con los estados asociados porque se hizo una
reunión en febrero en el año 2016, en Montevideo, donde vinieron todos los ministros de salud
de la región de los estados parte, estados asociados, incluso pidió para participar México, pidió
para participar Costa Rica porque querían, sobre todo por la presencia de Brasil, tener una idea
de la magnitud y el tipo de problema, y tratar de coordinar unas respuestas. CN1(148)

Participaram dessa reunião os países membros do Mercosul, incluindo a Venezuela, além dos estados associados Chile, Colômbia, Equador, Peru e Suriname e de países membros da CELAC: Costa Rica, México e República Dominicana. Além do Mercosul, também estavam presentes outras Organizações Regionais como ISAGS/Unasul, o ORAS-CONHU e a OPAS, com participação de sua Diretora, Carissa Etienne(231). A reunião foi uma proposta da Presidente Dilma Rousseff, feita no final de janeiro, no Equador, por ocasião da reunião da CELAC(182).

A convocação da reunião, após a ativação da emergência pela OMS, demonstra como não apenas os países, mas as organizações sub-regionais das quais participam, estavam alinhados à adesão e aplicação do RSI. Além disso, o protagonismo da presidente brasileira na chamada reforça seu papel de embaixadora da tese brasileira sobre a causalidade.

Nesse encontro, foi ressaltada a relevância da OPAS para a cooperação técnica; o organismo foi o único externo a fazer uma apresentação durante a reunião. Além de apresentar brevemente a situação epidemiológica das Américas, cita a associação temporal e espacial entre os casos de Zika e o aumento dos casos de microcefalia no Nordeste do Brasil, região que tem 
o Aedes Aegypti com circulação endêmica, mas cuja população não tinha imunidade para o vírus. Trata a relação causal como provável, citando os achados laboratoriais. (231)

Além disso, faz recomendações para a região como: fazer controle vetorial com um enfoque multisetorial, com destaque para a participação da população; fortalecer os sistemas de vigilância tanto para as arboviroses, como para doenças neurológicas e a SGB; preparar os serviços de saúde para que possam receber os casos e ações de comunicação, entre outras. Apresenta, ainda, definições de caso suspeito, confirmado e descartado para a vigilância de nascidos vivos com microcefalia associada ao Zika. (231)

Na Declaração dos Ministras e Ministros de Saúde do Mercosul e estados Associados diante da grave situação epidemiológica determinada por doenças transmitidas pelo Aedes Aegypti: Dengue, Chikungunya y Zika(181), assinada nessa ocasião, o papel da OPAS foi especificamente destacado por seu apoio aos países no desenho de suas respostas. Adicionalmente, a Organização assumiu o compromisso de apoiar as seguintes linhas de ação:

\begin{abstract}
"promover a cooperação horizontal, sul-sul entre os países da região em estreita articulação com a OPAS que se compromete a elaborar protocolos e diretrizes técnicas em diferentes áreas, como vigilância, comunicação de risco e manejo clínico de pacientes, através da conformação de uma equipe de especialistas da região" (Ponto 14).
\end{abstract}

Entre os compromissos indicados nesse documento estão adequar a estratégia de gestão integrada da dengue e outras doenças vetoriais como a principal medida para enfrentar a epidemia, considerada por eles como regional. Também foram definidas campanhas de educação e mecanismos de comunicação e informação, além do fomento à pesquisa e desenvolvimento e do desenho de protocolos e diretrizes clínicas, atualização de pessoal de saúde e o apoio recíproco para o diagnóstico da febre do vírus Zika e considerar a inclusão de medicamentos de SGB nas rodadas de negociação conjuntas do bloco. (181)

Com relação à cooperação internacional, declararam promover a cooperação horizontal Sul-Sul em articulação com a OPAS, solicitaram a orientação de recursos para o fortalecimento de ações e salientaram a coordenação de atividades para adequar a resposta de saúde pública com relação às doenças. Como importante ação, criou-se um Grupo Ad Hoc de seguimento da emergência, durante Presidência Pro Tempore (PPT) do Uruguai, país que à época, também exercia a PPT da Unasul. (181)

O movimento realizado pela reunião e a emissão da declaração tem efeitos prioritariamente políticos. Apesar dos inúmeros compromissos, não existem mecanismos estabelecidos para sua operacionalização, ou fontes de financiamento que pudessem dar conta da sua execução. 
Quando questionado sobre o status do desenvolvimento das ações acordadas na reunião,

CN1 informou que a comunicação sobre o tema entre os países foi intensificada, mas que a questão de medicamentos não foi levada adiante. Destaca ainda, que o principal tema tratado era a dengue.

Bueno, en la declaración, por un lado, permitió intensificar la comunicación entre los países sobre el estado de situación. Mucha información que permitió actualizar los datos que se tenían, e incluso, pasó a ser un tema en los informes semestrales, que se presentara a la Presidencia Pro Tempore. Y se pidió especialmente que los datos del estado de situación del Zika estuvieron presentes en esos informes cuando en la realidad, la prioridad, en este momento había muchas patologías y de casos vinculados al vector Aedes Aegypit era el tema dengue. Pero, se pidió incluir y eso mejoró bastante. Sobre el tema capacitación, se hicieron algunas actividades, no fueron muchas, pero se hicieron algunas. Todos que tienen que ver con el tema vinculado al control del vector, por un lado. Y después algunos aspectos vinculados a la parte diagnóstica. Y el tema medicamentos que también se planteó en esa declaración, esto, como la negociación de conjunta de medicamentos ${ }^{61}$ es un proceso complejo y cada paso implica un proceso que mueve a muchas, muchas organizaciones. No solamente los países de Mercosur, sino a la industria y se había un plan que tenía como primera etapa la hepatitis, y después los antirretrovirales, y después cáncer. No se logró incluir el tema, además por el hecho de que tampoco los medicamentos que se estaban planteando tenían el perfil de la negociación, que son los medicamentos de alto costo. En este caso, son medicamentos que no tienen un alto costo, que había en la región y que ese no fue un problema real para el tratamiento del Zika. CN1(148)

E complementa, resumindo as ações do bloco como sendo, principalmente, a continuação de projetos anteriormente desenhados, vinculados ao controle vetorial.

En este sentido, yo creo que lo principal que hizo Mercosur fue destacar esa reemergencia. Por otro lado, aparte de tomar las medidas vinculadas al vector, se quedó muy expectante todos los proyectos de investigación que ya se estaban haciendo vinculados a los problemas que se estaban dando[.... y manejamos los casos sobretodo de Brasil con la microcefalia y el caso de Colombia con los casos de síntomas neurológicos del Zika. En realidad, después, la respuesta general fue reforzar las medidas que teníamos en principio, que es el combate al vector. En la evolución que ha tenido el tema, después se hicieron reuniones y se creó un grupo especial coordinado por Uruguay, exclusivamente para ver este tema, que hoy ya lo hemos disuelto y quedó en la propia comisión de vigilancia, porque notamos de que más allá que se iban denunciando casos... No tiene la magnitud que tuvo en aquel momento. CN1(148)

\section{Como exemplo, o entrevistado explica que a epidemia acelerou a consolidação do}

LIRAa no bloco e possibilitou o avanço de outros temas, como a resistência a inseticidas e a alternativas de controle do Aedes Aegypti.

La prioridad máxima fue poner al día la estrategia de control del vector, que más allá que estaba siempre en la agenda, lo que tratamos de hacer es homogeneizar los criterios para definir el grado de infestación de mosquitos, de presencia de Aedes Aegypti. Para tener un, y por eso precisamos saber medir este grado de infestación, con el LIRAa, que es un mecanismo que permite medir cuántos mosquitos hay por una zona determinada, y este criterio pasó a ser común en todo Mercosur, el sistema LIRAa. [...] Pero, además, producto de esa presencia del vector, ahí se focalizaron una campaña en los países, y apareció acá yo me acuerdo un tercer tema, [...]que en algunos países ya había resistencia a los insecticidas. Eso motivó a que los países que no tenían,

${ }^{61}$ Para saber mais sobre o processo de negociação conjunta de medicamentos, consulte a dissertação de Oliveira (2019) em: https://www.arca.fiocruz.br/handle/icict/34932 
[...] empezamos a explorar las alternativas de otros insecticidas, para superar los que ya generaron resistencia. $\mathrm{CN} 1(148)$

Não foram encontrados documentos sobre reuniões desse Grupo ad Hoc. De acordo com a Declaração, um informe de seguimento seria entregue na primeira Reunião Ordinária do bloco daquele ano.

Em 2016, não existem atas disponíveis para o Comitê Coordenador no site do Mercosul. Uma das razões para tal é porque a reunião que ocorreu em fevereiro foi extraordinária, convocada por razões fora do padrão que impossibilitam muitas vezes que haja a preparação que uma reunião ordinária exige. Entretanto, existem informações sobre a existência de uma reunião ordinária naquele ano.

Primeiro, há uma minuta da Reunião virtual dos Coordenadores Nacionais, realizada em 01 de junho, que foi disponibilizada por e-mail pelo Coordenador Nacional do Uruguai, Gilberto Ríos. De acordo com o documento, haveria um Informe sobre as atividades desenvolvidas pelo Grupo Ah Hoc criado em fevereiro. Esse informe se encontra inacessível(232). Outra fonte é uma matéria jornalística de Silva(233), que indica que seriam tratadas nesta reunião temas como as medidas adotadas para a realização dos Jogos de 2016 pelo Brasil e a grande redução dos casos entre fevereiro e maio daquele ano (87\% de declínio) no país. No informe final da PPT do Uruguai, emitido pelo Ministério de Relações Exteriores do país, a reunião ordinária de Ministros XXXIX, que teria ocorrido em 17 de junho de 2016, é mencionada. Entretanto, a ata não está disponível para consulta, visto que, de acordo com o documento, os países não chegaram a um consenso sobre o traspasse da PPT e a convocatória para a reunião seguinte.(234)

Apesar de admitir, como visto, que poucas ações de fato foram concretizadas no âmbito da ESPII pelo Mercosul, o informante CN1 ressalta a importância do chamado político dos Ministros como elemento relevante, ressaltando a resposta em bloco.

\begin{abstract}
Yo creo que, a mí me parece que esa movilización, de los Ministros de Salud, esa declaración con un componente político, con una clara orientación para los ministerios de salud y los sistemas asistenciales de la región. Este fue, en el caso del Zika, lo más relevante. [...] un momento, digamos, que un régimen internacional se dio cuenta de una epidemia y avisó los países, o que un país empezó a actuar solo y después llegó a superarlo. Acá hubo una respuesta como bloque y creo que eso fue lo más relevante. CN1(148)
\end{abstract}

Nas instâncias temáticas vinculadas à RMS, tampouco o Zika foi protagonista. As Comissões Intergovernamentais diretamente envolvidas com o tema de vigilância; a saber, a Comissão Intergovernamental Implementação do RSI (CIRSI) e a Comissão 
Intergovernamental de Controle de enfermidades de Transmissão Vetorial (CICETV) não têm atas disponíveis para 2016. Isso também se repete com Comissões que poderiam ter tratado do tema, devido ao seu caráter intersetorial, durante o ano em que foi declarada a ESPII, como a Comissão Intergovernamental Saúde Sexual e Reprodutiva (CISSR) e a Comissão Intergovernamental de Determinantes Sociais de Saúde e Sistemas de Saúde (CIDSS).

Em 2011, os países decidiram positivamente sobre a inclusão de outras doenças vetoriais nas reuniões da CICD (ATA 01/11) (235) e a Comissão, em 2012, já havia mudado de nome para Comissão Intergovernamental de Controle de Doenças de Transmissão Vetorial (CICETV)(236). Em reunião realizada em 2015, em Assunção, Paraguai, apenas Brasil e Paraguai participaram. Controle vetorial e alternativas para esse fim como mosquitos transgênicos, a bactéria Wolbachia e a utilização de inseticida Piriproxifen foram os focos dos debates. Também foram apresentados resultados do LIRAA nas fronteiras, o monitoramento da resistência a inseticidas e a inclusão de mais tempo para tratar das doenças transmitidas pelo Aedes Aegypit (solicitação do Paraguai). O tema Zika foi tratado de forma rápida, no ponto da Situação epidemiológica e apenas o Brasil apresentava casos naquele momento. Não existe nenhuma menção sobre os casos de microcefalia, que já davam indícios alarmantes na região Nordeste brasileiro. (237)

Como vimos, o subgrupo de trabalho $\mathrm{N}^{\circ} 11$ Saúde atua sobre pautas que visam a harmonização de legislações, a articulação dos sistemas de saúde e a atenção integram à saúde das populações do bloco, com vistas a integração. Além das reuniões como grupo, também se apoia em estruturas para tratar de temas específicos. No âmbito da vigilância, pode-se citar a Subcomissão de Controle Sanitário de Portos, Aeroportos, Terminais e Fronteiras Terrestres (SCOCONTS), a COVIGSAL e a Comissão de Serviços de Atenção à Saúde (COSERATS).

Em 2015, antes da Declaração da ESPII, o SGT 11 se reuniu ordinariamente, mas não discutiu a questão do Zika. Em sua ata, pode-se observar o debate sobre a implementação do Memorandum de entendimento entre o bloco e a OPAS, reforçando o papel da organização nas ações do Mercosul. Ainda, foi levantada a questão da sobreposição de agendas entre a SCOCONTS e as CICETV e CIRSI, ficando acordado que o diálogo entre as mesmas fosse intensificado também por meio de reuniões conjuntas.(238)

Em 2016, o subgrupo se reuniu extraordinariamente, em maio, sem tratar o caso do Zika (239), o que pode ser explicado porque, em geral, reuniões extraordinárias têm objetivos bastante específicos. Não há ata disponível de sua reunião ordinária daquele ano. Entretanto, algumas instâncias subordinadas ao Subgrupo se reuniram. 
Em outubro de 2015 e abril de 2016, a SCOCONTS e a COVIGSAL realizaram reuniões conjuntas. Na primeira, não há menção ao Zika, microcefalia ou malformações congênitas associadas(240), Na segunda(241), observa-se que a emergência é tratada como "Emergência Sanitária das Doenças Transmitidas pelo Aedes Aegypit”, ou seja, de forma mais abrangente. Na ocasião, foi feita uma consulta ao Grupo Ad Hoc, criado pela Declaração do Ministros, sobre a necessidade de se implementar medidas adicionais nos pontos de fronteiras diante da Emergência das doenças transmitidas pelo vetor. A recomendação foi aumentar a mobilização comunitária nas cidades fronteiriças e realizar trabalhos conjuntos nas cidades, mas não incorporar novas ações. Nesse sentido, foi indicada a eliminação de barreiras sanitárias de baixo impacto e capacitação do pessoal que trabalha nas fronteiras para melhor abordagem, proposta que seria trabalhada em reuniões futuras.

Além disso, foi elevado à COVIGSAL o projeto de Resolução de aprovação dos Procedimentos Mínimos para o Controle Integrado de Vetores, Reservatórios e outros Animais Transmissores de Doenças em Portos, Aeroportos, Terminais e Passagens de Fronteira Terrestres no Mercosul e para os Meios de Transporte que por eles circulam (242). O projeto visa estabelecer trâmites mínimos de controle vetorial em fronteiras de maneira geral, prevenindo a disseminação de doenças e outros fatores de risco para a saúde.

A menção ao Zika ocorre ainda nos considerandos do documento: "A necessidade de prevenir e controlar riscos de eventos de saúde pública de importância regional, tais como dengue, leishmaniose, malária, febre Chikungunya, Zika, febre amarela, hidatidose, encefalites equinas, chagas, peste, raiva e outros relacionados com a transmissão vetorial e de outros animais". Sobre controle de artrópodes, especificamente, fala-se apenas de evitar a presença de criadouros. (242)

As atas das reuniões virtuais anteriores a esta, presencial, estão reservadas, não disponíveis no site.

A COVIGSAL trata o tema da Vigilância de forma mais ampla. Na última reunião de 2015, de outubro, delegados do Brasil e do Paraguai, diferentes das representantes que estavam presentes na reunião da CICETV. Das doenças priorizadas pelo Brasil em sua apresentação consta a Chikungunya e a Zika. Sobre a Zika, a delegação informa que, naquele momento, não se fazia uma vigilância universal, apenas a partir de novos casos. Paraguai não tinha a Zika como doença priorizada. O sistema de Vigilância em Saúde do bloco (VIGISAS), estava entrando em testes para operação no servidor da Secretaria do Mercosul e ainda não havia 
pessoas de cada país membro designadas para alimentá-lo. Além disso, os países debateram a necessidade de criar um plano de preparação frente a uma ESPII.(243)

Já em 2016, a COVIGSAL se reuniu com a participação dos membros. No encontro, a OPAS participou apresentou a situação epidemiológica das Américas, além de propor definições de $\operatorname{casos}^{62}$, a serem adaptados pelos países. A comunicação da situação epidemiológica pelo Brasil evidenciou o aumento no número de casos de infecções na população em geral e em gestantes, bem como o incremento de internações por SGB (com a observação de que não existia causalidade comprovada pelo Zika). Paraguai também apresentou sua situação (7 casos confirmados) e estratégias de vigilância adotadas para detectar e responder a novos casos, inclusive com notificação imediata de gestantes com exantema e síndrome neurológico associado. (239)

Sobre o diagnóstico laboratorial, os países expuseram a necessidade de capacitação para diagnóstico clínico e abordagem terapêutica, e a preocupação com os testes PCR negativos para Zika em pessoas com quadros compatíveis. Os países trataram também da adequação dos serviços de saúde para o manejo de pacientes com Zika (microcefalia e transfusões). Houve dificuldade em estabelecer cenários para a necessidade de insumos, visto que o vírus se comportava de forma diferente entre os países. Foi mantida a definição de caso de microcefalia como medida do perímetro cefálico menor ou igual a $31,5 \mathrm{~cm}$ em meninas e $31,9 \mathrm{~cm}$ em meninos. (239) Além disso, ficou acordado harmonizar as estratégias de vigilância para ter uma linha de base sobre o Zika e suas complicações:

\footnotetext{
Implementar la vigilancia de SGB de carácter obligatoria y universal, manteniendo los criterios de definición de SGB propuestos por OPS; Mantener la propuesta recomendada por OPS para la notificación de SGB asociado a infección por virus Zika; Establecer e implementar la vigilancia de manifestaciones neurológicas con antecedente de infección viral previa mediante estrategia centinela. (239) p.6
}

Tanto em reuniões do Comitê Coordenador do RMS, quanto em instâncias do SGT $\mathrm{N}^{\circ} 11$, durante o período estudado, foram debatidas a convergência de agendas entre a Unasul e o Mercosul e a necessidade de coordenar ações e evitar a duplicação de esforços $(239,240,244)$.

62 "Caso de síndrome congénito sospechoso de estar asociado a la infección por el virus del Zika: Recién nacido vivo que presente; microcefalia (medida de perímetro cefálico por debajo de -2 desvíos estándar a las 24 horas postparto, según referencias estandarizadas[3] de acuerdo a edad gestacional y sexo), o alguna malformación congénita del sistema nervioso central; y cuya madre, durante el embarazo, haya tenido antecedente de residencia o viaje a un área con presencia de vectores del virus del Zika, o haya tenido relaciones sexuales sin protección con una pareja con antecedente de residencia o viaje a un área con presencia de vectores del virus del Zika". (239) 
Outro ponto recorrente nas reuniões, especialmente de vigilância, foi a discussão sobre a reestruturação das instâncias que tratam desse tema(237,240,241,244).

Além dos espaços que abordam especificamente a Saúde, buscamos em documentos de 2016 menções ao Zika, microcefalia ou malformações congênitas relacionadas em outras instâncias do Mercosul como:

- Grupo Técnico da Comissão de Coordenação de Ministros de Assuntos Sociais do Mercosul (GT-CCMASM) (Mercosul, 2016

- Comissão de Coordenação de Ministros de Assuntos Sociais do Mercosul (CCMASM) (Mercosul, 2016k)

- Instituto de Políticas Públicas em Direitos Humanos (IPPDH)

- Instituto Social do Mercosul (ISM)

- Conselho do Instituto Social do Mercosul (CISM) (Mercosul, 2016i)

- Reunião de Altas Autoridades em Direitos Humanos (RAADH) (Mercosul, 2016n-p)

- Observatório Mercosul de Sistemas de Saúde (OMSS)

Não foram encontramos em documentos daquele ano (quando disponíveis) nenhuma menção aos temas buscados, inclusive nos sites das instituições fixas como o ISM e o IPPDH. O Observatório foi desativado e foi encontrado um informe com um relatório de atividades nos anexos da Reunião do Comitê Coordenador para a XXXVII RMS, de junho de 2015.

\subsubsection{A Aplicação do RSI}

De acordo com dois dos nossos entrevistados, o Mercosul teve participação de destaque ainda nas discussões para a elaboração de um novo Regulamento Sanitário Internacional no âmbito da OMS, embora não tivesse participação como bloco nas reuniões ordinárias da Organização.

Bueno, si lo pensamos en lo que es relevante, Mercosur fue un actor activo en la implementación del Reglamento Sanitario Internacional, al extremo que, cuando se terminó de laudar este nuevo reglamento en Ginebra, Mercosur dejaba una posición como el bloco internacional que más trabajó los aspectos más específicos del reglamento. CN1(148)

Além do bloco, alguns países da região também foram citados como tendo participação substantiva nos debates para o desenvolvimento do Regulamento e, ainda, que havia representantes pessoalmente engajados no tema.

Nas décadas passadas, o Brasil teve um papel muito ativo na redação, na negociação do regulamento sanitário. Liderou o Mercosul, junto com Argentina e Chile, Brasil tiveram um papel muito relevante. [...]. Então, todas as autoridades naquele momento do Ministério eram bem partícipes no regulamento, muitos tiveram protagonismo pessoal [...]. RCOI2(147) 
Após a aprovação do Regulamento, em 2005, o Mercosul criou uma Comissão Intergovernamental dedicada a fomentar sua aplicação. Ainda em 2015, a CIRSI se reuniu em outubro, com a participação apenas de Brasil e Paraguai. Nesse momento, os países debateram sobre a ESPII que estava em curso, a do Ebola; mas sobre o Zika, o Brasil apenas informou sua situação epidemiológica naquele momento, sem dar indicações mais claras de que a ESPIN estivesse por ser decretada.

Entre as estratégias de vigilância e resposta apresentadas estava, entretanto, o desenvolvimento e validação de protocolos de manifestações neurológicas associadas ao Zika, indicando que o país já demonstrava de alguma forma que estava detectando casos atípicos relacionados à infecção. Como lições aprendidas, o país destacou a necessidade de melhoria na comunicação entre os países e a intensificação a vigilância das síndromes neurológicas, adotando um modelo sindrômico. (244)

A comunicação entre os países, promovida pelos mecanismos do Regulamento, revela a importância do instrumento para o bloco, proporcionando informação sobre o que se passa nos países vizinhos, o que permite preparação e resposta. Além disso, $\mathrm{CN} 1$ chama atenção para, ao passo que o instrumento vai sendo aplicado a emergências internacionais, novas questões são levantadas para seu aperfeiçoamento.

Consideramos que eso es un instrumento que nos rige a todos los países, que permite que sepamos cuando hay una alerta de un episodio de importancia de salud pública internacional y que garantiza también, no solo la seguridad, sino un manejo de información real de lo que está pasando en cada uno de los países. [...] nuestra preocupación con el reglamento es que muchas veces cuando se tuvo que aplicarlo [...] sobretodo en el último período cuando se dio lo del ébola en África, muchas de las respuestas que se dieron, no se correspondieron al que estrictamente se decía en el reglamento, los cuales que, bueno, está motivando que haya una rediscusión del mismo. Hoy, la propia asamblea que está reunida hay un documento sobre el reglamento, porque más allá de todo el esfuerzo que se hizo, cada vez que hay un episodio de este tipo aparece alguna brecha que hay que tratar de cerrarla para que sea efectivamente un instrumento contundente y no tenga fisuras. CN1(148)

A existência de uma instância interna subordinada à RMS que busca apoiar a implementação do RSI nos países membros do bloco configura uma vontade e compromisso para o cumprimento do instrumento e reforça o movimento de adoção do mesmo promovido pela OPAS/OMS. Entretanto, observa-se que em 2015 a epidemia do Zika era tratada como mais uma arbovirose, com pouca atenção sendo dada à situação brasileira que poucas semanas depois dessas reuniões declarou Emergência Nacional. Ainda, pode-se dizer que as comissões estavam desmobilizadas, com a participação de apenas Brasil e Paraguai (que era a PPT naquele semestre) e a provável não realização de reuniões em 2016, mesmo com a situação da Emergência Internacional. 
Nota-se também participação fundamental da OPAS nesse tema, visto que tomou a frente das demais organizações, apresentando a situação regional na reunião de Ministros, figurando como protagonista de algumas propostas de sua declaração e propondo, por exemplo, definições de casos como de Zika e microcefalia (acatadas e adaptadas), indicando a abertura dos países no sentido de ter esta Organização presente como provedora de diretrizes e cooperação.

No caso da ESPII em foco, observa-se que o mecanismo institucional do Mercosul que operou foi especialmente o de promover espaços transnacionais. Suas reuniões foram importantes para a troca de informações epidemiológicas e para fortalecer e acelerar projetos que anteriormente estavam em processos mais lentos de implementação. Além disso, foi importante para esclarecer as demandas dos países no sentido de fortalecer seus sistemas de preparação e resposta a emergências.

O bloco sofreu revezes políticos importantes nos últimos anos devido ao processo de impeachment da presidente Dilma Rousseff e as diferenças diplomáticas dos Estados-membros com a Venezuela(245), país que, pela regra, deveria assumir a PPT do bloco no segundo semestre de 2016. Esse impasse sobre a PPT fez com que, em plena crise do Zika, muitas das instâncias que deveriam responder à emergência simplesmente não se reuniram para dar continuidade às ações, retomando as reuniões apenas no primeiro semestre de 2017.

Em que pese o impasse político, observa-se que o Mercosul, ao contrário do que veremos a seguir com a Unasul, não teve seu funcionamento totalmente comprometido. Primeiro, porque a engrenagem do Mercosul, apesar de suas dificuldades, vem se consolidando ao longo de quase 30 anos, sobrevivendo à alternância entre ondas progressistas e conservadoras na região. Segundo, como um projeto de integração regional(40), um espaço coordenação econômica e de políticas públicas, países como o Brasil optaram por manter sua baixa institucionalidade indo de encontro à alta delegação de soberania de que depende seu pleno funcionamento, aumentando a sua margem de manobra no bloco. Terceiro, a temática original no sentido da integração econômica tende, pelo menos em teoria, a se afastar mais de questões políticas, reforçando a técnica, o que faz com que o bloco não seja percebido como tendo uma linha ideológica.

\subsection{União de Nações Sul-americanas - Unasul}

No âmbito da ESPII pode-se dizer que a atuação da Unasul como bloco foi praticamente nula. Houve algumas declarações políticas por parte do CMRE e até do CSS, como veremos a 
seguir. Entretanto, durante o ano de 2016 o bloco passava por uma crise institucional sem precedentes, e antes mesmo desse pico, as instâncias responsáveis pela Vigilância em saúde estavam inativas.

\subsubsection{Os espaços transnacionais e a inatividade do GT de Vigilância}

Como vimos, o GT Rede de Vigilância e Resposta é o responsável pelo tema vigilância em saúde e, por consequência, pela aplicação do RSI, e seria o âmbito esperado para o tratamento da ESPII, envolvendo o maior país da América do Sul. Entretanto, o grupo já não se reunia havia anos e, por essa razão, não existem atas que possam dar conta do trabalho realizado no período da emergência. Muitos são os fatores apontados para a não atuação do grupo tais como o comprometimento dos países e da PPT do bloco, o papel dos coordenadores principais e alternos, e a falta de uma clareza em relação ao papel do GT frente a instâncias de outros blocos que lidavam com a mesma temática.

A importância do comprometimento político dos países que assumem a PPT do bloco no andamento das ações da Unasul foram abordadas na tese de Mariana Faria(41). Para a autora,

a Presidência Pro Tempore pode ser de um país que possui interesse na Unasul e, portanto, convoca reuniões e propõe temas de agenda ou, caso a Unasul não seja uma prioridade política na agenda do país que detém a PPT, a Unasul pode passar um ano inteiro sem nenhuma atividade e gerar perda de acúmulo institucional(41)p.133.

Em 2016, havia, grande expectativa sobre a liderança do Uruguai durante a PPT; porém o bloco atuou de forma aquém do esperado.

También hay una realidad que el grupo de vigilancia durante la presidencia de Uruguay no fue muy activo. No sé porque motivos, tampoco no creo que haya sido culpa de Uruguay, sino que fue una realidad. PF2(183)

No mesmo sentido, o comprometimento político dos países que assumem a coordenação ou secretaria de um GT ou Rede também influenciam o avanço ou não da agenda das instâncias(41), já que são eles os responsáveis por convocar e organizar as reuniões e mobilizar os países para o andamento dos projetos em curso. Isso é corroborado pela fala do entrevistado $\operatorname{POL}(246)$.

Então, os GTs tinham aquela questão de ter uma coordenação e uma subcoordenação, [...] O que existe são as pessoas que estão aqui dentro e que vão fazer o que será que vai ser feito, né? No caso do GT, quando você tem uma estrutura muito jovem, porque todas as estruturas da Unasul eram todas muito jovens, né? Uma estrutura que não tem nem uma questão física, um secretariado [...]. Então, o GT ele era muito dependente, não só dos países que o coordenavam, mas mais intrinsecamente das pessoas que estavam a frente dessas questões. [...] Quando você tem em um outro espaço, uma falta de clareza de quem está à frente do processo, as pessoas tão mudando com uma certa frequência por conta de mudanças, né, de ministros e tudo mais. Quem é que é responsável por isso? POL(246) 
Por conta da desmobilização, o grupo ficou diversos anos sem se reunir ordinariamente, o que certamente, afetou sua capacidade de resposta a emergências, como o caso do Zika.

E Unasul, agora eu lembro, quando cheguei aqui no ISAGS o GT estava desativado. Tinha, quando cheguei, em 2017, tinha três anos que não se reunia. Dois ou três anos. Então, a instância técnica não estava ativa, consequentemente, isso prejudicava, em certa medida, de acionar, né, os ministros, de levar posição comum, etc. Então, por algum motivo, isso se desestruturou. Por aí, 2017 conseguiu se reestruturar, até que os países começaram a sair da Unasul. RCG1/PF1(146)

Quando perguntado pontualmente por quê o GT estava desativado, o entrevistado informou não saber especificamente, mas acredita que um dos motivos seja pelo fato de os países entenderem que havia uma sobreposição de agendas e também dificuldades, principalmente de países menores, de participar de tantas atividades no exterior.

Houve esse sentimento 'Ah, não, essas agendas estão se sobrepondo'. Nós estamos tratando o mesmo tema. No grupo do Mercosul e no grupo da Unasul. Vamos priorizar temas. Tá. Então, vamos ser objetivos. Então vamos, na próxima reunião, estabelecer qual tema que vai ser definido aqui' e isso não se fez. [...] Então acho que foi falta de habilidade e, claro, tem a dificuldade de todos os países de estar em dois fóruns, mas o prejuízo termina sendo muito maior. É melhor você gastar uma passagem, três dias de diária, numa reunião dessa a cada semestre, do que no meio de uma epidemia, você não saber o que que está acontecendo na Colômbia. RCG1/PF1(146)

Outro informante complementa essa afirmação, apontando que os países não viam necessidade de levar a discussão da vigilância para a Unasul, já que ela era tratada de forma bastante forte na OPAS, por conta do RSI. Ainda, chama atenção para a importância do fator humano, ou seja, da personalidade que estava liderando o processo.

[...] cada um dos GTs, das próprias Redes, além da questão do fator humano, que eu acho que, pra mim, é o fator número 1, pra mim o segundo fator é o fato da necessidade. [...] E aí quando a gente pensa no tema da Vigilância, em que você tem um Regulamento Sanitário Internacional, que é uma das questões, dos documentos mais fortes e que é avaliado todo ano e tem isso fortemente incorporado na genética da própria Organização Pan-americana da Saúde e com um interesse, inclusive, dos Estados Unidos e do Canadá. Nesse tema, principalmente os Estados Unidos, que leva à frente essa agenda e ela acaba sendo uma agenda prioritária dentro desse espaço, qual a necessidade que os países têm de levar essa discussão para um outro espaço... porque é uma questão de necessidade. POL(246)

No âmbito global, o CSS também atuou sobre o tema, apresentando posição comum diante da Assembleia Mundial da Saúde em 2010. Como visto, a Unasul foi a única entre as organizações internacionais da América do Sul a se organizar anualmente para intervir sobre pontos estratégicos para o bloco na AMS, embora ainda não tenha obtido reconhecimento formal da OMS (11).

Em reunião extraordinária(247) realizada em maio de 2016 por ocasião da AMS, os Ministros se encontraram com o objetivo de debater as posições comuns que apresentariam naquela edição, apenas sobre as temáticas de pesquisa e desenvolvimento e medicamentos. A 
única menção na ata sobre o vírus Zika foi feita pela diretora da OPAS, Carissa Etienne, que costumava participar do momento de abertura da reunião, citando-o entre outros surtos e epidemias antes vividos pela região e salientando o protagonismo da autoridade nacional para a preparação e resposta a esses fenômenos.

Cerca de um mês antes, o Conselho de Ministras e Ministros de Relações exteriores da Unasul também se reuniu para debater ações sobre o recente terremoto por que passara o Equador e o traspasse da PPT do Uruguai para a Venezuela. Em declaração(248), os Ministros reafirmaram o compromisso com a integração sul-americana e, no campo da saúde, reforçaram a necessidade de cooperação regional com destaque para as doenças transmitidas por vetores, e outras, sob coordenação do CSS e do ISAGS. Além disso, remontam à reunião extraordinária conjunta com o Mercosul em que os países acordaram o combate ao Aedes Aegypit e suas consequências e se comprometeram a manter a cooperação e o intercâmbio no marco da OPAS.

Respondendo à uma solicitação do Secretário Geral da Unasul, o ISAGS e o GT elaboraram conjuntamente um relatório sobre a situação da epidemia do vírus Zika na região e as atividades em que o Conselho se envolveu sobre o tema vigilância e resposta, como a Oficina Internacional de Manejo Clínico da infecção por Chikungunya, que ocorreu no Paraguai e teve coorganização do governo do país, do GT e da OPAS; Oficina sobre políticas de saúde nas fronteiras, organizada pelo ISAGS, e Oficina Internacional sobre novas tecnologias de Vigilância em Saúde na fronteira, no marco da implementação do RSI (249).

Em coletiva de imprensa, o Secretário Ernesto Samper, e o então Diretor executivo do ISAGS, José Gomes Temporão, anunciaram a criação de um Protocolo Regional para o combate e prevenção do Vírus Zika, proposta que foi acolhida na reunião do Mercosul (250). O objetivo principal era fortalecer a cooperação, garantir a comunicação fluida, aumentar a troca de experiências, reforçar as capacidades de vigilância conjuntas nas fronteiras, entre outras ações (249). Não foram encontradas evidências sobre o desenvolvimento deste protocolo.

A crise política por que passava a Unasul, a qual nos referimos anteriormente, justamente no momento da epidemia, foi salientada pelo entrevistado PF2(183), quando questionado sobre como o bloco atuou antes da declaração da ESPII.

El problema es que justamente coincidente con la emergencia, hubo el problema de que algunos países salieron de Unasur. Entre los cuales, Paraguay, por lo cual realmente nosotros no llegamos a asumir el grupo de vigilancia. O sea, si como adjunto, pero no como titular. PF2(183) 
Ainda assim, destaca que algumas atividades foram organizadas na região, inclusive uma reunião em Montevidéu, em fevereiro de 2016, reforçando o mecanismo institucional de promoção de espaços internacionais. Segundo o entrevistado:

[...] en esa reunión, Brasil hizo un planteamiento fuerte con el tema porque había todavía una discusión sobre la asociación entre Zika y el Síndrome Congénito. Una presentación muy clara de Brasil respaldando con datos científicos que apoyaban en esa asociación, y se hizo una posición de los países, en donde acordaron una serie de compromisos que realmente no me acuerdo, que tenían que ver con el tema vectorial, en donde se planteaban acciones a nivel del país, como el tema de compartir experiencias exitosas con respecto del sector vectorial. Después había planteado algunas actividades, como, por ejemplo: las muestras en Brasil, que habían empoderado a la comunidad, en trabajo de tipo preventivo y de trabajar en el control vectorial, con el acompañamiento de las Fuerzas Militares, que nosotros estamos haciendo y también estaba haciendo Brasil, después del punto del trabajo con respecto de los casos de microcefalia, el tema de las clínicas, de atención a estos chicos y comparar un poco la experiencia que cada país tenía en eso. Compartir las investigaciones y los datos epidemiológicos [...] PF2(183)

Ainda segundo a entrevistada, por ocasião do Congresso Latino-americano TEPHINET, ao final daquele mesmo ano, em Ciudad del Este, houve um grupo de trabalho para discutir ações em cidades de fronteira:

El grupo que trabajó fuerte ahí fue el grupo de Brasil, Paraguay, Colombia y con la gente de Zika. En nuestro caso hubo una participación también de la gente de Itaipu, con el objetivo de compartir experiencias, y de compartir capacitaciones. Específicamente, nosotros en frontera probamos un módulo de capacitación dentro de la capacitación de epidemiologia básica, que estábamos haciendo tanto Paraguay y Brasil, con TEPHINET; se agregó, y se probó un módulo de frontera de capacitación, de vigilancia de frontera, enfocado a Zika. PF2(183)

Questionada de forma global sobre o que fato foi feito pela Unasul no âmbito da resposta regional à ESPII, a entrevistada ponderou:

Pero fue más eso, fue más intercambio de información. [...] Y posterior a eso, si hubo, sólo que yo no te puedo limitar: esto fue Unasur, esto fue Mercosur, esto fue OPS, porque muchas veces eran de los tres. PF2(183)

\subsubsection{A desmobilização política}

Em 2012, apenas 4 anos após a assinatura do Tratado Constitutivo da Unasul, os países membros do bloco decidiram que um novo Regulamento(57) deveria guiar suas ações. $\mathrm{O}$ instrumento burocratizou ainda mais as decisões e um dos resultados práticos das novas regras fez com que os Conselhos setoriais e, por conseguinte, os Ministros que deles participavam, perdessem muito do seu poder decisório.

O entrevistado POL(246) explica essa dinâmica, no caso do Conselho de Saúde.

Eu acho que essa foi uma grande questão. Especialmente, eu acho que [...], exatamente pelo fato de que o Conselho de Saúde e o próprio ISAGS, ele surgiu muito na contramão dos processos opasianos; as outras áreas não tinham essa referência. [...] Porque tinha esse cuidado muito grande de dar protagonismo aos países e que o ISAGS fosse sempre um facilitador e não alguém 
que ditasse o que ia ser feito. Tinha sempre essa preocupação, porque essa preocupação, no fundo, tinha exatamente essa comparação com o que a OPAS tinha se transformado. Onde a Diretora da OPAS era mais importante que um ministro de Saúde quando chegava em algum lugar... Então, como criar uma instituição que tivesse força, que tivesse reconhecimento e capacidade, mas que pudesse ser uma instituição que tivesse sempre dando protagonismo aos países. Que o Conselho de ministros fosse sempre o órgão superior, que não houvesse uma intervenção nas agendas do Instituto, que as agendas fossem definidas realmente pelos países. E aí. eu acho que quando a Secretaria Geral cria uma estrutura, né, megalomaníaca quase, né? Aquele prédio gigantesco e um corpo pesado de funcionários, com cargos e cria uma série de procedimentos pra aprovar coisas... aí vem a grande questão da perda total do Conselho Setorial porque o Conselho de ministros de Relações Exteriores vira o grande definidor de tudo. Tudo tinha que passar por eles. [...] POL(246)

Ele exemplifica, citando uma reunião em que os Ministros de Saúde ficaram debatendo as nomenclaturas do que eles poderiam aprovar, gerando constrangimento e questionamentos sobre o valor da presença daquelas autoridades nesse espaço.

[...] quando a gente vai pra reunião do Suriname é aquela coisa estranhíssima, porque aí já tem o Regulamento, tem os ministros e começa aquela discussão "não, mas o que que nós estamos aprovando, não é uma resolução. Porque a gente não pode mais aprovar uma resolução". [...] Aqueles ministros todos sentados ali e assim 'Meu Deus, o que que a gente tá fazendo aqui? porque se o nosso colega, dentro do espectro nacional, é um colega, é um peer, ele vai aprovar o que eu estou decidindo, acabou-se o mundo'. Então, é uma sensação muito ruim desse processo, em se cria uma instância intermediária entre as decisões de onde elas são emanadas. [...] Os Ministros setoriais são completamente desempoderados do seu processo e isso gera uma tensão muito grande. E inclusive um questionamento [...] 'ué, então, vamos parar de fazer o Conselho de Ministros, vamos reunir só os coordenadores nacionais, porque, se é pra passar pra uma outra instância, não vamos fazer os ministros passarem por isso'. POL(246)

Como um processo de regionalização, embora considerado menos ambicioso pela baixa delegação de soberania(40), a amplitude de temas e objetivos da Unasul se mostravam ambiciosos no longo prazo e exigiam concertação e negociações importantes que, ao final de tantas etapas, promoveriam por consenso a vontade dos países do bloco.

No entanto, além da desmobilização que já estava em curso, divergências políticas da região, que tiveram impactos bastante expressivos no Mercosul também afetaram a Unasul, visto que boa parte dos países membros daquele bloco, também são parte da União. Nesse contexto, o relacionamento entre os países e a PPT da Unasul, que em 2016 estava a cargo da Venezuela, também sofreram um desaquecimento, o que culminou na desaceleração de estruturas e projetos.

Outro fator relevante nesse contexto, como mencionado anteriormente foi o anúncio da saída do Secretário Geral em janeiro de 2017 (60), considerado um líder mobilizador importante na região. De acordo com um dos informantes, a "saída" não foi exatamente voluntária, mas uma reação do Brasil ao apoio de Samper à presidente Dilma Rousseff.

A saída do Samper também não é uma saída, né, ela é uma demissão. Ele é demitido sumariamente pelo chanceler brasileiro naquele momento. Ele vai visitá-lo e depois da visita, após o que a Dilma sofreu, o Samper pede pra sair. Não há nenhum pedido de demissão, nenhum 
pedido de saída, ele foi demitido sumariamente pelo país que pagava $50 \%$ da cota, por conta da carta que ele escreveu. Porque ele se manifestou politicamente em favor da presidente Dilma. $\operatorname{POL}(246)$

A vacância do cargo permanece até os dias atuais por falta de consenso e pela decisão de 6 dos 12 países membros de congelar suas ações no bloco; muitos em processo de saída definitiva, como já dito.

Quando perguntado sobre as causas dessa reação dos países e porque em relação ao Mercosul, por exemplo, não existem notícias de uma debandada semelhante, o entrevistado reforça o caráter político da Unasul, de construção de uma soberania regional e o fato de o projeto ter sido construído pelos governos de esquerda que dominavam o cenário político na América do Sul nos anos 2000.

[...] a Unasul é um projeto. Sempre foi. Ela marca um momento da América do Sul de um alinhamento político à esquerda. [...] Existiu um alinhamento à esquerda e a Unasul, como todos sabemos, ela é constituída, a CASA, como um contraponto a um projeto norte-americano, estadunidense. [...] eu diria que 2015 é o ápice, quando o negócio começa realmente a dar sinais de que está virando o jogo. E aí você começa a ter essa questão [...] tudo o que foi construído por esse grupo, que nunca deveria ter chegado ao poder, de acordo com essas elites políticas da América do Sul, é preciso ser destruído. Tudo precisa ser destruído. Os conceitos, as instituições, as nomenclaturas, as políticas, tudo. [...] É um projeto político potente, né? [...] E o Mercosul, ele não tem essa mesma reação, primeiro porque ele não surge nessa época, ele não é fruto dessa tomada de poder da esquerda, pelo contrário. Ele vai sendo moldado no período da esquerda pra se transformar em algo mais do que simplesmente um mercado, mas ele é um mercado e ele pode facilmente por essa política voltar a ter esse status, coisa que a Unasul nunca teve. A Unasul tinha um projeto político, um projeto político de soberania regional, um projeto político de ascensão da América do Sul, que o Mercosul nunca teve. POL(246)

\subsubsection{Tensões e disputas}

Como já demonstrado, existem diversas Organizações Internacionais que atuam na América do Sul na área da Saúde. Essas instituições foram criadas em momentos e contextos políticos muito distintos e, como também já mencionado, a atuação dos países em cada uma delas depende dos seus interesses.

Isso também é corroborado pela fala do entrevistado POL:

[...] eu acho que a grande questão da América do Sul é a proliferação dessas organizações. E aí como que cada uma, tendo suas agendas, suas prioridades. [...] Então, na verdade a gente tá falando dos mesmos países se reunindo em processos distintos e tentando trabalhar agendas que nem sempre são compatíveis porque existem diferentes interesses. POL(246)

O entrevistado RCG1/PG1(146) falou da ideia de transposição de agendas, o que pode ter gerado desmobilização do GT de Vigilância da Unasul, corroborando a ideia de que as Organizações disputam a liderança de determinada orientação na sua área de influência(138). Nesse ponto, POL(246) concorda. 
[...] eu acho que existe uma série de rupturas e de agendas que, ao invés de serem complementares acabam sendo duplicadoras de esforços pra países que já enfrentam um monte de desafios em termos de investimentos e outras questões. [...] se cada um tivesse um papel mais bem definido, eu acho que poderia ser algo benéfico, mas eu não sei se necessariamente foi isso que aconteceu, por um lado. POL(246)

Entretanto, entende que a criação da Unasul teve papel importante no sentido de ser um projeto contra hegemônico, dando voz aos países da região.

Por outro lado, assim... eu acho que o projeto da Unasul, e a questão do ISAGS, naquele momento, ele teve um valor muito importante que foi sacudir um pouco as bases que estavam estabelecidas. Então, quando se conforma o projeto da Unasul em detrimento de um outro projeto que vinha dos Estados Unidos... [...] e essa capacidade de balançar as estruturas e de se tornar capaz de ter uma voz onde antes não existia, eu acho que pra mim é o grande valor agregado da Unasul[...] POL(246)

No contexto da Saúde, POL(246) define a OPAS como o grande tensionador em relação à Unasul, mas, ao mesmo tempo, tendo papel de apoiador das demais instituições.

[...]Que é a questão de que a OPS passa muitos e muitos anos, décadas sendo um ator praticamente exclusivo. O próprio fato de emergirem, no caso, o CARICOM e o Caribe ali com a CARPHA e a própria comunidade Andina ... todos esses mecanismos de saúde são muito apoiados pela própria OPS. Tanto financeiramente como a coordenação deles têm uma relação muito simbiótica com a OPS. E aí o que acontece é que a Unasul veio meio que exatamente o contrário. POL(246)

Nesse sentido, ele complementa com a informação de que houve esforço na Unasul para que o Conselho de Saúde e o ISAGS não se transformasse na OPAS, que na visão dos países, tinha se burocratizado e que sua agenda não refletia plenamente a vontade de todos os seus países, como um desbalanço de poder. Essa insatisfação dos países também foi citada pelo entrevistado CN1(148). POL(246) considera esse movimento positivo, porque fez a OPAS rever seu posicionamento.

[...] sempre tinha uma comparação, de uma forma negativa de dizer 'a OPS ficou muito burocratizada'. 'A OPS já não representa o interesse dos países' 'ela tem uma agenda própria e a gente não quer que o ISAGS, no caso, o organismo que se conformava naquele momento, se transforme numa mini OPAS'. [...]porque os países, naquele momento, sentiam que a OPAS tinha uma interferência muito grande, né? pelas razões óbvias. $60 \%$ do orçamento é financiado pelos Estados Unidos. E, obviamente, quem paga mais manda mais, isso é um fato. [...] Porque existe um desbalanço, não sei se essa palavra existe também em português, mas um unbalance de poder, né? Onde você tem Estados Unidos e Canadá de um lado e você tem todos os países do outro [...] POL(246)

Frente a essa nova conjuntura, a OPAS, durante algum tempo, tentou minimizar o papel da Unasul nas suas reuniões, o que foi mudando ao longo do tempo, mas nunca foi reconhecida como ator nos órgãos de governança, mesmo com a apresentação de posicionamentos comuns como bloco.

[...] ao perceber que isso não ia parar esse movimento a OPS muda em algum momento, talvez 2012, ali já no segundo ano do ISAGS, a OPAS muda completamente de postura e começa a se acercar [...] Então, eu acho que passou por vários processos: de disputa, depois de um 
acercamento, mas uma consideração: a OPAS nunca deu o espaço, foi sempre batalhado o espaço oficial da Unasul, do próprio ISAGS como representante aqui, como a própria OMS dentro da sua Assembleia tem, né? Espaço pro AFRO, pro EURO, por exemplo, tem assento inclusive. Isso nunca foi reconhecido. POL(246)

A Unasul, então, tornou-se um espaço privilegiado para tratar de temas que a OPAS não valorizava em suas discussões, como determinação social da saúde. Ao mesmo tempo ressalta que agendas como a vigilância, plasmada na implementação do RSI não tinham razão de ser no bloco, já que era acompanhado de perto pela OPAS e uma necessidade dos países, que tinham apoio da Organização em diversos níveis, induzindo as discussões naquele fórum.

[...] Quando eu tenho, por outro lado, uma discussão muito forte, inclusive com acompanhamento metodológico do processo do regulamento sanitário tanto a nível mundial como no nível interno. Quando os outros países, os países do Norte que são normalmente os países que cooperam através da doação de recursos financeiros interessado nesse tema, a ponto de que quando um país não consegue alcançar metas estabelecidas, eles vão lá e cooperam financeiramente, então é uma vantagem pra mim como Paraguai, é uma vantagem pra mim como Suriname, uma vantagem pra mim como Bolívia ir pro espaço global e dizer 'Olha, eu não tô conseguindo' [...] Da necessidade que eu tenho de um tema naquele espaço subregional ou regional, né, como a gente quiser chamar e o quando eu tenho necessidade de outros temas naquele espaço, dependendo de como as outras arenas que estão colocadas estão facilitando ou dificultando aquela discussão. [...] POL(246)

A tensão também acontecia por parte da Unasul. O informante POL(246) conta que, durante a discussão sobre a criação de um banco de preços para a compra conjunta de medicamentos, o Secretário Geral teve de ser convencido de que usar os instrumentos já longamente estabelecidos pela OPAS seria vantajoso.

Todas as complicações em relação a questão de regulamentação, como fazer as medicações entrarem nos países, apesar das suas agências reguladoras, das diferenças e tal... e aí ( $o$ Secretário) entende o tamanho do buraco e começa a achar que era viável e válido realmente essa relação. POL(246)

Com relação ao Mercosul, a falta de institucionalidade da saúde, que não tinha um órgão fixo como o ISAGS/Unasul para tratar o tema, inibia as tensões. Além disso, menciona seu caráter prioritariamente econômico, mais técnico e o contexto em que foi criado como contribuindo para essa atenuação.

[...] a agenda da Unasul era muito mais ampla, não só em número de países, mas em termos de temática mesmo. A agenda do Mercosul era muito mais restrita na questão da saúde, sempre teve focos muito mais específicos. E o fato [...] de o Mercosul ter tido, num período muito curto, o Observatório [...] A operacionalização dele era através da Presidência Pro Tempore e dos países. [...] Os países se dão conta de que existiam benefícios no Mercosul porque o Mercosul já tinha tratados, já tinha mecanismos jurídicos, que poderiam avançar em determinados de temas [...] e ao mesmo tempo, onde a Unasul era mais forte: tinha um ISAGS, uma institucionalidade, um espaço maior de temas e de países, de todas as redes, GTs. POL(246) 


\section{Considerações finais deste capítulo}

Momentos de emergência aumentam a demanda e a pressão sobre os sistemas de saúde. Nesse sentido, a epidemia do Zika foi considerada como uma prova para a aplicação do RSI, demonstrando a importância de sistemas de saúde resilientes(215). Em sua resposta, o Brasil se destacou com seu sistema público de saúde e um sistema de vigilância com capacidade e capilaridade para a detecção e estruturação de uma resposta para a emergência que se desencadeava, alinhado ao regulamento. Isso levou o país a alcançar vantagens no sentido de acessar e captar recursos e insumos. Além do sistema em si, a equipe que estava à frente da resposta, era uma equipe experiente, que apostou na tese brasileira sobre a causalidade do vírus e ajudou a sua disseminação. Nesse sentido, a coalização de apoio político interna foi fundamental para a resposta nacional do Brasil.

No campo da cooperação internacional, o país priorizou a cooperação com os Estados Unidos, na área de pesquisa e desenvolvimento de diagnósticos, vacinas, tratamentos contra o Zika, em detrimento de uma atuação coordenada com os países da América do Sul. A escolha da política externa brasileira pela ação bilateral teve reflexos importantes nas organizações regionais, pelo papel central que o país ocupa nos processos de integração e regionalização sulamericanos.

Coordenação e intersetorialidade foram duas das características necessárias para dar conta da epidemia da Zika nas Américas. O caso da Zika foi emblemático pela pronta detecção de uma doença desconhecida. De fato, tanto o Brasil, quanto a OPAS e o Mercosul tiveram destaque para o controle vetorial, que claramente foi reforçado como um ponto fundamental na agenda de cooperação técnica. Entretanto, entende-se que é necessário dar conta de determinantes sociais e ambientais na disseminação dos mosquitos e exposição da população. Dessa forma, faz-se necessária uma integração entre vigilância, prevenção e controle de arboviroses.(6) Nessa linha, a emergência cria uma oportunidade para integrar a vigilância de doenças arbovirais de importância de saúde pública para a região e para o manejo integrado de vetores(215).

A situação endêmica de arboviroses nas Américas e a necessidade de pesquisas para se conhecer o impacto da infecção na população, bem como a relação entre o vírus e as malformações congênitas são ainda desafios a serem superados (6). Além disso, o acompanhamento de crianças e suas famílias ao longo do tempo também é considerado um grande desafio para os sistemas de saúde. 
Mira, lo que vimos en 2016, es todo lo que está alrededor del niño, de la familia, en términos de terapia, de fisioterapia, enfoque psicológico, capacitación de madres, de familiares, acceso a rehabilitación, acceso a oftalmología, a lentes especiales, etcétera. Permite, digamos, un desarrollo más "saludable" del niño. Quiere decir, el acompañamiento paramédico del niño permite una calidad de vida mucho mejor. Yo francamente pensaba, yo he tenido la oportunidad de seguir niños de manera virtual, con familias que se volvieron amigas. En el nordeste, en poblaciones rurales del estado de Pernambuco, en el interior de Pernambuco, y yo vi todo el nivel de más calidad de vida que puede aportar todas esas medidas que te hablé. RCOI1(154)

A epidemia do vírus Zika, demonstrou que é necessário superar enfoques fragmentados e desenvolver as capacidades básicas do Regulamento, que devem responder não apenas à questões pontuais, mas a ações sustentáveis(228). Há de se fortalecer a construção de confiança entre os países, para que eles possam se utilizar dos benefícios mútuos que o mesmo traz como o apoio à própria implementação do RSI, bem como lograr de uma proteção regional, com a preparação dos seus sistemas caso eventos passíveis de disseminação estejam ocorrendo em seus vizinhos.

Nesse sentido, as organizações regionais, especialmente a OPAS, demonstraram ser fundamentais para o estabelecimento de mecanismos que colaboraram para a disseminação de ideias, conhecimentos, políticas e do próprio regulamento no sentido de responder a uma epidemia de consequências importantes, como o caso das malformações congênitas. Apesar do momento político delicado que afetou a condução dos trabalhos tanto do Mercosul quanto e especialmente da Unasul, observou-se que a comunicação entre os pontos focais de vigilância dos países se manteve ativa e pode ser considerada um legado importante das instâncias regionais sul-americanas. 


\section{DISCUSSÃO DOS RESULTADOS}

O principal objetivo da presente tese foi aferir se existiu uma engrenagem regional sulamericana de vigilância em operação durante a emergência do Vírus Zika. Para responder a essa pergunta, analisa-se a seguir o processo de disseminação de uma "política" regional de vigilância.

Para isso, será utilizada a grade de análise construída com base na literatura sobre disseminação internacional de políticas públicas, apresentada na descrição dos materiais e métodos.

Como vimos, não são apenas políticas que podem ser difundidas ou circuladas. De fato, esse processo pode ocorrer com muitos tipos de elementos, como uma ideia, paradigmas, instituições, solução para a ação pública, normas e leis, programas, modelos, tecnologias e, por que não, teses, no sentido de uma proposição mais elaborada do que um conjunto de ideias.

No caso do estudo em foco, identificamos dois movimentos bastante evidentes, que vamos desenvolver adiante: a difusão da tese brasileira sobre o vínculo entre o vírus Zika e as malformações congênitas em bebês, e a circulação do RSI.

\subsection{A DIFUSÃO DA TESE BRASILEIRA SOBRE O VÍNCULO ENTRE O VÍRUS ZIKA E AS MALFORMAÇÕES CONGÊNITAS EM BEBÊS}

O primeiro fenômeno de disseminação internacional de políticas identificado tem a ver com a tese brasileira de que era o vírus Zika, até então pouco conhecido, o causador do aumento inédito do número de bebês nascidos com malformações congênitas. Pese a quantidade de teorias sobre a causalidade e o descrédito inicial de parte da comunidade internacional e de cientistas, o Brasil conseguiu difundir sua tese sobre a causalidade da microcefalia.

Os mecanismos de difusão que operaram nesse processo foram muitos e podem ser encontrados de forma sistemática na figura 10 abaixo, que corresponde à grade de análise apresentada na seção sobre materiais e métodos, com a sistematização do caso em tela.

Pode-se observar que a tese brasileira sobre a causalidade das malformações congênitas foi o elemento abstrato difundido desde o Brasil para a OPAS/OMS, seguido de sua adoção pelos demais países membros. 
Figura 10 Difusão da tese brasileira sobre a causalidade das malformações congênitas

\begin{tabular}{|c|c|c|c|}
\hline \multicolumn{4}{|r|}{ Grade de análise } \\
\hline & categoria & descrição & Tese Brasileira do vínculo entre o vírus Zika e distúrbios neurológicos \\
\hline $\begin{array}{l}\text { Elemento } \\
\text { difundido }\end{array}$ & $\begin{array}{l}\text { Concretos } \\
\text { Abstratos }\end{array}$ & $\begin{array}{l}\text { Ideia, paradigma, instituição, soluções para } \\
\text { ação pública, dispositivos normativos, } \\
\text { programas, modelos, tecnologias }\end{array}$ & $\begin{array}{l}\text { Elemento abstrato: a difusão da tese brasileira sobre o vínculo entre o vírus Zika e distúrbios } \\
\text { neurológicos. }\end{array}$ \\
\hline Direção & & Lugar de origem da política e lugar de adoção & Do Brasil para a OPAS/OMS e para o resto do mundo. \\
\hline \multirow[t]{2}{*}{$\begin{array}{l}\text { Mecanismos } \\
\text { Institucional }\end{array}$} & $\begin{array}{l}\text { Indução } \\
\text { institucional } \\
\text { (continuum) }\end{array}$ & $\begin{array}{l}\text { Alguma instituição/país promotor induziu a } \\
\text { adoção da política ou elemento, adotada de } \\
\text { forma racional, voluntária, condicionada ou } \\
\text { coercitiva }\end{array}$ & $\begin{array}{l}\text { Pouco depois que a hipótese da causalidade foi levantada, algumas instituições científicas de renome } \\
\text { provaram a relação causal em um pequeno número de casos, em um momento inicial. Com estes dados } \\
\text { científicos e confiáveis, o Ministério da Saúde e a Presidência da República, ou seja, o governo brasileiro, } \\
\text { defenderam a idéia e declararam a situação como Emergência de Saúde Pública de Importância } \\
\text { Nacional. } \\
\text { Neste sentido, a tese da relação causal foi adotada de forma racional e voluntária, por um lado, uma vez } \\
\text { que os dados científicos provaram a ligação. } \\
\text { Entretanto, com a evolução do processo, a declaração de emergência trouxe alguns benefícios, como a } \\
\text { possibilidade de medidas extraordinárias serem tomadas e o aumento do volume de recursos, além de } \\
\text { demonstrar a capacidade de oferecer uma resposta efetiva em meio à crise política que o país } \\
\text { atravessava. Negar esta tese seria também negar todos estes benefícios, o que de certa forma } \\
\text { condicionou sua adoção. }\end{array}$ \\
\hline & $\begin{array}{c}\text { Espaços } \\
\text { transnacionais }\end{array}$ & $\begin{array}{l}\text { A instituição/país promotor oferece espaços } \\
\text { para o debate e legitimação de } \\
\text { políticas/elementos em reuniões, cúpulas, } \\
\text { capacitações e workshops, etc. }\end{array}$ & $\begin{array}{l}\text { A relação entre Zika e os casos de microcefalia foi apresentada em algumas reuniões internacionais } \\
\text { como uma forma de difundir e legitimar a idéia. Houve inúmeras reuniões, como as da OPAS, OMS, Celac, } \\
\text { reuniões com o COI, entre outras. Naquele momento, o Brasil estava em foco não só por causa da } \\
\text { emergência sanitária, mas porque os Jogos Olímpicos estavam programados para } 2016 \text { no país, que } \\
\text { reuniria turistas e atletas de todo o mundo. }\end{array}$ \\
\hline \multirow{4}{*}{$\begin{array}{l}\text { Mecanismo } \\
\text { Construção } \\
\text { social }\end{array}$} & $\begin{array}{c}\text { Produção de } \\
\text { conhecimento }\end{array}$ & $\begin{array}{l}\text { Teorias, paradigmas e teses, produzidas pela } \\
\text { instituição/país promotor promovem a } \\
\text { legitimidade da política/elemento }\end{array}$ & $\begin{array}{l}\text { A produção de conhecimento foi um dos focos do Brasil para divulgar a tese. } \\
\text { Várias instituições brasileiras de pesquisa trabalharam e confirmaram a hipótese etiológica dos casos de } \\
\text { malformações congênitas em bebês. Isto serviu de alerta para os países vizinhos, a maioria deles com a } \\
\text { presença do transmissor vetorial, o mosquito Aedes Aegypti, em seus territórios. }\end{array}$ \\
\hline & $\begin{array}{l}\text { Legitimidade da } \\
\text { instituição } \\
\text { promotora }\end{array}$ & $\begin{array}{l}\text { A instituição/país promotor da política tem } \\
\text { legitimidade/ é reconhecida como autoridade } \\
\text { no assunto }\end{array}$ & $\begin{array}{l}\text { As instituições que promoveram a tese, como o próprio governo brasileiro e instituições como Fiocruz e } \\
\text { IEC, têm legitimidade política e científica para apoiar e sustentar tal afirmação. } \\
\text { O reconhecimento desta tese por outras instituições, como o CDC, a OPAS e a própria OMS, também } \\
\text { contribuiu para seu estabelecimento. }\end{array}$ \\
\hline & $\begin{array}{c}\text { Coalização de } \\
\text { apoio }\end{array}$ & $\begin{array}{l}\text { Houve coalização interna que apoiasse a } \\
\text { adoção de uma determinada política em uma } \\
\text { instituição/país }\end{array}$ & $\begin{array}{l}\text { Apesar destes conflitos e da crise política do momento, houve uma coalizão política que apoiou a } \\
\text { resposta a esta tese, como nos lembra o entrevistado RCG2(145), quando afirmou que forças políticas } \\
\text { opostas se uniram para estruturar uma série de medidas para dar resposta à emergência. }\end{array}$ \\
\hline & \begin{tabular}{c|c} 
Pressão & \\
internacional
\end{tabular} & $\begin{array}{l}\text { Diversos atores como Instituições, imprensa, } \\
\text { populações exercem pressão para a adoção da } \\
\text { política/elemebro }\end{array}$ & $\begin{array}{l}\text { Houve uma importante pressão internacional e mostrar que a situação estava controlada foi uma forma } \\
\text { de construir confiança no desempenho do Brasil no ambiente internacional. Parte desse trabalho foi feito } \\
\text { por diplomatas brasileiros, com base em informações do Ministério da Saúde. } \\
\text { A tese brasileira fez com que países como a Polinésia Francesa revisassem retrospectivamente o } \\
\text { contexto e os casos de abortos realizados em seu território durante a epidemia de Zika que ali ocorreu } \\
\text { em 2013; resignificando seus dados e reforçando a tese. }\end{array}$ \\
\hline $\begin{array}{l}\text { Mecanismo } \\
\text { individual }\end{array}$ & $\begin{array}{c}\text { Embaixadores/ } \\
\text { circulação } \\
\text { internacional } \\
\text { de indivíduos }\end{array}$ & $\begin{array}{l}\text { Indivíduos que têm autoridade sobre a política } \\
\text { (política, teórica, prática ou técnica); cuja ação } \\
\text { é independente da instituição a que } \\
\text { pertencem; e agem continuamente no } \\
\text { processo de sua promoção }\end{array}$ & $\begin{array}{l}\text { A presidente Dilma Rousseff foi uma das embaixadora, comprometendos-se com a causa e com a } \\
\text { resposta e mobilizando as forças políticas e burocráticas do país. } \\
\text { Entretanto, antes daquele momento, houve uma importante construção feita através da comunicação, } \\
\text { através de grupos de médicos do Whastapp, na qual alguns nomes se comprometeram a provar e divulgar } \\
\text { esta tese, como o Dr. Carlos Brito e o Dr. Kleber Luz. Além disso, é urgente destacar o papel da Dra. } \\
\text { Adriana Melo, que teve a idéia de enviar as primeiras amostras de líquido amniótico para estudo, como } \\
\text { uma forma de provar suas suspeitas. }\end{array}$ \\
\hline Outros fatores & $\begin{array}{l}\text { Tensões e } \\
\text { disputas }\end{array}$ & $\begin{array}{l}\text { Tensões entre instituições ou discursos para a } \\
\text { adoção de uma ou outra política. Entre países, } \\
\text { entre instituições e entre instituições e países }\end{array}$ & $\begin{array}{l}\text { Inicialmente, parte da comunidade científica não estava convencida da relação entre Zika e as } \\
\text { malformações congênitas e foram levantadas muitas hipóteses, não comprovadas, sobre a causalidades } \\
\text { das malformações em bebês. A OMS foi criticada por seu timing ao declarar a Emergência. }\end{array}$ \\
\hline
\end{tabular}

Fonte: elaboração própria

Nota-se que no processo operou o mecanismo institucional, que indica os instrumentos utilizados pela instituição promotora para induzir a difusão/circulação da política ou elemento e permite identificar em que ponto do continuum (Figura 5, (135) foi motivada essa adoção: de forma racional, voluntária, condicionada ou coercitiva. No caso estudado, pouco depois que a hipótese foi levantada, algumas instituições científicas de renome comprovaram a relação causal em um número pequeno de casos naquele momento inicial. Com esse dado científico e confiável, o Ministério da Saúde e a Presidência da República, ou seja, o governo brasileiro, 
defenderam a ideia, declarando a situação uma Emergência de Saúde Pública de Importância Nacional (ESPIN).

Nesse sentido, a tese da relação causal foi adotada de forma racional e voluntária, por um lado, visto que dados científicos comprovavam o vínculo. Porém, na medida que o processo evoluiu, a declaração de uma emergência, como também demonstrado, trouxe alguns benefícios, como a possibilidade de medidas extraordinárias serem tomadas e o aumento no volume de recursos, além de demonstrar a capacidade de oferecer uma resposta efetiva em meio à crise política por que passava o país. Negar essa tese, seria também negar todos esses benefícios, que de certa forma condicionavam sua adoção.

Os espaços transnacionais também fazem parte do mecanismo institucional e foram importantes para a disseminação e posterior adoção da tese brasileira. A relação entre o Zika e os casos de microcefalia foi apresentada em algumas reuniões internacionais como forma de difundir e legitimar a ideia. Foram inúmeros encontros, como as da OPAS, da OMS, da Celac, reuniões com o COI, entre outras como evidenciado no capítulo anterior. Naquele momento, o Brasil estava em foco não apenas pela emergência sanitária, mas porque havia Jogos Olímpicos marcados para 2016 no país, que reuniria turistas e atletas do mundo inteiro. O conhecimento do agente etiológico de uma doença/síndrome até então desconhecida trouxe consigo a segurança de saber qual "inimigo" atacar ou como se defender.

Nesse sentido, existia uma pressão internacional importante sobre o país e demonstrar segurança de que se tinha controle sobre a situação foi uma forma de construir confiança na atuação do Brasil no meio internacional. A securitização da resposta, como vimos, foi parte importante de demonstração de tomada de decisão no sentido de que o país tinha capacidade de responder de forma a tornar a realização dos jogos um evento seguro para o mundo e diante da crise política, foi uma escolha possível. Uma parte desse trabalho foi realizado pelos diplomatas brasileiros, com base em informações do Ministério da Saúde, como demonstramos anteriormente pelo estudo das 37 notas emitidas por embaixadores do país no exterior.

No que tange ao mecanismo de construção social, a produção de conhecimento foi um dos focos do Brasil para disseminar a tese. Como dito, diversas instituições brasileiras de pesquisa trabalharam e confirmaram a hipótese etiológica. Isso serviu de alerta aos países vizinhos, grande parte deles com a presença do vetor transmissor, o mosquito Aedes Aegypti, em seus territórios. Isso se deu por meio da Comunicação operada não apenas pelas reuniões citadas, mas também por redes de pesquisadores como a ReneZika. A comunicação entre os pontos focais de vigilância teve papel fundamental nesse processo, com uma rede de contatos 
previamente estabelecida, muito em decorrência, como vimos, de estruturas estabelecidas pelo Mercosul e pela Unasul e reforçados pela necessidade e pela vontade dos países para promover a implementar do Regulamento Sanitário Internacional.

As instituições que promoveram a tese, tais como o próprio governo brasileiro e organizações como a Fiocruz e o IEC, tiveram naquele momento (e ainda têm) legitimidade política e científica para embasar e sustentar tal assertiva. Um dos informantes faz um adendo à sua fala - quando perguntado sobre o valor agregado de ter instituições como a OPAS, a Unasul e o Mercosul atuando na saúde na América do Sul - para tratar da Fiocruz, como uma

[...] força centenária que gera e cria. E aí, eu teria também que ser justa e dizer OPAS e Fiocruz. Não dá pra falar só da OPAS... a importância dessas duas organizações em criar, há 100 anos, um quadro de sanitaristas muito potente na região. Porque a Fiocruz também vai para além da questão do Brasil, que enxerga na saúde um espaço importante de negociação e de trabalho, que outras regiões não estão necessariamente nessa mesma visão. POL(246)

O reconhecimento próprio dessa tese por outras instituições, como o CDC, a OPAS e a própria OMS, também a deram peso a sua legitimidade. Como lembrou o entrevistado RCG2(145), o CDC é reconhecido por ser um centro de excelência na resposta a emergências, e que possui recursos humanos bastante qualificados.

Sobre a posição da OPAS com relação à tese, o entrevistado RCOI2 reforça o apoio da instituição:

Primeiro, acreditamos no Vírus Zika, na aparição da síndrome congênita. Nem todo mundo, como falei antes, acreditava nisso. [...]Dentre muita gente, muita gente dentro da OMS, muita gente dentro do mundo científico, das organizações profissionais, alguns foram muito reticentes a acreditar. Foi uma briga. Outra briga que tivemos, evidente que não foi pequena, foram os boatos. Em nossa sala de situação havia uma pessoa específica pra detectar e responder boatos. [...]. RCOI2(147)

A OPAS criou uma Sala de Situação para monitorar a situação da epidemia no Brasil e, como também referido anteriormente, houve uma participação intensa dos seus profissionais na resposta nacional do Brasil - o entrevistado RCG2(145) chegou a dizer que os representantes da OPAS haviam se mudado para o Ministério da Saúde. Esse trabalho ativo dos representantes da OPAS no país, com visitas in loco e estreito relacionamento com o governo brasileiro, certamente levou a organização a ter uma quantidade e qualidade de dados sobre os acontecimentos relacionados ao vírus Zika no Brasil que nenhuma outra instituição tinha.

Dessa forma, o reconhecimento da emergência, por meio da ativação do seu sistema de gestão de incidentes, pode ser entendido como o ponto de virada(139) no âmbito internacional para a tese brasileira - entendendo esse momento como aquele em que o elemento de difusão começa a ser adotado por um conjunto de pessoas. 
As disputas discursivas pelos boatos, nesse caso, podem ser apontados como tensões importantes no sentido de adiar, em alguma medida, a adoção da teoria pela OMS, como lembraram alguns entrevistados, como o RCG1/PF1(146) e o RCOI2(147). Isso também foi reforçado pelo retardo de alguns países em comunicar que em seus territórios houve (no caso da Polinésia Francesa) ou existiam naquele momento casos de malformações congênitas em bebês nascidos de mães infectadas pelo Zika durante a gestação.

Novamente, surge a importância dos espaços transnacionais para a disseminação de informações:

Com essas instâncias, é exatamente o momento que você começa a depurar isso. Ao invés de apresentar um estudo desse, bonito, num congresso internacional, se isso fosse apresentado seis meses antes, no grupo, geraria interesse dos demais, de ver também como está nos seus países e de trocar informações de que 'olha, tem um grupo aqui, por exemplo, o CIDACS, da Fiocruz, eles estão analisando isso'. RCG1/PF1(146)

Nesse sentido, a tese brasileira fez países como a Polinésia Francesa reverem retrospectivamente o contexto e os casos de abortos realizados em seu território quando da epidemia de Zika que ocorreu ali em 2013; ressignificando seus dados e reforçando a tese.

Apesar desses conflitos e a crise política em curso, existiu uma coalização política que apoiou a resposta a essa tese, como lembra o entrevistado RCG2(145), quando afirmou que forças políticas opostas se uniram naquele momento para dar conta de estruturar uma série de medidas para dar conta do problema.

Além dessa coalização, que seria algo mais impessoal, também existiram embaixadores dessa tese, que acreditaram e promoveram a vinculação. A mais poderosa delas talvez tenha sido a própria Presidente do Brasil, Dilma Rousseff, que se comprometeu com a causa e com a resposta, mobilizando as forças políticas e burocráticas do país.

Contudo, antes desse momento, houve uma construção importante feita por meio da comunicação, por meio de grupos de médicos no Whastapp, em que alguns nomes se empenharam em comprovar e disseminar essa tese, como o Dr. Carlos Brito e o Dr. Kleber Luz. Além disso, é premente destacar o papel da Dra. Adriana Melo, quem teve a ideia de enviar as primeiras amostras de líquido amniótico para estudo, como forma de comprovar suas suspeitas.

A tese brasileira, as evidências científicas - mesmo com dúvidas de parte da comunidade internacional, que decorreram da sua comprovação - foram consideradas determinantes para da Declaração da ESPII pela OMS. O momento da declaração pode ser compreendido como o ponto de transbordamento da tese, quando ela começou de fato a se mover internacionalmente. Quando questionados sobre o que foi decisivo para que a OMS declarasse essa emergência, os 
entrevistados RCOI1(154) e RCOI2(147) explicam que o reconhecimento da OPAS foi importante:

La OMS es una organización cuyos suscribientes son los estados. Entonces se tú combinas medidas científicas y la presión política. Porque el ministerio de salud recibe presiones de parte de la población. So, tu tenías un conjunto de evidencias científicas, y al momento un conjunto de presiones de la población. Presiones comunitarias para ir adelante. Y eso es lo que desencadenó la declaración de emergencia. Y la verdad, que OPS hubiera declarado la emergencia antes, según sus procedimientos, que son más operativos. No hay un reglamento para las Américas, es un reglamento global. Hay uno, únicamente. Pero nosotros habíamos declarado y entonces yo creo que fue como la locomotora para la declaración de emergencia. RCOI1(154)

Bom, por toda evidência que isso foi acumulando. Também toda pressão nossa. A OPAS colocou isso desde o início, diante o momento que estamos, diante um problema de saúde pública de novo, e que ultrapassava fronteiras, porque também não era um só país. O foco é uma área. [...]. E que era motivos de declaração de emergência, acho que foi pressão, muita discussão e evidentemente quando havia evidências para declarar, foi declarada. RCOI2(147)

Dessa forma, no caso da tese brasileira, pode-se inferir que o que ocorreu foi o fenômeno da difusão(10,136), em que existe um movimento coletivo - nesse caso, realizado por médicos, cientistas, instituições, governos e organizações internacionais - de adoção da ideia de que o Zika era a causa do aumento incomum de malformações congênitas em bebês. A difusão da tese brasileira com a identificação do agente etiológico possibilitou não apenas uma melhor preparação e resposta no âmbito socio-sanitário, mas permitiu a realização dos Jogos Olímpicos, a manutenção da circulação de pessoas, produtos e capitais entre os países e reforçou a importância da existência de mecanismos internacionais de vigilância e resposta tanto no âmbito regional como global.

\subsection{A CIRCULAÇÃO DO RSI}

O segundo movimento seria a adoção, por meio de países e Organizações, do próprio Regulamento Sanitário Internacional, no caso da ESPII relacionada ao Zika e às malformações congênitas. Como braço da OMS nas Américas, esta seção irá analisar as ações da OPAS na região para proporcionar a circulação do RSI, como resumido na Figura 11.

Pode-se dizer que o processo e adesão ao RSI se enquadra numa forma mais branda de governança hierárquica(140). Apesar de ser um instrumento vinculante, de aplicação obrigatória aos países signatários, o instrumento, além de não conter sanções em caso de descumprimento, refere-se, como por exemplo em seu artigo 43, à premência da legislação nacional vigente, denotando também margem para alguma adaptação no âmbito do ordenamento interno. 
Outro fator importante é que nem todos os países conseguiram cumprir satisfatoriamente as capacidades básicas requeridas para sua aplicação até o momento e os prazos para sua aplicação definitiva continuam se estendendo. Isso se coaduna com essa forma mais branda de governança, em que as sanções para a não aplicação também o são. Nesse sentido, entende-se que o RSI e seus dispositivos estão em circulação, em um "movimento contínuo de produção de modelos, emissão, apropriação e tradução de seu conteúdo"(10) p.22 pelos países.

\section{Figura 11 A circulação do Regulamento Sanitário Internacional}

\begin{tabular}{|c|c|c|c|c|}
\hline \multicolumn{5}{|c|}{ Grade de análise } \\
\hline & categoria & descrição & \multicolumn{2}{|c|}{ ESPII relacionada às malformações genéticas causadas pelo vírus Zika } \\
\hline $\begin{array}{l}\text { Elemento } \\
\text { difundido }\end{array}$ & $\begin{array}{l}\text { Concretos } \\
\text { Abstratos }\end{array}$ & $\begin{array}{l}\text { Ideia, paradigma, instituição, soluções para ação pública, } \\
\text { dispositivos normativos, programas, modelos, tecnologias }\end{array}$ & \multicolumn{2}{|c|}{ Elemento concreto: a circulação do Regulamento Sanitário Internacional } \\
\hline Direção & & Lugar de origem da política e lugar de adoção & Da OPAS/OMS ao Brasil & $\begin{array}{l}\text { Da OPAS às Organizações Regionais: } \\
\text { Mercosul e Unasul }\end{array}$ \\
\hline \multirow[t]{2}{*}{$\begin{array}{l}\text { Mecanismos } \\
\text { Institucional }\end{array}$} & $\begin{array}{l}\text { Indução } \\
\text { institucional } \\
\text { (continuum) }\end{array}$ & $\begin{array}{l}\text { Alguma instituição/país promotor induziu a adoção da } \\
\text { política ou elemento, adotada de forma racional, } \\
\text { voluntária, condicionada ou coercitiva }\end{array}$ & $\begin{array}{l}\text { A não adoção formal do RSI implica que o país se } \\
\text { exclui de um sistema de vigilância. Em contraposição } \\
\text { à falta de sanções, essa exclusão indica uma adoção } \\
\text { com tons coercitivos, já que esse sistema se tornou } \\
\text { extremamente relevante principalmente no } \\
\text { combate às pandemias e ao chamado } \\
\text { "bioterrorismo". } \\
\text { Pertencer ao sistema permite receber apoio externo } \\
\text { para desenvolver as capacidades básicas nacionais e } \\
\text { fortalecer seus sistemas de vigilância. } \\
\text { No caso brasileiro, além disso: desviar o foco da } \\
\text { crise política para uma emergência de } \\
\text { saúde(WENHAM; FARIAS, 2019); demonstrar } \\
\text { internacionalmente a fortaleza do seu sistema de } \\
\text { vigilância, fundamental para que os investimentos } \\
\text { nos Jogos Olimpicos de 2016 mantidos, atrair } \\
\text { recursos e investimento para a resposta e para o } \\
\text { desenvolvimento de soluções para o problema. }\end{array}$ & $\begin{array}{l}\text { Introjeção do RSI nos blocos } \\
\text { Apesar de o GT de vigilância da Unasul } \\
\text { estar inativo, no momento da decisão de } \\
\text { sua agenda por meio do Plano } \\
\text { Quinquenal(UNASUR, 2008), um dos seus } \\
\text { resultados esperados era: "Capacidades } \\
\text { Básicas para la Vigilancia y Respuesta a } \\
\text { ESPIN y ESPII implementadas en } \\
\text { conformidad con el reglamento Sanitario } \\
\text { Internacional (RSI)". } \\
\text { Além disso, o Mercosul tem uma comissão } \\
\text { específica para tratar da implementação } \\
\text { do RSI no bloco. Isso por si só já denota a } \\
\text { incorporação da política. Nota-se, ainda, } \\
\text { que o bloco teve participação importante } \\
\text { na própria elaboração do regulamento, } \\
\text { como destacam dois dos entrevistados, } \\
\text { RCOI2(2019) e CN1(2019) }\end{array}$ \\
\hline & $\begin{array}{c}\text { Espaços } \\
\text { transnacionais }\end{array}$ & $\begin{array}{l}\text { A instituição/país promotor oferece espaços para o debate } \\
\text { e legitimação de políticas/elementos em reuniões, cúpulas, } \\
\text { capacitações e workshops, etc. }\end{array}$ & $\begin{array}{l}\text { A OPAS esteve presente em inúmeros espaços transn } \\
\text { convidada, mas foi a responsável por apresentar a sit } \\
\text { ao Zika(MERCOSUR, 2016) e também por difundir seu } \\
\text { Tal presença fica evidenciada nas inúmeras missões e } \\
\text { capacitações, principalmente no que tange ao diagnó } \\
\text { na organização de reuniões com especialistas e gover }\end{array}$ & $\begin{array}{l}\text { lacionais e não apenas participou como } \\
\text { tuação epidemiológica da região em relação } \\
\text { us protocolos e diretrizes clínicos. } \\
\text { enviadas aos países, aos treinamentos e } \\
\text { śtico laboratorial, na doação de insumos, e } \\
\text { rnos. }\end{array}$ \\
\hline \multirow{4}{*}{$\begin{array}{l}\text { Mecanismo } \\
\text { Construção } \\
\text { social }\end{array}$} & $\begin{array}{c}\text { Produção de } \\
\text { conhecimento }\end{array}$ & $\begin{array}{l}\text { Teorias, paradigmas e teses, produzidas pela instituição/país } \\
\text { promotor promovem a legitimidade da política/elemento }\end{array}$ & \multicolumn{2}{|c|}{$\begin{array}{l}\text { No campo do mecanismo de construção social, a OPAS trabalhou intensamente no caso do Zika } \\
\text { com a produção de conhecimento. Uma das suas ações visava homogeneizar parâmetros } \\
\text { diagnósticos, por exemplo, e práticas clínicas, por meio do lançamento de materiais como } \\
\text { protocolos, guias, entre outros. (PAHO, 2017) }\end{array}$} \\
\hline & $\begin{array}{c}\text { Legitimidade da } \\
\text { instituição } \\
\text { promotora }\end{array}$ & $\begin{array}{l}\text { A instituição/país promotor da política tem legitimidade/ é } \\
\text { reconhecida como autoridade no assunto }\end{array}$ & \multicolumn{2}{|c|}{$\begin{array}{l}\text { Quanto à legitimidade, a OPAS foi apontada como o principal destaque em termos de } \\
\text { organização regional atuante. Sua existência centenária, sua capacidade técnica reconhecida e } \\
\text { sua capilaridade por meio do trabalho estreito com os Ministérios da Saúde das Américas e seus } \\
27 \text { escritórios nacionais(PAHO, 2019), são aspectos que corroboram essa visão. }\end{array}$} \\
\hline & $\begin{array}{c}\begin{array}{c}\text { Coalização de } \\
\text { apoio }\end{array} \\
\text { a }\end{array}$ & $\begin{array}{l}\text { Houve coalização interna que apoiasse a adoção de uma } \\
\text { determinada política em uma instituição/pais }\end{array}$ & \multicolumn{2}{|c|}{$\begin{array}{l}\text { No caso do Brasil, havia uma coalização de apoio interna para a adoção de medidas do RSI; } \\
\text { inclusive com a própria participação de membros da Organização, seja pela Sala de Situação } \\
\text { dentro do Ministério, seja pelo apoio na difusão da tese sobre a causalidade. Além disso, um dos } \\
\text { requisitos do regulamento é a existência de um ponto focal dentro de cada país; ou seja, o } \\
\text { próprio instrumento criou uma estrutura endógena que facilitou sua circulação. }\end{array}$} \\
\hline & $\begin{array}{c}\text { Pressão } \\
\text { internacional }\end{array}$ & $\begin{array}{l}\text { Diversos atores como Instituições, imprensa, populações } \\
\text { exercem pressão para a adoção da política/elemebro }\end{array}$ & \multicolumn{2}{|c|}{$\begin{array}{l}\text { A pressão internacional sobre a OMS era grande, principalmente após a Emergência do Ebola. } \\
\text { Apesar do movimento anterior da OPAS, diversos entrevistados criticaram o timing para a } \\
\text { declaração da ESPII pela OMS. } \\
\text { A possibilidade de transmissão sexual e a realização das Olimpíadas em } 2016 \text { foram outros } \\
\text { fatores de pressão internacional relevantes. }\end{array}$} \\
\hline $\begin{array}{c}\text { Mecanismo } \\
\text { individual }\end{array}$ & $\begin{array}{l}\text { Embaixadores/ } \\
\text { circulação } \\
\text { internacional } \\
\text { de individuos }\end{array}$ & $\begin{array}{l}\text { Indivíduos que têm autoridade sobre a política (política, } \\
\text { teórica, prática ou técnica); cuja ação é independente da } \\
\text { instituição a que pertencem; e agem continuamente no } \\
\text { processo de sua promoção }\end{array}$ & \multicolumn{2}{|c|}{$\begin{array}{l}\text { No caso brasileiro, agentes importantes foram os coordenadores dessa resposta no país dentro } \\
\text { da Secretaria de Vigilância em Saúde como Eduardo Hage, que participou ativamente da própria } \\
\text { construção do RSI; Cláudio Maierovitch; Wanderson Kleber; e na OPAS Brasil, Enrique Vázquez. } \\
\text { Esses agentes também trabalharam, em alguma medida, como embaixadores do Regulamento, } \\
\text { promovendo seus mecanismos e sua aplicação. }\end{array}$} \\
\hline Outros fatores & $\begin{array}{l}\text { Tensões e } \\
\text { disputas }\end{array}$ & $\begin{array}{l}\text { Tensões entre instituições ou discursos para a adoção de } \\
\text { uma ou outra política. Entre países, entre instituições e } \\
\text { entre instituições e países }\end{array}$ & \multicolumn{2}{|c|}{$\begin{array}{l}\text { O Conselho de Saúde da Unasul foi criado como uma forma de projetar a América do Sul na área } \\
\text { da saúde global, sem a influência de atores poderosos como os EUA, grandes financiadores e } \\
\text { país-sede da OPAS/OMS. }\end{array}$} \\
\hline $\begin{array}{l}\text { Nível de } \\
\text { Governança }\end{array}$ & $\begin{array}{c}\text { Hierárquica/ } \\
\text { supranacional }\end{array}$ & Vertical/coercitiva & \multicolumn{2}{|c|}{$\begin{array}{l}\text { Forma branda da governança hierarquica: Apesar de ser um instrumento vinculante, de aplicação } \\
\text { obrigatória aos países signatários, o instrumento, além de não conter sanções em caso de } \\
\text { descumprimento. Os países, pelas regras, podem ainda adaptar o RSI de acordo a suas realidades } \\
\text { e políticas. }\end{array}$} \\
\hline
\end{tabular}

Fonte: elaboração própria 
De antemão, apenas com o processo de aprovação e adesão formal ao instrumento, observa-se nitidamente um mecanismo de indução institucional. A não adoção formal implica que o país se exclui de um sistema global de vigilância em saúde. Isso poderia indicar uma dimensão coercitiva, eis que essa rede internacional se tornou extremamente relevante, entre outras razões, por ser um instrumento de combate às epidemias, pandemias e ao chamado "bioterrorismo", como já foi mencionado anteriormente.

Igualmente, pertencer à rede permite receber apoio externo para desenvolver as capacidades básicas nacionais, como consta, por exemplo, do parágrafo $3^{\circ}$ do seu artigo $5^{\circ}$, que afirma que "a OMS proporcionará assistência aos Estados Partes, a pedido, no desenvolvimento, fortalecimento e manutenção das capacidades a que faz referência o parágrafo 1 do presente artigo"(123).

Como lembrou o entrevistado POL(246), é vantajoso para o país solicitar ajuda, o que inclui apoio técnico, mas também mobilização de recursos financeiros. Além disso, explica que, nos fóruns da OPAS e da OMS, existem vantagens de operar o tema da vigilância, em detrimento de outros, como a Unasul, cujo GT ficou desativado por alguns anos.

Outro entrevistado resume a importância da adesão ao RSI, que facilita a estruturação dos sistemas de vigilância dos países e também dá suporte à tomada de decisão para a resposta a emergências:

[...] acho que o regulamento sanitário atual, ele é importante por dois aspectos principais: primeiro na preparação do sistema nacionais para a vigilância em si, ou seja, para detecção, especialmente para a deteç̧ão rápida de mudanças de cenário epidemiológico, do surgimento de novas doenças e para comunicação rápida também...se estabelecem os prazos, estabelecem os fluxos e mecanismos para comunicação rápida; e em segundo lugar para a tomada de decisão, quer dizer que o fato de existir um instrumento que define condições que justificam, por exemplo, uma declaração de emergência nacional ou internacional, isso facilita muito para os decisores dar esse passo. Então isso cria justificativas formais inclusive que embasam a adoção de mecanismos de emergência, que em alguns casos tenham um significado legal dentro do país. Por exemplo, no momento que se faz uma compra emergencial uma contratação, qualquer coisa que signifique uma resposta imediata para a emergência, havendo uma vaga legal e formal que é um instrumento que tem uma força de um tratado internacional... Portanto uma vez que o Brasil internalizou, tem força de lei no país, isso ajuda, isso respalda no ponto de vista técnico, político e administrativo as ações dos governos RCG2(145)

Nesse sentido, a declaração de uma emergência estimula os países a calibrarem e melhorarem seus sistemas de vigilância. Uma das possíveis motivações para tanto está relacionada à proteção da população contra a "ameaça"; outra seria o apoio ofertado tanto pela OPAS, como pela OMS, para o fortalecimento dos sistemas de vigilância dos países. 
No caso brasileiro, como vimos anteriormente, outros fatores podem ser acrescentados. Trabalhar em prol a ativação dos mecanismos do RSI trouxe um benefício concreto. Primeiro, de desviar o foco da crise política para uma emergência de saúde. Segundo, para demonstração internacional da fortaleza do seu sistema de vigilância, elogiado por vários dos entrevistados, fundamental para que os investimentos nos Jogos Olímpicos de 2016 não fossem perdidos. E, terceiro, para atrair recursos e investimento para a resposta e para o desenvolvimento de soluções para o problema.

Ainda no mecanismo institucional observa-se, na resposta da OPAS, que a organização esteve presente em inúmeros espaços transnacionais e não apenas participou como convidada, mas foi a responsável por apresentar a situação epidemiológica da região em relação ao Zika e também por difundir seus protocolos e diretrizes clínicos. Tal presença ficou evidenciada nas inúmeras missões enviadas aos países, aos treinamentos e capacitações, principalmente no que tange ao diagnóstico laboratorial, na doação de insumos, e na organização de reuniões com especialistas e governos.

No campo do mecanismo de construção social, a OPAS trabalhou intensamente no caso do Zika com a produção de conhecimento. Uma das suas ações visava homogeneizar parâmetros diagnósticos, por exemplo, e práticas clínicas, por meio do lançamento de material como protocolos, guias, entre outros.

Quanto à legitimidade, é inegável que a OPAS foi apontada como o principal destaque em termos de organização regional atuante. Sua existência centenária, sua capacidade técnica reconhecida e sua capilaridade por meio do trabalho estreito com os Ministérios da Saúde das Américas são aspectos que corroboram essa visão.

No caso do Brasil, todo o contexto descrito anteriormente destaca que havia uma coalização de apoio interna para a adoção de medidas do RSI; inclusive com a própria participação de membros da Organização. Seja pela Sala de Situação dentro do Ministério, seja pelo apoio na difusão da tese sobre a causalidade. Além disso, um dos requisitos do regulamento é a existência de um ponto focal dentro de cada país; ou seja, o próprio instrumento criou uma estrutura endógena que facilitou sua circulação.

Nesse sentido, no caso brasileiro, os agentes importantes seriam os coordenadores dessa resposta no país dentro da Secretaria de Vigilância em Saúde como Eduardo Hage, que participou ativamente da própria construção do RSI; Cláudio Maierovitch; Wanderson Kleber; 
e na OPAS Brasil, Enrique Vázquez. Esses agentes também trabalharam, em alguma medida, como embaixadores do Regulamento, promovendo seus mecanismos e sua aplicação.

Um dos entrevistados citou a importância do trabalho in loco como um dos fatores determinantes para a Declaração da ESPII.

[...] los grandes tomadores de decisión fueron en el Nordeste de Brasil y tuvieron en sus manos esos niños con microcefalia, $80 \%$ de ellos vivos convulsionando en sus brazos, en el examen clínico, yo puedo decirte que esto cambió, el contacto directo. Yo tuve la oportunidad de ir de manera muy temprana a Pernambuco. Yo puedo decirte que atender a la consulta pediátrica con la pediatra de turno, en un hospital de Pernambuco público, a mí me cambió la vida. RCOI1(154)

Sobre a cooperação com organizações internacionais, o Artigo 14 do documento dispõe que a OMS irá cooperar e coordenar atividades com as organizações para a aplicação do RSI. Um exemplo dessa coordenação é a participação da OPAS na reunião do Mercosul e da Unasul de Montevidéu.

Apesar de o GT de vigilância da Unasul estar inativo, no momento da decisão de sua agenda por meio do Plano Quinquenal, um dos seus resultados esperados era: Capacidades Básicas para la Vigilancia y Respuesta a ESPIN y ESPII implementadas en conformidad con el reglamento Sanitario Internacional (RSI). Além disso, o Mercosul tem uma comissão específica para tratar da implementação do RSI no bloco. Isso por si só já denota esforços para a incorporação da política regulatória. Nota-se, ainda, que o bloco teve participação importante na própria elaboração do regulamento, como destacam dois dos entrevistados, RCOI2(147) e CN1(148).

No caso do Zika, é possível inferir o ponto de virada a partir da Declaração de Emergência de Saúde Pública e Importância Nacional, em novembro de 2015. Nesse momento, o país reconhece abertamente os dispositivos do Regulamento e, a partir dessa declaração, aciona uma série de mecanismos de vigilância. Novamente, o transbordamento está na ativação do sistema de emergências da OPAS, e do Comitê de Emergência pela própria OMS, que culminou com a declaração da ESPII.

Esse movimento também não foi unilateral, de modo que ambas as Organizações e, especialmente, a OMS, foram bastante pressionadas e criticadas pela demora em acionar esses mecanismos. A pressão internacional sobre a OMS era grande, principalmente após a Emergência do Ebola, que havia ocorrido dois anos antes, quando foi acusada de tardar para reagir. Diversos entrevistados criticaram o timing para a declaração da ESPII pela organização no caso do vírus Zika. A situação que se apresentava era, de certa forma, controversa. 
Essa organização, que tem por missão ser uma líder mundial no campo da saúde e que, com o apoio dos seus Estados-membros, criou o Regulamento Sanitário Internacional, era pressionada a aplicar sua própria política, em um caso de arbovirose que mesmo antes de acometer crianças, já atinge endemicamente milhares de pessoas nos países subtropicais.

A possibilidade de transmissão sexual, naquele momento, foi apontada como determinante:

Pero, del momento que hablábamos ya de transmisión sexual, en donde podía transmitirse también de aquellas personas que no tenían en aquellos países, en donde no había el vector. Yo creo que eso es lo que es, sensibilizó más y tuvo como una proyección más internacional [...]. Sin ella, por la afectación a nuestros países, por transmisión del vector, yo creo que no. Te soy bien honesta. Si no, dengue había existido una ESPII. PF2(183)

A iminência das Olimpíadas e a circulação internacional de pessoas que esse evento geraria também foi destacada:

[...]. Y este aspecto de migraciones humanas, quiere decir de viajes de mujeres en edad de tener niños. Eso fue la presión más importante, además de las Olimpiadas [...]. RCOI1(154)

Pelo exposto, pode-se observar que o RSI, no caso da Emergência do Zika, circulou na região das Américas não apenas pela atuação da própria OMS, por meio da OPAS, mas também dos países e organizações sub-regionais que tratam da saúde.

\subsection{A ENGRENAGEM REGIONAL DE VIGILÂNCIA}

Por todo o exposto, pode-se de afirmar que existiu uma engrenagem regional que operou no caso do Zika na América do Sul. A OPAS, sendo a instância que vela pela aplicação do Regulamento Sanitário Internacional na região, atuou de forma destacada, tanto no reconhecimento da emergência, como na ativação dos seus mecanismos. Entretanto, existia uma expectativa de que houvesse uma engrenagem regional operada pela Unasul, unindo todos os países da América do Sul, o que não se confirmou.

A Unasul, como um projeto político construído por mandatários em uma onda progressista por que passou a América do Sul, precisava ser "deletado", como afirmou o entrevistado POL(246). Com o giro ideológico que ocorreu na região, somado à perda de prestígio dos Conselhos Setoriais com o novo regulamento do bloco, e à falta de comprometimento e também de necessidade de debater o tema da vigilância fora do sistema OPAS, as ações nessa área não se sustentaram a ponto de colocar uma engrenagem própria em curso. 
Apesar disso, os entrevistados salientaram o fato de a comunicação entre os pontos focais de vigilância ocorrerem independente do GT de Vigilância da Unasul; ou seja, mesmo sem um GT atuante, os países estavam trocando informações epidemiológicas por meio de uma rede que se manteve ante a inatividade formal do grupo.

Embora, de qualquer forma, os canais de comunicação entre eles permaneceram ativos. [...] Entre os países do Mercosul, sempre eles estavam trocando informações, não só nas reuniões presenciais, mas, quando tinha alguma informação aqui ou ali, por exemplo, Águeda sempre estava precisando de algum apoio - Eu estive uma reunião no Mercosul, se eu não me engano, foi em 2016, primeiro semestre - E ela relatou, de que 'a gente não consegue detectar um caso de Zika, não sei se tem etc.', isso no primeiro semestre de 2016. RCG1/PF1(146)

Além disso, um dos entrevistados destacou o fato de vários pontos focais da Unasul e do Mercosul serem os mesmos, o que seria uma vantagem. Contudo, ele ignora o fato de os países fazerem usos distintos dos organismos e também que países acometidos, como a Colômbia, não participam como associados do Mercosul.

Bueno, efectivamente el grupo, de los cinco grupos de Unasur, porque había uno que era el grupo de vigilancia y respuesta, que tenía el objetivo de formar el escudo y la ventaja comparativa que se vio ahí es que gran parte de los puntos focales de esos grupos se correspondían con los puntos focales de los países que estaban en Mercosur y estados asociados [...] y prácticamente lo que se hacía en Mercosur por osmosis también fue lo que se procesó Unasur ${ }^{63}$, en una coincidencia con las estrategias que no es menor, aún más sumando los esfuerzos. [...] y por lo tanto prácticamente sería un funcionamiento de todos los países, jugando con los dos sombreros de Mercosur, y del el Escudo Epidemiológico de Unasur. CN1(148)

Dessa forma, a troca de informações feita pelos pontos focais do Mercosul não compreendeu toda a região. Isso impediu, em alguma medida, que os Estados tivessem um panorama do que de fato estava acontecendo em alguns dos países vizinhos ${ }^{64}$.

Então esse canal, ele permaneceu por conta do Mercosul, que já existia, mas, a desativação da
Unasul, dessa instância técnica, prejudicou isso, porque Colômbia estava fora. E Colômbia foi
um país afetado. Colômbia, se você vê os dados de Colômbia de microcefalia em relação à
epidemia de Zika, quase a mesma coisa do Brasil, proporcionalmente. [...] Não participava do
Mercosul. Participaria, se tivesse instância da Unasul. Como o GT de vigilância da Unasul não
estava ativo, então Colômbia ficou de fora um pouco, dessa discussão. Da mesma forma,
Equador, Venezuela. [...]. Enquanto Chile, Argentina e Paraguai e Uruguai, já tinham um canal,
por conta do Mercosul que, já era mais antigo e mantiveram, exceto no segundo semestre de
2016. RCG1/PF1(146) Sobre a atuação da Unasul no tema, POL(246) afirma que o GT de Vigilância realizou boas discussões e deu importantes resultados como o Livro de Vigilância, lançado pelo ISAGS,

${ }^{63}$ Aqui, o informante repetiu Mercosur no original, entretanto, pelo contexto, entende-se que foi Unasur.

${ }^{64}$ Pelo sistema OPAS/OMS, os países podem compartilhar informações de forma confidencial, sem que os demais saibam, de antemão, sua situação epidemiológica. Isso não ocorre nos âmbitos da Unasul e do Mercosul, em que as informações são trocadas diretamente pelos países membros. 
mas que não havia continuidade nas ações. Entretanto, chama atenção para o fato de os debates sobre o tema ocorrerem a despeito do seu funcionamento.

[...] não é que as pessoas que estavam responsáveis pelo tema de vigilância sanitária nos países não conversassem. O contato entre eles era permanente, só que não era o estabelecido pela Unasul. [...] E todas essas questões que no Ministério já tem essa relação porque, diferentemente de outros temas, esse tema é sabidamente um tema onde as fronteiras não funcionam. Então, já existe essa relação muito mais aberta e de negociação e por conta do próprio papel da OPS e da OMS nesse tema. E de toda estrutura que o Regulamento Sanitário Internacional provê pra esse tema, que não é menor e que as outras áreas não contam com isso. [...]Mas, ao mesmo tempo a sensação era de que os países poderiam sobreviver sem esse GT. Porque existiam outras estruturas in place que já faziam com que os mecanismos de comunicação entre os países pudesse continuar a despeito do GT. POL(246)

Para o entrevistado RCG1/PF1(146), essa engrenagem funcionou apenas durante um tempo e reforçou a sobreposição de agendas como uma possível razão para o desaquecimento do GT da Unasul.

Então, eu acho que ela funcionou durante um determinado período, mas, eu não sei por que, houve esse 'desaquecimento'. O que algumas pessoas relatavam depois, é que havia uma sobreposição de temas e tentaram, de alguma forma, reestruturar. O Wanderson, ele falava isso. De que 'não, a gente tem que dividir um pouco, que é o tema que o grupo técnico de vigilância da Unasul trata e o grupo de vigilância do Mercosul trata'. Mas me parece que eles não souberam achar essa equação. [...] RCG1/PF1(146)

Outro entrevistado também acredita no funcionamento desse mecanismo, visto que os países trabalharam de forma integrada e transparente.

Yo creo que sí. [...] la situación, por ejemplo, en la pandemia, que después hubo algunos países de que no pasaban toda la información, querían crear problemas en control de fronteras y todo eso. Sin embargo, con este tema no hubo nada de eso, hubo una amplia apertura, un trabajo más integrado en compartir experiencias, que yo creo que fue muy bueno. PF2(183)

Ao ser perguntado especificamente se ele acreditava que, caso o GT tivesse ativo, a Unasul daria uma resposta regional, RCG1/PF1(146) foi taxativo, reforçando a preponderância de reuniões para a cooperação entre os países para a construção de confiança entre as nações. Nesse sentido, é possível observar que o mecanismo da OPAS, que recebe informações de forma unilateral e até confidencial, falhou em termos de transparência com os sul-americanos.

Eu acho que sim. Em especial, de identificar, de que o mesmo problema estava ocorrendo nesses países. Porque nessas reuniões, é mais difícil você ter um diretor de vigilância, de ir pra uma reunião em que os outros vão apresentar os dados e o país fica ali, calado. [...] Então, se cria esse ambiente de confiança. E isso, muitas vezes, contribui pra que 'tá, então vamos escrever a situação aqui da região, divulgar isso e aí, consequentemente, quando retorna pro seu país ele diz: "olha, nós já divulgamos isso já".' A gente não pode esconder isso dos países, que não tem como esconder dados. [...] Que é dessa forma que esses laços se estabelecem. Que é o que faltou à Unasul, que no Mercosul tem. RCG1/PF1(146)

Apesar de disso, a maior parte dos informantes destacou a OPAS como preponderante na resposta à ESPII na América do Sul. 
RCG1/PF1(146) cita a Organização como importante nesse processo, por todo acompanhamento feito junto ao governo brasileiro. Ele aponta também a falta de reuniões no segundo semestre de 2016 e a paralisia do GT de vigilância da Unasul nesse momento.

[...] a OPAS, de fato, eu acompanhei, eu vi a importância que eles tiveram e o apoio que eles tiveram. Não só com o ministério, como apoiaram em vários locais. Estados, inclusive. Estiveram em Estados, mandaram, inclusive, pessoas trabalhar junto com o pessoal do estado, ajudando em várias questões. Desde análise de dados, até discussão sobre as ações que estavam sendo executadas, mesmo no nível do estado. Então, eu observei uma presença muito forte OPAS apoiando a resposta. A OMS, claro. A OMS... a OPAS estando presente, a representação sua própria ali. E o que eles fizeram, foi o que cabe pelo regulamento, que é o monitoramento pelo comitê de emergência, sem, me pareceu, sem dar uma repercussão mais grave do que, de fato, foi o evento. [...]Agora, do Mercosul, é isso. Eu não acompanhei não lembro o porquê. Por algum motivo não houve reunião. [...]E Unasul, agora eu lembro, mas aí quando cheguei aqui no ISAGS, é porque Unasul o GT estava desativado. RCG1/PF1(146)

Ela também foi citada como predominante tanto pelo tipo e evento quanto pelo tema; explicando a forma de atuação da Organização no Brasil.

Bom, pela própria natureza do evento e especificidade temática da organização a OPAS foi um grande destaque. Então, por exemplo, a representação local da OPAS aqui estruturou a sua própria sala de situação, passou a recolher informações continuamente, apresentar boletim, relatórios, e a fomentar um intercâmbio de informações entre os países da primeira onda, digamos assim, da doença... e as recomendações, muito com base do que acontecia no Brasil em relação ao que poderia ser feito em outros países. Nesse período, praticamente alguns técnicos da OPAS se mudaram para o Ministério da Saúde digamos assim, numa dupla função de colaborar, alguns deles eram ex-funcionários do Ministério da Saúde, inclusive pessoas especializadas na área de controle de vetores, mas também de promover esse intercâmbio de informações que pudesse ajudar nas respostas de outros países que começaram a enfrentar problemas depois do Brasil. RCG2(145)

A OPAS também foi referida como importante articulador e fonte de apoio técnico, e o Mercosul teria tomado a iniciativa na América do Sul. O entrevistado faz uma ressalva, afirmando que muitas vezes a OPAS atua de forma independente (reforçando o que POL(246) afirmou), mas no caso do Zika atendeu a um chamado dos países.

Bueno, en este caso concreto la OPS fue un articulador importante para ayudar con capacidad técnica para enfrentar y, además, lo hizo como una primer movida en torno del tema, más allá que coexistían Unasur y Mercosur, fue Mercosur que tomó la iniciativa en la región a la cual se sumó Unasur y OPS, fue un suporte técnico para ambos los bloques. Y creo que ahí también se pudo identificar, a veces vemos como OPS también tiene una planificación de cooperación a respeto de los temas que no son relevantes para los países. Y en estos casos, se vio lo que debería estar siempre así: los ministros demandaron una cooperación en torno de un problema de salud pública, y ellos respondieron con apoyo, con capacitación. Con estudios sobre resistencia, varias cosas que ayudaran al conjunto del bloque. [...] como respuesta regional el bloque activo fue Mercosur con ese grupo ad hoc coordinado, y después la cooperación técnica de OPS y algunas universidades de Brasil. CN1(148)

O corpo técnico da OPAS também foi aludido, e o entrevistado PF2(183) enfatizou o fato de que mesmo aqueles que faziam parte de outros blocos/países, não eram identificados como representantes das demais organizações. 
Yo creo que al menos en este caso colaboró mucho. Y yo creo que sí, el tema que es nosotros ni en UNASUR, ni en Mercosur no tenemos un directorio de expertos dentro de ambas agrupaciones, ¡porque hubo la participación de estos expertos! Pero no se visualizó como que estos expertos eran de Unasur o eran de Mercosur. Y eso creo que sea un error de parte nuestra. [...] Creo que el momento, y sobretodo que había una gran expertise, como en todos los países, pero yo creo que con un gran énfasis en Brasil y en Colombia. Y se utilizó estos recursos, pero en ningún momento se visualizó como un recurso de Unasur. Un recurso de la región. PF2(183)

Outra característica ressaltada foi a de catalizadora de diversos processos e enfatizou o caráter técnico da colaboração com o país.

fuimos el catalizador. [...]Catalizador de procesos de cooperación entre países, cooperación SurSur, cooperación interpaís, inter programática. Y el catalizador de poner lo que había funcionado en Brasil, en la misma mesa, personas de sectores, de subsectores de salud, bien, bien diferentes. La verdad, sin hablar de política, política brasileña, política nacional. [...]RCOI1(154)

Ele também enfatizou o papel da OPAS no sentido de ser um hub de dados científicos organizados e confiáveis no sentido de servir de base para a construção de protocolos e diretrizes.

Yo te hablé, es el catalizador de estos procesos. Son una mezcla de respuesta operativa y del proceso científico. Y de tener plataformas de acceso a información. [...] Lo importante es dónde poner la información accesible, clasificada, caracterizada, organizada. [...] Quiere decir que tu podrías ver estudios con protocolos aceptados para que haya como una armonización de los protocolos. Sus resultados preliminares y los resultados publicados. Yo te diría que eso, para mi, fue la otra chispa que logramos aportar. RCOI1(154)

O entrevistado RCG2(145) acredita que a resposta não foi diferente do que seria realizado apenas com a OPAS e a OMS e cita algumas ações feitas em âmbito regional.

mas a minha impressão é de que não foi diferente do que seria com os mecanismos habituais do RSI e da interação via OPAS e via OMS; também pela característica dos países da América do Sul. Nós temos o nosso bloco Mercosul, ele tem a sua relevância maior em grandes latitudes, pensando em Argentina, Uruguai, Paraguai um pouco menor a latitude, mas ainda assim ao sul, depois do engajamento do Chile, e naquele momento a Venezuela [...]começava a sua participação no Mercosul e ainda não tinha uma presença sequer constante, designação de representação, era uma coisa ainda muito incipiente. Então, não foi nesses locais o foco principal, de preocupação com a epidemia Zika; a Colômbia participando da Unasul, mas não participando do Mercosul, foi o segundo país com a maior preocupação e depois países Caribenhos e países da América Central que não fazem parte dessas organizações, mas fazem sim da OPAS. Então eu não consigo lembrar assim, identificar de coisas muito relevantes que tem sido feitas neste âmbito [...] RCG2(145)

Os motivos para o destaque da OPAS têm a ver com sua legitimidade, construída ao longo de mais de 100 anos (muito antes de a OMS existir), sua capilaridade técnica. A Organização também tem capacidade financeira e de mobilização/captação de recursos para apoiar tecnicamente os países, tornando-se um ator mais elegível num contexto de crise política.

Os entrevistados apontaram a organização como a que teve maior destaque na resposta. Isso se coaduna com os relatos e com os resultados da análise documental que confirmam essa premência, principalmente quando levamos em conta a atuação da Unasul e do Mercosul. 
Nesse sentido, mais do que geradores de uma engrenagem própria, principalmente no que se esperava dos países sul-americanos, plasmados nos objetivos do Conselho de Saúde da Unasul de criar uma Rede de Vigilância e Resposta, observa-se que também os blocos funcionaram no caso do Zika como operadores e facilitadores do processo de circulação do RSI. 


\section{CONSIDERAÇÕES FINAIS}

Este largo percurso de pesquisa resultou na tese de que existiu, durante a ESPII relativa à Síndrome Congênita do Vírus Zika, uma engrenagem regional resultante de um aspecto estrutural - a circulação do RSI que repercutiu na construção de um sistema, ainda que embrionário, de vigilância epidemiológica regional - e que propiciou uma difusão conjuntural, qual seja o achado brasileiro relativo à associação entre o vírus Zika, a microcefalia e outras malformações congênitas.

Neste processo, procurou-se descrever e analisar os mecanismos de respostas operadas por quatro importantes agentes que atuam técnica e politicamente na América do Sul.

O Brasil, além de ser o epicentro da epidemia, foi o primeiro país na região a identificar e ativar prontamente seu sistema de vigilância para alertar sobre as graves consequências que a infecção pelo vírus Zika trouxe para centenas de crianças recém-nascidas e, em última instância, para suas mães e familiares.

O sistema de vigilância brasileiro claramente funcionou, e o foco da sua resposta foi o controle do vetor transmissor, o mosquito Aedes Aegypti. A emergência foi declarada após o aumento incomum dos casos de microcefalia em bebês, mas as ações se focaram no controle vetorial, com acionamento até das Forças Armadas.

Seguindo essa lógica, era de se esperar que ações de curto prazo fossem abandonadas aos poucos, na contramão do peso que as sequelas vitalícias da infecção em crianças traziam. O período de crise política e financeira por que passou o Brasil justamente no momento da emergência do vírus Zika deixou impactos orçamentários importantes, que também se refletiram em perda de força política do tema. Até as pesquisas com vacinas, que seriam um alento para as mulheres em idade fértil, desaceleraram. As questões de saúde sexual e reprodutiva não tiveram o devido destaque. Certamente, a fragilidade política da presidente Dilma Rousseff naquele momento contribuiu para o não embate em questões como o aborto, ainda tratadas como um tabu no país e dominadas por um viés religioso que apenas massacra mulheres pobres.

Em termos de cooperação internacional, cabe ressaltar o interesse dos Estados Unidos na resposta à emergência. No campo de pesquisa e desenvolvimento, firmou acordos bilaterais com o Brasil, com ênfase para uma resposta técnica e biológica à epidemia, o que é evidenciado pelo protagonismo do CDC nesses acordos. 
No âmbito diplomático, observou-se o desinteresse do governo Dilma nos assuntos de política externa e de saúde, apesar da sua liderança que mobilizou recursos e pessoas para a resposta. Isso teve impactos importantes na região, visto que o Brasil é um ator relevante no cenário internacional. O MRE trabalhou muito mais no sentido de subsidiar seus embaixadores com informações sobre as ações do governo a fim manter os Jogos Olímpicos com "segurança" para os visitantes estrangeiros; e menos como negociador de acordos que de fato pudessem trazer benefícios para os mais afetados pela emergência em curso.

No âmbito regional, Unasul e Mercosul tiveram pequena participação na resposta regional à emergência. Além da reunião de Ministros, realizada em Montevidéu em fevereiro de 2016, o que ficou de concreto, pelo menos para o Mercado Comum, foi a aceleração de projetos já em curso, como a padronização dos graus de infestação (LIRAa). Novamente, o foco no controle vetorial foi destacado. A rede de vigilância criada pelo bloco também foi apontada como um fator importante, já que mesmo com o enfraquecimento da Unasul, manteve a maior parte dos países da região em contato.

Nesse sentido, a crise pela qual passava a Unasul interferiu na sua capacidade de resposta. No âmbito da Saúde, o Grupo Técnico que tratava de vigilância estava desmobilizado, sem reuniões ordinárias havia anos. Além disso, a emergência de governos conservadores na América do Sul resultou em um giro na diplomacia em curso na região desde os anos 2000, quando havia se estabelecido um ambiente de cooperação importante, que deu origem à própria Organização.

Soma-se a isso o processo de impeachment que retirou da Presidência do país Dilma Rousseff, que contribuiu ainda mais para a crise. Diversos países integrantes dessas OIs retiraram ou chamaram seus embaixadores no Brasil para consulta, caso da Bolívia, do Equador e da Venezuela, causando desgastes diplomáticos importantes. Em abril de 2017, seis dos 12 países da Unasul congelaram suas ações no bloco e alguns estão atualmente em processo de saída definitiva. Como processo político e diplomático, a Unasul não se adaptou ao novo momento da região e a disputa pelo seu espaço segue, com o surgimento de organismos como o Foro para o Progresso da América do Sul - ProSul.

A crise econômica e a consequente falta de financiamento também contribuíram para frear ações e projetos regionais de combate ao Vírus Zika, impactando no funcionamento dos sistemas de saúde do subcontinente. Juntos, esses fatores abalaram a atuação dessas organizações. 
Apesar dessas questões também afetarem a OPAS em alguma medida, por ser um organismo multilateral que atua nas Américas, observa-se que sua atuação foi a de maior destaque, com a deflagração dos mecanismos de vigilância e resposta dispostos no RSI. Além de ser mais antiga, mais estabelecida e institucionalizada, ambas têm grande penetração no campo da diplomacia em saúde e em seus Estados Partes, contribuindo para uma maior ressonância de suas intervenções. Soma-se a isso o grande interesse demonstrado pelos EUA, sede da organização e seu maior financiador, nessa questão. Além disso, os países que assumiram compromissos na implementação do Regulamento têm de fazer autoavaliações periódicas e recebem apoio para o desenvolvimento das suas capacidades básicas.

A Organização também atuou em outras frentes como a produção e disseminação de conhecimento, bem como na doação de insumos para diagnóstico, envio de recursos humanos e ações de capacitação. Assim, suas ações têm caráter bastante técnico, o que a distancia de divergências políticas maiores.

Os efeitos da declaração de uma ESPII são muitos e tornaram a epidemia do vírus Zika na América do Sul uma ocasião favorável para a cooperação internacional devido à demanda de ações coordenadas de vigilância e resposta. Alguns autores previam que o aumento da visibilidade da epidemia pudesse atrair maiores investimentos para seu combate $(129,251)$, fomentando a mobilização de estruturas regionais para dar conta de compromissos anteriormente assumidos. Entretanto, o que se observou é uma retração das ações das instâncias regionais - Unasul e Mercosul - para a articulação de ações no sentido de responder conjuntamente aos desafios regionais impostos pela ESPII.

Nesse sentido, esta tese buscou analisar o fenômeno das respostas no contexto da ESPII de forma a contribuir para a compreensão de futuras emergências de saúde pública. Com base nas informações colhidas, principalmente pelos informantes-chave, e a análise das dinâmicas que influenciaram as ações das organizações que atuam na região, buscou-se contribuir tanto com os estudos sobre integração regional como sobre saúde global.

Esse campo mostra-se especialmente importante e relevante no caso de uma Emergência de Saúde Pública de Importância Internacional, em que a iminência de uma propagação internacional ativa uma série de mecanismos que mobilizam países e organizações no sentido de conter o evento. O campo dos estudos críticos em saúde global também se destaca nesse caso, ao passo que apesar de a emergência ter sido declarada pelo aumento de casos do que se configurou como uma Síndrome Congênita que deixaria sequelas em crianças e famílias, o foco, mais uma vez foi no "inimigo" mosquito. 
A declaração da ESPII foi uma grande oportunidade para governos e sociedades(252) para chamar atenção para doenças há muito negligenciadas e que nunca atraíram tamanha atenção internacional. Trouxe à tona, ainda, a necessidade de estruturação dos sistemas de saúde como maneira de responder às consequências dessa epidemia, visto que os danos neurológicos em bebês são irreversíveis e demandam ações estruturantes e de longo prazo. Além disso, foi uma oportunidade para as OIs fortalecerem a diplomacia da saúde e a cooperação internacional, por meio da negociação de ações regionais que possam resultar em políticas comuns.

Mais uma vez, a resposta da saúde global demonstra seus limites(2). Parafraseando Milton Santos, precisamos de uma outra saúde global, que atenda aos interesses de fato das populações a quem diz se dirigir. As ações estruturantes, especialmente no caso das arboviroses, são não apenas fundamentais, elas são a única opção de longo prazo. Essas ações são intersetoriais por natureza, envolvem áreas afins da saúde, mas não apenas essa. Certamente, intervenções superficiais só atendem aos interesses de poucos, enquanto as populações, especialmente as mais vulneráveis, continuam sofrendo com epidemias com data para chegar.

Quase quatro anos após a declaração da ESPII, o vírus Zika desapareceu dos noticiários, das agendas de grandes atores da saúde global e regional. De certo, suas consequências ainda são pouco perceptíveis para a população geral. Em um Nordeste conhecido por suas inúmeras mazelas e por serviços públicos negligenciados, o resultado da infecção pelo Zika naquelas mulheres nordestinas e periféricas é mais um dado naturalizado da sua dura realidade.

Nesse sentido, notamos, logo no início do documento(7) que sintetiza as principais ações de resposta do Brasil à epidemia do vírus Zika, uma forma de pensamento que precisa ser revista imediatamente.

Brava gente nordestina, que mais uma vez soube enfrentar a adversidade. Vivendo
historicamente numa região de flagelos, [...] as mulheres do Nordeste nos deram uma lição de
fé, de esperança ao segurarem seus filhos no colo e buscarem ajuda nos serviços públicos de
saúde para garantirem um mínimo de conforto para seus bebês com microcefalia e outras graves
sequelas. [...] essas mulheres enfrentaram as adversidades do sertão, a falta de recursos, as
distâncias e estão criando seus filhos. [...] O Sistema Único de Saúde (SUS) ainda está devendo
uma resposta a elas. Tenho certeza de que essa resposta virá (Brasil, 2017, p. 9).

Os tempos são outros, mas padrões de pensamento arraigados em ideias pré-concebidas permanecem. É preciso urgentemente revisar e modificar a ideia de que o povo nordestino é resistente a qualquer coisa. Começar a ver essas mulheres como vítimas de um sistema de saúde que historicamente não responde às suas necessidades é urgente. Não há espaço para romantismo enquanto as necessidades da população seguem sendo mantidas em segundo plano. 
De maneira geral, falta um olhar ampliado para as causas capazes de tornar estrutural a epidemia aqui estudada. Se outras ações relativas à determinação social da doença e à transmissão desses vetores não foram executadas de maneira urgente, tenderemos a manter nossos discursos sobre a "brava gente nordestina", fazendo poesia com a miséria. 


\section{REFERÊNCIAS}

1. Diniz D. Zika: Do sertão nordestino à ameaça global. Rio de Janeiro: Civilização Brasileira; 2016. 192 p.

2. Nunes J, Pimenta DN. A Epidemia de Zika e os limites da Saúde Global. Lua Nov Rev Cult e Política. 2016;98:21-46;

3. Brasil. Ministério da Saúde. Secretaria de Vigilância em Saúde. Boletim Epidemiológico. Monitoramento dos casos de dengue, febre de chikungunya e febre pelo vírus Zika até a Semana Epidemiológica 32, 2016 [Internet]. Brasília; 2016. [acesso em 10 Set 2017] Disponível em: http://portalsaude.saude.gov.br/images/pdf/2016/setembro/16/2016-028---DengueSE32.pdf

4. Brasil. Ministério da Saúde. Gabinete do Ministro. PORTARIA No ${ }^{\circ}$.813, DE 11 DE NOVEMBRO DE 2015 Declara Emergência em Saúde Pública de importância Nacional (ESPIN) por alteração do padrão de ocorrência de microcefalias no Brasil. [Internet]. 2015 [acesso em 10 Set 2017]. Disponível em: http://bvsms.saude.gov.br/bvs/saudelegis/gm/2015/prt1813_11_11_2015.html

5. World Health Organization (WHO). International Health Regulations (2005) Second Edition. WHO. 2005.

6. Pan American Health Organization (PAHO). Response to the Epidemic of Zika Virus in the Americas. December 2015 - 2016. Washington, D.C.; 2017.

7. Brasil. Vírus Zika no Brasil: : a resposta do SUS [Internet]. Ministério da Saúde. Secretaria de Vigilância em Saúde. Brasília; 2017136 p. [acesso em 05 Dez 2017]. Disponível em: https://sistemas.mre.gov.br/kitweb/datafiles/SaoFrancisco/ptbr/file/Fact_Sheet_Zika_Virus_Marco16.pdf

8. World Health Organization (WHO). WHO statement on the first meeting of the International Health Regulations (2005) (IHR 2005) Emergency Committee on Zika virus and observed increase in neurological disorders and neonatal malformations. Geneva; 2016.

9. Stone D. Transfer agents and global networks in the "transnationalization" of policy. Vol. 11, Journal of European Public Policy. 2004. 545-566+568 p.

10. Porto de Oliveira O, Faria CAP de. Policy Transfer, Diffusion ,. Novos Estud. 2017;36(1):13-32.

11. Faria M, Giovanella L, Bermudez L. A Unasul na Assembleia Mundial da Saúde: posicionamentos comuns do Conselho de Saúde Sul-Americano. Saúde em Debate. 2015;39(107):920-934;

12. Cervo AL, Lessa AC. O declínio: Inserção internacional do Brasil (2011-2014). Rev Bras Polit Int. 2014;57(2):133-151;

13. Brasil. Ministério da Saúde. Secretaria de Vigilância em Saúde. Boletim Epidemiológico. Monitoramento dos casos de dengue, febre de chikungunya e febre pelo vírus Zika até a Semana Epidemiológica 32, 2016 [Internet]. Vol. 47. 2016. [acesso em 12 Set 2017]. Disponível em: http://portalsaude.saude.gov.br/images/pdf/2016/setembro/16/2016-028---DengueSE32.pdf

14. Jouannic JM, Friszer S, Leparc-Goffart I, Garel C, Eyrolle-Guignot D. Zika virus 
infection in French Polynesia. Lancet. 2016;387(10023):1051-2.

15. Heymann DL, Hodgson A, Sall AA, Freedman DO, Staples JE, Althabe F, et al. Zika virus and microcephaly: Why is this situation a PHEIC? Lancet [Internet]. 2016;387(10020):719-21. [acesso em 10 Ago 2017]. Disponível em: http://dx.doi.org/10.1016/S0140-6736(16)00320-2

16. Brasil. Ministério da Saúde. Informe Epidemiológico N ${ }^{0} 57$ - Semana Epidemiológica (Se) 52/2016 (25 a 31/12/2016) Monitoramento dos Casos de Microcefalia no Brasil. 2016. [acesso em 12 Set 2017]. Disponível em: Http//CombateaedesSaudeGovBr/Images/Pdf/ Inf. 2016;57:Ministério da Saúde.

17. Lima-camara TN. Arboviroses emergentes e novos desafios para a saúde pública no Brasil. 2016;50:1-7.

18. Oliveira CS De, da Costa Vasconcelos PF. Microcefalia e vírus zika. J Pediatr (Versão em Port [Internet]. 2016;92:103-5. [acesso em 12 Ago 2017]. Disponível em: www.jped.com.br

19. Frontline. The Zika outbreak: How Brazilians use Whatsapp to Connect on Zika. 2016. $\begin{array}{lllll}\text { [acesso em } & 12 & \text { Ago 2017]. Disponível }\end{array}$ https://www.pbs.org/wgbh/frontline/article/how-brazilians-use-whatsapp-to-connecton-zika/

20. Brito C. Zika Virus: A New Chapter in the History of Medicine. Acta Med Port. 2016;28(6):679.

21. Victora CG, Schuler-Faccini L, Matijasevich A, Ribeiro E, Pessoa A, Barros FC. Microcephaly in Brazil: How to interpret reported numbers? The Lancet. 2016; 351(6269):110-1.

22. Bogaz C. Brasil adota recomendação da OMS e reduz medida para microcefalia. Portal Ministério da Saúde. Portal Ministério da Saúde [Internet]. 10 Mar 2016. [acesso em 12 Ago 2016]. Disponível em: http://www.saude.gov.br/noticias/sas/22577-brasil-adotarecomendacao-da-oms-e-reduz-medida-para-microcefalia

23. Mendes A. Ministério da Saúde ativa centro de monitoramento em saúde. Portal Ministério da Saúde [Internet]. 2016 Jul 29. [acesso em 12 Ago 2016]. Disponível em: https://saude.gov.br/noticias/agencia-saude/24872-ministerio-da-saude-ativa-centro-demonitoramento-em-saude.

24. Lucey DR, Gostin LO. The emerging zika pandemic: Enhancing preparedness. JAMA J Am Med Assoc. 2016;315(9):865-6.

25. World Health Organization (WHO). WHO statement on the 2nd meeting of IHR Emergency Committee on Zika virus and observed increase in neurological disorders and neonatal malformation. Geneva; 2016;

26. World Health Organization (WHO). WHO statement on the third meeting of the International Health Regulations (2005) (IHR(2005)) Emergency Committee on Zika virus and observed increase in neurological disorders and neonatal malformations. Geneva; 2016.

27. World Health Organization (WHO). Fourth meeting of the Emergency Committee under the International Health Regulations (2005) regarding microcephaly, other neurological disorders and Zika virus. Geneva; 2016.

28. World Health Organization (WHO). Situation Report Zika Virus Microcephaly Guillain- 
Barré Syndrome 8 September 2016 [Internet]. 2016. [acesso em 12 Dez 2016]. Disponível https://apps.who.int/iris/bitstream/handle/10665/250049/zikasitrep8Sep16eng.pdf;jsessionid=40B1DD207217C0C81A635B34E1E3C6DA?sequence $=1$

29. World Health Organization (WHO). Fifth meeting of the Emergency Committee under the International Health Regulations (2005) regarding microcephaly, other neurological disorders and Zika virus [Internet]. 2016. [acesso em 12 Dez 2016]. Disponível em: https://www.who.int/en/news-room/detail/18-11-2016-fifth-meeting-of-the-emergencycommittee-under-the-international-health-regulations-(2005)-regarding-microcephalyother-neurological-disorders-and-zika-virus

30. Pinheiro L. Política externa brasileira: 1889-2002. Rio de Janeiro: Jorge Zahar editor; 2004. $81 \mathrm{p}$.

31. Milani CRS, Pinheiro L. Política Externa Brasileira: Os Desafios de sua Caracterização como Política Pública. Context Int. 2013; 35(1);11-41.

32. Saraiva MG. A diplomacia brasileira e as visões sobre a inserção externa no Brasil: institucionalistas pragmáticos x autonomistas. Mural Int. 2010;1(1):45-52.

33. Pinheiro L. Traídos pelo Desejo: Um Ensaio sobre a Teoria e a Prática da Política Externa Brasileira Contemporânea. Context Int. 2000;22(2):305-35.

34. Vigevani T, Cepaluni G. A política externa de Lula da Silva: a estratégia da autonomia pela diversificação. Context Int. 2007; 29(2)273-335.

35. Saraiva M, Gomes Z. Os limites da política externa de Dilma Rousseff para a América do Sul. Relac Int. 2016;(50):81-97.

36. Gomes M, Afonso P, Júnior V. A política externa brasileira e o "fim de ciclo" na América do Sul: Para onde vamos? Pensam Propio. 2016;0(44);295-324.

37. Saraiva MG. Balanço da política externa de Dilma Rousseff: perspectivas futuras? Relações Int. 2014;(44):25-35.

38. Casarões GSP e. A Política Externa interina e os riscos à integração regional. Conjunt Austral. 2016;7(37):81.

39. Nery T. A política externa brasileira, as coalizões de poder e a Unasul: ascensão e desconstrução da América do Sul como bloco geopolítico | Brazilian foreign policy, the coalitions of power and UNASUR: rise and deconstruction of South America as a geopolitical b. Mural Int. 2017;8(2):250-64.

40. De Lima MRS. Relações interamericanas: A nova agenda sulamericana e o Brasil. Lua Nov. 2013;(90):167-201.

41. Teixeira MF. O Conselho de Saúde da Unasul e os desafios para a construção de soberania sanitária. Tese [Doutorado em Ciências] Escola Nacional de Saúde Pública, Fundação Oswaldo Cruz; 2017.

42. Secretaria Mercosur, Mercado Común del Sur (Mercosur). Textos Fundacionales [Internet]. 2012. [acesso em 12 Jan 2016]. Disponível em: http://www.mercosur.int/innovaportal/file/2485/1/textos_fundacionales_es_agosto_201 2.pdf

43. Ventura D. Saúde Pública e Integração Regional: tensões entre o direito à saúde e o comércio internacional. In: Von Bogdandy A, Piovesan F, Antoniazzi MM, editors. Direitos Humanos, Democracia e Integração Jurídica na América do Sul. Rio de Janeiro: 
Max Planck Institute/Lumen Juris/PUC-SP; 2011;449-72.

44. Brasil. Ministério da Saúde. A saúde no Mercosul. Brasília: Editora do Ministério da Saúde; 2006.

45. Mercosul Brasil. Organograma do Mercosul [Internet]. Mercosul Brasil; 2019 [acesso em 10 Nov 2019]. Disponível em: http://www.mercosul.gov.br/images/pdf/Organograma_MSUL_2019.pdf

46. Comunicado de Brasília. I Reunión de Presidentes de América del Sur [Internet]. Brasília; 2000. [acesso em 10 Set 2016]. Disponível em: http://www.comunidadandina.org/documentos/dec_int/di1-9-00.htm

47. Riggirozzi P, Grugel J. Políticas de salud en UNASUR: Legitimidad, democracia y legitimidad de resultado. Pensam Propio. 2016;0(43):173-200.

48. Declaración de Cusco. III Reunión de Presidentes de América del Sur . Cusco [Internet]. Cusco; 2004. [acesso em 10 Set 2016]. Disponível em: http://www.comunidadandina.org/documentos/dec_int/cusco_sudamerica.htm

49. Comunidad Suramericana de Naciones. I Reunião dos Chefes de Estado da Comunidade Sul-americana de Nações. Brasília; 2005.

50. Comunidad Suramericana de Naciones. Declaración de Cochabamba. II Cumbre de Jefes de Estado de la Comunidad Sudamericana de Naciones. [Internet]. Cochabamba; 2006. [acesso em $10 \quad$ Set 2016]. Disponível em: http://www.comunidadandina.org/documentos/dec_int/declaracion_cochabamba.htm

51. Comunidad Suramericana de Naciones. Hacia la construcción de una política y agenda regional en materia de salud. Cochabamba; 2006.

52. Comunidad Suramericana de Naciones. Decisiones del Diálogo Político entre los Jefes de Estado y de Gobierno. I Cumbre Energética Suramericana. [Internet]. Isla Margarita; 2007. [acesso em 10 Set 2016]. Disponível em: http://www.comunidadandina.org/documentos/dec_int/unasur17-4-07.htm

53. Nery T. Unasul: a dimensão política do novo regionalismo sul-americano. Cad CRH [Internet]. 2016;29(spe3):59-75. [acesso em 16 Dez 2016]. Disponível em: http://www.scielo.br/pdf/ccrh/v29nspe3/0103-4979-ccrh-29-spe3-0059.pdf

54. União de Nações Sul-americanas (Unasul). Tratado Constitutivo da União de Nações Sul-Americanas. [Internet]. 2008. [acesso em 16 Dez 2014]. Disponível em: http://www.itamaraty.gov.br/sala-de-imprensa/notas-a- imprensa/2008/05/23/tratadoconstitutivo-da-uniao-de-nacoes-sul/?searchterm=constituição -unasul

55. Simões AJF. Unasul: a América do Sul e a construção de um mundo multipolar. In: IV Conferência Nacional de Política Externa e Política Internacional: textos acadêmicos. Brasília: Fundação Alexandre de Gusmão; 2009.

56. Riggirozzi P. Regionalism through social policy: collective action and health diplomacy in South America. Econ Soc. 2014;43(3):432-54.

57. Unión de Naciones Suramericanas (Unasur). Reglamento General de UNASUR. Vol. 0, Relaciones Internacionales. Bogotá; 2012.

58. Cervo AL. Integração da América do Sul depende do Brasil. Bol Meridiano 47. 2008;9(96):3-4.

59. Vigevani T, Júnior HR. Autonomia, integração regional e política externa brasileira: 
Mercosul e Unasul. Dados. 2014;57(2):517-52.

60. Unión de Naciones Suramericanas (Unasur). Ernesto Samper no aspira su reelección en la Secretaría General y continuará en UNASUR hasta enero de 2017. [Internet]. 2016 [acesso em 10 Ago 2016]. Disponível em: http://www.unasursg.org/es/node/905

61. Fidler DP. The globalization of public health: The first 100 years of international health diplomacy. Bulletin of the World Health Organization. 2001.

62. Alcazar SLBF. A inserção da saúde na política exterior brasileira. Instituto Rio Branco; 2005.

63. Cervo AL, Bueno C. História da Política exterior do Brasil. Brasília: Universidade de Brasília; 2010.

64. Sato E. Cooperação internacional: uma componente essencial das relações internacionais. RECIIS. 2010;4(1). [Internet]. [acesso em 10 Ago 2013]. Disponível em: https://www.reciis.icict.fiocruz.br/index.php/reciis/article/view/698/1343

65. Hirst M, Lima MRS De, Pinheiro L. A política externa brasileira em tempos de novos horizontes e desafios. Nueva Sociedad. 2010(Dez);22-41.

66. Oslo Ministerial Declaration-global health: a pressing foreign policy issue of our time. Lancet. 2007.

67. Kickbusch I, Novotny TE, Drager N, Silberschmidt G, Alcazar S. Global health diplomacy: training across disciplines. World Hosp Health Serv. 2007 85(12):971-3;

68. Feldbaum H, Michaud J. Health diplomacy and the enduring relevance of foreign policy interests. PLoS Med. 2010 7(4): e1000226 Internet]. [acesso em 10 Ago 2013]. Disponível

em:

https://journals.plos.org/plosmedicine/article?id=10.1371/journal.pmed.1000226

69. de Mello e Souza A. Saúde pública, patentes e atores não estatais: a política externa do Brasil ante a epidemia de aids. In: Pinheiro L, Milani CRS, editors. Política externa brasileira: as práticas da política e a política das práticas. Rio de Janeiro: Editora FGV; 2012;203-40.

70. Kerouedan D. Como a saúde se tornou um desafio geopolítico. Le Monde Dipl Bras [Internet]. 2013;(72). [acesso em 10 Dez 2015]. Disponível em: https://diplomatique.org.br/como-a-saude-se-tornou-um-desafio-geopolitico/

71. Ottersen OP, Dasgupta J, Blouin C, Buss P, Chongsuvivatwong V, Frenk J, et al. Comissão da Universidade de Oslo sobre Governança Global - As origens políticas das inequidades em saúde: perspectivas de mudança. Comissões The Lancet. 2014;

72. Kickbusch I, Silberschmidt G, Buss P. Global health diplomacy: The need for new perspectives, strategic approaches and skills in global health. Bulletin of the World Health Organization. 2007; 85(3),230-232.

73. Buss PM, Tobar SS, Buss PM, Tobar SS. Health Diplomacy in the Political Process of Integration in Latin America and the Caribbean. Oxford Res Encycl Glob Public Heal [Internet]. 2017;(May):1-27. [acesso em 22 Dez 2017]. Disponível em: http://publichealth.oxfordre.com/view/10.1093/acrefore/9780190632366.001.0001/acre fore-9780190632366-e-24?print=pdf

74. Panisset U. Conceitos Operacionais para diplomacia da Saúde: promovendo desenvolvimento humano por meio da cooperação internacional. In: Buss PM, Tobar S, editors. Diplomacia em Saúde e Saúde Global: perspectivas latino-americanas. Rio de 
Janeiro: Editora Fiocruz; 2017;87-114.

75. Tobar S, Coitiño A, Kleiman A. Os Ministérios da Saúde e o Desenvolvimento da Diplomacia da Saúde. In: Buss PM, Tobar S, editors. Diplomacia em Saúde e Saúde Global: perspectivas latino-americanas. Rio de Janeiro: Editora Fiocruz; 2017;587-607.

76. Kickbush I, Berger C. Diplomacia da Saúde Global. RECIIS. 2010;4(1). [acesso em 10 Ago 2013]. Disponível em: https://www.reciis.icict.fiocruz.br/index.php/reciis/article/view/693

77. Brown TM, Cueto M, Fee E. A transição de saúde pública "internacional” para "global" e a Organização Mundial da Saúde. Historia, Ciencias, Saude - Manguinhos. 2006;13(3);623-347.

78. Koplan JP, Bond TC, Merson MH, Reddy KS, Rodriguez MH, Sewankambo NK, et al. Towards a common definition of global health. The Lancet. 2009; 373(9679):1993-5.

79. Birn A-E. Reconceptualización de la salud internacional: perspectivas alentadoras desde América Latina. Rev Panam Salud Publica. 2011; 30(2) 101-105. [acesso em 10 Jul 2015]. Disponível http://www.scielosp.org/scielo.php?script=sci_arttext\&pid=S102049892011000800002

80. Berlinguer G. Globalização e saúde global. Estud Avançados. 1999; 13(35), 21-38.

81. Fortes PA de C, Ribeiro H. Saúde Global em tempos de globalização. Saude e Soc. 2014;23(2);366-375.

82. Santos M. Por uma outra globalização. Rio de janeiro: Record. 2000.

83. Biehl J. Theorizing global health. Med Anthropol Theory| An open-access J Anthropol Heal illness, Med. 2016; 3(2).

84. Biehl J, Petryna A. Peopling Global Health. Saúde e Soc. 2014;23(2);376-389.

85. Biehl J, Petryna A. Critical global health. In: When People Come First: Critical Studies in Global Health. Princeton University Press,. Princeton, 2013.

86. de Oliveira MF, Luvizotto CK. Cooperação técnica internacional: Aportes teóricos. Rev Bras Polit Int. 2011;54(2);05-21.

87. Organization for Economic Cooperation and Development. Rome Declaration on Harmonisation. First High Level Forum on Aid Effectiveness. Rome; 2003.

88. Organização para a Cooperação e Desenvolvimento Económico. Declaração de Paris sobre a Eficácia da Ajuda ao desenvolvimento: apropriação, harmonização, alinhamento, resultados e responsabilidade mútua. Paris; 2005.

89. Organização para a Cooperação e Desenvolvimento Económico. Agenda para ação de Acra. $3^{\circ}$ Fórum de Alto Nível sobre a eficácia da Ajuda. Acra; 2008.

90. Organization for Economic Cooperation and Development. Busan partnetship for effective development cooperation. 4th High level forum on aid effectiveness. Busan; 2011.

91. Leite I. Cooperação Sul-Sul: Conceito, História e Marcos Interpretativos. Obs On-line [Internet]. 2012;7(3). [acesso em 10 Jul 2013]. Disponível em: http://www.opsa.com.br/images/pdf/observador/observador_v_7_n_03_2012.pdf

92. Almeida C, Campos RP de, Buss P, Ferreira JR, Fonseca LE. A concepção brasileira de 
“cooperação Sul-Sul estruturante em saúde.” RECIIS. 2010;

93. Ventura D. Saúde Pública e Política Externa Brasileira. Rev Int Direitos Humanos. 2013;10(19);99-117.

94. Brasil. Ministério de Relações Exteriores. Balanço de Política Externa 2003/2010 1.1.6 América do Sul - Saúde [Internet]. 2011. [acesso em 10 Jan 2012]. Disponível em: http://www.itamaraty.gov.br/temas/balanco-de-politica-externa-2003-2010/1.1.6$\% 0$ Aamerica-do-sul-saude/view

95. Almeida C. Política externa e cooperação internacional no Brasil: eixos estratégicos e agendas. In: Buss PM, Tobar S, editors. Diplomacia em Saúde e Saúde Global: perspectivas latino-americanas. Rio de Janeiro: Editora Fiocruz; 2017;487-532.

96. Gómez E, Perez FA. Brazilian foreign policy in health during Dilma Rousseff's administration (2011-2014). Lua Nov. 2016;(98); 171-197.

97. Riggirozzi P, Herrero MB, Tussie D, Pensamiento CDEL. Viraje Político y la Agenda regional en Salud. Cuad DEL Pensam CRÍTICO Latinoam. 2018;(60):1-3.

98. Kickbusch I, Szabo MMC. A new governance space for health. Global Health Action. 2014.

99. Pan American Health Organization (PAHO). BASIC DOCUMENTS of the Pan American Health Organization [Internet]. 19th ed. Washington, D.C.; 2017. 158 p. [acesso em 10 Jan 2018]. Disponível em: http://apps.who.int/gb/bd

100. Pan American Health Organization (PAHO)|Governing Bodies [Internet]. Pan American Health Organizatio (PAHO). 2019 [acesso em 21 Set 2019]. Disponível em: https://www.paho.org/hq/index.php?Itemid=419\&lang=en

101. Tobar S. Governança da Saúde Global e Regional: OMS/OPAS. In: Buss PM, Tobar S, editors. Diplomacia em Saúde e Saúde Global: perspectivas latino-americanas. Rio de Janeiro: Editora Fiocruz; 2017;385-420.

102. Pan American Health Organization (PAHO). PAHO/WHO | About the Pan American Health Organization (PAHO) [Internet]. 2019 [acesso em 20 Set 2019]. Disponível em: https://www.paho.org/hq/index.php?option=com_content\&view=article\&id=91:aboutpaho\&Itemid=220\&lang=en

103. Organización Panamericana de la Salud. Resolución CD52/11 del 52 Consejo Directivo. Tema Cooperación para el desarrollo sanitario en las Américas. Washington, D.C.; 2013.

104. Organización Panamericana de la Salud. Agenda de Salud Para las Américas 2008-2017. Ciudad de Panamá: Organización Mundial de la Salud; 2007. 25 p.

105. Sánchez DM. Procesos de integración en salud: una reflexión sobre los desafíos del MERCOSUR en salud TT - Health integration processes: challenges for MERCOSUR in the health field. Cad saúde pública. 2007; 23( Suppl 2 ): S155-S163.

106. Queiroz LG, Giovanella L. Agenda regional da saúde no mercosul: Arquitetura e temas. Rev Panam Salud Publica/Pan Am J Public Heal. 2011;30(2):182-8.

107. Unión de Naciones Suramericanas (Unasur). Consejo de Jejas y Jefes de Estado y de Gobierno. Decisión para el establecimiento del Consejo de Salud Suramericano. 2008.

108. Instituto Sul Americano de Governo em Saúde (ISAGS). Estatuto do Instituto Sulamericano de Governo em Saúde. 2011.

109. Bermudez LOZ. O Instituto Sul-Americano de Governo em Saúde e Cooperação Sul-Sul 
Rio de Janeiro. Dissertação [Mestrado em Ciências]. Escola Nacional de Saúde Pública Sergio Arouca, Fundação Oswaldo Cruz, 2017.

110. Unión de Naciones Suramericanas. Consejo de Salud Suramericano. Plan Quinquenal 2010-2015. Cuenca; 2008.

111. Unasur. Consejo de Salud Suramericano. Resolución 01/2011 del 14 de abril de 2011. 2011;

112. Carmo EH, Gemal A, Oliveira S. Vigilancia em Salud en Suramérica: epidemiológica,sanitária y ambiental. In: Vigilancia em Salud en Suramérica: epidemiológica,sanitária y ambiental. ISAGS; 2013. p. 115-28.

113. Unión de Naciones Suramericanas. Consejo de Salud Suramericano. Resolución 07/2009 del Consejo de Salud de Unasur. 24 de novembro de 2009. 2009.

114. Buss PM, Tobar S, Feo O, Matida Á, Hoirisch C. A saúde nos processos de integração da América Latina e Caribe. In: Buss PM, Tobar S, editors. Diplomacia em Saúde e Saúde Global: perspectivas latino-americanas. Rio de Janeiro: Editora Fiocruz; 2017; 421-84.

115. Thedim F, Bueno C, Faria M. A Cooperação Sul-Sul e as Redes Estruturantes do Conselho de Saúde da Unasul como instrumentos de desenvolvimento regional. 2013;83-100.

116. Bueno FTC, Faria M, Bermudez L. A Cooperação Sul-Sul e as Redes Estruturantes do Conselho de Saúde da Unasul como instrumentos de desenvolvimento regional. 2013;83-100.

117. Organización Mundial de la Salud. Constitución de la Organización Mundial de la Salud. Documentos básicos. 2014;

118. Ventura D, Perez FA. Crise e reforma da Organização Mundial da Saúde. Lua Nov. 2014;97;45-77.

119. Instituto Sul Americano de Governo em Saúde (ISAGS). $65^{\text {a }}$ AMS discutiu reforma da OMS com destacada atuação da Unasul. Rio de Janeiro; 2012.

120. Ventura D. Direito e saúde global. São Paulo: Expressão Popular, Dobra Editorial; 2013.

121. World Health Organization (WHO). The future of financing for WHO. Summary of the Director-General's concluding remarks 1. 22 January 2011. 2011.

122. Kastler F. Focus OMS - Des résolutions et une réforme cruciale en cours. Les Trib la Santé. 2013;39:13-4.

123. World Health Organization (WHO). International Health Regulations (2005). 3rd ed. Geneva; 2016.

124. Espinal M, Aldighieri S, John RS, Etienne C. El Reglamento Sanitario Internacional , la enfermedad por el virus del Ébola y las enfermedades infecciosas emergentes en América Latina y el Caribe *. 2016;39(3):174-8.

125. Gostin LO, Katz R. The International Health Regulations: The Governing Framework for Global Health Security. Milbank Q. 2016;94(2):264-313.

126. Torronteguy MAA, Ventura D de FL. El derecho a la salud construido internacionalmente. In: Delduque MC, Junior JG de S, Costa AB, Alves SMC, Pereira MF, Cardoso AJC, editors. El derecho desde la calle: Introducción crítica al Derecho a la Salud. Brasília: FUB, CEAD; 2012;81-9. 
127. Instituto Sul Americano de Governo em Saúde (ISAGS). Informe Especial sobre a $69^{a}$ Sessão da Assembleia Mundial da Saúde. Rio de Janeiro; 2016.

128. Marks-Sultan G, Tsai F, Anderson E, Kastler F, Sprumont, D, Burris S. National public health law: a role for WHO in capacity-building and promoting transparency. Bull World Health Organ. 2016;94(7):534-9.

129. Ventura D. Ebola e Zika são incomparáveis [Internet]. Blog Saúde Global. 2016 [acesso 10 Fev 2016]. Disponível em: https://saudeglobal.org/2016/02/01/ebola-e-zika-saoincomparaveis-por-deisy-ventura/

130. Ventura D. Não há segurança sem acesso universal e gratuito à saúde [Internet]. Revista Eletrônica de Jornalismo Científico. 2016 [acesso 10 Out 2016]. Disponível em: http://comciencia.br/comciencia/handler.php?section=8\&edicao=126\&id=1536

131. Ventura D de FL. Do Ebola ao Zika: As emergências internacionais e a securitização da saúde global. Cad Saude Publica. 2016;32(4):1-4.

132. Oliveira GC de. A crise do ebola e a gramática dos problemas de segurança. [Internet]. Entrevista a Patricia Fachin. 2014 [acesso 24 Set 2015]. Disponível em: http://www.ihu.unisinos.br/entrevistas/536774-a-crise-do-ebola-e-a-gramatica-dosproblemas-de-seguranca-entrevista-especial-com-gilberto-carvalho-de-oliveira

133. Nunes J. Health, Politics and Security. e-cadernos CES. 2012;(15). [acesso 15 Set 2016]. Disponível em: http://journals.openedition.org/eces/989.

134. Hanrieder T, Kreuder-Sonnen C. WHO decides on the exception? Securitization and emergency governance in global health. Secur Dialogue. 2014; 45(5):331-348.

135. Dolowitz DP, Marsh D. Learning from Abroad: The Role of Policy Transfer in Contemporary Policy-Making. Governance. 2000;13(1):5-23.

136. Oliveira OP de, Lavalle AG. Embaixadores da participação: a difusão internacional do Orçamento Participativo a partir do Brasil [Internet]. 2013 . [acesso em 10 set 2016]. Disponível em: http://www.teses.usp.br/teses/disponiveis/8/8131/tde-19022014102112/

137. Oliveira OP De. Novas fronteiras e direções na pesquisa sobre transferência, difusão e circulação de políticas públicas: agentes, espaços, resistência e traduções. 2018;52(2):199-220.

138. Faria CAP de. As organizações internacionais como difusoras de políticas públicas. Monções Rev Relações Int da UFGD. 2018;7(13):29-49.

139. Porto de Oliveira O. Mecanismos da difusão global do Orçamento Participativo: Indução internacional, construção social e circulação de indivíduos. Opiniao Publica. 2016;22(2):219-49.

140. Bulmer S, Padgett S. Policy transfer in the European Union: An institutionalist perspective. Br J Polit Sci. 2004;35(1):103-26.

141. Pereira AE, Bernardo GJ, Culpi LA, Pessali HF. A governança facilitada no Mercosul: transferência de políticas e integração nas áreas de educação, migração e saúde. Rev Adm Pública. 2018;52(2):285-302.

142. MINAYO MC de S. Pesquisa social : teoria, método e criatividade. 23rd ed. Petrópolis: Vozes; 2009. 
143. DESLAURIERS JP, KÉRISIT M. O delineamento da pesquisa qualitativa. In: Poupart J, Deslauriers J-P, Groulx L-H, Laperrière A, Mayer R, Pires ÁP, editors. A pesquisa qualitativa: enfoques epistemológicos e metodológicos. Petrópolis: Vozes; 2008;12754.

144. Hernández Sampieri R, Fernández Collado C, Baptista Lucio M del P. Metodologia de Pesquisa. 5th ed. Porto Alegre: Penso; 2013.

145. RCG2. Entrevista realizada por Flávia Thedim Costa Bueno, gravação digital. Whatsapp. 14 de junho de 2019. 2019.

146. RCG1/PF1. Entrevista realizada por Flávia Thedim Costa Bueno, gravação digital. Rio de Janeiro. 21 de maio de 2019.; 2019.

147. RCOI2. Entrevista realizada por Flávia Thedim Costa Bueno, gravação digital. Whatsapp. 23 de maio de 2019. 2019.

148. CN1. Entrevista realizada por Flávia Thedim Costa Bueno, gravação digital. Skype. 21 de maio de 2019. 2019.

149. Brasil. Ministério da Saúde. Secretaria de Vigilância em Saúde. Departamento de Vigilância em Saúde Ambiental e Saúde do Trabalhador. Plano de Resposta às Emergencias em saúde publica. Brasília: Ministério da Saúde; 2014.

150. Brasil. Ministério da Saúde. Secretaria de Vigilância em Saúde. Nota Informativa $n^{0} 01$ - 17/11/2015 - Procedimentos preliminares a serem adotados para a vigilância dos casos de microcefalia no Brasil. Bras Ministério da Saúde. 2015;1-21.

151. Brasil. Ministério da Saúde. Plano Nacional de Enfrentamento à Microcefalia. [acesso em 10 set 2016]. Disponível em: http://portalarquivos2.saude.gov.br/images/campanhas/dengue2015/Broadside_Microc efalia_20x28_V2.pdf. 2015.

152. Brasil. Casa Civil. Estratégia de Resposta ao vírus Zika e o combate ao mosquito transmissor. 2016;

153. Brasil. Ministério da Saúde. Secretaria de Vigilância em Saúde. Ações Realizadas para Enfrentamento da Emergência em Saúde Pública Relacionada à microcefalia. Apresentação de Powerpoint. Brasília; 2016.

154. RCOI1. Entrevista realizada por Flávia Thedim Costa Bueno, gravação digital. Whatsapp. 29 de maio de 2019. 2019.

155. Mendes A. Ministério da Saúde repassa R $\$ 152$ milhões de recurso adicional para combate ao Aedes [Internet]. 2016 [acesso em 10 Nov 2019]. Disponível em: http://www.saude.gov.br/noticias/agencia-saude/27120-ministerio-da-saude-repassa-r152-milhoes-de-recurso-adicional-para-combate-ao-aedes

156. Brasil. Constituição da República Federativa do Brasil. Texto constitucional originalmente publicado no Diário Oficial da União de 5 de outubro de 1988. 1988.

157. Brasil. Portaria Interministerial $\mathrm{N}^{\circ}$ 405, de 15 de março de 2016. Brasília: 16 de março de 2016c. Ministerio da Saúde. 2016.

158. Brasil. Presidência da Repúbica. Decreto $n^{0} 8.716$, de 20 de abril de 2016. Institui o programa de prevenção e proteção individual de gestantes em situação de vulnerabilidade socioeconômica contra o Aedes aegypti. A. 2016.

159. Brasil. Ministério da Saúde. Gabinete do Ministro. PORTARIA No 779, DE 20 DE 
ABRIL DE 2016. Institui, no âmbito do Sistema Único de Saúde (SUS), o Sistema de Registro de Atendimento às Crianças com Microcefalia. Economia 2016.

160. BRASIL. Ministério da Saúde. Secretaria de Gestão do Trabalho e da Educação na Saúde. PORTARIA N ${ }^{\circ}$ 3, DE 11 DE JANEIRO DE 2016. Dispõe sobre a implantação de Centros Colaboradores em processos de qualificação de profissionais no plano de resposta à ocorrência de microcefalia relacionada à infecção pelo vírus Zika. 2016.

161. Caldas M. Centros Colaboradores ajudarão na capacitação para o cuidado aos pacientes com microcefalia. [Internet]. Portal Ministério da Saúde. 2016 [acesso em 10 Set 2017]. Disponível em: http://portalms.saude.gov.br/noticias/agencia-saude/21656-centroscolaboradores-ajudarao-na-capacitacao-para-o-cuidado-aos-pacientes-commicrocefalia

162. Silva P. Curso de Zika estará disponível para profissionais de todos os países. Portal do Ministério da Saúde. [Internet]. Portal Ministério da Saúde. 2016. [acesso em 10 Set 2017]. Disponível em: http://www.saude.gov.br/noticias/agencia-saude/23230-cursode-zika-estara-disponivel-para-profissionais-de-todos-os-paises

163. Caixote D. Brasil reforça cooperação internacional para aleitamento materno. [Internet]. Portal Ministério da Saúde. 2016 [acesso em 10 Set 2017]. Disponível em: http://www.saude.gov.br/noticias/agencia-saude/23770-brasil-reforca-cooperacaointernacional-para-aleitamento-materno

164. Silva P. Ministério da Saúde vai financiar mais 1 mil bolsas de residência. Portal Ministério da Saúde. 2016. [acesso em 10 Set 2017]. Disponível em: https://saude.gov.br/noticias/agencia-saude/26048-ministerio-da-saude-vai-financiarmais-1-mil-bolsas-de-residencia

165. Caixote D. Saúde divulga diretriz nacional para estimulação precoce de bebês com microcefalia. Portal Ministério da Saúde. 2016.

166. Caixote D. Saúde faz mapeamento de assistência a bebês com microcefalia. Portal Ministério da Saúde [Internet]. 29 Fev 2016. [acesso em 10 Set 2017]. Disponível em: http://www.saude.gov.br/noticias/agencia-saude/22352-saude-faz-mapeamento-deassistencia-a-bebes-com-microcefalia

167. Caixote D. Saúde amplia acesso a diagnóstico e cuidado das gestantes e bebês. [Internet]. Portal Ministério da Saúde. 2016 [acesso em 10 Set 2017]. Disponível em: http://www.saude.gov.br/noticias/agencia-saude/26385-saude-amplia-acesso-adiagnostico-e-cuidado-das-gestantes-e-bebes

168. Diniz D. Vírus Zika e mulheres. 2016;32(5):1-4. [acesso em 10 Set 2017]. Disponível em: http://dx.doi.org/10.1590/0102-311X00046316

169. Associação Nacional dos Defensores Públicos (ANADEP). AÇÃO DIRETA DE INCONSTITUCIONALIDADE $\mathrm{N}^{\circ} 5581$ [Internet]. 2016. [acesso em 11 Set 2017]. Disponível em: http://www.sbdp.org.br/wp/wp-content/uploads/2018/03/ADI-5581Manifestação-AGU.pdf

170. Wenham C, Arevalo A, Coast E, Corrêa S, Cuellar K, Leone T, et al. Zika, abortion and health emergencies: a review of contemporary debates. Global Health. 2019;15(1):1-7.

171. Rocha G. Vacina para Zika estará disponível para testes em novembro. Portal Ministério da Saúde. 20 Mai 2016. [acesso em 11 Set 2017]. Disponível em: https://saude.gov.br/noticias/agencia-saude/23788-vacina-para-zika-estara-disponivelpara-testes-em-novembro 
172. Bogaz C. Brasil ganha centro para produção de insumos e medicamentos biológicos. [Internet]. Portal Ministério da Saúde. 2016 [acesso em 10 Set 2017]. Disponível em: http://www.saude.gov.br/noticias/agencia-saude/26780-brasil-ganha-centro-paraproducao-de-insumos-e-medicamentos-biologicos

173. Coelho N. Ministério da Saúde anuncia R \$ 10 milhões para pesquisas contra o vírus Zika. [Internet]. Portal Ministério da Saúde. 2016 [acesso em 10 Set 2017]. Disponível em: http://www.saude.gov.br/noticias/sas/22599-ministerio-da-saude-anuncia-r-10milhoes-para-pesquisas-contra-o-virus-zika

174. Kopko G. Ministério da Saúde investe R \$ 100 milhões para vacina da dengue. [Internet]. Portal Ministério da Saúde. 2016 [acesso em 10 Set 2017]. Disponível em: http://www.saude.gov.br/noticias/agencia-saude/22260-ministerio-da-saude-investe-r100-milhoes-para-vacina-da-dengue

175. Saúde. BM da. Instituto Butantan não entregou documento para liberação de recursos do soro da Zika. [Internet]. Portal Ministério da Saúde. 2016 [acesso em 10 Set 2017]. Disponível em: http://portalms.saude.gov.br/noticias/agencia-saude/22091-ministerioda-saude-reforca-cooperacao-com-orgaos-internacionais

176. Kopko G. Ministério da Saúde anuncia edital de R \$ 20 milhões para pesquisas contra o Aedes aegypti. [Internet]. Portal Ministério da Saúde. 2016 [acesso em 10 Set 2017]. Disponível em: http://www.saude.gov.br/noticias/agencia-saude/22727-ministerio-dasaude-anuncia-edital-de-r-20-milhoes-para-pesquisas-contra-o-aedes-aegypti

177. Maciel V. Governo Federal destina R \$ 65 milhões para pesquisas sobre o vírus Zika. [Internet]. Portal Ministério da Saúde. 2016 [acesso em 10 Set 2017]. Disponível em: http://www.saude.gov.br/noticias/agencia-saude/23942-governo-federal-destina-r-65milhoes-para-pesquisas-sobre-o-virus-zika

178. Mendes A. Governo Federal une esforços no combate ao mosquito. Portal Ministério da Saúde [Internet]. 2 Dez 2016 [acesso em 10 Set 2017]. Disponível em: http://www.saude.gov.br/noticias/agencia-saude/26667-governo-federal-une-esforcosno-combate-ao-mosquito

179. Brasil. Ministério da Saúde. Nota do Ministério sobre declaração da OMS [Internet]. Portal Ministério da Saúde. 2016 [acesso em 10 Set 2017].. Disponível em: http://portalms.saude.gov.br/noticias/agencia-saude/21975-nota-do-ministerio-sobredeclaracao-da-oms

180. Hack J. Brasil e Colômbia criam Sala de Coordenação do combate ao Aedes aegypti. [Internet]. Portal Ministério da Saúde. 2016 [acesso em 10 Set 2017]. Disponível em: http://www.saude.gov.br/noticias/agencia-saude/23585-acoes-de-saneamento-basicodeve-ser-prioridade

181. Mercado Común del Sur (Mercosur). Declaración de las Ministras y Ministros de Salud del MERCOSUR y Estados Asociados ante la grave situación epidemiológica determinada por enfermedades transmitida por el Aedes Aegypti: Dengue, Chikungunya y Zika. II RMS Ext. [Internet]. Montevideo; 2016 [acesso em 10 Mar 2016]. Disponível em: http://www.mercosur.int

182. Caixote D. Brasil oferece aos países do Mercosul treinamento para teste de Zika. [Internet]. Portal Ministério da Saúde. 2016 [acesso em 10 Set 2017]. Disponível em: http://portalms.saude.gov.br/noticias/svs/22103-brasil-oferece-aos-paises-do-mercosultreinamento-para-teste-de-zika 
183. PF2. Entrevista realizada por Flávia Thedim Costa Bueno, gravação digital. Whatsapp. 14 de junho de 2019. 2019.

184. Pittas TM. A resposta do governo brasuleuro à epidemia do vírus Zika: segurança em saúde e política externa. Dissertação [Mestrado em Relações Internacionais]. Universidade Federal de Santa Catarina; 2018.

185. Agência Saúde. Ministério da Saúde reforça cooperação com órgãos internacionais. [Internet]. Portal Ministério da Saúde. 2016 [acesso em 10 Set 2017]. Disponível em: http://portalms.saude.gov.br/noticias/agencia-saude/22091-ministerio-da-saude-reforcacooperacao-com-orgaos-internacionais

186. Saúde. BM da. Nota à Imprensa. Brasil e EUA definem agenda estratégica contra o vírus Zika. [Internet]. Portal Ministério da Saúde. 2016 [acesso em 10 Set 2017]. Disponível em: http://portalms.saude.gov.br/noticias/agencia-saude/22019-brasil-e-eua-definemagenda-estrategica-contra-o-virus-zika

187. Penido A. Notificação de casos de vírus zika passa a ser obrigatória no Brasil [Internet]. Portal Ministério da Saúde. 2016 [acesso em 10 Set 2017]. Disponível em: http://portalms.saude.gov.br/noticias/agencia-saude/22237-notificacao-de-casos-pelovirus-zika-passa-a-ser-obrigatoria-no-brasil

188. Brasil e Estados Unidos. PLANO DE COOPERAÇÃO EM SAÚDE PARA O ENFRENTAMENTO DO VÍRUS ZIKA - MONITORAMENTO E RESULTADOS. 2018;1-9.

189. Penido A. Brasil vai desenvolver teste para detecção de Zika nas bolsas de sangue. [Internet]. Portal Ministério da Saúde. 2016 [acesso em 10 Set 2017]. Disponível em: http://portalms.saude.gov.br/noticias/agencia-saude/22256-brasil-vai-desenvolver-testepara-deteccao-de-zika-nas-bolsas-de-sangue

190. Agência Saúde. Novos casos suspeitos de microcefalia são divulgados pelo Ministério da Saúde. [Internet]. Portal Ministério da Saúde. 2016 [acesso em 10 Set 2017]. Disponível em: http://portalms.saude.gov.br/noticias/agencia-saude/21677-novoscasos-suspeitos-de-microcefalia-sao-divulgados-pelo-ministerio-da-saude

191. Mendes A. Brasil e EUA iniciam estudo na Paraíba sobre microcefalia associada ao vírus Zika. Portal Ministério da Saúde [Internet]. 2016 Feb 16 [acesso em 10 Set 2017]. Disponível em: http://www.saude.gov.br/noticias/agencia-saude/22199-brasil-e-euainiciam-estudo-na-paraiba-sobre-microcefalia-associada-ao-virus-zika

192. Kopko G, Mendes A. Vacina contra zika foi tema de reunião do ministro no Butantan [Internet]. Portal Ministério da Saúde. 2016 [acesso em 10 Set 2017]. Disponível em: http://portalms.saude.gov.br/noticias/agencia-saude/21760-vacina-contra-zika-foitema-de-reuniao-do-ministro-no-butantan

193. Coelho N. Brasil e EUA firmam acordo para desenvolver vacina contra vírus Zika. [Internet]. Portal Ministério da Saúde. 2016 [acesso em 10 Set 2017]. Disponível em: http://portalms.saude.gov.br/noticias/sas/22140-brasil-e-eua-firmam-acordo-paradesenvolver-vacina-contra-virus-zik

194. Brasil e Estados Unidos. Carta de Intenções em saúde e ciências médicas entre o Ministério da Saúde e a Universidade do Texas Medical Branch. 2016.

195. Bogaz C. Brasil e EUA irão realizar estudo com grávidas em países com Zika [Internet]. Portal Ministério da Saúde. 2016 [acesso em 10 Set 2017]. Disponível em: http://www.saude.gov.br/noticias/agencia-saude/24198-brasil-e-eua-irao-realizar- 
estudo-com-gravidas-em-paises-com-zika

196. Bogaz C, Ruas F. Saúde acompanha avaliação [Internet]. Portal Ministério da Saúde. 2016 [acesso em 10 Set 2017]. Disponível em: http://www.saude.gov.br/noticias/agencia-saude/24076-saude-acompanha-avaliacaode-qualidade-de-teste-rapido-de-zika

197. Mendes A, Maciel V. Ministério da Saúde vai distribuir teste rápido de Zika. Portal do Ministério da Saúde. [Internet]. Portal Ministério da Saúde. 2016 [acesso em 10 Set 2017]. Disponível em: http://www.saude.gov.br/noticias/agencia-saude/26155ministerio-da-saude-vai-distribuir-teste-rapido-de-zika

198. Codeço C, Villela D, Gomes MF, Bastos L, Cruz O, Struchiner C, et al. Zika is not a reason for missing the olympic games in rio de janeiro: Response to the open letter of $\mathrm{dr}$ attaran and colleagues to dr margaret chan, director - General, WHO, on the zika threat to the olympic and paralympic games. Mem Inst Oswaldo Cruz. 2016;111(6):414-5.

199. Agência Saúde. SBI divulga nota de apoio à realização dos jogos no Rio de Janeiro. Agência Saúde [Internet]. 13 Jun 2016 [acesso 2017 Sep 10]; Disponível em: http://www.saude.gov.br/noticias/svs/24082-sbi-divulga-nota-de-apoio-a-realizacaodos-jogos-no-rio

200. Mendes A. Brasil apresenta redução de $87 \%$ nas notificações dos casos de Zika [Internet]. Portal Ministério da Saúde. 2016 [acesso em 10 Set 2017]. Disponível em: http://www.saude.gov.br/noticias/svs/24064-brasil-apresenta-reducao-de-87-nasnotificacoes-dos-casos-de-zika

201. Palma N. Ministro da Saúde apresenta ações para o Comitê Olímpico Internacional. Portal Ministério da Saúde [Internet]. 24 Mai 2016 [acesso em 10 Set 2017]. Disponível em: http://portalms.saude.gov.br/noticias/agencia-saude/22237-notificacao-de-casospelo-virus-zika-passa-a-ser-obrigatoria-no-brasil

202. Organização Pan-americana da Saúde (OPAS). RELATÓRIO ANUAL DO DIRETOR

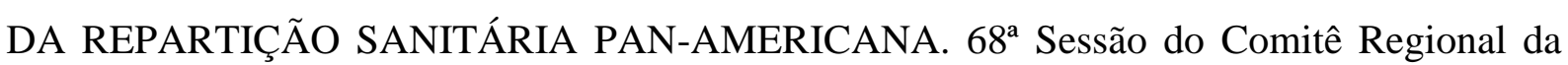
OMS para as Américas. 2016;

203. Instituto Sul Americano de Governo em Saúde (ISAGS). As Olimpíadas do Rio e a Vigilância em Saúde. Rio de Janeiro; 2016.

204. Costa A. Ministério da Saúde reforça atendimento durante os Jogos Olímpicos. Portal do Ministério da Saúde [Internet]. Portal Ministério da Saúde. 2016 [acesso em 10 Set 2017]. Disponível em: http://www.saude.gov.br/noticias/svs/22772-ministerio-dasaude-reforca-atendimento-durante-os-jogos-olimpicos

205. Américo C. Ministério da Saúde lança novo portal Saúde do Viajante [Internet]. Portal Ministério da Saúde. 2016 [acesso em 10 Set 2017]. Disponível em: http://www.saude.gov.br/noticias/svs/24515-novo-portal-saude-do-viajante-ja-esta-noar

206. Hack J. Estados manterão vistorias durante Olimpíada. [Internet]. Portal Ministério da Saúde. 2016 [acesso em 10 Set 2017]. Disponível em: http://www.saude.gov.br/noticias/agencia-saude/23585-acoes-de-saneamento-basicodeve-ser-prioridade

207. Penido A. Saúde registrou 11.235 atendimentos nos Jogos Olímpicos [Internet]. Portal da Saude. 2016 [acesso em 10 Set 2016]. Disponível em: http://www.saude.gov.br/noticias/agencia-saude/25428-saude-registrou-11-235- 
atendimentos-nos-jogos-olimpicos

208. Gómez EJ, Perez FA, Ventura D. What explains the lacklustre response to Zika in Brazil? Exploring institutional, economic and health system context. BMJ Glob Heal. 2018;3(5):e000862.

209. Wenham C, Farias DBL. Securitizing Zika: The case of Brazil. Secur Dialogue. 2019; 50(5);398-415.

210. Organización Panamericana de la Salud (OPS). CD55/12, Rev. 1 APLICACIÓN DEL REGLAMENTO SANITARIO INTERNACIONAL (RSI). 55.o CONSEJO DIRECTIVO. 68.a SESIÓN DEL COMITÉ REGIONAL DE LA OMS PARA LAS AMÉRICAS. 16 de septiembre del 2016. Washington, D.C.; 2016.

211. Pan American Health Organization (PAHO). Epidemiological Alert. Zika virus infection. 7 May 2015. [Internet]. 2015. [acesso em 10 Set 2017]. Disponível em: https://www.paho.org/hq/dmdocuments/2015/2015-may-7-cha-zika-virus-epi-alert.pdf

212. Organización Panamericana de la Salud (OPS). CD54/FR. INFORME FINAL. 2015;

213. Pan American Health Organization (PAHO). Strategy for Enhancing National Capacity to Respond to Zika virus Epidemic in the Americas. June 2016. 2016;

214. Pan American Health Organization (PAHO). Epidemiological Alert Neurological syndrome, congenital malformations, and Zika virus infection. Implications for public health in the Americas 1 December 2015 [Internet]. 2015. [acesso em 12 fev 2016]. Disponível em: https://www.paho.org/hq/dmdocuments/2015/2015-dec-1-cha-epi-alertzika-neuro-syndrome.pdf

215. Organización Panamericana de la Salud (OPS). CE158/INF/6. ACTUALIZACIÓN SOBRE EL VIRUS DEL ZIKA EN LA REGIÓN DE LAS AMÉRICAS. 2016;

216. Vazquez E. The Zika Menace in the Americas: Challenges and Perspectives. Apresentação de Powerpoint. 2016;

217. Organización Panamericana de la Salud (OPS). CD54/FR - Informe final. 67.a sesión del Comité Regional de la OMS para las Américas; 2015;

218. Organización Panamericana de la Salud (OPS). CE158-FR - Informe Final. 158 Sesión del Comite Ejecutivo. 2016;80-2. [acesso em 12 Dez 2016]. Disponível em: http://iris.paho.org/xmlui/bitstream/handle/123456789/33796/CE158-FR-

s.pdf? sequence $=4 \&$ isAllowed $=\mathrm{y}$

219. Organización Panamericana de la Salud (OPS). CD55/16. ESTRATEGIA PARA LA PREVENCIÓN Y EL CONTROL DE LAS ENFERMEDADES ARBOVIRALES. 2016.

220. Organización Panamericana de la Salud (OPS). CD55.R6. RESOLUCIÓN ESTRATEGIA PARA LA PREVENCIÓN Y EL CONTROL DE LAS ENFERMEDADES ARBOVIRALES. 2016.

221. Organización Panamericana de la Salud (OPS). CE158-FR - Informe Final. 158 Sesión del Comite Ejecutivo. 2016;80-2. [acesso em 12 Dez 2016]. Disponível em: http://iris.paho.org/xmlui/bitstream/handle/123456789/33796/CE158-FR-

s.pdf? sequence $=4 \&$ isAllowed $=\mathrm{y}$

222. Organización Panamericana de la Salud (OPS). CD55/INF/11. ESTRATEGIA Y PLAN DE ACCIÓN REGIONALES SOBRE SALUD NEONATAL EN EL CONTEXTO DEL PROCESO CONTINUO DE LA ATENCIÓN DE LA MADRE, DEL RECIÉN 
NACIDO Y DEL NIÑO: INFORME FINAL. 2016.

223. Organización Panamericana de la Salud (OPS). NoCE158/INF/13. INFORMES DE PROGRESO SOBRE ASUNTOS TÉCNICOS. 2016.

224. Pan American Health Organization (PAHO). Zika: Missions to support countries. 2016.

225. Organización Panamericana de la Salud (OPS). Actualización sobre el virus del Zika en la region de las Américas. CD55/INF/4. [Internet]. Washington, D.C.; 2016. Disponível em: http://iris.paho.org/xmlui/bitstream/handle/123456789/33654/CD55-INF-4s.pdf? sequence $=9 \&$ is Allowed $=\mathrm{y}$

226. Pan American Health Organization (PAHO). PAHO/WHO Regional research agenda related to Zika virus infection. Development of a research agenda for characterizing the Zika outbreak and its public health implications in the Americas. Washington, D.C.: PAHO; 2016. 64 p.

227. de Araújo TVB, Rodrigues LC, de Alencar Ximenes RA, de Barros Miranda-Filho D, Montarroyos UR, de Melo APL, et al. Association between Zika virus infection and microcephaly in Brazil, January to May, 2016: preliminary report of a case-control study. Lancet Infect Dis. 2016;16(12):1356-63.

228. Organización Panamericana de la Salud. CE158/INF/14. B. ORGANIZACIONES SUBREGIONALES. 2016.

229. Mercado Común del Sur (Mercosur). MERCOSUR/RMS/ACTA N ${ }^{\circ}$ 02/15 Corr.1 XXXVIII REUNIÓN DE MINISTROS DE SALUD. Asunción, Paraguay. 13 nov 2015. 2015.

230. Mercado Común del Sur (Mercosur). MERCOSUR/CC-RMS/ACTA N ${ }^{\circ}$ 02/15 REUNIÓN ORDINARIA DEL COMITÉ COORDINADOR PREPARATORIA DE LA XXXVIII REUNIÓN DE MINISTROS DE SALUD. Asunción, Paraguay. 11-12 nov 2015. 2015.

231. Mercado Común del Sur (Mercosur). MERCOSUR/RMS/ACTA N ${ }^{\circ}$ 01/16. II REUNIÓN EXTRAORDINARIA DE MINISTROS DE SALUD. 03 fev 2016. [Internet]. 2016 [acesso 2017 Mar 10]. Disponível em: http://www.mercosur.int

232. Mercado Común del Sur (Mercosur). REUNIÓN VIRTUAL DE COORDINADORES NACIONALES DE LA RMS PREPARATORIA DE LA XXXIX REUNIÓN DE MINISTROS DE SALUD DEL MERCOSUR. Videconferencia. 01 jun 2016. 2016.

233. Silva P. Mercosul: Brasil reforça risco mínimo de Zika nas Olimpíadas. [Internet]. 2016 [acesso em 10 Set 2017]. Disponível em: http://saude.gov.br/noticias/agenciasaude/24118-mercosul-brasil-reforca-risco-minimo-de-zika-nas-olimpiadas

234. URUGUAI. MINISTERIO DE RELACIONES EXTERIORES DE LA REPÚBLICA ORIENTAL DE URUGUAY/DIRECCIÓN GENERAL PARA ASUNTOS DE INTEGRACIÓN Y MERCOSUR. INFORME FINAL PPTU 2016. 2016.

235. Mercado Común del Sur (Mercosur). MERCOSUR/RMS/CIDCD/ACTAn ${ }^{\circ} 01 / 11$. REUNIÓN DE LA COMISIÓN INTERGUBERNAMENTAL DE CONTROL DEL DENGUE, PREPARATORIA PARA LA XXX REUNIÓN DE MINISTROS DE SALUD DEL MERCOSUR. Asunción, Paraguay. 04-06 abril 2011. 2011.

236. Mercado Común del Sur (Mercosur). MERCOSUL/RMS/CICETV/ATA N N 02/12. REUNIÃO DA COMISSÃO INTERGOVERNAMENTAL DE CONTROLE DE DOENÇAS DE TRANSMISSÃO VETORIAL (CICETV), PREPARATÓRIA DA 
XXXIII REUNIÃO DE MINISTROS DA SAÚDE DO MERCOSUL. Foz do Iguaçu, Brasil. 22-24 out 2012. 2012.

237. Mercado Común del Sur (Mercosur). MERCOSUR/RMS/CICETV/ACTA No 01/15. REUNIÓN DE LA COMISIÓN INTERGUBERNAMENTAL DE CONTROL DE ENFERMEDADES DE TRANSMISIÓN VECTORIAL (CICETV), PREPARATORIA DE LA XXXVIII REUNIÓN DE MINISTROS DE SALUD (RMS). Asunción, Paraguai. 5-6 out 2015. 2015.

238. Mercado Común del Sur (Mercosur). MERCOSUR/SGT No 11/ACTA N ${ }^{\circ}$ 02/15. XLIV REUNIÓN ORDINARIA DEL SUBGRUPO DE TRABAJO No 11 "SALUD". Asunción, Paraguay. 5-9 out 2015. 2015.

239. Mercado Común del Sur (Mercosur). MERCOSUR / XLV REUNIÓN ORDINARIA DE SGT N" 11 "SALUD" / COMISIÓN DE VIGILANCIA EN SALUD / ACTA Nº1/16. Montevideo, Uruguay. 11-14 abr 2016. 2016.

240. Mercado Común del Sur (Mercosur). XLIV REUNIÓN ORDINARIA DE SGT N 11 "SALUD"/COMISIÓN DE VIGILANCIA EN SALUD / SUBCOMISIÓN DE CONTROL SANITARIOS DE PUERTOS, AEROPUERTOS, TERMINALES Y PASOS DE ENTRADA TERRESTRES “SCOCONTS"/ACTA N 02/15. Asunción, Paraguay. 5-7 out 2015. 2015.

241. Mercado Común del Sur (Mercosur). MERCOSUR / XLV REUNIÓN ORDINARIA DE SGT No 11 "SALUD" / COMISIÓN DE VIGILANCIA EN SALUD / ACTA No 01/16. 11-14 abr 2016. Montevideo; 2016.

242. Mercado Común del Sur (Mercosur). MERCOSUL/XLV SGT N ${ }^{\circ}$ 11/P. RES. /16. PROCEDIMENTOS MÍNIMOS PARA O CONTROLE INTEGRADO DE VETORES, RESERVATÓRIOS E OUTROS ANIMAIS TRANSMISSORES DE DOENÇAS EM PORTOS, AEROPORTOS, TERMINAIS E PASSAGENS DE FRONTEIRA TERRESTRES NO MERCOSUL E PARA. 2016.

243. Mercado Común del Sur (Mercosur). XLIV REUNIÓN ORDINARIA DE SGT N ${ }^{\circ} 11$ "SALUD"/ COMISIÓN DE VIGILANCIA EN SALUD "COVIGSAL"/ACTA N 02/15. Asunción, Paraguay. 5-9 out 2015. 2015.

244. Mercado Común del Sur (Mercosur). MERCOSUR/RMS/CIRSI/ACTA N ${ }^{\circ}$ 02/15. REUNIÓN DE LA COMISIÓN INTERGUBERNAMENTAL DE REGLAMENTO SANITARIO INTERNACIONAL, PREPARATORIA DE LA XXXVIII REUNIÓN DE MINISTROS DE SALUD (RMS). 8-9 out 2015. 2015.

245. Télam D. Governo da Venezuela se declara presidente pro tempore do Mercosul. 05 Ago 2016 [acesso 15 Out 2016] Disponível em: http://agenciabrasil.ebc.com.br/internacional/noticia/2016-08/governo-da-venezuelaproclama-se-presidente-pro-tempore-do-mercosul

246. POL. Entrevista realizada por Flávia Thedim Costa Bueno, gravação digital. Whatsapp. 27 de agosto de 2019. 2019.

247. Unasur. Consejo de Salud Suramericano. XXII REUNIÓN EXTRAORDINARIA DEL CONSEJO DE SALUD SURAMERICANO DE LA UNIÖN DE NACIONES SURAMERICANAS. 22 de mayo de 2016. 2016;

248. UNASUR. Consejo de Ministras y Ministros de Relaciones Exteriores. Declaración de la Reunión Ordinaria del Consejo de Ministras y Ministros de Relaciones Exteriores de UNASUR. 23 de abril de 2016. 2016; 
249. UNASUR. GTVIG; Secretaría General; ISAGS. INFORME Acciones Regionales sobre Dengue, Zika y Chikungunya en 2014, 2015 y 2016. 2016.

250. Instituto Sul Americano de Governo em Saúde (ISAGS). Unasul se mobiliza para enfrentar o vírus Zika. Informe janeiro 2016. [Internet]. Rio de Janeiro; 2016. [acesso em 10 Ago 2019] Disponível em: https://drive.google.com/file/d/1ZwmvdCKEmg97czryCmhYF6DeVab2v0vk/view?us $\mathrm{p}=$ sharing

251. Instituto Sul Americano de Governo em Saúde (ISAGS). Entrevista: José Gomes Temporão. Informe fevereiro 2016. Rio de Janeiro; 2016.

252. Horton R. Offline: Brazil - The unexpected opportunity that Zika presents. Lancet. 2016;387(10019):633.

253. Oliveira WK De. Emergência de Saúde Pública de Importância Internacional : resposta brasileira à síndrome congênita associada à infecção pelo Zika vírus , 2015 e 2016. Tese [Doutorado em Epidemiologia]. Universidade Federal do Rio Grande do Sul, 2017;

254. Pan American Health Organization (PAHO). Timeline of Emergence of Zika virus in the Americas [Internet]. 2019 [acesso em 12 Set 2019]. Disponível em: https://www.paho.org/hq/index.php?option=com_content \&view=article\&id=11959:tim eline-of-emergence-of-zika-virus-in-the-americas\&Itemid=41711\&lang=en

255. Pan American Health Organization (PAHO). Epidemiological Update. Zika virus infection. 16 October 2015. 2015.

256. Brasil. Ministério da Saúde. Linha do tempo: Vírus Zika e casos de microcefalia [Internet]. Blog da Saúde. 2016 [acesso em 17 Set 2019]. Disponível em: http://www.blog.saude.gov.br/index.php/combate-ao-aedes/50571-linha-do-tempovirus-zika-e-casos-de-microcefalia

257. Garcia LP. Epidemia do vírus zika e microcefalia no brasil: emergência, evolução e enfrentamento.Texto para discussão. IPEA, 2018.

258. BRASIL. Ministério da Saúde. Secretaria de Vigilância em Saúde. COESMICROCEFALIAS. INFORME EPIDEMIOLÓGICO $\mathrm{N}^{\circ} 01 / 2015$ - SEMANA EPIDEMIOLÓGICA 46 (15 A 21/11/2015). MONITORAMENTO DOS CASOS DE MICROCEFALIAS NO BRASIL. 2015.

259. Formenti L. Diretor do Ministério da Saúde aconselha que mulheres de PE adiem planos de gravidez - Saúde - Estadão [Internet]. 2015. [acesso em 13 set 2019]. Disponível em: https://saude.estadao.com.br/noticias/geral,diretor-do-ministerio-da-saude-aconselhamulheres-de-pe-a-adiar-gravidez,10000001872

260. Portal de Notícias G1 PB. Exames confirmam infecção por Zika vírus em dois casos de microcefalia - notícias em Paraíba. 17 nov 2015 [acesso em 16 Set 2019]; Disponível em: http://g1.globo.com/pb/paraiba/noticia/2015/11/exames-comprovam-infeccao-por-zikavirus-em-dois-casos-de-microcefalia.html

261. Pan American Health Organization (PAHO). Epidemiological Alert Increase of microcephaly in the northeast of Brazil 17 November 2015 [Internet]. 2015. [acesso em 16 Set 2016] Disponível em: https://www.paho.org/hq/dmdocuments/2015/2015-nov17-cha-microcephaly-epi-alert.pdf

262. Cauchemez S, Besnard M, Bompard P, Dub T, Guillemette-Artur P, Eyrolle-Guignot D, et al. Association between Zika virus and microcephaly in French Polynesia, 2013-15: A retrospective study. Lancet [Internet]. 2016;387(10033):2125-32. [acesso em 16 Set 
2018] Disponível em: http://dx.doi.org/10.1016/S0140-6736(16)00651-6

263. Brasil. Ministério da Saúde. Secretaria de Vigilância em Saúde. Brasil. Ministério da Saúde. COES-MICROCEFALIAS. INFORME EPIDEMIOLÓGICO No 04/2015 SEMANA EPIDEMIOLÓGICA 49 (06 A 12/12/2015) MONITORAMENTO DOS CASOS DE MICROCEFALIAS NO BRASIL. 2015;

264. Penido A. Notificação de casos pelo vírus Zika passa a ser obrigatória no Brasil. Portal Ministério da Saúde [Internet]. 17 Fev 2016 [acesso em 17 Set 2019]; Disponível em: http://www.saude.gov.br/noticias/agencia-saude/22237-notificacao-de-casos-pelovirus-zika-passa-a-ser-obrigatoria-no-brasil

265. CDC. CDC Concludes Zika Causes Microcephaly and Other Birth Defects. Media Statement. [Internet]. 2016. [acesso em 10 Set 2017] Disponível em: https://www.cdc.gov/media/releases/2016/s0413-zika-microcephaly.html

266. Coelho N. Ministério da Saúde e Cartoon Network convocam crianças a combater o Aedes aegypti. Portal Ministério da Saúde [Internet]. 19 Mai 2016; [acesso em 10 Set 2017] Disponível em: http://www.saude.gov.br/noticias/agencia-saude/23768ministerio-da-saude-e-cartoon-network-convocam-criancas-a-combater-o-aedesaegypti

267. Mendes A. Ministério da Saúde cria jogo para alertar importância de combater o Aedes aegypti. Portal Ministério da Saúde [Internet]. 12 Mai 2016 [acesso em 10 Set 2017]; Disponível em: http://www.saude.gov.br/noticias/agencia-saude/23828-ministerio-dasaude-ensina-brincando-como-combater-o-aedes-aegypti

268. Letter to WHO Urging the Postponement or Movement of Brazil Olympics due to Concerns over Zika | National Center for Health Research [Internet]. [acesso em 10 Set 2019]. Disponível em: http://www.center4research.org/letter-urging-postponementmovement-brazil-olympics-due-concerns-zika/

269. Agência Saúde. SBI divulga nota de apoio à realização dos jogos no Rio. Portal do Ministério da Saúde. Portal Ministério da Saúde [Internet]. 13 Jun 2016; [acesso em 10 Set 2018]. Disponível em: http://www.saude.gov.br/noticias/svs/24082-sbi-divulganota-de-apoio-a-realizacao-dos-jogos-no-rio

270. Saraiva MG. As estratégias de cooperação Sul-Sul nos marcos da Política Externa Brasil de 1993 a 2007. Rev Bras Política Int. 2007;50(2):42-59.

271. Cueto M. Saúde global: uma breve história. Ed. Fiocruiz, Rio de Janeiro: 2015, 120p.

272. Carmo EH. Regulamento Sanitário Internacional, Emergências de Saúde Pública, Liberdades Individuais e Soberania. Rev Direito Sanitário. 2007;8(1):61-4.

273. Mendes. Estudo reforça relação do Zika com casos de microcefalia. [Internet]. Portal Ministério da Saúde. 2016 [acesso em 10 Set 2017]. Disponível em: http://www.saude.gov.br/noticias/agencia-saude/24872-ministerio-da-saude-ativacentro-de-monitoramento-em-saude

274. Organización Panamericana de la Salud (OPS). La OPS y laboratorios de las Américas acuerdan pautas comunes para identificar y monitorear el virus del Zika. Portal de la OPS. [Internet] $26 \mathrm{Fev}$ 2016. 2016. [acesso em 03 Ago 2016] Disponível em: https://www.paho.org/hq/index.php?option=com_content\&view=article\&id=11703:20 16-paho-laboratories-set-guidelines-to-identify-confirm-zikavirus \&Itemid=135\&lang=es 


\section{REFERÊNCIAS EM ORDEM ALFABÉTICA}

Agência Saúde. Ministério da Saúde reforça cooperação com órgãos internacionais. [Internet]. Portal Ministério da Saúde. 2016 [acesso em 10 Set 2017]. Disponível em: http://portalms.saude.gov.br/noticias/agencia-saude/22091-ministerio-da-saude-reforcacooperacao-com-orgaos-internacionais

Agência Saúde. Novos casos suspeitos de microcefalia são divulgados pelo Ministério da Saúde. [Internet]. Portal Ministério da Saúde. 2016 [acesso em 10 Set 2017]. Disponível em: http://portalms.saude.gov.br/noticias/agencia-saude/21677-novos-casos-suspeitos-demicrocefalia-sao-divulgados-pelo-ministerio-da-saude

Agência Saúde. SBI divulga nota de apoio à realização dos jogos no Rio de Janeiro. Agência Saúde [Internet]. 13 Jun 2016 [acesso 2017 Sep 10]; Disponível em: http://www.saude.gov.br/noticias/svs/24082-sbi-divulga-nota-de-apoio-a-realizacao-dosjogos-no-rio

Agência Saúde. SBI divulga nota de apoio à realização dos jogos no Rio. Portal do Ministério da Saúde. Portal Ministério da Saúde [Internet]. 13 Jun 2016; [acesso em 10 Set 2018]. Disponível em: http://www.saude.gov.br/noticias/svs/24082-sbi-divulga-nota-deapoio-a-realizacao-dos-jogos-no-rio

Alcazar SLBF. A inserção da saúde na política exterior brasileira. Instituto Rio Branco; 2005.

Almeida C, Campos RP de, Buss P, Ferreira JR, Fonseca LE. A concepção brasileira de “cooperação Sul-Sul estruturante em saúde.” RECIIS. 2010;

Almeida C. Política externa e cooperação internacional no Brasil: eixos estratégicos e agendas. In: Buss PM, Tobar S, editors. Diplomacia em Saúde e Saúde Global: perspectivas latino-americanas. Rio de Janeiro: Editora Fiocruz; 2017;487-532.

Américo C. Ministério da Saúde lança novo portal Saúde do Viajante [Internet]. Portal Ministério da Saúde. 2016 [acesso em 10 Set 2017]. Disponível em: http://www.saude.gov.br/noticias/svs/24515-novo-portal-saude-do-viajante-ja-esta-no-ar Associação Nacional dos Defensores Públicos (ANADEP). AÇÃO DIRETA DE INCONSTITUCIONALIDADE $\mathrm{N}^{\circ} 5581$ [Internet]. 2016. [acesso em 11 Set 2017]. 
Disponível em: http://www.sbdp.org.br/wp/wp-content/uploads/2018/03/ADI-5581Manifestação-AGU.pdf

Berlinguer G. Globalização e saúde global. Estud Avançados. 1999; 13(35), 21-38.

Bermudez LOZ. O Instituto Sul-Americano de Governo em Saúde e Cooperação Sul-Sul Rio de Janeiro. Dissertação [Mestrado em Ciências]. Escola Nacional de Saúde Pública Sergio Arouca, Fundação Oswaldo Cruz, 2017.

Biehl J, Petryna A. Critical global health. In: When People Come First: Critical Studies in Global Health. Princeton University Press,. Princeton, 2013.

Biehl J, Petryna A. Peopling Global Health. Saúde e Soc. 2014;23(2);376-389.

Biehl J. Theorizing global health. Med Anthropol Theory|An open-access J Anthropol Heal illness, Med. 2016; 3(2).

Birn A-E. Reconceptualización de la salud internacional: perspectivas alentadoras desde América Latina. Rev Panam Salud Publica. 2011; 30(2) 101-105. [acesso em 10 Jul 2015]. Disponível em: http://www.scielosp.org/scielo.php?script=sci_arttext\&pid=S102049892011000800002

Bogaz C, Ruas F. Saúde acompanha avaliação [Internet]. Portal Ministério da Saúde. 2016 [acesso em 10 Set 2017]. Disponível em: http://www.saude.gov.br/noticias/agenciasaude/24076-saude-acompanha-avaliacao-de-qualidade-de-teste-rapido-de-zika

Bogaz C. Brasil adota recomendação da OMS e reduz medida para microcefalia. Portal Ministério da Saúde. Portal Ministério da Saúde [Internet]. 10 Mar 2016. [acesso em 12 Ago 2016]. Disponível em: http://www.saude.gov.br/noticias/sas/22577-brasil-adotarecomendacao-da-oms-e-reduz-medida-para-microcefalia

Bogaz C. Brasil e EUA irão realizar estudo com grávidas em países com Zika [Internet]. Portal Ministério da Saúde. 2016 [acesso em 10 Set 2017]. Disponível em: http://www.saude.gov.br/noticias/agencia-saude/24198-brasil-e-eua-irao-realizar-estudocom-gravidas-em-paises-com-zika

Bogaz C. Brasil ganha centro para produção de insumos e medicamentos biológicos. [Internet]. Portal Ministério da Saúde. 2016 [acesso em 10 Set 2017]. Disponível em: http://www.saude.gov.br/noticias/agencia-saude/26780-brasil-ganha-centro-paraproducao-de-insumos-e-medicamentos-biologicos 
Brasil e Estados Unidos. Carta de Intenções em saúde e ciências médicas entre o Ministério da Saúde e a Universidade do Texas Medical Branch. 2016.

Brasil e Estados Unidos. PLANO DE COOPERAÇÃO EM SAÚDE PARA O ENFRENTAMENTO DO VÍRUS ZIKA - MONITORAMENTO E RESULTADOS. 2018;1-9.

Brasil. Casa Civil. Estratégia de Resposta ao vírus Zika e o combate ao mosquito transmissor. 2016;

Brasil. Constituição da República Federativa do Brasil. Texto constitucional originalmente publicado no Diário Oficial da União de 5 de outubro de 1988. 1988.

Brasil. Ministério da Saúde. A saúde no Mercosul. Brasília: Editora do Ministério da Saúde; 2006.

Brasil. Ministério da Saúde. Gabinete do Ministro. PORTARIA No 1.813, DE 11 DE NOVEMBRO DE 2015 Declara Emergência em Saúde Pública de importância Nacional (ESPIN) por alteração do padrão de ocorrência de microcefalias no Brasil. [Internet]. 2015 [acesso em $10 \quad$ Set 2017]. Disponível em: http://bvsms.saude.gov.br/bvs/saudelegis/gm/2015/prt1813_11_11_2015.html

Brasil. Ministério da Saúde. Gabinete do Ministro. PORTARIA No 779, DE 20 DE ABRIL DE 2016. Institui, no âmbito do Sistema Único de Saúde (SUS), o Sistema de Registro de Atendimento às Crianças com Microcefalia. Economia 2016.

Brasil. Ministério da Saúde. Informe Epidemiológico No 57 - Semana Epidemiológica (Se) 52/2016 (25 a 31/12/2016) Monitoramento dos Casos de Microcefalia no Brasil. 2016. [acesso em 12 Set 2017]. Disponível em: Http//CombateaedesSaudeGovBr/Images/Pdf/Inf. 2016;57:Ministério da Saúde.

Brasil. Ministério da Saúde. Linha do tempo: Vírus Zika e casos de microcefalia [Internet]. Blog da Saúde. 2016 [acesso em 17 Set 2019]. Disponível em: http://www.blog.saude.gov.br/index.php/combate-ao-aedes/50571-linha-do-tempo-viruszika-e-casos-de-microcefalia

Brasil. Ministério da Saúde. Nota do Ministério sobre declaração da OMS [Internet]. Portal Ministério da Saúde. 2016 [acesso em 10 Set 2017].. Disponível em: http://portalms.saude.gov.br/noticias/agencia-saude/21975-nota-do-ministerio-sobredeclaracao-da-oms 
Brasil. Ministério da Saúde. Plano Nacional de Enfrentamento à Microcefalia. [acesso em 10 set 2016]. Disponível em: http://portalarquivos2.saude.gov.br/images/campanhas/dengue2015/Broadside_Microcefal ia_20x28_V2.pdf. 2015.

BRASIL. Ministério da Saúde. Secretaria de Gestão do Trabalho e da Educação na Saúde. PORTARIA No 3, DE 11 DE JANEIRO DE 2016. Dispõe sobre a implantação de Centros Colaboradores em processos de qualificação de profissionais no plano de resposta à ocorrência de microcefalia relacionada à infecção pelo vírus Zika. 2016.

Brasil. Ministério da Saúde. Secretaria de Vigilância em Saúde. Ações Realizadas para Enfrentamento da Emergência em Saúde Pública Relacionada à microcefalia. Apresentação de Powerpoint. Brasília; 2016.

Brasil. Ministério da Saúde. Secretaria de Vigilância em Saúde. Boletim Epidemiológico. Monitoramento dos casos de dengue, febre de chikungunya e febre pelo vírus Zika até a Semana Epidemiológica 32, 2016 [Internet]. Brasília; 2016. [acesso em 10 Set 2017] Disponível em: http://portalsaude.saude.gov.br/images/pdf/2016/setembro/16/2016-028--Dengue-SE32.pdf

Brasil. Ministério da Saúde. Secretaria de Vigilância em Saúde. Boletim Epidemiológico. Monitoramento dos casos de dengue, febre de chikungunya e febre pelo vírus Zika até a Semana Epidemiológica 32, 2016 [Internet]. Vol. 47. 2016. [acesso em 12 Set 2017]. Disponível em: http://portalsaude.saude.gov.br/images/pdf/2016/setembro/16/2016-028--Dengue-SE32.pdf

Brasil. Ministério da Saúde. Secretaria de Vigilância em Saúde. Brasil. Ministério da Saúde. COES-MICROCEFALIAS. INFORME EPIDEMIOLÓGICO No 04/2015 - SEMANA EPIDEMIOLÓGICA 49 (06 A 12/12/2015) MONITORAMENTO DOS CASOS DE MICROCEFALIAS NO BRASIL. 2015;

BRASIL. Ministério da Saúde. Secretaria de Vigilância em Saúde. COESMICROCEFALIAS. INFORME EPIDEMIOLÓGICO N $\mathrm{N}^{\circ} 01 / 2015$ - SEMANA EPIDEMIOLÓGICA 46 (15 A 21/11/2015). MONITORAMENTO DOS CASOS DE MICROCEFALIAS NO BRASIL. 2015.

Brasil. Ministério da Saúde. Secretaria de Vigilância em Saúde. Departamento de Vigilância em Saúde Ambiental e Saúde do Trabalhador. Plano de Resposta às Emergências em saúde pública. Brasília: Ministério da Saúde; 2014. 
Brasil. Ministério da Saúde. Secretaria de Vigilância em Saúde. Nota Informativa no 01 17/11/2015 - Procedimentos preliminares a serem adotados para a vigilância dos casos de microcefalia no Brasil. Ministério da Saúde. 2015;1-21.

Brasil. Ministério de Relações Exteriores. Balanço de Política Externa 2003/2010 1.1.6 América do Sul - Saúde [Internet]. 2011. [acesso em 10 Jan 2012]. Disponível em: http://www.itamaraty.gov.br/temas/balanco-de-politica-externa-2003-2010/1.1.6$\% 0$ Aamerica-do-sul-saude/view

Brasil. Portaria Interministerial No 405, de 15 de março de 2016. Brasília: 16 de março de 2016c. Ministério da Saúde. 2016.

Brasil. Presidência da República. Decreto no 8.716, de 20 de abril de 2016. Institui o programa de prevenção e proteção individual de gestantes em situação de vulnerabilidade socioeconômica contra o Aedes aegypti. A. 2016.

Brasil. Vírus Zika no Brasil: a resposta do SUS [Internet]. Ministério da Saúde. Secretaria de Vigilância em Saúde. Brasília; 2017136 p. [acesso em 05 Dez 2017]. Disponível em: https://sistemas.mre.gov.br/kitweb/datafiles/SaoFrancisco/pt-

br/file/Fact_Sheet_Zika_Virus_Marco16.pdf

Brito C. Zika Virus: A New Chapter in the History of Medicine. Acta Med Port. 2016;28(6):679.

Brown TM, Cueto M, Fee E. A transição de saúde pública "internacional” para "global” e a Organização Mundial da Saúde. Historia, Ciencias, Saude - Manguinhos. 2006;13(3);623347.

Bueno FTC, Faria M, Bermudez L. A Cooperação Sul-Sul e as Redes Estruturantes do Conselho de Saúde da Unasul como instrumentos de desenvolvimento regional. 2013;83100.

Bulmer S, Padgett S. Policy transfer in the European Union: An institutionalist perspective. Br J Polit Sci. 2004;35(1):103-26.

Buss PM, Tobar S, Feo O, Matida Á, Hoirisch C. A saúde nos processos de integração da América Latina e Caribe. In: Buss PM, Tobar S, editors. Diplomacia em Saúde e Saúde Global: perspectivas latino-americanas. Rio de Janeiro: Editora Fiocruz; 2017; 421-84.

Buss PM, Tobar SS, Buss PM, Tobar SS. Health Diplomacy in the Political Process of Integration in Latin America and the Caribbean. Oxford Res Encycl Glob Public Heal 
[Internet]. 2017;(May):1-27. [acesso em 22 Dez 2017]. Disponível em: http://publichealth.oxfordre.com/view/10.1093/acrefore/9780190632366.001.0001/acrefor e-9780190632366-e-24?print=pdf

Caixote D. Brasil oferece aos países do Mercosul treinamento para teste de Zika. [Internet]. Portal Ministério da Saúde. 2016 [acesso em 10 Set 2017]. Disponível em: http://portalms.saude.gov.br/noticias/svs/22103-brasil-oferece-aos-paises-do-mercosultreinamento-para-teste-de-zika

Caixote D. Brasil reforça cooperação internacional para aleitamento materno. [Internet]. Portal Ministério da Saúde. 2016 [acesso em 10 Set 2017]. Disponível em: http://www.saude.gov.br/noticias/agencia-saude/23770-brasil-reforca-cooperacaointernacional-para-aleitamento-materno

Caixote D. Saúde amplia acesso a diagnóstico e cuidado das gestantes e bebês. [Internet]. Portal Ministério da Saúde. 2016 [acesso em 10 Set 2017]. Disponível em: http://www.saude.gov.br/noticias/agencia-saude/26385-saude-amplia-acesso-adiagnostico-e-cuidado-das-gestantes-e-bebes

Caixote D. Saúde divulga diretriz nacional para estimulação precoce de bebês com microcefalia. Portal Ministério da Saúde. 2016.

Caixote D. Saúde faz mapeamento de assistência a bebês com microcefalia. Portal Ministério da Saúde [Internet]. 29 Fev 2016. [acesso em 10 Set 2017]. Disponível em: http://www.saude.gov.br/noticias/agencia-saude/22352-saude-faz-mapeamento-deassistencia-a-bebes-com-microcefalia

Caldas M. Centros Colaboradores ajudarão na capacitação para o cuidado aos pacientes com microcefalia. [Internet]. Portal Ministério da Saúde. 2016 [acesso em 10 Set 2017]. Disponível em: http://portalms.saude.gov.br/noticias/agencia-saude/21656-centroscolaboradores-ajudarao-na-capacitacao-para-o-cuidado-aos-pacientes-com-microcefalia

Carmo EH, Gemal A, Oliveira S. Vigilancia em Salud en Suramérica: epidemiológica,sanitária y ambiental. In: Vigilancia em Salud en Suramérica: epidemiológica,sanitária y ambiental. ISAGS; 2013. p. 115-28.

Carmo EH. Regulamento Sanitário Internacional, Emergências de Saúde Pública, Liberdades Individuais e Soberania. Rev Direito Sanitário. 2007;8(1):61-4. 
Casarões GSP e. A Política Externa interina e os riscos à integração regional. Conjunt Austral. 2016;7(37):81.

Cauchemez S, Besnard M, Bompard P, Dub T, Guillemette-Artur P, Eyrolle-Guignot D, et al. Association between Zika virus and microcephaly in French Polynesia, 2013-15: A retrospective study. Lancet [Internet]. 2016;387(10033):2125-32. [acesso em 16 Set 2018] Disponível em: http://dx.doi.org/10.1016/S0140-6736(16)00651-6

CDC. CDC Concludes Zika Causes Microcephaly and Other Birth Defects. Media Statement. [Internet]. 2016. [acesso em 10 Set 2017] Disponível em: https://www.cdc.gov/media/releases/2016/s0413-zika-microcephaly.html

Cervo AL, Bueno C. História da Política exterior do Brasil. Brasília: Universidade de Brasília; 2010.

Cervo AL, Lessa AC. O declínio: Inserção internacional do Brasil (2011-2014). Rev Bras Polit Int. 2014;57(2):133-151;

Cervo AL. Integração da América do Sul depende do Brasil. Bol Meridiano 47. 2008;9(96):3-4.

CN1. Entrevista realizada por Flávia Thedim Costa Bueno, gravação digital. Skype. 21 de maio de 2019. 2019.

Codeço C, Villela D, Gomes MF, Bastos L, Cruz O, Struchiner C, et al. Zika is not a reason for missing the olympic games in rio de janeiro: Response to the open letter of dr attaran and colleagues to dr margaret chan, director - General, WHO, on the zika threat to the olympic and paralympic games. Mem Inst Oswaldo Cruz. 2016;111(6):414-5.

Coelho N. Brasil e EUA firmam acordo para desenvolver vacina contra vírus Zika. [Internet]. Portal Ministério da Saúde. 2016 [acesso em 10 Set 2017]. Disponível em: http://portalms.saude.gov.br/noticias/sas/22140-brasil-e-eua-firmam-acordo-paradesenvolver-vacina-contra-virus-zik

Coelho N. Ministério da Saúde anuncia R \$ 10 milhões para pesquisas contra o vírus Zika. [Internet]. Portal Ministério da Saúde. 2016 [acesso em 10 Set 2017]. Disponível em: http://www.saude.gov.br/noticias/sas/22599-ministerio-da-saude-anuncia-r-10-milhoespara-pesquisas-contra-o-virus-zika

Coelho N. Ministério da Saúde e Cartoon Network convocam crianças a combater o Aedes aegypti. Portal Ministério da Saúde [Internet]. 19 Mai 2016; [acesso em 10 Set 2017] 
Disponível em: http://www.saude.gov.br/noticias/agencia-saude/23768-ministerio-dasaude-e-cartoon-network-convocam-criancas-a-combater-o-aedes-aegypti

Comunicado de Brasília. I Reunión de Presidentes de América del Sur [Internet]. Brasília; 2000. [acesso em 10 Set 2016]. Disponível em: http://www.comunidadandina.org/documentos/dec_int/di1-9-00.htm

Comunidad Suramericana de Naciones. Decisiones del Diálogo Político entre los Jefes de Estado y de Gobierno. I Cumbre Energética Suramericana. [Internet]. Isla Margarita; 2007. [acesso em 10 Set 2016]. Disponível em: http://www.comunidadandina.org/documentos/dec_int/unasur17-4-07.htm

Comunidad Suramericana de Naciones. Declaración de Cochabamba. II Cumbre de Jefes de Estado de la Comunidad Sudamericana de Naciones. [Internet]. Cochabamba; 2006. [acesso em 10 Set 2016]. Disponível em: http://www.comunidadandina.org/documentos/dec_int/declaracion_cochabamba.htm

Comunidad Suramericana de Naciones. Hacia la construcción de una política y agenda regional en materia de salud. Cochabamba; 2006.

Comunidad Suramericana de Naciones. I Reunião dos Chefes de Estado da Comunidade Sul-americana de Nações. Brasília; 2005.

Costa A. Ministério da Saúde reforça atendimento durante os Jogos Olímpicos. Portal do Ministério da Saúde [Internet]. Portal Ministério da Saúde. 2016 [acesso em 10 Set 2017]. Disponível em: http://www.saude.gov.br/noticias/svs/22772-ministerio-da-saude-reforcaatendimento-durante-os-jogos-olimpicos

Cueto M. Saúde global: uma breve história. Ed. Fiocruiz, Rio de Janeiro: 2015, 120p.

DA REPARTIÇÃO SANITÁRIA PAN-AMERICANA. 68ª Sessão do Comitê Regional da OMS para as Américas. 2016;

de Araújo TVB, Rodrigues LC, de Alencar Ximenes RA, de Barros Miranda-Filho D, Montarroyos UR, de Melo APL, et al. Association between Zika virus infection and microcephaly in Brazil, January to May, 2016: preliminary report of a case-control study. Lancet Infect Dis. 2016;16(12):1356-63.

De Lima MRS. Relações interamericanas: A nova agenda sulamericana e o Brasil. Lua Nov. 2013;(90):167-201. 
de Mello e Souza A. Saúde pública, patentes e atores não estatais: a política externa do Brasil ante a epidemia de aids. In: Pinheiro L, Milani CRS, editors. Política externa brasileira: as práticas da política e a política das práticas. Rio de Janeiro: Editora FGV; 2012;203-40.

de Oliveira MF, Luvizotto CK. Cooperação técnica internacional: Aportes teóricos. Rev Bras Polit Int. 2011;54(2);05-21.

Declaración de Cusco. III Reunión de Presidentes de América del Sur . Cusco [Internet]. Cusco; 2004. [acesso em 10 Set 2016]. Disponível em: http://www.comunidadandina.org/documentos/dec_int/cusco_sudamerica.htm

DESLAURIERS JP, KÉRISIT M. O delineamento da pesquisa qualitativa. In: Poupart J, Deslauriers J-P, Groulx L-H, Laperrière A, Mayer R, Pires ÁP, editors. A pesquisa qualitativa: enfoques epistemológicos e metodológicos. Petrópolis: Vozes; 2008;127-54.

Diniz D. Vírus Zika e mulheres. 2016;32(5):1-4. [acesso em 10 Set 2017]. Disponível em: http://dx.doi.org/10.1590/0102-311X00046316

Diniz D. Zika: Do sertão nordestino à ameaça global. Rio de Janeiro: Civilização Brasileira; 2016. 192 p.

Dolowitz DP, Marsh D. Learning from Abroad: The Role of Policy Transfer in Contemporary Policy-Making. Governance. 2000;13(1):5-23.

Espinal M, Aldighieri S, John RS, Etienne C. El Reglamento Sanitario Internacional, la enfermedad por el virus del Ébola y las enfermedades infecciosas emergentes en América Latina y el Caribe *. 2016;39(3):174-8.

Faria CAP de. As organizações internacionais como difusoras de políticas públicas. Monções Rev Relações Int da UFGD. 2018;7(13):29-49.

Faria M, Giovanella L, Bermudez L. A Unasul na Assembleia Mundial da Saúde: posicionamentos comuns do Conselho de Saúde Sul-Americano. Saúde em Debate. 2015;39(107):920-934;

Feldbaum H, Michaud J. Health diplomacy and the enduring relevance of foreign policy interests. PLoS Med. 2010 7(4): e1000226 Internet]. [acesso em 10 Ago 2013]. Disponível em: https://journals.plos.org/plosmedicine/article?id=10.1371/journal.pmed.1000226 
Fidler DP. The globalization of public health: The first 100 years of international health diplomacy. Bulletin of the World Health Organization. 2001.

Formenti L. Diretor do Ministério da Saúde aconselha que mulheres de PE adiem planos de gravidez - Saúde - Estadão [Internet]. 2015. [acesso em 13 set 2019]. Disponível em: https://saude.estadao.com.br/noticias/geral,diretor-do-ministerio-da-saude-aconselhamulheres-de-pe-a-adiar-gravidez,10000001872

Fortes PA de C, Ribeiro H. Saúde Global em tempos de globalização. Saude e Soc. $2014 ; 23(2) ; 366-375$.

Frontline. The Zika outbreak: How Brazilians use Whatsapp to Connect on Zika. 2016. [acesso em 12 Ago 2017]. Disponível em: https://www.pbs.org/wgbh/frontline/article/howbrazilians-use-whatsapp-to-connect-on-zika/

Garcia LP. Epidemia do vírus zika e microcefalia no brasil: emergência, evolução e enfrentamento.Texto para discussão. IPEA, 2018.

Gomes M, Afonso P, Júnior V. A política externa brasileira e o "fim de ciclo" na América do Sul: Para onde vamos? Pensam Propio. 2016;0(44);295-324.

Gómez E, Perez FA. Brazilian foreign policy in health during Dilma Rousseff's administration (2011-2014). Lua Nov. 2016;(98); 171-197.

Gómez EJ, Perez FA, Ventura D. What explains the lacklustre response to Zika in Brazil? Exploring institutional, economic and health system context. BMJ Glob Heal. 2018;3(5):e000862.

Gostin LO, Katz R. The International Health Regulations: The Governing Framework for Global Health Security. Milbank Q. 2016;94(2):264-313.

Hack J. Brasil e Colômbia criam Sala de Coordenação do combate ao Aedes aegypti. [Internet]. Portal Ministério da Saúde. 2016 [acesso em 10 Set 2017]. Disponível em: http://www.saude.gov.br/noticias/agencia-saude/23585-acoes-de-saneamento-basicodeve-ser-prioridade

Hack J. Estados manterão vistorias durante Olimpíada. [Internet]. Portal Ministério da Saúde. 2016 [acesso em 10 Set 2017]. Disponível em: http://www.saude.gov.br/noticias/agencia-saude/23585-acoes-de-saneamento-basicodeve-ser-prioridade 
Hanrieder T, Kreuder-Sonnen C. WHO decides on the exception? Securitization and emergency governance in global health. Secur Dialogue. 2014; 45(5):331-348.

Hernández Sampieri R, Fernández Collado C, Baptista Lucio M del P. Metodologia de Pesquisa. 5th ed. Porto Alegre: Penso; 2013.

Heymann DL, Hodgson A, Sall AA, Freedman DO, Staples JE, Althabe F, et al. Zika virus and microcephaly: Why is this situation a PHEIC? Lancet [Internet]. 2016;387(10020):71921. [acesso em 10 Ago 2017]. Disponível em: http://dx.doi.org/10.1016/S01406736(16)00320-2

Hirst M, Lima MRS De, Pinheiro L. A política externa brasileira em tempos de novos horizontes e desafios. Nueva Sociedad. 2010(Dez);22-41.

Horton R. Offline: Brazil - The unexpected opportunity that Zika presents. Lancet. 2016;387(10019):633.

Instituto Sul Americano de Governo em Saúde (ISAGS). 65a AMS discutiu reforma da OMS com destacada atuação da Unasul. Rio de Janeiro; 2012.

Instituto Sul Americano de Governo em Saúde (ISAGS). As Olimpíadas do Rio e a Vigilância em Saúde. Rio de Janeiro; 2016.

Instituto Sul Americano de Governo em Saúde (ISAGS). Entrevista: José Gomes Temporão. Informe fevereiro 2016. Rio de Janeiro; 2016.

Instituto Sul Americano de Governo em Saúde (ISAGS). Estatuto do Instituto Sulamericano de Governo em Saúde. 2011.

Instituto Sul Americano de Governo em Saúde (ISAGS). Informe Especial sobre a 69a Sessão da Assembleia Mundial da Saúde. Rio de Janeiro; 2016.

Instituto Sul Americano de Governo em Saúde (ISAGS). Unasul se mobiliza para enfrentar o vírus Zika. Informe janeiro 2016. [Internet]. Rio de Janeiro; 2016. [acesso em 10 Ago 2019] Disponível em: https://drive.google.com/file/d/1ZwmvdCKEmg97czryCmhYF6DeVab2v0vk/view?usp=s haring

Jouannic JM, Friszer S, Leparc-Goffart I, Garel C, Eyrolle-Guignot D. Zika virus infection in French Polynesia. Lancet. 2016;387(10023):1051-2. 
Kastler F. Focus OMS - Des résolutions et une réforme cruciale en cours. Les Trib la Santé. 2013;39:13-4.

Kerouedan D. Como a saúde se tornou um desafio geopolítico. Le Monde Dipl Bras [Internet]. 2013;(72). [acesso em 10 Dez 2015]. Disponível em: https://diplomatique.org.br/como-a-saude-se-tornou-um-desafio-geopolitico/

Kickbusch I, Novotny TE, Drager N, Silberschmidt G, Alcazar S. Global health diplomacy: training across disciplines. World Hosp Health Serv. 2007 85(12):971-3;

Kickbusch I, Silberschmidt G, Buss P. Global health diplomacy: The need for new perspectives, strategic approaches and skills in global health. Bulletin of the World Health Organization. 2007; 85(3),230-232.

Kickbusch I, Szabo MMC. A new governance space for health. Global Health Action. 2014. Kickbush I, Berger C. Diplomacia da Saúde Global. RECIIS. 2010;4(1). [acesso em 10 Ago 2013]. Disponível em: https://www.reciis.icict.fiocruz.br/index.php/reciis/article/view/693 Kopko G, Mendes A. Vacina contra zika foi tema de reunião do ministro no Butantan [Internet]. Portal Ministério da Saúde. 2016 [acesso em 10 Set 2017]. Disponível em: http://portalms.saude.gov.br/noticias/agencia-saude/21760-vacina-contra-zika-foi-temade-reuniao-do-ministro-no-butantan

Kopko G. Ministério da Saúde anuncia edital de $\mathrm{R}$ \$ 20 milhões para pesquisas contra o Aedes aegypti. [Internet]. Portal Ministério da Saúde. 2016 [acesso em 10 Set 2017]. Disponível em: http://www.saude.gov.br/noticias/agencia-saude/22727-ministerio-dasaude-anuncia-edital-de-r-20-milhoes-para-pesquisas-contra-o-aedes-aegypti

Kopko G. Ministério da Saúde investe R $\$ 100$ milhões para vacina da dengue. [Internet]. Portal Ministério da Saúde. 2016 [acesso em 10 Set 2017]. Disponível em: http://www.saude.gov.br/noticias/agencia-saude/22260-ministerio-da-saude-investe-r-100milhoes-para-vacina-da-dengue

Koplan JP, Bond TC, Merson MH, Reddy KS, Rodriguez MH, Sewankambo NK, et al. Towards a common definition of global health. The Lancet. 2009; 373(9679):1993-5.

Leite I. Cooperação Sul-Sul: Conceito, História e Marcos Interpretativos. Obs On-line [Internet]. 2012;7(3). [acesso em 10 Jul 2013]. Disponível em: http://www.opsa.com.br/images/pdf/observador/observador_v_7_n_03_2012.pdf 
Letter to WHO Urging the Postponement or Movement of Brazil Olympics due to Concerns over Zika | National Center for Health Research [Internet]. [acesso em 10 Set 2019]. Disponível em: http://www.center4research.org/letter-urging-postponement-movementbrazil-olympics-due-concerns-zika/

Lima-camara TN. Arboviroses emergentes e novos desafios para a saúde pública no Brasil. 2016;50:1-7.

Lucey DR, Gostin LO. The emerging zika pandemic: Enhancing preparedness. JAMA - J Am Med Assoc. 2016;315(9):865-6.

Maciel V. Governo Federal destina R \$ 65 milhões para pesquisas sobre o vírus Zika. [Internet]. Portal Ministério da Saúde. 2016 [acesso em 10 Set 2017]. Disponível em: http://www.saude.gov.br/noticias/agencia-saude/23942-governo-federal-destina-r-65milhoes-para-pesquisas-sobre-o-virus-zika

Marks-Sultan G, Tsai F, Anderson E, Kastler F, Sprumont, D, Burris S. National public health law: a role for WHO in capacity-building and promoting transparency. Bull World Health Organ. 2016;94(7):534-9.

Mendes A, Maciel V. Ministério da Saúde vai distribuir teste rápido de Zika. Portal do Ministério da Saúde. [Internet]. Portal Ministério da Saúde. 2016 [acesso em 10 Set 2017]. Disponível em: http://www.saude.gov.br/noticias/agencia-saude/26155-ministerio-dasaude-vai-distribuir-teste-rapido-de-zika

Mendes A. Brasil apresenta redução de 87\% nas notificações dos casos de Zika [Internet]. Portal Ministério da Saúde. 2016 [acesso em 10 Set 2017]. Disponível em: http://www.saude.gov.br/noticias/svs/24064-brasil-apresenta-reducao-de-87-nasnotificacoes-dos-casos-de-zika

Mendes A. Brasil e EUA iniciam estudo na Paraíba sobre microcefalia associada ao vírus Zika. Portal Ministério da Saúde [Internet]. 2016 Feb 16 [acesso em 10 Set 2017]. Disponível em: http://www.saude.gov.br/noticias/agencia-saude/22199-brasil-e-euainiciam-estudo-na-paraiba-sobre-microcefalia-associada-ao-virus-zika

Mendes A. Governo Federal une esforços no combate ao mosquito. Portal Ministério da Saúde [Internet]. 2 Dez 2016 [acesso em 10 Set 2017]. Disponível em: http://www.saude.gov.br/noticias/agencia-saude/26667-governo-federal-une-esforcos-nocombate-ao-mosquito 
Mendes A. Ministério da Saúde ativa centro de monitoramento em saúde. Portal Ministério da Saúde [Internet]. 2016 Jul 29. [acesso em 12 Ago 2016]. Disponível em: https://saude.gov.br/noticias/agencia-saude/24872-ministerio-da-saude-ativa-centro-demonitoramento-em-saude.

Mendes A. Ministério da Saúde cria jogo para alertar importância de combater o Aedes aegypti. Portal Ministério da Saúde [Internet]. 12 Mai 2016 [acesso em 10 Set 2017]; Disponível em: http://www.saude.gov.br/noticias/agencia-saude/23828-ministerio-dasaude-ensina-brincando-como-combater-o-aedes-aegypti

Mendes A. Ministério da Saúde repassa R 152 milhões de recurso adicional para combate ao Aedes [Internet]. 2016 [acesso em 10 Nov 2019]. Disponível em: http://www.saude.gov.br/noticias/agencia-saude/27120-ministerio-da-saude-repassa-r152-milhoes-de-recurso-adicional-para-combate-ao-aedes

Mendes. Estudo reforça relação do Zika com casos de microcefalia. [Internet]. Portal Ministério da Saúde. 2016 [acesso em 10 Set 2017]. Disponível em: http://www.saude.gov.br/noticias/agencia-saude/24872-ministerio-da-saude-ativa-centrode-monitoramento-em-saude

Mercado Común del Sur (Mercosur). Declaración de las Ministras y Ministros de Salud del MERCOSUR y Estados Asociados ante la grave situación epidemiológica determinada por enfermedades transmitida por el Aedes Aegypti: Dengue, Chikungunya y Zika. II RMS Ext. [Internet]. Montevideo; 2016 [acesso em 10 Mar 2016]. Disponível em: http://www.mercosur.int

Mercado Común del Sur (Mercosur). MERCOSUL/RMS/CICETV/ATA No 02/12. REUNIÃO DA COMISSÃO INTERGOVERNAMENTAL DE CONTROLE DE DOENÇAS DE TRANSMISSÃO VETORIAL (CICETV), PREPARATÓRIA DA XXXIII REUNIÃO DE MINISTROS DA SAÚDE DO MERCOSUL. Foz do Iguaçu, Brasil. 22-24 out 2012. 2012.

Mercado Común del Sur (Mercosur). MERCOSUL/XLV SGT N ${ }^{\circ}$ 11/P. RES. /16. PROCEDIMENTOS MÍNIMOS PARA O CONTROLE INTEGRADO DE VETORES, RESERVATÓRIOS E OUTROS ANIMAIS TRANSMISSORES DE DOENÇAS EM PORTOS, AEROPORTOS, TERMINAIS E PASSAGENS DE FRONTEIRA TERRESTRES NO MERCOSUL E PARA. 2016. 
Mercado Común del Sur (Mercosur). MERCOSUR / XLV REUNIÓN ORDINARIA DE SGT No 11 “SALUD” / COMISIÓN DE VIGILANCIA EN SALUD / ACTA No 01/16. Montevideo, Uruguay. 11-14 abr 2016. 2016.

Mercado Común del Sur (Mercosur). MERCOSUR / XLV REUNIÓN ORDINARIA DE SGT No 11 "SALUD” / COMISIÓN DE VIGILANCIA EN SALUD / ACTA No 01/16. 11-14 abr 2016. Montevideo; 2016.

Mercado Común del Sur (Mercosur). MERCOSUR/CC-RMS/ACTA No 02/15 REUNIÓN ORDINARIA DEL COMITÉ COORDINADOR PREPARATORIA DE LA XXXVIII REUNIÓN DE MINISTROS DE SALUD. Asunción, Paraguay. 11-12 nov 2015. 2015.

Mercado Común del Sur (Mercosur). MERCOSUR/RMS/ACTA No 01/16. II REUNIÓN EXTRAORDINARIA DE MINISTROS DE SALUD. 03 fev 2016. [Internet]. 2016 [acesso 2017 Mar 10]. Disponível em: http://www.mercosur.int

Mercado Común del Sur (Mercosur). MERCOSUR/RMS/ACTA No 02/15 Corr.1 XXXVIII REUNIÓN DE MINISTROS DE SALUD. Asunción, Paraguay. 13 nov 2015. 2015.

Mercado Común del Sur (Mercosur). MERCOSUR/RMS/CICETV/ACTA No 01/15. REUNIÓN DE LA COMISIÓN INTERGUBERNAMENTAL DE CONTROL DE ENFERMEDADES DE TRANSMISIÓN VECTORIAL (CICETV), PREPARATORIA DE LA XXXVIII REUNIÓN DE MINISTROS DE SALUD (RMS). Asunción, Paraguai. 5-6 out 2015. 2015.

Mercado Común del Sur (Mercosur). MERCOSUR/RMS/CIDCD/ACTAno01/11. REUNIÓN DE LA COMISIÓN INTERGUBERNAMENTAL DE CONTROL DEL DENGUE, PREPARATORIA PARA LA XXX REUNIÓN DE MINISTROS DE SALUD DEL MERCOSUR. Asunción, Paraguay. 04-06 abril 2011. 2011.

Mercado Común del Sur (Mercosur). MERCOSUR/RMS/CIRSI/ACTA N N $^{\circ}$ 2/15. REUNIÓN DE LA COMISIÓN INTERGUBERNAMENTAL DE REGLAMENTO SANITARIO INTERNACIONAL, PREPARATORIA DE LA XXXVIII REUNIÓN DE MINISTROS DE SALUD (RMS). 8-9 out 2015. 2015.

Mercado Común del Sur (Mercosur). MERCOSUR/SGT No 11/ACTA No 02/15. XLIV REUNIÓN ORDINARIA DEL SUBGRUPO DE TRABAJO No 11 “SALUD”. Asunción, Paraguay. 5-9 out 2015. 2015. 
Mercado Común del Sur (Mercosur). REUNIÓN VIRTUAL DE COORDINADORES NACIONALES DE LA RMS PREPARATORIA DE LA XXXIX REUNIÓN DE MINISTROS DE SALUD DEL MERCOSUR. Videconferencia. 01 jun 2016. 2016.

Mercado Común del Sur (Mercosur). XLIV REUNIÓN ORDINARIA DE SGT N 11 “SALUD”/COMISIÓN DE VIGILANCIA EN SALUD / SUBCOMISIÓN DE CONTROL SANITARIOS DE PUERTOS, AEROPUERTOS, TERMINALES Y PASOS DE ENTRADA TERRESTRES “SCOCONTS”/ACTA N 02/15. Asunción, Paraguay. 5-7 out 2015. 2015.

Mercado Común del Sur (Mercosur). XLIV REUNIÓN ORDINARIA DE SGT No 11 “SALUD”/ COMISIÓN DE VIGILANCIA EN SALUD "COVIGSAL”/ACTA No 02/15. Asunción, Paraguay. 5-9 out 2015. 2015.

Mercosul Brasil. Organograma do Mercosul [Internet]. Mercosul Brasil; 2019 [acesso em 10 Nov 2019]. Disponível em: http://www.mercosul.gov.br/images/pdf/Organograma_MSUL_2019.pdf

Milani CRS, Pinheiro L. Política Externa Brasileira: Os Desafios de sua Caracterização como Política Pública. Context Int. 2013; 35(1);11-41.

MINAYO MC de S. Pesquisa social : teoria, método e criatividade. 23rd ed. Petrópolis: Vozes; 2009.

Nery T. A política externa brasileira, as coalizões de poder e a Unasul: ascensão e desconstrução da América do Sul como bloco geopolítico | Brazilian foreign policy, the coalitions of power and UNASUR: rise and deconstruction of South America as a geopolitical b. Mural Int. 2017;8(2):250-64.

Nery T. Unasul: a dimensão política do novo regionalismo sul-americano. Cad CRH [Internet]. 2016;29(spe3):59-75. [acesso em 16 Dez 2016]. Disponível em: http://www.scielo.br/pdf/ccrh/v29nspe3/0103-4979-ccrh-29-spe3-0059.pdf

Nunes J. Health, Politics and Security. e-cadernos CES. 2012;(15). [acesso 15 Set 2016]. Disponível em: http://journals.openedition.org/eces/989.

Nunes J, Pimenta DN. A Epidemia de Zika e os limites da Saúde Global. Lua Nov Rev Cult e Política. 2016;98:21-46; 
Oliveira CS De, da Costa Vasconcelos PF. Microcefalia e vírus zika. J Pediatr (Versão em Port [Internet]. 2016;92:103-5. [acesso em 12 Ago 2017]. Disponível em: www.jped.com.br

Oliveira GC de. A crise do ebola e a gramática dos problemas de segurança. [Internet]. Entrevista a Patricia Fachin. 2014 [acesso 24 Set 2015]. Disponível em: http://www.ihu.unisinos.br/entrevistas/536774-a-crise-do-ebola-e-a-gramatica-dosproblemas-de-seguranca-entrevista-especial-com-gilberto-carvalho-de-oliveira

Oliveira OP de, Lavalle AG. Embaixadores da participação: a difusão internacional do Orçamento Participativo a partir do Brasil [Internet]. 2013 . [acesso em 10 set 2016]. Disponível em: http://www.teses.usp.br/teses/disponiveis/8/8131/tde-19022014-102112/

Oliveira OP De. Novas fronteiras e direções na pesquisa sobre transferência, difusão e circulação de políticas públicas: agentes, espaços, resistência e traduções. 2018;52(2):199-220.

Oliveira WK De. Emergência de Saúde Pública de Importância Internacional : resposta brasileira à síndrome congênita associada à infecção pelo Zika vírus , 2015 e 2016. Tese [Doutorado em Epidemiologia]. Universidade Federal do Rio Grande do Sul, 2017;

Organização Pan-americana da Saúde (OPAS). RELATÓRIO ANUAL DO DIRETOR

Organização para a Cooperação e Desenvolvimento Económico. Agenda para ação de Acra. 3o Fórum de Alto Nível sobre a eficácia da Ajuda. Acra; 2008.

Organização para a Cooperação e Desenvolvimento Económico. Declaração de Paris sobre a Eficácia da Ajuda ao desenvolvimento: apropriação, harmonização, alinhamento, resultados e responsabilidade mútua. Paris; 2005.

Organización Mundial de la Salud. Constitución de la Organización Mundial de la Salud. Documentos básicos. 2014;

Organización Panamericana de la Salud (OPS). Actualización sobre el virus del Zika en la región de las Américas. CD55/INF/4. [Internet]. Washington, D.C.; 2016. Disponível em: http://iris.paho.org/xmlui/bitstream/handle/123456789/33654/CD55-INF-4s.pdf?sequence $=9 \&$ isAllowed $=\mathrm{y}$

Organización Panamericana de la Salud (OPS). CD54/FR — Informe final. 67.a sesión del Comité Regional de la OMS para las Américas; 2015; 
Organización Panamericana de la Salud (OPS). CD54/FR. INFORME FINAL. 2015;

Organización Panamericana de la Salud (OPS). CD55.R6. RESOLUCIÓN ESTRATEGIA PARA LA PREVENCIÓN Y EL CONTROL DE LAS ENFERMEDADES ARBOVIRALES. 2016.

Organización Panamericana de la Salud (OPS). CD55/12, Rev. 1 APLICACIÓN DEL REGLAMENTO SANITARIO INTERNACIONAL (RSI). 55.o CONSEJO DIRECTIVO. 68.a SESIÓN DEL COMITÉ REGIONAL DE LA OMS PARA LAS AMÉRICAS. 16 de septiembre del 2016. Washington, D.C.; 2016.

Organización Panamericana de la Salud (OPS). CD55/16. ESTRATEGIA PARA LA PREVENCIÓN Y EL CONTROL DE LAS ENFERMEDADES ARBOVIRALES. 2016.

Organización Panamericana de la Salud (OPS). CD55/INF/11. ESTRATEGIA Y PLAN DE ACCIÓN REGIONALES SOBRE SALUD NEONATAL EN EL CONTEXTO DEL PROCESO CONTINUO DE LA ATENCIÓN DE LA MADRE, DEL RECIÉN NACIDO Y DEL NIÑO: INFORME FINAL. 2016.

Organización Panamericana de la Salud (OPS). CE158/INF/6. ACTUALIZACIÓN SOBRE EL VIRUS DEL ZIKA EN LA REGIÓN DE LAS AMÉRICAS. 2016;

Organización Panamericana de la Salud (OPS). CE158-FR - Informe Final. 158 Sesión del Comite Ejecutivo. 2016;80-2. [acesso em 12 Dez 2016]. Disponível em: http://iris.paho.org/xmlui/bitstream/handle/123456789/33796/CE158-FR-

s.pdf?sequence $=4 \&$ isAllowed $=\mathrm{y}$

Organización Panamericana de la Salud (OPS). La OPS y laboratorios de las Américas acuerdan pautas comunes para identificar y monitorear el virus del Zika. Portal de la OPS. [Internet] 26 Fev 2016. 2016. [acesso em 03 Ago 2016] Disponível em: https://www.paho.org/hq/index.php?option=com_content \&view=article\&id=11703:2016paho-laboratories-set-guidelines-to-identify-confirm-zika-virus\&Itemid=135\&lang=es Organización Panamericana de la Salud (OPS). NoCE158/INF/13. INFORMES DE PROGRESO SOBRE ASUNTOS TÉCNICOS. 2016.

Organización Panamericana de la Salud. Agenda de Salud Para las Américas 2008-2017. Ciudad de Panamá: Organización Mundial de la Salud; 2007. 25 p.

Organización Panamericana de la Salud. CE158/INF/14. B. ORGANIZACIONES SUBREGIONALES. 2016. 
Organización Panamericana de la Salud. Resolución CD52/11 del 52 Consejo Directivo. Tema Cooperación para el desarrollo sanitario en las Américas. Washington, D.C.; 2013. Organization for Economic Cooperation and Development. Busan partnetship for effective development cooperation. 4th High level forum on aid effectiveness. Busan; 2011.

Organization for Economic Cooperation and Development. Rome Declaration on Harmonisation. First High Level Forum on Aid Effectiveness. Rome; 2003.

Oslo Ministerial Declaration-global health: a pressing foreign policy issue of our time. Lancet. 2007.

Ottersen OP, Dasgupta J, Blouin C, Buss P, Chongsuvivatwong V, Frenk J, et al. Comissão da Universidade de Oslo sobre Governança Global - As origens políticas das inequidades em saúde: perspectivas de mudança. Comissões The Lancet. 2014;

Pan American Health Organization (PAHO). Governing Bodies [Internet]. Pan American Health Organizatio (PAHO). 2019 [acesso em 21 Set 2019]. Disponível em: https://www.paho.org/hq/index.php?Itemid=419\&lang=en

Palma N. Ministro da Saúde apresenta ações para o Comitê Olímpico Internacional. Portal Ministério da Saúde [Internet]. 24 Mai 2016 [acesso em 10 Set 2017]. Disponível em: http://portalms.saude.gov.br/noticias/agencia-saude/22237-notificacao-de-casos-pelovirus-zika-passa-a-ser-obrigatoria-no-brasil

Pan American Health Organization (PAHO). BASIC DOCUMENTS of the Pan American Health Organization [Internet]. 19th ed. Washington, D.C.; 2017. 158 p. [acesso em 10 Jan 2018]. Disponível em: http://apps.who.int/gb/bd

Pan American Health Organization (PAHO). Epidemiological Alert Increase of microcephaly in the northeast of Brazil 17 November 2015 [Internet]. 2015. [acesso em 16 Set 2016] Disponível em: https://www.paho.org/hq/dmdocuments/2015/2015-nov-17-chamicrocephaly-epi-alert.pdf

Pan American Health Organization (PAHO). Epidemiological Alert Neurological syndrome, congenital malformations, and Zika virus infection. Implications for public health in the Americas 1 December 2015 [Internet]. 2015. [acesso em 12 fev 2016]. Disponível em: https://www.paho.org/hq/dmdocuments/2015/2015-dec-1-cha-epi-alertzika-neuro-syndrome.pdf 
Pan American Health Organization (PAHO). Epidemiological Alert. Zika virus infection. 7 May 2015. [Internet]. 2015. [acesso em 10 Set 2017]. Disponível em: https://www.paho.org/hq/dmdocuments/2015/2015-may-7-cha-zika-virus-epi-alert.pdf Pan American Health Organization (PAHO). Epidemiological Update. Zika virus infection. 16 October 2015. 2015.

Pan American Health Organization (PAHO). PAHO/WHO | About the Pan American Health Organization (PAHO) [Internet]. 2019 [acesso em 20 Set 2019]. Disponível em: https://www.paho.org/hq/index.php?option=com_content $\&$ view=article \&id=91:aboutpaho\&Itemid=220\&lang=en

Pan American Health Organization (PAHO). PAHO/WHO Regional research agenda related to Zika virus infection. Development of a research agenda for characterizing the Zika outbreak and its public health implications in the Americas. Washington, D.C.: PAHO; 2016. 64 p.

Pan American Health Organization (PAHO). Response to the Epidemic of Zika Virus in the Americas. December 2015 - 2016. Washington, D.C.; 2017.

Pan American Health Organization (PAHO). Strategy for Enhancing National Capacity to Respond to Zika virus Epidemic in the Americas. June 2016. 2016;

Pan American Health Organization (PAHO). Timeline of Emergence of Zika virus in the Americas [Internet]. 2019 [acesso em 12 Set 2019]. Disponível em: https://www.paho.org/hq/index.php?option=com_content\&view=article\&id=11959:timeli ne-of-emergence-of-zika-virus-in-the-americas \&Itemid=41711\&lang=en

Pan American Health Organization (PAHO). Zika: Missions to support countries. 2016.

Panisset U. Conceitos Operacionais para diplomacia da Saúde: promovendo desenvolvimento humano por meio da cooperação internacional. In: Buss PM, Tobar S, editors. Diplomacia em Saúde e Saúde Global: perspectivas latino-americanas. Rio de Janeiro: Editora Fiocruz; 2017;87-114.

Penido A. Brasil vai desenvolver teste para detecção de Zika nas bolsas de sangue. [Internet]. Portal Ministério da Saúde. 2016 [acesso em 10 Set 2017]. Disponível em: http://portalms.saude.gov.br/noticias/agencia-saude/22256-brasil-vai-desenvolver-testepara-deteccao-de-zika-nas-bolsas-de-sangue 
Penido A. Notificação de casos de vírus zika passa a ser obrigatória no Brasil [Internet]. Portal Ministério da Saúde. 2016 [acesso em 10 Set 2017]. Disponível em: http://portalms.saude.gov.br/noticias/agencia-saude/22237-notificacao-de-casos-pelovirus-zika-passa-a-ser-obrigatoria-no-brasil

Penido A. Saúde registrou 11.235 atendimentos nos Jogos Olímpicos [Internet]. Portal da Saude. 2016 [acesso em 10 Set 2016]. Disponível em: http://www.saude.gov.br/noticias/agencia-saude/25428-saude-registrou-11-235atendimentos-nos-jogos-olimpicos

Pereira AE, Bernardo GJ, Culpi LA, Pessali HF. A governança facilitada no Mercosul: transferência de políticas e integração nas áreas de educação, migração e saúde. Rev Adm Pública. 2018;52(2):285-302.

PF2. Entrevista realizada por Flávia Thedim Costa Bueno, gravação digital. Whatsapp. 14 de junho de 2019. 2019.

Pinheiro L. Política externa brasileira: 1889-2002. Rio de Janeiro: Jorge Zahar editor; 2004. $81 \mathrm{p}$.

Pinheiro L. Traídos pelo Desejo: Um Ensaio sobre a Teoria e a Prática da Política Externa Brasileira Contemporânea. Context Int. 2000;22(2):305-35.

Pittas TM. A resposta do governo brasuleuro à epidemia do vírus Zika: segurança em saúde e política externa. Dissertação [Mestrado em Relações Internacionais]. Universidade Federal de Santa Catarina; 2018.

POL. Entrevista realizada por Flávia Thedim Costa Bueno, gravação digital. Whatsapp. 27 de agosto de 2019. 2019.

Portal de Notícias G1 PB. Exames confirmam infecção por Zika vírus em dois casos de microcefalia - notícias em Paraíba.17 nov 2015 [acesso em 16 Set 2019]; Disponível em: http://g1.globo.com/pb/paraiba/noticia/2015/11/exames-comprovam-infeccao-por-zikavirus-em-dois-casos-de-microcefalia.html

Porto de Oliveira O, Faria CAP de. Policy Transfer, Diffusion ,. Novos Estud. 2017;36(1):13-32.

Porto de Oliveira O. Mecanismos da difusão global do Orçamento Participativo: Indução internacional, construção social e circulação de indivíduos. Opiniao Publica. 2016;22(2):219-49. 
Queiroz LG, Giovanella L. Agenda regional da saúde no mercosul: Arquitetura e temas. Rev Panam Salud Publica/Pan Am J Public Heal. 2011;30(2):182-8.

RCG1/PF1. Entrevista realizada por Flávia Thedim Costa Bueno, gravação digital. Rio de Janeiro. 21 de maio de 2019.; 2019.

RCG2. Entrevista realizada por Flávia Thedim Costa Bueno, gravação digital. Whatsapp. 14 de junho de 2019. 2019.

RCOI1. Entrevista realizada por Flávia Thedim Costa Bueno, gravação digital. Whatsapp. 29 de maio de 2019. 2019.

RCOI2. Entrevista realizada por Flávia Thedim Costa Bueno, gravação digital. Whatsapp. 23 de maio de 2019. 2019. 


\section{ANEXOS}

ANEXO I: Linha do tempo - Síndrome Congênita do Vírus Zika como ESPII

\begin{tabular}{|c|c|}
\hline Ano & Evento \\
\hline 1947 & Isolamento do vírus em Uganda \\
\hline 1958 & $\begin{array}{l}4 \text { amostras identificadas pelo ZIKV em Belém pela Fundação Rockefeller. (Causey \& Theiler, } \\
1958 \text { apud (253) }\end{array}$ \\
\hline 2007 & $\begin{array}{l}\text { No Pacífico, foi a partir de abril de } 2007 \text { que a epidemia iniciou com quadro de doença } \\
\text { exantemática seguida de conjuntivite e artralgia, descrita na ilha de Yap/Micronésia. (211) }\end{array}$ \\
\hline 2013 & $\begin{array}{l}\text { Surto na Polinésia Francesa, seguido por surtos na a Nova Caledônia, Ilhas Cook e Ilha de } \\
\text { Páscoa. (211) }\end{array}$ \\
\hline 2014 & $\begin{array}{l}\text { Em fevereiro de 2014, a circulação autóctone do vírus Zika foi confirmada na Ilha de Páscoa, } \\
\text { Chile (7). }\end{array}$ \\
\hline 2015 & $\begin{array}{l}11 \text { de fevereiro de 2015: Autoridades brasileiras respondem a uma consulta da OPAS sobre } \\
\text { informação sobre um surto de uma doença exantemática no Maranhão. (254) }\end{array}$ \\
\hline 2015 & $\begin{array}{l}29 \text { de abril: pesquisadores da UFBA Gúbio Soares e Silvia Sardi identificaram o vírus em } \\
\text { amostras de pessoas atendidas em Camaçari (BA) }(1,7)\end{array}$ \\
\hline 2015 & $\begin{array}{l}7 \text { de maio de 2015: a OPAS lançou o alerta epidemiológico "Zika Virus Infection", } \\
\text { recomendando que os países usassem seus sistemas de vigilância existentes para outras arboviroses como } \\
\text { Dengue, aumentando sua sensibilidade para detectar casos de Zika. (211) }\end{array}$ \\
\hline 2015 & $\begin{array}{l}14 \text { de maio: o diagnóstico laboratorial feito pelo IEC indicou que o novo vírus era mesmo o Zika } \\
\text { (7) e se identificou aumento dos casos de Síndrome de Guillain-Barré (153). }\end{array}$ \\
\hline 2015 & $\begin{array}{l}14 \text { de maio: Arthur Chioro anuncia a identificação do Zika no Brasil e indicou que era uma } \\
\text { doença branda (7). }\end{array}$ \\
\hline 2015 & $\begin{array}{l}9 \text { de junho: autoridades brasileiras reportaram aumento de circulação de Zika em } 8 \text { estados: } \\
\text { Alagoas, Bahia, Maranhão, Pará, Rio Grande do Norte, Rio de Janeiro, Roraima, São Paulo. (254) }\end{array}$ \\
\hline 2015 & $\begin{array}{l}14 \text { de junho: os Drs. Ernesto Marques, Marli Tenório e Lindomar Pena comunicaram o } \\
\text { isolamento do vírus Zika em casos de distúrbios neurológicos. (7) }\end{array}$ \\
\hline 2015 & $\begin{array}{l}9 \text { de julho: autoridades brasileiras reportaram } 58 \text { casos de complicações neurológicas foram } \\
\text { identificados na Bahia até o dia } 4.29 \text { dos quais eram SGB e } 19 \text { desses tinham histórico de infecção por } \\
\text { Zika. (254) }\end{array}$ \\
\hline 2015 & $\begin{array}{l}16 \text { de julho: autoridades brasileiras reportaram que mais } 4 \text { estados identificaram a circulação do } \\
\text { Zika: Alagoas, Bahia, Ceará, Maranhão, Pará, Paraíba, Paraná, Pernambuco, Rio Grande do Norte, Rio } \\
\text { de Janeiro, Roraima, e São Paulo. (254) }\end{array}$ \\
\hline 2015 & $\begin{array}{l}\text { Entre julho e novembro de } 2015 \text {, pesquisadores do Estado do Ceará realizaram estudos com } \\
\text { primatas não-humanos do novo mundo, domiciliados e de vida livre, em que foi detectado o Zika. } \\
\text { (Favoretto et al., } 2016 \text { apud (253) }\end{array}$ \\
\hline 2015 & 6 de outubro: Marcelo Castro assume o Ministério da Saúde no lugar de Arthur Chioro. \\
\hline 2015 & $\begin{array}{l}16 \text { de outubro: a OPAS publica uma atualização epidemiológica "Infecção pelo Vírus Zika" com } \\
\text { recomendações e uma definição de casos provisória. (255) }\end{array}$ \\
\hline 2015 & $\begin{array}{l}16 \text { de outubro: Colômbia confirma os primeiros } 9 \text { casos de Zika no país (MINSALUD) e informa } \\
\text { a OPAS (254) }\end{array}$ \\
\hline 2015 & $\begin{array}{l}19 \text { de outubro: Dr. Carlos Brito foi procurado pelas Dras. Vanessa Van der Linden e Adélia } \\
\text { Henriques, que relataram um aumento atípico de casos de microcefalia. A médica Jucille Menezes, do } \\
\text { Hospital Mateiro Infantil de PE também havia observado fenômeno semelhante. (7) }\end{array}$ \\
\hline 2015 & $\begin{array}{l}22 \text { de outubro: Notificação de PE ao MS do aumento incomum de casos de microcefalia em } \\
\text { bebês. }(153,256)\end{array}$ \\
\hline
\end{tabular}


23 de outubro: O evento foi notificado à Organização Mundial da Saúde (OMS) por meio do Ponto de Contato Regional do Regulamento Sanitário Internacional.(150) O ponto focal do RSI no Brasil informou a OPAS o aumento inesperado de casos de microcefalia em Pernambuco desde agosto de 2015, com 26 casos detectados em serviços de saúde público e privados. (254)

201526 outubro: uma missão do MS (256) com a OPAS visitaram Recife/PE. (7)

Novembro: uma missão de especialistas veio ao Brasil, sob o comando do GOARN (Global Outbreak Alert and Response Network ou Rede Mundial de Alerta e Resposta ante Surtos Epidêmicos (GOARN) para apoiar as autoridades locais. (6)

2015 Novembro: Criação do Registro de Eventos de Saúde Pública (Resp) para notificação dos casos de microcefalia passaram a ser notificados neste sistema específico, além do Sistema de Informações sobre Nascidos Vivos (Sinasc). (257)

Especialistas passaram a usar o termo "Síndrome associada à infecção congênita por Zika" ou "Zika congênito", visto que as malformações não estavam apenas relacionadas a microcefalia. (227)

2 de novembro: autoridades do Suriname informam a OPAS sobre 2 casos autóctones de infecção pelo Zika. (254)

201510 de novembro: Ativação do o Centro de Operações de Emergência em Saúde Pública (COES). $(256,258)$

201511 de novembro: a Dra Ana Bispo da Fiocruz Rio de Janeiro notificou ao Ministério da Saúde a identificação de RNA viral do Zika no líquido amniótico de duas crianças com exames de ultrassonografia com alterações. (7)

201511 de novembro: Declaração de Emergência em Saúde Pública de Importância Nacional (ESPIN). (4,256)

201512 de novembro: Cláudio Maierovitch, diretor do departamento de Vigilância de Doenças Transmissíveis do Ministério da Saúde aconselha mulheres a adiarem a gestação: "Não engravidem agora. Esse é o conselho mais sóbrio que pode ser dado". (259)

2015

Estabelecimento das primeiras diretrizes nacionais para microcefalia $(>33 \mathrm{~cm}) .(153)$

201517 de novembro: foi confirmada a presença do vírus Zika em líquido amniótico de duas gestantes, coletados pela Dra. Adriana Melo, da Paraíba. $(7,260)$

201517 de novembro: Boletim epidemiológico com acompanhamento dos casos de microcefalia passa a ser divulgado semanalmente. (256)

201517 de novembro: a OPAS emite o primeiro alerta sobre o aumento de casos de microcefalia no Nordeste brasileiro. (261)

201518 de novembro: Instituto Oswaldo Cruz anuncia descoberta de Zika em líquido amniótico de 2 bebês. (1)

Convocação do Grupo Executivo Interministerial de Emergências em Saúde Pública de Importância Nacional e Internacional (GEI-ESPII). (256)

201524 de novembro: autoridades da Polinésia Francesa revelaram resultado de um estudo retrospectivo em que relataram aumento de malformações em fetos e recém-nascidos em 2014-2015, período em que havia um surto de Zika nas ilhas. $(214,262)$

201527 de novembro: autoridades do Paraguai comunicaram a OPAS o primeiro caso autóctone. $(254)$

2015 de novembro: Dr Pedro Vasconcelos, virologista do IEC, também detecta o vírus em sangue e tecidos de dois natimortos e o Ministério da Saúde estabelece a relação entre o vírus e os casos de microcefalia $(7,214)$ 
Primeiro óbito de um bebê causado pelo Zika. (256)

\begin{tabular}{|c|c|}
\hline & Primeiro óbito de um bebê causado pelo Zika. (256) \\
\hline 2015 & 30 de novembro: Venezuela e México anunciaram casos autóctones de transmissão do Zika. \\
\hline 2015 & $\begin{array}{l}\text { Dezembro: Publicação do Protocolo de Vigilância e Resposta à Ocorrência de Microcefalia e/ou } \\
\text { Alterações do Sistema Nervoso Central (SNC). }\end{array}$ \\
\hline 2015 & $\begin{array}{l}01 \text { de dezembro: a OPAS lança o Alerta epidemiológico "Neurological syndrome, congenital } \\
\text { malformations and Zika virus infection: implications for public health in the Americas", salientando o } \\
\text { aumento incomum de casos de anomalias cong enitas e síndromes neurológicas no Brasil. (214) }\end{array}$ \\
\hline 2015 & $\begin{array}{l}\text { Em dezembro ainda ocorreu a elaboração do Plano Nacional de Enfrentamento do Aedes e suas } \\
\text { consequências. (151) }\end{array}$ \\
\hline 2015 & $\begin{array}{l}01 \text { de dezembro: } 1^{\circ} \text { anúncio oficial sobre a epidemia em coletiva de imprensa e início da } \\
\text { veiculação de Campanha contra o Aedes Aegypti, incluindo informações sobre Zika. }(7,153)\end{array}$ \\
\hline 2015 & 2 de dezembro: protocolação do pedido de impeachment da Presidente Dilma Rousseff. \\
\hline 2015 & 4 de dezembro: Forças armadas chegam a Pernambuco (256) \\
\hline 2015 & $\begin{array}{l}5 \text { de dezembro: Presidente Dilma Rousseff lança Plano Nacional de Enfrentamento da } \\
\text { Microcefalia. }(7,256,263)\end{array}$ \\
\hline 2015 & $\begin{array}{l}8 \text { de dezembro: A OPAS ativa seu Sistema de gerenciamento de Incidentes (IMS, em inglês). (6) } \\
\text { Lançamento do Protocolo de Vigilância e resposta à Microcefalia relacionada ao Zika. (256) }\end{array}$ \\
\hline 2015 & $\begin{array}{l}9 \text { de dezembro: a Presidente Dilma Rousseff se reúne com governadores para a construção de } \\
\text { estratégias de enfrentamento. (256) }\end{array}$ \\
\hline 2015 & $\begin{array}{l}14 \text { de dezembro: lançamento do Protocolo de Atenção à Saúde e Resposta à Ocorrência de } \\
\text { Microcefalia. (257) }\end{array}$ \\
\hline & 18 de dezembro: Fiocruz implanta um Gabinete de Enfrentamento à ESPIN. (7) \\
\hline 2015 & $\begin{array}{l}\text { Portaria GM/MS no } 2.121 \text {, que altera atribuições dos membros das equipes de atenção básica } \\
\text { para reforçar as ações voltadas ao controle e à redução dos riscos em saúde, com foco no controle de } \\
\text { vetores. }\end{array}$ \\
\hline 2015 & $\begin{array}{l}21 \text { de dezembro: Decreto Presidencial no 8.612: Implantação da Sala Nacional de Comando e } \\
\text { Controle (SNCC). }\end{array}$ \\
\hline 2015 & $\begin{array}{l}\text { Nas semanas entre o Natal e Ano Novo foram realizadas Videoconferências com todas as } \\
\text { Secretarias Estaduais de Saúde. (153) }\end{array}$ \\
\hline 2015 & 30 de dezembro: Os Estados Unidos reportaram transmissão autóctone do vírus em Porto Rico. \\
\hline 2016 & $\begin{array}{l}06 \text { de janeiro: se inicia a alimentação de dados sobre visitas domiciliares no Sistema } \\
\text { Informatizado de Monitoramento da Presidência da República (SIMPR). (153) }\end{array}$ \\
\hline 2016 & $\begin{array}{l}11 \text { de janeiro: PORTARIA SGTES N }{ }^{\circ} \text { 3: Dispõe sobre a implantação de Centros Colaboradores } \\
\text { em processos de qualificação de profissionais no plano de resposta à ocorrência de microcefalia } \\
\text { relacionada à infecção pelo vírus Zika. }\end{array}$ \\
\hline 2016 & $\begin{array}{l}12 \text { de janeiro: foi publicada a Diretriz nacional para estimulação precoce de bebês com } \\
\text { microcefalia. (153) }\end{array}$ \\
\hline & $\begin{array}{l}13 \text { de janeiro: dá-se início a conferências semanais com as Salas Estaduais de Comando o } \\
\text { Controle. (153) }\end{array}$ \\
\hline 2016 & Lançamento das diretrizes para estimulação precoce de bebês com microcefalia. (256) \\
\hline
\end{tabular}


15 de janeiro: Governo federal destina R $\$ 500$ milhões extras para combate ao Aedes aegypti e a microcefalia. (256)

\begin{tabular}{|c|c|}
\hline 2016 & 16 de janeiro: autoridades da Bolívia reportaram os primeiros casos autóctones do Zika. (254) \\
\hline 2016 & $\begin{array}{l}17 \text { de janeiro: a OPAS publicou uma atualização epidemiológica: "Neurological syndrome, } \\
\text { congenital malformations and Zika virus infection", detalhando o aumento de casos de SGB na região. } \\
(214)\end{array}$ \\
\hline 2016 & $\begin{array}{l}18 \text { de janeiro: Autoridades da França reportaram casos autóctones nas ilhas de San Martin e } \\
\text { Guadalupe. (254) }\end{array}$ \\
\hline 2016 & 20 de janeiro: foi identificado vírus Zika em placenta. (153). \\
\hline 2016 & 25 de janeiro: Os Estados Unidos reportaram transmissão autóctone do vírus Nas Ilhas Virgens. \\
\hline 2016 & 29 de janeiro: a Presidente Dilma Rousseff visita a SNCC. (153) \\
\hline 2016 & 29 de janeiro: ocorre o Dia da Faxina nos órgãos Federais. (153) \\
\hline 2016 & Publicação da Medida Provisória n. 712, de 29/01/2016, que regula entrada em imóveis fechados. \\
\hline 2016 & $\begin{array}{l}\text { Publicação do Decreto n. 8.662, de 01/02/2016, que institui medidas de controle do Aedes em } \\
\text { órgãos públicos. }\end{array}$ \\
\hline 2016 & $\begin{array}{l}01 \text { de fevereiro: Declaração da Emergência em Saúde Pública de Importância Internacional pela } \\
\text { OMS (ESPII), após a primeira reunião do Comitê de emergências convocado pela Diretora Geral da OMS. } \\
\text { (8) }\end{array}$ \\
\hline 2016 & $\begin{array}{l}3 \text { de fevereiro: Declaración de las Ministras y Ministros de Salud del MERCOSUR y Estados } \\
\text { Asociados ante la grave situación epidemiológica determinada por enfermedades transmitida por el } \\
\text { Aedes Aegypti: Dengue, Chikungunya y Zika. (181) }\end{array}$ \\
\hline 2016 & $\begin{array}{l}05 \text { de fevereiro: autoridades dos EUA reportaram a confirmação laboratorial de um caso de } \\
\text { transmissão sexual. (254) }\end{array}$ \\
\hline 2016 & 13 de fevereiro: Dia Nacional de Mobilização "Zika Zero" \\
\hline 2016 & $\begin{array}{l}\text { 15-16-26 de fevereiro: Autoridades da Holanda reportaram casos autóctones em Bonaire, Aruba } \\
\text { e Saint Maarten, respectivamente. (254) }\end{array}$ \\
\hline 2016 & $\begin{array}{l}16 \text { de fevereiro: Encontro com Embaixadores dos Estados-membros da União Europeia. (7) } \\
\text { Início do estudo de caso controle de microcefalia relacionada a infecção pelo vírus Zika na } \\
\text { Paraíba, segundo estado em número de casos suspeitos de microcefalia naquele momento, em parceria do } \\
\text { MS com o CDC. (191) }\end{array}$ \\
\hline 2016 & $\begin{array}{l}\text { Portaria GM/MS no 204, de } 17 \text { de fevereiro de } 2016 \text { que a Zika como uma doença de notificação } \\
\text { compulsória. }\end{array}$ \\
\hline 2016 & $\begin{array}{l}18 \text { e } 19 \text { de fevereiro: Reunião Bilateral entre Brasil e Estados Unidos, com a elaboração do } \\
\text { "Plano de Cooperação em Saúde Brasil-Estados Unidos para o enfrentamento ao Zika e suas } \\
\text { complicações". (187,264) }\end{array}$ \\
\hline 2016 & 19 de fevereiro: Dia Nacional da Educação contra o Zika (DIA “Z”). (7) \\
\hline 2016 & $\begin{array}{l}22 \text { de fevereiro: Início do mapeamento por telefone para monitoramento da assistência } \\
\text { (diagnóstico e tratamento) de bebês nascidos com microcefalia. (166) }\end{array}$ \\
\hline 2016 & $\begin{array}{l}\text { 21-24 de fevereiro de 2016: Visita da da Dra. Diretora-Geral da OMS, Dra. Margareth Chan e } \\
\text { de Carissa Etienne, Diretora-Geral da OPAS ao Brasil. (7) }\end{array}$ \\
\hline 2016 & $\begin{array}{l}26 \text { de fevereiro: autoridades da Argentina reportaram investigação de um caso de potencial } \\
\text { transmissão sexual, confirmado em } 22 \text { de março. }(254)\end{array}$ \\
\hline
\end{tabular}




\begin{tabular}{|c|c|}
\hline 2016 & $\begin{array}{l}\text { Em março, estudo publicado no NEJM indica que uma mulher lituana gestante, que esteve no } \\
\text { Brasil, identificou malformações fetais. Foi identificado o vírus Zika. (1) }\end{array}$ \\
\hline 2016 & Lançamento do aplicativo "Guardiões da Saúde" \\
\hline 2016 & $\begin{array}{l}8 \text { de março: Segunda Reunião do Comitê de Emergência da OMS. Ainda não havia } \\
\text { reconhecimento formal do vínculo entra o Zika e o aumento de casos de microcefalia. (25) }\end{array}$ \\
\hline 2016 & $\begin{array}{l}9 \text { de março: o MS passou a adotar novas medidas de perímetro cefálico, seguindo os padrões da } \\
\text { OMS: valores iguais ou menores de } 31,5 \mathrm{~cm} \text { para meninas e } 31,9 \text {, para meninos. (22) }\end{array}$ \\
\hline 2016 & 10 de março: Lançamento da versão 2.0 do Protocolo de Vigilância. (153) \\
\hline 2016 & 11 de março: visita de representantes do Ministério da Saúde da Argentina a SNCC. (153) \\
\hline 2016 & $\begin{array}{l}15 \text { de março: Portaria Interministerial Conjunta MS/MDS no 405, de 15/03/2016 - institui no } \\
\text { âmbito do SUS e SUAS a Estratégia de Ação Rápida para o Fortalecimento da Atenção à Saúde e da } \\
\text { Proteção Social de Crianças com Microcefalia }\end{array}$ \\
\hline 2016 & $\begin{array}{l}\text { Portaria 535, de 30/03/2016 que revisa o quantitativo máximo de ACE passivo de contratação } \\
\text { devido a ESPIN. }\end{array}$ \\
\hline 2016 & $\begin{array}{l}2 \text { de abril: autoridades da Colômbia reportaram casos de microcefalia em investigação para } \\
\text { infecção pelo Vírus Zika.(254) }\end{array}$ \\
\hline 2016 & $\begin{array}{l}2 \text { de abril: assinatura da Carta de intenções entre o IEC e a Universidade do Texas Medical } \\
\text { Branch para o desenvolvimento da vacina contra o vírus Zika. (194) }\end{array}$ \\
\hline 2016 & $\begin{array}{l}5-9 \text { de abril: Semana da Família na Escola, mobilização nas escolas de educação básica em todo } \\
\text { o País. (153) }\end{array}$ \\
\hline 2016 & $\begin{array}{l}20 \text { de abril: Implantação, do Sistema de Informação para Acompanhamento das Crianças com } \\
\text { Diagnósticos de Microcefalia -SIRAM. (159) }\end{array}$ \\
\hline 2016 & 13 de abril: o CDC reconheceu a relação entre o vírus Zika e a microcefalia. (265) \\
\hline 2016 & $\begin{array}{l}20 \text { de abril: Decreto 8.716, que institui o programa de prevenção e proteção individual de } \\
\text { gestantes em situação de vulnerabilidade socioeconômica contra o Aedes aegypti. (158) }\end{array}$ \\
\hline 2016 & 29 de abril: autoridades do Peru reportaram os primeiros casos autóctones confirmados. (254) \\
\hline 2016 & $\begin{array}{l}\text { Maio: lançamento da campanha MS/OPAS/UNICEF com o canal infantil Cartoon Network, } \\
\text { convocando crianças para participar do combate ao Aedes Aegypti. (266) e do jogo gigante "Zika Zero", } \\
\text { instalado em todas as capitais do NE. (267) }\end{array}$ \\
\hline 2016 & $\begin{array}{l}10 \text { de maio: publicação pela Casa Civil da "Estratégia de Resposta ao vírus Zika e o combate ao } \\
\text { mosquito Transmissor". (152) }\end{array}$ \\
\hline 2016 & $\begin{array}{l}10 \text { de maio: foi publicado documento "Orientações para prevenção da transmissão sexual do } \\
\text { Vírus Zika" assinado pelos Secretários da SAS e SVS. (153) }\end{array}$ \\
\hline 2016 & $\begin{array}{l}18 \text { de maio: autoridades da Argentina reportaram os primeiros casos autóctones confirmados; e } \\
\text { dos EUA reportaram o primeiro caso de síndrome congênita em Porto Rico. (254) }\end{array}$ \\
\hline 2016 & $\begin{array}{l}20 \text { de maio: Portaria } N^{\circ} 1.046 \text {, que institui a Rede Nacional de Especialistas em Zika e doenças } \\
\text { correlatas - ReneZika. }\end{array}$ \\
\hline 2016 & $\begin{array}{l}20 \text { de maio: Diretor do IEC anuncia que em novembro de } 2016 \text { a vacina contra o Zika estaria } \\
\text { disponível para testes pré-clínicos e até fevereiro de 2017, para estudos em humanos. (171) }\end{array}$ \\
\hline 2016 & $\begin{array}{l}\text { 23-24 de maio: Ministro da Saúde, Ricardo Barros, apresenta à Organização Mundial da Saúde } \\
\text { (OMS) e ao Comitê Olímpico Internacional (COI) as ações de combate ao Aedes aegypti desenvolvidas } \\
\text { no Brasil. (201) }\end{array}$ \\
\hline 2016 & $\begin{array}{l}27 \text { de maio: Brasil e Colômbia fazem parceria para combater o Aedes aegypti. Dois municípios } \\
\text { que estão localizados na região de fronteira entre Brasil e Colômbia, Tabatinga e Leticia, terão Sala } \\
\text { Binacional de Coordenação e Controle ao Aedes. (7) }\end{array}$ \\
\hline
\end{tabular}




\begin{tabular}{|c|c|}
\hline 2016 & $\begin{array}{l}27 \text { de maio: especialistas enviam carta à OMS solicitando o cancelamento ou adiamento dos } \\
\text { Jogos } \\
\text { Em resposta, especialistas da Fiocruz e da FGV reforçaram a ideia de que não havia risco para transmissão } \\
\text { do Zika durante os Jogos, que deveriam ser mantidos (198) }\end{array}$ \\
\hline 2016 & $\begin{array}{l}02 \text { de junho: Publicado Edital conjunto (MS, MEC, MCTIC) de } 65 \text { milhões do Programa } \\
\text { Nacional de Pesquisa Integrada sobre o vírus Zika (CNPq) (Chamada MCTIC/FNDCT-CNPq/MEC- } \\
\text { CAPES/MS-Decit/no14/2016) }\end{array}$ \\
\hline 2016 & $\begin{array}{l}3 \text { de junho: Resolução Normativa - RN no 407: altera a RN no } 387 \text {, de } 28 \text { de outubro de } 2015 \text {, } \\
\text { que dispõe sobre o rol de procedimentos e eventos em saúde no âmbito da saúde suplementar para } \\
\text { regulamentar a cobertura obrigatória e a utilização de testes diagnósticos para infecção pelo vírus Zika. }\end{array}$ \\
\hline 2016 & $\begin{array}{l}3 \text { de junho: Determinação das ações articuladas das redes de assistência social e previdência } \\
\text { social na atenção às crianças com microcefalia para o acesso ao Benefício de Prestação Continuada da } \\
\text { Assistência Social - BPC (Portaria no } 58 \text { do Ministério do Desenvolvimento Social e Agrário). }\end{array}$ \\
\hline 2016 & 10 de junho: autoridades de El Salvador reportaram o primeiro caso de síndrome congênita. (254) \\
\hline 2016 & $\begin{array}{l}13 \text { de junho: A Sociedade Brasileira de Infectologia divulgou posicionamento destacando o } \\
\text { notório trabalho desenvolvido pelo país na comunicação transparente de informações e orientações para } \\
\text { a população em relação ao Zika, bem como as ações de vigilância desenvolvidas. (269) }\end{array}$ \\
\hline 2016 & $\begin{array}{l}14 \text { de junho: Terceira reunião do Comitê de Emergências da OMS, reconhecendo o vínculo entre } \\
\text { o Zika e as malformações congênitas e a SGB. Durante esse encontro, os especialistas consideraram muito } \\
\text { baixo o risco de aumento de casos de infecção pelo vírus Zika devido às aglomerações resultado da } \\
\text { concentração de pessoas no Rio de Janeiro para os Jogos Olímpicos. (26) }\end{array}$ \\
\hline 2016 & $\begin{array}{l}20 \text { de junho: autoridades do Reino Unido reportaram o primeiro caso de transmissão autóctone } \\
\text { do vírus Zika em Anguilla e a França, o primeiro caso de síndrome congênita na Guiana Francesa. }(254)\end{array}$ \\
\hline 2016 & $\begin{array}{l}14 \text { de julho: Ministério das Cidades dispensa famílias que possuam membro com microcefalia } \\
\text { do sorteio para o programa Minha Casa Minha Vida (Portaria no 321, do Ministério das Cidades). }\end{array}$ \\
\hline 2016 & $\begin{array}{l}\text { Sancionada a lei derivada da medida provisória (MP no 716/2016) que liberou R\$ } 420 \text { milhões } \\
\text { do orçamento federal para ações de combate à microcefalia e ao A. aegypti. A Lei também autoriza a } \\
\text { entrada forçada de agentes de combate ao A. aegypti em imóveis públicos ou particulares abandonados } \\
\text { (Lei no 13.301, de } 27 \text { de junho de 2016: dispõe sobre a adoção de medidas de vigilância em saúde quando } \\
\text { verificada situação de iminente perigo à saúde pública pela presença do mosquito transmissor do vírus da } \\
\text { dengue, do vírus Chikungunya e do vírus Zika; e altera a Lei no 6.437, de } 20 \text { de agosto de 1977). (257) }\end{array}$ \\
\hline 2016 & $\begin{array}{l}\text { Em } 01 \text { de julho, a OPAS estabeleceu o Núcleo Nordeste de Cooperação Técnica decentralizada } \\
\text { em Zika para trabalhar com cinco estados: Alagoas, Paraíba, Pernambuco, Rio Grande do Norte e Sergipe. } \\
\text { (7) }\end{array}$ \\
\hline 2016 & $\begin{array}{l}\text { Ministério das Cidades dispensa famílias que possuam membro com microcefalia do sorteio para } \\
\text { o programa Minha Casa Minha Vida (Portaria no 321, de } 14 \text { de julho de 2016, do Ministério das Cidades). }\end{array}$ \\
\hline 2016 & $\begin{array}{l}19 \text { de julho: inauguração do CIOCS (Centro Integrado de Operações Conjuntas da Saúde) para } \\
\text { apoio nos Jogos Olímpicos, com previsão de funcionamento até } 20 \text { de setembro. (23) }\end{array}$ \\
\hline 2016 & $\begin{array}{l}26 \text { de julho: Autoridades do Reino Unido reportaram o primeiro caso autóctone nas ilhas Turks } \\
\text { e Caicos. (254) }\end{array}$ \\
\hline 2016 & $\begin{array}{l}27 \text { de julho: autoridades do Paraguai reportaram o primeiro caso de microcefalia associada à } \\
\text { infecção pelo Zika confirmado por laboratório. (254) }\end{array}$ \\
\hline 2016 & 29 de julho: autoridades dos EUA confirmaram 4 casos de casos autóctones de Zika na Flórida. \\
\hline 2016 & $\begin{array}{l}5 \text { de agosto: autoridades do Canadá reportaram o primeiro caso de transmissão vertical do Zika, } \\
\text { com severas anormalidades neurológicas. }(254)\end{array}$ \\
\hline 2016 & 5 de agosto: Início dos Jogos Olímpicos no Rio de Janeiro. \\
\hline 2016 & $\begin{array}{l}\text { 10-11 de agosto: autoridades de Costa rica e Honduras, respectivamente reportaram o primeiro } \\
\text { caso de SGB associada ao Zika. (254) }\end{array}$ \\
\hline
\end{tabular}


20 de agosto: autoridades da República Dominicana reportaram o primeiro caso de microcefalia

2016 associada ao vírus Zika. (254)

23 de agosto: autoridades da Costa Rica reportaram o primeiro caso de microcefalia associada ao vírus Zika; e o Haiti reportou 14 casos de malformações congênitas, com 1 caso confirmado de 2016 associação ao Zika. (254)

26 de agosto: autoridades do Reino Unidos reportaram os primeiros casos confirmados de transmissão autóctone nas Ilhas Virgens. (254)

31 de agosto: A presidente Dilma Rousseff tem seu mandato cassado. Assume Michel Temer, 2016 vice da chapa de Dilma.

2 de setembro: Quarta reunião do Comitê de Emergência da OMS, que informou não haver casos confirmados entre os frequentadores dos locais de realização dos Jogos Olímpicos, congratulando o Brasil por suas ações de prevenção e controle. (27)

15 de setembro: Publicado artigo no The Lancet, demonstrando associação forte entre os casos de microcefalia e a infecção pelo vírus Zika. "Association between Zika virus infection and microcephaly in Brazil, January to May, 2016: preliminary report of a case-control study". (227)

07 de outubro: autoridades de Granada reportaram à OPAS o primeiro caso confirmado em 2016 laboratório de síndrome congênita. (254)

201623 de outubro: autoridades da Guatemala reportaram aumento nos casos de SGB. (254)

01 de novembro: autoridades de Trinidad e Tobago reportaram o primeiro caso confirmado em 2016 laboratório de síndrome congênita. (254)

2 de novembro: autoridades da Bolívia reportaram os três primeiros casos confirmados em 2016 laboratório de síndrome congênita. (254)

4 de novembro: autoridades do Reino Unido reportaram o primeiro caso confirmado de caso 2016 autóctone em Montserrat. (254)

7 de novembro: autoridades da Argentina reportaram o primeiro caso confirmado em laboratório 2016 de síndrome congênita. (254)

11 de novembro: autoridades da França reportaram o primeiro caso confirmado em laboratório 2016 de síndrome congênita em Guadalupe. (254)

18 de novembro: Em sua quinta reunião, o Comitê de Emergência da OMS declarou encerrada 2016 a ESPII, indicando que outras ações, mais robustas, deveriam ser levadas a cabo para combater a situação.

201619 de novembro: autoridades da Bolívia reportaram o primeiro caso de SGB associada ao Zika.

2 de dezembro: Dia "D" da mobilização nacional de eliminação dos focos do Aedes Aegypti.

2016 (178)

6 de dezembro: autoridades da Nicarágua reportaram o primeiro caso confirmado em laboratório 2016 de síndrome congênita. (254)

8 de dezembro: autoridades da França reportaram o primeiro caso confirmado SGB associada ao Zika em Saint Martin, e um caso de síndrome neurológica, ambos confirmados em laboratório. (254)

Declaração do encerramento da Emergência em Saúde Pública de Importância Nacional (Espin) 
ANEXO II: Sistematização de documentos do Ministério de Relações Exteriores do Brasil

\begin{tabular}{|c|c|c|c|c|}
\hline $\mathbf{N}$ & Título da entrada & Tema & Tipo & $\begin{array}{l}\text { Jogos } \\
\text { Olímpicos? }\end{array}$ \\
\hline 1 & $\begin{array}{l}\text { Prevenção e combate - Dengue, Zika e } \\
\text { Chikungunya ... }\end{array}$ & Hotsite sobre as arboviroses & outros & Não \\
\hline 2 & $\begin{array}{l}\text { Declaração pela OMS do fim da "Emergência de } \\
\text { Saúde Pública de Preocupação Internacional" } \\
\text { associada ao vírus Zika - nota conjunta entre o } \\
\text { Ministério da Saúde e o Ministério das Relações } \\
\text { Exteriores ... } \\
\end{array}$ & $\begin{array}{l}\text { Nota conjunta entre o Ministério da Saúde e o } \\
\text { Ministério das Relações Exteriores sobre o } \\
\text { fim da ESPII }\end{array}$ & Nota conjunta MRE - MS & Não \\
\hline 3 & $\begin{array}{l}\text { Resposta ao vírus Zika no contexto dos Jogos } \\
\text { Olímpicos e Paralímpicos Rio } 2016 \ldots \\
\end{array}$ & Nota sobre a resposta do Brasil ao Zika & outros & Sim \\
\hline 4 & $\begin{array}{l}\text { Brazil handling Zika risk in advance of Olympic } \\
\text { Games (Vancouver Sun, Canadá, 18/4/2016) } \\
\text { [Inglês }] \text {... }\end{array}$ & $\begin{array}{l}\text { Nota do Embaixador Ernesto Rubarth, Cônsul- } \\
\text { Geral do Brasil em Vancouver, Canadá }\end{array}$ & Nota de Embaixador & Sim \\
\hline 5 & $\begin{array}{l}\text { Con juego colectivo venceremos al zika (El } \\
\text { Espectador, Colômbia, 31/03/2016) [Espanhol] ... }\end{array}$ & $\begin{array}{l}\text { Nota da Embaixadora do Brasil na Colômbia, } \\
\text { Maria Elisa Berenguer }\end{array}$ & Nota de Embaixador & Sim \\
\hline 6 & $\begin{array}{l}\text { Brasil da batalla contra el virus Zika (Clarín, } \\
\text { Argentina, 26/03/2016) [Espanhol] ... } \\
\end{array}$ & $\begin{array}{l}\text { Nota do Embaixador do Brasil na Argentina, } \\
\text { Everton Vargas }\end{array}$ & Nota de Embaixador & Sim \\
\hline 7 & $\begin{array}{l}\text { Zika, microcefalia y los Juegos Olímpicos y } \\
\text { Paralímpicos de 2016 (El Telégrafo, Equador, } \\
\text { 21/03/2016) [Espanhol] ... } \\
\end{array}$ & $\begin{array}{l}\text { Nota do Embaixador do Brasil no Equador, } \\
\text { Carlos Alfredo Lazary Teixeira }\end{array}$ & Nota de Embaixador & Sim \\
\hline 8 & $\begin{array}{l}\text { Brazil serious about protecting people } \\
\text { from Zika virus (Jamaica Observer, Jamaica, } \\
\text { 16/03/2016) [Inglês] ... }\end{array}$ & $\begin{array}{l}\text { Nota do Embaixador do Brasil na Jamaica, } \\
\text { Carlos Alberto M. Den Hartog }\end{array}$ & Nota de Embaixador & Sim \\
\hline 9 & $\begin{array}{l}\text { Il Brasile e il virus Zika (L'Unitá, Itália, } \\
\text { 11/03/2016) [Italiano] ... }\end{array}$ & $\begin{array}{l}\text { Nota do Embaixador do Brasil na Itália, } \\
\text { Ricardo Neiva Tavares }\end{array}$ & Nota de Embaixador & Sim \\
\hline 10 & $\begin{array}{l}\text { Engaged in fighting Zika (The Star, Malásia, } \\
\text { 11/03/2016) [Inglês] ... }\end{array}$ & $\begin{array}{l}\text { Nota do Embaixador do Brasil na Malásia e no } \\
\text { Brunei, Carlos Martins Ceglia }\end{array}$ & Nota de Embaixador & Sim \\
\hline 11 & $\begin{array}{l}\text { Brazil Plays Part In Fighting Zika (The Thursday } \\
\text { Voice, Santa Lúcia, 10/03/2016) [Inglês ] ... }\end{array}$ & $\begin{array}{l}\text { Nota do Embaixador do Brasil em Santa Lúcia, } \\
\text { Sergio Couri }\end{array}$ & Nota de Embaixador & Sim \\
\hline
\end{tabular}


¿Cómo está el gobierno de Brasil atacando el zika? (La Estrella de Panamá, Panamá, 10/03/2016)

12 Espanhol] ...

'Zika is not a new Ebola': Brazilian Ambassador combats 'misinformation' (The Sydney Morning

13 Herald, Austrália, 10/03/2016) [Inglês] ...

Brazil declares war on the Zika virus (Ma'an News 14 Arat

Agency, Palestina, 9/3/2016) [Inglês] ...

Brazilian Actions in the Global Fight Against the Zika Virus (Tehran Times, Irã, 06/03/2016)

15 [Inglês] ...

Brasil y Bolivia se unen contra el zika (La Razón,

16 Bolívia, 06/03/2016) [Espanhol] ...

O Brasil no combate contra o Zika (O Democrata,

17 Guiné-Bissau, 3/3/2016) ...

Brasil e Cabo Verde, juntos no combate

18 ao Zika (A Nação, Cabo Verde, 3/3/2016) ...

Brazília a Zika-vírus ellen (Népszabadság,

19 Hungria, 3/3/2016) [Húngaro][Português] ...

Brazil is doing its part in Zika fight (The Daily

20 Times, Malawi, 2/3/2016) [Inglês] ...

Head of the WHO praises Brazil's efforts to combat the Zika virus ahead of the Olympics

21 (Akhbar Al-Youm, Egito, 2/3/2016) [Inglês] ... Le Brésil vaincra Zika (Les Echos, França,

22 1/3/2016) [Francês] ...

Brazil Taking Extreme Precautions at Olympic Sites, Fighting Zika With U.S. Help (Global

23 Atlanta, 1/3/2016) [Inglês] ...

"Le Zika ne peut se comparer au virus de l'Ebola"

(L'Oeil du Sahel, Cameroun, 29/02/2016)

$24[$ Francês] ...
Nota do Embaixador do Brasil no Panamá, Adalnio Senna Ganem

Nota do Embaixador do Brasil na Austrália Manuel Innocencio de Lacerda Santos Jr

Nota do Embaixador Representante junto ao

Estado da Palestina, Francisco Mauro de Brasil e Holanda

Nota do Embaixador do Brasil no Irã, Santiago Irazabal Mourão

Nota do Embaixador do Brasil na Bolívia,

Raymundo Santos Rocha Magno

Nota do Embaixador do Brasil na Guiné-

Bissau, Fernando Apparicio da Silva

Nota do Embaixador do Brasil em Cabo

Verde, João Inácio Padilha

Nota do Embaixador do Brasil da Hungria, Valter Pecly Moreira

Nota do Embaixador do Brasil no Malawi, Gustavo Martins Nogueira

Nota do Embaixador no Brasil no Egito, Ruy Amaral

Nota do Embaixador do Brasil na França,

Paulo C. de Oliveira Campos

\begin{tabular}{|c|c|}
\hline Nota de Embaixador & Sim \\
\hline Nota de Embaixador & Sim \\
\hline Nota de Embaixador & Sim \\
\hline Nota de Embaixador & Sim \\
\hline Nota de Embaixador & Sim \\
\hline Nota de Embaixador & Sim \\
\hline Nota de Embaixador & Sim \\
\hline Nota de Embaixador & Sim \\
\hline Nota de Embaixador & Sim \\
\hline Nota de Embaixador & Sim \\
\hline Nota de Embaixador & Sim \\
\hline Nota de Embaixador & Sim \\
\hline Nota de Embaixador & Sim \\
\hline
\end{tabular}

Nota do Embaixador do Brasil no Cameroun,
Ney Futuro Bitencourt

Nota do Cônsul-Geral do Brasil em Atlanta, EUA, Hermano Telles Ribeiro 
Brazil's engagement in the fight against the Zika virus epidemic (Ekathimerini, Grécia,

25 29/2/2016) [Inglês] ...

Le Brésil joue sa partition dans la lutte contre

le Zika (Le Nouvelliste, Haiti, 25/02/2016)

26 [Francês] ...

Brazil pledges to fight Zika virus (MMEGI,

27 Botsuana, 25/2/2016) [Inglês] ...

Le Brésil et la lutte contre le virus Zika (La Presse,

28 Tunísia, 25/02/2016) [Francês] ...

Brazil's efforts to overcome the Zika virus (The

29 Jordan Times, Jordânia, 24/2/2016) [Inglês] ...

Brazil is doing its part in the global fight

against Zika (Gulf Times, Qatar, 24/02/2016)

30 [Inglês] ...

Acciones brasileñas en la lucha global para

combate al vírus Zika (El Mercurio, Chile,

31 23/02/2016) [Espanhol] ...

Brasil está haciendo su parte en el combate del

virus Zika (La Prensa Grafica, El Salvador,

32 22/02/2016) [Espanhol] ...

Brazil ready to confront Zika virus ahead of the

Rio Olympics Games (The Standard,Quênia,

33 21/02/2016) [Inglês] ...

Aliança contra o Zika (Diário de Notícias,

34 Portugal, 12/02/2016) ...

Brazil Is Doing Its Part in the Global Fight

Against Zika (Americas Quarterly, EUA,

35 5/2/2016) [Inglês] ...

Pronunciamento da Presidenta da República,

Dilma Rousseff, em cadeia nacional de rádio e

televisão, sobre o combate ao mosquito Aedes

aegypti, transmissor do vírus Zika - 3 de fevereiro

36 de $2016 \ldots$
Nota do Embaixador do Brasil em Atenas,

Edgard Antonio Casciano

Nota do Embaixador do Brasil no Haiti, Fernando de Mello Vidal

Nota do Embaixador do Brasil em Botsuana Ricardo Diniz

Nota do Embaixador do Brasil na Tunísia,

José Estanislau do Amaral

Nota do Embaixador do Brasil na Jordânia,

Francisco Carlos Soares Luz

Nota do Embaixador do Brasil no Qatar, Roberto Abdalla

Nota do Embaixador do Brasil no Chile,

Georges Lamazièr

\begin{tabular}{|c|c|}
\hline Nota de Embaixador & Sim \\
\hline Nota de Embaixador & Sim \\
\hline Nota de Embaixador & Sim \\
\hline Nota de Embaixador & Sim \\
\hline Nota de Embaixador & Sim \\
\hline Nota de Embaixador & Sim \\
\hline Nota de Embaixador & Não \\
\hline Nota de Embaixador & Sim \\
\hline Nota de Embaixador & Sim \\
\hline Nota de Embaixador & Sim \\
\hline Nota de Embaixador & Sim \\
\hline Pronunciamento presidencial & Não \\
\hline
\end{tabular}

Nota do Embaixador do Brasil em El Salvador, José Fiuza Neto

Nota da Embaixadora do Brasil no Quênia,

Marcela Nicodemos

Nota do Embaixador do Brasil em Portugal, Mario Vilalva

Nota do Embaixador do Brasil nos Estados Unidos, Luiz Alberto Figueiredo Machado

Pronunciamento da Presidenta da República,

Dilma Rousseff, em cadeia nacional de rádio

televisão, sobre o combate ao mosquito Aedes

aegypti, transmissor do vírus Zika -3 de

fevereiro de 2016 


\begin{tabular}{|c|c|c|c|c|}
\hline 37 & $\begin{array}{l}\text { Brasil e Reino Unido lançam Ano Conjunto de } \\
\text { Ciência e Inovação - } 27 \text { de fevereiro de } 2018 \\
\end{array}$ & $\begin{array}{l}\text { Primeiro "Ano Conjunto de Ciência e } \\
\text { Inovação" entre Brasil e Reino Unido }\end{array}$ & Outros & Não \\
\hline 38 & $\frac{\text { Calendário de eventos entre } 19 \text { e } 25 \text { de junho de }}{\underline{2017}}$ & $\begin{array}{l}\text { 22/JUN - Brasília. I Simpósio do Centro } \\
\text { Argentino-Brasileiro de Biotecnologia } \\
\text { (CBAB/CABBIO) de Temas Atuais em } \\
\text { Biotecnologia: Zika. }\end{array}$ & Calendário & NA \\
\hline 39 & $\begin{array}{l}\text { Calendário de eventos entre } 28 \text { de novembro e } 4 \\
\text { de dezembro de } 2016\end{array}$ & $\begin{array}{l}28 \text { e 29/NOV - Brasília, Brasil. Oficina } \\
\text { Regional sobre Vigilância, Controle e Manejo } \\
\text { de Zika, Dengue e Chikungunya na Região } \\
\text { Amazônica, OTCA. } \\
\text { 30/NOV a 2/DEZ - São Paulo, Brasil. Oficina } \\
\text { de Trabalho da América Latina e Caribe sobre } \\
\text { o Vírus Zika, no âmbito da Colaboração } \\
\text { Global de Pesquisa para Capacidade de Pronta } \\
\text { Reação a Doenças Infecciosas (GloPID-R). }\end{array}$ & Calendário & NA \\
\hline 40 & $\begin{array}{l}\text { "85.000 agents de sécurité déployés et les profils } \\
\text { de 400.000 personnes analysés pour assurer la } \\
\text { sécurité des JO" (Le Matin, 17/07/2016) [Francês] }\end{array}$ & $\begin{array}{l}\text { Nota do Vice-Presidente do Comitê Olímpico } \\
\text { Internacional, Nawal El Moutawakel }\end{array}$ & outros & Sim \\
\hline 41 & $\begin{array}{l}\text { Jogos Olímpicos no Brasil, um país de braços } \\
\text { abertos ao mundo (5/7/2016) }\end{array}$ & Nota do Presidente do Brasil, Michel Temer & Pronunciamento presidencial & $\operatorname{sim}$ \\
\hline 42 & $\begin{array}{l}\text { Rio } 2016 \text { and the International Olympic Day (The } \\
\text { Huffington Post, EUA, 21/6/2016) [Inglês] }\end{array}$ & $\begin{array}{l}\text { Nota embaixador do Brasil nos Estados } \\
\text { Unidos, Luiz Alberto Figueiredo Machado }\end{array}$ & Nota de Embaixador & Sim \\
\hline 43 & $\begin{array}{l}\text { "Os brasileiros sempre encontram uma solução" } \\
\text { (Berliner Morgenpost, 27/01/2016) }\end{array}$ & $\begin{array}{l}\text { Nota da Embaixadora do Brasil na Alemanha, } \\
\text { Maria Luiza Ribeiro Viotti }\end{array}$ & Nota de Embaixador & Sim \\
\hline 44 & $\begin{array}{l}\text { Virus Zica: Un défi qui será gagné (Les Éco, } \\
\text { Marrocos, 12/4/2016) [Francês] }\end{array}$ & $\begin{array}{l}\text { Nota do Embaixador do Brasil no Marrocos } \\
\text { José Humberto de Brito Cruz }\end{array}$ & Nota de Embaixador & Sim \\
\hline 45 & $\begin{array}{l}\text { Brasil y la lucha contra el Aedes Aegypti (El } \\
\text { Observador, Uruguai, 12/3/2016) [Espanhol] }\end{array}$ & $\begin{array}{l}\text { Nota do Embaixador do Brasil no Uruguai, } \\
\text { Hadil da Rocha Vianna }\end{array}$ & Nota de Embaixador & Sim \\
\hline
\end{tabular}




\begin{tabular}{|c|c|c|c|c|}
\hline 46 & $\begin{array}{l}\text { Comunicado Conjunto Brasil-Marrocos - Rabat, } \\
\underline{10 \text { de março de } 2016}\end{array}$ & $\begin{array}{l}\text { Comunicado Conjunto adotado por ocasião da } \\
\text { Visita Oficial do Ministro das Relações } \\
\text { Exteriores da República Federativa do Brasil a } \\
\text { convite do Ministro dos Negócios Estrangeiros } \\
\text { e da Cooperação do Reino do Marrocos }\end{array}$ & outros & Sim \\
\hline 47 & $\begin{array}{l}\text { Comunicat De Presă Ambasada Braziliei La } \\
\text { București (Agerpres, Romênia, 3/3/2016) } \\
\text { [Romeno][Português] }\end{array}$ & $\begin{array}{l}\text { Nota do Embaixador do Brasil na Romênia, } \\
\text { Eduardo Augusto Ibiapina de Seixas }\end{array}$ & Nota de Embaixador & Sim \\
\hline 48 & $\begin{array}{l}\frac{\text { Viagem da Presidenta da República ao Chile }-}{\text { Comunicado Conjunto }- \text { Santiago, 26 e } 27 \mathrm{de}} \\
\text { fevereiro de 2016 [Espanhol] } \\
\end{array}$ & $\begin{array}{l}\text { Comunicado Conjunto con motivo de la Visita } \\
\text { Oficial a Chile } \\
\text { de la Presidenta de la República Federativa del } \\
\text { Brasil, Dilma Rousseff }\end{array}$ & outros & Não \\
\hline 49 & $\begin{array}{l}\text { Visita da Diretora-Geral da Organização Mundial } \\
\text { da Saúde, Dra. Margaret Chan - Brasília, 23 e } 24 \\
\text { de fevereiro }\end{array}$ & $\begin{array}{l}\text { Nota sobre a Visita da Diretora-Geral da } \\
\text { Organização Mundial da Saúde, Dra. Margaret } \\
\text { Chan - Brasília, 23 e } 24 \text { de fevereiro }\end{array}$ & Nota visita OMS & Não \\
\hline
\end{tabular}


ANEXO III: Lista de notícias do Ministério da Saúde do Brasil

\begin{tabular}{|c|c|c|c|c|}
\hline $\mathbf{N}$ & Mês & Data de publicação & Tema & Título \\
\hline 1 & Janeiro & $29 / 01 / 2016$ & COMBATE AO AEDES & 13:14 - Imóveis visitados para combate ao Aedes aegypti ultrapassam 10,9 milhões \\
\hline 2 & Janeiro & & MOBILIZAÇÃO NACIONAL & 11:44 - Governo federal realiza mutirão de combate ao Aedes nos prédios públicos \\
\hline 3 & Janeiro & 28/01/2016 & COOPERAÇÃO & 18:36 - OMS afirma que Brasil tem agido rápido nas investigações do vírus Zika \\
\hline 4 & Janeiro & & AVISO DE PAUTA & $\begin{array}{l}\text { 17:24 - Ministro da Saúde se reúne com autoridades federais e estaduais para o } \\
\text { enfrentamento do Aedes aegypti }\end{array}$ \\
\hline 5 & Janeiro & $27 / 01 / 2016$ & AVISO DE PAUTA & $\begin{array}{l}\text { 19:45 - Brasil participa de debate sobre vírus Zika promovido pela Organização } \\
\text { Mundial de Saúde }\end{array}$ \\
\hline 6 & Janeiro & & BOLETIM & 12:36 - Ministério da Saúde investiga 3.448 casos suspeitos de microcefalia \\
\hline 7 & Janeiro & 22/01/2016 & MOBILIZAÇÃO & 18:47 - Seminário discute ações sobre dengue, chikungunya e zika no Piauí \\
\hline 8 & Janeiro & & COMBATE AO AEDES & 17:09 - Ministério da Saúde reforça importância das visitas domiciliares \\
\hline 9 & Janeiro & & MOBILIZAÇÃO NACIONAL & 14:57 - Ministro da Saúde inicia caravana de combate ao Aedes aegypti pelo Ceará \\
\hline 10 & Janeiro & $21 / 01 / 2016$ & AVISO DE PAUTA & $\begin{array}{l}\text { 19:11 - Ministro da Saúde participa de seminário sobre dengue, chikungunya e zika em } \\
\text { Teresina (PI) }\end{array}$ \\
\hline 11 & Janeiro & & AVISO DE PAUTA & $\begin{array}{l}\text { 19:07 - Ministro da Saúde inicia caravana nacional de mobilização ao combate do } \\
\text { Aedes aegypti pelo Ceará }\end{array}$ \\
\hline 12 & Janeiro & $20 / 01 / 2016$ & CONARES & $\begin{array}{l}\text { 18:57 - Ministro da Saúde convoca gestores estaduais e municipais para o combate ao } \\
\text { Aedes aegypti }\end{array}$ \\
\hline 13 & Janeiro & & MICROCEFALIA & 17:18 - Laboratórios ampliam em 20 vezes a capacidade para testes de Zika \\
\hline 14 & Janeiro & $18 / 01 / 2016$ & TESTAGEM & 13:22 - Saúde encomendará 500 mil testes para zika, chikungunya e dengue \\
\hline 15 & Janeiro & $15 / 01 / 2016$ & PESQUISA & 18:46 - Vacina contra zika foi tema de reunião do ministro no Butantan \\
\hline 16 & Janeiro & & AVISO DE PAUTA & 17:23 - Ministro da Saúde visita Fiocruz \\
\hline 17 & Janeiro & & VIGILÂNCIA & $\begin{array}{l}\text { 14:19 - Governo federal destina } \mathrm{R} \$ 500 \text { mi extras para combate ao Aedes aegypti e a } \\
\text { microcefalia }\end{array}$ \\
\hline 18 & Janeiro & $14 / 01 / 2016$ & AVISO DE PAUTA & 17:08 - Ministro da Saúde visita Instituto Butantan \\
\hline 19 & Janeiro & $13 / 01 / 2016$ & ASSISTÊNCIA & $\begin{array}{l}\text { 16:22 - Saúde divulga diretriz nacional para estimulação precoce de bebês com } \\
\text { microcefalia }\end{array}$ \\
\hline
\end{tabular}




\begin{tabular}{|c|c|c|c|c|}
\hline 20 & Janeiro & $12 / 01 / 2016$ & BOLETIM & 19:23 - Novos casos suspeitos de microcefalia são divulgados pelo Ministério da Saúde \\
\hline 21 & Janeiro & & VÍRUS ZIKA & $\begin{array}{l}\text { 15:50 - Centros Colaboradores ajudarão na capacitação para o cuidado aos pacientes } \\
\text { com microcefalia }\end{array}$ \\
\hline 22 & Janeiro & $08 / 01 / 2016$ & MOBILIZAÇ̃̃̃ & 12:59 - Maranhão lança plano estadual de combate ao Aedes aegypti \\
\hline 23 & Janeiro & $07 / 01 / 2016$ & MOBILIZAÇ̃̃O & 19:52 - Ministro reforça combate ao Aedes aegypti no Mato Grosso do Sul \\
\hline 24 & Janeiro & & AVISO DE PAUTA & $\begin{array}{l}\text { 18:17 - Ministro da Saúde participa do lançamento do plano de combate ao Aedes } \\
\text { aegypti em São Luís (MA) }\end{array}$ \\
\hline 25 & Janeiro & & AVISO DE PAUTA & 10:57 - Ministro reforça combate ao Aedes aegypti no Mato Grosso do Sul \\
\hline 26 & Janeiro & $05 / 01 / 2016$ & BOLETIM & 15:48 - Ministério da Saúde atualiza casos suspeitos de microcefalia \\
\hline 27 & Fevereiro & 29/02/2016 & NOTA À IMPRENSA & 20:57 - Informações sobre o Boletim Epidemiológico de Microcefalia \\
\hline 28 & Fevereiro & & VÍRUS ZIKA & 18:02 - OMS esclarece boatos sobre Zika e microcefalia \\
\hline 29 & Fevereiro & & ASSISTÊNCIA & 13:35 - Saúde faz mapeamento de assistência a bebês com microcefalia \\
\hline 30 & Fevereiro & 26/02/2016 & COMBATE AO AEDES & 16:15 - Imóveis visitados aumentam 51\% em uma semana \\
\hline 31 & Fevereiro & & ZIKA/MICROCEFALIA & 12:16 - Estudo com EUA será em 60 municípios da Paráíba \\
\hline 32 & Fevereiro & 25/02/2016 & \#ZIKAZERO & $\begin{array}{l}\text { 20:47 - Governo está fazendo tudo que é necessário para o combate ao Aedes aegypti, } \\
\text { diz ministro }\end{array}$ \\
\hline 33 & Fevereiro & 24/02/2016 & AGENDA INTERNACIONAL & 20:37 - OMS reconhece que o Brasil está preparado para enfrentar o vírus Zika \\
\hline 34 & Fevereiro & & VIGILÂNCIA & 12:54 - Curso capacitará profissionais para abordagem clínica do vírus Zika \\
\hline 35 & Fevereiro & & COOPERAÇÃ̃ & $\begin{array}{l}\text { 08:47 - Diretora-geral da OMS elogia transparência e empenho do governo brasileiro } \\
\text { no combate ao Aedes aegypti }\end{array}$ \\
\hline 36 & Fevereiro & 23/02/2016 & MICROCEFALIA & 17:27 - Casos suspeitos chegam a 4.107 em todo o país \\
\hline 37 & Fevereiro & 22/02/2016 & COMBATE AO AEDES & 14:07 - Ministério da Saúde investe $R \$ 100$ milhôes para vacina da dengue \\
\hline 38 & Fevereiro & $19 / 02 / 2016$ & INTERNACIONAL & 21:12 - Brasil vai desenvolver teste para detecção de Zika nas bolsas de sangue \\
\hline 39 & Fevereiro & & AVISO DE PAUTA & 16:47 - Ministro da Saúde encerra reunião bilateral com os EUA \\
\hline 40 & Fevereiro & & COMBATE AO AEDES & 13:26 - Ministro da Saúde visita escola em Brasília para conscientização de estudantes \\
\hline 41 & Fevereiro & & MOBILIZAÇ̃̃̃O & 10:26 - COMBATE AO AEDES: 40\% dos imóveis já foram vistoriados \\
\hline
\end{tabular}




\begin{tabular}{|c|c|c|c|c|}
\hline 42 & Fevereiro & $18 / 02 / 2016$ & COMBATE AO AEDES & 19:32 - Governo Federal mobiliza escolas para conscientização dos estudantes \\
\hline 43 & Fevereiro & & VIGILÂNCIA & 18:41 - Notificação de casos pelo vírus Zika passa a ser obrigatória no Brasil \\
\hline 44 & Fevereiro & & AVISO DE PAUTA & $\begin{array}{l}\text { 18:11 - Ministro da Saúde participa da Mobilização Nacional da Educação \#ZZikaZero } \\
\text { em Brasília (DF) }\end{array}$ \\
\hline 45 & Fevereiro & & AVISO DE PAUTA & $\begin{array}{l}\text { 10:05 - Ministro da Saúde participa de reunião bilateral com os EUA e anuncia novas } \\
\text { medidas sobre o Zika }\end{array}$ \\
\hline 46 & Fevereiro & $17 / 02 / 2016$ & BOLETIM & 11:54 - Microcefalia: casos em investigação chegam a 3.935 no país \\
\hline 47 & Fevereiro & $16 / 02 / 2016$ & COMBATE AO AEDES & $\begin{array}{l}\text { 15:08 - Brasil e EUA iniciam estudo na Paraíba sobre microcefalia associada ao vírus } \\
\text { Zika }\end{array}$ \\
\hline 48 & Fevereiro & $15 / 02 / 2016$ & AVISO DE PAUTA & $\begin{array}{l}\text { 19:21 - Ministro da Saúde se reúne com embaixadores da União Europeia para tratar do } \\
\text { vírus Zika }\end{array}$ \\
\hline 49 & Fevereiro & & MOBILIZAÇÃO & 16:49 - Mutirão dá continuidade às ações de combate ao Aedes \\
\hline 50 & Fevereiro & $13 / 02 / 2016$ & NA & 15:51 - Esclarecimento sobre o uso do larvicida pyriproxifen \\
\hline 51 & Fevereiro & $12 / 02 / 2016$ & AVISO DE PAUTA & $\begin{array}{l}\text { 19:44 - Ministério da Saúde participa do Dia Nacional de Mobilização \#ZikaZero em } \\
\text { Porto Seguro (BA) }\end{array}$ \\
\hline 52 & Fevereiro & & AVISO DE PAUTA & $\begin{array}{l}\text { 19:37 - Ministério da Saúde participa do Dia Nacional de Mobilização \#ZikaZero em } \\
\text { Colatina (ES) }\end{array}$ \\
\hline 53 & Fevereiro & & ZIKA ZERO & 19:33 - Governo Federal mobiliza 6 mil militares para combater Aedes na Bahia \\
\hline 54 & Fevereiro & & AVISO DE PAUTA & $\begin{array}{l}\text { 18:52 - Ministério da Saúde participa do Dia Nacional de Mobilização \#ZikaZero em } \\
\text { Alagoinhas (BA) }\end{array}$ \\
\hline 55 & Fevereiro & & AVISO DE PAUTA & $\begin{array}{l}\text { 18:44 - Ministério da Saúde participa do Dia Nacional de Mobilização \#ZikaZero em } \\
\text { São Gonçalo (RJ) }\end{array}$ \\
\hline 56 & Fevereiro & & AVISO DE PAUTA & $\begin{array}{l}\text { 18:39 - Ministério da Saúde participa do Dia Nacional de Mobilização \#ZikaZero em } \\
\text { São Leopoldo (RS) }\end{array}$ \\
\hline 57 & Fevereiro & & COMBATE AO AEDES & $\begin{array}{l}\text { 18:38 - Governo Federal mobiliza } 900 \text { militares no Espírito Santo para conscientizar a } \\
\text { população }\end{array}$ \\
\hline 58 & Fevereiro & & COMBATE AO AEDES & $\begin{array}{l}\text { 18:18 - Governo Federal mobiliza } 71 \text { mil militares no Rio de Janeiro para conscientizar } \\
\text { a população }\end{array}$ \\
\hline 59 & Fevereiro & & COMBATE AO AEDES & $\begin{array}{l}\text { 18:04 - Ministro da Saúde e militares vão às ruas para conscientizar a população em } \\
\text { Salvador (BA) }\end{array}$ \\
\hline 60 & Fevereiro & & COMBATE AO AEDES & 17:58 - Governo Federal mobiliza 18 mil militares no Rio Grande do Sul \\
\hline 61 & Fevereiro & & AVISO DE PAUTA & $\begin{array}{l}\text { 17:55 - Ministério da Saúde participa do Dia Nacional de Mobilização \#ZikaZero em } \\
\text { Londrina (PR) }\end{array}$ \\
\hline
\end{tabular}




\begin{tabular}{|c|c|c|c|c|}
\hline 62 & Fevereiro & & AVISO DE PAUTA & $\begin{array}{l}\text { 17:48 - Ministro da Saúde abre Dia Nacional de Mobilização \#ZikaZero em Salvador } \\
\text { (BA) }\end{array}$ \\
\hline 63 & Fevereiro & & COMBATE AO AEDES & $\begin{array}{l}\text { 17:45 - Governo Federal mobiliza } 3,7 \text { mil militares para conscientizar a população no } \\
\text { Paraná }\end{array}$ \\
\hline 64 & Fevereiro & & BOLETIM & 17:21 - Ministério da Saúde investiga 3.852 casos suspeitos de microcefalia no país \\
\hline 65 & Fevereiro & & MOBILIZAÇ̃̃̃O & 11:27 - Imóveis vistoriados para o combate ao Aedes já chegam a 23,8 milhões \\
\hline 66 & Fevereiro & $11 / 02 / 2016$ & PESQUISA VÍRUS ZIKA & 13:43 - Brasil e EUA firmam acordo para desenvolver vacina contra vírus Zika \\
\hline 67 & Fevereiro & & & 08:39 - Ministro da Saúde anuncia parceria internacional para combate ao Zika \\
\hline 68 & Fevereiro & 05/02/2016 & MOBILIZAÇÃO & 14:07 - Mais de 30\% dos imóveis já foram visitados para combate ao Aedes \\
\hline 69 & Fevereiro & & NOTA À IMPRENSA & 13:18 - Fiocruz detecta vírus ativo do Zika em saliva \\
\hline 70 & Fevereiro & & COMBATE AO AEDES & $\begin{array}{l}\text { 12:47 - Ministério da Saúde orienta foliões a realizarem vistorias em suas casas neste } \\
\text { Carnaval }\end{array}$ \\
\hline 71 & Fevereiro & $04 / 02 / 2016$ & PESQUISA VÍRUS ZIKA & 15:07 - Ministério da Saúde reforça cooperação com órgãos internacionais \\
\hline 72 & Fevereiro & $03 / 02 / 2016$ & MOBILIZAÇÃO & 18:19 - Servicicos de saúde realizam limpeza de seus prédios \\
\hline 73 & Fevereiro & & $\begin{array}{l}\text { VIGILÂNCIA } \\
\text { EPIDEMIOLÓGICA }\end{array}$ & 15:41 - Brasil oferece aos países do Mercosul treinamento para teste de Zika \\
\hline 74 & Fevereiro & & ENCONTRO INTERNACIONAL & 14:50 - Mercosul discute ações de enfrentamento ao Aedes e à microcefalia \\
\hline 75 & Fevereiro & $02 / 02 / 2016$ & BOLETIM & 19:26 - Saúde investiga 3.670 casos suspeitos de microcefalia no país \\
\hline 76 & Fevereiro & & NOTA À IMPRENSA & 18:29 - Brasil e EUA definem agenda estratégica contra o vírus Zika \\
\hline 77 & Fevereiro & & COMBATE AO AEDES & $\begin{array}{l}\text { 16:31 - Governo Federal define ações para eliminação de focos do mosquito em órgãos } \\
\text { públicos }\end{array}$ \\
\hline 78 & Fevereiro & & VIGILÂNCIA & 15:53 - Ministério da Saúde abre novo canal para auxiliar no combate ao Aedes \\
\hline 79 & Fevereiro & $01 / 02 / 2016$ & ZIKA/MICROCEFALIA & 20:05 - Nota do Ministério sobre declaração da OMS \\
\hline 80 & Fevereiro & & COMBATE AO AEDES & $\begin{array}{l}\text { 17:17 - Governo federal autoriza entrada em casas abandonadas para eliminação do } \\
\text { mosquito Aedes aegypti }\end{array}$ \\
\hline 81 & Março & $31 / 03 / 2016$ & $2^{\circ}$. CICLO & 17:51 - Estatais fazem ações de combate ao Aedes aegypti \\
\hline 82 & Março & & & 09:27 - Ministério da Saúde lança série educativa "Crianças contra Zika" \\
\hline
\end{tabular}




\begin{tabular}{|c|c|c|c|c|}
\hline 83 & Março & 29/03/2016 & BOLETIM & 17:07 - Microcefalia: Ministério da Saúde investiga 4.291 casos suspeitos no país \\
\hline 84 & Março & 28/03/2016 & AEDES AEGYPTI & 18:22 - Cidades reforçam ações de combate ao mosquito \\
\hline 85 & Março & $24 / 03 / 2016$ & OLIMPÍADAS 2016 & 16:07 - Ministério da Saúde reforça atendimento durante os Jogos Olímpicos \\
\hline 86 & Março & $23 / 03 / 2016$ & NOVAS TECNOLOGIAS & $\begin{array}{l}\text { 19:09 - Ministério da Saúde anuncia edital de } \mathrm{R} \$ 20 \text { milhões para pesquisas contra o } \\
\text { Aedes aegypti }\end{array}$ \\
\hline 87 & Março & 22/03/2016 & BOLETIM & 18:29 - Ministério da Saúde investiga 4.293 casos de microcefalia no país \\
\hline 88 & Março & & AVISO DE PAUTA & $\begin{array}{l}\text { 16:54 - Governo federal anuncia investimento em pesquisas para o combate ao Aedes } \\
\text { aegypti }\end{array}$ \\
\hline 89 & Março & 21/03/2016 & SAÚDE DA MULHER & 13:06 - Ministério libera $\mathrm{R} \$ 157,3$ mil para testes de gravidez em Goiás \\
\hline 90 & Março & & SAÚDE DA MULHER & 13:04 - Ministério libera $R \$ 352,7$ mil para testes rápidos de gravidez na Bahia \\
\hline 91 & Março & & SAÚDE DA MULHER & 13:02 - Ministério libera $R \$ 28$ mil para testes rápidos de gravidez no Acre \\
\hline 92 & Março & & SAÚDE DA MULHER & 13:01 - Ministério libera $\mathrm{R} \$ 213,1$ mil para testes rápidos de gravidez no Ceará \\
\hline 93 & Março & & SAÚDE DA MULHER & 13:00 - Ministério libera $\mathrm{R} \$ 88,2$ mil para testes rápidos de gravidez em Alagoas \\
\hline 94 & Março & & SAÚDE DA MULHER & 12:58 - Ministério libera $\mathrm{R} \$ 73$ mil para testes rápidos de gravidez no $\mathrm{DF}$ \\
\hline 95 & Março & & SAÚDE DA MULHER & 12:57 - Ministério libera $R \$ 130$ mil para testes rápidos de gravidez no Amazonas \\
\hline 96 & Março & & SAÚDE DA MULHER & 12:55 - Ministério libera $\mathrm{R} \$ 88,7$ mil para testes de gravidez no Espírito Santo \\
\hline 97 & Março & & SAÚDE DA MULHER & 12:52 - Ministério libera $\mathrm{R} \$ 70,9$ mil para testes rápidos no Mato Grosso do Sul \\
\hline 98 & Março & & SAÚDE DA MULHER & 12:50 - Ministério libera $\mathrm{R} \$ 80,8$ mil para testes de gravidez no Mato Grosso \\
\hline 99 & Março & & SAÚDE DA MULHER & 12:48 - Ministério libera R $\$ 194,5$ mil para testes de gravidez no Maranhão \\
\hline 100 & Março & & SAÚDE DA MULHER & $12: 46$ - Ministério libera $R \$ 231,2$ mil para testes rápidos de gravidez no Pará \\
\hline 101 & Março & & SAÚDE DA MULHER & 12:45 - Ministério libera $R \$ 438,5$ mil para testes de gravidez em Minas Gerais \\
\hline 102 & Março & & SAÚDE DA MULHER & - Ministério libera $R \$ 95,5$ mil para testes rápidos de gravidez \\
\hline
\end{tabular}




\begin{tabular}{|c|c|c|c|c|}
\hline 103 & Março & & SAÚDE DA MULHER & 12:42 - Ministério libera $R \$ 258,9$ mil para testes rápidos de gravidez no Paraná \\
\hline 104 & Março & & SAÚDE DA MULHER & 12:41 - Ministério libera $\mathrm{R} \$ 373,9$ mil para testes de gravidez no Rio de Janeiro \\
\hline 105 & Março & & SAÚDE DA MULHER & 12:39 - Ministério libera $\mathrm{R} \$ 237,5$ mil para testes de gravidez em Pernambuco \\
\hline 106 & Março & & SAÚDE DA MULHER & 12:38 - Ministério libera $\mathrm{R} \$ 78,8$ mil para testes rápidos no Rio Grande do Norte \\
\hline 107 & Março & & SAÚDE DA MULHER & 12:36 - Ministério libera $R \$ 80,6$ mil para testes rápidos de gravidez no Piauí \\
\hline 108 & Março & & SAÚDE DA MULHER & 12:35 - Ministério libera $\mathrm{R} \$ 44,5$ mil para testes rápidos de gravidez em Rondônia \\
\hline 109 & Março & & SAÚDE DA MULHER & 12:32 - Ministério libera $\mathrm{R} \$ 149,9$ mil para testes de gravidez em Santa Catarina \\
\hline 110 & Março & & SAÚDE DA MULHER & 12:31 - Ministério libera $\mathrm{R} \$ 53,3$ mil para testes rápidos de gravidez em Sergipe \\
\hline 111 & Março & $21 / 03 / 2016$ & SAÚDE DA MULHER & 12:29 - Ministério libera $\mathrm{R} \$ 17,8$ mil para testes rápidos de gravidez em Roraima \\
\hline 112 & Março & & SAÚDE DA MULHER & 12:27 - Ministério libera $\mathrm{R} \$ 1$ milhão para testes de gravidez em São Paulo \\
\hline 113 & Março & & SAÚDE DA MULHER & 12:25 - Ministério libera $\mathrm{R} \$ 233,9$ mil para testes rápidos no Rio Grande do Sul \\
\hline 114 & Março & & SAÚDE DA MULHER & 12:22 - Ministério libera $R \$ 41,2$ mil para testes rápidos de gravidez no Tocantins \\
\hline 115 & Março & & SAÚDE DA MULHER & 11:46 - Ministério libera $R \$ 4,8$ milhões para testes rápidos de gravidez \\
\hline 116 & Março & $18 / 03 / 2016$ & MOBILIZAÇÃO & 18:22 - Equipes de saúde continuam vistoriando imóveis para combater aedes aegypti \\
\hline 117 & Março & $16 / 03 / 2016$ & BOLETIM & 16:13 - Microcefalia: 4.268 casos suspeitos continuam em investigação \\
\hline 118 & Março & & VIGILÂNCIA & 10:49 - Saúde seleciona boas experiências de combate ao Aedes Aegypti \\
\hline 119 & Março & $11 / 03 / 2016$ & ASSISTÊNCIA & 15:47 - Curso capacitará profissionais para estimulação precoce de bebês \\
\hline 120 & Março & & SAÚDE NA ESCOLA & 13:17 - Ministro da Saúde participa de mobilização contra o Aedes aegypti em Brasília \\
\hline 121 & Março & $10 / 03 / 2016$ & COMBATE AO AEDES & 19:02 - Ministério da Saúde anuncia $R \$ 10$ milhões para pesquisas contra o vírus Zika \\
\hline 122 & Março & & MOBILIZAÇ̃̃O & 18:59 - Deputados integrarão ações de combate ao Aedes \\
\hline
\end{tabular}




\begin{tabular}{|c|c|c|c|c|}
\hline 123 & Março & $09 / 03 / 2016$ & BOLETIM & 18:02 - Saúde investiga 4.231 casos de microcefalia \\
\hline 124 & Março & & MICROCEFALIA & 17:47 - Brasil adota recomendação da OMS e reduz medida para microcefalia \\
\hline 125 & Março & & MOBILIZAÇÃO & $\begin{array}{l}\text { 16:57 - Ministro da Saúde participa de mobilização das ações de combate ao Aedes } \\
\text { aegypti em Goiás }\end{array}$ \\
\hline 126 & Março & & PRONATEC & 16:48 - Acordo com Educação amplia vagas para profissionalização em Saúde \\
\hline 127 & Março & & NOTA DE ESCLARECIMENTO & $\begin{array}{l}\text { 15:05 - Instituto Butantan não entregou documento para liberação de recursos do soro } \\
\text { da Zika }\end{array}$ \\
\hline 128 & Março & $08 / 03 / 2016$ & NOTA À IMPRENSA & 19:22 - Ministério da Saúde esclarece recomendações da OMS sobre o vírus Zika \\
\hline 129 & Março & & MOBILIZAÇÃO & $\begin{array}{l}\text { 10:41 - Saúde na Escola mobiliza } 257 \text { mil estudantes no Mato Grosso do Sul no } \\
\text { combate ao Aedes aegypti }\end{array}$ \\
\hline 130 & Março & & MOBILIZAÇÃO & $\begin{array}{l}\text { 10:37 - Saúde na Escola mobiliza } 449 \text { mil estudantes em Mato Grosso no combate ao } \\
\text { Aedes aegypti }\end{array}$ \\
\hline 131 & Março & & MOBILIZAÇÃO & $\begin{array}{l}\text { 10:31 - Saúde na Escola mobiliza } 223 \text { mil estudantes em Tocantins para o combate ao } \\
\text { Aedes aegypti }\end{array}$ \\
\hline 132 & Março & & MOBILIZAÇÃO & $\begin{array}{l}\text { 10:29 - Saúde na Escola mobiliza 1,9 milhão de estudantes em São Paulo no combate } \\
\text { ao Aedes aegypti }\end{array}$ \\
\hline 133 & Março & & MOBILIZAÇÃO & $\begin{array}{l}\text { 10:23 - Saúde na Escola mobiliza } 551 \text { mil estudantes no Piauí no combate ao Aedes } \\
\text { aegypti }\end{array}$ \\
\hline 134 & Março & & MOBILIZAÇÃO & $\begin{array}{l}\text { 10:22 - Saúde na Escola mobiliza } 485 \text { mil estudantes no Rio Grande do Norte para o } \\
\text { combate ao Aedes aegypti }\end{array}$ \\
\hline 135 & Março & & MOBILIZAÇÃO & $\begin{array}{l}\text { 10:21 - Saúde na Escola mobiliza } 644 \text { mil estudantes da Paraíba no combate ao Aedes } \\
\text { aegypti }\end{array}$ \\
\hline 136 & Março & & MOBILIZAÇÃO & $\begin{array}{l}\text { 10:20 - Saúde na Escola mobiliza 1,2 milhão de estudantes no Ceará no combate ao } \\
\text { Aedes aegypti }\end{array}$ \\
\hline 137 & Março & & MOBILIZAÇÃO & $\begin{array}{l}\text { 10:19 - Saúde na Escola mobiliza } 632 \text { mil estudantes em Goiás no combate ao Aedes } \\
\text { aegypti }\end{array}$ \\
\hline 138 & Março & & MOBILIZAÇÃO & $\begin{array}{l}\text { 10:18 - Saúde na Escola mobiliza 1,7 milhão de estudantes na Bahia no combate ao } \\
\text { Aedes aegypti }\end{array}$ \\
\hline 139 & Março & & MOBILIZAÇÃO & $\begin{array}{l}\text { 10:17 - Saúde na Escola mobiliza } 280 \text { mil estudantes no Sergipe no combate ao Aedes } \\
\text { aegypti }\end{array}$ \\
\hline 140 & Março & & MOBILIZAÇÃO & $\begin{array}{l}\text { 10:16 - Saúde na Escola mobiliza } 101 \text { mil estudantes no Distrito Federal no combate ao } \\
\text { Aedes aegypti }\end{array}$ \\
\hline 141 & Março & $08 / 03 / 2016$ & MOBILIZAÇÃO & $\begin{array}{l}\text { 10:16 - Saúde na Escola mobiliza } 964 \text { mil estudantes em Pernambuco no combate ao } \\
\text { Aedes aegypti }\end{array}$ \\
\hline 142 & Março & & MOBILIZAÇÃO & $\begin{array}{l}\text { 10:11 - Saúde na Escola mobiliza } 48 \text { mil estudantes em Roraima no combate ao Aedes } \\
\text { aegypti }\end{array}$ \\
\hline
\end{tabular}




\begin{tabular}{|c|c|c|c|c|}
\hline 143 & Março & & MOBILIZAÇÃO & $\begin{array}{l}\text { 10:10 - Saúde na Escola mobiliza 1,1 milhão de estudantes no Maranhão no combate ao } \\
\text { Aedes aegypti }\end{array}$ \\
\hline 144 & Março & & MOBILIZAÇÃO & $\begin{array}{l}\text { 10:10 - Saúde na Escola mobiliza um milhão de estudantes no Pará para o combate ao } \\
\text { Aedes aegypti }\end{array}$ \\
\hline 145 & Março & & MOBILIZAÇÃO & $\begin{array}{l}\text { 10:08 - Saúde na Escola mobiliza } 40 \text { mil estudantes no Amapá para o combate ao } \\
\text { Aedes aegypti }\end{array}$ \\
\hline 146 & Março & & MOBILIZAÇÃO & $\begin{array}{l}\text { 10:07 - Saúde na Escola mobiliza } 411 \text { mil estudantes no Amazonas para o combate ao } \\
\text { Aedes aegypti }\end{array}$ \\
\hline 147 & Março & & MOBILIZAÇÃO & $\begin{array}{l}\text { 10:06 - Saúde na Escola mobiliza } 565 \text { mil estudantes em Alagoas para o combate ao } \\
\text { Aedes aegypti }\end{array}$ \\
\hline 148 & Março & & MOBILIZAÇÃO & $\begin{array}{l}\text { 10:03 - Saúde na Escola mobiliza } 154 \text { mil estudantes em Rondônia para o combate ao } \\
\text { Aedes aegypti }\end{array}$ \\
\hline 149 & Março & & MOBILIZAÇÃO & $\begin{array}{l}\text { 10:00 - Saúde na Escola mobiliza } 91 \text { mil estudantes no Acre para o combate ao Aedes } \\
\text { aegypti }\end{array}$ \\
\hline 150 & Março & & MOBILIZAÇÃO & $\begin{array}{l}\text { 09:58 - Saúde na Escola mobiliza } 1 \text { milhão de estudantes no Rio de Janeiro no combate } \\
\text { ao Aedes aegypti }\end{array}$ \\
\hline 151 & Março & & MOBILIZAÇÃO & $\begin{array}{l}\text { 09:56 - Saúde na Escola mobiliza } 181 \text { mil estudantes no Espírito Santo no combate ao } \\
\text { Aedes aegypti }\end{array}$ \\
\hline 152 & Março & & MOBILIZAÇÃO & $\begin{array}{l}\text { 09:52 - Saúde na Escola mobiliza } 548 \text { mil estudantes no Rio Grande do Sul no combate } \\
\text { ao Aedes aegypti }\end{array}$ \\
\hline 153 & Março & & MOBILIZAÇÃO & $\begin{array}{l}\text { 09:51 - Saúde na Escola mobiliza 1,9 milhão de estudantes em Minas Gerais no } \\
\text { combate ao Aedes aegypti }\end{array}$ \\
\hline 154 & Março & & MOBILIZAÇÃO & $\begin{array}{l}\text { 09:49 - Saúde na Escola mobiliza } 547 \text { mil estudantes em Santa Catarina no combate ao } \\
\text { Aedes aegypti }\end{array}$ \\
\hline 155 & Março & & MOBILIZAÇÃO & $\begin{array}{l}\text { 09:45 - Saúde na Escola mobiliza } 948 \text { mil estudantes no Paraná no combate ao Aedes } \\
\text { aegypti }\end{array}$ \\
\hline 156 & Março & 07/03/2016 & MOBILIZAÇÃO & $\begin{array}{l}\text { 14:46 - Saúde na Escola mobiliza } 18 \text { milhões de estudantes no combate ao Aedes } \\
\text { aegypti }\end{array}$ \\
\hline 157 & Março & $04 / 03 / 2016$ & COMBATE AO AEDES & 14:49 - Visitas alcançam 88,8\% dos domicílios brasileiros \\
\hline 158 & Março & & SAÚDE DA MULHER & 12:33 - Amazonas recebe caderneta que orienta gestantes contra Aedes aegypti \\
\hline 159 & Março & & SAÚDE DA MULHER & 17:07 - Minas recebe caderneta que orienta gestantes contra Aedes aegypti \\
\hline 160 & Março & & SAÚDE DA MULHER & 17:06 - Bahia recebe caderneta que orienta gestantes contra Aedes aegypti \\
\hline 161 & Março & & SAÚDE DA MULHER & 17:03 - Pará recebe caderneta que orienta gestantes contra Aedes aegypti \\
\hline 162 & Março & & SAÚDE DA MULHER & 17:02 - Ceará recebe caderneta que orienta gestantes contra Aedes aegypti \\
\hline
\end{tabular}




\begin{tabular}{|c|c|c|c|c|}
\hline 163 & Março & & SAÚDE DA MULHER & 17:01 - Goiás recebe caderneta que orienta gestantes contra Aedes aegypti \\
\hline 164 & Março & & SAÚDE DA MULHER & 17:00 - Maranhão recebe caderneta que orienta gestantes contra Aedes aegypti \\
\hline 165 & Março & & SAÚDE DA MULHER & 16:59 - Rio de Janeiro terá caderneta que orienta gestante contra Aedes aegypti \\
\hline 166 & Março & & SAÚDE DA MULHER & 16:19 - Alagoas recebe caderneta que orienta gestantes contra Aedes aegypti \\
\hline 167 & Março & & SAÚDE DA MULHER & 16:18 - Espírito Santo terá caderneta que orienta gestante contra Aedes aegypti \\
\hline 168 & Março & & SAÚDE DA MULHER & 16:18 - Paraíba recebe caderneta que orienta gestantes contra Aedes aegypti \\
\hline 169 & Março & & SAÚDE DA MULHER & 16:16 - DF recebe caderneta que orienta gestantes contra Aedes aegypti \\
\hline 170 & Março & & SAÚDE DA MULHER & 16:15 - Mato Grosso recebe caderneta que orienta gestante contra Aedes aegypti \\
\hline 171 & Março & 03/03/2016 & SAÚDE DA MULHER & 16:14 - Piauí recebe caderneta que orienta gestantes contra Aedes aegypti \\
\hline 172 & Março & & SAÚDE DA MULHER & 16:01 - Pernambuco recebe caderneta que orienta gestante contra Aedes aegypti \\
\hline 173 & Março & & SAÚDE DA MULHER & $\begin{array}{l}\text { 16:01 - Mato Grosso do Sul recebe caderneta que orienta gestantes contra Aedes } \\
\text { aegypti }\end{array}$ \\
\hline 174 & Março & & SAÚDE DA MULHER & 15:59 - Amapá recebe caderneta que orienta gestantes contra Aedes aegypti \\
\hline 175 & Março & & SAÚDE DA MULHER & 15:58 - Acre recebe caderneta que orienta gestantes contra Aedes aegypti \\
\hline 176 & Março & & SAÚDE DA MULHER & 15:57 - Paraná recebe caderneta que orienta gestantes contra Aedes aegypti \\
\hline 177 & Março & & SAÚDE DA MULHER & 15:25 - Roraima recebe caderneta que orienta gestantes contra Aedes aegypti \\
\hline 178 & Março & & SAÚDE DA MULHER & $\begin{array}{l}\text { 15:23 - Rio Grande do Norte recebe caderneta que orienta gestantes contra Aedes } \\
\text { aegypti }\end{array}$ \\
\hline 179 & Março & & SAÚDE DA MULHER & 15:21 - Rondônia recebe caderneta que orienta gestantes contra Aedes aegypti \\
\hline 180 & Março & & SAÚDE DA MULHER & 13:29 - Rio Grande do Sul terá caderneta que orienta gestantes contra Aedes aegypti \\
\hline 181 & Março & & SAÚDE DA MULHER & 13:26 - Tocantins recebe caderneta que orienta gestantes contra Aedes aegypti \\
\hline
\end{tabular}




\begin{tabular}{|c|c|c|c|c|}
\hline 182 & Março & & SAÚDE DA MULHER & 13:24 - São Paulo recebe caderneta que orienta gestantes contra Aedes aegypti \\
\hline 183 & Março & & SAÚDE DA MULHER & 13:21 - Sergipe recebe caderneta que orienta gestantes contra Aedes aegypti \\
\hline 184 & Março & & SAÚDE DA MULHER & 13:15 - Santa Catarina recebe caderneta que orienta gestantes contra Aedes aegypti \\
\hline 185 & Março & $01 / 03 / 2016$ & INFORME & 19:40 - Saúde investiga 4.222 casos suspeitos de microcefalia no país \\
\hline 186 & Março & & NOTA À IMPRENSA & 11:34 - Informações sobre o Boletim Epidemiológico de Microcefalia \\
\hline 187 & Março & & SAÚDE DA MULHER & 11:26 - Nova caderneta da gestante orienta contra Aedes aegypti \\
\hline 188 & Abril & $29 / 04 / 2016$ & COMBATE AO AEDES & 12:51 - Estados terão mais apoio para manter ações \\
\hline 189 & Abril & $26 / 04 / 2016$ & BOLETIM & 17:36 - Saúde confirma 1.198 casos de microcefalia no país \\
\hline 190 & Abril & & BOLETIM & 17:15 - Saúde divulga primeiro balanço com casos de Zika no país \\
\hline 191 & Abril & & AVISO DE PAUTA & $\begin{array}{l}\text { 12:59 - Ministério da Saúde tira dúvidas sobre boletim epidemiológico de dengue, } \\
\text { chikungunya e Zika }\end{array}$ \\
\hline 192 & Abril & & EVENTO INTERNACIONAL & 10:57 - SUS é tema de debate durante conferência na Universidade de Harvard \\
\hline 193 & Abril & $22 / 04 / 2016$ & AEDES AEGYPTI & 11:22 - Saúde quer ampliar engajamento de gestores em ações permanentes \\
\hline 194 & Abril & $20 / 04 / 2016$ & BOLETIM & 12:50 - Microcefalia: 1.168 casos foram confirmados em todo o país \\
\hline 195 & Abril & $18 / 04 / 2016$ & COMBATE AO AEDES & 10:59 - Uma em cada cinco cidades já tem Salas de Controle \\
\hline 196 & Abril & $15 / 04 / 2016$ & COMBATE AEDES & 15:19 - Ministério da Saúde e Cufa fazem "faxinaço" nas periferias do país \\
\hline 197 & Abril & & AVISO DE PAUTA & $\begin{array}{l}\text { 13:40 - Ministério da Saúde e Cufa lançam mobilização contra ao Aedes aegypti na } \\
\text { Rocinha (RJ) }\end{array}$ \\
\hline 198 & Abril & $14 / 04 / 2016$ & MICROCEFALIA & 13:41 - CDC reconhece relação do vírus Zika e microcefalia \\
\hline 199 & Abril & $13 / 04 / 2016$ & CAPACITAÇÃO & 13:21 - Curso de Zika estará disponível para profissionais de todos os países \\
\hline 200 & Abril & $12 / 04 / 2016$ & NOVO BOLETIM & 17:49 - Saúde confirma 1.113 casos de microcefalia no país \\
\hline 201 & Abril & & COMBATE AO AEDES & 16:46 - 86,8\% de imóveis no Mato Grosso foram visitados no último mês \\
\hline 202 & Abril & & COMBATE AO AEDES & 16:45 - 98\% de imóveis no Tocantins foram visitados no último mês \\
\hline 203 & Abril & & COMBATE AO AEDES & 16:44 - 83,5\% de imóveis no Mato Grosso do Sul foram visitados no último mês \\
\hline 204 & Abril & & COMBATE AO AEDES & 16:41 - 87,7\% de imóveis em Rondônia foram visitados no último mês \\
\hline
\end{tabular}




\begin{tabular}{|c|c|c|c|c|}
\hline 205 & Abril & & COMBATE AO AEDES & 16:39 - 80,6\% de imóveis em Minas Gerais foram visitados no último mês \\
\hline 206 & Abril & & COMBATE AO AEDES & 16:38 - 95\% de imóveis no Piauí foram visitados no último mês \\
\hline 207 & Abril & & COMBATE AO AEDES & 16:36 - 75,5\% de imóveis em Goiás foram visitados no último mês \\
\hline 208 & Abril & $08 / 04 / 2016$ & COMBATE AO AEDES & 17:46 - Mais de 34 milhões de imóveis foram visitados no último mês \\
\hline 209 & Abril & $07 / 04 / 2016$ & DIA MUNDIAL DA SAÚDE & 12:21 - Ministério da Saúde reforça importância do enfrentamento ao Aedes aegypti \\
\hline 210 & Abril & $06 / 04 / 2016$ & VÍRUS ZIKA & 19:34 - Hospitais universitários capacitarão para cuidado à microcefalia \\
\hline 211 & Abril & & AVISO DE PAUTA & $\begin{array}{l}\text { 19:09 - Ministro da Saúde anuncia nova fase da pesquisa da Fiocruz contra o Aedes } \\
\text { aegypti em Niterói (RJ) }\end{array}$ \\
\hline 212 & Abril & & MOBILIZAÇÃO & 12:55 - Ministério da Saúde participa de ação contra o Aedes aegypti nas escolas \\
\hline 213 & Abril & $05 / 04 / 2016$ & MICROCEFALIA & 18:50 - Estudo aponta que $1^{\circ}$ trimestre pode ser de maior risco para grávidas \\
\hline 214 & Abril & $04 / 04 / 2016$ & COMBATE AO AEDES & 13:02 - Saúde amplia verbas para contratação de ACE \\
\hline 215 & Maio & $31 / 05 / 2016$ & ZIKA ZERO & 10:47 - Maceió recebe jogo que incentiva o combate ao Aedes aegypti \\
\hline 216 & Maio & $27 / 05 / 2016$ & AÇÕES CONJUNTAS & 16:59 - Brasil e Colômbia criam Sala de Coordenação do combate ao Aedes aegypti \\
\hline 217 & Maio & & SEMINÁRIO & 16:47 - Ministério dialoga sobre saúde pública na América Latina e Caribe \\
\hline 218 & Maio & & ZIKA ZERO & 10:58 - Aracaju recebe jogo que incentiva o combate ao Aedes aegypti \\
\hline 219 & Maio & $25 / 05 / 2016$ & GESTÃO & 17:44 - Antônio Nardi é o novo Secretário-Executivo do Ministério da Saúde \\
\hline 220 & Maio & $24 / 05 / 2016$ & BOLETIM & 18:12 - Microcefalia: Ministério da Saúde confirma 1.434 casos no país \\
\hline 221 & Maio & & OLIMPÍADAS & 15:24 - Ministro da Saúde apresenta ações para o Comitê Olímpico Internacional \\
\hline 222 & Maio & & ZIKA & 11:23 - Criada rede de especialistas para apoiar enfrentamento ao vírus \\
\hline 223 & Maio & $23 / 05 / 2016$ & ASSEMBLEIA MUNDIAL & 16:07 - Brasil investigará outras consequências do Zika em crianças \\
\hline 224 & Maio & & ZIKA ZERO & $\begin{array}{l}\text { 10:41 - Ministério da Saúde cria jogo para alertar importância de combater o Aedes } \\
\text { aegypti }\end{array}$ \\
\hline 225 & Maio & $20 / 05 / 2016$ & COMBATE AEDES & 16:09 - Vacina para Zika estará disponível para testes em novembro \\
\hline
\end{tabular}




\begin{tabular}{|c|c|c|c|c|}
\hline 226 & Maio & & COMBATE AEDES & 15:45 - Ministério da Saúde e Cufa fazem "faxinaço" nas periferias de Recife \\
\hline 227 & Maio & & COMBATE AEDES & 15:30 - Ministério da Saúde e Cufa fazem "faxinaço" nas periferias de João Pessoa \\
\hline 228 & Maio & & EVENTO INTERNACIONAL & $\begin{array}{l}\text { 15:13 - Brasil priorizará Olimpíadas e combate ao Aedes em Assembleia Mundial da } \\
\text { Saúde }\end{array}$ \\
\hline 229 & Maio & & COMBATE AEDES & 14:49 - Sala Nacional apresenta balanço de ações a deputados \\
\hline 230 & Maio & $19 / 05 / 2016$ & DOAÇÃO DE LEITE & 16:49 - Brasil reforça cooperação internacional para aleitamento materno \\
\hline 231 & Maio & & PREVENÇÃO & $\begin{array}{l}\text { 15:29 - Ministério da Saúde e Cartoon Network convocam crianças a combater o Aedes } \\
\text { aegypti }\end{array}$ \\
\hline 232 & Maio & $18 / 05 / 2016$ & SISTEMAS DE INFORMAÇÃO & 19:50 - Ministro pede engajamento de secretários de saúde \\
\hline 233 & Maio & & BOLETIM & 16:33 - Microcefalia: Ministério da Saúde confirma 1.384 casos no país \\
\hline 234 & Maio & $13 / 05 / 2016$ & COMBATE AO AEDES & 18:41 - Municípios intensificam vistorias em locais públicos \\
\hline 235 & Maio & $12 / 05 / 2016$ & VIGILÂNCIA & 16:07 - Prefeitos recebem carta de compromisso para combater Aedes aegypti \\
\hline 236 & Maio & $11 / 05 / 2016$ & BOLETIM & 11:42 - Ministério da Saúde confirma 1.326 casos de microcefalia no país \\
\hline 237 & Maio & $07 / 05 / 2016$ & COMBATE AEDES & 10:09 - Ministério da Saúde e Cufa fazem "faxinaço" nas periferias de Salvador \\
\hline 238 & Maio & & COMBATE AEDES & 10:07 - Ministério da Saúde e Cufa fazem "faxinaço" nas periferias de Aracaju \\
\hline 239 & Maio & $06 / 05 / 2016$ & COMBATE AO AEDES & 15:34 - Ações de saneamento básico deve ser prioridade \\
\hline 240 & Maio & & AVISO DE PAUTA & $\begin{array}{l}\text { 15:09 - Ministério da Saúde e Cufa realizam mobilização contra ao Aedes aegypti em } \\
\text { Aracaju (SE) }\end{array}$ \\
\hline 241 & Maio & & AVISO DE PAUTA & $\begin{array}{l}\text { 13:37 - Ministério da Saúde e Cufa realizam mobilização contra ao Aedes aegypti em } \\
\text { Salvador (BA) }\end{array}$ \\
\hline 242 & Maio & & & 12:47 - Mutirão em Anápolis se estende por todas quadras da cidade \\
\hline 243 & Maio & $04 / 05 / 2016$ & NOVO BOLETIM & 16:35 - Microcefalia: Ministério da Saúde confirma 1.271 casos no país \\
\hline 244 & Junho & $30 / 06 / 2016$ & BOLETIM & 12:40 - Casos de dengue no Brasil apresentam queda antecipada \\
\hline 245 & Junho & & BOLETIM & 11:27 - Microcefalia: 1.638 casos confirmados pelo Ministério da Saúde \\
\hline 246 & Junho & $29 / 06 / 2016$ & ESTUDO ZIKA & 19:57 - Brasil avalia mudanças no protocolo de microcefalia \\
\hline 247 & Junho & $28 / 06 / 2016$ & COMBATE & 17:50 - Sancionada lei que permite entrada forçada em imóveis contra o Aedes \\
\hline
\end{tabular}




\begin{tabular}{|c|c|c|c|c|}
\hline 248 & Junho & $22 / 06 / 2016$ & BOLETIM & 09:09 - Ministério da Saúde confirma 1.616 casos de microcefalia em todo o país \\
\hline 249 & Junho & $21 / 06 / 2016$ & VIGILÂNCIA & 18:01 - Brasil e EUA irão realizar estudo com grávidas em países com Zika \\
\hline 250 & Junho & $20 / 06 / 2016$ & ZIKA ZERO & 12:35 - Piauí recebe jogo que incentiva o combate ao Aedes aegypti \\
\hline 251 & Junho & $17 / 06 / 2016$ & INTEGRAÇÃO & 09:03 - Mercosul: Brasil reforça risco mínimo de Zika nas Olimpíadas \\
\hline 252 & Junho & $15 / 06 / 2016$ & ZIKA ZERO & 16:59 - Ceará recebe jogo que incentiva o combate ao Aedes aegypti \\
\hline 253 & Junho & & BOLETIM & 12:10 - Microcefalia: 1.581 casos confirmados em todo o país \\
\hline 254 & Junho & $14 / 06 / 2016$ & VÍRUS ZIKA & 18:55 - OMS reafirma segurança para a realização das Olimpíadas no Brasil \\
\hline 255 & Junho & & AVISO DE PAUTA & $\begin{array}{l}\text { 17:54 - Ministro da Saúde atende a imprensa sobre reunião internacional de Zika e } \\
\text { Olimpíadas }\end{array}$ \\
\hline 256 & Junho & $13 / 06 / 2016$ & OLIMPÍADAS & 18:05 - SBI divulga nota de apoio à realização dos jogos no Rio \\
\hline 257 & Junho & & TECNOLOGIA & 16:21 - Saúde acompanha avaliação de qualidade de teste rápido de Zika \\
\hline 258 & Junho & & ZIKA ZERO & 15:42 - Rio Grande do Norte recebe jogo que incentiva o combate ao Aedes aegypti \\
\hline 259 & Junho & $10 / 06 / 2016$ & AVISO DE PAUTA & 19:26 - Teste rápido de Zika da Bahiafarma é apresentado ao Ministério da Saúde \\
\hline 260 & Junho & & JOGOS OLÍMPICOS & 11:59 - Brasil apresenta redução de $87 \%$ nas notificações dos casos de Zika \\
\hline 261 & Junho & $09 / 06 / 2016$ & AVISO DE PAUTA & $\begin{array}{l}\text { 15:31 - Ministro da Saúde concede entrevista à imprensa estrangeira sobre ações para } \\
\text { os Jogos Olímpicos }\end{array}$ \\
\hline 262 & Junho & 07/06/2016 & ZIKA ZERO & 18:02 - Paraíba recebe jogo que incentiva o combate ao Aedes aegypti \\
\hline 263 & Junho & & BOLETIM & 17:35 - Saúde confirma 1.551 casos de microcefalia no país \\
\hline 264 & Junho & & OLIMPÍADAS & 09:00 - Pesquisadores brasileiros apoiam a realização dos jogos no Rio de Janeiro \\
\hline 265 & Junho & $05 / 06 / 2016$ & NOTA A IMPRENSA & 12:22 - Posicionamento sobre a reunião do comitê de emergências da OMS \\
\hline 266 & Junho & $03 / 06 / 2016$ & COMBATE AO AEDES & 18:04 - Estados manterão vistorias durante Olimpíada \\
\hline 267 & Junho & & ZIKA ZERO & 17:11 - Recife recebe jogo que incentiva o combate ao Aedes aegypti \\
\hline 268 & Junho & $02 / 06 / 2016$ & PESQUISA ZIKA & 11:50 - Governo Federal destina $R \$ 65$ milhões para pesquisas sobre o vírus Zika \\
\hline 269 & Junho & $01 / 06 / 2016$ & DIÁLOGO & 19:27 - Ministro da Saúde reafirma compromisso com o SUS \\
\hline
\end{tabular}




\begin{tabular}{|c|c|c|c|c|}
\hline 270 & Junho & & AVISO DE PAUTA & 18:43 - Governo Federal divulga edital de $\mathrm{R} \$ 65$ milhões para pesquisas de Zika \\
\hline 271 & Junho & & BOLETIM & 15:21 - Ministério da Saúde confirma 1.489 casos de microcefalia no país \\
\hline 272 & Julho & $29 / 07 / 2016$ & OLIMPÍADAS & 18:21 - Ministério da Saúde ativa centro de monitoramento em saúde \\
\hline 273 & Julho & $27 / 07 / 2016$ & BOLETIM & 18:20 - Microcefalia: 1.749 casos confirmados no Brasil \\
\hline 274 & Julho & $26 / 07 / 2016$ & VIGILÂNCIA & 09:20 - Eliminação do sarampo no Brasil tem reconhecimento internacional \\
\hline 275 & Julho & $25 / 07 / 2016$ & COMBATE AO AEDES & 17:16 - Inscrições para pesquisas sobre o Zika são prorrogadas até 10 de agosto \\
\hline 276 & Julho & $21 / 07 / 2016$ & PESQUISA ZIKA & 17:25 - Nota sobre mosquito Culex \\
\hline 277 & Julho & 20/07/2016 & BOLETIM & 16:55 - Ministério da Saúde confirma 1.709 casos de microcefalia \\
\hline 278 & Julho & $15 / 07 / 2016$ & AEDES AEGYPTI & 12:00 - Sala Nacional de Coordenação e Controle continuará ações de combate \\
\hline 279 & Julho & $14 / 07 / 2016$ & ASSISTÊNCIA & $\begin{array}{l}\text { 15:39 - Famílias com casos de microcefalia terão prioridade no Minha Casa, Minha } \\
\text { Vida }\end{array}$ \\
\hline 280 & Julho & $13 / 07 / 2016$ & BOLETIM & $\begin{array}{l}\text { 16:49 - Mais de } 60 \% \text { dos casos suspeitos de microcefalia estão com investigação } \\
\text { concluída }\end{array}$ \\
\hline 281 & Julho & $12 / 07 / 2016$ & OLIMPÍADAS & 19:28 - Ministro fala a embaixadores sobre ações de combate ao Aedes \\
\hline 282 & Julho & $11 / 07 / 2016$ & JOGOS OLÍMPICOS & 17:14 - Ministério da Saúde lança novo portal Saúde do Viajante \\
\hline 283 & Julho & $07 / 07 / 2016$ & BOLETIM & 17:38 - Ministério da Saúde confirma 1.656 casos de microcefalia \\
\hline 284 & Julho & $06 / 07 / 2016$ & TRANSPARÊNCIA & 17:11 - Ministro apresenta ações de gestão e promoção à saúde a senadores \\
\hline 285 & Julho & $04 / 07 / 2016$ & ASSISTENNCIA & 16:59 - Ministro visita unidades de saúde em Pernambuco \\
\hline 286 & Julho & $01 / 07 / 2016$ & INFORME À IMPRENSA & 16:02 - Nota sobre achado em fetos com malformação \\
\hline 287 & Agosto & $24 / 08 / 2016$ & ENFRENTAMENTO & 10:41 - Oficina debate desafios e lições do combate ao Aedes aegypti \\
\hline 288 & setembro & $29 / 09 / 2016$ & COMBATE AO AEDES & 17:20 - Amapá faz mutirão para recolher pneus \\
\hline 290 & setembro & $28 / 09 / 2016$ & COMBATE AO AEDES & 15:33 - Paraíba faz mutirão para recolher pneus \\
\hline 291 & setembro & $27 / 09 / 2016$ & COMBATE AO AEDES & 15:13 - Rio de Janeiro faz mutirão para recolher pneus \\
\hline 292 & setembro & & COMBATE AO AEDES & 15:10 - São Paulo faz mutirão para recolher pneus \\
\hline 293 & setembro & & COMBATE AO AEDES & 14:49 - Pará faz mutirão para recolher pneus \\
\hline 294 & setembro & $26 / 09 / 2016$ & INTERNACIONAL & 19:25 - Assinada renovação do Mais Médicos em reunião da OPAS \\
\hline 295 & setembro & & COMBATE AO AEDES & 16:41 - Bahia promove mutirão para recolher pneus \\
\hline 296 & setembro & $23 / 09 / 2016$ & COMBATE AO AEDES & $\begin{array}{l}\text { 16:18 - Rio Grande do Norte faz mutirão para recolher pneus e prevenir possíveis focos } \\
\text { do mosquito }\end{array}$ \\
\hline 297 & setembro & $20 / 09 / 2016$ & COMBATE AO AEDES & 16:07 - Sergipe faz mutirão para recolher pneus \\
\hline
\end{tabular}




\begin{tabular}{|c|c|c|c|c|}
\hline 298 & setembro & & COMBATE AO AEDES & 16:06 - Piauí faz mutirão para recolher pneus \\
\hline 299 & setembro & $16 / 09 / 2016$ & VÍRUS ZIKA & 16:20 - Estudo reforça relação do Zika com casos de microcefalia \\
\hline 300 & setembro & $14 / 09 / 2016$ & COMBATE AO AEDES & 15:34 - Mutirão recolhe pneus para eliminar criadouros do mosquito \\
\hline 301 & setembro & $02 / 09 / 2016$ & BALANCCO OLIMPÍADAS & 16:51 - Saúde registrou 11.235 atendimentos nos Jogos Olímpicos \\
\hline 302 & outubro & $26 / 10 / 2016$ & GESTÃO & 16:45 - Ministro apresenta balanço na Câmara dos deputados \\
\hline 303 & outubro & $25 / 10 / 2016$ & COMBATE AO AEDES & 18:52 - Ministério da Saúde vai distribuir teste rápido de Zika \\
\hline 304 & outubro & & AVISO DE PAUTA & 14:44 - Ministério anuncia nova ação para enfrentar o vírus Zika \\
\hline 305 & outubro & $17 / 10 / 2016$ & PRÓ-RESIDÊNCIA & 12:57 - Ministério da Saúde vai financiar mais 1 mil bolsas de residência \\
\hline 306 & novembro & $30 / 11 / 2016$ & COMBATE AO AEDES & 16:14 - Especialistas se reúnem para discutir pesquisas sobre vírus Zika \\
\hline 307 & novembro & $29 / 11 / 2016$ & MOBILIZAÇÃO NACIONAL & 13:07 - Saúde convoca estados para combater o mosquito \\
\hline 308 & novembro & $28 / 11 / 2016$ & AVISO DE PAUTA & $\begin{array}{l}\text { 19:50 - Ministro da Saúde convoca todos os estados para combate ao mosquito Aedes } \\
\text { aegypti }\end{array}$ \\
\hline 309 & novembro & $25 / 11 / 2016$ & REFORÇO & 16:55 - Fiocruz recebe $\mathrm{R} \$ 23$ milhões do BNDES para combate ao Zika \\
\hline 310 & novembro & & MOBILIZAÇÃO & $\begin{array}{l}\text { 14:23 - São Paulo registra } 28 \text { municípios em situação de alerta de surto de dengue, } \\
\text { chikungunya e zika }\end{array}$ \\
\hline 311 & novembro & & MOBILIZAÇÃO & $\begin{array}{l}\text { 14:18 - Tocantins registra quatro municípios em situação de alerta de surto de dengue, } \\
\text { chikungunya e zika }\end{array}$ \\
\hline 312 & novembro & & MOBILIZAÇ̃̃O & $\begin{array}{l}\text { 14:12 - Sergipe registra } 29 \text { municípios em situação de alerta ou risco de surto de } \\
\text { dengue, chikungunya e zika }\end{array}$ \\
\hline 313 & novembro & & MOBILIZAÇÃO & $\begin{array}{l}\text { 14:11 - Rio Grande do Sul registra nove municípios em situação de alerta ou risco de } \\
\text { surto de dengue, chikungunya e zika }\end{array}$ \\
\hline 314 & novembro & & MOBILIZAÇÃO & $\begin{array}{l}\text { 14:06 - Santa Catarina tem quatro municípios em situação satisfatória quanto a surto de } \\
\text { dengue, chikungunya e zika }\end{array}$ \\
\hline 315 & novembro & & MOBILIZAÇÃO & $\begin{array}{l}\text { 14:05 - Roraima registra } 10 \text { municípios em situação de alerta ou risco de surto de } \\
\text { dengue, chikungunya e zika }\end{array}$ \\
\hline 316 & novembro & & MOBILIZAÇÃO & $\begin{array}{l}\text { 14:04 - Rondônia registra } 17 \text { municípios em situação de alerta ou risco de surto de } \\
\text { dengue, chikungunya e zika }\end{array}$ \\
\hline 317 & novembro & & MOBILIZAÇÃO & $\begin{array}{l}\text { 14:01 - Rio Grande do Norte registra } 21 \text { municípios em situação de alerta ou risco de } \\
\text { surto de dengue, chikungunya e zika }\end{array}$ \\
\hline 318 & novembro & & MOBILIZAÇÃO & $\begin{array}{l}\text { 14:00 - Rio de Janeiro registra } 20 \text { municípios em situação de alerta ou risco de surto de } \\
\text { dengue, chikungunya e zika }\end{array}$ \\
\hline 319 & novembro & & MOBILIZAÇ̃̃O & $\begin{array}{l}\text { 13:59 - Pernambuco registra } 105 \text { municípios em situação de alerta ou risco de surto de } \\
\text { dengue, chikungunya e zika }\end{array}$ \\
\hline
\end{tabular}




\begin{tabular}{|c|c|c|c|c|}
\hline 320 & novembro & & MOBILIZAÇÃO & $\begin{array}{l}\text { 13:58 - Paraíba registra } 71 \text { municípios em situação de alerta ou risco de surto de } \\
\text { dengue, chikungunya e zika }\end{array}$ \\
\hline 321 & novembro & & MOBILIZAÇÃO & $\begin{array}{l}\text { 13:41 - Minas Gerais registra } 80 \text { municípios em situação de alerta ou risco de surto de } \\
\text { dengue, chikungunya e zika }\end{array}$ \\
\hline 322 & novembro & & MOBILIZAÇÃO & $\begin{array}{l}\text { 13:35 - Pará registra } 39 \text { municípios em situação de alerta ou risco de surto de dengue, } \\
\text { chikungunya e zika }\end{array}$ \\
\hline 323 & novembro & & MOBILIZAÇÃO & $\begin{array}{l}\text { 13:33 - Maranhão registra } 33 \text { municípios em situação de alerta ou risco de surto de } \\
\text { dengue, chikungunya e zika }\end{array}$ \\
\hline 324 & novembro & & MOBILIZAÇÃO & $\begin{array}{l}\text { 13:32 - Mato Grosso registra } 19 \text { municípios em situação de alerta ou risco de surto de } \\
\text { dengue, chikungunya e zika }\end{array}$ \\
\hline 325 & novembro & & MOBILIZAÇÃO & $\begin{array}{l}\text { 13:31 - Mato Grosso do Sul registra } 10 \text { municípios em situação de alerta ou risco de } \\
\text { surto de dengue, chikungunya e zika }\end{array}$ \\
\hline 326 & novembro & & MOBILIZAÇÃO & 13:15 - Brasília não apresenta risco de surto de dengue, chikungunya e zika \\
\hline 327 & novembro & & MOBILIZAÇÃO & $\begin{array}{l}\text { 13:13 - Paraná registra } 68 \text { municípios em situação de alerta e risco de surto de dengue, } \\
\text { chikungunya e zika }\end{array}$ \\
\hline 328 & novembro & & MOBILIZAÇÃO & $\begin{array}{l}\text { 13:12 - Piauí registra dez municípios em situação de alerta de surto de dengue, } \\
\text { chikungunya e zika }\end{array}$ \\
\hline 329 & novembro & & MOBILIZAÇÃO & $\begin{array}{l}\text { 13:10 - Goiás registra } 17 \text { municípios em situação de alerta de surto de dengue, } \\
\text { chikungunya e zika }\end{array}$ \\
\hline 330 & novembro & & MOBILIZAÇÃO & $\begin{array}{l}\text { 13:08 - Bahia registra } 165 \text { municípios em situação de alerta ou risco de surto de dengue, } \\
\text { chikungunya e zika }\end{array}$ \\
\hline 331 & novembro & & MOBILIZAÇÃO & $\begin{array}{l}\text { 13:06 - Alagoas registra } 24 \text { municípios em situação de alerta ou risco de surto de } \\
\text { dengue, chikungunya e zika }\end{array}$ \\
\hline 332 & novembro & & MOBILIZAÇÃO & $\begin{array}{l}\text { 13:03 - Espírito Santo registra } 10 \text { municípios em situação de alerta ou risco de surto de } \\
\text { dengue, chikungunya e zika }\end{array}$ \\
\hline 333 & novembro & & MOBILIZAÇÃO & $\begin{array}{l}\text { 13:02 - Amazonas registra nove municípios em situação de alerta ou risco de surto de } \\
\text { dengue, chikungunya e zika }\end{array}$ \\
\hline 334 & novembro & & MOBILIZAÇÃO & $\begin{array}{l}\text { 13:00 - Ceará registra } 46 \text { municípios em situação de alerta ou risco de surto de dengue, } \\
\text { chikungunya e zika }\end{array}$ \\
\hline 335 & novembro & & MOBILIZAÇÃO & $\begin{array}{l}\text { 12:58 - Amapá registra um município em situação de alerta de surto de dengue, } \\
\text { chikungunya e zika }\end{array}$ \\
\hline 336 & novembro & $25 / 11 / 2016$ & MOBILIZAÇÃO & $\begin{array}{l}\text { 12:56 - Acre registra } 10 \text { municípios em situação de alerta ou risco de surto de dengue, } \\
\text { chikungunya e zika }\end{array}$ \\
\hline 337 & novembro & $24 / 11 / 2016$ & MOBILIZAÇÃO & 14:05 - Ministério da Saúde convoca sociedade para combate ao mosquito \\
\hline 338 & novembro & $23 / 11 / 2016$ & AVISO DE PAUTA & $\begin{array}{l}\text { 19:22 - Ministério da Saúde lança campanha de combate ao Aedes e atualização do } \\
\text { LIRAa } 2016\end{array}$ \\
\hline
\end{tabular}




\begin{tabular}{|c|c|c|c|c|}
\hline 339 & novembro & $21 / 11 / 2016$ & PROTEÇÃO & 16:56 - Ministério da Saúde lança edital do pregão para a compra de repelentes \\
\hline 340 & novembro & $18 / 11 / 2016$ & ENFRENTAMENTO AO ZIKA & 12:31 - Saúde amplia acesso a diagnóstico e cuidado das gestantes e bebês \\
\hline 341 & novembro & $17 / 11 / 2016$ & AVISO DE PAUTA & 18:13 - Saúde anuncia ações de cuidado a gestantes e bebês afetados pelo Zika \\
\hline 342 & novembro & $09 / 11 / 2016$ & 10 E 11 DE NOVEMBRO & $\begin{array}{l}\text { 15:50 - } 287^{\text {a }} \text { Reunião Ordinária do Conselho Nacional de Saúde será transmitida ao } \\
\text { vivo }\end{array}$ \\
\hline 343 & novembro & $03 / 11 / 2016$ & MOBILIZAÇÃO & 19:48 - Toda sexta-feira será o dia de combate ao Aedes aegypti \\
\hline 344 & dezembro & $30 / 12 / 2016$ & AEDES AEGYPTI & $\begin{array}{l}\text { 16:35 - Ministério da Saúde convoca o cidadão para que no novo ano o combate ao } \\
\text { mosquito faça parte da rotina }\end{array}$ \\
\hline 345 & dezembro & & DENGUE/ZIKA/CHIKUNGUNYA & $\begin{array}{l}\text { 16:02 - Ministério da Saúde repassa R } \$ 152 \text { milhões de recurso adicional para combate } \\
\text { ao Aedes }\end{array}$ \\
\hline 346 & dezembro & $23 / 12 / 2016$ & \#MOSQUITONÃO & 17:45 - Toda sexta-feira é dia de faxina contra o Aedes aegypti \\
\hline 347 & dezembro & & TRATAMENTO & 12:24 - Saúde publica novo guia de manejo clínico para chikungunya \\
\hline 348 & dezembro & $21 / 12 / 2016$ & PREVENÇÃO & 13:04 - Distrito Federal inicia teste da vacina contra dengue \\
\hline 349 & dezembro & $16 / 12 / 2016$ & INCENTIVO À CIÊNCIA & $\begin{array}{l}\text { 16:01 - Ministério lança publicações com opções para o enfrentamento de problemas } \\
\text { saúde }\end{array}$ \\
\hline 350 & dezembro & $09 / 12 / 2016$ & PROTEÇÃO & 16:57 - Ministério da Saúde finaliza pregão para compra de repelentes \\
\hline 351 & dezembro & & TECNOLOGIA & 13:32 - Brasil ganha centro para produção de insumos e medicamentos biológicos \\
\hline 352 & dezembro & $02 / 12 / 2016$ & MOBILIZAÇÃO NACIONAL & 12:14 - Governo Federal une esforços no combate ao mosquito \\
\hline 353 & dezembro & $01 / 12 / 2016$ & AVISO DE PAUTA & $\begin{array}{l}\text { 20:11 - Ministério da Saúde convoca população para combater o mosquito no Distrito } \\
\text { Federal }\end{array}$ \\
\hline 354 & dezembro & & AVISO DE PAUTA & 18:33 - Ministro da Saúde convoca população para combater o mosquito \\
\hline
\end{tabular}


ANEXO IV: Lista de documentos do Mercado Comum do Sul

\begin{tabular}{|c|c|c|c|c|c|}
\hline Instância & Documento & Data & $\begin{array}{l}\text { Países e outros } \\
\text { participantes }\end{array}$ & PPT & Zika/Microcefalia/Malformações Congênitas \\
\hline $\begin{array}{l}\text { Reunião dos } \\
\text { Ministros de Saúde } \\
\text { (RMS) }\end{array}$ & $\begin{array}{l}\text { MERCOSUR/RMS/ACTA No } 01 / 16 \text { : II REUNIÓN EXTRAORDINARIA } \\
\text { DE MINISTROS DE SALUD }\end{array}$ & 03.02 .2016 & $\begin{array}{l}\text { Argentina, Brasil, } \\
\text { Paraguai, } \\
\text { Uruguai, } \\
\text { Venezuela } \\
\text { Chile, Colômbia, } \\
\text { equador, Peru e } \\
\text { Suriname } \\
\text { Costa Rica, } \\
\text { México, } \\
\text { República } \\
\text { Dominicana } \\
\\
\text { ISAGS/UNASU } \\
\text { L, OPAS e } \\
\text { ORAS-CONHU }\end{array}$ & Uruguai & $\begin{array}{l}\text { A OPAS e o Brasil fizeram apresentações sobre a situação } \\
\text { epidemiológica da região e do país, respectivamente e as delegações } \\
\text { acordaram ser pertinente trocar experiências e informações das } \\
\text { investigações feitas pelo Brasil. } \\
\text { Os países firmaram a "Declaración de las Ministras y Ministros de } \\
\text { Salud del MERCOSUR y Estados Asociados ante la Grave Situación } \\
\text { Epidemiológica determinada por Enfermedades Transmitidas por el } \\
\text { Aedes Aegypti: Dengue, Zika y chikungunya". }\end{array}$ \\
\hline $\begin{array}{l}\text { Reunião dos } \\
\text { Ministros de Saúde } \\
\text { (RMS) }\end{array}$ & $\begin{array}{l}\text { ANEXO: } \\
\text { 65566_RMS_2017_ACTA01_ANE06_ES_PresenEstadoEpidemiologicoR } \\
\text { MS 16-06-2017-v4 - AR_d }\end{array}$ & 03.02 .2016 & $\begin{array}{l}\text { Apresentação } \\
\text { PPTU }\end{array}$ & Uruguai & $\begin{array}{l}\text { Apresentação do relatório epidemiológico da região de acordo com } \\
\text { os critérios MERCOSUL sobre o vetor Aedes Aegypti e doenças por } \\
\text { ele transmitidas: coloca como principais desafios a preparação dos } \\
\text { países, capacitação de recursos humanos, preparação dos serviços de } \\
\text { saúde e o impacto sobre a população e serviços de saúde } \\
\text { (especificamente sobre Zika, trata de microcefalia e doenças } \\
\text { neurológicas comoa SGB), fortalecer a vigiância das malformações } \\
\text { congênitas e doenças neurológicas e o desenvolvimento de uma } \\
\text { resposta integral. }\end{array}$ \\
\hline $\begin{array}{l}\text { Reunião dos } \\
\text { Ministros de Saúde } \\
\text { (RMS) }\end{array}$ & $\begin{array}{l}\text { ANEXO: 60879_RMS_2016_ACTA01- } \\
\text { Ext_ANE05_ES_PresentaciónZikaMicrocefaliaBrasil_d }\end{array}$ & 03.02 .2016 & $\begin{array}{l}\text { Apresentação } \\
\text { Brasil }\end{array}$ & Uruguai & $\begin{array}{l}\text { A apresentação do Brasil sobre sua situação epidemiológica } \\
\text { apresenta a relação entre o Zika e a microcefalia como uma } \\
\text { possibilidade, a pesar de se referir à presença do vírus no líquido } \\
\text { amniótico, sengue e tecidos atestadas por laboratórios de referência } \\
\text { no país. } \\
\text { Consta também as duas iniciativas apoiadas pelo Ministério da } \\
\text { Saúde para o desenvolvimento de vacinas contra o Zika: Bio- } \\
\text { manguinhos (IEC, Universidade do Texas e GSK) e Instituto } \\
\text { Butantan (NIH e USP) }\end{array}$ \\
\hline
\end{tabular}




\begin{tabular}{|c|c|c|c|c|c|}
\hline $\begin{array}{l}\text { Reunião dos } \\
\text { Ministros de Saúde } \\
\text { (RMS) }\end{array}$ & $\begin{array}{l}\text { ANEXO: 60878_RMS_2016_ACTA01- } \\
\text { Ext_ANE04_ES_PresentacionSituacionZycaAmericas_d }\end{array}$ & 03.02 .2016 & $\begin{array}{l}\text { Apresentação } \\
\text { OPAS }\end{array}$ & Uruguai & $\begin{array}{l}\text { Apresenta uma associação temporal e espacial entre os casos de Zika } \\
\text { e o aumento dos casos de miceocefalia no Nordeste do Brasol, região } \\
\text { que tem o Aedes Aegypit com circulação endêmica, mas cuja } \\
\text { populaão não tinha imunidade para o vírus. } \\
\text { Tratata a relação causal como provável, citando os achados de } \\
\text { laboratório. } \\
\text { Faz recomendações para a região como: fazer controle vetorial com } \\
\text { um enfoque multisetorial, com enfoque na participação da } \\
\text { população; o fortalecimento dos sistemas de vigilância tanto para as } \\
\text { arboviroses, como para doenças neurológicas e a SGB; preparação } \\
\text { para que os serviços de saúde possam receber os casos e ações de } \\
\text { comunicação. } \\
\text { Apresenta, ainda, definiçõos de caso suspeito, conirmado e } \\
\text { descartado para a vigilância de nascidos vivos com microcefalia } \\
\text { associada ao Zika. }\end{array}$ \\
\hline $\begin{array}{l}\text { Reunião dos } \\
\text { Ministros de Saúde } \\
\text { (RMS) }\end{array}$ & $\begin{array}{l}\text { Declaración de las Ministras y Ministros de Salud del Mercosur y estados } \\
\text { Asociados antes la grave situación epidemiológica determinada por } \\
\text { enfermedades transmitidas por el Aedes Aegypti: Dengue, Chikungunya y } \\
\text { Zika }\end{array}$ & 03.02 .2016 & $\begin{array}{l}\text { Argentina, Brasil, } \\
\text { Paraguai, } \\
\text { Uruguai, } \\
\text { Venezuela } \\
\text { Chile, Colômbia, } \\
\text { equador, Peru e } \\
\text { Suriname } \\
\\
\text { Costa Rica, } \\
\text { México, } \\
\text { República } \\
\text { Dominicana }\end{array}$ & Uruguai & \\
\hline $\begin{array}{l}\text { Reunião dos } \\
\text { Ministros de Saúde } \\
\text { (RMS) }\end{array}$ & $\begin{array}{l}\text { MERCOSUR/RMS/ACTA N } N^{\circ} 02 / 15 \\
\text { Corr.1 } \\
\text { XXXVIII REUNIÓN DE MINISTROS DE SALUD }\end{array}$ & 13.11 .2015 & $\begin{array}{l}\text { Argentina, Brasil, } \\
\text { Paraguai, } \\
\text { Uruguai, } \\
\text { Venezuela } \\
\\
\text { Bolívia,Chile, } \\
\text { Peru e Suriname } \\
\text { OPAS }\end{array}$ & Paraguai & $\begin{array}{l}\text { Não existe menç̃o sobre Zika ou microcefalia ou malformações } \\
\text { congênitas associadas na ata. }\end{array}$ \\
\hline
\end{tabular}




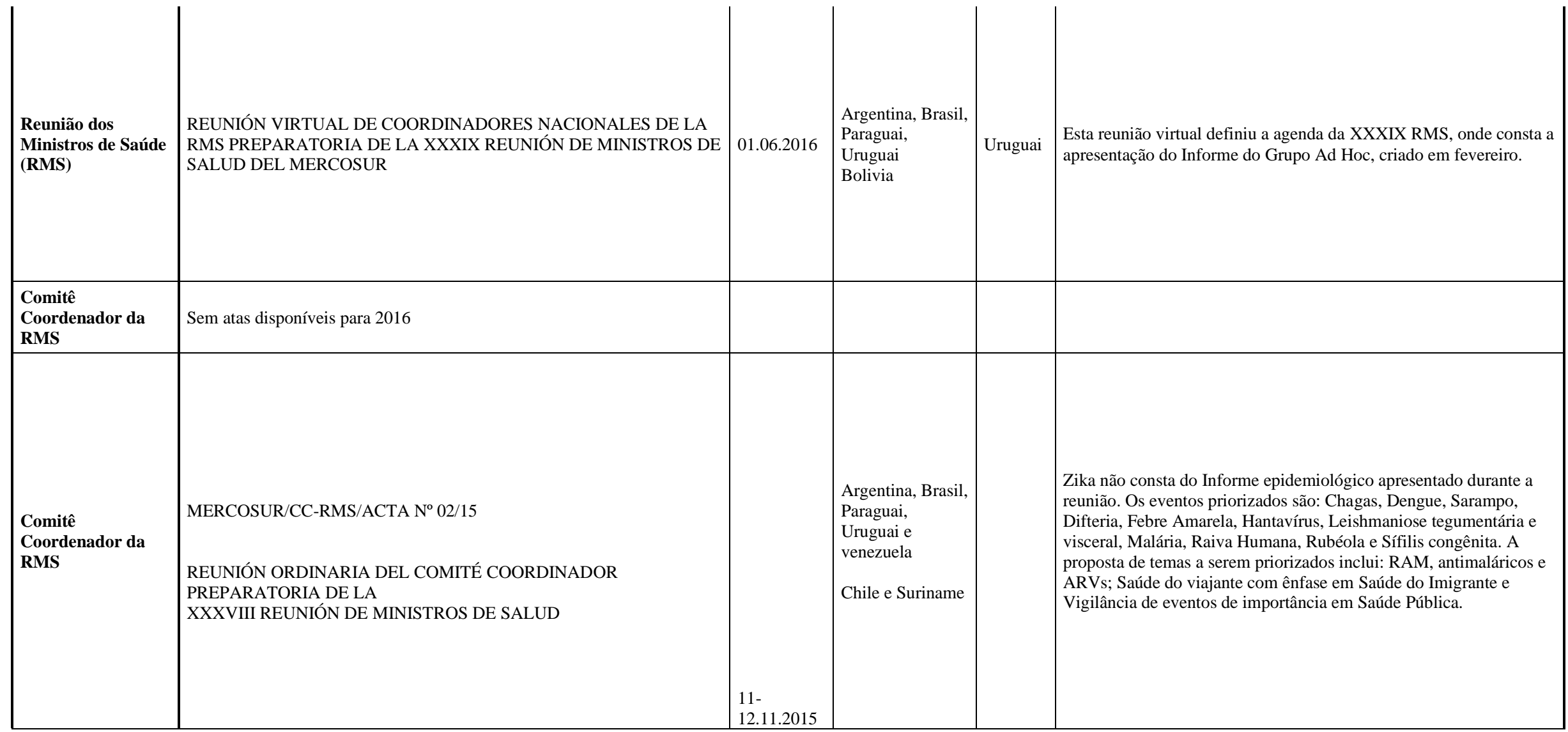




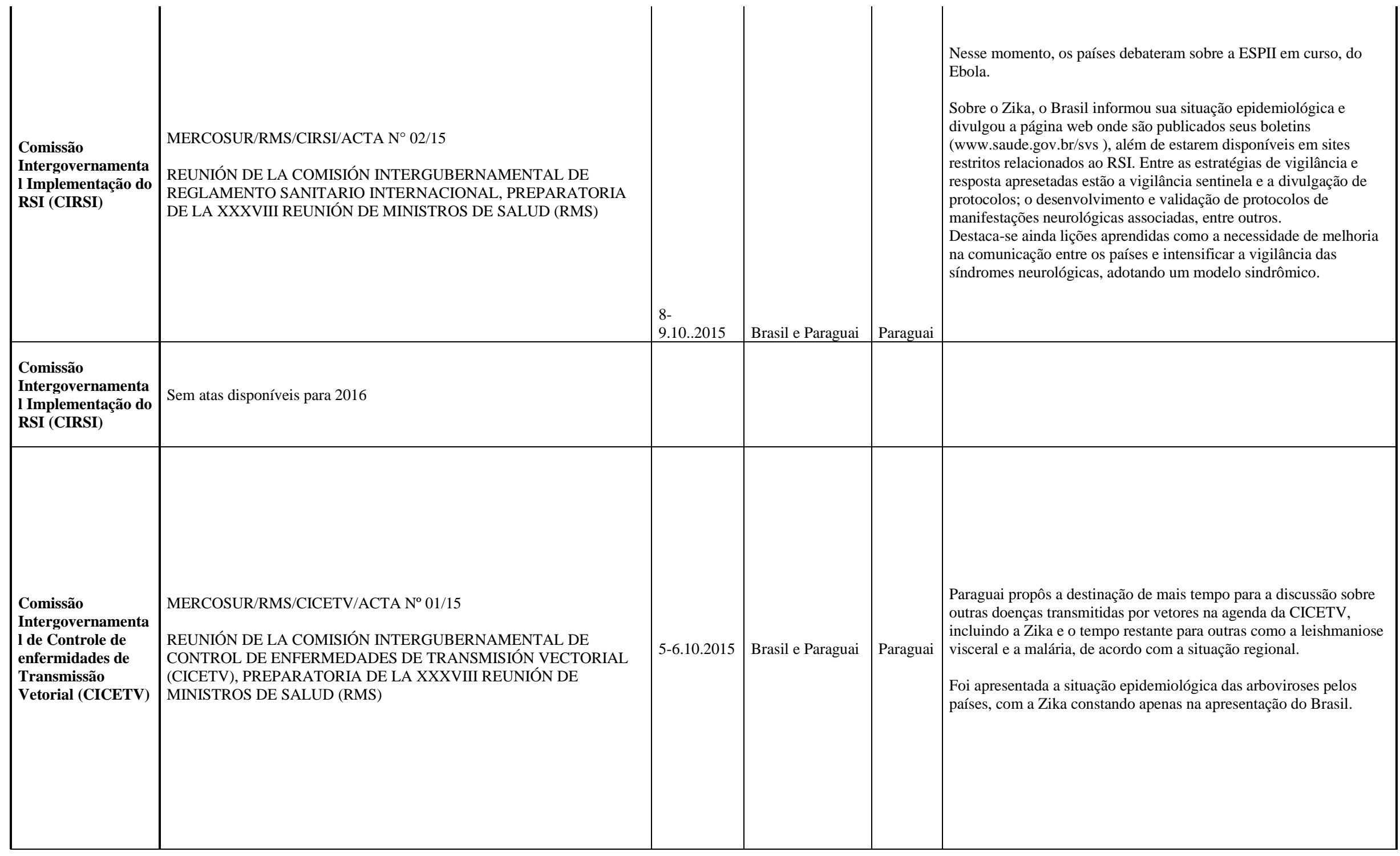




\begin{tabular}{|c|c|c|c|c|c|}
\hline $\begin{array}{l}\text { Comissão } \\
\text { Intergovernamenta } \\
\text { I de Controle de } \\
\text { enfermidades de } \\
\text { Transmissão } \\
\text { Vetorial (CICETV) }\end{array}$ & Sem atas disponíveis para 2016 & & & & \\
\hline $\begin{array}{l}\text { Comissão } \\
\text { Intergovernamenta } \\
\text { I Saúde Sexual e } \\
\text { Reprodutiva } \\
\text { (CISSR) }\end{array}$ & Sem atas disponíveis para 2016 & & & & \\
\hline $\begin{array}{l}\text { Comissão } \\
\text { Intergovernamenta } \\
\text { I de Determinantes } \\
\text { Sociais de Saúde e e } \\
\text { Sistemas de Saúde } \\
\text { (CIDSS) }\end{array}$ & Sem atas disponíveis para 2016 & & & & \\
\hline $\begin{array}{l}\text { Subgrupo de } \\
\text { Trabalho no } 11 \\
\text { Saúde (SGT 11) }\end{array}$ & $\begin{array}{l}\text { MERCOSUR/SGT No } 11 / \text { ACTA No } 02 / 15 \\
\text { XLIV REUNIÓN ORDINARIA DEL SUBGRUPO DE TRABAJO No } 11 \\
\text { "SALUD" }\end{array}$ & $5-9.10 .2015$ & $\begin{array}{l}\text { Brasil, Paraguai, } \\
\text { Uruguai, } \\
\text { Venezuela }\end{array}$ & Paraguai & $\begin{array}{l}\text { Não existe menção sobre Zika ou microcefalia ou malformações } \\
\text { congênitas associadas na ata. }\end{array}$ \\
\hline $\begin{array}{l}\text { Comissão de } \\
\text { Vigilância da } \\
\text { Saúde (COVIGSA } \\
\text { L) }\end{array}$ & $\begin{array}{l}\text { XLIV REUNIÓN ORDINARIA DE SGT No } 11 \text { "SALUD"/ COMISIÓN } \\
\text { DE VIGILANCIA EN SALUD "COVIGSAL" /ACTA No } 02 / 15\end{array}$ & $5-7.10 .2015$ & $\begin{array}{l}\text { Brasil, Paraguai, } \\
\text { Uruguai, } \\
\text { Venezuela }\end{array}$ & Paraguai & $\begin{array}{l}\text { Neste momento, a delegação brasileira informa que não houve, até a a } \\
\text { Semana Epidemiologica } 39 \text { uma ESPIN. } \\
\text { Das doenças priorizadas pelo país consta a Chikungunya e a Zika. } \\
\text { Sobre a Zika, se informa que não se faz uma vigilância universal, } \\
\text { apenas a partit de novos casoso. Paraguai não tem a Zika como } \\
\text { doença priorizada, no momento. }\end{array}$ \\
\hline
\end{tabular}




\begin{tabular}{|c|c|c|c|c|c|}
\hline $\begin{array}{l}\text { Comissão de } \\
\text { Vigiâancia da } \\
\text { Sauude (COVIGSA } \\
\text { L) }\end{array}$ & $\begin{array}{l}\text { MERCOSUR / XLV REUNIÓN ORDINARIA DE SGT No } 11 \text { "SALUD" } \\
\text { / COMISIÓN DE VIGILANCIA EN SALUD / ACTA No } 01 / 16\end{array}$ & $\begin{array}{l}11- \\
14.04 .2016\end{array}$ & $\begin{array}{l}\text { Argentina, Brasil, } \\
\text { Paraguai, } \\
\text { Uruguai }\end{array}$ & Uruguai & 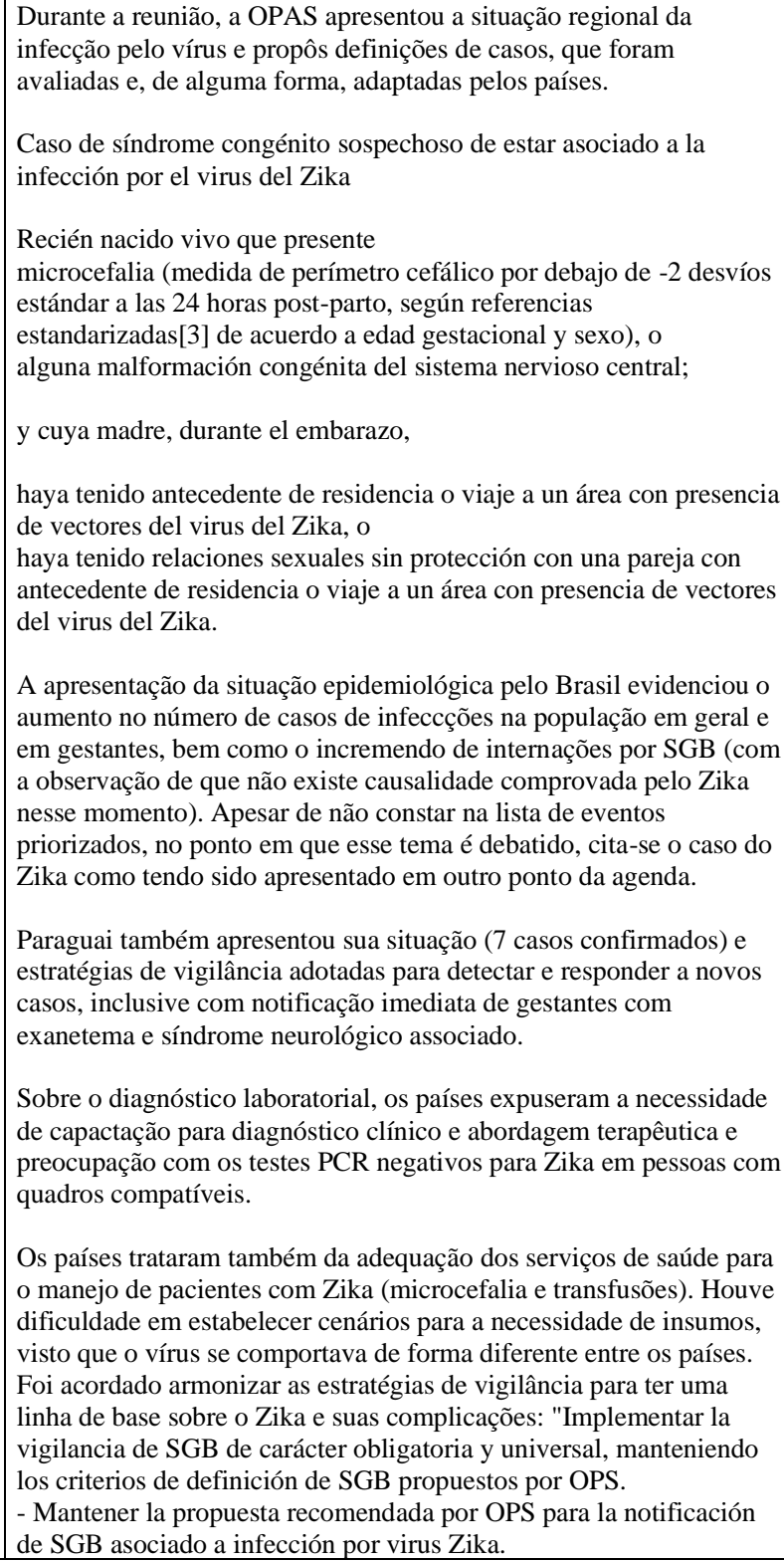 \\
\hline
\end{tabular}




$$
\| 1
$$




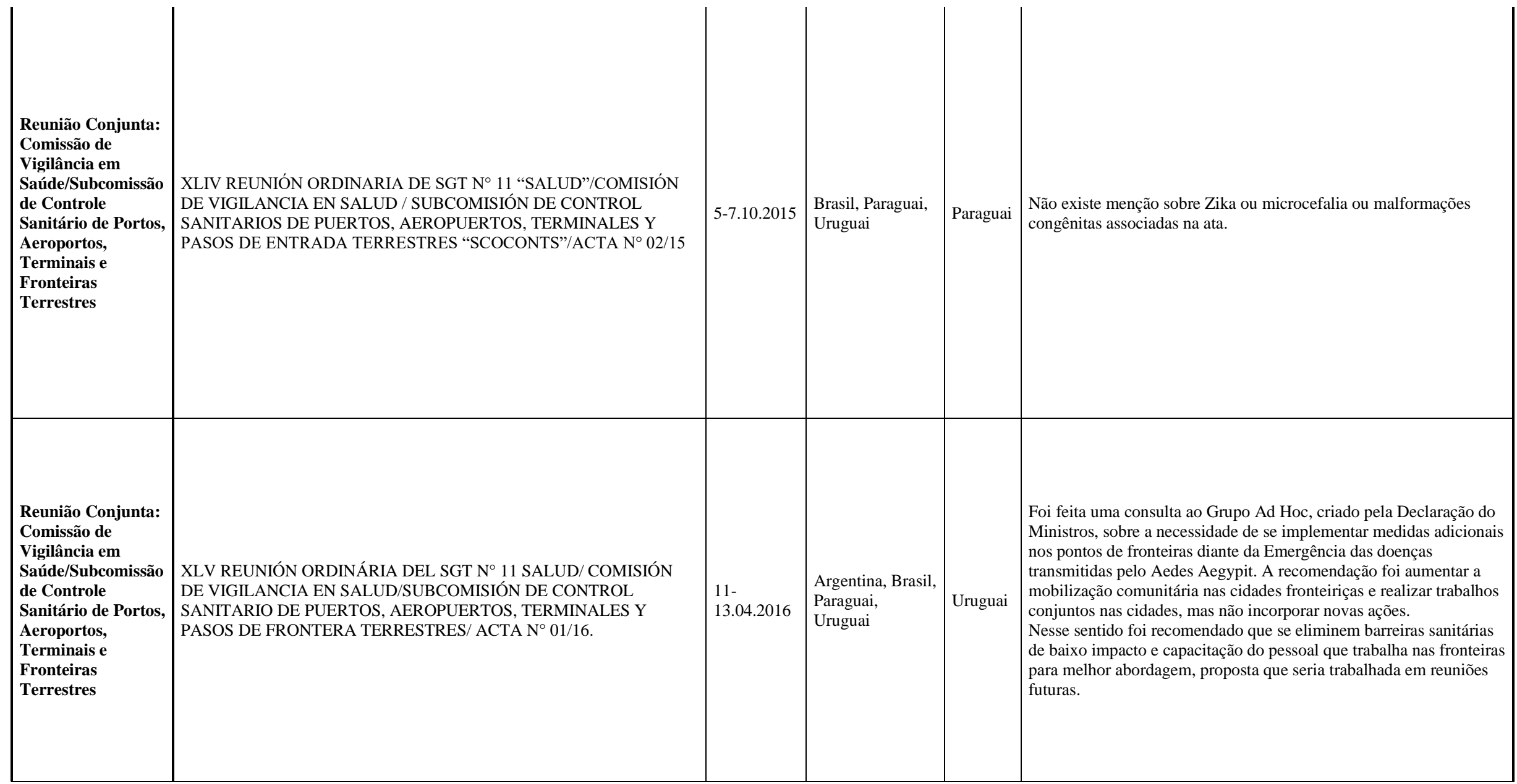




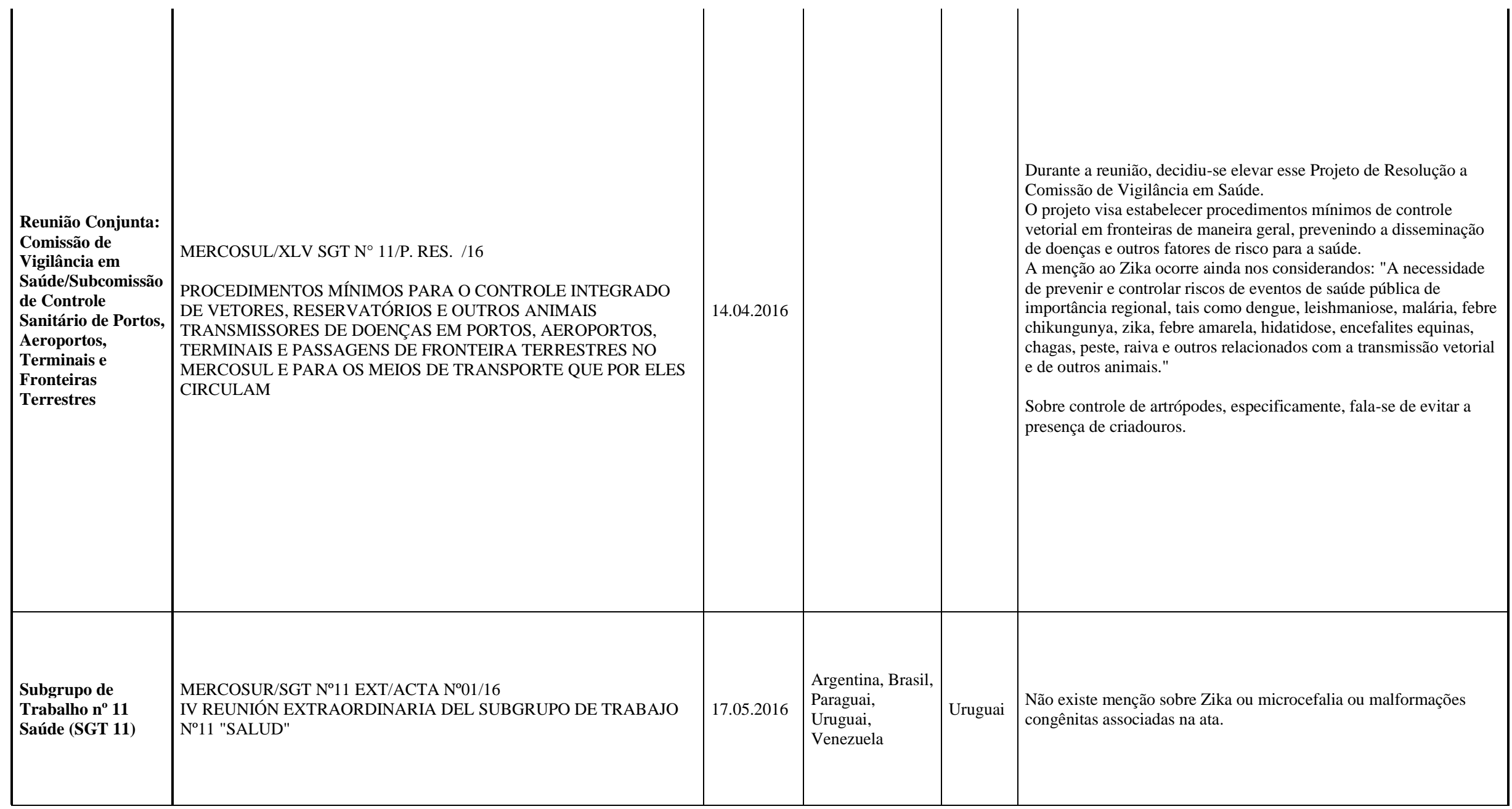




\begin{tabular}{|c|c|c|c|c|c|}
\hline $\begin{array}{l}\text { Comisión de } \\
\text { Servicios de } \\
\text { Atención a la Salud } \\
\text { (COSERATS) }\end{array}$ & $\begin{array}{l}\text { MERCOSUR/ XLIV REUNIÓN ORDINARIA DEL SGT No } 11 \\
\text { "SALUD"/COMISION DE SERVICIOS DE ATENCION A LA } \\
\text { SALUD/ACTA No } 02 / 15\end{array}$ & 5-8.10.2015 & $\begin{array}{l}\text { Argentina, Brasil, } \\
\text { Paraguai, } \\
\text { Uruguai }\end{array}$ & Paraguai & $\begin{array}{l}\text { Não existe menç̃o sobre Zika ou microcefalia ou malformações } \\
\text { congênitas associadas na ata. }\end{array}$ \\
\hline $\begin{array}{l}\text { Comisión de } \\
\text { Servicios de } \\
\text { Atención a la Salud } \\
\text { (COSERATS) }\end{array}$ & $\begin{array}{l}\text { XLV REUNION ORDINARIA DEL SUBGRUPO DE TRABAJO No } 11 \\
\text { "SALUD" MERCOSUR/COMISION DE SERVICIOS DE ATENCION A } \\
\text { LA SALUD/ ACTA N } 01 / 16\end{array}$ & $\begin{array}{ll}11- \\
14.04 .2016\end{array}$ & Brasil e Uruguai & Uruguai & $\begin{array}{l}\text { Nõo existe menç̃o sobre Zika ou microcefalia ou malformações } \\
\text { congênitas associadas na ata. }\end{array}$ \\
\hline PPTU & $\begin{array}{l}\text { MINISTERIO DE RELACIONES EXTERIORES DE LA REPÚBLICA } \\
\text { ORIENTAL DE URUGUAYIDIRECCIÓN GENERAL PARA } \\
\text { ASUNTOS DE INTEGRACIÓN Y MERCOSUR } \\
\text { INFORME FINAL PPTU } 2016\end{array}$ & & & Uruguai & $\begin{array}{l}\text { O informe final menciona que houve a XXXIX em } 17 \text { de junho de } \\
\text { 2016, mas a ata não está disponível para consulta pois os páses não } \\
\text { chegaram a um consenso sobre o traspasse da PPT e a convocatória } \\
\text { para a reunião seguinte. }\end{array}$ \\
\hline $\begin{array}{l}\text { Grupo Técnico da } \\
\text { Comissão de } \\
\text { Coordenação de } \\
\text { Ministros de } \\
\text { Assuntos Sociais do } \\
\text { Mercosul (GT- } \\
\text { CCMASM) }\end{array}$ & Sem atas disponíveis para 2016 & & & & \\
\hline
\end{tabular}




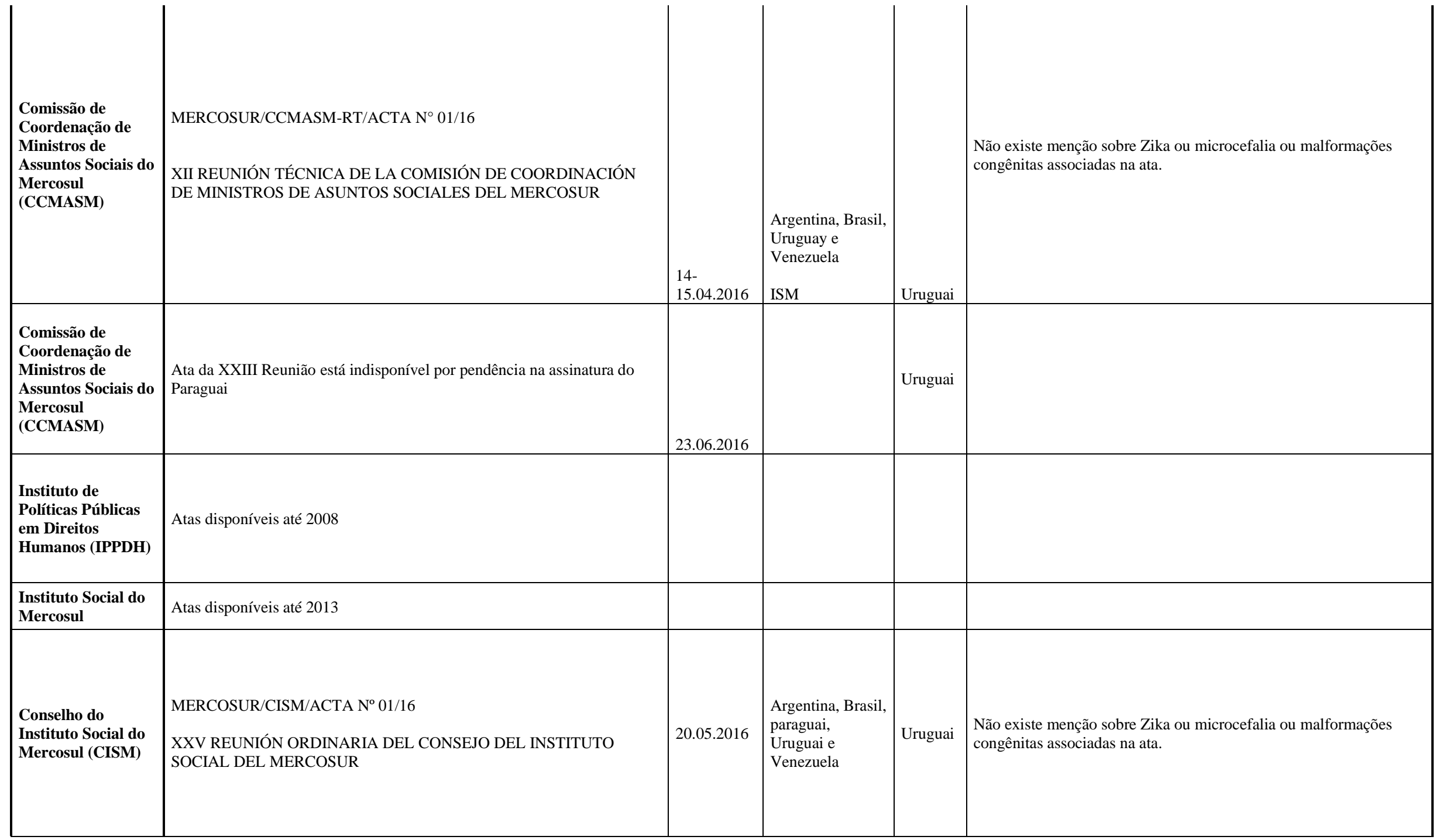




\begin{tabular}{|c|c|c|c|c|c|}
\hline $\begin{array}{l}\text { Reunião de Altas } \\
\text { Autoridades em } \\
\text { Direitos Humanos } \\
\text { (RAADH) }\end{array}$ & $\begin{array}{l}\text { MERCOSUR/RAADDHH/ACTA No } 01 / 16 \\
\text { REUNIÓN DEL GRUPO DE TRABAJO Y DERECHOS HUMANOS DE } \\
\text { LAS MUJERES }\end{array}$ & 25.05.2016 & $\begin{array}{l}\text { Argentina, } \\
\text { Paraguai, } \\
\text { Uruguai e } \\
\text { Venezuela. } \\
\text { Bolivia e } \\
\text { Equador }\end{array}$ & Uruguai & $\begin{array}{l}\text { Nõo existe menção sobre Zika ou microcefalia ou malformações } \\
\text { congênitas associadas na ata. }\end{array}$ \\
\hline $\begin{array}{l}\text { Reunião de Altas } \\
\text { Autoridades em } \\
\text { Direitos Humanos } \\
\text { (RAADH) }\end{array}$ & $\begin{array}{l}\text { MERCOSUR/RAADDHH/ACTA N } 01 / 16 \\
\text { COMISIÓN PERMANENTE DE PROMOCIÓN Y PROTECCIÓN DE } \\
\text { LOS DERECHOS DE LAS PERSONAS COM DISCAPACIDAD }\end{array}$ & 25.05.2016 & $\begin{array}{l}\text { Argentina, Brasil, } \\
\text { Paraguai, } \\
\text { Uruguai e } \\
\text { Venezuela } \\
\text { Bolivia }\end{array}$ & Uruguai & $\begin{array}{l}\text { Não existe menção sobre Zika ou microcefalia ou malformações } \\
\text { congênitas associadas na ata. }\end{array}$ \\
\hline $\begin{array}{l}\text { Reunião de Altas } \\
\text { Autoridades em } \\
\text { Direitos Humanos } \\
\text { (RAADH) }\end{array}$ & $\begin{array}{l}\text { MERCOSUR/RAADDHH/ACTA No } 01 / 16 \\
\text { REUNIÓN PREPARATORIA DE LA XXVIII REUNIÓN DE ALTAS } \\
\text { AUTORIDADES SOBRE DERECHOS HUMANOS DEL MERCOSUR }\end{array}$ & 26.05.2016 & $\begin{array}{l}\text { Argentina, Brasil, } \\
\text { Paraguai, } \\
\text { Uruguai e } \\
\text { Venezuela. } \\
\text { Bolivia, Chile, } \\
\text { Colômbia, } \\
\text { Equador e Peru }\end{array}$ & Uruguai & $\begin{array}{l}\text { Não existe menção sobre Zika ou microcefalia ou malformações } \\
\text { congênitas associadas na ata. }\end{array}$ \\
\hline
\end{tabular}




\begin{tabular}{|l|l|l|l|l|} 
& & & \\
$\begin{array}{l}\text { Reunião de Altas } \\
\text { Autoridades em } \\
\text { Direitos Humanos } \\
\text { (RAADH) }\end{array}$ & $\begin{array}{l}\text { MERCOSUR/RAADDHH/ACTA No } 01 / 16 \\
\text { XXVIII REUNIÓN DE ALTAS AUTORIDADES SOBRE DERECHOS } \\
\text { HUMANOS DEL MERCOSUR (RAADDHH) }\end{array}$ & 27.05 .2016 & $\begin{array}{l}\text { Argentina, Brasil, } \\
\text { Paraguai, } \\
\text { Uruguai e } \\
\text { Venezuela. } \\
\text { Bolivia, Chile, } \\
\text { Colômbia, } \\
\text { Equador e Peru }\end{array}$ \\
\hline
\end{tabular}

ANEXO V: Lista de documentos da União de Nações Sul-americanas

\begin{tabular}{|c|c|c|c|c|c|}
\hline Instância & Documento & Data & PPT & Zika/Microcefalia/Malformações Congênitas & Outros temas relevantes \\
\hline $\begin{array}{l}\text { Conselho de } \\
\text { Ministras e } \\
\text { Ministros } \\
\text { de Relações } \\
\text { Exteriores }\end{array}$ & $\begin{array}{l}\text { Declaración de } \\
\text { la Reunión del } \\
\text { Conselho de } \\
\text { Ministras e } \\
\text { Ministros de } \\
\text { Relações } \\
\text { Exteriores de } \\
\text { UNASUR }\end{array}$ & 23.04 .2016 & $\begin{array}{l}\text { Troca PPT do Uruguai para } \\
\text { Venezuela }\end{array}$ & $\begin{array}{l}\text { A declaração apresenta dois pontos relacionados à sapude. O ponto } 28 \text { cita o Zika, no } \\
\text { contexto da reafirmação do compromisso do combate ao mosquito Aedes Aegypit e } \\
\text { suas consequências. Remonta, ainda, à reunião extraordinária do Mercosul que trata } \\
\text { da questão e da qual participaram países do bloco e o ISAGS/UNASUL. }\end{array}$ & $\begin{array}{l}\text { Reafirmam seu compromisso de trabalhar } \\
\text { cooperando com a OPAS, chamando atenção } \\
\text { para o papel do ISAGS/UNASUL na promoção } \\
\text { de cooperação entre os países e no desenho de } \\
\text { propostas de respostas de controle vetorial e } \\
\text { assistência. }\end{array}$ \\
\hline $\begin{array}{l}\text { Conselho de } \\
\text { Saúde Sul- } \\
\text { americano }\end{array}$ & $\begin{array}{l}\text { XXII Reunión } \\
\text { extraordinaria } \\
\text { del Consejo de } \\
\text { Salud } \\
\text { Suramericano }\end{array}$ & 22.05 .2016 & Venezuela & $\begin{array}{l}\text { A reunião foi realizada no dia anterior ao início da } 69^{\mathrm{a}} \text { Assembleia Mundial da Saúde } \\
\text { em Genebra, Suíça. A única meção ao Zika foi feita pela Diretora da OPAS, que } \\
\text { enfatizou a capacidade da região de responder a sutors e emergências e saúde. }\end{array}$ & $\begin{array}{l}\text { Foram aprovadas posicionamentos comuns } \\
\text { sobre os seguintes temas: A69/40 - Seguimiento } \\
\text { del informe del Grupo Consultivo de expertos } \\
\text { en investigaciön y desarrollo: financiaciön y } \\
\text { coordinaciön-informe de la reunión de } \\
\text { composiciön abierta de Estados Miembros. } \\
\text { 2. A69/41 - Productos mdicos de caiidad } \\
\text { subestandar, espurios, de etiquetado engaiioso, } \\
\text { falsificados o de imitaciön- SSFFC. } \\
\text { 3. A69/42 - La Escasez Mundial de } \\
\text { Medicamentos y la Seguridad y Accesibilidad } \\
\text { de los Medicamentos Peditricos. }\end{array}$ \\
\hline
\end{tabular}


ANEXO VI: Lista de documentos da OPAS

\begin{tabular}{|c|c|c|c|c|}
\hline Instância & Documento & Data & Membros do CE & Zika/Microcefalia/Malformações Congênitas \\
\hline $\begin{array}{c}\text { Comitê } \\
\text { Executivo }\end{array}$ & $\begin{array}{l}\text { CE157/FR Informe } \\
\text { Final }\end{array}$ & 02/10/2015 & \begin{tabular}{l|} 
Antígua e Barbuda, \\
Argentina, Chile, \\
Costa Rica, Equador, \\
Estados Unidos da \\
América e Trinidad e \\
Tabago. \\
Observadores: \\
Brasil, Canadá, \\
Colômbia, Haiti, \\
México, Paraguai, \\
Peru e Porto Rico \\
\end{tabular} & Não há menção sobre Zika ou malformações congênitas relacionadas no documento. \\
\hline
\end{tabular}


Antígua e Barbuda, Argentina, Bahamas, Chile, Costa Rica, Equador, Estados

Equador, Estados América, Guatemala e Trinida

Comitê Executivo Final

A doença causada pelo Zika é tratada brevemente no ponto sobre Sistemas de Saúde resilientes (Documento CE158/14), como exemplo de que os sistemas dos países ainda se encontravam vulneráveis. Brasil e Equador salientaram que seus países demonstraram a importância da resiliência dos sistemas no enfrentamento do Zika e do Terremoto, respectivamente.

No ponto sobre a Estratégia para a prevenção e o controle de arboviroses (Documento CE158/20, Rev. 1), a OPAS propõe que, com a introdução do Zika, a estratégia deva fazer frente à todas as arboviroses com um enfoque abrangente e holístico. O CE concordou que as arboviroses tornaram-se prioritárias na região com os recentes surtos de chickungunya e Zika. Houve consenso sobre a necessidade de ações sustentáveis de resposta: controle vetorial, diagnóstico, fortalecimento dos sistemas de vigilância, diagnóstico laboratorial

Na discussão sobre o ponto Atualização sobre o vírus Zika na Região das Américas (CE158/INF/6): houve breve descrição da dispersão do vírus na região de das ações realizadas até então para responder a emergência do Zika em três pilares: deteç̧ão, prevenção e resposta dos serviços de saúde, além do fomento à pesquisa. Os delegados acordaram que a prioridade deveria ser a redução de riscos para gestantes e outras mulheres em idade reprodutiva. Foi mencionado que o esforço, iniciado em 1996, para erradicar o Aedes Aegypti das Américas não foi levado a cabo por falta de vontade política.

O Brasil destacou a transparência com que o país vinha trabalhando e destacou que as políticas implementadas se concentraram no controle vetorial, na atenção às famílias e nos protocolos de vigilância, além do fomento à pesquisas, como para o desenvolvimento de uma vacina. Sobre os jogos Olímpicos, a delegada informou ser mínima a chance de transmissão na época dos jogos.

A Diretora, Carissa Etienne, destacou o compromisso e liderança políticos para o avanço da resposta e a importância de sistemas de vigilância fortalecidos, como o do Brasil; pontuou ainda que o desafio da região é manter o mesmo nível de compromisso no médio e longo prazo.

24/06/2016 e Tobago

Observadores: Brasil, Canadá, El Salvador, Espanha, Honduras, México, Panamá,

Paraguai e São

Cristóvão e Névis

Outro ponto em que o Zika é tratado, foi o debate sobre a Estratégia e plano de ação regionais sobre a saúde do recém-nascido no contexto do processo contínuo da atenção à mãe, ao recém-nascido e à criança: Relatório final (Documento CE158/INF/12). Foi destacada a necessidade de cooperação para enfrentar os impactos do Zika, em virtude das possíveis consequências para a saúde de crianças e o Dr. Francisco Serpa (Diretor, Departamento da Família, Gênero e Ciclo de Vida, RSPA) salientou que o vírus salientou brechas nos programas de saúde materno infantil, reforçando a importância do fortalecimento desses programas e do pré-natal e parto A Diretora chamou atenção para a necessidade de um diagnóstico diferencial para a infecção neonatal pelo Zika.

Já nos Relatórios de progresso sobre assuntos técnicos (Documento CE158/INF/13), foi destacado que não foram mencionados os vínculos ou ações que são necessárias para fechar as brechas na conexão entre o tema do Plano de ação para a saúde do adolescente e do jovem e a resposta ao Zika, como a falta de acesso à informações de saúde sexual e reprodutiva.

O Dr. Francisco Serpa observou que naquele momento o plano estava sendo ajustado para se adequar à nova realidade, como a inclusão de atenção especial para gestantes, inclusive adolescentes.

No ponto Resoluções e outras ações das organizações intergovernamentais de interesse para a OPAS (Documento CE158/INF/14), foi mencionada a resolução emitida na reunião de fevereiro do Mercosul com a Unasul e o convênio desta organização com a OPAS para o acesso ao Fundo Estratégico, ampliando o acesso a medicamentos de alto custo. 


\begin{tabular}{|c|c|c|c|c|}
\hline $\begin{array}{c}\text { Comitê } \\
\text { Executivo }\end{array}$ & $\begin{array}{l}\text { CE159/FR Rev.1 } \\
\text { Informe Final }\end{array}$ & 30/09/2016 & $\begin{array}{l}\text { Antígua e Barbuda, } \\
\text { Argentina, Brasil, } \\
\text { Chile, Colômbia, } \\
\text { Estados Unidos da } \\
\text { América, Guatemala, } \\
\text { Panamá e Trinidad e } \\
\text { Tabago. } \\
\\
\text { Observadores: } \\
\text { Canadá, Equador, } \\
\text { México, Nicarágua e } \\
\text { Paraguai. }\end{array}$ & Não há menção sobre Zika ou malformações congênitas relacionadas no documento. \\
\hline
\end{tabular}




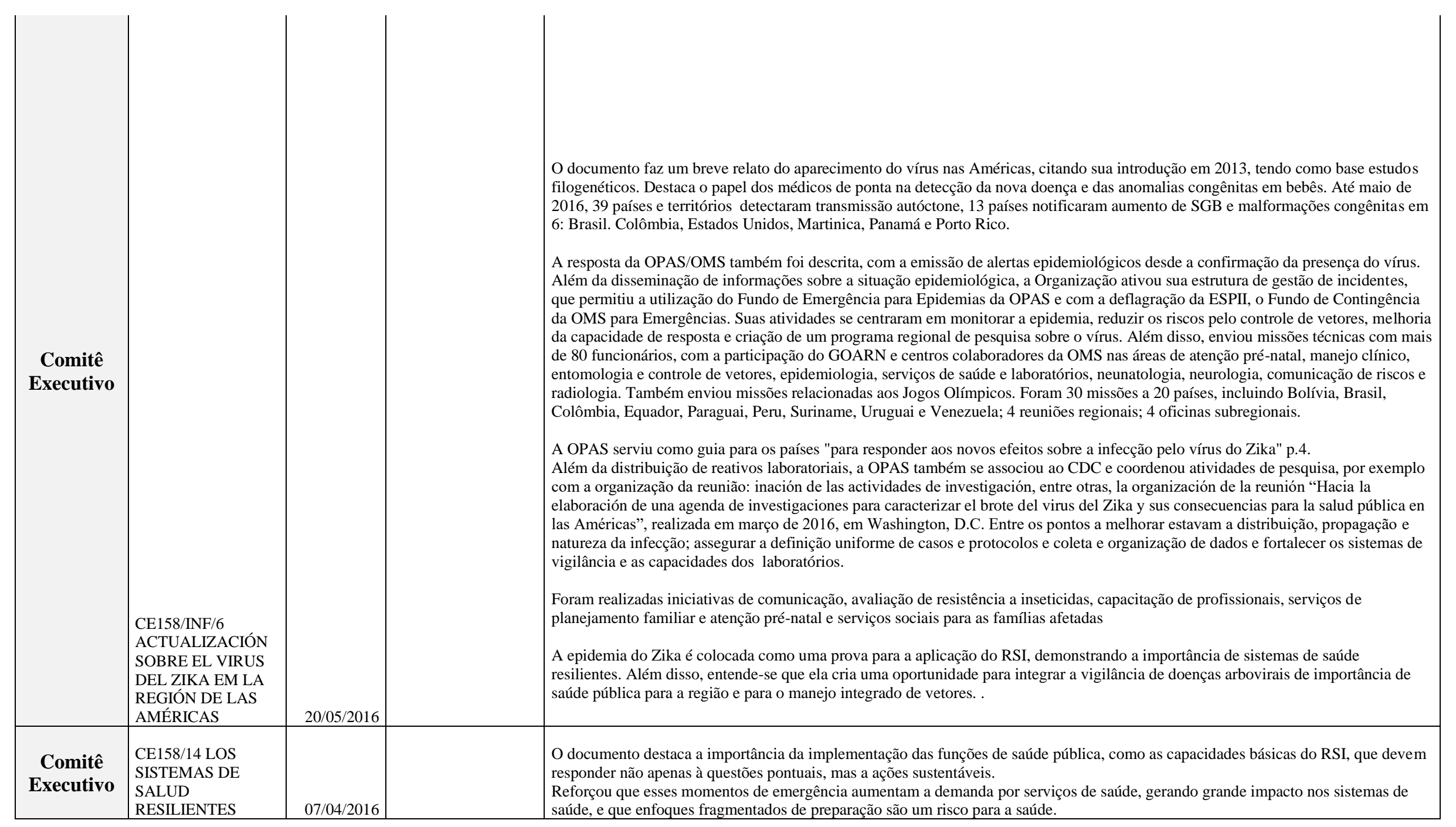




\begin{tabular}{|c|c|c|c|}
\hline $\begin{array}{c}\text { Comitê } \\
\text { Executivo }\end{array}$ & $\begin{array}{l}\text { CE158/20, Rev. } 1 \\
\text { ESTRATEGIA } \\
\text { PARA LA } \\
\text { PREVENCIÓN Y EL } \\
\text { CONTROL DE LAS } \\
\text { ENFERMEDADES } \\
\text { ARBOVIRALES }\end{array}$ & $28 / 04 / 2016$ & $\begin{array}{l}\text { A Estratégia coloca em destaque a necessidade de integração das estratégias de combate às arboviroses de importância para a saúde } \\
\text { pública das Américas. A introdução de novos vírus dificulta o diagnóstico diferenciado e como o vírus Zika ainda é desconhecido, } \\
\text { deveria ser foco de estudos sobre seu comportamento clínico e epidemiológico. A ideia é estabelecer formas de fortalecer a vigilância, } \\
\text { diagnóstico e manejo das arboviroses 1) promovendo um enfoque integrado; 2) fortalecendo os serviços de saúde para diagnóstico e } \\
\text { manejo; 3) fortalecendo a capacidade dos países para vigilância e manejo de vetores e, 4) estabelecendo e fortalecendo a capacidade da } \\
\text { Rede de Laboratórios de Diagnóstico de Arbovírus nas américas (RELDA). }\end{array}$ \\
\hline $\begin{array}{c}\text { Comitê } \\
\text { Executivo }\end{array}$ & $\begin{array}{l}\text { CE158/INF/12 } \\
\text { ESTRATEGIA Y } \\
\text { PLAN DE ACCIÓN } \\
\text { REGIONALES } \\
\text { SOBRE SALUD } \\
\text { NEONATAL EN EL } \\
\text { CONTEXTO DEL } \\
\text { PROCESO } \\
\text { CONTINUO } \\
\text { DE LA ATENCIÓN } \\
\text { DE LA MADRE, } \\
\text { DEL RECIÉN } \\
\text { NACIDO Y DEL } \\
\text { NIÑO: INFORME } \\
\text { FINAL }\end{array}$ & . & Não há menção sobre Zika ou malformações congênitas relacionadas no documento. \\
\hline $\begin{array}{c}\text { Comitê } \\
\text { Executivo }\end{array}$ & $\begin{array}{l}\text { CE158/INF/13 B. } \\
\text { PLAN DE ACCIÓN } \\
\text { SOBRE LA SALUD } \\
\text { DE LOS } \\
\text { ADOLESCENTES Y } \\
\text { LOS } \\
\text { JÓVENES }\end{array}$ & 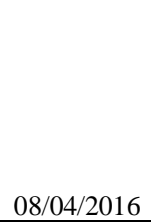 & Não há menção sobre Zika ou malformações congênitas relacionadas no documento. \\
\hline
\end{tabular}




\begin{tabular}{|c|c|c|c|}
\hline $\begin{array}{c}\text { Comitê } \\
\text { Executivo }\end{array}$ & $\begin{array}{l}\text { CE158/INF/14 B. } \\
\text { ORGANIZACIONES } \\
\text { SUBREGIONALES } \\
\end{array}$ & $30 / 04 / 2016$ & $\begin{array}{l}\text { O documento visa informar sobre avanços e acordos feitos com a OPAS e outras Organizaçães Internacionais. } \\
\text { Com o COMISCA, a OPAS aprovou o plano subregional para a prevenção e controle do vírus Zika na América Central e República } \\
\text { Dominicana. } \\
\text { Com o Projeto Mesoamérica, no marco do Convênio entre a OPAS e a AMEXID (Agência Mexicana de Cooperação Internacional } \\
\text { para o Desenvolvimento, apoiou a elaboração de planos nacionais contra o Zika. } \\
\text { Com o SICA (Sistema de Integração Centro-americano) participou de reunião virtual extraordinária de Chefes de estado e de Governo } \\
\text { para apresentar diretrizes gerais para a resposta à epidemia. Com base nessas orientações, o COMISCA criou o Plano de ação para a } \\
\text { prevenção e Controle do vírus Zika na América Central e República Dominicana. } \\
\text { No Caribe, a OPAS trabalhou com o CARICOM e com a CARPHA para promover capacitações, a Primeira Semana de } \\
\text { Conscientização sobre os Mosquitos no Caribe (9-15 maio), além de promover capacitaç̃̃es em conjunto com o CDC e o Organismo } \\
\text { de Saúde Oúbolica do Canadá, em que } 10 \text { técnicos de laboratório de } 6 \text { países foram treinados. } \\
\text { Na América do Sul, o documento menciona a reunião da RMS do Mercosul, a Unasul e a CELAC, realizada em fevereiro de 2016, } \\
\text { para a qual a Diretora apresentou informação e respaldou os acordos realizados. Menciona também que o plano de trabalho } \\
\text { subregional pra a América do Sul tem como componente a promoção da CSS e a prevenção e controle de doenças transmissíveis, } \\
\text { respaldando sua participação na reunião do Mercosul. }\end{array}$ \\
\hline $\begin{array}{l}\text { Conselho } \\
\text { Diretivo } \\
\end{array}$ & $\begin{array}{l}\text { CD54/FR INFORME } \\
\text { FINAL } \\
\end{array}$ & $02 / 10 / 2015$ & $\begin{array}{l}\text { No ponto sobre o Informe anual del Director de la Oficina Sanitaria Panamericana (documento CD54/3), a Diretora falou sobre a } \\
\text { resposta a introdução recente do vírus Zika no Brasil, em trabalho em colaboração com o CDC, prestando cooperação em diagnóstico } \\
\text { e acompanhamento da doença, focando na promoção da saúde em todas as políticas e em atividades multisetoriais. } \\
\text { No debate sobre o Informe sobre la transmisión del virus del chikunguña y su repercusión en la Región de las Américas (documento } \\
\text { CD54/INF/3), a representante do CE informou que no Comitê se observou a ameaça da introdução do Zika e destacou-se a } \\
\text { necessidade de acelerar as medidas de controle vetorial, além de melhorar o manejo de resíduos sólidos para a eliminação dos } \\
\text { criadouros. }\end{array}$ \\
\hline $\begin{array}{l}\text { Conselho } \\
\text { Diretivo }\end{array}$ & $\begin{array}{l}\text { CD54/3 INFORME } \\
\text { ANUAL DEL } \\
\text { DIRECTOR DE LA } \\
\text { OFICINA } \\
\text { SANITARIA } \\
\text { PANAMERICANA } \\
\text { Abogar por la salud } \\
\text { hacia el desarrollo } \\
\text { sostenible y la } \\
\text { equidad: } \\
\text { liderar con el ejemplo }\end{array}$ & $04 / 08 / 2015$ & $\begin{array}{l}\text { O vírus Zika é mencionado no ponto em que a Diretora trata de doenças emergentes transmitidas por mosquitos, enfatizando o papel } \\
\text { da OPAS nesse primeiro momento, que foi de produzir e disseminar diretrizes técnicas e algoritmos para diagnóstico do vírus e } \\
\text { facilitar a capacitação necessárias pelos países, em colaboração com outros associados. }\end{array}$ \\
\hline
\end{tabular}




\begin{tabular}{|c|c|c|c|}
\hline $\begin{array}{l}\text { Conselho } \\
\text { Diretivo } \\
\end{array}$ & \begin{tabular}{|l} 
CD54/INF/3 \\
INFORME SOBRE \\
LA TRANSMISIÓN \\
DEL VIRUS DEL \\
CHIKUNGUÑA Y \\
SU \\
REPERCUSIÓN EN \\
LA REGIÓN DE \\
LAS AMÉRICAS \\
\end{tabular} & $10 / 08 / 2015$ & Não há menção sobre Zika ou malformações congênitas relacionadas no documento. \\
\hline & & & 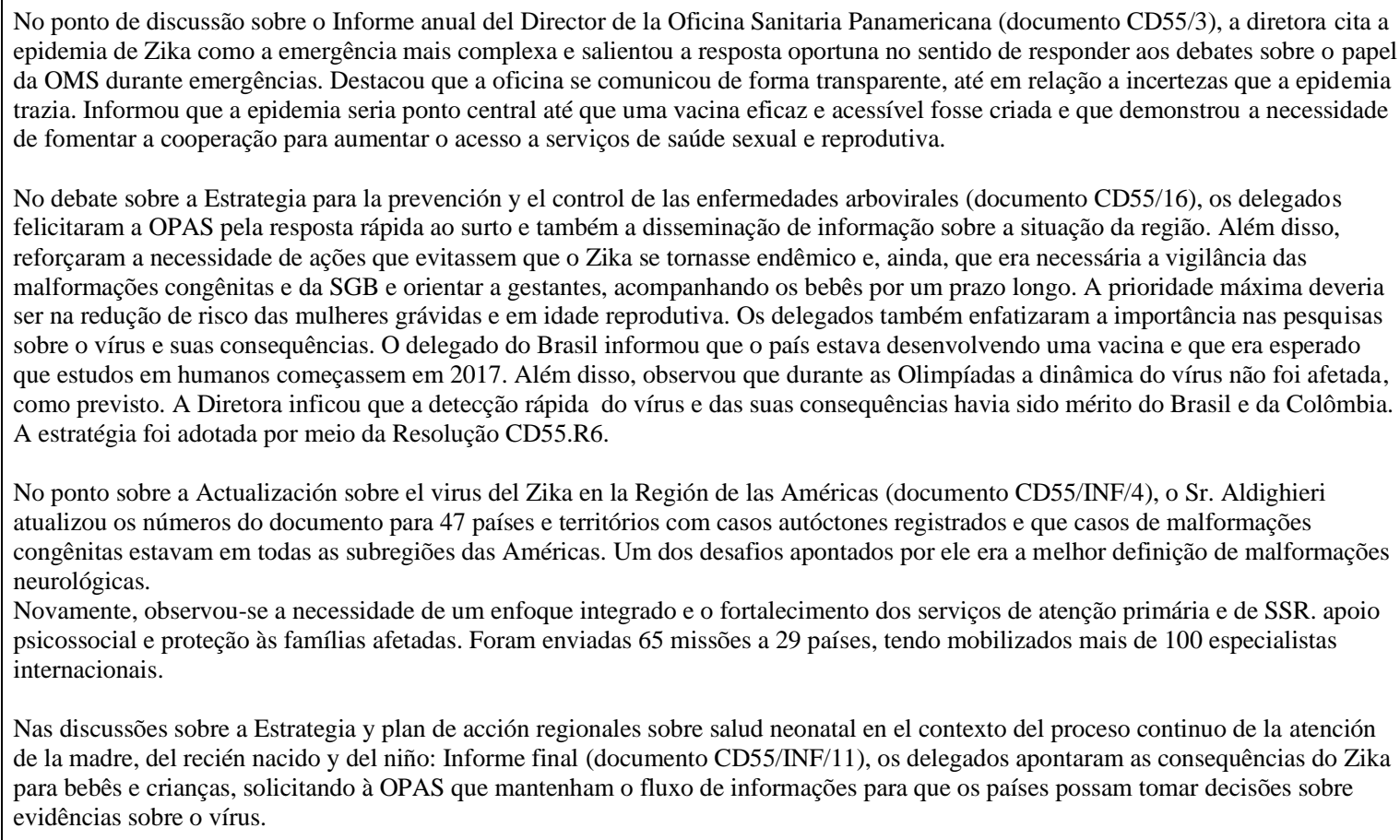 \\
\hline $\begin{array}{l}\text { Conselho } \\
\text { Diretivo }\end{array}$ & $\begin{array}{l}\text { CD55/FR Informe } \\
\text { Final }\end{array}$ & $30 / 09 / 2016$ & \\
\hline
\end{tabular}




\begin{tabular}{|l|l|} 
CD55/INF/11 & \\
ESTRATEGIA Y & \\
PLAN DE ACCIÓN & \\
REGIONALES & \\
SOBRE SALUD & \\
NEONATAL EN EL & \\
CONTEXTO DEL & \\
PROCESO & \\
CONTINUO & \\
DE LA ATENCIÓN & \\
DE LA MADRE, & \\
DEL RECIÉN & \\
NACIDO Y DEL & \\
NIÑO: & \\
INFORME FINAL & $28 / 07 / 2016$
\end{tabular}




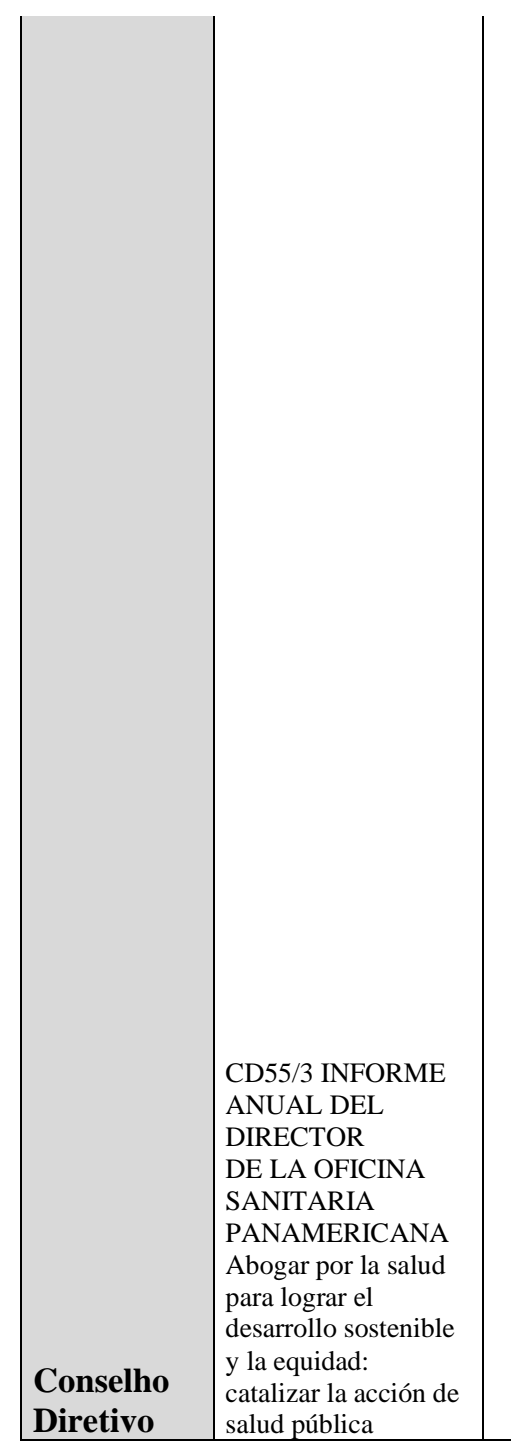

No documento, a Diretora ressalta a coordenação da OPAS com a OMS e outros organismos das Nações Unidas para conduzir uma ação conjunta de resposta à emergência do Zika e salientou o papel da Organização na resposta a emergências. Apresentou a resposta da Organização até então, salientando que a OPAS ativou sua equipe de Operações de Alerta e Resposta (OAR) e o Sistema de Gestão

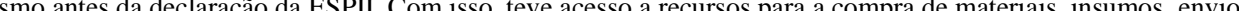
de missões, capacitações etc.

A Diretora nota que em abril de 2016, foi feita uma Consulta internacional sobre a epidemia do Zika e ética, financiada pela Wellcome Trust, cujas recomendações foram:

- "Todas as mulheres devem ter acesso a informações e serviços integrais em matéria sexual e reprodutiva inclusive planejamento

familiar, saúde materna, testagem pré-natal, interrupção segura da gravidez, orientação e serviços de atenção pós-natal.

- O direito moral das mulheres de escolherem suas opções reprodutivas deve ser respeitado durante o surto do vírus Zika.

- As mulheres devem poder escolher livremente com base nas opções relevantes, inclusive a contracepção, a interrupção da gravidez e a manutenção de uma gravidez potencialmente afetada. Nenhuma opção deve ser associada à contingência de um diagnóstico específico ou à probabilidade de um resultado negativo da gravidez.

- As mulheres devem receber apoio social adequado a suas decisões reprodutivas e assistência para administrar as dificuldades relacionadas à infecção causada pelo vírus Zika e à síndrome congênita do Zika (SCZ).

- As autoridades sanitárias devem-se esforçar por minimizar a discriminação e a estigmatização, prestando continuamente informações ao público sobre a importância de se respeitarem as diferentes crenças, valores e escolhas.

- Devem ser proporcionadas às mulheres informações honestas, completas, corretas e atualizadas sobre o vírus Zika e a SCZ.

- O avanço da pesquisa sobre o Zika é um imperativo ético, e os pesquisadores têm uma responsabilidade ética de divulgar os dados e os resultados de pesquisa para permitir respostas imediatas a essa emergência de saúde." (p.8)

Foram convocados especialistas de diversas áreas para formular guias para diagnóstico, vigilância e atenção à gestante e aos bebês com microceflaia e outras malformações congênitas. Os especialistas da OPAS trabalharam de forma coordenada com a OMS para estabelecer critérios para o diagnóstico ecográfico precoce da microcefalia e SCVK. Além disso, a Diretora mencionou sua participação em reuniões de Organizações regionais como a do Mercosul com a Unasul. Citou ainda o Banco Mundial e o Banco Interamericano de Desenvolvimento como parceiros na elaboração de um instrumento para avaliar e determinar custos para detectar as lacunas nas capacidades nacionais de resposta, com os custos das soluções; além da cooperação com a OMS e outras agências das Nações Unidas.

Foi criado um Grupo Técnico Assessor de Entomologia em Saúde Pública em março de 2016, com participantes da OMS, Fiocruz, CDC, USAIS, Universidade Monash da Austrália, a Fundação Bill e Melinda Gates e o escritório da Casa Branca para Políticas de Ciência e Tecnologia dos EUA. Esse grupo recomendou a melhoria do controle e vigilância dos vetores e capacitação nessas áreas, a preparação de um protocolo para vigilância de resistência a inseticidas, uso de alternativas como mosquitos estéreis e transgênicos e ação intersetorial, com participação da comunidade para eliminar focos do mosquito.

Por meio de um convênio com o Comitê Olímpico Internacional, com autoridades brasileiras, a OPAS e a OMS ofereceram apoio para a redução de risco de contágio durante os Jogos Olímpicos, com recomendações como a eliminação dos criadouros e fumigação, além de participação da comunidade e distribuição de repelentes e materiais informativos para os atletas e turistas.

No Brasil, foram aproveitadas redes existentes como a REDLA, cujos laboratórios decidiram ampliar seu alcance para fazer uma vigilância integrada. Destacou ainda que a OPAS se comunicou de forma transparente, até em relação a incertezas que a epidemia trazia. Informou que a epidemia seria ponto central até que uma vacina eficaz e acessível fosse criada e que demonstrou a necessidade de fomentar a cooperação para aumentar o acesso a serviços de saúde sexual e reprodutiva. 


\begin{tabular}{|c|c|c|c|}
\hline $\begin{array}{l}\text { Conselho } \\
\text { Diretivo }\end{array}$ & $\begin{array}{l}\text { CD55/12, Rev. } 1 \\
\text { APLICACIÓN DEL } \\
\text { REGLAMENTO } \\
\text { SANITARIO } \\
\text { INTERNACIONAL } \\
\text { (RSI) }\end{array}$ & $16 / 09 / 2016$ & $\begin{array}{l}\text { Na atualização sobre o progresso da aplicação do RSI nas Américas, consta que em } 201599 \text { eventos foram avaliados como possível } \\
\text { evento de importância internacional, } 45 \text { foram considerados comprovadamente de importância internacional, } 15 \text { deles relacionados ao } \\
\text { Zika. Das capacidades básicas regionais, apenas as capacidade de responder a emergências químicas (57\%) e os riscos relacionados à } \\
\text { radiação (55\%), a média das demais capacidades nas Américas está acima de } 75 \% \text {. Na América do Sul, esses valores são ainda mais } \\
\text { elevados, com pelo menos } 6 \text { capacidades com percentuais superiores a } 90 \% \text { (legislação, políticas e financiamento; coordenação e } \\
\text { comunicação com o Centro Nacional de Ligação; Vigilância; resposta; Comunicação de riscos; e eventos zoonóticos). As menores } \\
\text { percentagens ficaram com capacidade de responder a emergências químicas ( } 68 \% \text { ) e recursos humanos (70\%). } \\
\text { A intensificaçãa do apoio da OPAS para o controle do Zika na região se deu pelo acompanhamento da epidemia, a redução de riscos, } \\
\text { melhoria da capacidade de resposta com foco nos serviços de saúde, comunicação de riscos e controle de vetores, e enfoque nas } \\
\text { pesquisas sobre o vírus. Mobilização de recursos, em coordenação com outras agências da ONU, BID, BM e a OMS; produção e } \\
\text { difusão de diretrizes técnicas; organização de reuniões virtuais e capacitação presencial em serviços laboratoriais, vigilância } \\
\text { entomológica e controle de vetores, monitoramento de gestantes e comunicação de risco nacional, regional e subregional. envio de } \\
\text { missões técnicas e distribuição de insumos como reativos de laboratórios, coordenação de esforços de pesquisa, com a elaboração de } \\
\text { uma agenda de pesquisa regional, entre outras ações. }\end{array}$ \\
\hline $\begin{array}{l}\text { Conselho } \\
\text { Diretivo }\end{array}$ & $\begin{array}{l}\text { CD55/16 } \\
\text { ESTRATEGIA } \\
\text { PARA LA } \\
\text { PREVENCIÓN Y EL } \\
\text { CONTROL DE LAS } \\
\text { ENFERMEDADES } \\
\text { ARBOVIRALES }\end{array}$ & $10 / 07 / 2016$ & $\begin{array}{l}\text { A introdução e rápida disseminação de novos arbovírus são consideramos relevantes para ampliar a estratégia como uma ferramenta } \\
\text { útil na abordagem integral das arboviroses. O documento aponta a necessidade de aumentar a pesquisa sobre o vírus e suas dinâmicas, } \\
\text { bem como suas consequências. Colocam ainda o desafio para diagnóstico laboratorial com tantas arboviroses circulantes. } \\
\text { A proposta inclui } 4 \text { linhas estratégicas de ação, entendendo que cada país vai elaborar seus planos de ação adaptados aos seus } \\
\text { contextos: 1) promover um enfoque integrado; 2) fortalecer os serviços de saúde para diagnóstico e manejo; 3) fortalecer a capacidade } \\
\text { dos países para vigilância e manejo de vetores e, 4) estabelecer e fortalecer a capacidade da Rede de Laboratórios de Diagnóstico de } \\
\text { Arbovírus nas américas (RELDA). }\end{array}$ \\
\hline $\begin{array}{l}\text { Conselho } \\
\text { Diretivo }\end{array}$ & $\begin{array}{l}\text { CD55/INF/4 } \\
\text { ACTUALIZACIÓN } \\
\text { SOBRE EL VIRUS } \\
\text { DEL ZIKA EN } \\
\text { LA REGIÓN DE } \\
\text { LAS AMÉRICAS }\end{array}$ & $15 / 08 / 2016$ & $\begin{array}{l}\text { em dezembro de } 2015 \text { a OPAS ativou uma estrutura de gestão de incidentes, permitindo a alocação de recursos do seu Fundo de } \\
\text { Emergências para Epidemias com a finalidade de financiar açães de um marco estratégico que envolvem o acompanhamento da } \\
\text { epidemia, o controle de vetores, o fortalecimento dos sistemas de saúde e o fomento a pesquisas sobre o Zika vírus. Entretanto, ainda } \\
\text { persiste uma lacuna de } 70 \% \text { no orçamento total necessário para dar cabo das ações propostas pela Organização. Além disso, a } \\
\text { Organização tem realizado esforços no sentido de disponibilizar informação e materiais de comunicação como forma de mitigar os } \\
\text { riscos e fomentar o controle do mosquito . }\end{array}$ \\
\hline
\end{tabular}


ANEXO VII: Modelo de entrevista

1. Antes da declaração de emergência internacional pela OMS, como o MS atuou em relação ao Zika?

2. O que mudou quando a OMS declarou a ESPII? Isso potencializou a resposta de alguma maneira?

3. Qual foi a prioridade de atuação do MS no combate ao Zika? Você considera que essa ação prioritária foi efetiva? Por quê?

4. O que você considera que foi determinante para que a OMS declarasse essa emergência internacional, a primeira que teve como epicentro a América do Sul?

5. Qual a importância do RSI instrumento para a vigilância em saúde?

6. Qual a relevância de essa epidemia ter sido localizada no Brasil?

7. Que fatores sociais, econômicos e políticos você destacaria como tendo impacto na resposta do MS?

8. Durante a emergência, o MS atuou em conjunto com alguma outra organização ou país? Em caso afirmativo, quais foram as parcerias formadas e com quais objetivos?

9. Na cooperação internacional relacionada a pesquisa do vírus, que instituições brasileiras e estrangeiras, que trabalharam com o Brasil, destacaria?

10. Como funcionou a Sala Binacional Brasil-Colômbia?

11. A maior parte da cooperação para tecnologia e desenvolvimento do Brasil foi feita com organizações dos EUA. Por que você considera que o país teve tamanho destaque?

12. Qual a relevância da OPAS, do MERCOSUL e da UNASUL nessa resposta? 9Bis Qual você destacaria como a de maior protagonismo na região? Por quê?

13. Quando foi criado o Conselho de saúde da UNASUL, um dos seus eixos fundamentais foi a criação de uma rede de vigilância, inicialmente chamado de escudo epidemiológico. Como essa engrenagem tem funcionado? Como ela operou no caso do Zika?

14. Que fatores você destacaria que desempenharam papel mais importante na resposta à emergência?

15. O Brasil deu bastante enfoque ao combate ao vetor. Que ações de longo prazo estão sendo adotadas no sentido de controlar o vetor para prevenir outras epidemias?

16. E em relação às consequências da síndrome do Zika sobre as crianças atingidas? 


\title{
ANEXO VII: Modelo de Termo de Consentimento Livre e Esclarecido
}

\author{
Universidade de São Paulo \\ Faculdade de Saúde Pública
}

Av. Dr. Arnaldo, 715 - CEP 01246-904 - São Paulo - Brasil

\section{TERMO DECONSENTIMENTO LIVRE E ESCLARECIDO \\ Título do Projeto: VIGILÂNCIA E RESPOSTA EM SAÚDE NO PLANO REGIONAL: O CASO DA FEBRE DO VÍRUS ZIKA}

\section{Pesquisador Responsável: Flávia Thedim Costa Bueno}

Você está sendo convidado para participar da pesquisa "VIGILÂNCIA E RESPOSTA EM SAÚDE NO PLANO REGIONAL: O CASO DA FEBRE DO VÍRUS ZIKA". Sua participação não é obrigatória. A qualquer momento você pode desistir de participar e retirar seu consentimento; e sua recusa não trará nenhum prejuízo em sua relação com o pesquisador ou com a instituição da qual ele faz parte.

Este projeto tem o objetivo de analisar a resposta regional sul-americana com relação à declaração da microcefalia e outros distúrbios neurológicos como Emergência de Saúde Pública de Importância Internacional, feita pela Organização Mundial da Saúde em 2016, a fim de verificar as relações entre os atores que participaram dessa resposta e avaliar a compatibilidade ou não com a resposta internacional e com a principal resposta nacional (brasileira).

Para tanto, serão realizadas entrevistas semiestruturadas, que consistirão em perguntas sobre o contexto e as ações realizadas no âmbito da resposta a esta Emergência, dentro do seu escopo de atuação. As entrevistas serão realizadas objetivando aprofundar o assunto em questão, conhecer melhor a agenda de sua instituição acerca do tema, expectativas e/ou resultados das ações empreendidas, entre outros assuntos que possam surgir após a análise documental. estudo.

Sua participação nesta pesquisa consistirá em responder a perguntas concernentes aos objetivos do

Caso seu relato ou partes de suas respostas sejam incluídas nos documentos oriundos da pesquisa, não iremos claramente citar seu nome, cargo e/ou instituição de vínculo. No entanto, existe a possibilidade de que leitores o(a) identifiquem, a partir do relato de suas experiências únicas e/ou participação direta nas ações de resposta à emergência.

As informações obtidas por meio dessa pesquisa serão utilizadas exclusivamente para elaboração desta tese de doutorado e, posteriormente, em artigos científicos.

Caso sua entrevista seja gravada, o arquivo de áudio será mantido em segurança e arquivado em computador protegido por senha. Caso sua entrevista seja realizada por e-mail, o texto com suas respostas também será arquivado em segurança. As transcrições ou textos de e-mail serão arquivados durante 5 anos, como prevê a legislação brasileira.

Durante a execução da entrevista, os riscos de sua participação são mínimos, podendo consistir em desconforto ou até um constrangimento pelo teor dos questionamentos. Entretanto, como pesquisa inédita, esta tese pode contribuir para a democratização do acesso a informações e ao conhecimento no campo da cooperação internacional em saúde.

Após ler e receber explicações sobre a pesquisa, e ter meus direitos de:

1. receber resposta a qualquer pergunta e esclarecimento sobre os procedimentos, riscos, benefícios e outros relacionados à pesquisa;

2. retirar o consentimento a qualquer momento e deixar de participar do estudo; 
3. não ser identificado e ser mantido o caráter confidencial das informações relacionadas à privacidade.

4. Receber uma via deste termo de consentimento livre e esclarecido.

5. procurar esclarecimentos com o Comitê de Ética em Pesquisa da Faculdade de Saúde Pública da Universidade de São Paulo, sito à Av. Dr. Arnaldo, 715, Cerqueira César - CEP 01246-904, São Paulo, SP - Telefone: (11) 3061-7779 - e-mail: coep@fsp.usp.br, em caso de dúvidas ou notificação de acontecimentos não previstos.

Declaro que concordo em participar desse estudo e que me foi dada a oportunidade de ler e esclarecer as minhas dúvidas.

São Paulo, 14 de junho de 2019 .

Nome do sujeito ou do responsável legal:

Assinatura:

Eu, Flávia Thedim Costa Bueno, declaro que forneci todas as informações referentes ao projeto ao participante e/ou responsável.

Data:14/06/2019

Telefone: +5521 99965-0686 